\title{
2. SITE 530: SOUTHEASTERN CORNER OF THE ANGOLA BASIN ${ }^{1}$
}

\author{
Shipboard Scientific Party ${ }^{2}$
}

\section{HOLE 530}

Date occupied: 29 July 1980

Date completed: 30 July 1980

Time on hole: 1 day, $8 \mathrm{hr}$., $30 \mathrm{~min}$.

Position (latitude; longitude): $19^{\circ} 11.26^{\prime} \mathrm{S} ; 9^{\circ} 23.15^{\prime} \mathrm{E}$

Water depth (sea level; corrected m, echo-sounding): 4629

Water depth (rig floor; corrected m, echo-sounding): 4639

Bottom felt (m, drill pipe): 4645

Penetration (m): 125

Number of cores: 2

Total length of cored section $(\mathrm{m}): 11.0$

Total core recovered $(\mathrm{m}): 9.2$

Core recovery (\%): 83.6

Oldest sediment cored:

Depth sub-bottom (m): 125

Nature: Unlithified debris conglomerate and diatomaceous clay

Age: late Pliocene

Measured velocity $(\mathrm{km} / \mathrm{s}): 1.5$ (disturbed)

Basement:

Depth sub-bottom (m):

Nature:

Velocity range $(\mathrm{km} / \mathrm{s})$ :

\section{HOLE 530A}

Date occupied: 30 July 1980

Date departed: 15 August 1980

Time on hole: 15 days, $7 \mathrm{hr}$., $51 \mathrm{~min}$.

Position (latitude; longitude): $19^{\circ} 11.26^{\prime} \mathrm{S} ; 9^{\circ} 23.15^{\prime} \mathrm{E}$

Water depth (sea level; corrected m, echo-sounding): 4629

\footnotetext{
${ }^{1}$ Hay, W. W., Sibuet, J.-C., et al., Init. Repts. DSDP, 75: Washington (U.S. Govt. Printing Office).

2 William W. Hay (Co-Chief Scientist), Joint Oceanographic Institutions Inc., $2600 \mathrm{Vir}-$ ginia Avenue, N. W., Washington, D.C. (present address: Museum, University of Colorado, Boulder, Colorado); Jean-Claude Sibuet (Co-Chief Scientist), Centre Océanologique de Bretagne, Brest Cedex, France; Eric J. Barron, Rosenstiel School of Marine and Atmospheric Science, University of Miami, Miami, Florida (present address: National Center for Atmospheric Research, Boulder, Colorado); Robert E. Boyce, Deep Sea Drilling Project, Scripps Institution of Oceanography, La Jolla, California; Simon C. Brassell, Organic Geochemistry Unit, University of Bristol, Bristol BS8 ITS, United Kingdom; Walter E. Dean, Branch of Regional Geochemistry, U.S. Geological Survey, Denver, Colorado; Alain Y. Huc, Institut de Recherche, Ressources et Matériaux Minéraux, Université d’Orleans, Orléans Cedex, France (present address: Institut Français du Pétrole; B.P. 311, 92506 Rueil-Malmaison France (present address: Institut Français du Pétrole; B.P. 311, 92506 Rueil-Malmaison Manoa, Honolulu, Hawaii; Charles L. McNulty, Department of Geology, University of Texas at Arlington, Arlington, Texas; Philip A. Meyers, Department of Atmospheric and Oceanic Science, University of Michigan, Ann Arbor, Michigan; Masato Nohara; Geologica Survey of Japan. Ibaraki 305, Japan; Roger E. Schallreuter, Geologisch-Paläontologisches

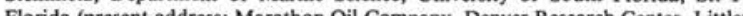
Florida (present address: Marathon Oil Company, Denver Research Center, Littleton, Colorado); Dorrik Stow, British National Oil Corporation, Glasgow G2 SLJ, United Kingdom (present address: Grant Institute of Geology, University of Edinburgh, Edinburgh EH9 3JW United Kingdom); Herbert Stradner, Geologische Bundesanstalt, 3, Rasumofskygasse, A-1031 Vienna, III, Austria.
}

Water depth (rig floor; corrected m, echo-sounding): 4639

Bottom felt (m, drill pipe): 4645

Penetration (m): 1121.0

Number of cores: 108

Total length of cored section $(\mathrm{m}): 996.0$

Total core recovered $(\mathrm{m}): 619.46$

Core recovery $(\%): 62.2$

Oldest sediment cored:

Depth sub-bottom (m): 1103

Nature: Brown clay

Age: late Albian

Measured velocity $(\mathrm{km} / \mathrm{s}): 2.3$

Basement:

Depth sub-bottom (m): 1103

Nature: Basalt

Velocity range $(\mathrm{km} / \mathrm{s}): 4.8$

\section{HOLE 530B}

Date occupied: 15 August 1980

Date departed: 18 August 1980

Time on hole: 3 days, $10 \mathrm{hr}$., $57 \mathrm{~min}$.

Position (latitude; longitude): $19^{\circ} 11.26^{\prime} \mathrm{S}, 9^{\circ} 23.17^{\prime} \mathrm{E}$

Water depth (sea level; corrected m, echo-sounding): 4629

Water depth (rig floor; corrected m, echo-sounding): 4639

Bottom felt (m, drill pipe): 4643

Penetration (m): 180.6

Number of cores: 48

Total length of cored section $(\mathrm{m}): 180.6$

Total core recovered $(\mathrm{m}): 155.08$

Core recovery $(\%): 85.9$

Oldest sediment cored:

Depth sub-bottom (m): 180.6

Nature: Nannofossil clay

Age: early Miocene

Measured velocity $(\mathrm{km} / \mathrm{s}): 1.52$

\section{PRINCIPAL CONCLUSIONS}

1. Two hundred sixty beds of organic carbon-rich black shale (1-60 cm thick, $1-16 \%$ organic carbon) were recovered through $165 \mathrm{~m}$ of late Albian-early Santonian pelagic and fine-grained turbiditic basinal sediments. Turbidites may have contributed to both the down-slope transport and the concentration of organic carbon from an upper-slope source where anoxic conditions periodically prevailed.

2. The organic matter of the black shales is immature; it is mainly derived from marine sources, but part may be of terrigenous origin. 
3. A major deep-sea fan sequence $(250 \mathrm{~m}$ thick, rich in volcanogenic sands) prograded into the area during the early Santonian-early Campanian. This fan was gradually replaced by a detrital carbonate fan, which reflects the northward drift of the shallow-water source area into a climatic zone permitting extensive reef development during the Maestrichtian and Paleogene.

4. The southern Angola Basin was starved of sediment from the middle Eocene to the early Miocene, in part because of a shallowing of the carbonate compensation depth (CCD) (related to sea level changes?) and in part because of a relative dearth of terrigenous input via turbidity currents.

5. The dominant terrigenous sediment source from the late Albian through the Miocene was the African continental margin.

6. Debris-flow deposits ( $>30 \mathrm{~m}$ thick, $20 \mathrm{~km}$ downslope movement) together with thick (up to $80 \mathrm{~cm}$ ), organic-rich (up to $6 \%$ organic carbon), diatom-nannofossil ooze turbidites, from the latest Miocene through Plio-Pleistocene were derived from the adjacent Walvis Ridge.

7. The late Miocene-Recent sediments are rich in organic matter of marine origin, generally increasing and then decreasing with depth and reflecting the history of upwelling.

8. The maximum content of organic matter occurs in beds deposited during the early Pleistocene.

9. The Pliocene-Pleistocene turbidites contain higher amounts of organic matter than other lithologies.

10. The basement age of about 102.5 m.y. supports the hypothesis of a Ridge jump in latest Albian time, just after salt deposition.
11. The lowest of the major seismic discontinuities corresponds to a hiatus between the early Coniacian and Cenomanian.

12. Site 530 basement depth and age are important in calculating an empirical seafloor subsidence curve for the Angola and Brazil basins.

13. The nannofossil assemblages at the Cretaceous/ Tertiary boundary are well preserved; they do not reveal a distinct "event" but indicate an interfingering of assemblages.

14. The sediments at Site 530 have been above and below the CCD during the Cenozoic, and many of the falls of sea level proposed by Vail et al. (1977) may be reflected in the boundaries of carbonate and noncarbonate sediments.

15. The red claystone overlying basalt appears to be altered by hydrothermal activity or by baking.

16. Good measurements of physical properties of the upper sediments were obtained from undisturbed hydraulic piston cores.

\section{BACKGROUND AND OBJECTIVES}

\section{Geologic Setting}

Site 530 is located in the southeastern corner of the Angola Basin, about $20 \mathrm{~km}$ north of the Walvis Escarpment, near the eastern end of the easternmost (or Frio) segment of the Walvis Ridge (Figs. 1, 2). It lies on the abyssal floor of the Angola Basin and exhibits a seismic stratigraphic sequence typical for the entire deep part of the basin.

Site 530 was located near one of the three candidate sites in this area (Fig. 2). It was intended to be at $19^{\circ}$

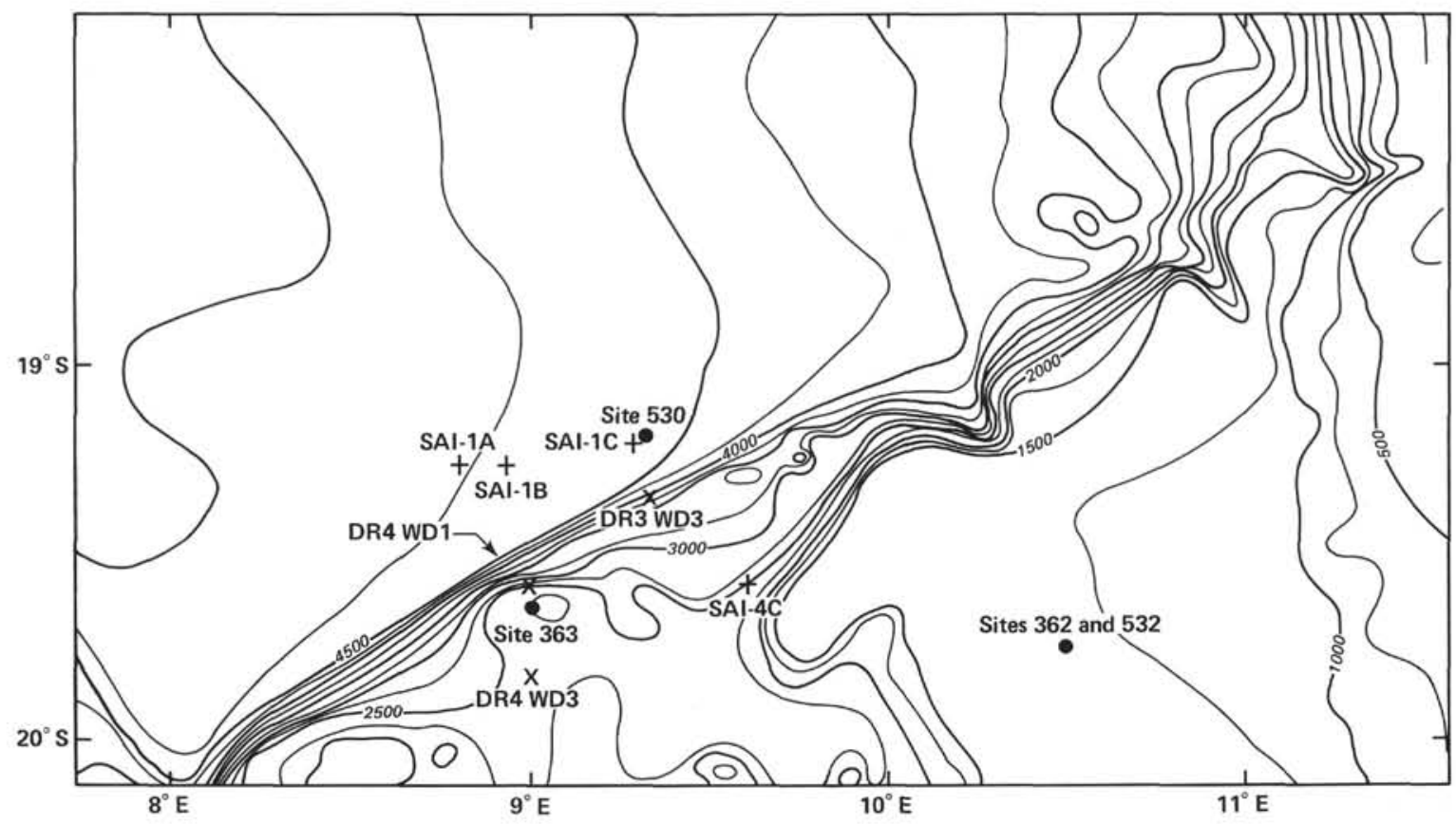

Figure 1. Eastern end of the Frio segment of the Walvis Ridge, showing the location of R/V Jean Charcot dredge sites DR3 WD3, DR4 WD1, and DR4 WD3 (Hékinian, 1972; Pastouret and Goslin, 1974). Also shown are DSDP Sites 362 and 363 (Bolli, Ryan, et al., 1978); Site 530, and candidate sites SAI-1A, SAI-1B, SAI-1C, and SAI-4C. 


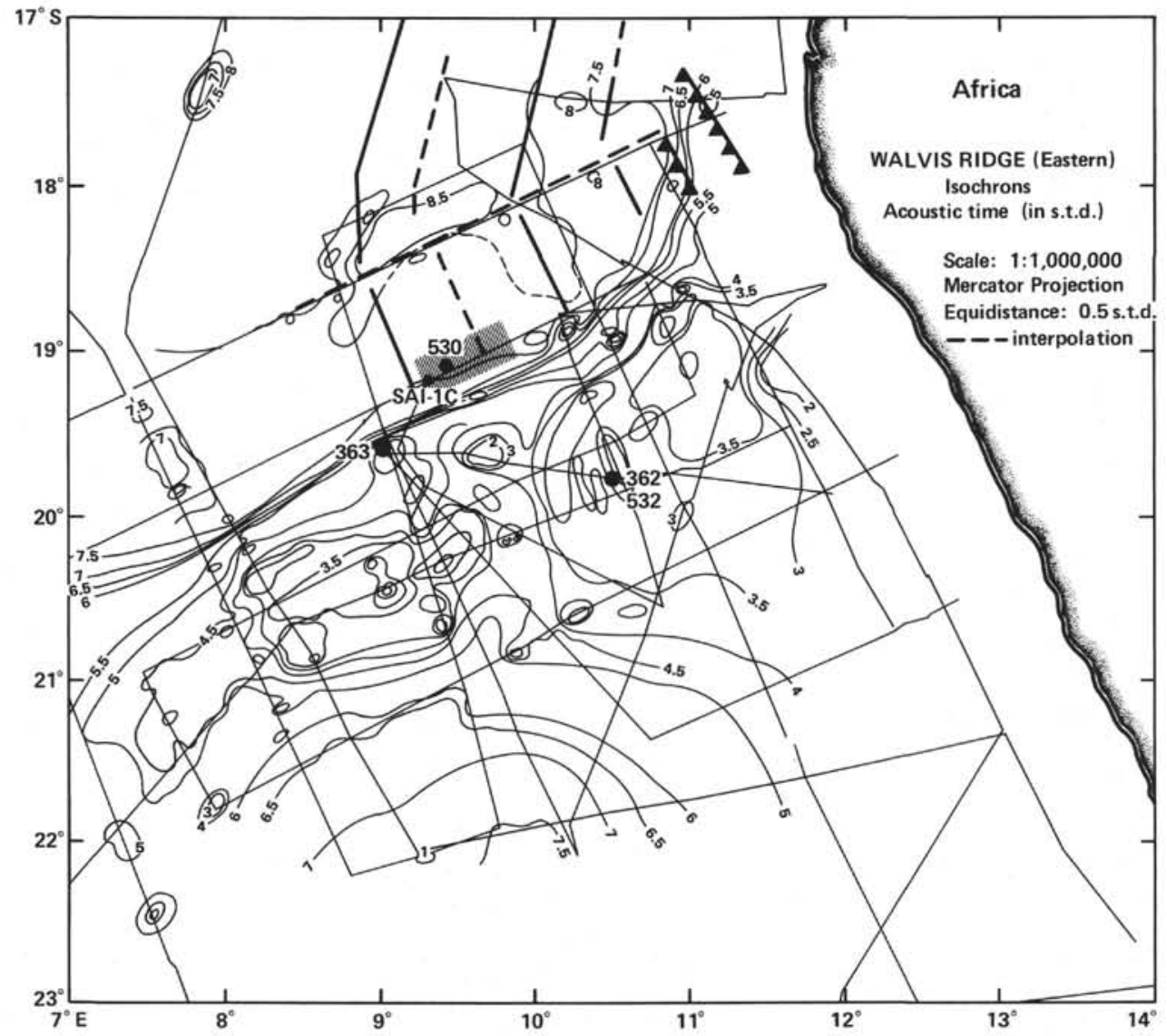

Figure 2. Chart showing magnetic lineations of the southern Angola Basin as interpreted by Sibuet et al. (in prep.), the trace of a small fracture zone, depth to acoustic basement, and the area of candidate Site SAI-1C.

$11.5^{\prime} \mathrm{S}$ and $9^{\circ} 20.5^{\prime} \mathrm{E}$ at shot point 3240 on the multichannel seismic profile BGR-41 taken by the Bundesanstalt für Geowissenschaften und Rohstoffe; during planning of the cruise this site was known as SAI-1C. The other two candidate sites, SAI-1A and SAI-1B, were located, respectively, at $19^{\circ} 17^{\prime} \mathrm{S}, 8^{\circ} 47.5^{\prime} \mathrm{E}$ and $19^{\circ}$ $17^{\prime} \mathrm{S}, 8^{\circ} 56^{\prime} \mathrm{E}$ on multichannel seismic profiles taken by the R/V Fred H. Moore of the University of Texas Marine Science Institute (UTMSI). SAI-1A was on UTMSI line 36 at shot point 2500 and showed a similar seismic stratigraphic sequence, but was located on a low rise of the basement and might not have the oldest strata preserved. SAI-1B was on UTMSI line 31 at shot point 9990 and presents the sequence in an area with a shallow pond. SAI-1C was selected because it appears to have the oldest strata in the region preserved in a sediment pond between low basement rises. The location as the easternmost of the candidate sites improved the chance of recovering the oldest sediment in the area.

\section{Geology of the Basement}

Magnetic lineations of the basement are not distinct in the area immediately north of the Walvis Ridge. The $\mathrm{M}$ sequence (M0 to M11) has been identified in the Cape Basin south of Walvis Ridge by Rabinowitz (1976). In the Angola Basin farther north of the ridge several magnetic lineations, parallel to the coastline, have been identified by Sibuet et al. (in prep.) (Fig. 2). Cande and
Rabinowitz (1978) published an interpretation of the Angola Basin anomalies, suggesting that a Ridge jump occurred about the time of Anomaly M0 or later, so that the basement at Site 530 would be early Aptian or younger. A major objective of drilling at this site was to determine the age of basement.

The easternmost segment of the Walvis Ridge is oriented $\mathrm{N} 60^{\circ} \mathrm{E}$ along the flow lines of the initial opening of the South Atlantic. This segment, known as the Frio Ridge, is about $130 \mathrm{~km}$ wide in its narrower part and lies at a water depth of $2500 \mathrm{~m}$ west of $9.5^{\circ} \mathrm{E}$. Gravity data suggest that the Walvis Ridge was created at the same time as or just after the adjacent oceanic basins (Goslin and Sibuet, 1975; Kogan, 1979; Detrick and Watts, 1979). Site 363, drilled on the Walvis Ridge about 30 nautical miles $(55 \mathrm{~km})$ southwest of Site 530 , bottomed in early Aptian strata $35 \mathrm{~m}$ above inferred basement. The ages of adjacent parts of the Walvis Ridge and Angola Basin are probably no more than $10 \mathrm{~m}$.y. different.

Site 530 is located on typical oceanic crust far from fracture zones, the nearest being a small offset fracture zone about $80 \mathrm{~km}$ to the north.

\section{Geology of Nearby DSDP Sites}

Site 530 is located on the plain of the Angola Basin north of the foot of the Walvis Ridge. It is 80 nautical miles $(145 \mathrm{~km})$ west-northwest of Site 362 and 30 nauti- 
cal miles $(55 \mathrm{~km})$ northeast of Site 363 , both of which were drilled on the Walvis Ridge during Leg 40 (Bolli, Ryan et al., 1978; see Fig. 1).

Site 362 was located on the Abutment Plateau of the Frio Ridge segment of the Walvis Ridge, at a water depth of $1336 \mathrm{~m}$ (drill-pipe measurement). Two holes were drilled at the site, penetrating a total of $1081 \mathrm{~m}$ and bottoming in early Eocene limestones. The section was reported to be essentially continuous from Holocene to early Eocene, and four lithologic units were recognized (see Fig. 3). Unit 1 was a Pleistocene to late Miocene diatomaceous marly nannofossil ooze and chalk with radiolarians and silicoflagellates extending to $188 \mathrm{~m}$ subbottom, with indications of some erosion in the late Miocene. Unit 2 was a late Miocene to latest Oligocene foraminiferal nannofossil chalk with well-bedded cyclic intercalations of marly material and with a strong dissolution cycle in the middle Miocene; the unit extends from 188 to $820 \mathrm{~m}$ sub-bottom. Unit 3 was Oligocene Braarudosphaera chalk with many pure white layers of pentaliths of $B$. bigelowi intercalated with marly chalk showing evidence of dissolution and winnowing; the unit extends from $820-924 \mathrm{~m}$ sub-bottom. Unit 4 was a late to early Eocene, recalcified and cemented marly nannofossil chalk and limestone, extending from 924$1081 \mathrm{~m}$ sub-bottom.

Drilling at Site 362 permitted calibration of an important regional seismic stratigraphic horizon, the prominent regional seismic reflector at $0.94 \mathrm{~s}$ correlated with the top of the Braarudosphaera chalk. This reflector can be traced as far away as Site $\mathbf{3 6 0}$ in the Cape Basin.

Fragments of Albian to Cenomanian limestone, typical of a shelf environment, have been dredged on the northern flank of the Walvis Ridge at a water depth of $2700 \mathrm{~m}$ (Pastouret and Goslin, 1974).

Site 363 was located on an isolated basement high on the northfacing escarpment of the Frio Ridge portion of the Walvis Ridge, at a water depth of $2247 \mathrm{~m}$ (drill pipe measurement), and less than $10 \mathrm{~km}$ from Pastouret and Goslin's dredge site. A single hole was drilled, penetrating sediment to a depth of $715 \mathrm{~m}$ and bottoming in early Aptian limestones. The section younger than late Oligocene is condensed at this site, the early to late Miocene being represented by a single core. Three lithologic units were recognized; they are not correlative with the lithologic units distinguished at Site 362 . Unit 1 consisted of late Miocene to early Maestrichtian nannofossil oozes and chalks extending from 31 to $373 \mathrm{~m}$ sub-bottom. The Oligocene interval again contained many white layers of Braarudosphaera chalk. Unit 2 was Campanian to early Aptian nannofossil marl extending from 373 to $696 \mathrm{~m}$ sub-bottom and showing many erosional contacts. Albian sediments contained dark layers with disseminated pyrite, interpreted as indicating at least localized reducing conditions. The cyclic occurrence of terrigenous clays in the marls was interpreted as being climatically controlled. Unit 3 was early Aptian limestone, interlayered with calcarenites containing fragments of lamellibranchs and calcareous algae, and interpreted as suggesting a high-energy, near shore environment.

A more important regional seismic stratigraphic horizon was calibrated by drilling at Site 363 ; it was found to correspond to a hiatus between upper Coniacian and upper Albian strata. This prominent discontinuity had been recognized by Goslin et al. (1974) and shown on interpreted profiles 2,9 , and 11 of their figure 7 . They indicated its extent across the sedimentary basin on top of the Walvis Ridge and into both the Angola and Cape Basins on their interpreted profiles.

Although Sites 362 and 363 are close to Site 530, they are on the Walvis Ridge in water depths so much shallower that their stratigraphy can be expected to differ significantly from that of the deep basin site.

Drilling at greater depths in the Angola Basin had been accomplished at Sites 364 and 365, which were located on the continental margin about 460 nautical miles $(840 \mathrm{~km})$ to the north of Site 530 (see Fig. 3). At Site 364 , in a water depth of $2439 \mathrm{~m}$ (drill-pipe measurement), sediments were drilled to a depth of $1086 \mathrm{~m}$ subbottom. Here the section was not continuous, and most of the Oligocene and late Eocene were represented by a hiatus. Seven lithologic units were recognized; they do not correlate with units recognized at either Site 362 or 363. Unit 1 was Pleistocene to late Pliocene dark olive gray calcareous mud and black clay with plant debris extending to a sub-bottom depth of $55 \mathrm{~m}$. Unit 2 was early Pliocene to middle Miocene marly nannofossil ooze and mud extending from $55-131 \mathrm{~m}$ sub-bottom. Unit 3 was yellow brown pelagic clay and greenish gray radiolarian mud of early Miocene to middle Oligocene age extending from $131-250 \mathrm{~m}$ sub-bottom. Unit 4 was middle Eocene to late Coniacian nannofossil chalks from 250-577 $\mathrm{m}$ sub-bottom. Unit 5 was late Coniacian to late Albian marly chalks with finely laminated "sapropelic" shales extending from $577-710 \mathrm{~m}$ sub-bottom. Unit 6 was late and middle Albian limestone and marly limestone extending from $710-962 \mathrm{~m}$ sub-bottom. Unit 7 was middle Albian to late Aptian dolomite with black "sapropelic" shales extending from $962-1086 \mathrm{~m}$ sub-bottom.

The prominent deeper acoustic reflector was found to correspond to the base of lithologic Unit 5, which includes late Coniacian to late Turonian and late Albian marly chalks and limestones with "sapropels" separated by a hiatus representing the Cenomanian and early Turonian.

Site 365 was located in $3040 \mathrm{~m}$ water depth (drill pipe measurement) but penetrated only $687 \mathrm{~m}$ of sediment, bottoming in Oligo-Miocene radiolarian clays and mudstones. Only seven cores were taken. The site was located on the eastern side of a partly buried submarine canyon cut into Cenozoic and Mesozoic sediments. The sediment was Neogene terrigenous canyon fill including allochthonous blocks of Coniacian-Santonian nannofossil ooze and Cenomanian-upper Albian "sapropelic" mudstones from the canyon walls. The Miocene and Oligocene beds appeared to have been deposited below the CCD.

Other sites which have been drilled in the Angola Basin include 17 and 18 of Leg 3, located on the flank of the Mid-Atlantic Ridge in water depths of 4277 and $4022 \mathrm{~m}$ and the oldest sediments late Oligocene and early Miocene, respectively. Sites 519, 520, 521, 522, and 523 were drilled on Leg 73 on the flank of the Mid-Atlantic Ridge in water depths ranging from $3778-4572 \mathrm{~m}$, 
Site 365

$11^{\circ} 39.10^{\prime} \mathrm{S}, 11^{\circ} 53.72^{\prime} \mathrm{E}$
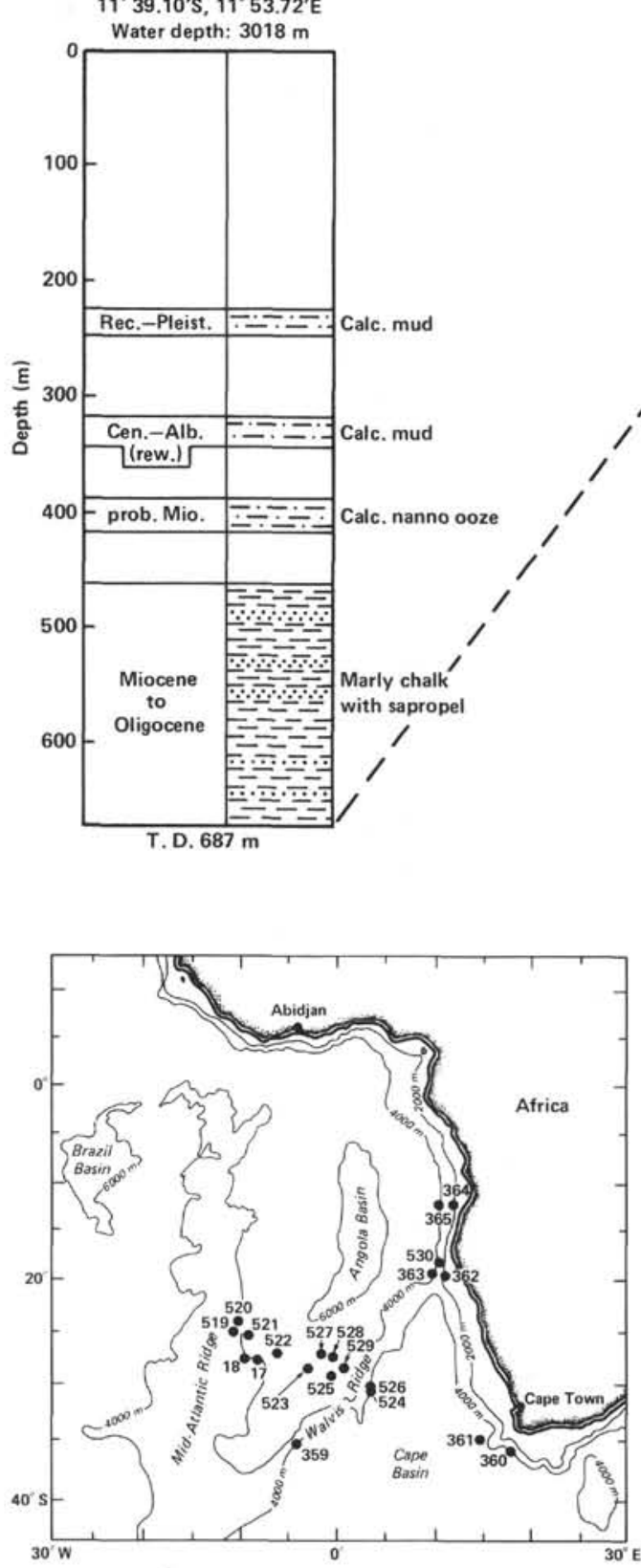

Site 364

'34.32's, 11 $58.30^{\circ} \mathrm{E}$

Water depth: $2448 \mathrm{~m}$

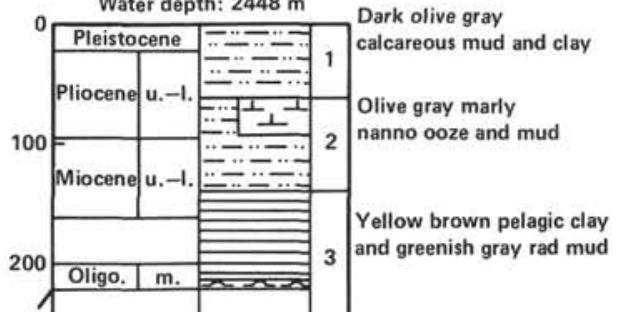

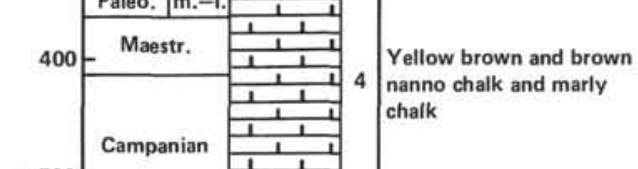

ite 362, 362A

$9^{\circ} 45.45^{\prime} \mathrm{S}, 10^{\circ} 31.95^{\prime} \mathrm{E}$

हᄐ

E

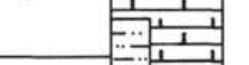

Water depth: $1325 \mathrm{~m}$

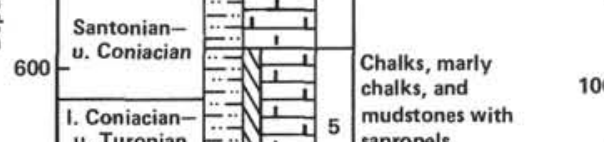

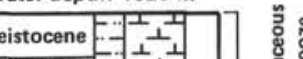

or
$=\mathcal{\perp}$

Pleistocene-.- $\perp$ -

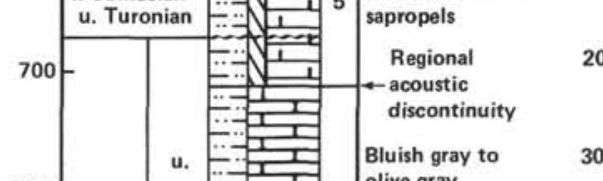

-1 Pliocene -1 - 1

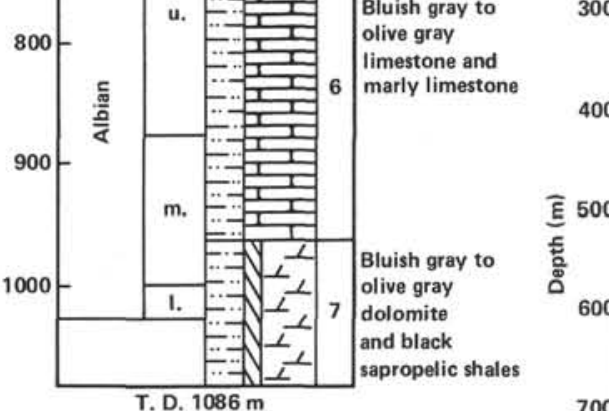

u.

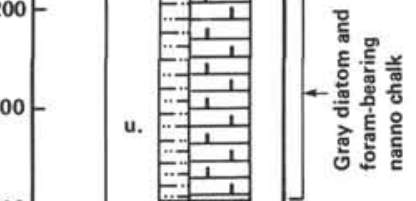

-

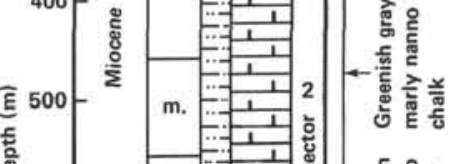

600

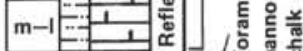

D. $1086 \mathrm{~m}$

Site 363

$19^{\circ} 38.75 ' \mathrm{~S}, 09^{\circ} 02.80^{\prime} \mathrm{E}$

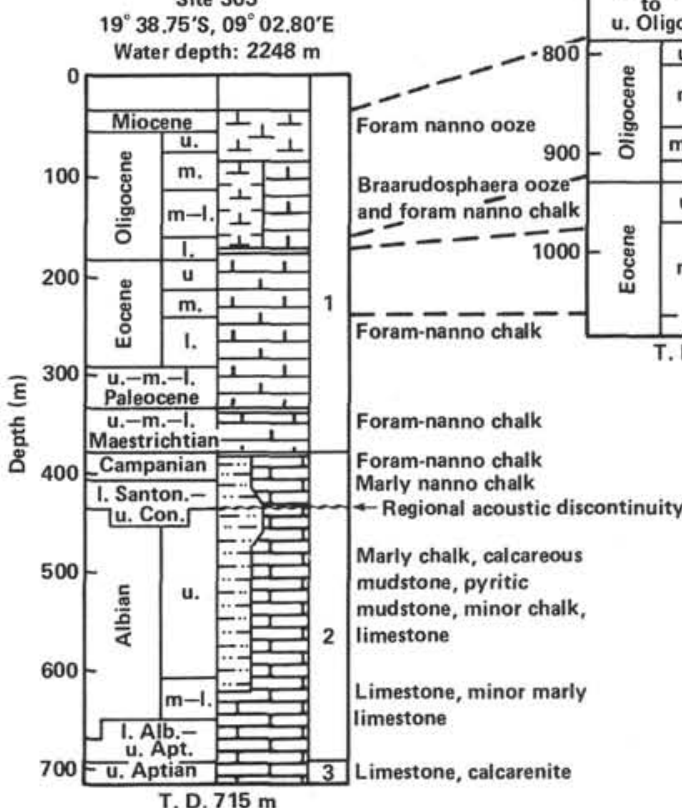

1. $\frac{1}{11}$

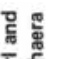


with oldest sediments ranging from late Miocene to middle Eocene in age. Sites 525, 526, 528, and 529 were drilled along a northwest-southeast transect located between $1^{\circ}$ and $4^{\circ} \mathrm{E}$ and extending from the crest of the Walvis Ridge at a water depth of $1054 \mathrm{~m}$ into the basin to $4427 \mathrm{~m}$. The oldest sediments were Maestrichtian except at the shallowest site which bottomed in Paleocene sands.

\section{Seismic Stratigraphy}

The basic technique of the stratigraphic interpretation of seismic data (Payton, 1977) is recognition of sedimentary sequences between discontinuities which are calibrated by using drill hole data. The seismic stratigraphic framework is established through lateral tracing of the discontinuities and determination of the facies represented by the sequences.

Using results from drilling at Sites 362 and 363 and seismic profile BGR-36 along the Walvis Ridge, three main sequences bounded by discontinuities had been identified. The lowest surface, discontinuity 1 , was thought to be a paraconformity where the Cenomanian and much or all of the Turonian is missing, as at Site 363; the middle discontinuity, 2, was thought to be the top of the Braarudosphaera chalk, dated as early Oligocene as noted at Sites 362 and 363; the upper discontinuity, 3, was thought to be middle Miocene, dated by drilling at Site 362. Because of the difference in water depth and probable differences in sedimentary facies, it was realized that it would be highly speculative to extend this seismic stratigraphy to the deep Angola Basin, except for discontinuity 1 which was thought to be recognizable throughout the area and which had also been established as approximating a Cenomanian-Turonian hiatus near the base of a black shale sequence at Site 364 . Consequently, prior to drilling, detailed interpretation of the seismic stratigraphy was limited to tracing this discontinuity and the sequences above and below it.

A map of bottom paleocurrents was drawn using the basal onlap of the sequence above discontinuity 1 shown in Figure 4. From this map, it appears that the main source of sediment was from the northeast. The paleo-

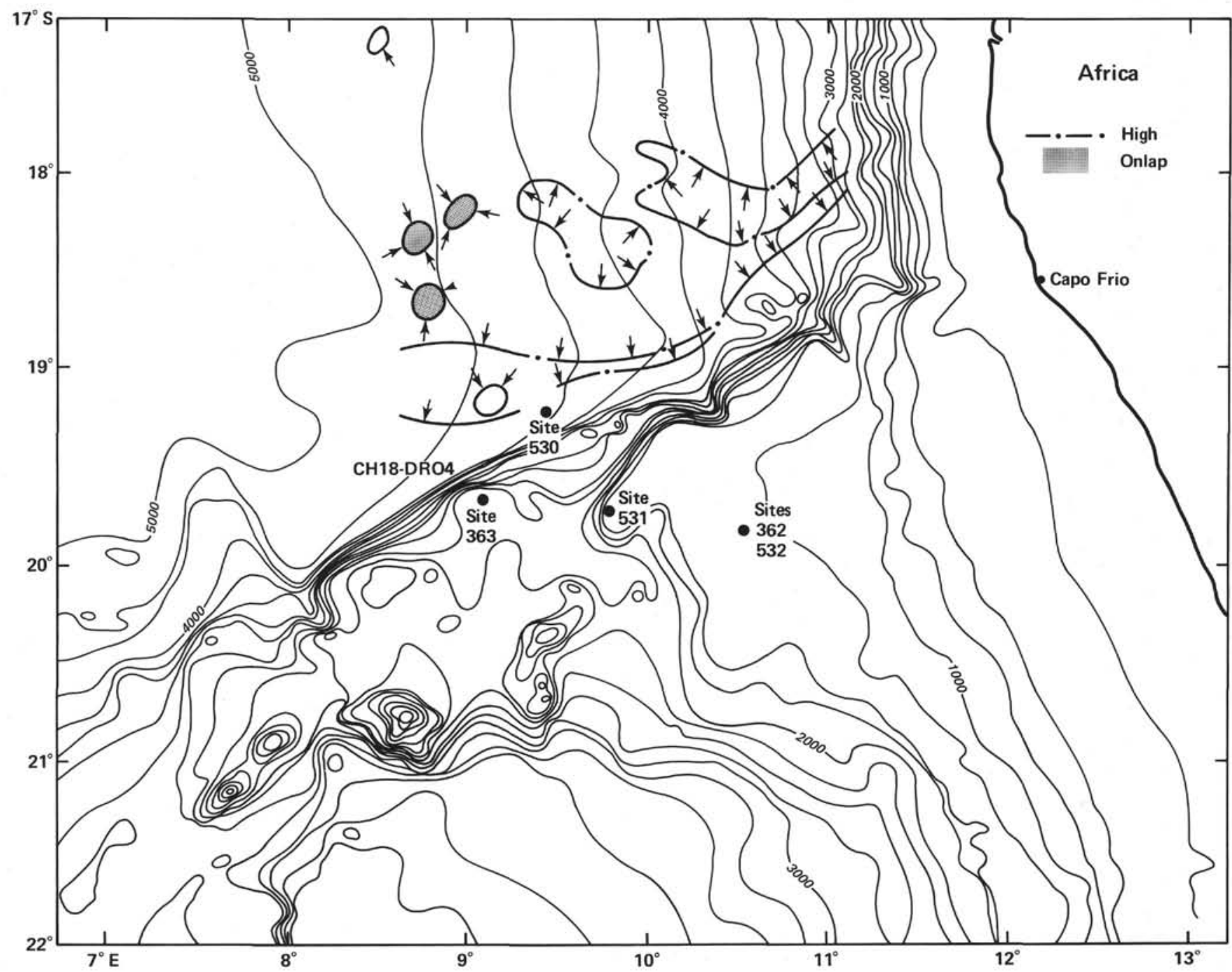

Figure 4. Paleocurrents indicated by basal onlap of the stratigraphic sequence above discontinuity 1 . 
currents appear to have carried sediment south along the continental margin and to have changed direction at the northern wall of the Ridge where the continental slope is dissected by submarine canyons. Part of the sediment was carried into the Angola Basin, producing the onlap features seen on the seismic profiles. The remainder of the sediment was deposited in the basin on the Walvis Ridge and in the Cape Basin, as shown by the prograding series on the southern flank of the ridge. The sequence beneath discontinuity 1 is well stratified. The paleocurrent direction in the basins followed the isobaths, and a lesser amount of sediment was delivered by submarine canyons.

\section{Oceanographic Setting}

Site 530 lies beneath the gently northward flowing Benguela Current $(<25 \mathrm{~cm} / \mathrm{s})$ and at the northern end of the upwelling region and seasonally developed divergence off southwest Africa. The thickness of the Benguela Current is on the order of $200 \mathrm{~m}$ and its width is about $600 \mathrm{~km}$ in this area. It may be underlain by a southward flowing counter-current concentrated along the African margin in its shallower depths, but extending seaward as much as $400 \mathrm{~km}$ at depths of $400-500 \mathrm{~m}$.

The Walvis Ridge acts as a barrier to the flow of deeper water. The eastern or Frio segment of the Ridge is everywhere shallower than $2000 \mathrm{~m}$. The middle segment runs north-south and is separated from the eastern segment by a depression more than $3000 \mathrm{~m}$ deep, but is otherwise less than $2000 \mathrm{~m}$ deep. The western segment, which trends northeast-southwest, is lower and has the deepest passage into the Cape Basin, with a sill depth between 3500 and $4000 \mathrm{~m}$. The Walvis Ridge effectively blocks the entry of Antarctic Bottom Water (AABW) into the Angola Basin, except from the north where AABW enters after passing through the Romanche Fracture Zone and over the Guinea Rise which has a sill depth of $4600 \mathrm{~m}$. Neumann and Pierson (1966) estimated that the bottom water of the Angola Basin contains only $7 \% \mathrm{AABW}$; it has a potential temperature of $+2.00^{\circ} \mathrm{C}$ compared with a potential temperature of $-0.45^{\circ} \mathrm{C}$ for $\mathrm{AABW}$ near its source.

The intermediate waters of the Angola Basin consist of an upper component originating as Antarctic Intermediate Water (AAIW) with a core at about $650-750 \mathrm{~m}$ depth and a deeper component (DW) which is a mixture of Mediterranean Water and Arctic Bottom Water. The AAIW can flow across the Walvis Ridge, and the DW enters the basin from the northwest. Current velocities in all of the water column below the warm surface waters are thought to be very slow.

The Angola Basin occupies a unique position in the modern ocean. In the Atlantic it is the basin most remote from all the major sources for deep water.

\section{Predicted Stratigraphy}

The seismic profile BGR-41, on which candidate drill site SAI-1C was defined (Fig. 5), parallels the Walvis Ridge about $20 \mathrm{~km}$ north of the foot of the Ridge. The most well-defined seismic marker is discontinuity 1 , which had been interpreted as the Cenomanian-Turonian hiatus at 0.6 s.d.t.t. below the seabottom (about $600 \mathrm{~m}$ ).
The thickness of the whole sedimentary section is about 1.3 s.d.t.t. (about $1300 \mathrm{~m}$ ). Above discontinuity 1, a $0.25(200 \mathrm{~m})$ transparent sequence was expected to correspond to the Turonian-Santonian black shales identified at Site 364 on the Angola continental margin. Below discontinuity $1,0.25(200 \mathrm{~m})$ of strong reflectors overlie another $0.3-0.45(300-400 \mathrm{~m})$ seismically transparent unit which was expected to correspond to the late Aptian-early Albian black shales drilled at Site 364 .

If the depositional sequence at Site 530 were correctly predicted and typical, reflecting general conditions in the basin, it would be expected that most of the sediments would have been deposited above the CCD. A hiatus or dissolution facies was expected for the middle Miocene-late Oligocene interval and at the Paleocene/ Maestrichtian boundary. Sediments rich in organic carbon were expected in the Cenomanian-Coniacian and Aptian-Albian sequence. Because this site is in deep water and because drilling was to penetrate the entire sedimentary sequence in basinal facies, it was anticipated that other dissolution facies and anoxic beds might be discovered.

\section{Objectives}

Organic-carbon-rich laminated sediments indicative of an anaerobic depositional environment are not extensively developed in the modern open ocean; however, the location and extent of such depositional environments are of exceptional interest because high concentrations of organic carbon can accumulate and be preserved under such conditions. Today such environments are restricted either to isolated basins whose bottom waters are not (or are only very slowly) renewed or to substrates beneath the oceanic mid-water oxygen minimum developed under highly fertile and productive surfacewater masses along continental margins. The prime examples of the first case, euxinic conditions, are the Black Sea and the Cariaco Trench. Examples of the second case are known from the continental margins off west India, southwest Africa, western South America, southwestern North America, and from the Gulf of California. The two types of depositional environment are similar because laminated sediments with a high organic carbon content occur in both, but they can be distinguished by reconstruction of their paleogeographic and paleobathymetric setting and by analysis of the fossil content of their sediments.

Conditions favorable to the development of black shales in the deep ocean occurred several times during the Cretaceous when organic-carbon-rich sediments were laid down under anaerobic waters over wide regions of several ocean basins. Global paleoceanographic scenarios which might cause these apparently isochronous events are being modeled, and the origin of the organic matter accumulated in the anaerobic sediments is presently under intense investigation.

Many models have been proposed for the depositional environment of black shales; these fall into three groups:

1. Restricted water circulation leads to oxygen-deficient bottom waters which favor preservation of organic material. Restricted circulation caused by: (a) a topo- 


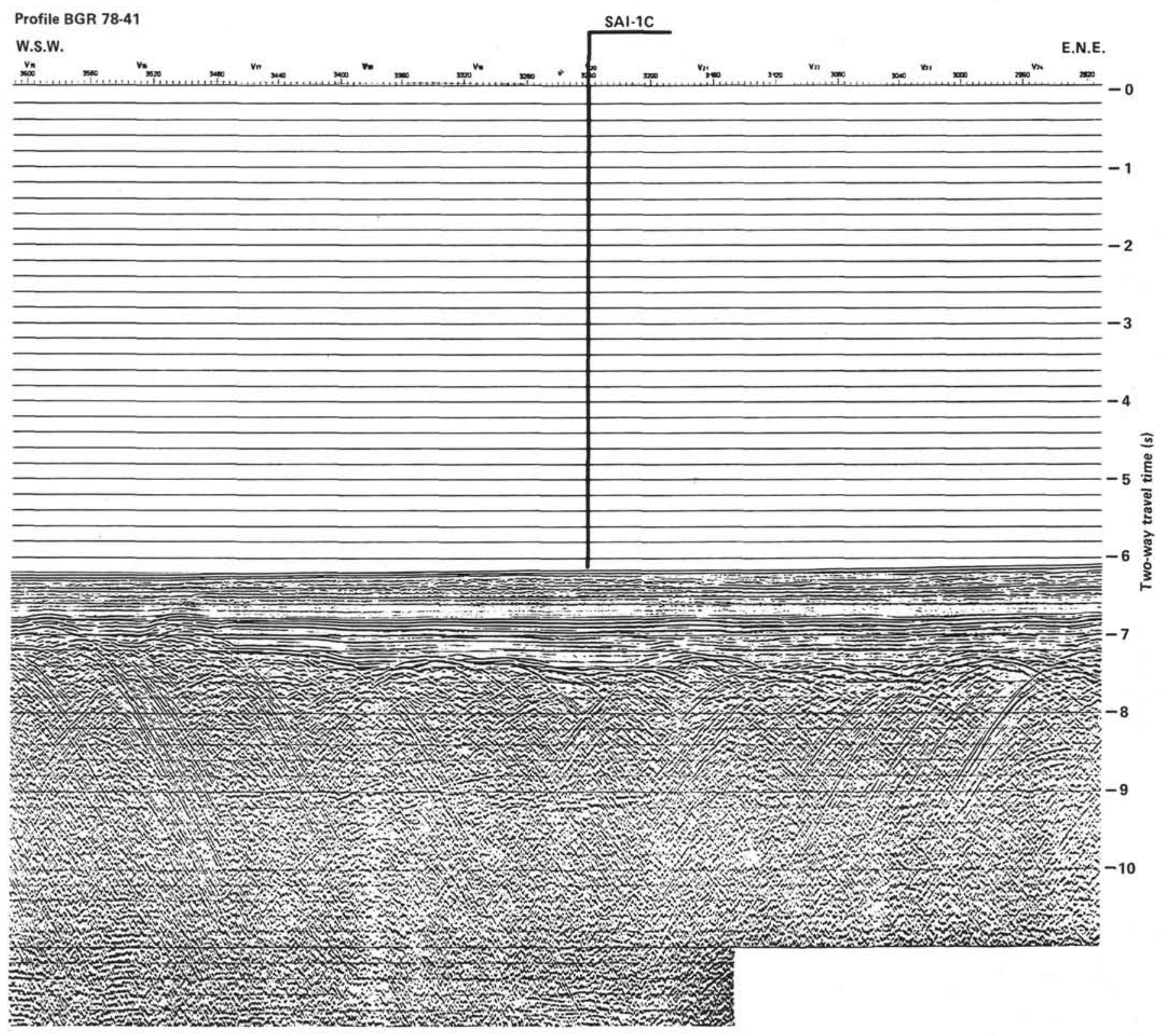

Figure 5. Multichannel seismic profile BGR 78-41, showing the location of candidate drill site SAI-1C.

graphic barrier (Degens and Stoffers, 1976); (b) a strong halocline (Olausson, 1960); (c) a strong thermocline (Tyson et al., 1979); (d) a wide shelf and depression of waves (Hallam, 1967); depression of tidal activity (Hallam and Bradshaw, 1979).

2. High planktonic productivity leads to an expanded oxygen minimum zone within the water column and anoxic bottom conditions where this zone intersects with the seafloor, (Gallois, 1976; Thiede and van Andel, 1977; Jenkyns, 1980). This may be related to secular variations in: (a) climate (Fisher and Arthur, 1977); (b) salinity (Arthur and Natland, 1979).

3. High rates of sedimentation lead to rapid burial and preservation of organic matter in anoxic subsurface conditions. This is especially important where there is high input of organic-rich terrestrial material (Cornford et al., 1979; Welte et al., 1979).

4. Filling of the basin by plumes of warm salty bottom water with low oxygen content (Brass et al., 1982).

The main objective of drilling at Site 530 was to define the paleoenvironmental history of the Angola Basin in order to determine its paleoceanographic evolution, particularly during the mid-Cretaceous, when black shales were deposited in this part of the Atlantic. Drilling was expected to reveal whether the black shales were deposited throughout the bottom of an anoxic basin or only at mid-depths within the oxygen-minimum layer of a quasi-normal oceanic basin, and whether the anoxia was a result of an abnormally high influx of organic matter or was caused by salinity or temperature-induced 
stratification. A detailed stratigraphic analysis of the sedimentary sequence of the Angola Basin is needed to resolve these alternatives.

Linked to this prime objective was the study of the paleoceanographic effects of the subsidence of an aseismic ridge attached to a passive continental margin. Drilling was expected to determine the extent to which the Walvis Ridge has served as a dam to paleocirculation and to current-transported sediments. The information sought would complement that gained on Legs 73 and 74 and permit definition of the depth zonation of lithofacies (and/or paleoenvironments) across the northern flank of the Walvis Ridge and of the history of calcium carbonate compensation in the Angola Basin.

The Cretaceous/Tertiary boundary was to receive special examination in order to provide additional information for discriminating between current hypotheses relating it to astronomical or paleoceanographic causes.

Paleomagnetic studies were to be conducted to establish the polarity reversal sequence for Cretaceous sediments of the Angola Basin and to correlate the reversal sequence with the established Cretaceous magnetostratigraphic time scale. The Early Cretaceous reversal stratigraphy anticipated at Site 530 was expected to be used as a reference section for a regional comparison of sites from DSDP Legs 40-44 (Keating and Helsley, 1978a, b and 1979).

With respect to the regional geology, drilling at Sites 530 would calibrate the seismic stratigraphy of the deeper part of the Angola Basin. It would also discriminate between the alternative views of the early spreading history of this area.

\section{OPERATIONS}

\section{Site Approach}

Glomar Challenger departed Walvis Bay, South Africa, on 27 July 1980 at $1600 \mathrm{hr}$. After a stop for thruster tests at $1823 \mathrm{hr}$., the vessel was underway with a course of $307^{\circ}$ in direction of a point in the Angola Basin $\left(19^{\circ} \mathrm{S} ; 9^{\circ} 46^{\prime} \mathrm{E}\right)$ on seismic profile BGR-41. Continuous seismic profiles, magnetics, bathymetry, and $3.5-\mathrm{kHz}$ data were collected. The track was planned so as not to duplicate other seismic profiles in the region, crossing the easternmost part of the Walvis Ridge.

The vessel approached Site SAI-1C (Site 530) on a course of $242^{\circ}$ at a speed of 8.0 knots, following the BGR-41 profile for 30 nautical miles. Using two $40 \mathrm{CU}$ air guns, the penetration was about 1.0 s.d.t.t. The regional seismic discontinuity 1 , the presumed Cenomanian-Turonian hiatus, and the layered sequence beneath this discontinuity were well defined on the Glomar Challenger record. However, because rough oceanic basement could not be seen and because the sedimentary layers are flat, it was decided to locate the final site using satellite navigation. A double life beacon was dropped at $0917 \mathrm{hr} ., 29$ July 1980 . The vessel continued on the $242^{\circ}$ course for $5 \mathrm{n}$. mi. in an attempt to establish the correspondence between the seismic profiles, but no basement features could be detected. At $0952 \mathrm{hr}$. we reversed course and commenced pulling the towed gear.
At $1100 \mathrm{hr}$. we were on Site 530. Figure 6 shows the ship's track for the approach on site.

The drill string was assembled with a 9-7/8" F93CK bit and the run-in started at 1124 . Hole 530 was spudded in at 2344. The first core was taken at the seafloor ( $4645.0 \mathrm{~m}$ below rig floor; $4629 \mathrm{~m}$ water depth) to a subbottom depth of $1.5 \mathrm{~m}$ (Table 1), and recovered on deck at 0101 on 30 July. The interval from 1.5 to $115.5 \mathrm{~m}$ sub-bottom was washed in 27 minutes. A second core was cut from 115.5 to $125.0 \mathrm{~m}$ and recovered at 0607 . The heat-flow tool was then dropped but could not be retrieved. The drill string was pulled, and the bit with the bent heat-flow tool arrived on deck at 1954. The probe of the tool was broken off at the bottom of the bit and crushed. It could not be removed until the bent edges had been cut off with a torch.

The drill string was reassembled and run-in started with no offset from the earlier hole. Hole 530A was spudded in at 0727 on 31 July and washed to a depth of $125 \mathrm{~m}$ sub-bottom in 42 minutes. The first core was on deck at 1130 on 31 July and coring proceeded continuously unitl 1830, 5 August, when, after very poor recovery in Cores 65 and 66 taken from 733-752 m sub-bottom, a center bit was dropped twice to try to clear the plugged bit. The operation was successful, and coring continued at 2100. By the morning of 7 August, the time to cut a core had increased to an average of about one hour, and it was decided to use knobby pipe and the shorter $(9 \mathrm{~m})$ core barrel from Core 83 to the bottom of the hole. The ten stands of knobby pipe were recycled once on 8 August and once on 9 August. Basalt was encountered at the base of Core 105, at 1103 m sub-bottom. Cores 106 through 108 were drilled in basalt, and Core 106 was cut in 52 minutes, but Cores 107 and 108 required 263 minutes and 745 minutes, respectively. Because the time required to cut a 9-m core was in excess of $12 \mathrm{hr}$., it was decided to terminate the hole at 0941 on 11 August. Core cutting times and percent recovery in Hole 530A are plotted in Figure 7.

Preparation for logging operations in Hole 530A started with a wiper run and flushing of the hole with mud, which was completed 1650 . The heat-flow probe was used to make measurements of the water temperature near the bottom of the hole just outside the bit, at two intermediate levels inside the pipe, and at the mudline inside the pipe. The heat-flow probe was recovered on deck at 1955. The bit was released at 2047 , and the pipe pulled up so that its bottom was at $1099 \mathrm{~m}$ subbottom.

The first log run was made with the Gamma Ray LogNeutron Log tool inside the pipe. The logging was started at 2154 , and the tool returned on deck at 0856 on 12 August. The pipe was then pulled up to $198 \mathrm{~m}$ subbottom for open hole logging. A rig of the Temperature Log-Absolute and Density Log (Gamma-Ray Borehole Compensated) as a tool was started in the hole at 1106 , but was stopped shortly after leaving the pipe by encountering a bridge in the hole at a sub-bottom depth of $276 \mathrm{~m}$. Attempts to clear the bridge failed, and the tool was returned to deck at 1548 . The hole was cleaned and flushed, and the bottom of the pipe set at $312 \mathrm{~m}$ sub- 


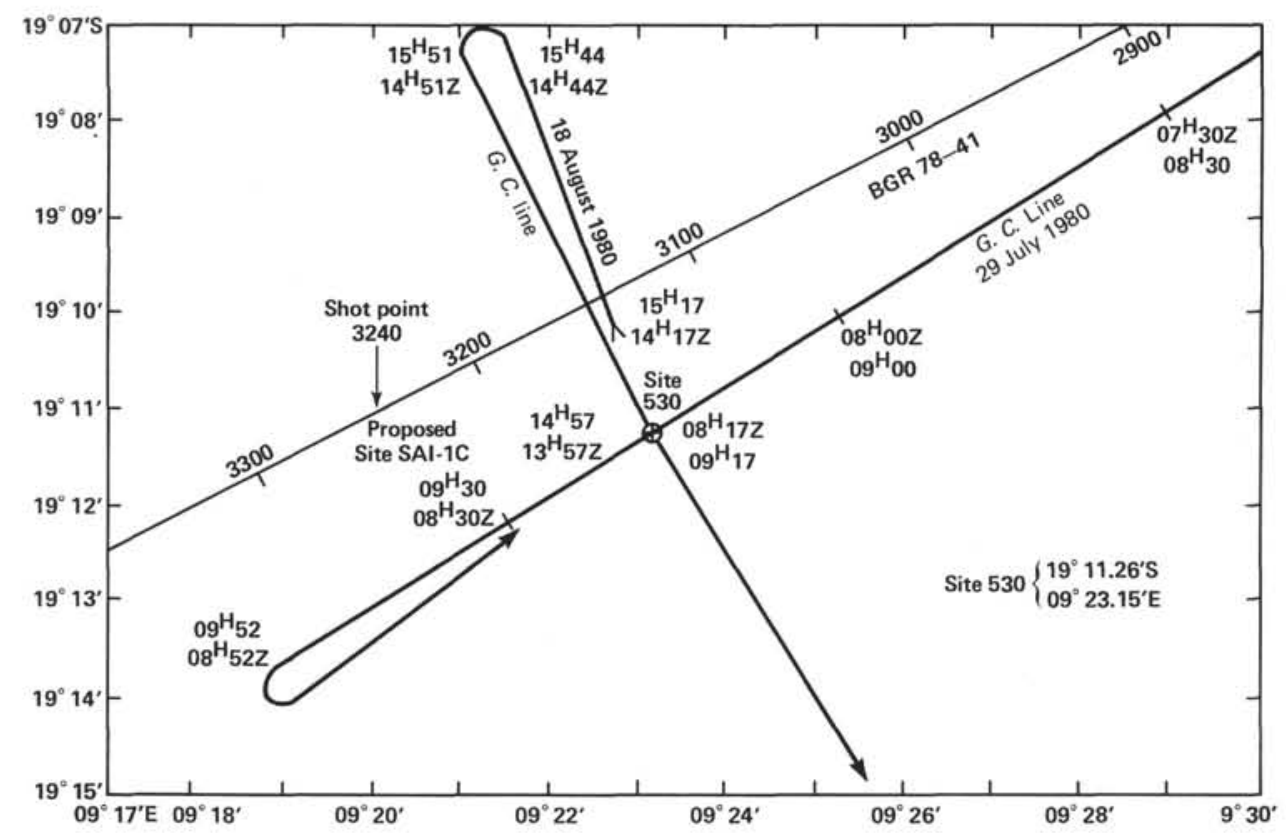

Figure 6. Glomar Challenger's approach to and departure from Site 530, plus location of BGR seismic line 78-41.

bottom. The tool was again stopped by a bridge in the hole, this time at $316 \mathrm{~m}$ sub-bottom. The tool was returned to the deck at 0239 on 13 August, and it was found that the Density Log part of the tool with its source had been left in the hole. The hole was again cleaned and flushed with mud and the pipe set at $628 \mathrm{~m}$ sub-bottom. The Gamma-Ray Log-Compensated and Sonic Log (Borehole Compensated) were rigged as a tool and run, starting in the hole at 1318 . The tool was able to descend to $940 \mathrm{~m}$ sub-bottom and logged the interval from there to the bottom of the pipe at $628 \mathrm{~m}$ subbottom. The tool returned on deck at 1940 . The source of the Density Log tool was found on the run-out to be at $341 \mathrm{~m}$ sub-bottom. The Gamma-Ray Log-Compensated was then rigged with the Induction Log starting in the hole at 2000. The tool descended to $912 \mathrm{~m}$ sub-bottom and logged the interval between there and $625 \mathrm{~m}$ sub-bottom, returning on deck at 0155 on 14 August. The Gamma-Ray Log-Calibrated was then rigged with the Laterolog and Neutron Log and this suite started in the pipe at 0214 . The tool descended to $888 \mathrm{~m}$ sub-bottom and the interval between this depth and $625 \mathrm{~m}$ subbottom was logged. The tools returned on deck at 0903 . The Temperature Log-Absolute tool was then rigged and started in the hole at 0920 . The tool descended to $859 \mathrm{~m}$, logged the interval up to the bottom of the pipe and returned on deck at 1452 .

The drill bit was dropped and collet for hydraulic piston coring seated at 2102 .

Hole 530A was then plugged with cement. The abandonment program began at 2146 and was completed, and the pipe cleared the mudline at 0345 on 15 August.

Hole 530B was offset a short distance and spudded in at 0938 . The first hydraulic piston core arrived on deck at 1008. Coring continued to a sub-bottom depth of
$180.6 \mathrm{~m}$, reached after taking 48 cores, at 0159 on 18 August.

As the drill string was pulled, the bottom-hole assemblage was inspected by magnaflux; the work was complete at 1424, and the ship got underway for the next site.

The ship departed Site 530 on a course of $340^{\circ}$ turning at 1544 on 18 August 1980 to cross the site with the seismic profiling gear. The course of $153^{\circ}$ crossing the site from the NW is at a right angle to the trend of the Walvis Ridge and was continued until near the top of the ridge. The seismic and $3.5-\mathrm{kHz}$ records are shown in Figures 8 and 9.

\section{LITHOLOGIC SUMMARY}

\section{Introduction}

Nine lithologic units have been recognized at Site 530: eight sedimentary units and basalt (Table 2; Fig. 10). Unit 1 consists of sediments containing mixtures of nannofossils, diatoms, and clay, in roughly that order of abundance. The end-members are classified as nannofossil ooze and diatom ooze; mixtures with more than $30 \%$ clay are classified as marls, smarls, and sarls depending upon the relative proportions of siliceous and calcareous microfossils (see lithologic classification in Chapter 1: Introduction). Debris-flow deposits and turbidites are superimposed on these background pelagic sediments at a number of horizons within the lithologic unit. Unit 1 is subdivided into two subunits on the basis of relative abundance of diatoms and nannofossils. Unit 2 consists of nannofossil clay, marl, and ooze with several thick debris-flow deposits at the top of the unit. Unit 3 consists of interbedded red and green mud. The dominant lithologies of Unit 4 are red and green mud- 
Table 1. Coring summary, Hole 530.

\begin{tabular}{|c|c|c|c|c|c|c|c|}
\hline & & & $\begin{array}{l}\text { Depth from } \\
\text { drill floor } \\
\text { (m) }\end{array}$ & $\begin{array}{c}\text { Depth below } \\
\text { seafloor } \\
(\mathrm{m})\end{array}$ & $\begin{array}{l}\text { Length } \\
\text { cored }\end{array}$ & $\begin{array}{l}\text { Length } \\
\text { recovered }\end{array}$ & \\
\hline Core & & Time & Top Bottom & Top Bottom & & & ry \\
\hline
\end{tabular}

Hole 530

\begin{tabular}{|c|c|c|c|c|c|c|c|}
\hline 1 & $\begin{array}{c}\text { July } \\
{ }_{30}\end{array}$ & 0101 & $4645.0-4646.5$ & $0.0-1.5$ & 1.5 & 1.4 & 93 \\
\hline 2 & 30 & 0607 & $4760.5-4770.0$ & $115.5-125.0$ & 9.5 & 7.8 & 82 \\
\hline & & & & & 11.0 & 9.2 & 83.6 \\
\hline
\end{tabular}

Hole 530A

\begin{tabular}{|c|c|c|c|c|c|c|}
\hline & & & & & & \\
\hline 31 & $\begin{array}{l}1130 \\
1310\end{array}$ & $\begin{array}{r}4770.0-4779.5 \\
4779.5-47890\end{array}$ & $125.0-134.5$ & 9.5 & $\begin{array}{l}4.2 \\
4.78\end{array}$ & 44 \\
\hline $\begin{array}{l}31 \\
31\end{array}$ & 1441 & $4789.0-4798.5$ & $\begin{array}{l}134.5-144.0 \\
144.0-153.5\end{array}$ & $\begin{array}{l}9.5 \\
9.5\end{array}$ & ${ }_{0.1}^{4.78}$ & $\begin{array}{l}50 \\
1\end{array}$ \\
\hline 31 & 1611 & $4798.5-4808.0$ & $153.5-163.0$ & 9.5 & 7.82 & $\begin{array}{l}1 \\
82 \\
\end{array}$ \\
\hline 31 & 1756 & $4808.0-4817.5$ & $163.0-172.5$ & 9.5 & 9.21 & 97 \\
\hline 31 & 1937 & $4817.5-4827.0$ & $172.5-182.0$ & 9.5 & 3.53 & 37 \\
\hline 31 & 2109 & $4827.0-4836.5$ & $182.0-191.5$ & 9.5 & 8.39 & 88 \\
\hline $\begin{array}{c}31 \\
\text { Augus }\end{array}$ & 2242 & $4836.5-4846.0$ & $191.5-201.0$ & 9.5 & 9.70 & 102 \\
\hline & & & & & & \\
\hline 1 & 0145 & $4855.5-4865.0$ & $210.5-220.5$ & 9.5 & 9.75 & $\begin{array}{r}54 \\
103\end{array}$ \\
\hline 1 & 0325 & $4865.0-4874.5$ & $220.0-229.5$ & 9.5 & 8.83 & 93 \\
\hline 1 & 0457 & $4874.5-4884.0$ & $229.5-239.0$ & 9.5 & 8.54 & 90 \\
\hline 1 & 0622 & $4884.0-4893.5$ & $239.0-248.5$ & 9.5 & 8.37 & 88 \\
\hline 1 & $\begin{array}{l}0747 \\
0.924\end{array}$ & $\begin{array}{l}4893.5-4903.0 \\
40301.2\end{array}$ & $\begin{array}{r}248.5-258.0 \\
2580-67.5\end{array}$ & 9.5 & 4.71 & 50 \\
\hline 1 & 1053 & $4912,5-4922,0$ & $\begin{array}{l}285.0-267.5 \\
267.5-277.0\end{array}$ & 9.5 & 8.69 & 91 \\
\hline i & 1228 & $4922.0-4931.5$ & $277.0-286.5$ & 9.5 & $\begin{array}{l}1.74 \\
8.74\end{array}$ & ${ }_{92}^{11}$ \\
\hline i & 1358 & $4931.5-4941.0$ & $286.5-296.0$ & 9.5 & 7.8 & 82 \\
\hline 1 & 1531 & $4941.0-4950.5$ & $296.0-305.5$ & 9.5 & 9.75 & 103 \\
\hline i & 1711 & $4950.5-4960.0$ & $305.5-315.0$ & 9.5 & 9.81 & 103 \\
\hline 1 & 1853 & $4960.0-4969.5$ & $315.0-324.5$ & 9.5 & 9.78 & 103 \\
\hline i & 2045 & $4969.5-4979.0$ & $324.5-334.0$ & 9.5 & 9.73 & 102 \\
\hline i & 2224 & $4979.0-4988.5$ & $334.0-343.5$ & 9.5 & 0.23 & 2 \\
\hline 2 & 0016 & $4988.5-4998.0$ & $343.5-353.0$ & 9.5 & 9.35 & 98 \\
\hline 2 & 0207 & $4998,0-5007.5$ & $353.0-362.5$ & 9.5 & 9.69 & 102 \\
\hline 2 & 0343 & $5007.5-5017.0$ & $362.5-372.0$ & 9.5 & 7.98 & 84 \\
\hline 2 & 0536 & $5017.0-5026.5$ & $372.0-381.5$ & 9.5 & 9.48 & 100 \\
\hline 2 & 0725 & $5026.5-5036.0$ & $381.5-391.0$ & 9.5 & 9.93 & 105 \\
\hline 2 & 0914 & $5036.0-5045.5$ & $391.0-400.5$ & 9.5 & 8.55 & 90 \\
\hline 2 & 1113 & $5045.5-5055.0$ & $400.5-410.0$ & 9.5 & 8.93 & 94 \\
\hline 2 & 1315 & $5055.0-5064.5$ & $410.0-419.5$ & 9.5 & 7.83 & 82 \\
\hline 2 & 1522 & $5064.5-5074.0$ & $419.5-429.0$ & 9.5 & 4.65 & 49 \\
\hline 2 & 1702 & $5074.0-5083.5$ & $429.0-438.5$ & 9.5 & 5.37 & 57 \\
\hline 2 & 1917 & $5083.5-5093.0$ & $438.5-448.0$ & 9.5 & 9.89 & 104 \\
\hline 2 & 2110 & $5093.0-5102.5$ & $448.0-457.5$ & 9.5 & 6.87 & 72 \\
\hline 2 & 2315 & $5102.5-5112.0$ & $457.5-467.0$ & 9.5 & $1.47 \mathrm{Y}>\mathrm{C}$ & 15 \\
\hline 3 & 0112 & $5112.0-5121.5$ & $467.0-476.5$ & 9.5 & 4.08 & 43 \\
\hline 3 & 0328 & $5121.5-5131.0$ & $476.5-486.0$ & 9.5 & 3.05 & 32 \\
\hline 3 & 0532 & $5131.0-5140.5$ & $486.0-495.5$ & 9.5 & 2.90 & 31 \\
\hline 3 & 0757 & $5140.5-5150.0$ & $495.5-505.0$ & 9.5 & 5.70 & 60 \\
\hline 3 & 0957 & $5150.0-5159.5$ & $505.0-514.5$ & 9.5 & 4.67 & 49 \\
\hline 3 & 1148 & $5159.5-5169.0$ & $514.5-524.0$ & 9.5 & 3.50 & 37 \\
\hline 3 & 1338 & $5169.0-5178.5$ & $524.0-533.5$ & 9.5 & 3.15 & 33 \\
\hline 3 & 1525 & $5178.5-5188.0$ & $533.5-543.0$ & 9.5 & 2.80 & 29 \\
\hline 3 & 1715 & $5188.0-5197.5$ & $543.0-552.5$ & 9.5 & 0.96 & 10 \\
\hline 3 & 1918 & $5197.5-5207.0$ & $552.5-562.0$ & 9.5 & 0.64 & 7 \\
\hline 3 & 2103 & $5207.0-5216.5$ & $562.0-571.5$ & 9.5 & 2.38 & 25 \\
\hline 3 & 2248 & $5216.5-5226.0$ & 571.5-581.0 & 9.5 & 2.13 & 22 \\
\hline 4 & 0059 & $5226.0-5235.5$ & $581.0-590.5$ & 9.5 & 2.17 & 23 \\
\hline 4 & 0412 & $5235.5-5245.0$ & $590.5-600.0$ & 9.5 & 5.64 & 59 \\
\hline 4 & 0705 & $5245.0-5254.5$ & $600.0-609.5$ & 9.5 & 7.46 & 79 \\
\hline 4 & 0903 & $5254.5-5264.0$ & $609.5-619.0$ & 9.5 & 1.37 & 14 \\
\hline 4 & 1056 & $5264.0-5273.5$ & $619.0-628.5$ & 9.5 & 2.51 & 26 \\
\hline 4 & 1305 & $5273.5-5283.0$ & $628.5-638.0$ & 9.5 & 1.36 & 14 \\
\hline 4 & 1528 & $5283.0-5292.5$ & $638.0-647.5$ & 9.5 & 7.46 & 79 \\
\hline 4 & 1804 & $5292.5-5302.0$ & $647.5-657.0$ & 9.5 & 2.68 & 28 \\
\hline 4 & 2030 & $5302.0-5311.5$ & $657.0-666.5$ & 9.5 & 2.71 & 29 \\
\hline 4 & 2704 & 5311.5-5321.0 & $666.5-676.0$ & 9.5 & 1.51 & 16 \\
\hline 5 & 0123 & $5321.0-5330.5$ & $676.0-685.5$ & 9.5 & 3. & 32 \\
\hline 5 & 0340 & $5330.5-5340.0$ & $685.5-695.0$ & 9.5 & 2.88 & 30 \\
\hline 5 & 0617 & $5340.0-5349.5$ & $695.0-704.5$ & 9.5 & 6.58 & 69 \\
\hline 5 & 0853 & $5349.5-5359.0$ & 704.5-714.0 & 9.5 & 6.17 & 65 \\
\hline 5 & 1111 & $5359.0-5368.5$ & $714.0-723.5$ & 9.5 & 4.70 & 49 \\
\hline 5 & 1323 & $5368.5-5378.0$ & $723.5-733.0$ & 9.5 & 6.00 & 70 \\
\hline 5 & 1521 & $5378.0-5387.5$ & $733.0-742.5$ & 9.5 & 0. & 0 \\
\hline 5 & 1812 & 5387.5-5397.0 & $742.5-752.0$ & 9.5 & 0.12 & 1 \\
\hline 5 & 2352 & $5397.0-5406.5$ & $752.0-761.5$ & 9.5 & 4.58 & 48 \\
\hline 6 & 0202 & $5406.5-5$ & $761.5-7$ & 9.5 & 9.05 & 95 \\
\hline 6 & 0437 & $5416.0-5425.5$ & $771.0-7$ & 9.5 & 4.85 & 51 \\
\hline 6 & 0646 & 5425.5 & $780.5-7$ & 9. & 4. $>>$ & 45 \\
\hline 6 & 0910 & $5435.0-5444.5$ & 790.0 .0 & 9.5 & & 57 \\
\hline 6 & 1134 & 5444. & 799. & 9.5 & & 87 \\
\hline 6 & 1404 & $5454.0-5463.5$ & 809. & 9. & & 99 \\
\hline 6 & 1559 & $5463.5-5473.0$ & $818.5-8$ & 9. & & 61 \\
\hline 6 & 1807 & $5473.0-5482.5$ & $828.0-83$ & 9. & 6. & 71 \\
\hline 6 & 2117 & $5482.5-5492.0$ & $837.5-847.0$ & 9.5 & 7.46 & 79 \\
\hline 6 & 2349 & $5492.0-5501.5$ & $847.0-856.5$ & 9.5 & 9.98 & 105 \\
\hline 7 & 0143 & & $856.5-866.0$ & 9.5 & 9.88 & 104 \\
\hline 7 & 0355 & $5511.0-5520.5$ & $866.0-875.5$ & 9.5 & 7.61 & 80 \\
\hline 7 & 0801 & $5520.5-5530.0$ & $875.5-885.0$ & 9.5 & 4.66 & 49 \\
\hline 7 & 1036 & $5530.0-5539.5$ & $885.0-894.5$ & 9.5 & 5.01 & 53 \\
\hline 7 & 1301 & $5539.5-5549.0$ & $894.5-904.0$ & 9.5 & & 83 \\
\hline $7_{7}^{7}$ & $\begin{array}{l}1530 \\
1819\end{array}$ & $5549.0-5558.0$ & $904.0-913.0$ & 9.0 & $\begin{array}{l}5.95 \\
5.22\end{array}$ & $\begin{array}{l}66 \\
58\end{array}$ \\
\hline
\end{tabular}

Table 1. (Continued).

\begin{tabular}{|c|c|c|c|c|c|c|c|}
\hline \multirow[b]{2}{*}{ Core } & \multirow{2}{*}{$\begin{array}{c}\text { Date } \\
(1980)\end{array}$} & \multirow[b]{2}{*}{ Time } & \multirow{2}{*}{$\begin{array}{c}\begin{array}{c}\text { Depth from } \\
\text { drill floor } \\
(\mathrm{m})\end{array} \\
\text { Top Bottom }\end{array}$} & \multirow{2}{*}{$\begin{array}{l}\begin{array}{c}\text { Depth below } \\
\text { seafloor } \\
(\mathrm{m})\end{array} \\
\text { Top Bottom }\end{array}$} & \multirow{2}{*}{$\begin{array}{l}\text { Length } \\
\text { cored } \\
\text { (m) }\end{array}$} & \multirow{2}{*}{$\begin{array}{l}\begin{array}{c}\text { Length } \\
\text { recovered } \\
\text { (m) }\end{array}\end{array}$} & \multirow{2}{*}{$\begin{array}{l}\text { Percent } \\
\text { recovery }\end{array}$} \\
\hline & & & & & & & \\
\hline \multicolumn{8}{|c|}{ Hole 530A (Cont.) } \\
\hline 85 & 7 & 7132 & $5567.0-5576.0$ & $922.0-931.0$ & 9.0 & 8.80 & 98 \\
\hline 86 & 8 & & $5576.0-5585.0$ & $931.0-940.0$ & 9.0 & 9.35 & 104 \\
\hline 87 & 8 & 0218 & $5585.0-5594.0$ & $940.0-949.0$ & 9.0 & 7.02 & 78 \\
\hline 88 & 8 & 0524 & $5594.0-5603.0$ & $949.0-958.0$ & 9.0 & 4.49 & so \\
\hline & 8 & 0808 & $5603.0-5612.0$ & $958.0-967.0$ & 9.0 & 9.22 & 102 \\
\hline 90 & 8 & 1118 & $5612.0-5621.0$ & $967.0-976.0$ & 9.0 & 4.47 & 50 \\
\hline $\begin{array}{l}90 \\
91\end{array}$ & 8 & 1409 & $5621.0-5630.0$ & $976.0-985.0$ & 9.0 & 5.73 & 64 \\
\hline $\begin{array}{l}11 \\
92\end{array}$ & 8 & 1759 & $5630.0-5635.0$ & $985.0-990.0$ & 5.0 & 1.54 & 31 \\
\hline 93 & 8 & 2028 & $5635.0-5644.0$ & $990.0-999.0$ & 9.0 & 9.17 & 102 \\
\hline 94 & 8 & 2354 & $5644.0-5653.0$ & $999.0-1008.0$ & 9.0 & 2.75 & 31 \\
\hline 95 & 9 & 0255 & $5653.0-5662.0$ & $1008.0-1017.0$ & 9.0 & 6.55 & 73 \\
\hline 96 & 9 & 0547 & $5662.0-5671.0$ & $1017.0-1026.0$ & 9.0 & 7.97 & 89 \\
\hline & 9 & 0842 & $5671.0-5680.0$ & $1026.0-1035.0$ & 9.0 & 6.09 & 68 \\
\hline & 9 & 1118 & $5680.0-5689.0$ & $1035.0-1044.0$ & 9.0 & 5.00 & 56 \\
\hline & 9 & 1405 & $5689.0-5698.0$ & $1044.0-1053.0$ & 9.0 & 7.34 & 82 \\
\hline 100 & 9 & 1718 & $5698.0-5707.0$ & $1053.0-1062.0$ & 9.0 & 6.70 & 74 \\
\hline 101 & 9 & 2023 & $5707.0-5716.0$ & $1062.0-1071.0$ & 9.0 & 9.92 & 110 \\
\hline 102 & 9 & 2328 & $5716.0-5725.0$ & $1071.0-1080.0$ & 9.0 & 7.99 & \\
\hline 103 & 10 & 0452 & $5725.0-5730.0$ & $1080.0-1085.0$ & 5.0 & 6.03 & 121 \\
\hline 104 & 10 & 0806 & $5730.0-5739.0$ & $1085.0-1094.0$ & 9.0 & 7.91 & 88 \\
\hline 105 & 10 & 1106 & $5739.0-5748.0$ & $1094.0-1103.0$ & 9.0 & 8.01 & 89 \\
\hline 106 & 10 & 1336 & $5748.0-5750.0$ & $1103.0-1105.0$ & 2.0 & 0.16 & 8 \\
\hline 107 & 10 & 1939 & $5750.0-5767.0$ & $1105.0-1112.0$ & 7.0 & 2.82 & 40 \\
\hline \multirow[t]{2}{*}{108} & 11 & 0941 & $5767.0-5776.0$ & $1112.0-1121.0$ & 9.0 & 3.04 & 34 \\
\hline & & & & & 996.0 & 619.46 & 62.2 \\
\hline
\end{tabular}

Hole 530B

\begin{tabular}{|c|c|c|c|c|c|c|c|}
\hline & & & & & & & \\
\hline$\frac{1}{2}$ & 15 & 1008 & $\begin{array}{l}4643.0-4645.4 \\
4645.4-4649.8\end{array}$ & $\begin{array}{r}0-2.4 \\
2.4-6.8\end{array}$ & $\begin{array}{l}2.4 \\
4.4\end{array}$ & $\begin{array}{l}2.43 \\
4.44\end{array}$ & $\begin{array}{l}101 \\
101\end{array}$ \\
\hline & $\begin{array}{l}15 \\
15\end{array}$ & $\begin{array}{l}1142 \\
1301\end{array}$ & $\begin{array}{l}4645.4-46699.8 \\
4649.8-4654.2\end{array}$ & $\begin{array}{l}2.4-6.8 \\
6.8-11.2\end{array}$ & 4.4 & 4.49 & 102 \\
\hline & 15 & $\begin{array}{l}1301 \\
1426\end{array}$ & $4654.2-4658.6$ & $11.2-15.6$ & 4.4 & 4.58 & 104 \\
\hline $\begin{array}{l}3 \\
4 \\
5\end{array}$ & 15 & 1542 & $4658.6-4663.0$ & $15.6-20.0$ & 4.4 & 0 & 0 \\
\hline & 15 & 1722 & $4663.0-4666.4$ & $20.0-23.4$ & 3.4 & 4.64 & 136 \\
\hline & 15 & 1847 & $4666.4-4670.8$ & $23.4-27.8$ & 4.4 & 3.92 & 89 \\
\hline 8 & 15 & 2014 & $4670.8-4675.2$ & $27.8-32.2$ & 4.4 & 4.79 & 109 \\
\hline $\begin{array}{l}8 \\
9\end{array}$ & 15 & 2129 & $4675.2-4679.6$ & $32.2-36.6$ & 4.4 & 3.60 & 82 \\
\hline $\begin{array}{r}9 \\
10\end{array}$ & 15 & 2251 & $4679.6-4684.0$ & $36.6-41.0$ & 4.4 & 4.28 & 97 \\
\hline \multirow{2}{*}{$\begin{array}{l}11 \\
12\end{array}$} & 16 & 0006 & $4684.0-4688.4$ & $41.0-45.4$ & 4.4 & 3.79 & 86 \\
\hline & 16 & 0126 & $4688.4-4692.8$ & $45.4-49.8$ & 4.4 & 4.14 & 94 \\
\hline \multirow{2}{*}{$\begin{array}{l}12 \\
13 \\
14\end{array}$} & 16 & 0250 & $4692.8-4697.2$ & $49.8-54.2$ & 4.4 & 4.46 & 101 \\
\hline & 16 & 0427 & $4697.2-4701.6$ & $54.2-58.6$ & 4.4 & 4.68 & 106 \\
\hline 14 & 16 & 0545 & 4701.6-4706.0 & $58.6-63.0$ & 4.4 & 3.20 & 73 \\
\hline \multirow{2}{*}{$\begin{array}{l}16 \\
17\end{array}$} & 16 & 0707 & $4706.0-4710.4$ & $63.0-67.4$ & 4.4 & 4.27 & 97 \\
\hline & 16 & 0823 & 4710.4-4714.8 & $67.4-71.8$ & 4.4 & 3.78 & 86 \\
\hline $\begin{array}{l}\begin{array}{l}77 \\
18\end{array} \\
18\end{array}$ & 16 & 1004 & 4714.8-4719.2 & $71.8-76.2$ & 4.4 & 3.43 & 78 \\
\hline 18 & 16 & 1154 & $\begin{array}{r}4719.2-4723.6 \\
\end{array}$ & $76.2-80.6$ & 4.4 & & 0 \\
\hline $\begin{array}{l}15 \\
2 c \\
2\end{array}$ & 16 & 1307 & $\begin{array}{l}4723.6-4728.0 \\
47282\end{array}$ & $80.6-85.0$ & 4.4 & 3.62 & 82 \\
\hline 21 & 16 & $\begin{array}{l}1430 \\
1545\end{array}$ & $4728.0-4731,0$ & $85.0-88.0$ & 3.0 & 2.37 & 79 \\
\hline 22 & $\begin{array}{l}16 \\
16\end{array}$ & 1545 & $\begin{array}{r}4731.0-4735.4 \\
473354788\end{array}$ & $88.0-92.4$ & 4.4 & 4.78 & 109 \\
\hline 24 & $\begin{array}{l}16 \\
16\end{array}$ & $\begin{array}{l}1700 \\
1826\end{array}$ & $\begin{array}{l}47735.4-4738.4 \\
4738.4-4742.8\end{array}$ & $92.4-95.8$ & 3.0 & 2.97 & 99 \\
\hline 25 & 16 & $\begin{array}{l}1826 \\
1941\end{array}$ & $\begin{array}{l}47388.4-4772.8 \\
4742.4745 .8\end{array}$ & 95.4-99.8 & 4.4 & 4.34 & 99 \\
\hline 26 & 16 & 2105 & $4745.8-4750.2$ & $\begin{array}{c}99.8-102.8 \\
102.8-107.2\end{array}$ & 3.0 & 3.47 & .116 \\
\hline & 16 & 2215 & $4750.2-4753.2$ & $\begin{array}{l}102.8-107.2 \\
107.2-110.2\end{array}$ & $\begin{array}{l}4.4 \\
3.0\end{array}$ & $\begin{array}{l}4.0 \\
2.96\end{array}$ & 91 \\
\hline 28 & 16 & 2323 & $4753.2-4756.2$ & $110.2-113.2$ & $\begin{array}{l}3.0 \\
3.0\end{array}$ & $\begin{array}{l}2.96 \\
0.05\end{array}$ & $\begin{array}{r}99 \\
2\end{array}$ \\
\hline 29 & 17 & 0045 & $4756.2-4759.2$ & $113.2-116.2$ & 3.0 & 3.31 & 110 \\
\hline 30 & 17 & 0200 & $4759.2-4761.2$ & $116.2-118.2$ & 2.0 & trace & 0 \\
\hline 31 & 17 & 0331 & $4761.2-4765.6$ & $118.2-122.6$ & 4.4 & 3.83 & 87 \\
\hline 32 & 17 & 0456 & $4765.6-4770.0$ & $122.6-127.0$ & 4.4 & 3.18 & 72 \\
\hline 3 & 17 & 0617 & $4770.0-4774.4$ & $127.0-131.4$ & 4.4 & 3.20 & 73 \\
\hline 3. & 17 & 0750 & $4774.4-4777.4$ & $131.4-134.4$ & 3.0 & 2.48 & 83 \\
\hline 3. & 17 & 0906 & $4777.4-4781.8$ & $134.4-138.8$ & 4.4 & 3.14 & 71 \\
\hline 36 & 17 & 1026 & $4781.8-4785.2$ & $138.8-142.2$ & 3.4 & 3.61 & 106 \\
\hline 37 & 17 & 1159 & $4785.2-4788.2$ & $142.2-145.2$ & 3.0 & 3.08 & 103 \\
\hline 38 & 17 & 1317 & $4788.2-4792.2$ & $145.2-149.2$ & 4.0 & 3.69 & 92 \\
\hline 39 & 17 & 1431 & $4792.2-4796.6$ & $149.2-153.6$ & 4.4 & 4.15 & 94 \\
\hline 40 & 17 & 1541 & $4796.6-4797.6$ & $153.6-154.6$ & 1.0 & 0.08 & 8 \\
\hline 4. & 17 & 1654 & $4797.6-4801.0$ & $154.6-158.0$ & 3.4 & 3.66 & 108 \\
\hline 42 & 17 & 1814 & $4801.1-4803.0$ & $158.0-160.0$ & 2.0 & & \\
\hline 43 & 17 & 1436 & $4803.0-4805.0$ & $160.0-163.0$ & 3.0 & 3.07 & 102 \\
\hline 44 & 17 & 2047 & $4805.0-4809.4$ & $163.0-167.4$ & 4.4 & 4.04 & 92 \\
\hline 45 & 17 & 2154 & $4809.4-4813.8$ & $167.4-170.8$ & 3.4 & 3.57 & 105 \\
\hline 46 & 17 & 2316 & $4813.8-4817.2$ & $170.8-174.2$ & 3.4 & 3.11 & 91 \\
\hline 47 & 18 & 0034 & $4817.2-4820.6$ & $174.2-177.6$ & 3.4 & 3.43 & 100 \\
\hline & 18 & 0159 & $4820.6-4823.6$ & $177.6-180.6$ & 3.0 & 2.97 & 85 \\
\hline & & & & & 180.6 & 155.08 & 85.9 \\
\hline
\end{tabular}

stone and marlstone with numerous interbeds of clastic limestone and nannofossil chalk. Unit 5 consists of a complex interbedding of mudstone, marlstone, clastic limestone, and siliclastic sandstone. It is subdivided into three subunits on the basis of amount of carbonate and relative proportions of clastic limestone and siliciclastic sandstone. Unit 6 is a carbonate-cemented volcanogenic sandstone occurring in thick, graded turbidite beds. 


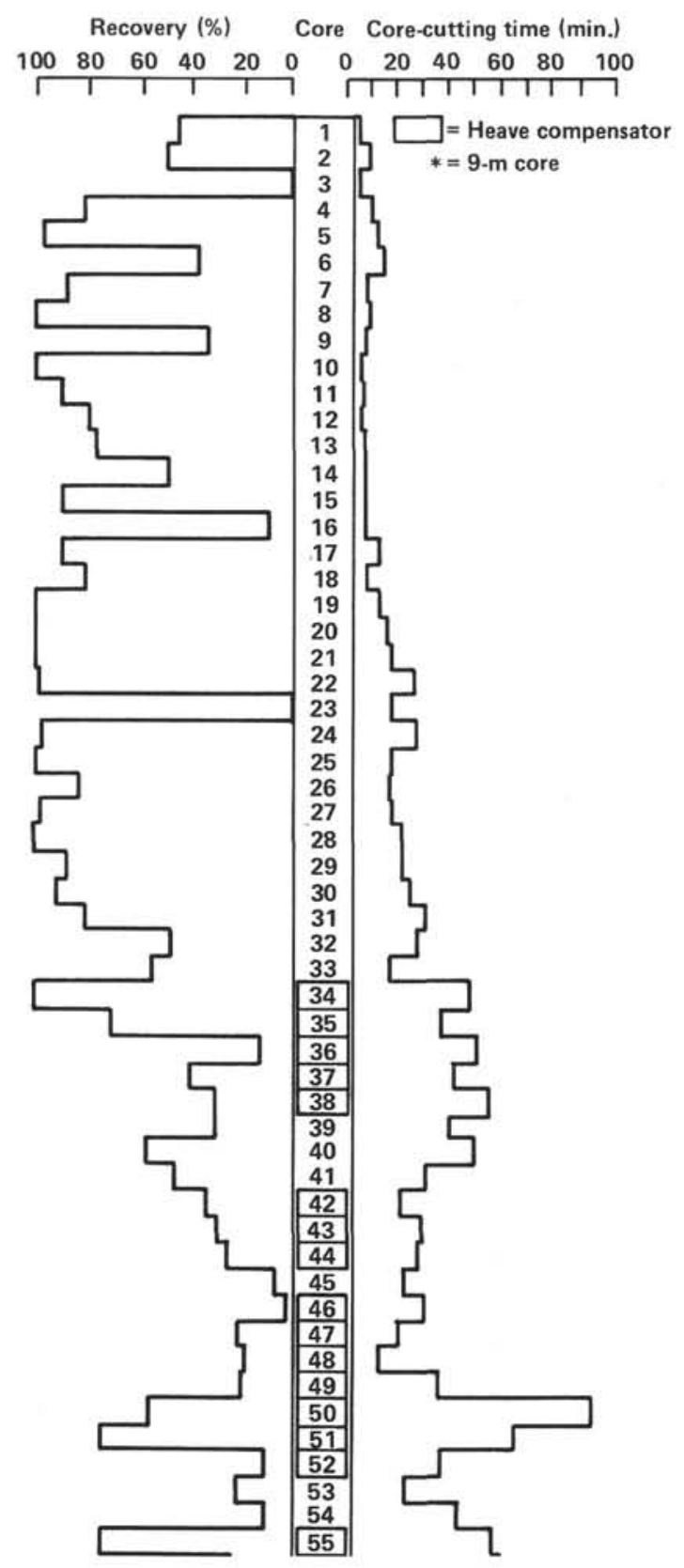

Figure 7. Time to cut cores and percent recovery in Hole 530A.

Unit 7 consists of variegated red and green claystone, siltstone, and sandstone in numerous turbidite beds. Unit 8 consists of red and green claystone similar to those in Unit 7 with the addition of numerous beds of black shale containing up to $18 \%$ organic carbon. At the bottom of Hole $530 \mathrm{~A}$ we recovered $19 \mathrm{~m}$ of finegrained basalt that comprise Unit 9. Detailed descriptions of these units, a discussion of their significant aspects, and a brief history of sediment accumulation in the southern Angola Basin are given below.

\section{Unit 1: Nannofossil and Diatom Smarl, Marl, and Ooze, Diatom Ooze, and Debris-Flow Deposits (0-110 $\mathrm{m}$ sub-bottom)}

Unit 1 consists mostly of sediments with varying proportions of nannofossils, diatoms, and clay (marls,

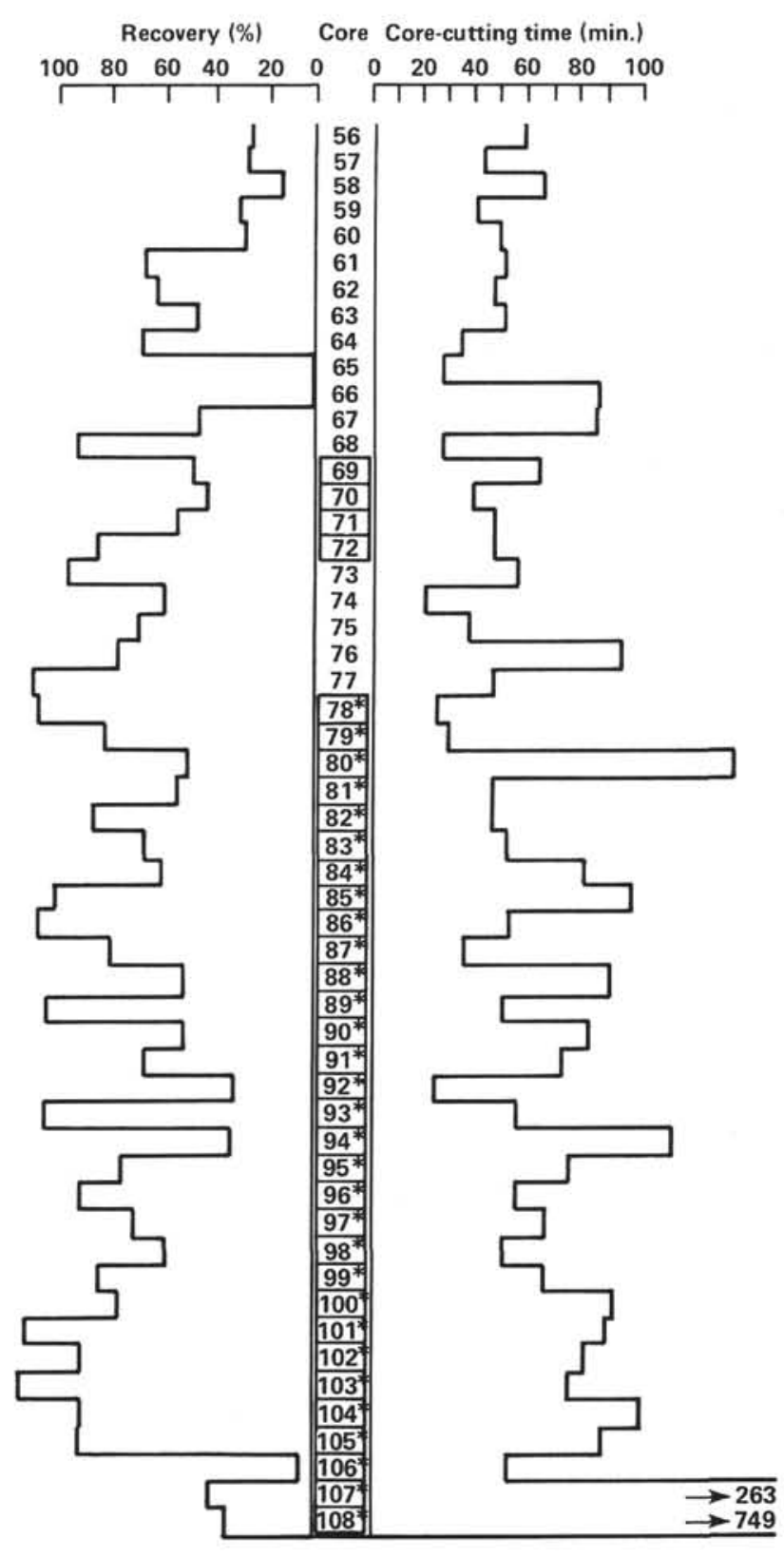

smarls, and sarls; Fig. 11 and Appendix A). Colors of all sediments are shades of olive and olive-gray; darker sediments are generally more diatom-rich and lighter sediments are generally more nannofossil-rich. Most of the sediments in Unit 1 contained intermediate mixtures of clay and microfossils and usually could not be classified as clay (more than $60 \%$ clay) or ooze (more than $60 \%$ of a dominant microfossil) (Fig. 11).

Debris-flow deposits consisting of matrix-supported, rounded, mud-clast "conglomerates" appear throughout Unit 1: the thickest deposit in the unit (at least $6 \mathrm{~m}$ ) occurs in Cores 530B-14 through 16.

Unit 1 is subdivided into two subunits on the basis of relative abundances of diatoms and nannofossils.

Subunit 1a: Diatom nannofossil smarl and ooze and debris-flow deposits (0-58 m sub-bottom). Sediments of 


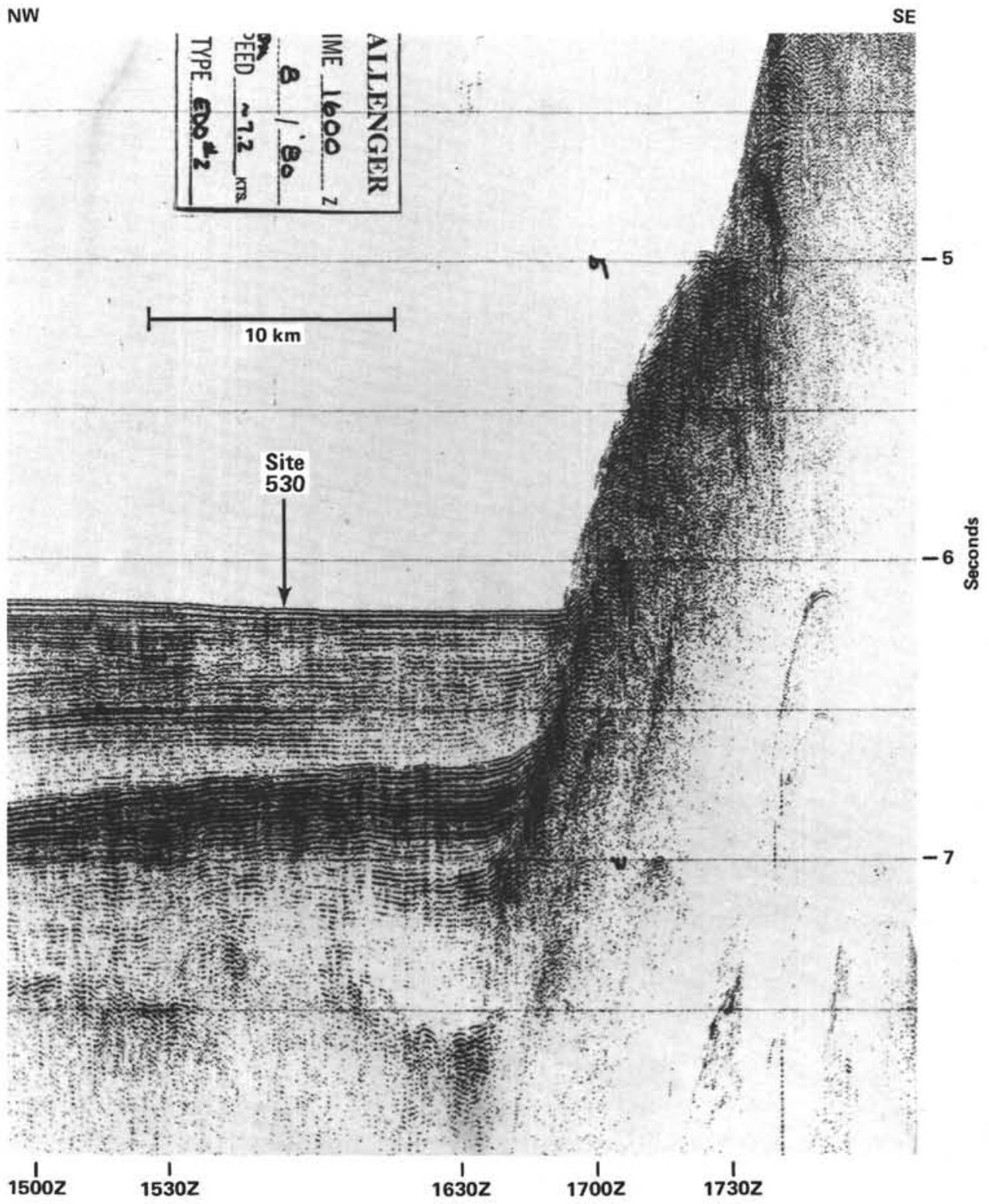

Figure 8. Standard Glomar Challenger seismic profile taken on departure from Site 530.

Subunit 1a contain mixtures of nannofossils, diatoms, and clay in that order of abundance for the entire subunit. Dominant lithologies, therefore, are diatom nannofossil smarl (and some ooze) between 0 and $40 \mathrm{~m}$ subbottom, and nannofossil diatom sarl between 40 and 58 $\mathrm{m}$ sub-bottom. The diatom-rich and nannofossil-rich sediments are often interbedded as turbidites in Cores 530B-2 through 12; examples are shown in Figures 12, 13 , and 14. The darker, more diatom-rich layers are often size graded and are usually color graded into lighter colored nannofossil-rich layers.

Debris-flow deposits occur in Cores 530B-7 through 14. The thickest bed in Subunit 1a is $130 \mathrm{~cm}$, in Core 530B-8 (Fig. 15), but most are less than $1 \mathrm{~m}$ in thickness. The base of this unit is at the top of a debris-flow deposit occurring in the base of Core 530B-14 and continuing into Cores 15 and 16 of Subunit $1 \mathrm{~b}$ for a total thickness of at least $6 \mathrm{~m}$. The flows are very similar, with multicolored mud, marl, and ooze clasts supported in a nannofossil diatom ooze matrix. The long axes of clasts tend to be oriented more or less parallel to stratification; imbrication of clasts is common. The clasts vary considerably in size and lithology, ranging from less than $1 \mathrm{~cm}$ to a maximum observed diameter of $20 \mathrm{~cm}$; the lithologies of the clasts are mostly those observed in undisturbed sections above and below the flow. More complete descriptions of debris-flow deposits are given in the descriptions for Subunit $1 \mathrm{~b}$ and Unit 2.

Subunit 1b: Diatom sarl and ooze and debris-flow deposits (58 to $110 \mathrm{~m}$ sub-bottom). The distinction between Subunits $1 \mathrm{a}$ and $1 \mathrm{~b}$ is the decrease in abundance of nannofossils to nil, and the increase in relative abundance of diatoms to more than $40 \%$ in most of Subunit 1b (Fig. 11 and Appendix A). The dominant lithology of this subunit is therefore a diatom sarl with minor (less than 20\%) nannofossils in Cores 530B-21 through 27.

Debris-flow deposits occur in Cores 530B-15, 16, and 20. The top of the thickest deposit is at the base of Core 


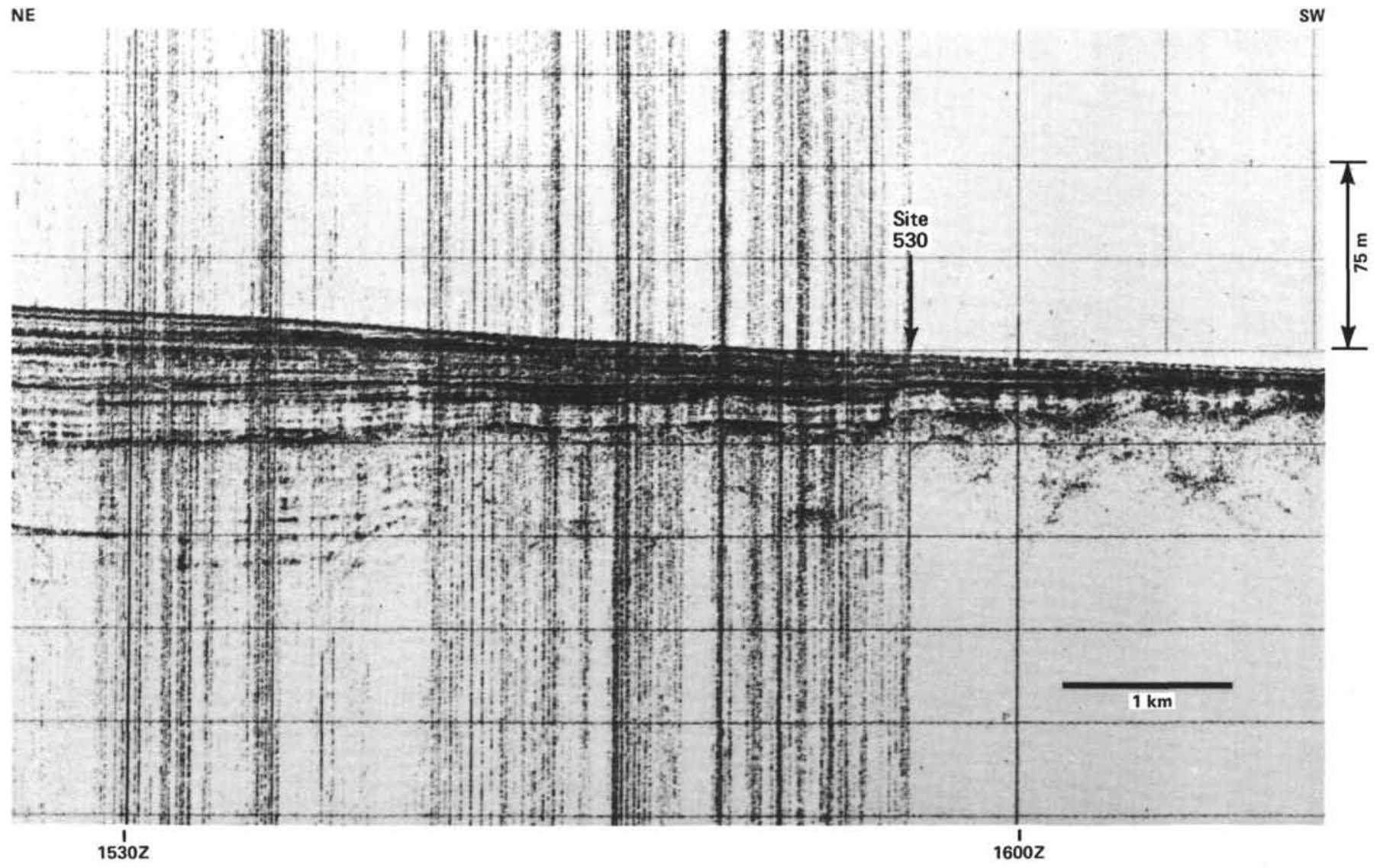

Figure 9. 3.5-kHz seismic record taken on departure from Site 530 .

Table 2. Lithologic units at Site 530, southern Angola Basin.

\begin{tabular}{|c|c|c|c|c|c|c|}
\hline Unit & Lithology & Core-Section & $\begin{array}{l}\text { Sub-bottom } \\
\text { depth } \\
\text { (m) }\end{array}$ & $\begin{array}{l}\text { Thickness } \\
\text { (m) }\end{array}$ & Age & $\begin{array}{c}\text { Sedimentation } \\
\text { rate } \\
(\mathrm{m} / \mathrm{m} \cdot \mathrm{y} .)\end{array}$ \\
\hline la & $\begin{array}{l}\text { Diatom nannofossil smarl and } \\
\text { ooze and debris-flow } \\
\text { deposits }\end{array}$ & $\begin{array}{l}\text { Hole 530B, Core 1-14, } \\
\text { Sections } 1,2\end{array}$ & $0-58$ & 58 & $\begin{array}{l}\text { Holocene to } \\
\text { Pleistocene }\end{array}$ & 65 \\
\hline lb & $\begin{array}{l}\text { Diatom smarl and ooze and } \\
\text { debris-flow deposits }\end{array}$ & $\begin{array}{l}\text { Hole 530B, Core } 14 \text {, } \\
\text { Section } 3 \text { to } \\
\text { Core } 27\end{array}$ & $58-110$ & 52 & Pleistocene & \\
\hline 2 & $\begin{array}{l}\text { Nannofossil clay, marl and ooze } \\
\text { and debris-flow deposits }\end{array}$ & $\begin{array}{l}\text { Hole } 530 \mathrm{~B}, \text { Cores } 28 \\
\text { to } 48 \\
\text { Hole } 530 \mathrm{~A} \text {, } \\
\text { Cores } 1 \text { to } 16\end{array}$ & $110-277$ & 167 & $\begin{array}{l}\text { Pleistocene to late } \\
\text { Miocene (1.7-10 } \\
\text { m.y. ago) }\end{array}$ & 20 \\
\hline 3 & Red and green mud & $\begin{array}{l}\text { Hole } 530 \mathrm{~A} \text {, Cores } 17 \\
\text { to } 36\end{array}$ & $277-467$ & 190 & $\begin{array}{l}\text { late Miocene to } \\
\text { Oligocene (10- } \\
37 \text { m.y. ago) }\end{array}$ & 7 \\
\hline 4 & $\begin{array}{l}\text { Multicolored mudstone, marl- } \\
\text { stone, chalk, and clastic } \\
\text { limestone }\end{array}$ & $\begin{array}{l}\text { Hole } 530 \mathrm{~A} \text {, Cores } 37 \\
\text { to } 50\end{array}$ & $467-600$ & 133 & $\begin{array}{l}\text { Eocene to Maestrich- } \\
\text { tian (37- 66 } \\
\text { m.y. ago) }\end{array}$ & 5 \\
\hline $5 \mathrm{a}$ & $\begin{array}{l}\text { Dark green mudstone, marl- } \\
\text { stone, and clastic limestone }\end{array}$ & $\begin{array}{l}\text { Hole } 530 \mathrm{~A} \text {, Cores } 50 \\
\text { to } 55\end{array}$ & $600-647.5$ & 47.5 & $\begin{array}{l}\text { Maestrichtian } \\
(\sim 66-68 \mathrm{~m} . y . \\
\text { ago })\end{array}$ & 23.7 \\
\hline $5 b$ & $\begin{array}{l}\text { Dark green mudstone, marl- } \\
\text { stone, clastic limestone, and } \\
\text { siliciclastic sandstone }\end{array}$ & $\begin{array}{l}\text { Hole } 530 \mathrm{~A}, \text { Cores } 56 \\
\text { to } 61\end{array}$ & $647.5-704.5$ & 57 & $\begin{array}{l}\text { early Maestrichtian } \\
\text { to late Cam. } \\
\text { panian }(\sim 68- \\
71.5 \text { m.y. ago) }\end{array}$ & 16.3 \\
\hline $5 \mathrm{c}$ & $\begin{array}{l}\text { Dark green mudstone, marl- } \\
\text { stone, and calcareous silici- } \\
\text { clastic sandstone }\end{array}$ & $\begin{array}{l}\text { Hole } 530 \mathrm{~A} \text {, Cores } 62 \\
\text { to } 70\end{array}$ & $704.5-790$ & 85.5 & $\begin{array}{l}\text { late to early Cam- } \\
\text { panian }(-71.5- \\
77 \text { m.y. ago })\end{array}$ & 15.5 \\
\hline 6 & Volcanogenic sandstone & $\begin{array}{l}\text { Hole } 530 \mathrm{~A} \text {, Cores } 71 \\
\text { to } 75 \text {, Sections } 1,2\end{array}$ & $790-831$ & 41 & $\begin{array}{l}\text { carly Campanian } \\
(77-79.5 \mathrm{~m} . \mathrm{y} \text {. } \\
\text { ago) }\end{array}$ & 16.4 \\
\hline 7 & $\begin{array}{l}\text { Variegated red, green, and pur- } \\
\text { ple claystone, siltstone, and } \\
\text { sandstone }\end{array}$ & $\begin{array}{l}\text { Hole } 530 \mathrm{~A}, \text { Core } 75 \text {, } \\
\text { Sect. } 3 \text { to } 86\end{array}$ & $831-940$ & 109 & $\begin{array}{l}\text { early Campanian- } \\
\text { early Santonian } \\
(79.5-84.5 \text { m.y. } \\
\text { ago) }\end{array}$ & 21.8 \\
\hline 8 & $\begin{array}{l}\text { Red and green claystone and } \\
\text { marlstone with interbedded } \\
\text { black shale }\end{array}$ & $\begin{array}{l}\text { Hole } 530 \mathrm{~A} \text {, Cores } 87 \\
\text { to } 105\end{array}$ & $940-1103$ & 163 & $\begin{array}{l}\text { early Santonian to } \\
\text { late Albian } \\
\text { (84.5-102.5 m.y. } \\
\text { ago) }\end{array}$ & 9.1 \\
\hline 9 & Basalt & Hole Cores 105 & $1103-1121$ & 19 & & \\
\hline
\end{tabular}




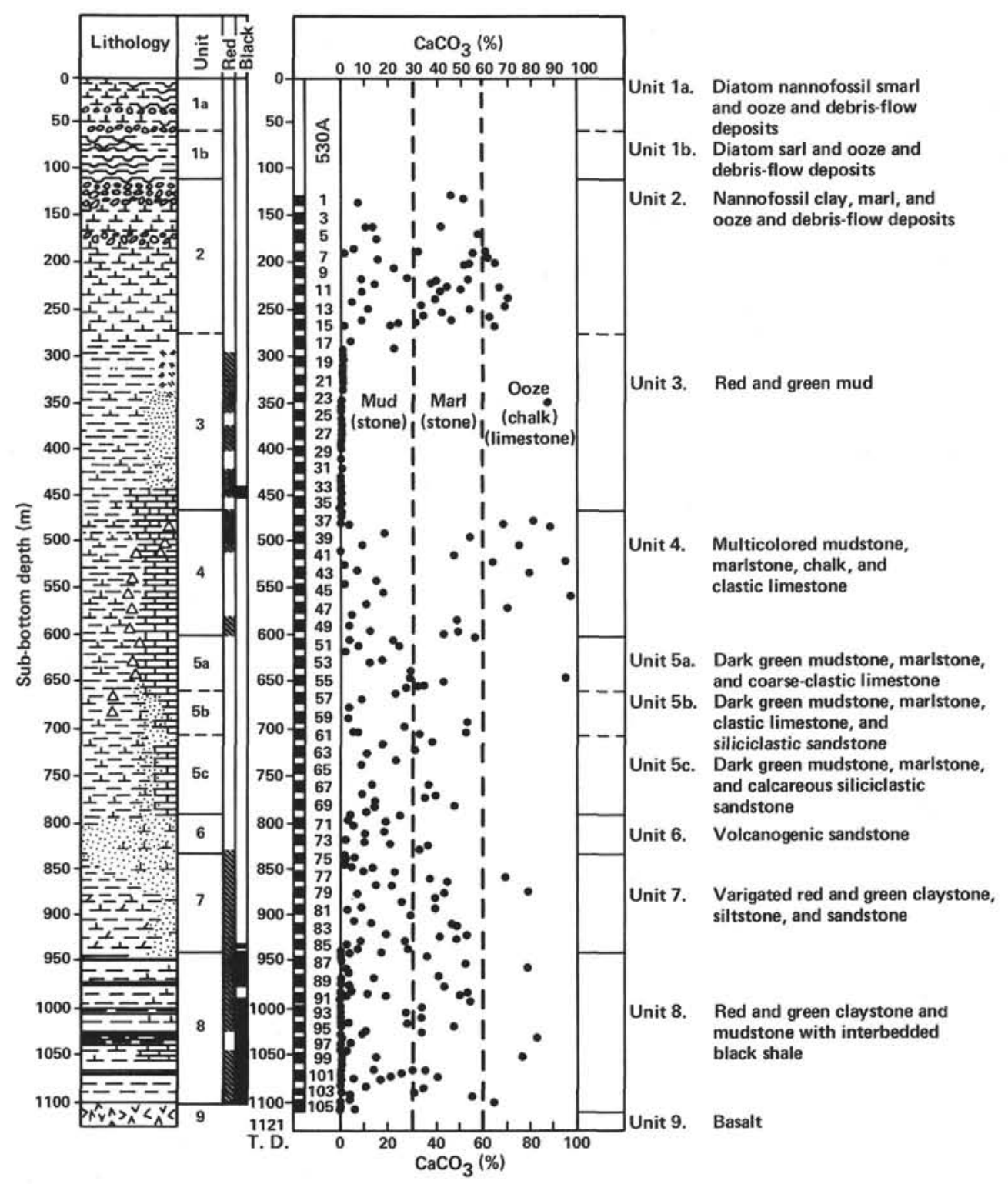

Figure 10. Summary stratigraphic column for Holes 530A and 530B, and summary of carbonate bomb analyses for Hole 530A.

530B-14; the bottom is in Core 530B-16. The clasts of this debris-flow deposit and the one in Core 530B-20 are of at least seven or eight different lithologies observed in overlying and underlying sequences, and include calcareous and siliceous marls, sarls, muds, and rare sandy clasts and shell fragments. Sizes of clasts are very variable and range from about $5 \mathrm{~mm}$ to at least $40 \mathrm{~cm}$ in maximum dimension. Most clasts are elongate with a dominant long-axis/short-axis ratio of about 2 , and are subrounded to well rounded. There are varying stages of disintegration of clasts, from those with sharp, well-defined outlines to completely smeared-out multicolored streaks and mottles. The degree of smearing is at least in part related to the hardness of the clasts. The clasts are variously consolidated, but all are relatively soft. Some clasts are in contact with each other, but most are supported in a matrix that appears to be dominantly a diatom nannofossil ooze. Many clasts tend to be imbri- cated and roughly horizontal, although all orientations from horizontal to vertical have been observed.

Unit 2: Nannofossil Marl, Clay, and Ooze and Debris-Flow Deposits (110 to $277 \mathrm{~m}$ sub-bottom)

Unit 2 consists mainly of calcareous biogenic sediments interbedded with thick debris-flow deposits and thin mud turbidites. Colors of the sediments range from light greenish gray to olive to olive-gray; the darker colors reflect an increasing clay content. The biogenic sediments are composed dominantly of nannofossils, with variable contents of foraminifers and clay, and rare siliceous material. Many of the lighter colored sediments were initially described as nannofossil ooze, but subsequent carbonate analyses showed that these sediments rarely contain more than $60 \%$ carbonate (Fig. 10). An average of 45 measurements of carbonate on samples selected from all lithologies present is $35 \%$, with most val- 


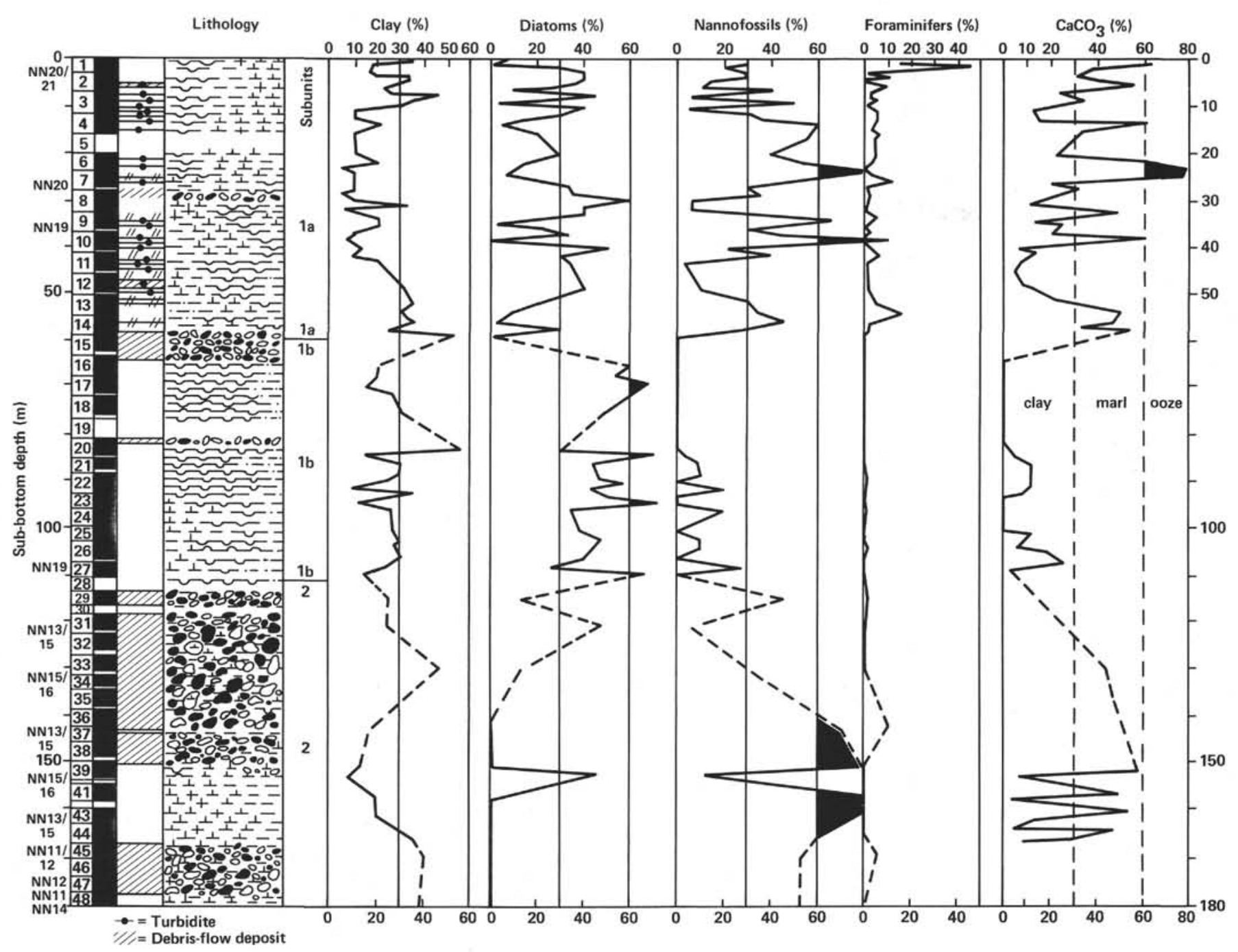

Figure 11. Summary stratigraphic column for Hole 530B. Percentages of clay, nannofossils, foraminifers, and diatoms were determined from smear slides; percent carbonate was determined by carbonate bomb.

ues between 25 and $50 \%$. The darker turbidite muds contain mainly illite, quartz, feldspar, and $2-10 \%$ carbonate. The silt and sand layers are quartz rich and often contain minor amounts of feldspar, pyrite, and glauconite.

Clay-rich and carbonate-rich sediments usually occur as cyclic interbeds ranging from 10 to $80 \mathrm{~cm}$ thick. Figure 16 illustrates a typical cycle. The base is a clay unit with a sharp lower contact and a highly bioturbated upper contact with the overlying more carbonate-rich unit (nannofossil marl or ooze). The thicker, more carbonate-rich upper part of a cycle is usually structureless except for common black streaks and specks of pyrite. The bases of darker, more clay-rich beds often contain interlaminations of coarser (sand) and finer (silt and clay) materials. The clay-carbonate cycles are present throughout but are best developed in Cores 530A-10 through 530A-14.

The dominant components observed on smear slides (Appendix A) are clay and nannofossils. Foraminifers are common in smear slides from lithologies from several cores, especially Cores $8,12,13$, and 14 from Hole
530A where the dominant lithology is a foraminifernannofossil marl. Foraminifer-rich marls and oozes are the dominant lithologies in some cores (e.g., Hole 530A, Cores $8,12,13$, and 14), but other cores (Hole 530B, Cores 41 and 44 ) contain turbidite marls grading from foraminifer marl at the base to nannofossil marl at the top.

Thick debris-flow deposits extend from Core 530B29 through the top of Core 530B-39, and from Core 530B-45 through the top of Core 530B-48 (Figs. 11, 17, and 18 ). These same debris flows are probably represented in Hole 530A in Cores 1 and 2 and in Cores 5 through 7 , but the sediments in these cores have been severely disturbed by drilling. Thinner debris-flow deposits were identified in Hole $530 \mathrm{~A}$ in Cores 8,11 , and 12. These debris-flow deposits are all similar, and most of the following description applies to them all.

The flow in Cores 530B-29 through 37 probably extends from Core 530B-28, from which only one basalt pebble and one fragment of nannofossil ooze were recovered. Also, thin zones of nannofossil marl that may have been deposited between flows were recovered in 


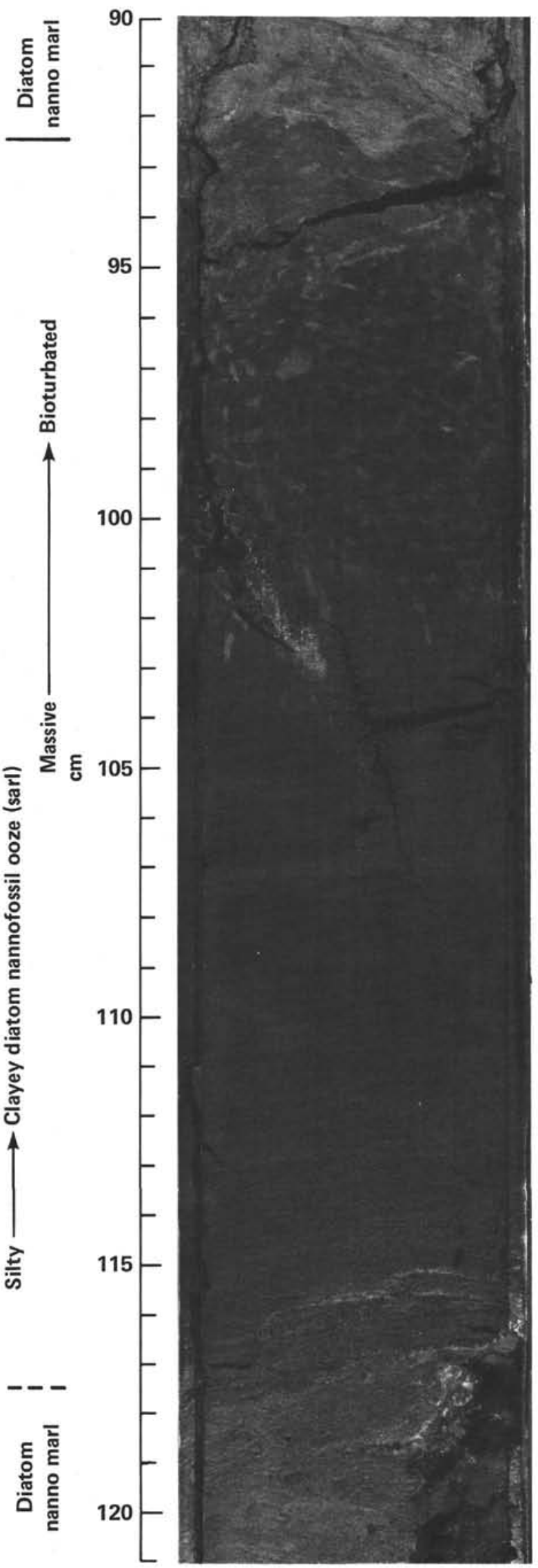

Figure 12. Turbidite cycle typical of lithologic Unit 1a; Sample 530B$3-2,90-120 \mathrm{~cm}$.

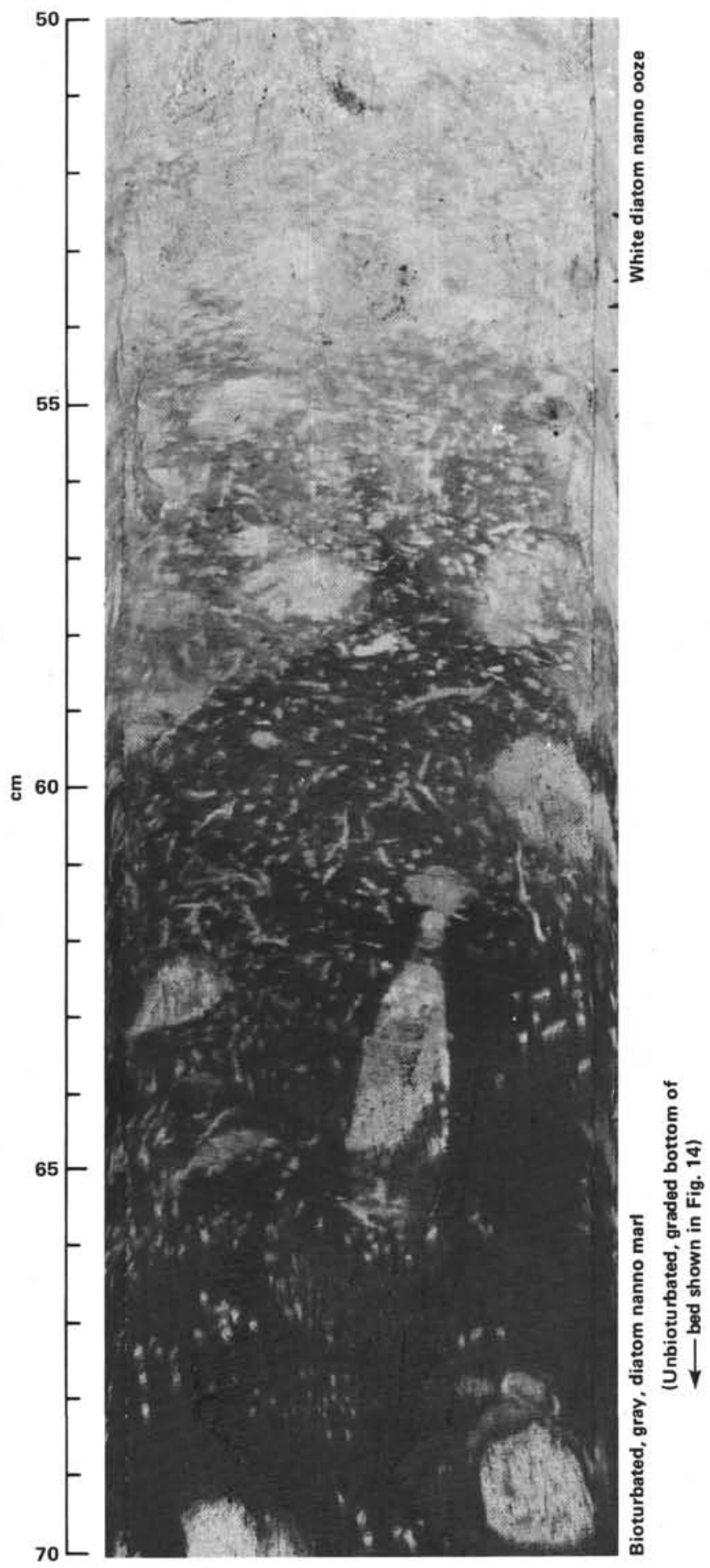

Figure 13. Bioturbated contact between diatom-rich, darker nannofossil marl at base of a turbidite cycle and less diatom-rich, lighter nannofossil ooze at top of overlying turbidite cycle. Lithologic Unit 1a; Sample 530B-6-3, 50-70 cm.

the core catcher of Core 530B-31 and in 530B-32-1, 120$140 \mathrm{~cm}$. The definite base of this thick flow, however, is the beginning of nannofossil ooze in 530B-37, Section 1, $30 \mathrm{~cm}$. The total thickness of this deposit, therefore, must be at least $32 \mathrm{~m}$. The clasts in the debris-flow deposits include at least seven or eight multicolored lithologies, most of which are recognized as lithologies 


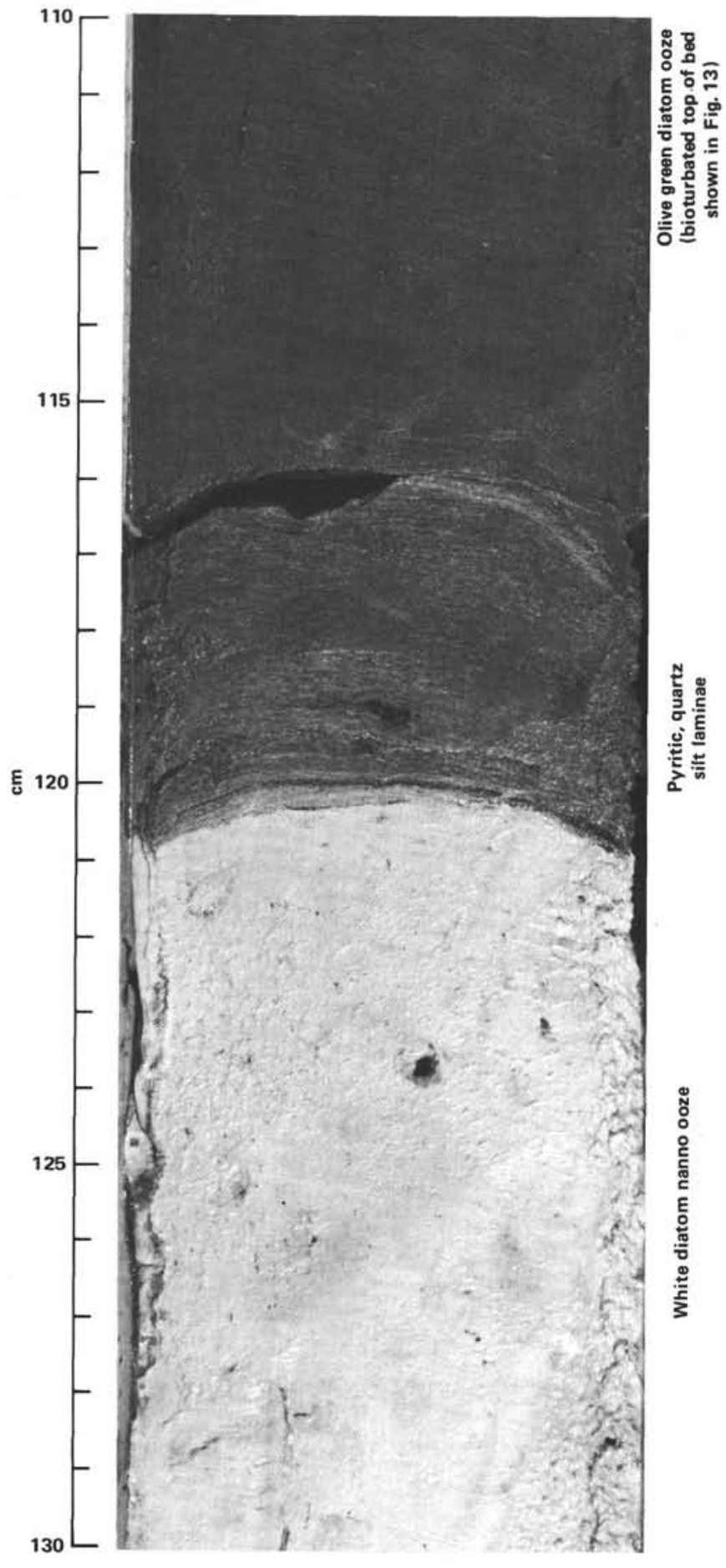

Figure 14. Sharp basal contact between diatom-rich, darker nannofossil marl of one turbidite cycle (top of this bed shown in Fig. 13) and white diatom nannofossil ooze at the top of underlying turbidite cycle. Lithologic Unit 1a; Sample 530B-6-3, 110-130 cm.

that exist in the enclosing strata of the flow, including muds, marls, sarls, and oozes, and rare basalt pebbles. Sizes of clasts range from a few millimeters to at least 60 $\mathrm{cm}$. Most clasts are elongate and rounded to subrounded. There are variable stages of disintegration of clasts ranging from clasts with distinct, sharp outlines (Fig. 17) to those which have lost their identities as clasts and

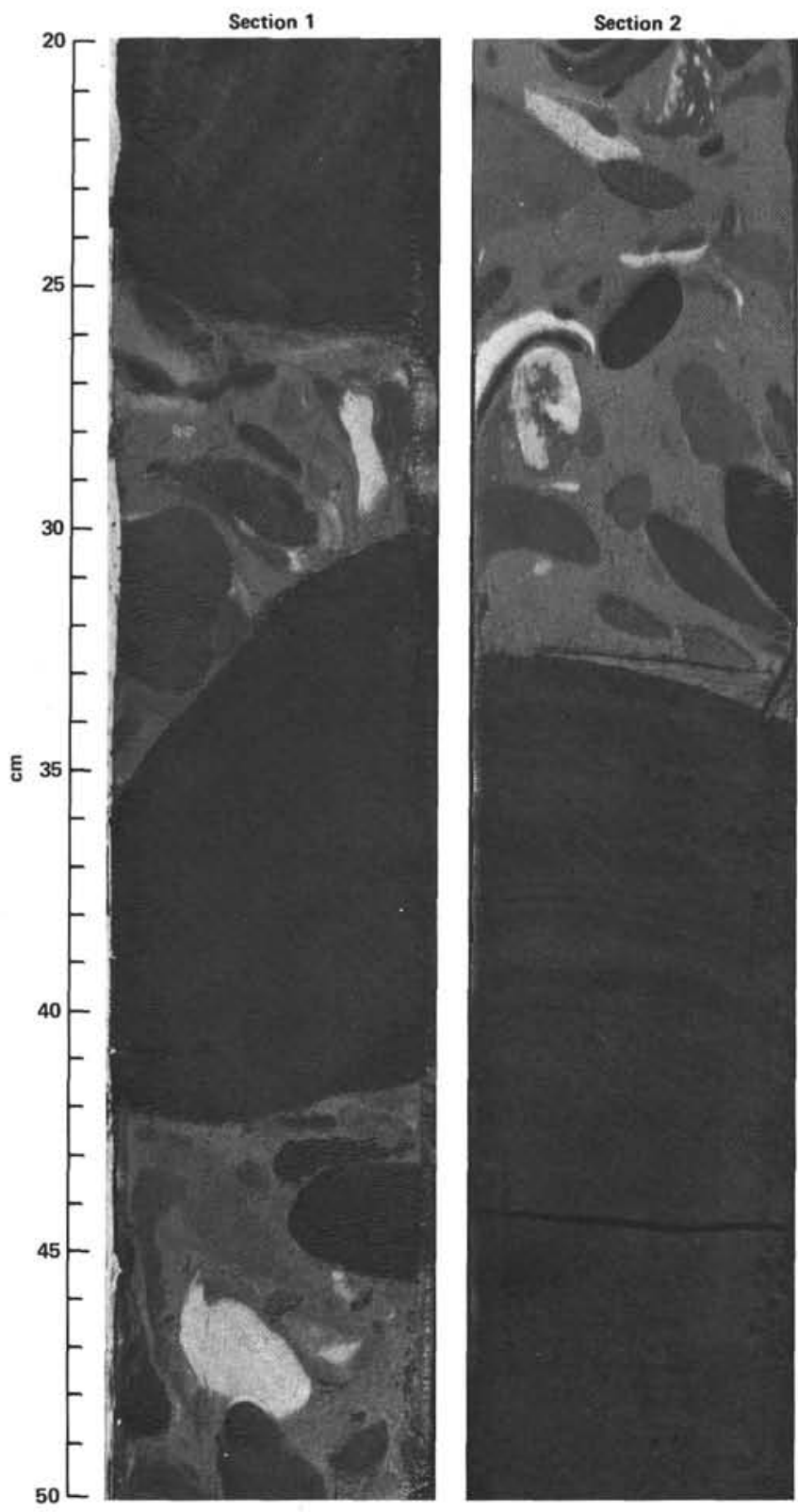

Figure 15. Debris-flow deposit with soft-sediment, matrix-supported clasts of mixed lithologies. Lithologic Unit 1a; Core 530B-8, Section 1 and Section 2, 20-50 cm.

are smeared-out color streaks or mottles (Fig. 18). Many clasts tend to be oriented with their long axes near horizontal, but all orientations have been observed. Subparallel orientation of clasts and a tendency for imbrication are the only clear structures visible. Some of the largest clasts occur in Cores 530B-31 to 33, suggesting that there might be some size grading. Some clasts are in contact, but most are supported by a matrix of yellowish gray diatom-nannofossil marl. In general, there is more matrix toward the base of the flow in Cores 530B-32 through 36 . Clasts are also more lithified in Core 530B-26.

The debris-flow deposit (or possibly several deposits) between Cores 530B-29 (28?) and 530B-39 is included in the top of Unit 2 rather than the base of Subunit 1b be- 

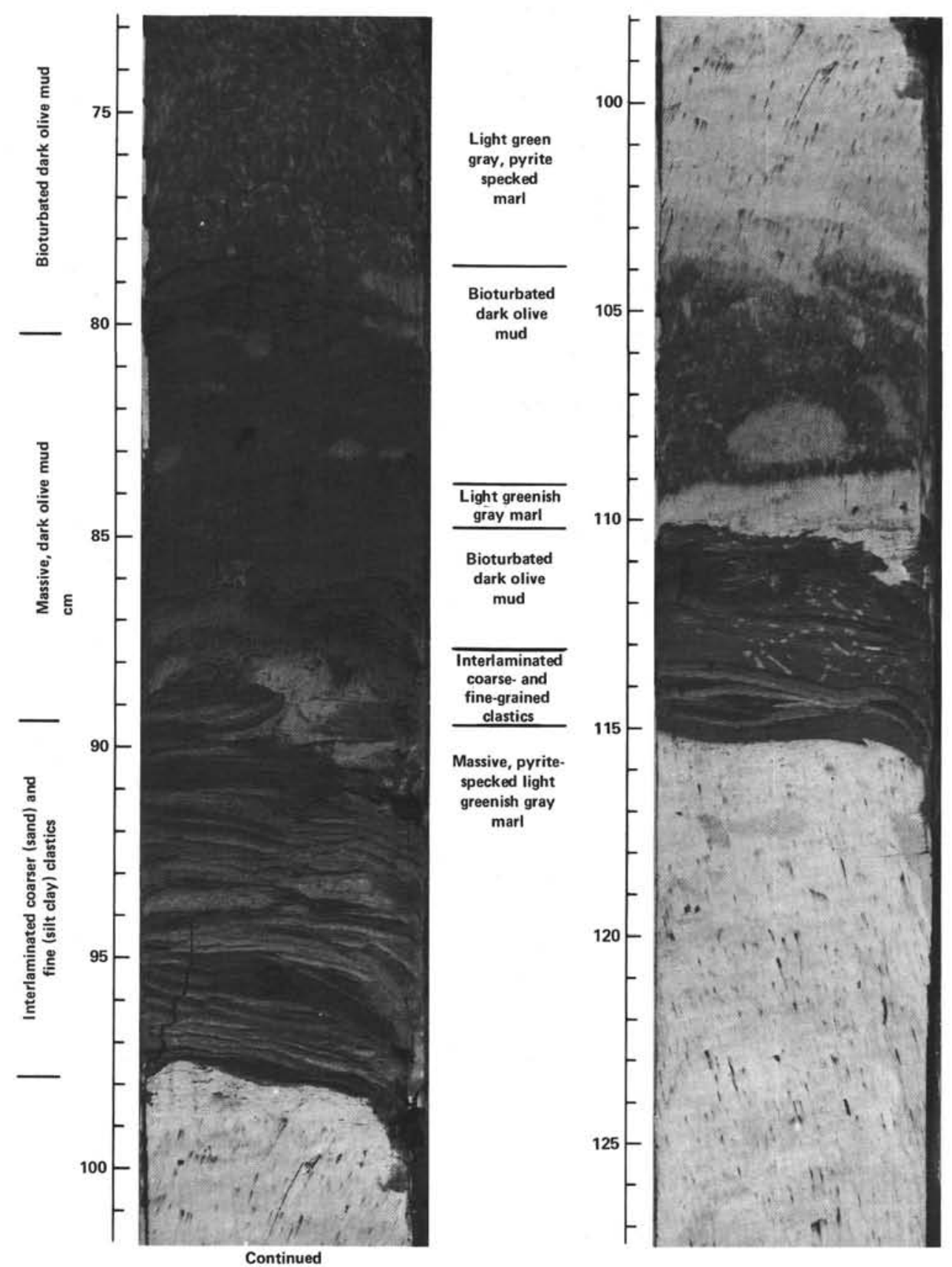

Figure 16. Parts of four mud-marl cycles typical of lithologic Unit 2; Sample 530A-7-3, 73-127 cm.

cause the dominant matrix of this deposit appears to be nannofossil marl, the dominant composition of Unit 2.

The boundary between Units 2 and 3 occurs as a transition in Cores 530A-16 and 17 as the amount of carbonate decreases and the dominant lithology changes from marl to clay (decrease in calcareous microfossils and increase in clay, Figs. 10 and Appendix A). The boundary is placed at the base of Core 530A-16. This boundary also coincides with a change in sonic velocity and density of the sediment.

\section{Unit 3: Green and Red Mud (277 to $467 \mathrm{~m}$ sub-bottom)}

Unit 3 comprises very soft, interbedded red and green muds, with rare, thin, dark greenish black turbidite silts and muds, scattered layers of volcanic ash, and rare foraminifer-nannofossil ooze. The dominant green colors are shades of greenish gray; the dominant "red" colors are olive-gray, moderate yellowish brown, and dark reddish brown. These colors may be closely interbedded or intermottled by bioturbation, or they may occur in thicker, monocolored layers.

There is very little difference in composition between green and red muds. Both contain a high proportion of clay-size material, including quartz, feldspar, illite, mixed-layer clays, minor chlorite-kaolinite, and probable zeolites. The silt fraction is mostly volcanic glass or palagonite, particularly from Core 530A-22 through Core 530A-36 (Appendix A). 


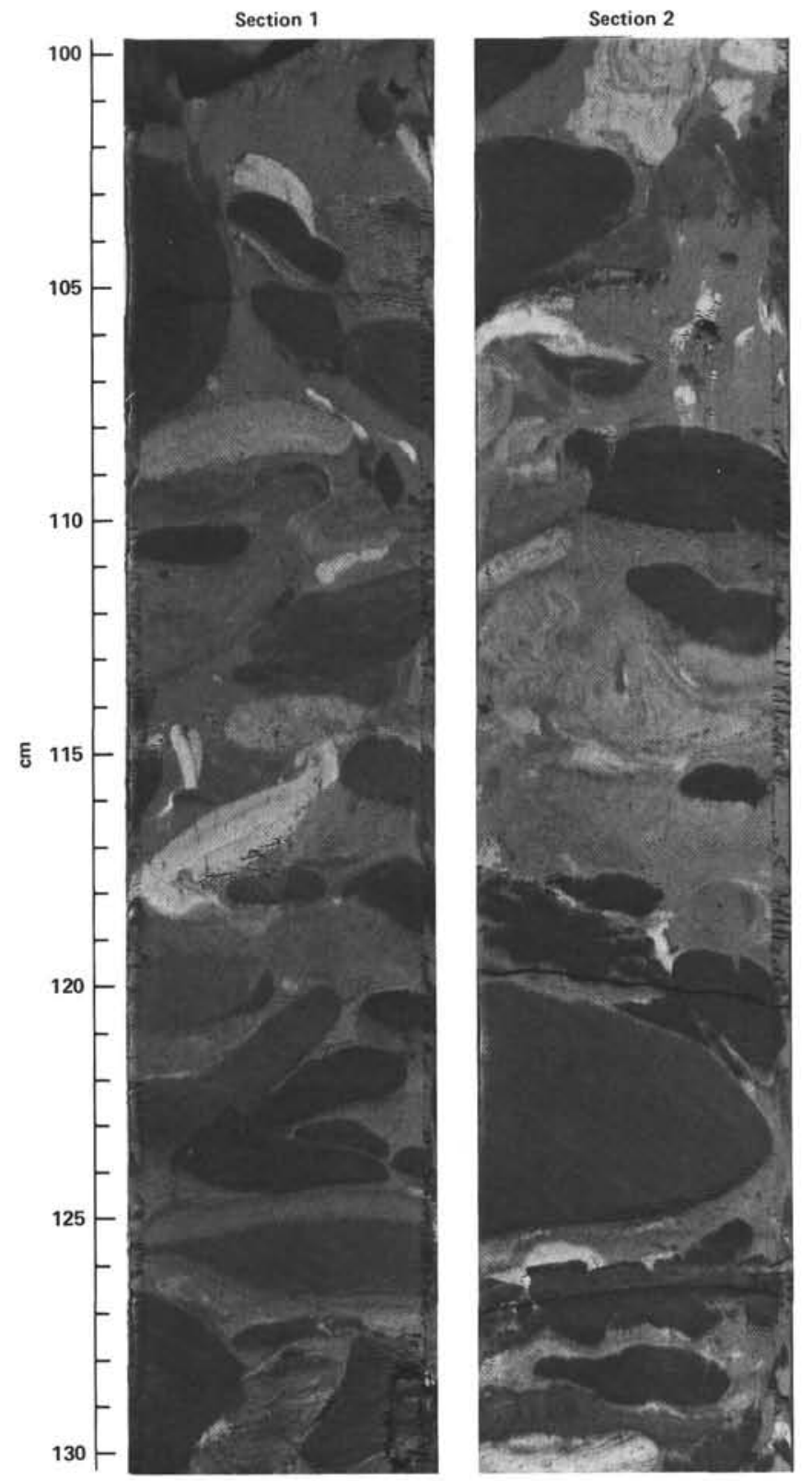

Figure 17. Debris-flow deposit with soft-sediment clasts of mixed lithologies in a matrix of diatom nannofossil marl. Lithologic Unit 2; Core 530B-29, Section 1 and Section 2, 100-130 cm.

Thin green halos often occur around laminae, lenses, and blebs of either dark gray pyritic quartz silt or light gray quartz silt in predominantly "reddish" mud. The green coloration is the result of reduction of iron in the red mud in the immediate vicinity of the silt.

Quartz silt mainly occurs at the bases of dark green turbidite layers that are common from Core 530A-19 down. A typical turbidite cycle (1-10 cm thick) consists of a lower quartz silt layer with a sharp, often scoured lower boundary and an upper boundary grading into dark green, bioturbated mud. These dark green turbidite layers occur within both the dominant lighter green and red muds.

Thin beds of highly altered volcanic ash occur in Hole 530A, Cores 19, 20, 21, and 22, and a carbonate-

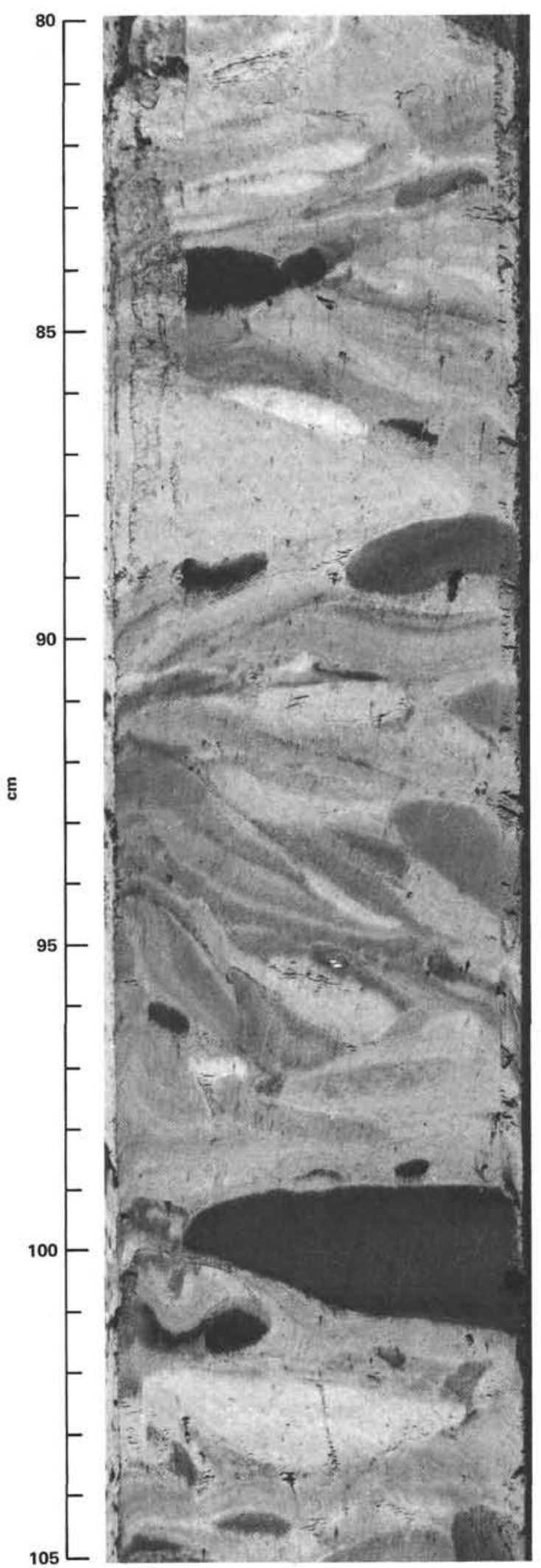

Figure 18. Debris-flow deposit with soft sediment clasts of mixed lithologies. Notice that most of the clasts have been smeared-out into multicolored streaks and mottles. Lithologic Unit 2; Sample 530B-37-1, 80-105 cm. 
cemented volcanic-foraminifer breccia was the only material recovered from Core 530A-23. Minor foraminifernannofossil ooze is present in Core 530A-18 and Core 530A-24.

The boundary between Units 3 and 4 is in part diagenetic and in part a change in composition and is placed at the base of Core 530A-36 ( $467 \mathrm{~m}$ sub-bottom). The main compositional change is the presence of more carbonate in Unit 4 (Fig. 10) in the form of variable mixtures with clay (mudstone-marlstone-chalk) and thin beds of clastic limestone. Carbonate mixed with clay does not occur in Core 530A-37, but seven beds of clastic limestone occur in Core 530A-35, which represents a transition between Units 3 and 4 (Fig. 19). Core $530 \mathrm{~A}-36$ recovered only one section of mudstone and other lithologies may be present in the unrecovered sections. The diagenetic change between Units 3 and 4 is one of lithification by compaction (mud to mudstone; marl to marlstone) and cementation by carbonate and silica; there is a progressive increase in stiffness of the mud throughout Unit 3.

Unit 4: Multicolored Mudstone, Marlstone, Chalk, and Clastic Limestone (467 to $600 \mathrm{~m}$ sub-bottom)

Unit 4 comprises minor red and dominant green mudstone, calcareous mudstone, and marlstone, with common interbeds of nannofossil chalk and clastic limestone. The colors vary with the proportions of carbonate present-white and bluish white limestone; yellowish gray chalk; greenish and olive-gray mudstone; dark greenish gray mudstone; pale yellow marlstone; brownish gray mudstone.

The carbonate content is very variable and ranges from less than $2 \%$ to $97 \%$ (Fig. 10). An average of 40 samples from different lithologies is $36 \%$. The clay in the fine-grained lithologies includes smectite, mixedlayer minerals, illite, chlorite, kaolinite, and zeolites. The red and green mudstones contain quartz-palagonite silt and calcareous microfossils. The chalks contain nannofossils, foraminifers, and unspecified carbonate (Appendix A) in addition to the clay components listed above. The clastic limestone beds contain mainly shallow-water carbonate debris, including benthic reef foraminifers, shell debris, and fragments of calcareous algae and bryozoa, mixed with volcanic rock fragments, quartz, feldspar, glauconite, and heavy minerals. The clastic limestones are mostly well cemented by micritic and sparry calcite, although in some samples these have been replaced by dolomite(?) and silica.

The carbonate and mud lithologies in Unit 4 tend to occur as turbidites with sharp, scoured, and loaded bases, and more gradational, bioturbated tops (Figs. 20 and 21). There are three common turbidite sequences: thin $(2-4 \mathrm{~cm})$ marl-mud turbidites; thicker $(5-20 \mathrm{~cm})$ chalk-marl-mud turbidites; and even thicker (10-30 $\mathrm{cm}$ ) limestone-chalk-marl-mud turbidites.

The complete sequence is: bioturbated marlstone and mudstone; fine-grained, parallel- and/or cross-laminated chalk and marlstone; coarse-grained, paralleland/or cross-laminated limestone and chalk; and pebble-granule-coarse sand-size, graded, parallel-laminated or massive clastic limestone with a sharp, scoured base.

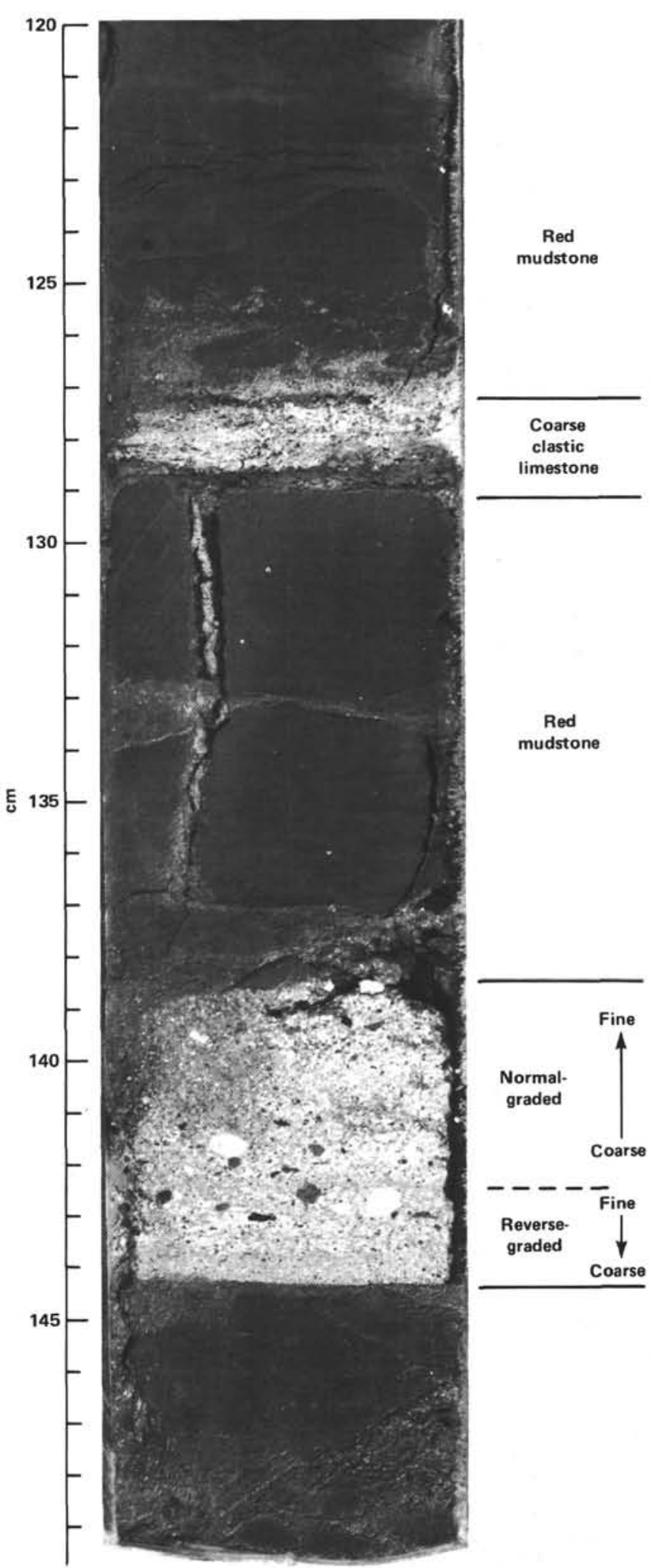

Figure 19. Two beds of clastic limestone in red mudstone. Lithologic Unit 3 (transition with Unit 4); Sample 530A-35-3, 120-150 $\mathrm{cm}$.

The highest obvious partial silicification of limestone (and less frequently, mudstone and marlstone) occurs in Core 530A-39. The highest chert occurs in Core 530A47 but is not very common in that core or in underlying 


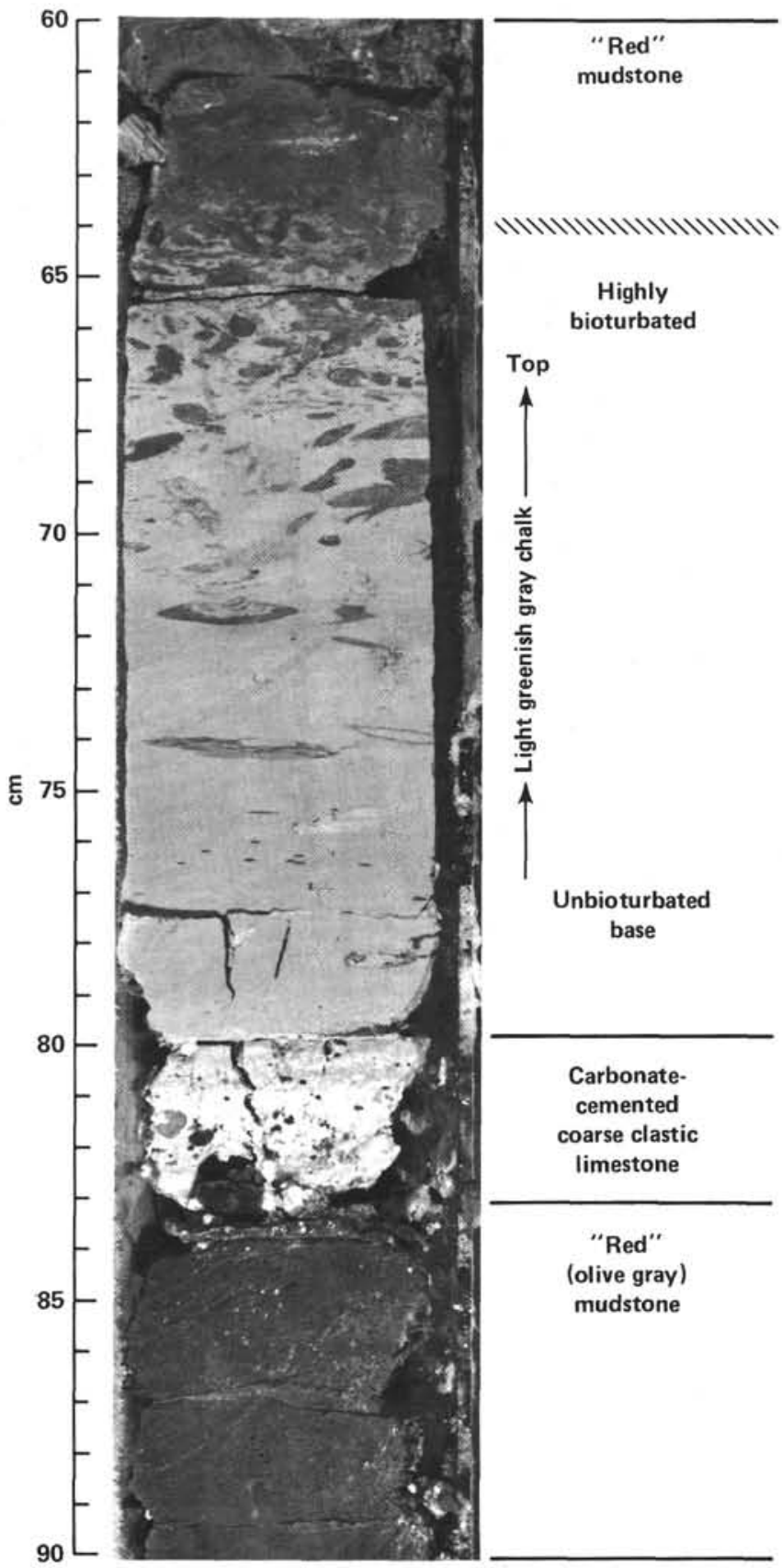

Figure 20. Clastic limestone, chalk, marlstone, and mudstone cycles typical of lithologic Unit 4; Sample 530A-38-1, 60-90 cm.

cores. The limestone beds usually contain minor silica cement and some chalk horizons are silicified to a white silicified limestone.

\section{Unit 5: Mudstone, Marlstone, Clastic Limestone, and Siliciclastic Sandstone (600 to $790 \mathrm{~m}$ sub-bottom)}

The main transition between Units 4 and 5 is a decrease in amount of carbonate so that in Unit 5 there are no beds of chalk, and mudstone is more common than marlstone (Fig. 10). Interbeds of clastic limestone are still present in Subunit 5a, but they become less com- mon downward within the unit. The carbonate clastic debris is replaced by dark-colored siliciclastics and, in Cores 530A-69 and 70, by volcanogenic sandstone. We subdivided Unit 5 into three subunits $(5 \mathrm{a}, 5 \mathrm{~b}$, and $5 \mathrm{c})$ mainly on the basis of abundance and composition of coarse clastics.

Subunit 5a: Dark green mudstone, marlstone, and clastic limestone (600 to $647.5 \mathrm{~m}$ sub-bottom). The dominant lithology in Subunit 5a is dark greenish gray to greenish gray highly bioturbated, calcareous mudstone. Lighter colored mudstones generally have larger amounts of carbonate and many are rich enough to be called marlstone (Fig. 10). An average concentration of carbonate in 15 samples of all lithologies from Subunit $5 \mathrm{a}$ is $26 \%$. Well-cemented clastic limestone turbidites are commonly interbedded with greenish gray mudstone. The clastic limestone beds are mostly 2 to $5 \mathrm{~cm}$ thick, but become thicker (up to $60 \mathrm{~cm}$ ) and more abundant in Cores 530A-54 and 530A-55 where they comprise 30 and $40 \%$, respectively, of the recovered material. They are generally graded (Fig. 22), with parallel lamination (Figs. 23 and 24), and/or cross lamination (Fig. 25). Most clastic limestone beds are partly silicified (Plate 1, Fig. 3).

Fragments of the large mollusk Inoceramus (Figs. 24 and 27) were first recovered in Core 530A-55 and are present in many of the underlying cores. The occurrences of Inoceramus are given in Table 1 of Barron et al., this volume. The fragments consist of $0.5-$ to $1.0-\mathrm{cm}$ thick slabs of fibrous calcite (the prismatic layer of the mollusk shell), are usually oriented parallel to stratification, and often occur as continuous or partly broken layers truncated on both sides of the core (Fig. 24). All Inoceramus fragments from Subunit 5a have a brownish gray outer rim of varying thickness in which the calcite has been replaced by silica.

Subunit 5b: Dark-green mudstone, marlstone, clastic limestone, and siliciclastic sandstone 1647.5 to $704.5 \mathrm{~m}$ sub-bottom). The dominant lithologies of Subunit $5 \mathrm{~b}$ (green mudstone and marlstone) are similar to those of Subunit $5 \mathrm{a}$. The main difference between the two subunits is the appearance of thin dark-gray siliciclastic sandstone beds in Core 530A-57 and the increase in abundance and thickness of these beds downward. They are mainly quartz-rich sandstones, with variable amounts of feldspar, heavy minerals, glauconite, and clay, and with a pervasive sparry or micritic carbonate cement (Plate 1, Fig. 4). The thin siliciclastic sandstones commonly form the sharp scoured bases of turbidite beds that grade upward from dark, parallel- or crosslaminated sandstone to dark greenish gray siltstone, to greenish gray, bioturbated or faintly laminated mudstone, and are overlain by light greenish gray bioturbated marlstone. These thin sandstone layers are usually 1-3 cm thick, and the complete turbidite beds are usually $3-10 \mathrm{~cm}$ thick.

The concentration of carbonate is somewhat lower in Subunit $5 \mathrm{~b}$ than in Subunit 5a, mainly as a result of the introduction of the siliciclastic sandstone beds and a decrease in number and thickness of clastic limestone beds 


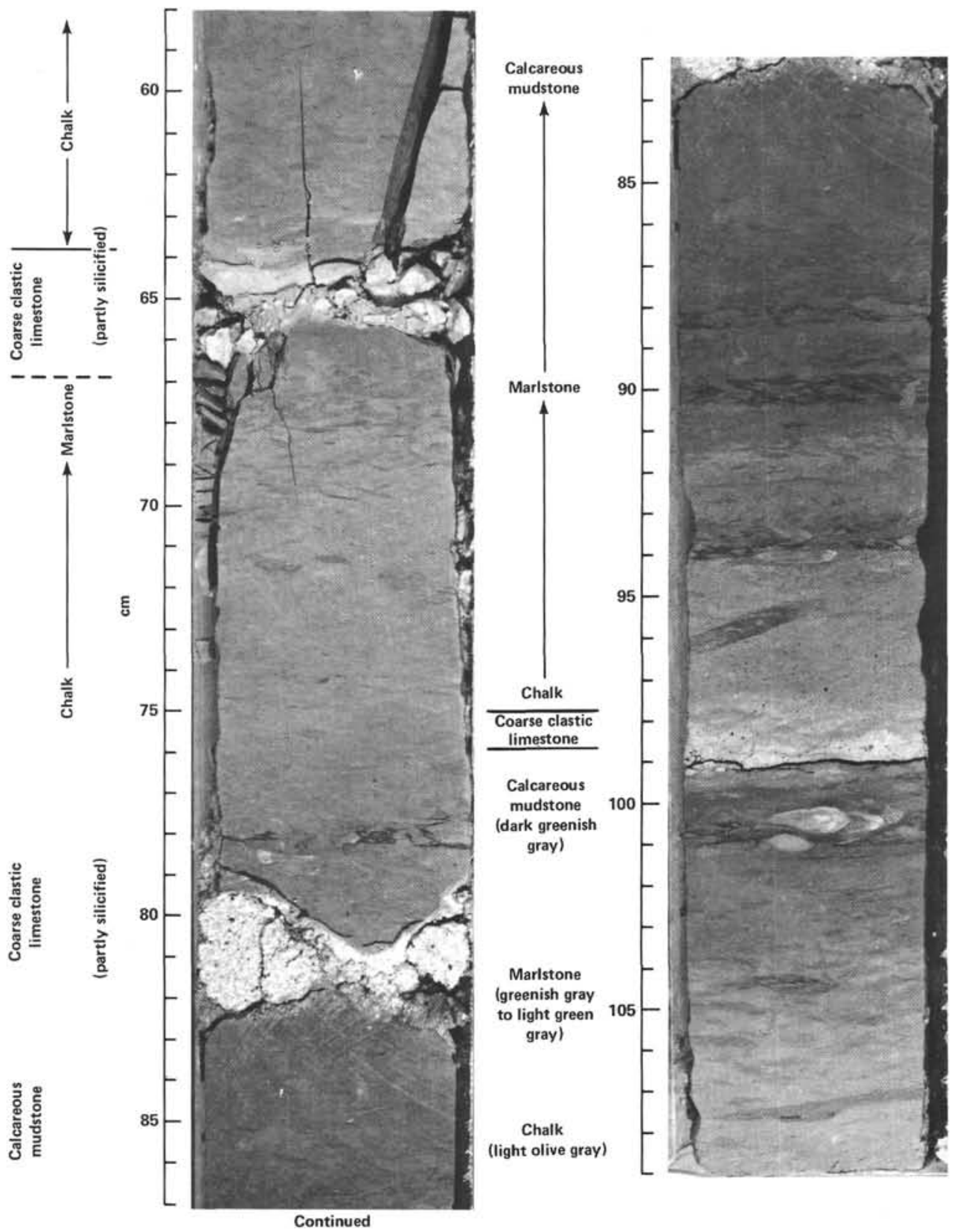

Figure 21. Clastic limestone, chalk, marlstone, and mudstone cycles typical of lithologic Unit 4; Sample $530 \mathrm{~A}-40-4,58-109 \mathrm{~cm}$.

downward within the subunit. The average of nine measurements of carbonate in samples from Subunit $5 \mathrm{~b}$ is $23 \%$.

Fibrous calcite fragments of the prismatic layers of Inoceramus shells occur in Hole 530A, Cores 56, 60, and 61 . Inoceramus fragments in Core 56 are partly silicified.

Subunit 5c: Dark Green Mudstone, Marlstone, and Calcareous Siliciclastic Sandstone (704.5 to $790 \mathrm{~m}$ subbottom). The dominant lithologies of Subunit 5c, like those of Subunits $5 \mathrm{a}$ and $5 \mathrm{~b}$, are green mudstone and marlstone reflecting varying proportions of silt, clay, and carbonate. Gray siliciclastic sandstone-green mudstone turbidite beds, common in Subunit $5 \mathrm{~b}$, are also common in Subunit 5c (Fig. 26). Fibrous calcite fragments of Inoceramus shells occur in Cores 530A-63 and 64 (Fig. 27). The main distinction between Subunits 5b and $5 \mathrm{c}$ is the dominance of siliciclastic sand replacing clastic carbonate in medium-bedded $(10-30 \mathrm{~cm})$, structurally well-defined turbidites of calcareous sandstone. The dark-colored siliciclastic sand and light-colored carbonate sand occur as massive mixtures or, more commonly, as an interlamination of the two sand types (Figs. 28 and 29). The amount of carbonate sand decreases downward within the subunit. In Cores 530A-63 and 64 , there are all gradations between calcareous sandstone and clastic limestone depending upon the relative proportions of the two sand types. By Cores 


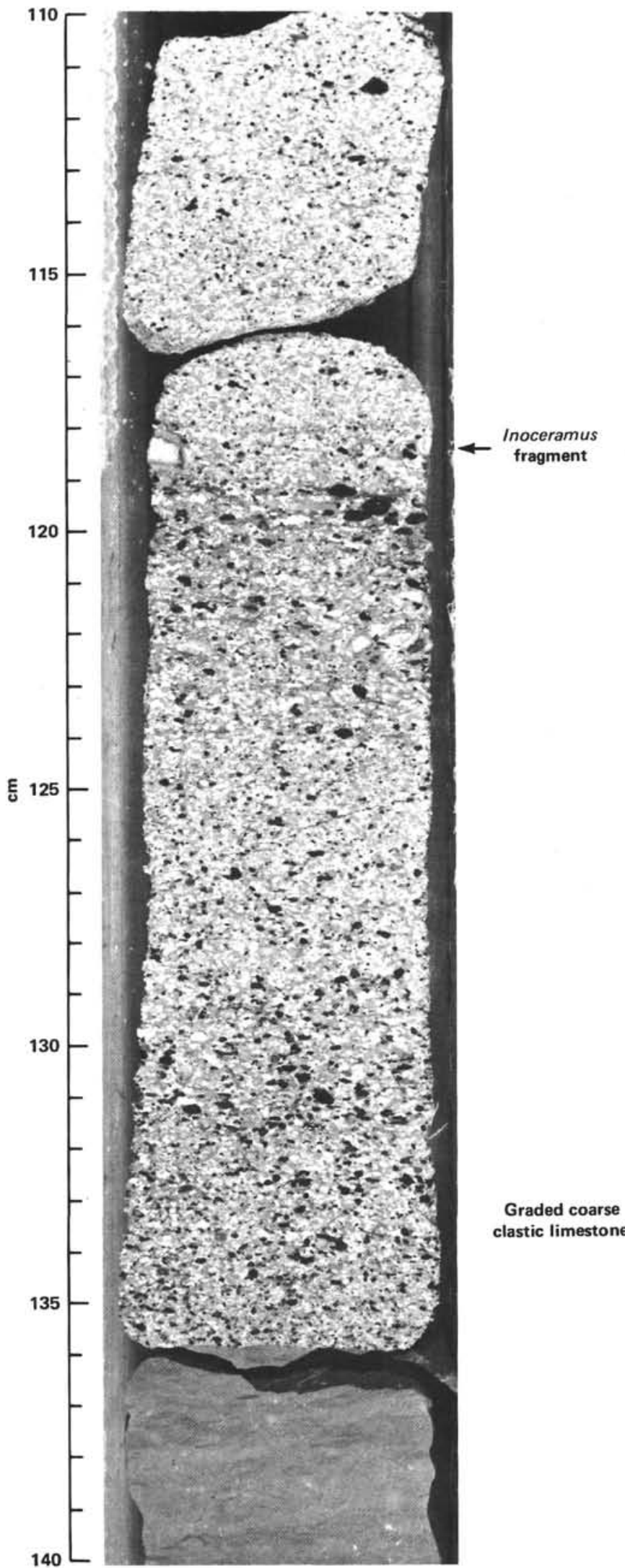

Figure 22. Graded bed of clastic limestone. Lithologic Unit 5a; Sample $530 \mathrm{~A}-55-1,110-140 \mathrm{~cm}$.

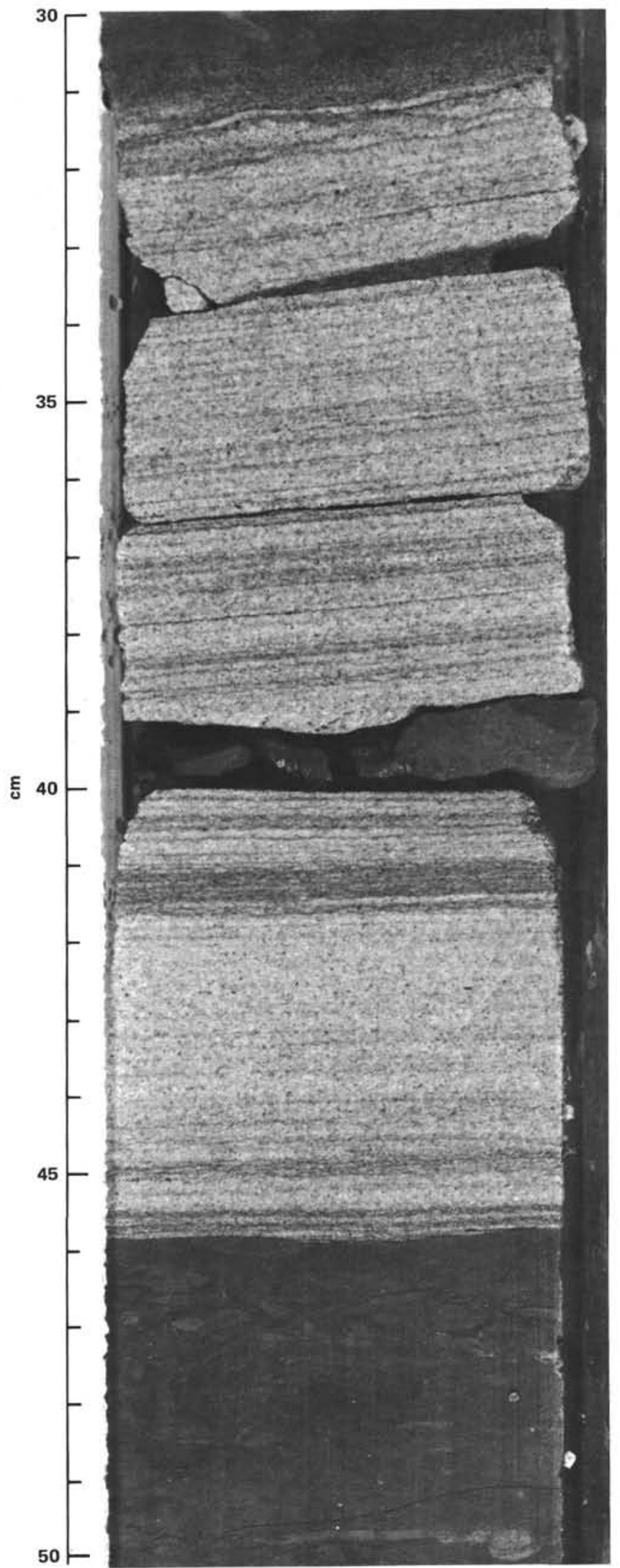

Figure 23. Laminated clastic limestone in dark greenish gray calcareous mudstone. Lithologic Unit 5a; Sample 530A-55-3, 30-50 cm. 


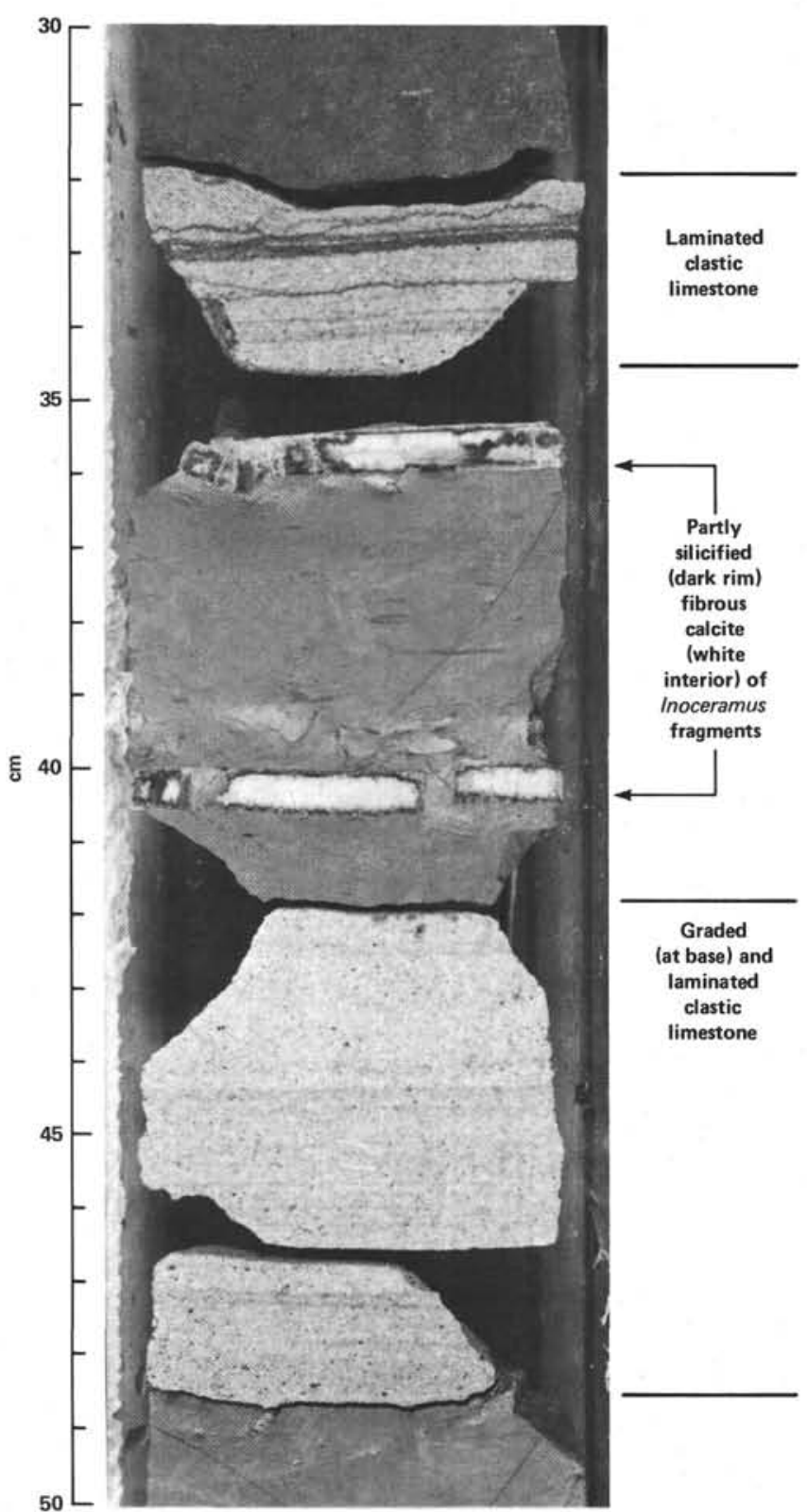

Figure 24. Two beds of clastic limestone and partly silicified fragments of the fibrous, prismatic layer of Inoceramus in greenish gray calcareous mudstone and marlstone. Lithologic Unit 5a; Sample 530A-55-1, 30-50 cm.

530A-67 and 68, the recovered material consists of about $25 \%$ laminated, gray calcareous sandstone and about $75 \%$ mudstone and marlstone. By Core 530A-69, the coarse-clastic interbeds consist mainly of an interlamination or massive mixture of dark gray siliciclastic sand and light green volcanogenic sand in sandstone beds totaling about $25 \%$ of the recovered material in Cores $530 \mathrm{~A}-69$ and 70 .

Core 530A-70 represents a transition between Subunit $5 \mathrm{c}$ and Unit 6 . In this core the clastic carbonate has disappeared, and carbonate-cemented, siliciclastic and volcanogenic sands are present in about equal abundance. This transition is also marked by an increase in sonic velocity and a decrease in density reflecting the

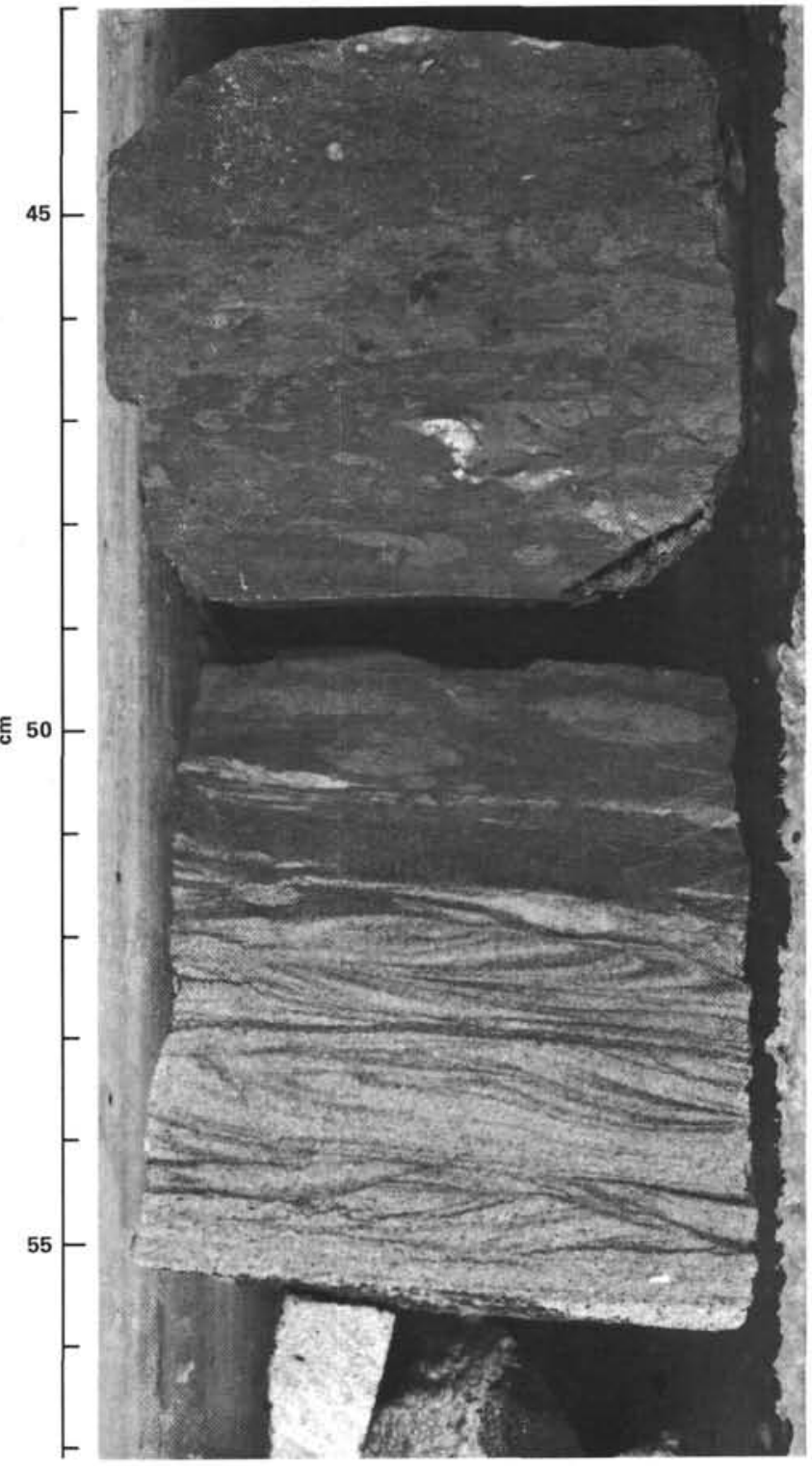

Figure 25. Cross-laminated clastic limestone in dark greenish gray calcareous mudstone. Lithologic Unit 5a; Sample 530A-56-1, $45-55 \mathrm{~cm}$.

fact that the glauconitic sandstone of Unit 6 has a relatively high velocity but a low density.

\section{Unit 6: Volcanogenic Sandstone (790 to $831 \mathrm{~m}$ sub-bottom)}

The dominant lithology of Unit 6 is carbonate-cemented, greenish black volcanogenic sandstone that occurs as thin $(5-10 \mathrm{~cm})$ to thick $(1-3 \mathrm{~m})$ graded turbidites. Many of the turbidites show complete Bouma sequences (Bouma, 1962) as follows:

1. Dark green, massive to bioturbated mudstone (=pelitic or Bouma E-division);

2. Greenish black, laminated siltstone to mudstone (= upper parallel-laminated or Bouma D-division);

3 . Cross-laminated fine sandstone (=current-ripplelaminated or Bouma C-division); 


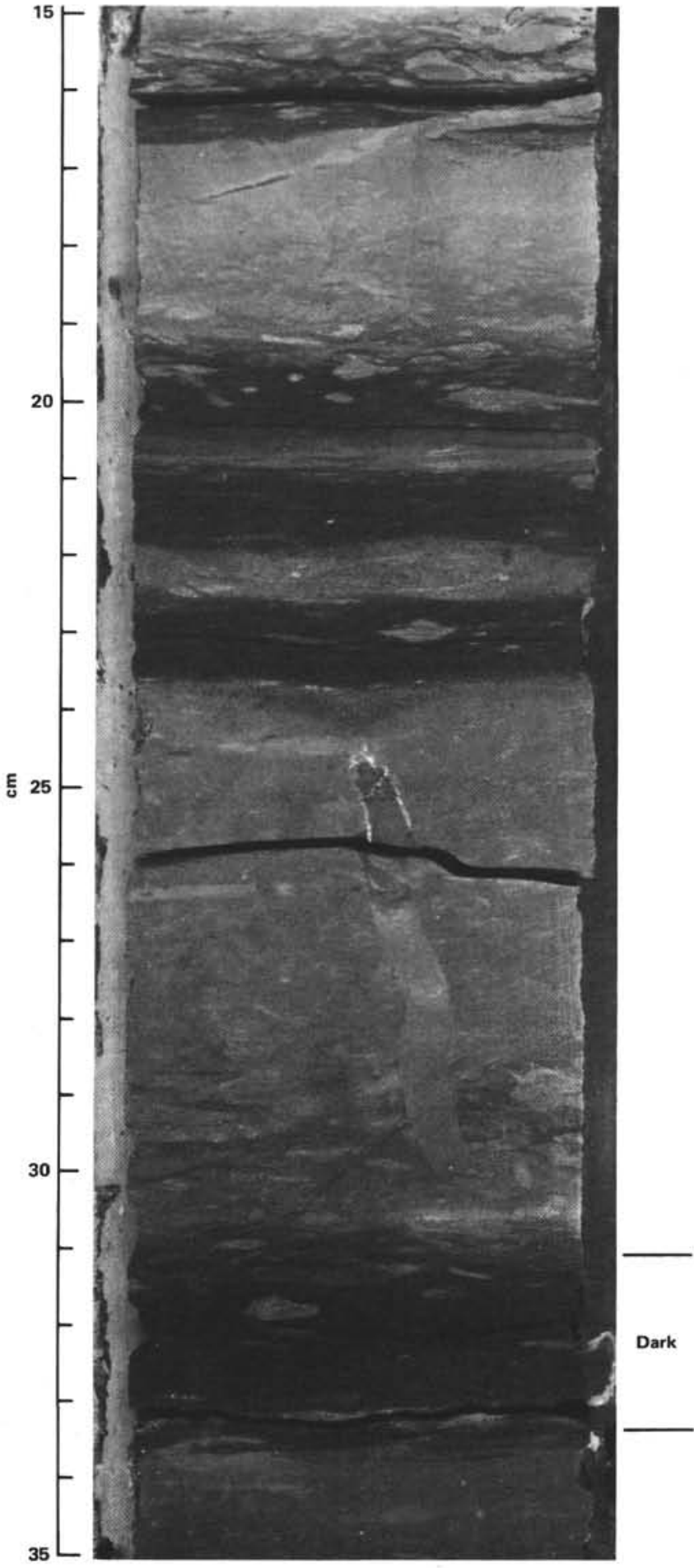

Figure 26. Turbidite cycles of massive to laminated, gray, fine-grained sandstone and dark green, bioturbated mudstone in olive mudstone and marlstone. Lithologic Unit 5c; Sample 530A-62-1, 15-35 $\mathrm{cm}$.

4. Parallel-laminated medium sandstone ( $=$ lower parallel-laminated or Bouma B-division); and

5. Greenish-black, massive, coarse to very coarse sandstone with sharp, scoured lower contact (= massive or graded Bouma A-division).

The dark green mudstone tops of these turbidites are commonly overlain by 2 - to 10 -cm-thick beds of lighter

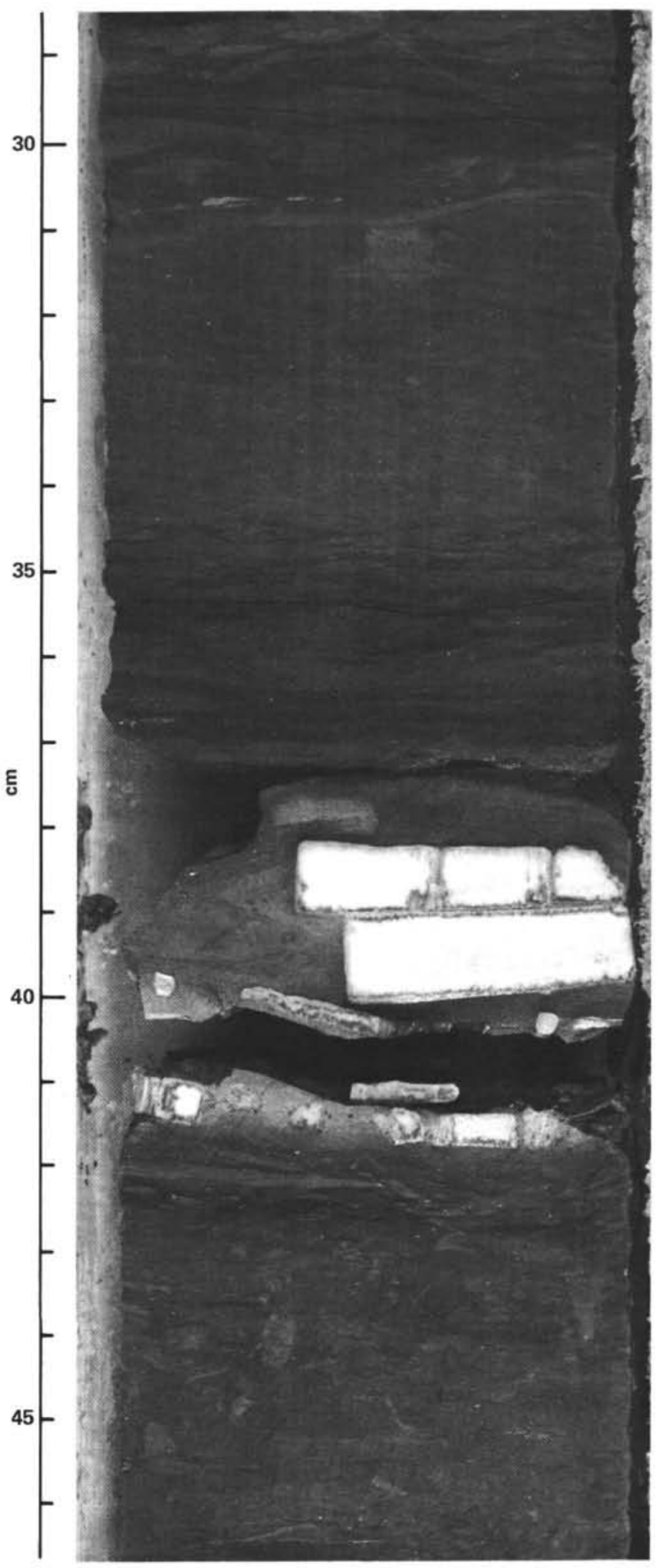

Figure 27. Fragments of the fibrous-calcite prismatic layer of Inoceramus partly replaced by silica (dark rim) in olive gray calcareous mudstone. Lithologic Unit 5c; Sample 530A-63-1, 30-45 cm.

green, bioturbated, calcareous mudstone or marlstone. The basal Bouma A-division sandstone may have 1 to 3 $\mathrm{cm}$ of reverse grading at the very bottom. The sands have a complex and varied mineralogy, including vol- 


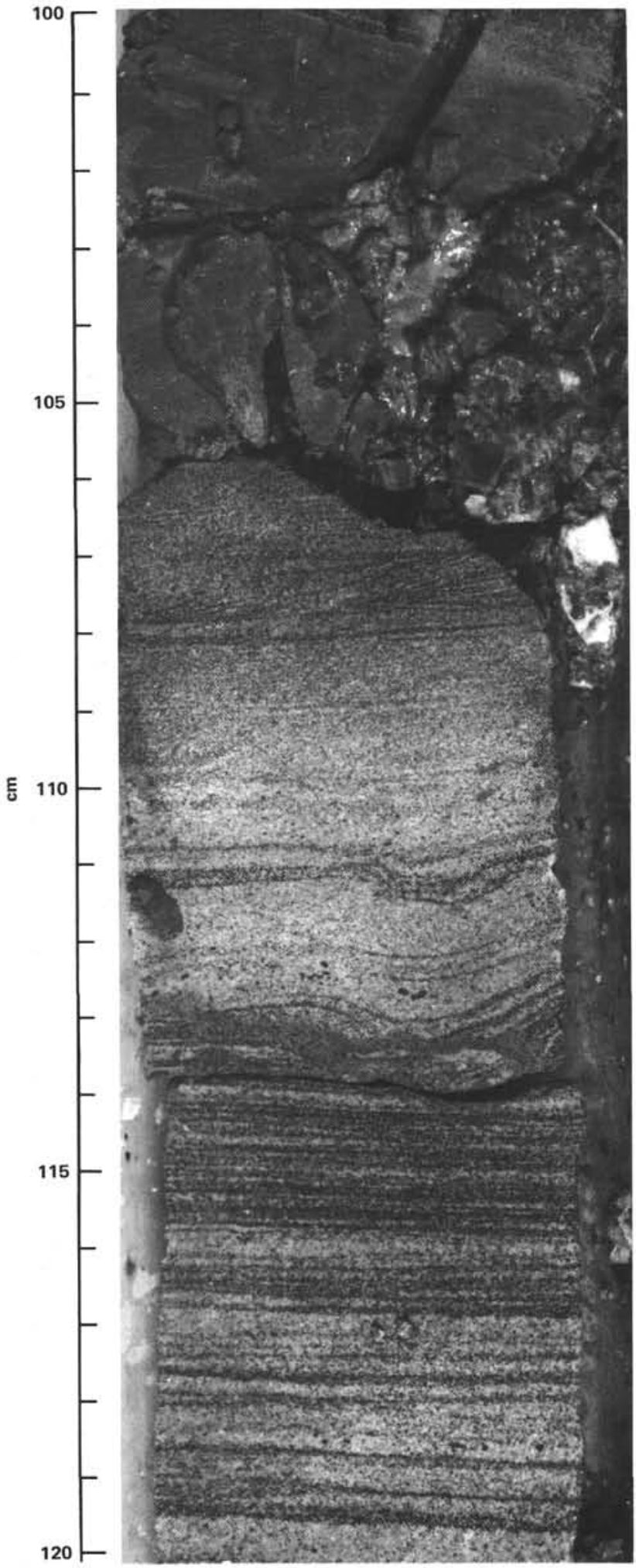

Figure 28. Interlamination of dark siliciclastic sandstone and light clastic limestone within olive-gray calcareous limestone. Lithologic Unit 5c; Sample 530A-63-3, 100-120 cm.

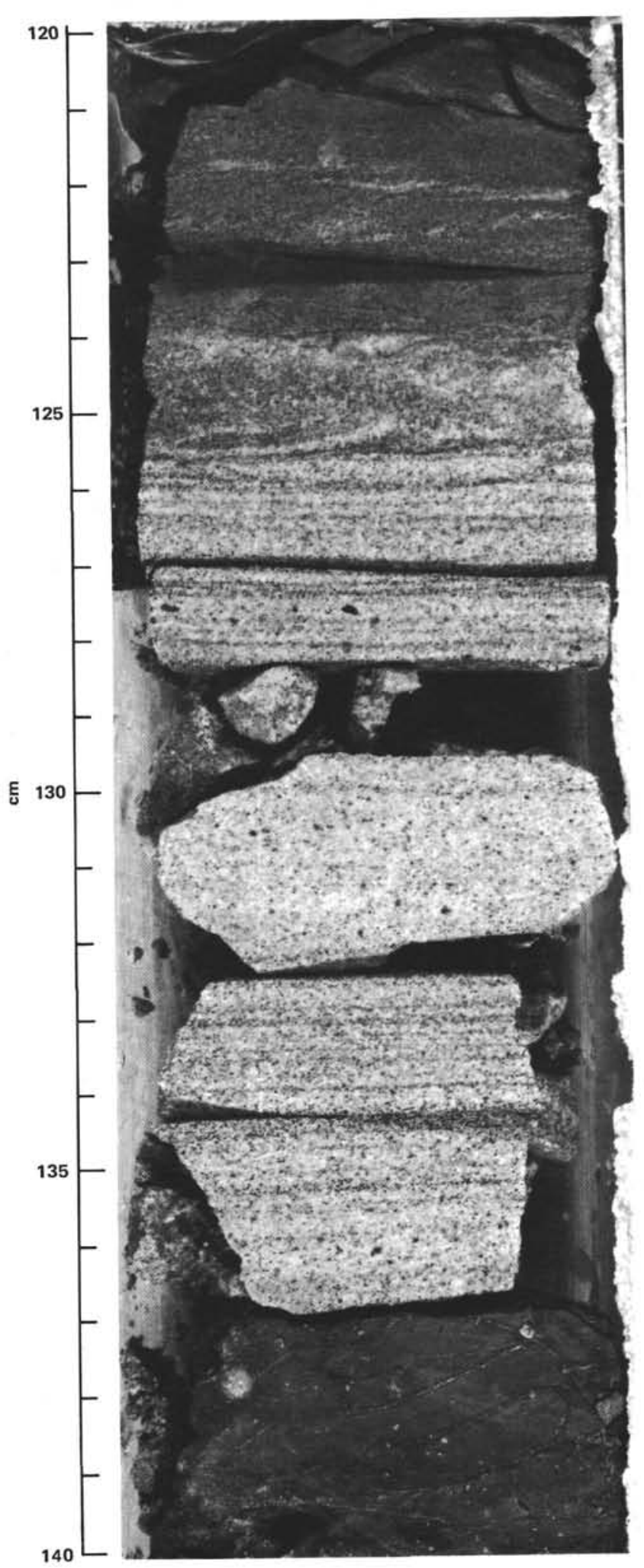

Figure 29. Interlamination of dark olive-gray calcareous mudstone. Lithologic Unit 5c; Sample 530A-63-2, 120-140 cm. 
canic material, glauconite, quartz, feldspar, pyrite, other opaque minerals, and clays of the smectite group. Cementation is mainly by carbonates (sparry calcite and siderite) and minor limonite.

These turbidites continue with variable thickness but little change in character through Core 530A-74, within which there is an increase in amount of white carbonate cement and the dominant color changes from greenish black to pale green between Sections 1 and 3. The sandstones also become more massive and finer-grained downward. This dominant light green, fine-grained sandstone grades downward to darker green, coarser-grained sandstone in Sections 1 and 2 of Core 530A-75 and abruptly overlies the red and green claystones at the base of Section 2 and in the rest of Core 530A-75.

\section{Unit 7: Variegated Red, Green, and Purple Claystone,} Siltstone, and Sandstone (831 to $940 \mathrm{~m}$ sub-bottom)

The dominant lithology of Unit 7 is red claystone with interbeds of green, red, and purple siltstone and claystone and green sandstone in numerous repeated turbidite sequences. The red claystone appears to be composed mainly of clay minerals (illite and mixed-layer expanding clays), altered volcanic glass, iron oxides, pyrite, quartz, feldspar, and unspecified carbonate (Appendix A).

About 10 to $20 \%$ of the recovered material in Cores $530 \mathrm{~A}-76$ and 77 consists of thick-bedded (up to $50 \mathrm{~cm}$ ), massive to graded sandstone, interbedded with red and green claystone and siltstone present as very thin-bedded (1-3 cm thick), often indistinct, turbidites. By Core 530A-78, we could recognize well-developed turbidite sequences 2 to $30 \mathrm{~cm}$ thick, each consisting of gradations in size, color, and structures. Complete turbidite sequences, illustrated in Figures 30, 31, and 32, consist of the following lithologies and sedimentary structures: (1) light brown claystone, bioturbated; (2) grayish red claystone, parallel laminations; and (3) greenish gray sandstone, massive at base with a sharp, scoured lower contact, grading upward into finer-grained, parallellaminated material, and finally cross-laminated finegrained sandstone.

The thickness of individual turbidites decreases downward in Core 530A-78 mainly at the expense of sandstone, so that by the base of this core, most of the turbidites consist only of reddish purple and red siltstone and claystone. Most of the turbidites in Cores 530A-79 and 80 are only 1 to $2 \mathrm{~cm}$ thick, and consist of green siltstone at the bases of dominant reddish purple-red claystone cycles (Fig. 33). Most of the green color in these thinner turbidites is the result of iron-reduction halos around thin siltstone layers and laminae in a dominant red siltstone-claystone lithology.

Silt-size dolomite rhombs were first recognized in smear slides from claystone beds in Core 530A-79. Dolomite increases in abundance downward so that many of the claystone lithologies are dolomitic silty claystone. The presence of dolomite accounts for much of the relatively high carbonate content of claystone below core 530A-79. Most of the sandstone beds also contain minor carbonate cement. The average carbonate content in 38 samples from lithologies in Unit 7 is $21 \%$.

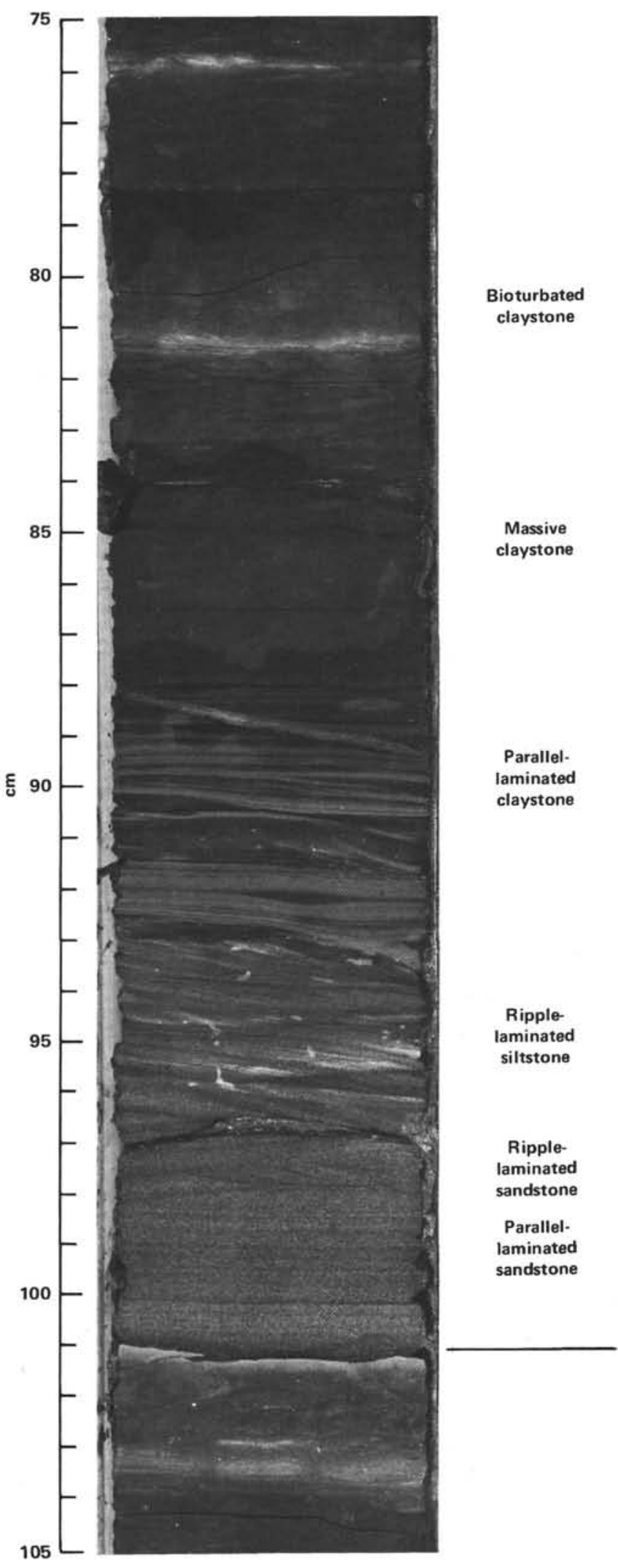

Figure 30. Well-developed turbidite cycle at top of Unit 7. Complete sequence of Bouma turbidite divisions is shown from massive and parallel-laminated sandstone base with sharp, scoured lower contact, to ripple-laminated sandstone and siltstone, to parallel-laminated claystone, to massive claystone, to bioturbated claystone; Sample 530A-78-4, 75-105 cm. 

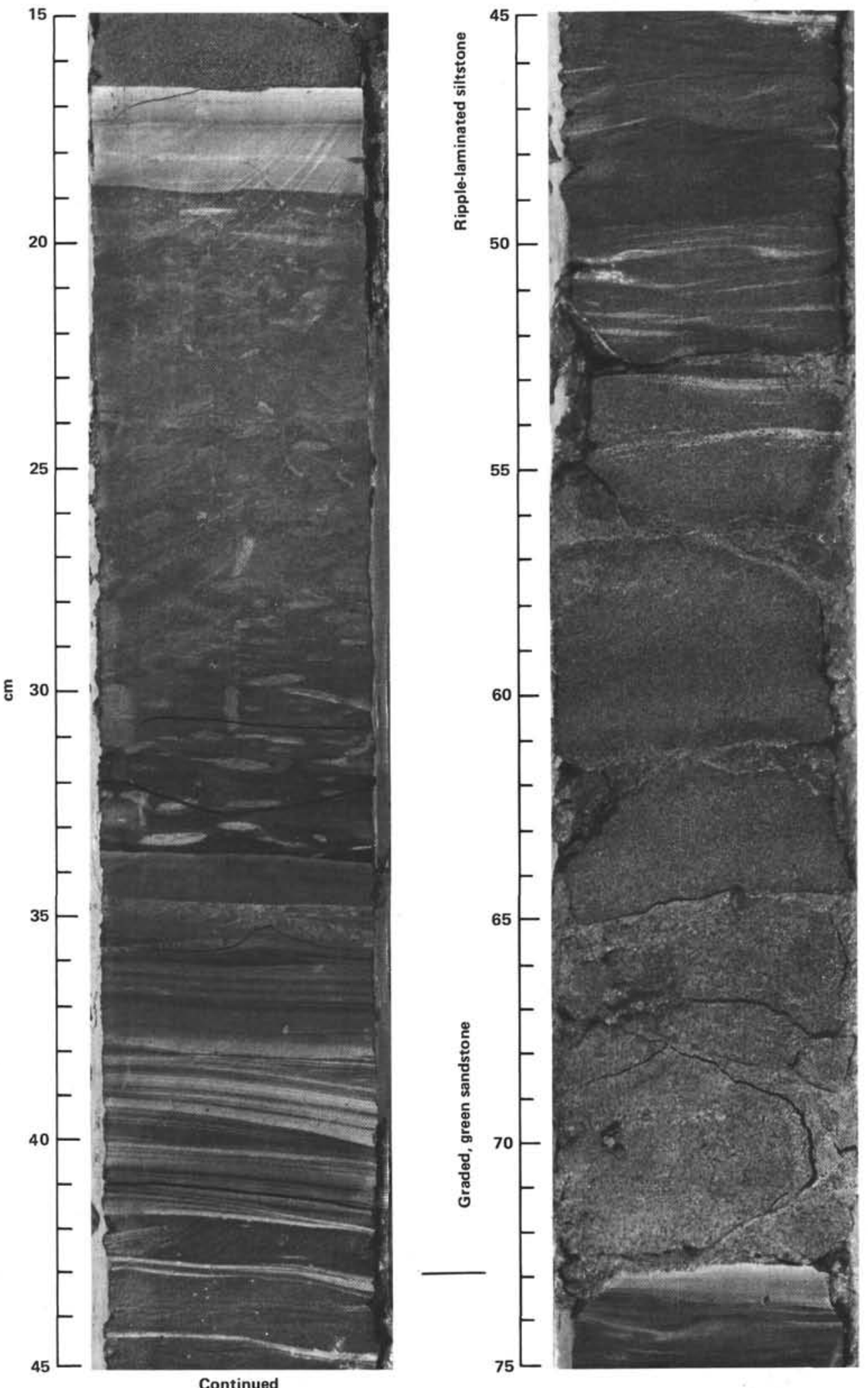

Figure 31. Thick, sandy, graded turbidite cycle, grading from green sandstone to ripple-laminated siltstone, to parallel-laminated claystone, to bioturbated reddish purple claystone. Lithologic Unit 7; Sample 530A-77-5, $15-75 \mathrm{~cm}$. 


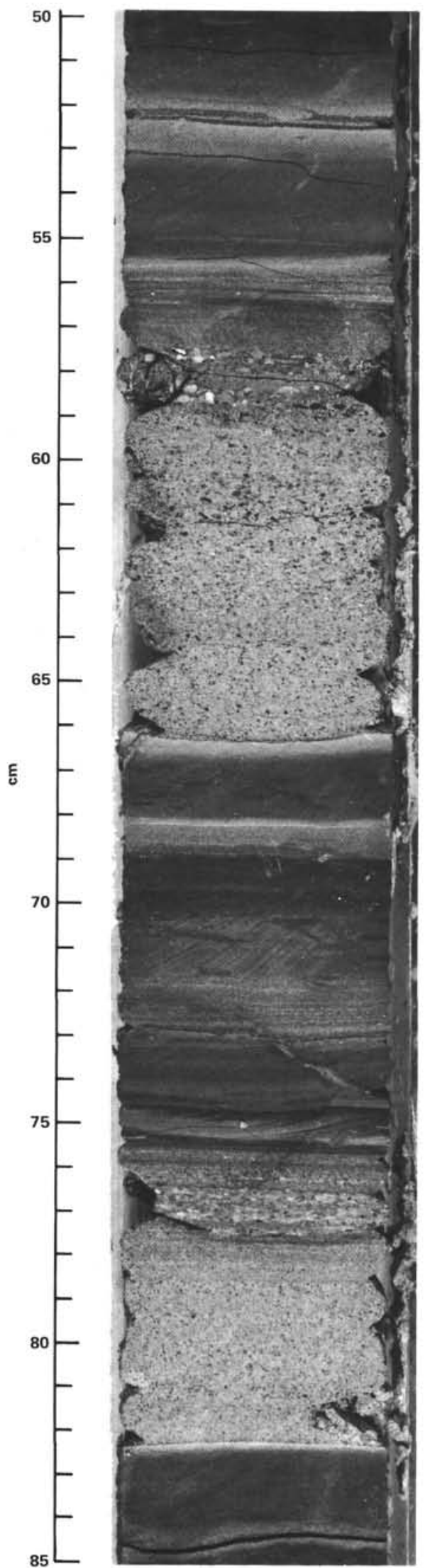

Figure 32. Two sandy turbidite beds and several thinner, silty turbidite sequences, each grading upward into red claystone. Lithologic Unit 7; Sample 530A-77-4, 50-85 cm.
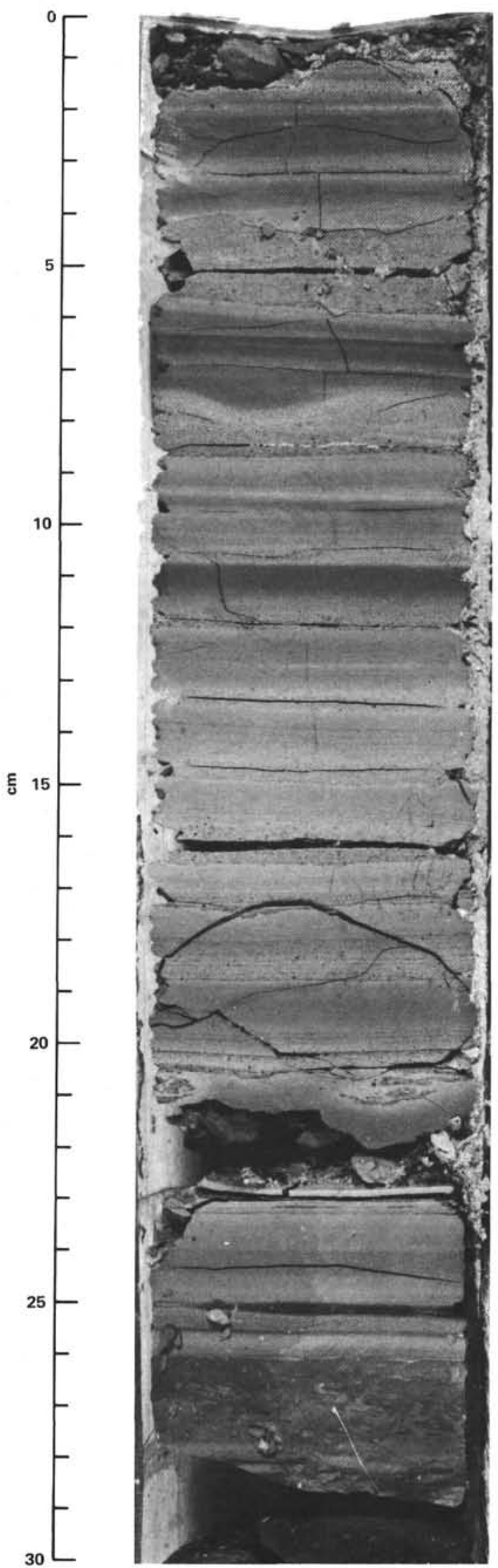

Figure 33. Numerous thin, green siltstone-purple claystone turbidites common in lithologic Unit 7; Sample 530A-79-4, 0-30 cm. 
Nannofossils increase in abundance below Core 530A82 (Appendix A) although most of the carbonate is probably still silt-sized dolomite. A complete turbidite cycle (8-10 cm thick) in Core 530A-83 consists of the following lithologies and structures: (1) light brown nannofossil marlstone or claystone, bioturbated; (2) red-brown claystone, massive; (3) greenish gray mudstone, parallel-laminated; (4) greenish gray siltstone, low-amplitude ripple-laminated; and (5) light green to white sandstone, massive to graded at base, grading upward into parallel-laminated and ripple-laminated sandstone at the top.

Fibrous-calcite fragments of the prismatic layers of Inoceramus shells occur in Hole 530A, Cores 79, 80, 83, and 85 (Plate 1, Fig. 6).

Unit 8: Red and Green Claystone and Marlstone with Interbedded Black Shale (940 to $1103 \mathrm{~m}$ sub-bottom)

The dominant lithologies of Unit 8 are similar to the red and green claystone lithologies at the base of Unit 7 with the addition of beds of black shale. The claystone beds occasionally contain thin (1-5 mm) green siltstone turbidite layers and are usually bioturbated, although many of the red claystone beds appear to be massive.

One thin bed of black shale occurs in Core 530A-86 at the base of Unit 7, but shale beds are much more abundant in Unit 8. Between Core 530A-87 and Core $530 \mathrm{~A}-96$, inclusive, there is an average of five black shale beds per core (range of 2 to 12; Table 3 ). The black shale beds are usually several centimeters thick, but vary between 1 and $62 \mathrm{~cm}$. The maximum amount of black shale occurs in Cores 530A-97 and 98 which contain 50 and $40 \%$ of black shale, respectively, interbedded with green claystone. These two cores do not contain any red claystone. The black shale beds may contain very lowamplitude ripples as well as faint, fine, horizontal lamination (Fig. 34). They commonly appear to be massive and, more rarely, bioturbated. The black shale beds usually have a distinct fissility that is particularly notice- able in the eroded edges of the cores and in the way that the beds cut with a diamond saw.

The amount of carbonate, present as nannofossils, silt-size dolomite rhombs, or as unspecified carbonate (Appendix A), is highly variable so that the actual "claystone" compositions range from claystone to calcareous claystone to marlstone to chalk (rare). In gener$\mathrm{al}$, there is more chalk and marlstone in the lower part of Unit 8 (Core 530A-98 downward), although this is not readily apparent in Figure 10. The average content of carbonate measured in 94 samples from lithologies within Unit 8 is $14 \%$. This value is probably low as an average for Unit 8 because the noncarbonate black shales are over-represented in the samples taken for analyses.

Pyrite is commonly associated with both green claystone and black shale as disseminated crystals and as large aggregates (Figs. 35-38). Many of the siltstone layers within claystone beds are also pyritized.

Fibrous calcite fragments of the prismatic layers of Inoceramus shells occur in Cores 530A-88 and 89.

\section{Unit 9: Basalt (1103 to $1121 \mathrm{~m}$ sub-bottom)}

Unit 9 consists of $19 \mathrm{~m}$ of medium gray, fine-grained basalt containing veins and vugs filled with calcite. The contact between the basalt and red mudstone of Unit 8 occurs in the core catcher of Core 530A-105. Here, the basalt is light gray with a thin white altered glassy layer immediately below the mudstone. White veins and veinlets of calcite (Plate 1, Fig. 7) extend from the basalt into the overlying red mudstone for a distance of about 5 $\mathrm{cm}$. (See the section on igneous rocks for a more complete description of the basalt of Unit 9.)

\section{DISCUSSION}

\section{Introduction}

The stratigraphic section recovered at Site 530 contains an almost complete record of sediment accumula-

Table 3. Black shale beds in lithologic Unit 8 for Hole 530A, Cores 86 through 105 .

\begin{tabular}{|c|c|c|c|c|c|c|c|c|c|c|}
\hline & \multirow[b]{2}{*}{ Core } & \multirow{2}{*}{$\begin{array}{l}\text { Core } \\
\text { length } \\
(\mathrm{cm})\end{array}$} & \multirow{2}{*}{$\begin{array}{l}\text { No. of } \\
\text { black } \\
\text { shale } \\
\text { beds }\end{array}$} & \multirow{2}{*}{$\begin{array}{l}\text { Total } \\
\text { thickness } \\
\text { of black } \\
\text { shale beds } \\
(\mathrm{cm})\end{array}$} & \multirow{2}{*}{$\begin{array}{l}\text { Average } \\
\text { thickness } \\
(\mathrm{cm})\end{array}$} & \multirow[b]{2}{*}{$\begin{array}{l}\text { Standard } \\
\text { deviation }\end{array}$} & \multirow{2}{*}{$\begin{array}{l}\text { Percent of } \\
\text { total } \\
\text { core } \\
\text { thickness }\end{array}$} & \multicolumn{3}{|c|}{ Organic carbon $(\%)$} \\
\hline & & & & & & & & $\begin{array}{l}\text { Black } \\
\text { shale }\end{array}$ & $\begin{array}{l}\text { Gray } \\
\text { shale }\end{array}$ & Other \\
\hline & 86 & 935 & 1 & 5 & 5 & & 1 & 2.0 & 1.3 & $0.2 ; 0.3$ \\
\hline & 87 & 703 & 12 & 52 & 4.2 & 2.5 & 7.6 & $5.4 ; 6.2$ & 1.3 & $0.2 ; 0.3$ \\
\hline & 88 & 448 & 5 & 25 & 5.0 & 2.1 & 5.6 & $9.7 ; 2.8$ & & 0.1 \\
\hline & 89 & 922 & 9 & 23 & 2.6 & 1.6 & 2.5 & 9.6 & & \\
\hline & 90 & 446 & 5 & 23 & 4.6 & 2.1 & 5.2 & 10.5 & & 0.6 \\
\hline & 91 & 574 & 1 & 2 & & & & & & 1.2 \\
\hline & 92 & Disturbed & & & & & & & & \\
\hline & 93 & 918 & 12 & 38 & 3.2 & 1.9 & 4. & & & $0.9 ; 0.9 ; 0.2 ; 0.1$ \\
\hline & 94 & 273 & 5 & 15 & 3.0 & 2.0 & 5.5 & 12.3 & & 0.3 \\
\hline & 95 & 656 & 12 & 35 & 2.9 & 4.0 & 5.3 & 1.7 & & 0.2 \\
\hline & 96 & 795 & 19 & 70 & 3.7 & 2.5 & 8.8 & 5.8 & 1.8 & $0.1 ; 0.4$ \\
\hline & 97 & 607 & 30 & 316 & 10.5 & 12.5 & 52 & $8.0 ; 7.3$ & & 0.2 \\
\hline & 98 & 501 & 58 & 180 & 3.1 & 4.3 & 36 & $1.4 ; 8.0$ & & $0.3 ; 0.5$ \\
\hline & 99 & 735 & 25 & 66 & 2.6 & 2.5 & 9.0 & 1.7 & 0.4 & 0.2 \\
\hline & 100 & 672 & 19 & 79 & 4.2 & 5.4 & 12 & 12.0 & 1.9 & 0.3 \\
\hline & 101 & 995 & 9 & 46 & 5.1 & 4.8 & 4.5 & 4.5 & 5.1 & $0.9 ; 1.3$ \\
\hline & 102 & 800 & 4 & 28 & 7.0 & 3.3 & 3.2 & 3.5 & $1.2 ; 1.7$ & 0.4 \\
\hline & 103 & 600 & 3 & 13 & 4.3 & 4.9 & 2.2 & 2.2 & 7.1 & \\
\hline & 104 & 790 & 4 & 22 & 5.5 & 2.6 & 7.8 & 2.8 & 5.2 & $0.4 ; 0.5 ; 0.6 ; 0.2$ \\
\hline & 105 & 800 & 16 & 79 & 5.0 & 5.0 & 9.8 & 9.8 & 5.3 & $0.2 ; 0.2 ; 0.2$ \\
\hline Totals: & 20 & $\begin{array}{c}11,170 \\
\text { recovered } \\
17,200 \\
\text { drilled }\end{array}$ & 260 & 1105 & $\begin{array}{l}128 \text { bed } \\
34 \text { beds } \\
6 \text { beds } \\
\text { thickness }\end{array}$ & $\begin{array}{l}1.3 \\
1-2 \mathrm{~cm} \\
>10 \mathrm{~cm} \\
>20 \mathrm{~cm} \\
=62 \mathrm{~cm}\end{array}$ & 8.4 & 5.7 & 1.2 & 0.3 \\
\hline
\end{tabular}




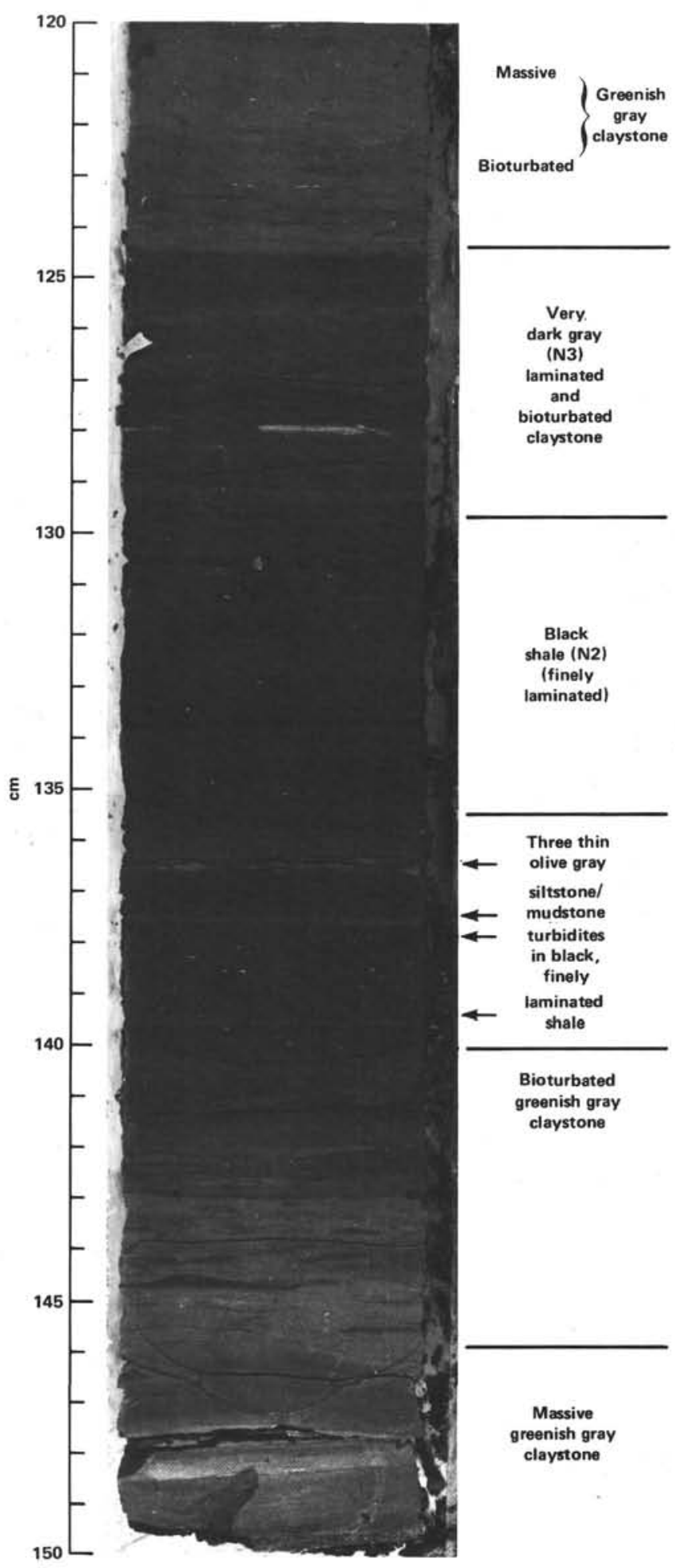

Figure 34. Typical black shale bed in greenish gray claystone. Lithologic Unit 8; Sample 530A-96-4, 120-150 cm.

tion in the southern Angola Basin during the past 102 m.y. The site is located at the southeastern margin of the Angola Basin about $150 \mathrm{~km}$ from the base of the continental slope of southwest Africa, which has slopes of 3 to 4 degrees, and only $10-15 \mathrm{~km}$ from the steep (about $7^{\circ}$ ) northern slope of Walvis Ridge. Most of the strati-

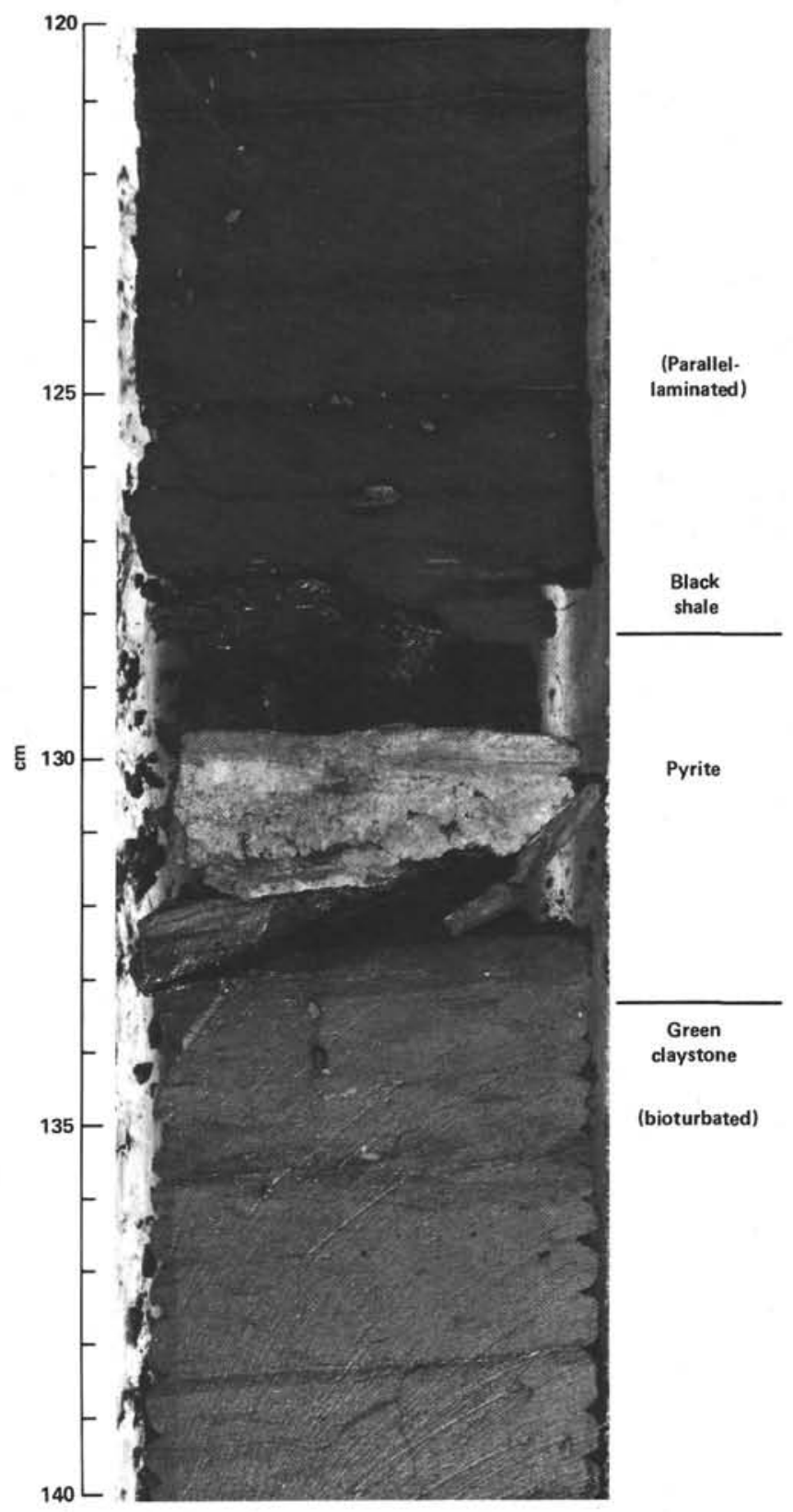

Figure 35. Pyrite nodule at contact between black shale and green claystone. Lithologic Unit 8; Sample 530A-97-1, 120-140 cm.

graphic section consists of downslope sediments deposited mainly by turbidity currents and debris flows. The black shales of late Albian to early Santonian, interbedded with and covered by open-ocean pelagic and hemipelagic sediments interbedded with red and green claystones represent deposition under unique conditions in the young South Atlantic Ocean.

The record of downslope sediment transport at Site 530 , as represented by debris-flow deposits and different types of turbidites, is complex. Thin-bedded ( 5 to 15 $\mathrm{cm}$ ) mud turbidites near the base of Unit 8 decrease in thickness and frequency upward through the lower $40 \mathrm{~m}$ of the unit and are replaced by very thin-bedded distal turbidites interbedded with pelagic and hemipelagic mudstones. The beds of black shale that are distinctive of 


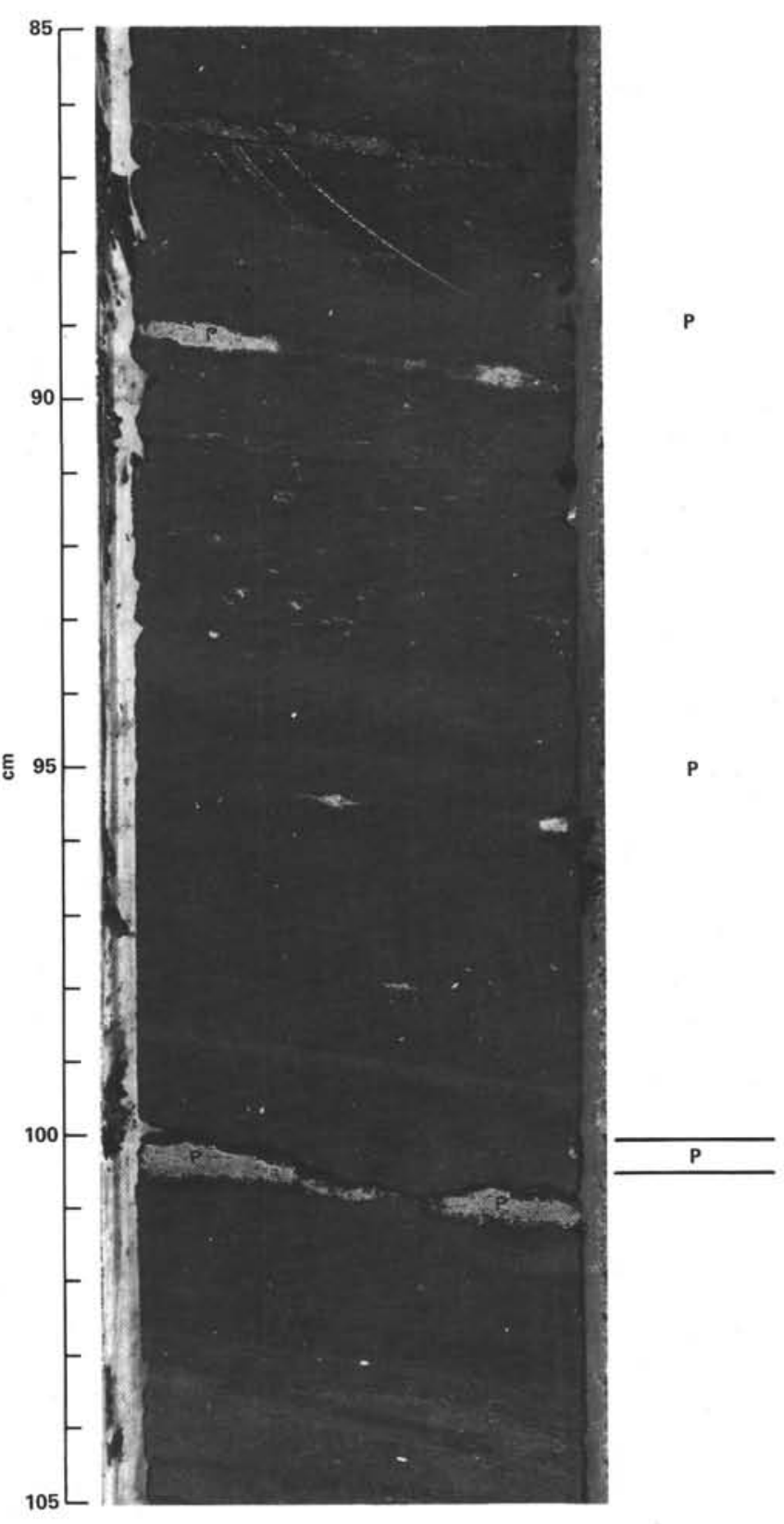

Figure 36. Pyrite (P) in black shale. Lithologic Unit 8; Sample 530A98A-2, 85-105 cm.

Unit 8 occur within this basinal sequence (see following discussion). Turbidites are not particularly well developed in Unit 8, but become better developed, thicker, and coarser in Units 7 (Figs. 30-32), 6, and 5c (about $250 \mathrm{~m}$ of section). The thickness and grain size of siliciclastic and volcanogenic turbidites increase to a maximum (more than $3 \mathrm{~m}$; coarse sand-size) in Unit 6 and decrease through Unit $5 \mathrm{c}$.

The lithologic and electric log records suggest that the sediments in Units 8 through 6 comprise a classic progradational submarine fan sequence, grading from basinal (Unit 8) and lower-fan deposits (Unit 7), through middle fan lobe and channel sediments (Unit 7), to thick upper-fan channel sandstones (Unit 6). These are followed by a thinning- and fining-upward channel-fill se-

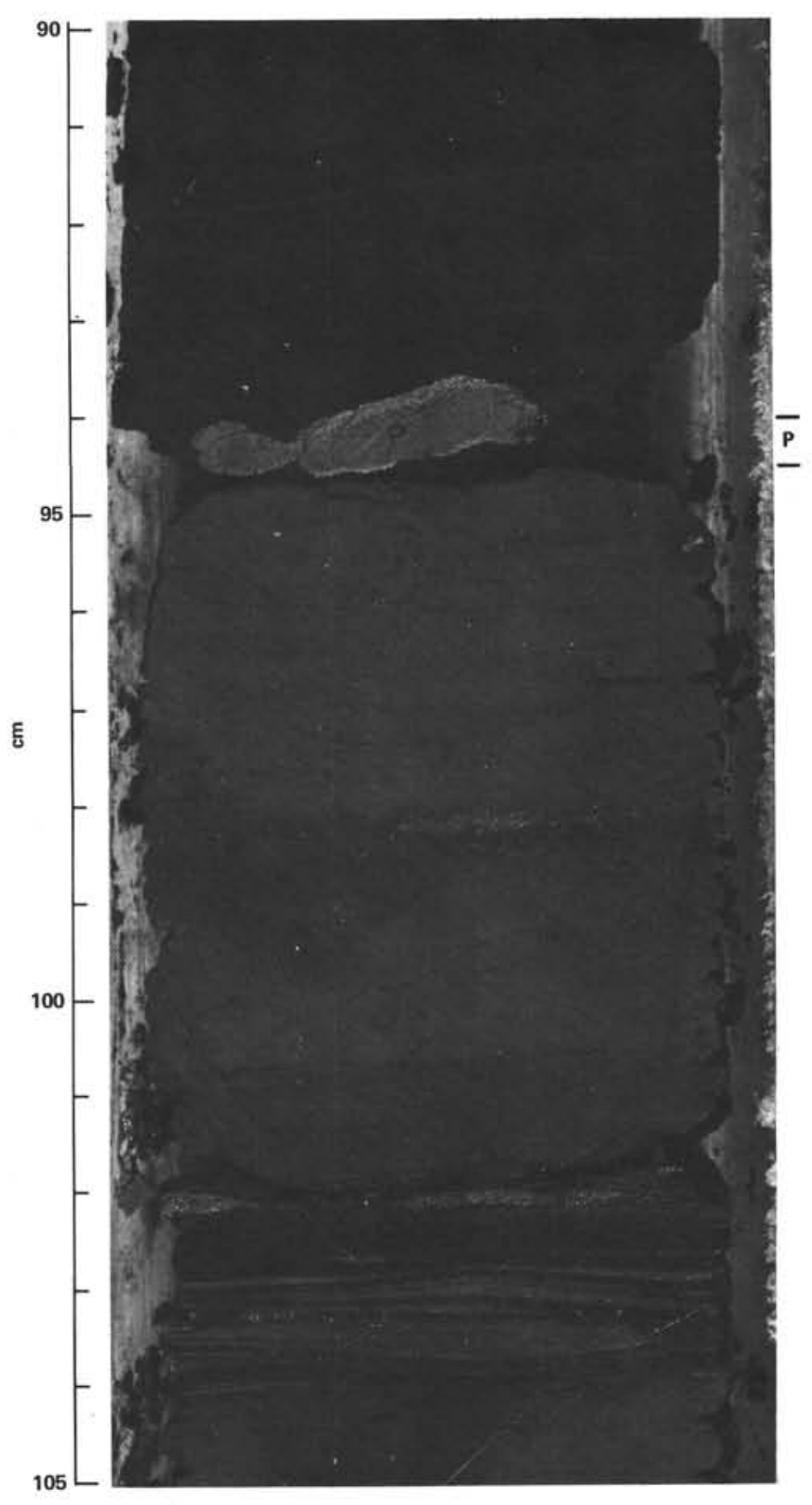

Figure 37. Pyrite $(\mathrm{P})$ nodule at contact between black shale and green claystone. Lithologic Unit 8; Sample 530A-98-3, 90-105 cm.

quence (Unit 5c). We do not yet have any direct evidence for the source of these basinal and fan sediments, but the shape of the sedimentary wedge on seismic reflection profiles suggests that the African continental margin is the primary source area. The coarse-clastic turbidites consists mostly of shallow-water debris; this is particularly evident for the carbonate sands. These different materials, first volcanogenic sand, then siliciclastic sand, and finally carbonate sand, were progressively supplied to Site 530 either by change in sediment type in the same general source area or by contributions from several different sources. The fact that we commonly observed massive or interlaminated mixtures of siliciclastic and carbonate sands suggests that they were supplied from the same general source area either by exposure of different sediments or, more likely, by progressive formation and accumulation of different sediment types. It is 


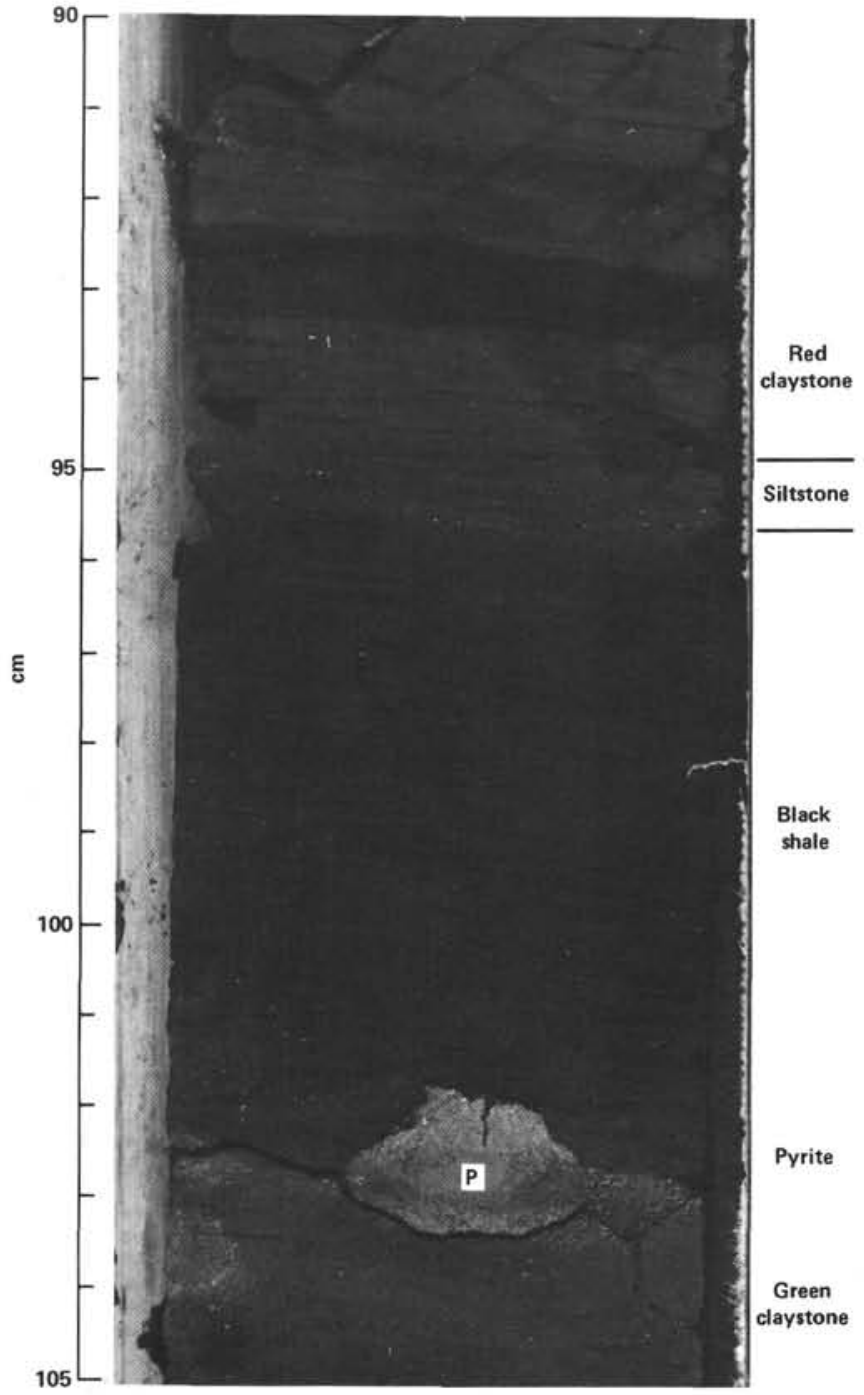

Figure 38. Pyrite (P) at contact between black shale and green claystone. Lithologic Unit 8; Sample 530A-104-3, 90-105 cm.

possible that one or more volcanic islands or seamounts with shallow-water platforms may have been present to contribute the volcanogenic sand, but at present there is no bathymetric evidence for these features closer than $200 \mathrm{~km}$ to the SW. We suggest that the volcanogenic sand was derived from the Walvis Ridge and that the siliciclastic and carbonate sands were probably transported by turbidity currents from the African continental margin, perhaps channeled into the basin down submarine canyons.

Coarse-clastic limestone and finer-grained chalk and marl are the dominant turbidite types in Units $5 \mathrm{a}$ and 4 (Figs. 20 and 21). There are several irregular thickening and thinning sequences in Units $5 a$ and 4 that may have been deposited on fan lobes and small channels.

Unit 3 comprises very thin-bedded basinal turbidites, pelagic clay, and volcanic-palagonitic silt deposited during the late Oligocene following a period of much reduced sedimentation during middle Eocene through early Oligocene time. Seismic reflection profiles show that the equivalent of this unit extends over much of the An- gola Basin and was dominated by sediment input from the African continental margin. Thicker mud turbidites $(5-20 \mathrm{~cm})$ form $20-30 \%$ of Unit 2 and are interbedded with dominant carbonate (marl and ooze) pelagic sediments (Fig. 24) and debris-flow deposits (Figs. 15-18).

The debris-flow deposits increase in thickness to a maximum of at least $32 \mathrm{~m}$ at the top of Unit 2 and are present at several horizons within Unit 1 . The clasts within the debris-flow deposits have been derived from approximately contemporaneous sediments on Walvis Ridge, and the larger flows can be seen on seismic reflection profiles to have moved downslope 15 to $20 \mathrm{~km}$. Thick (20-100 cm) clay-diatom turbidites (Figs. 12-14) are approximately equal in abundance to pelagic ooze and marl in Unit 1a. The turbidites also probably were derived from Walvis Ridge, where similar materials of the same age were recovered at Sites 362 and 532 .

These observations and interpretations of the section at Site 530 suggest the following general depositional history of the southern Angola Basin. From the Albian to the Eocene, the dominant sediments supplied to the southern Angola Basin were fine-grained distal turbidites derived from the African continental margin. From the Coniacian to the Eocene, minor coarse-clastic turbidites of varying composition were also supplied from the African continental margin, perhaps by channeling down submarine canyons. All of these sediments contain a variable but mostly minor carbonate component supplied from both pelagic and continental margin sources, indicating that the site was above the CCD except for brief intervals in the Maestrichtian and Paleocene and during most of the Eocene. The mud turbidites of Unit 3 suggest that from late Oligocene through the late Miocene (30-10 m.y.) turbidity currents were still supplying fine-grained background sediment from the African continental margin, although the supply of coarse-clastic debris had stopped. The almost complete lack of carbonate suggest that during this time the site was below the CCD. The marked increase in carbonate accumulation as nannofossil marl and ooze of Unit 2 beginning in the late Miocene was probably the result of a combination of rapid deepening of the CCD and increased productivity as evidenced by the marked increase in organic carbon beginning in upper Miocene sediments. Turbidity currents were still supplying fine-grained clastics that formed the clay-marl-ooze cycles of Unit 2 (Fig. 16), but most of the sediment that accumulated was pelagic nannofossil debris. The first evidence that we would interpret as an indication of sediment supplied from Walvis Ridge is recorded by the debris-flow deposits that began to accumulate in Unit 2 during the late Miocene. Increased diatom productivity during the Pliocene, probably associated with the initiation of upwelling conditions off the coast of southwest Africa, and shoaling of the CCD, as indicated by low concentrations of carbonate, resulted in the accumulation of diatom-rich, carbonate-poor sediments interbedded with Ridge-derived debris-flow deposits of Unit $1 \mathrm{~b}$. An increase in nannofossil abundance followed by an increase in foraminifer abundance in Unit 1a records deepening of the CCD during the Pleistocene and Holocene with continued 
high productivity of diatoms. The Pleistocene and Holocene sediments, rich in both diatoms and calcareous microfossils, are interbedded with debris-flow deposits and diatom-rich turbidites, both derived from Walvis Ridge.

\section{Black Shales}

One of the most striking features of the black shales of Unit 8 is their interbedding with green and red claystones, shown in Figure 39. The amount of interbedding of black shale is indicated in Table 3 and Figure 40 for Cores 530A-87 through 105 .

The red mudstones and marlstones make up about $44 \%$ of the unit and were deposited in a relatively deep $(3.5 \mathrm{~km})$, narrow ocean basin by pelagic, hemipelagic, and turbiditic processes under oxygenated bottom water. The green mudstones and marlstones, composing about $47 \%$ of the unit, are closely associated with the black shales and were deposited in the same manner as the red mudstones. There are two possible interpreta- tions for the green coloration: it is the result either of diagenetic reduction of iron in red muds around layers rich in organic matter or of iron reduction during deposition of sediments in poorly oxygenated bottom waters.

In the first interpretation, the high biological and chemical oxygen demand of the organic-carbon-rich (black shale) layers produced reducing conditions in the underlying and overlying sediments for a period of time before oxidizing conditions were re-established. This results in black shale "sandwiched" by green sediment in a red mudstone sequence or, with closely spaced black shales, in a sequence of alternating black and green beds. The accompanying migration of iron and sulfate ions toward the organic-rich beds concentrated $\mathrm{FeS}$ locally at the black-green boundary. In time this was converted to the pyrite commonly observed at the contact between a black shale and underlying green mudstone.

In the second interpretation, the green mudstones represent a transition, commonly through a gray, more
A

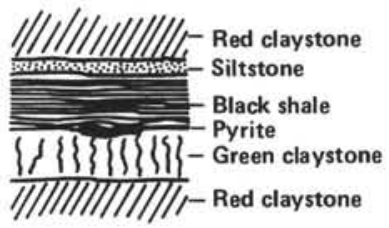

(e.g., Samples 530A-104-2, 80-90 cm and $530 \mathrm{~A}-104-3,95-120 \mathrm{~cm}$ )

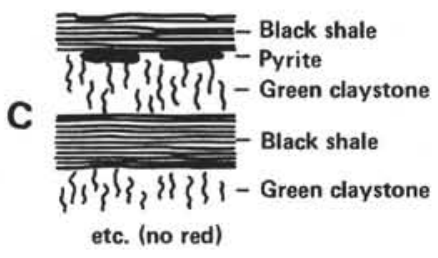

(e.g., Samples $97-1,120-140 \mathrm{~cm}$ and 98-3, 90-105 cm)

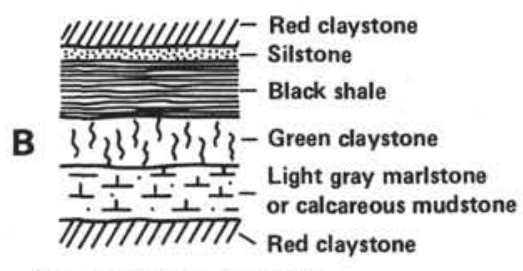

(e.g., Hole 530A, Core 101

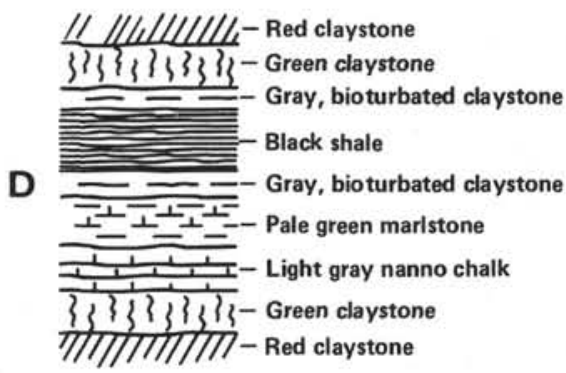

(e.g., Hole 530A, Cores 89 through 96)

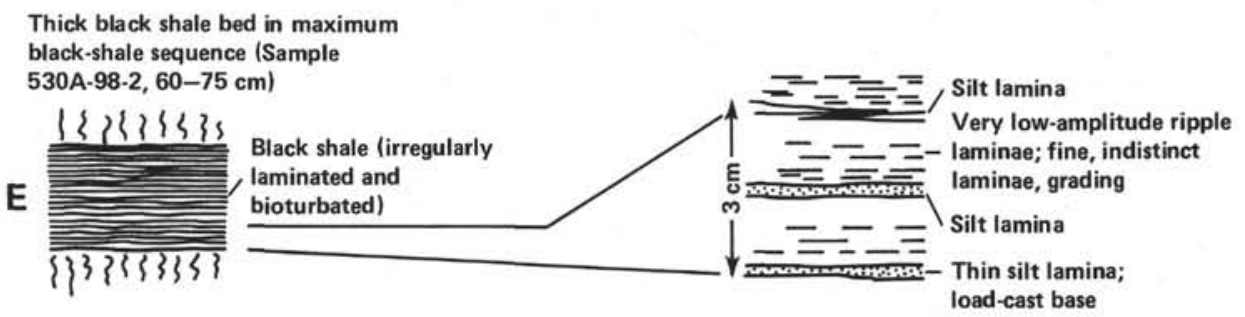

Thinnest black shale-green claystone layers in maximum black-shale sequence (Sample 530A-98-1, 110-112 cm):

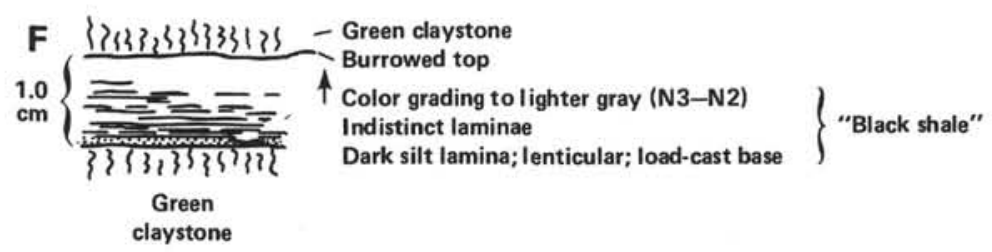

Figure 39. Details of interbedding of green and red mudstone and black shale in lithologic Unit 8, Hole 530A, Cores 87-105. 


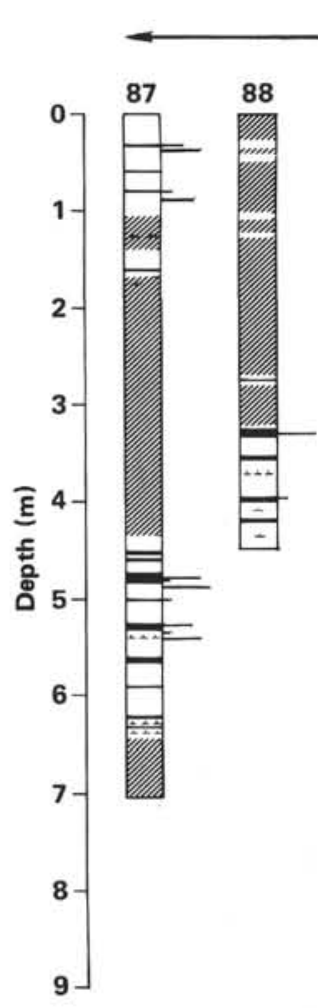

- Coniacian-Santonian
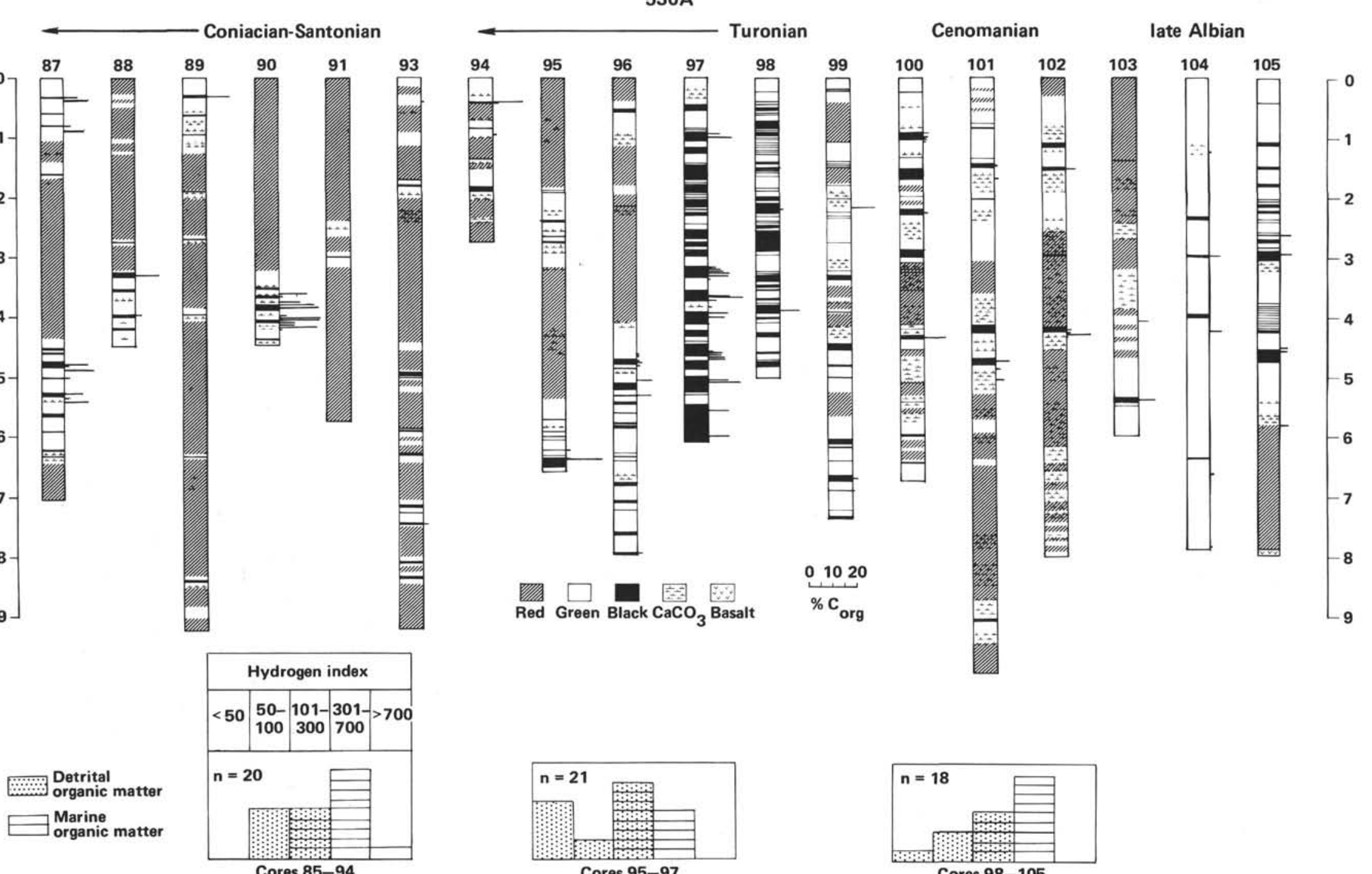

Cores 95-97

Cores $98-105$

Figure 40. Summary stratigraphic columns of Cores 87 through 105 from Hole 530A showing the distribution of red and green claystone, black shale, and CaCO ${ }_{3}$ Concentrations of organic carbon $\left(\mathrm{C}_{\text {org }}\right)$ are indicated by bars to the right of each column; $\mathrm{C}_{\mathrm{org}}$ data are from Deroo et al., and Meyers, Brassell, and Huc (this volume). Histograms of the Rock-Eval hydrogen index for organic matter in Cores 85-94, 95-97, and 98-105 are from Deroo et al. (this volume). 
organic-rich layer, to reducing bottom water conditions in which organic matter was preserved as black shale.

These two interpretations are not mutually exclusive, and both processes may have operated. An increase in organic productivity and supply of organic matter to the sediments would place an increased oxygen demand on the water column as well as on the sediments. If the bottom waters were delicately poised at a low oxygen level, an increased oxygen demand could result in anoxic bottom water to help preserve the organic matter. The common interbedding of red, green, and black layers, and the bioturbation of much of the sediment but its absence in parts of the black shales, suggests that there was a delicate balance between oxidizing and reducing conditions in the Angola Basin waters and sediments at this time.

There are three groups of factors affecting oxygen concentration that are related to black shale deposition at Site 530: tent:

I. Factors acting to reduce seawater oxygen con-

1) Deposition in a relatively small, silled basin with restricted circulation;

2) Transport of terrestrial plant material seawards during transgression over low-lying land areas;

3) Presence of local restricted anoxic shelf basins and coastal lagoons or swamps, providing sinks for organic matter;

4) Enhanced production of marine plankton on wide shelves;

5) Increased evaporation over wide shelves, producing dense saline oxygen-depleted waters; and

6) Density currents transporting warm, saline, oxygen-depleted waters as well as organic-rich sediments to the basin.

II. Factors acting to increase seawater oxygenation:

1) Wind-forced advection of water masses;

2) Geothermal heating of the basin causing mixing or overturn; and

3) Circulation and overturn by saline water and turbidity current movement.

III. Factors affecting oxygen content of sediments:

1) Oxygen content of overlying sea water; and

2) Rate of supply of organic material, rate of burial, and rate of consumption by aerobic benthic organisms and chemical oxidation.

Black shales in the South Atlantic were formed during two distinct periods: the Aptian to early Albian and late Albian to early Santonian. These periods probably represent a coincidence of several factors acting to produce and preserve organic matter. The earlier event was widespread; it has been observed in the Angola Basin (Site 354), the Cape Basin (Site 361), and the Falkland Plateau (Sites 327, 330, and 511). The later event is of more limited occurrence, being previously known as late Albian to Coniacian, and described from the Angola Basin (Sites 363 and 364) and the northern slope of the Rio Grande Rise (Site 516).

During most of the Late Cretaceous the Angola Basin was sufficiently oxygenated to support an active benthic infauna. There were periods of shorter and longer duration when several of the factors noted above combined to produce bottom water conditions that fluctuated between mildly oxic and barely anoxic. Pelagic, hemipelagic, and turbiditic processes continued during these periods, but the black and gray-black sediments deposited contained and preserved a higher content of organic material and were not bioturbated or at least less bioturbated.

At Site 530, black shales of late Albian to early Santonian age contain up to $18 \%$ organic carbon and are comparable with those of similar age from Site 364. Shipboard analyses show that the organic matter in the black shales is mainly derived from marine organisms, but a few samples also contain organic matter of terrestrial origin. This situation is very similar to that at Site 364 where the upper Albian-Coniacian black shales contain organic matter either of marine origin or of mixed marine/terrestrial origins with up to $8 \%$ plant debris. In contrast, the organic matter of the earlier Aptian-Albian black shales at Site 364 was derived wholly from marine sources. All of the organic matter within the black shales is immature, as shown by the low production index, the temperature of the maximum hydrocarbon production during Rock-Eval pyrolysis, and the absence of significant levels of gaseous hydrocarbons formed by diagenetic processes.

\section{Inoceramus and Isotopic Paleotemperatures}

Inoceramus shells are only rarely associated with turbidite deposits at Hole 530A. This fact suggests that the Inoceramus lived at depths of $3500-4500 \mathrm{~m}$, based on thermal subsidence curves for normal oceanic crust. This greatly extends the depth habitat of Inoceramus from that described previously from DSDP cores (Thiede and Dinkelman, 1976; <2000 m).

The calcite ostracum of Inoceramus is typically well preserved and provides good material for oxygen isotopic analyses. Inoceramus can be an important source of paleotemperature data at Mesozoic sites lacking well preserved foraminifers. Samples from Site 530A typically give isotopic temperatures of $14-17^{\circ} \mathrm{C}$ (see discussion by Barron et al., this volume).

\section{BIOSTRATIGRAPHY}

\section{Calcareous Nannoplankton}

\section{Hole 530}

Calcareous nannofossils were found in both cores taken in Hole 530. They were common to abundant in both core-catcher samples studied, and showed moderately good preservation. Diatoms and silicoflagellates were noted in both samples.

A Pleistocene assemblage was found in Sample 530-1, CC (1.5 m sub-bottom) as indicated by the presence of:

Gephyrocapsa oceanica Umbilicosphaera mirabilis Syracosphaera histrica Rhabdosphaera clavigera 
The presence or absence of Emiliania huxleyi will be determined with the electron microscope in shore-based studies.

The second sample studied, Sample 530-2,CC (123.8 $\mathrm{m}$ sub-bottom) contained an assemblage characteristic of the late Pliocene:

\begin{tabular}{ll}
\hline Discoaster surculus & Discoaster brouweri \\
Discoaster pentaradiatus & Discoaster asymmetricus \\
Ceratolithus delicatus & Reticulofenestra pseudoumbilica \\
\hline
\end{tabular}

\section{Hole 530A}

Calcareous nannofossils were found in varying abundances and states of preservation in most of the 105 sediment cores from Hole 530A. Several intervals were encountered in which nannofossils were completely absent. Unfortunately some of these cover important biostratigraphic transitions. Drilling operations at Hole $530 \mathrm{~A}$ consisted of washing down to $125.0 \mathrm{~m}$ sub-bottom before taking the first core; hence recovery began in sediments of Pliocene age.

\section{Pliocene}

Sediment samples from 1,CC to 7,CC (129.2 m-190.4 $\mathrm{m}$ sub-bottom) contain abundant, moderately well-preserved assemblages indicative of the early Pliocene. Typically present are:

\begin{tabular}{ll} 
Discoaster asymmetricus & Discoaster brouweri \\
Discoaster challengeri & Discoaster pentaradiatus \\
Reticulofenestra pseudoumbilica & Cyclococcolithus macintyrei \\
Cyclococcolithus leptoporus & \\
\hline
\end{tabular}

Generally there is the expected increase in age of assemblage with depth (i.e., 1,CC is NN15, 7,CC is NN13); however, this is in part obscured by the presence of reworked Oligocene and Miocene nannofossils in 2,CC and $3, \mathrm{CC}$. Diatoms and silicoflagellates are present in notable amounts in 1,CC and 2,CC but are absent throughout the remainder of Hole 530A.

\section{Miocene}

There is a progression of species from the upper Miocene into the Pliocene without evidence of a hiatus between Miocene and Pliocene sediments. Late Miocene sediments were recovered in $8, \mathrm{CC}$ through $17, \mathrm{CC}$ (201.0-285.4 m sub-bottom). Nannofossils are for the most part abundant and moderately well preserved. Nannofossil Zone NN11 is present in 8,CC with:

\begin{tabular}{ll}
\hline Discoaster quinqueramus & Discoaster brouweri \\
Discoaster pentaradiatus & Ceratolithus tricorniculatus \\
Ceratolithus delicatus & Sphenolithus abies \\
Reticulofenestra pseudoumbilica & \\
\hline
\end{tabular}

The middle to late Miocene Discoaster quinqueramus Zone, NN11, is also present in 9,CC through $14, \mathrm{CC}$ as is indicated by the presence of:
Discoaster quinqueramus Discoaster neohamatus

Discoaster calcaris Discoaster bollii

The Discoaster calcaris Zone, NN10, is present in 15,CC through $17, \mathrm{CC}$ as indicated by the occurrence of:

$\begin{array}{ll}\begin{array}{l}\text { Discoaster neorectus } \\ \text { Discoaster stellulus }\end{array} & \text { Discoaster pansus } \\ \text { Discoaster bollii } & \text { Discoaster icarus }\end{array}$

Middle Miocene assemblages are moderately well to poorly preserved in Section 18-3 (289 m) and Sections $22, \mathrm{CC}$ to $24-1$ (334.0 to $344.3 \mathrm{~m}$ ). The Discoaster kugleri Zone, NN7, is present in $22, \mathrm{CC}$ as indicated by the occurrence of:

\section{Discoaster kugleri Discoaster pseudovariabilis} Discoaster exilis Discoaster variabilis

The Sphenolithus heteromorphus Zone, NN5, is represented in 23,CC and 24-1 by Sphenolithus heteromorphus, Sphenolithus moriformis, and Cyclicargolithus floridanus.

Samples $24, \mathrm{CC}$ through $33, \mathrm{CC}(352.9-434.4 \mathrm{~m})$ contain little or no carbonate, and these sediments, or presumably early Miocene or latest Oligocene age, are barren of nannofossils.

\section{Oligocene}

Sediments containing Oligocene nannofossils were found in Sections 34-6, 35-3, and 37-1 (446.0, 451.1, and $468.0 \mathrm{~m}$, respectively). Samples of Sections 34-6 and 35-3 contain an assemblage indicative of the middlelate Oligocene:

$\begin{array}{ll}\text { Sphenolithus distentus } & \text { Sphenolithus ciperoensis } \\ \text { Helicosphera intermedia } & \text { Cyclicargolithus floridanus } \\ \text { Discoaster trinidadensis } & \text { Reticulofenestra bisecta }\end{array}$

Samples of Section 37-1 contain a mixed assemblage of Oligocene and Eocene forms. Braarudosphaera bigelowi is very abundant, and Sphenolithus distentus indicates NP23 to NP25 (middle to late Oligocene). Discoaster saipanensis and $D$. tani suggest a late Eocene admixture. Samples 35,CC and 36,CC (455.9 and $459.0 \mathrm{~m}$, respectively) are barren of nannofossils.

\section{Eocene}

Sediments of Eocene age are present in Sections 37-2 to $39, \mathrm{CC}(469.3-488.9 \mathrm{~m})$. Nannofossils present are common and poorly to moderately well preserved. The late Eocene (NP19/20) is present in Section 37-2 as indicated by the occurrence of:

$\begin{array}{ll}\text { Isthmolithus recurvus } & \text { Discoaster saipanensis } \\ \text { Reticulofenestra bisecta } & \text { Reticulofenestra umbilica } \\ \text { Sphenolithus moriformis } & \end{array}$


The middle Eocene Nannotetrina alata Zone, NP15, occurs in 37,CC. Notable are the following species:

$\begin{array}{ll}\text { Nannotetrina alata } & \text { Nannotetrina swasticoides } \\ \text { Chiasmolithus consuetus } & \text { Heliorthus fallax } \\ \text { Triquetrorhabdulus inversus } & \end{array}$

The early to middle Eocene Discoaster lodoensis Zone, NP13, is present in $38, \mathrm{CC}$ and $39, \mathrm{CC}$. This is indicated by the occurrence of:

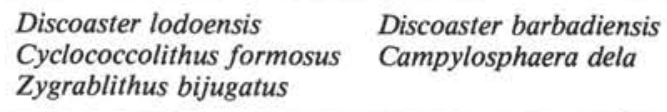

Several nannofossil zones are missing between the early-middle Eocene found in $39, \mathrm{CC}$ and the latest $\mathrm{Pa}$ leocene of $40, \mathrm{CC}$. Possibly these missing nannoplankton zones (NP10/NP12) will be found in the samples from the sections taken for shore-based studies.

\section{Paleocene}

Paleocene sediments were recovered in Sections 40, $\mathrm{CC}$ to 50-2 (501.2-592.0 m). Nannofossils are rare to abundant and poorly to well preserved.

The late Paleocene Zones NP8 and NP9 were recovered in $40, \mathrm{CC}$ to $43, \mathrm{CC}$. The Discoaster multiradiatus Zone, NP9, occurs in 40,CC and 41,CC (501.2-509.7 $\mathrm{m})$. Commonly present are:

$\begin{array}{ll}\text { Discoaster multiradiatus } & \text { Discoaster ornatus } \\ \text { Discoaster lenticularis } & \text { Rhomboaster cuspis } \\ \text { Fasciculithus involutus } & \text { Ellipsolithus macellus } \\ \text { Toweius eminens } & \end{array}$

The Heliolithus riedeli Zone, NP8, occurs in 42,CC and $43, \mathrm{CC}(518.0-527.2 \mathrm{~m})$. Typically present are:

$\begin{array}{ll}\text { Discoaster gemmeus } & \text { Heliolithus riedeli } \\ \text { Fasciculithus involutus } & \text { Chiasmolithus bidens }\end{array}$

The middle Paleocene Zones NP5 and NP6 are present in 44,CC to 47,CC (536.3-564.4 m). The Heliolithus kleinpelli Zone, NP6, occurs in $44, \mathrm{CC}$ to $46, \mathrm{CC}$, as indicated by the presence of:

$\begin{array}{ll}\text { Heliolithus kleinpelli } & \text { Prinsius bisulcus } \\ \text { Fasciculithus involutus } & \text { Toweius eminens }\end{array}$

The only occurrence of the Fasciculithus tympaniformis Zone, NP5, was observed in 47,CC (564.4 m) with poorly preserved:

\section{Fasciculithus tympaniformis Markalius astroporus \\ Zygodiscus plectopons Cruciplacolithus tenuis}

The early Paleocene Ellipsolithus macellus Zone, NP4, was not encountered in the core-catcher samples.
Zones NP3 to NP1, however, were noted in 48,CC to 50-2 (573.6-592.0 m).

The Chiasmolithus danicus Zone, NP3, is present in $48, \mathrm{CC}$ as indicated by:

Chiasmolithus danicus Cruciplacolithus tenuis

Zygodiscus plectopons Coccolithus crassus

The Cruciplacolithus tenuis Zone, NP2, in 49,CC $(583.2 \mathrm{~m})$ is indicated by the presence of:
Cruciplacolithus tenuis
Coccolithus crassus
Thoracosphaera operculata Thoracosphaera saxea
Toweius cf. callosus

The Markalius inversus Zone, NP1, is present just above the Cretaceous/Tertiary boundary at $50-2,14 \mathrm{~cm}$. Commonly present and exceptionally well preserved are:

$\begin{array}{ll}\text { Markalius inversus } & \text { Coccolithus pelagicus } \\ \text { Coccolithus crassus } & \text { Thoracosphaera operculata } \\ \text { Thoracosphaera saxea } & \text { Zygodiscus sigmoides } \\ \text { Biantholithus sparsus } & \end{array}$

Reworked Maestrichtian nannofossils are also present.

\section{Cretaceous/Tertiary Boundary}

The Cretaceous/Tertiary boundary is well represented by nannofossils in Section 50-2 $(593.0 \mathrm{~m})$. The nannofossils are moderately well preserved and common to abundant. Table 4 shows the occurrences of nannofossils at intervals sampled in Core 50, Section 2. They reveal that the boundary, as far as can be judged by calcareous nannoplankton, lies between 14 and $53 \mathrm{~cm}$ in Section 2. Paleomagnetic studies (Keating, this volume) show a shift in polarity from normal above to reversed below, presumably coinciding with the boundary event, between 62 and $63 \mathrm{~cm}$. Further shore-based studies should reveal the precise location of the boundary in terms of first occurrences of Tertiary nannoplankton.

\section{Upper Cretaceous}

Cretaceous calcareous nannofossils were encountered from Core 50 down to Core 105, Section 4 (590.5-1098.5 $\mathrm{m})$. Within Core 50, where the Cretaceous/Tertiary boundary lies, the late Maestrichtian Micula mura Zone with well-preserved nannofossils was found overlapping the early Paleocene NP1 Markalius inversus Zone. Either there was reworking of nannofossils by burrowing animals or there is an actual overlap of the ranges.

$\begin{array}{ll}\text { Micula mura } & \text { Arkhangelskiella cymbiformis } \\ \text { Zygodiscus spiralis } & \text { Cribrosphaerella numerosa } \\ \text { Biscutum constans } & \text { Microrhabdulus stradneri } \\ \text { Micula prinsii } & \text { Nephrolithus frequens } \\ \text { Cylindralithus gallicus } & \text { Prediscosphaera spinosa }\end{array}$

This assemblage is assigned to the upper Maestrichtian.

From 51,CC to 54,CC (607.5-629.9 m) there are abundant Micula staurophora and Arkhangelskiella cymbi- 
Table 4. Occurrence of calcareous nannofossils at the Cretaceous/Tertiary boundary, Section 530A-50-2.

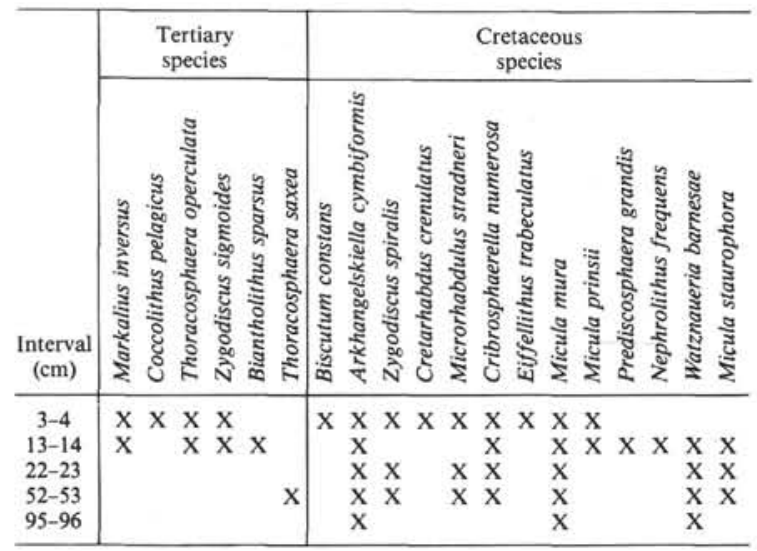

formis (large-sized specimens), but the diversity of the assemblage is reduced because of poor preservation.

From 55,CC down to 63,CC (645.5-718.7 m), we found Quadrum trifidum ( $=$ Tetralithus trifidus) which is correlated with upper Campanian to lower Maestrichtian. Using calcareous microfossils, the Campanian/ Maestrichtian boundary is best marked by the extinction of Broinsonia parca, which was found from 56,CC down to $70, \mathrm{CC}(650.2-784.3 \mathrm{~m})$. On board ship the Campanian/Maestrichtian boundary was tentatively assumed to be within Core 56. This, however, is not in agreement with subsequent paleomagnetic data indicating that the base of the Maestrichtian lies between Cores 59 and 60 .

The Ceratolithus aculeus Zone, which, according to Thierstein (1976), ranges from middle to late Campanian, was found in $64, \mathrm{CC}$ to $66, \mathrm{CC}(729.5-742.7 \mathrm{~m})$. The base of the Broinsonia parca range zone seems to be in Core $77, \mathrm{CC}(856.5 \mathrm{~m})$, indicating the base of the Campanian. Below Core 77 no Broinsonia were encountered.

According to van Hinte (1970) the range zone of Marthasterites furcatus, which at Hole 530A occurs from $76, \mathrm{CC}(845.0 \mathrm{~m})$ down to $94-2(1009.5 \mathrm{~m})$, is middle Santonian to middle Coniacian, but most recent authors (Perch-Nielsen, 1978; Thierstein, 1976; Sissingh, 1977) consider it to range from middle Santonian to the base of the Coniacian. Micula staurophora, which first appears in the upper Turonian, also has its lowermost occurrence in Core $94, \mathrm{CC}$, so that it can be assumed that there is a hiatus between 94-2 and 95,CC.

\section{Mid-Cretaceous}

Below 94,CC no representative of Micula or Quadrum was found. Gartnerago obliquum in 95,CC (1014.6 $\mathrm{m}$ ) indicates an age of late Cenomanian or younger (according to Perch-Nielsen, 1979).

Between Cores 96 and 105 only very reduced nannoplankton assemblages were found, with all the more delicate species destroyed by corrosion. In addition to Watznaueria barnesae, Lithastrinus floralis, Lithastrinus moratus, and Eprolithus apertior are common. The co-occurrence of species of the genera Eiffellithus and Prediscosphaera in Section 105-4 indicate the Eiffellithus tur-

riseiffeli nannoplankton zone, which ranges from middle Albian to lower Cenomanian. No peak in abundance was observed for $E$. turriseiffeli.

According to the ranges given by Perch-Nielsen (1979), Eprolithus apertior ranges from upper Aptian to lower Cenomanian. This species was found from Section 97-3 down to 105-4 (1029.0-1098.5 m), whereas the range of $L$. moratus, which was found in Core 96 and Section 97-3 indicates upper Cenomanian to Coniacian.

On the basis of these ranges of $L$. moratus and $E$. apertior, Cores 96 and 97 are considered Cenomanian, those below as upper Albian to lower Cenomanian.

\section{Hole 530B}

Calcareous nannofossils recovered from Hole 530B were for the most part common to abundant and moderately to well preserved. Of the 48 core-catcher samples studied (to $180.6 \mathrm{~m}$ sub-bottom), only two were completely barren of nannofossils: $17, \mathrm{CC}$ and $22, \mathrm{CC}$.

\section{Quaternary}

Sediments from core-catchers 1 through $7(0-27.8 \mathrm{~m}$ sub-bottom) are Pleistocene/Holocene age, NN20/21. Abundant and moderately well preserved assemblages of nannofossils consist of Gephyrocapsa oceanica, Gephyrocapsa sp., Crenalithus doronicoides, Helicosphaera carteri, Coccolithus pelagicus, and Cyclococcolithus leptoporus. The presence or absence of Emiliania huxleyi will be determined in shore-based studies with electron microscope.

The top of the Pseudoemiliania lacunosa (=Emiliania ovata) Zone, NN19, is indicated by the highest occurrence of $E$. ovata in 8,CC (32.2 m). This zone continues through $29, \mathrm{CC}(116.2 \mathrm{~m})$. Characteristic in the assemblage are:

Emiliania ovata

Crenalithus doronoicoides

Helicosphaera carteri

Reticulofenestra pseudoumbilica

The assemblage is supplemented downcore with the following highest occurrences within this zone:

$\begin{array}{llr}\text { Cyclococcolithus macintyrei } & \text { 14,CC } & 58.6 \mathrm{~m} \\ \text { Helicosphaera sellii } & \text { 21,CC } & 88.0 \mathrm{~m} \\ \text { Emiliania annula } & \text { 21,CC } & 88.0 \mathrm{~m} \\ \text { Ceratolithus cristatus } & \text { 29,CC } & 116.2 \mathrm{~m}\end{array}$

\section{Pliocene}

The Plio/Pleistocene boundary is located between $29, \mathrm{CC}$ and $30, \mathrm{CC}$ (116.2 $\mathrm{m}$ and $118.2 \mathrm{~m}$, respectively), although the exact horizon is probably obscured by sediment debris flows.

In 30,CC the simultaneous first occurrences of Discoaster brouweri, D. tamalis, D. variabilis, and D. surculus, as well as Sphenolithus abies, indicate that the upper Miocene and lower and upper Pliocene are thoroughly mixed. The remainder of the section to $48, C C$ $(180.6 \mathrm{~m})$ is a mixture of these transported sediments. 
Throughout this mixed interval are found common to abundant assemblages of moderately to well-preserved nannofossils. Included are:

\begin{tabular}{ll} 
Coccolithus pelagicus & Helicosphaera carteri \\
Cyclococcolithus leptoporus & Cyclococcolithus macintyrei \\
Reticulofenestra pseudoumbilica & Discoaster exilis \\
Discoaster asymmetricus & Discoaster pentaradiatus \\
Discoaster kugleri & Ceratolithus delicatus \\
Ceratolithus tricorniculatus & \\
\hline
\end{tabular}

Diatoms and radiolarians also occur, especially in the darker portions of sediment. They decrease in numbers downhole until only rare sponge spicules are the sole siliceous fossils.

\section{Foraminifers}

The foraminiferal record of Holes 530 and $530 \mathrm{~A}$ is meager except for the Pliocene and younger sediments. The sparsity of the Cretaceous record results from the recrystallized condition of specimens, which disaggregate during the preparation of samples, as well as from the barren condition of the rock. The poor record of the pre-Pliocene part of the Tertiary is the result of the absence of foraminifers in the sediments, apparently as a result of deposition below the lysocline.

\section{Hole 530}

\section{Quaternary}

A sample from Core 1,CC (1.5 m) contains a Pleistocene planktonic assemblage, including Globorotalia truncatulinoides. G. inflata is abundant, and many tropical planktonic species are absent or reduced, as would be expected from the location of the site in the Transitional Province of Bé, 1977.

\section{Pliocene}

Samples from Core $2(115.5-125.0 \mathrm{~m})$ lack Globorotalia truncatulinoides but contain some late Pliocene species, including Globoquadrina altispira, Globigerinoides extremus, and Sphaeroidinellopsis subdehiscens (s.l.). Globorotalia inflata is abundant, suggesting correlation with the late Pliocene part of the Globorotalia inflata Zone.

\section{Hole 530A}

\section{Pliocene}

Residues from Cores 1 through 3 (125.0-153.5 m) contain both Globorotalia inflata and G. puncticulata, indicating the upper Globorotalia puncticulata Zone of the late Pliocene. Cores 4 through 7 (153.5-191.5 m) contain G. margaritae as well as G. puncticulata, which provides close correlation with the $G$. margaritae Zone and the middle of the G. puncticulata Zone, of the early Pliocene.

\section{Miocene}

Foraminiferal populations from Cores 8 through 20 $(191.5-315.0 \mathrm{~m})$ are small, infrequent, and poorly pre- served (etched, broken, and typically dominated by tiny, simple globigeriniforms). Because of the $G$. margaritae zone above and the $G$. fohsi Zone below, this interval can be assigned to the late Miocene but cannot be correlated more precisely with confidence; it may be in part middle Miocene.

Infrequent samples from Cores 21 through 23 (315.0$343.5 \mathrm{~m})$ contain rare but definite Globorotalia fohsi peripheroronda and abundant elements of the Globigerinoides sicanus-Praeorbulina glomerosa plexus, which indicate respectively the $G$. fohsi peripherorond $a$ and $P$. glomerosa Zones of the middle Miocene.

The interval of Cores 24 through 29 (343.5-400.5 m) was correlated with the lower Miocene because of the presence of very rare Globigerinatella insueta (Samples 530A-24-1, 85-87 cm and 29-2, 25-27 cm), of infrequent, poorly preserved, but apparent Globorotalia siakensis and G. kugleri, and, in lower cores, of large ?Globigerina tripartita.

\section{Oligocene}

The interval of Cores 30 through 36 (400.5-467.0 m) was assigned to the Oligocene, but there is little evidence of how much is actually of that age. The few samples containing foraminifers in number are displaced populations, composed in the main of large, abraded, organic grains of apparent shelf origin. In these, the foraminiferal populations are dominated by very large specimens of the Globigerina linaperta group, such as G. tripartita, which are characteristic of the Oligocene but appear before and continue after the epoch. Species of Catapsydrax are also prominent and have a similar range. It seems that the planktonic fauna is displaced as well as the megafossil grains. Very rare tiny specimens of $G$. angulosuturalis and $G$. angioporoides were found in Sample 503A-34-6, 14-15 cm.

\section{Paleogene}

The distribution of Paleogene planktonic foraminifers is shown in Table 5. The interval from Cores 37 through $39(467.0-495.5 \mathrm{~m})$ contains rare and poorly preserved Globorotalia aragonensis and $G$. bullbrooki, indicating correlation with late early to middle Eocene (P8-10).

Cores 40 through $42(495.5-524.0 \mathrm{~m})$ yielded a few very poorly preserved and consequently questionable $G$. aequa, G. subbotinae, and $G$. velascoensis. Globigerina linaperta is common in some samples. The assemblage suggests late Paleocene-early Eocene (P6).

The interval of Cores 46 through $49(552.5-590.5 \mathrm{~m})$ was assigned to the early-middle Paleocene (P1-P3) because of rare, persistent Globigerina triloculinoides. One specimen of Globorotalia angulata, one of G. pusilla, and one of Globigerina mckannai in sequence suggest that the succession records the three zones.

\section{Cretaceous/Tertiary Boundary}

Foraminiferal evidence of the Cretaceous/Tertiary boundary is poor. Globotruncanids occur as high as Samples 530A-49-1, 30-32 cm, but specimens of Globigerina triloculinoides (Plummer) continue down to Sample $530 \mathrm{~A}-50-1,39-41 \mathrm{~cm}$. One to three very poorly pre- 
Table 5. Distribution of selected planktonic foraminiferal species for the Paleogene, Hole 530A.

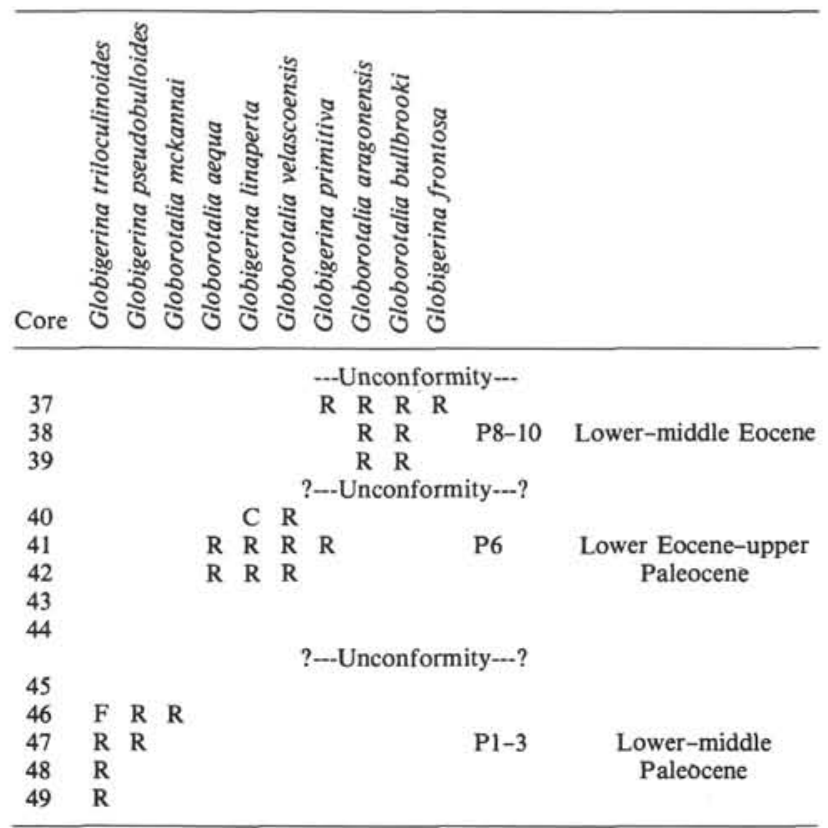

served specimens of globotruncanids occur in Sample $530 \mathrm{~A}-50-4,18-20 \mathrm{~cm}$ and infrequently in subsequent samples down through Core 55. Benthonic specimens are more frequent and numerous than planktonic specimens in Cores 50 through 55, but they are rare to sparse in all but a few samples (e.g., Sample 530A-51-2, 62-64 $\mathrm{cm})$. The benthonic fauna is characterized by species that continue into the Tertiary and is of little help in the boundary problem.

\section{Upper Cretaceous}

The interval from Sample 530A-50-2, 10-14 cm through Core $80, \mathrm{CC}$ is Maestrichtian-Campanian. It is distinguished by rare and infrequent, basic and simple globotruncanids and a changing association of benthonic forms. The most persistent globotruncanids are Globotruncana arca (Cushman), G. fornicata Plummer, and $G$. linneiana d'Orbigny. The most persistent benthonic species are Aragonia ouezzanensis (Rey), Gyroidina diversus (Belford), Lenticulina velascoensis White, Nuttallides? sp., Nuttallinella? spinea (Cushman), Reussella szajnochae (Grzybowski), Spiroplectammina dentata (Alth.), and Valvulineria? whitei (Martin). Some other benthonic and planktonic species occur only one or two times but have chronostratigraphic significance, as will be mentioned. (See Table 6 for distribution of selected Cretaceous species.)

One or two poor specimens of Globotruncana contusa (Cushman), G. gansseri Bolli, questionable Abathomphalus mayaroensis (Bolli), and Pseudotextularia deformis (Kikoine) were found in residues from Cores 50 through 60 , but no other evidence of Maestrichtian and none of the Maestrichtian/Campanian boundary were provided by the plankton.
The lower boundary of this interval and of the Campanian was chosen at $80, \mathrm{CC}$ because of the overlying appearance of Dicarinella asymetrica (Sigal), Globotruncana elevata (Brotzen), G. stuartiformis Dalbiez, G. ventricosa White, Planoglobulina glabrata (Cushman), Aragonia ouezzanensis (Rey), Lenticulina velascoensis White, Reussella szajnochae (Grzybowski), and Spiroplectammina dentata (Alth.). Some of these, such as $G$. elevata and $P$. glabrata, are rare and are present in only one or two samples from Core 79. Others, such as A. trinitatensis and Reussella szajnochae, have variously reported appearances which include some older than Campanian. Nevertheless, the general aspect of the fauna is Campanian.

The interval from Core 80 through Core 92 is Santonian to Coniacian. It is distinguished by simple, doublekeeled marginotruncanids and varying benthonic forms. The margintruncanids include Marginotruncana coronata Bolli, $M$. pseudolinneiana Pessagno, $M$. concavata (Brotzen), and $M$. sinuosa Porthault, of which all are double-keeled forms. The benthonic fauna includes $A$. materna kugleri Beckmann and Koch, Nuttallinella? sp. (= Gyroidinoides conicus of authors), Osangularia popenoei (Trujillo), and Spiroplectammina chicoana Lalicker. The marginotruncanids are not very useful, except for $M$. concavata, which is confined to the Coniacian and Santonian. However, the benthos and the infrequent, rare presence of Hedbergella flandrini Porthault indicate a maximum age of latest Turonian; the persistent occurrence of A. materna kugleri through most of the section is also persuasive.

The interval from Core 93 through Core 95 contains foraminifers of contradictory implications. The bicarinate marginotruncanids continue through this interval to Sample 530A-95-2, 9-10 cm. However, $M$. concavata and $H$. flandrini were not seen, nor were the helpful benthonic species of the overlying interval, with the possible exception of $S$. chicoana. Moreover, the prominence of Dorothia filiformis (Berthelin), Pseudoclavulina gaultina (Morozova), and Schackoina cenomana bicornis Reichel (not to be confused with S. multispina) give the faunules an aspect of the Cenomanian, or older. Of course, these may be reworked specimens; alternatively, the marginotruncanids could be from cavings. Possibly both reworking and redrilling have affected residues of a short, erratically interrupted sequence, assigned herein to ?lower Turonian, representing a sedimentary gap widely reported for the South Atlantic (Sliter, 1977, p. 531).

\section{Lower Cretaceous}

The interval from Core 96 to the bottom of the sedimentary succession in Core 105 is distinguished by an extreme rarity of planktonic species and dominance of benthonic species. Neither the plankton nor the benthos provides detailed correlation, but the benthonic species are definitely of Lower Cretaceous aspect, and more of the Albian than of the Aptian. Except for one or two specimens elsewhere, the planktonic fauna is known on- 
Table 6. Distribution of selected species for the Cretaceous, Hole 530A.

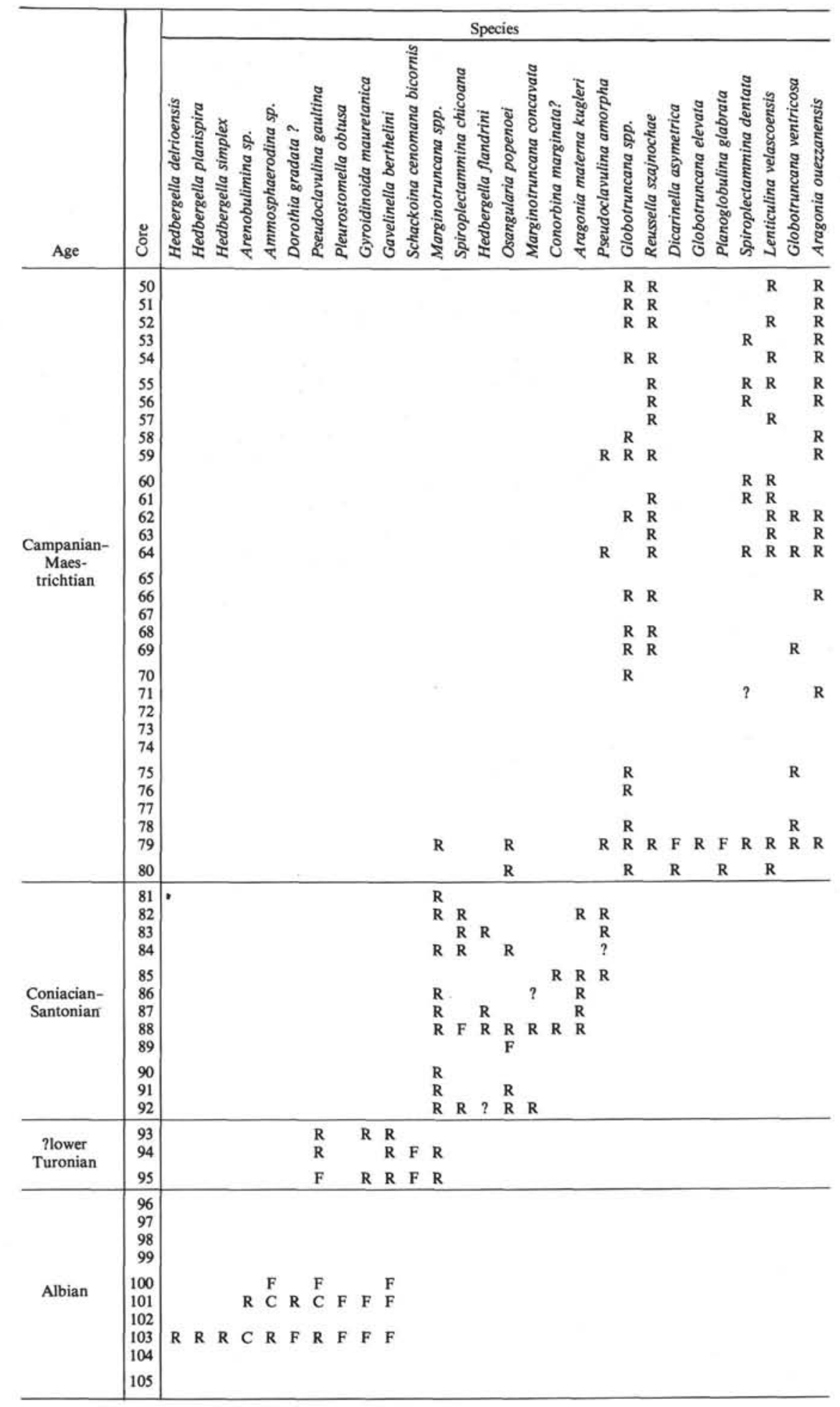

ly from Sample 530A-104-2, 40-42 cm, in which a narrow assemblage of hedbergellids occurs: $H$. delrioensis (Carsey), H. planispira (Tappan), and H. simplex (Morrow). The specimens appear to have come from a turbiditic foraminiferal calcarenite.

The pale red claystones of this interval contain rare, primitive, agglutinated quartzose species, such as $\mathrm{Am}$ modiscus, Bathysiphon, Glomospira, Hyperammina, and Trochammina. Similar faunas and sediments have been reported (Krasheninnikov, 1973, 1975; McNulty, 1979) and interpreted as deposits situated well below the carbonate compensation depth (Arthur and Natland, 1979).

Light gray claystones and lamina of calcarenite yielded common to abundant benthonic species from four samples. This fauna is characterized by large, smoothly 
finished agglutinates, relatively diverse but individually rare displaced lagenids, narrowly diverse pleurostomellids, and narrowly diverse cassidulinids. Conspicuous among the agglutinates are: Ammosphaeroidina sp., Arenobulimina sp., Dorothia gradata (Berthelin)?, and Pseudoclavulina gaultina (Morozova). The hyaline species are general and conservative forms (e.g., Gavelinella berthelini (Keller), Gyroidina? mauretanica Charbonnier, Lingulogavelinella sp., and Pleurostomella obtusa Berthelin). Typically, they occur as a few specimens in one or two of the samples; the total fauna is larger than that from one sample, but they are, as a group, indicative only of late Early Cretaceous.

It should be noted that radiolarians are common to abundant at several horizons of this interval. Their abundance appears to coincide with olive greenish gray claystones and, typically, with rarity or total absence of foraminifers. Inoceramid prisms occur in several samples of this interval. Their occurrence coincides with common foraminifers in two cases but does not in others.

No coincidence of biogenic grains and dark grayblack claystones was observed. Foraminifers were absent from the black claystones of Cores 97 and 98, although pyritized radiolarians were found. However, the best preserved and most abundant planktonic specimens of the Mesozoic came from the black claystones of Sample $530 \mathrm{~A}-88-3,120-122 \mathrm{~cm}$.

About $25 \%$ of the 148 samples from the Mesozoic of Hole $530 \mathrm{~A}$ yielded relatively common $\left(0.2 \mathrm{~cm}^{3}\right.$ specimens from $10 \mathrm{~cm}^{3}$ sample) foraminifers. The infrequency results in part from (1) recrystallization and induration, such as is found in Cores 50 through 60; in part from (2) diagenetic dissolution and rupture from treatment-swelling volcanogenic clays, such as occur in Cores 65 through 75; and in part from presumably both preand post-depositional dissolution, such as occurs throughout the samples.

Populations are dominated by species resistant to dissolution, such as certain agglutinates and cassidulinids. Planktonic forms are infrequent, poorly preserved, and typically rare when present. Reworking is common, and the actual age is indicated by the younger component. When the latter is represented by one to four specimens of one to three species, the question of redrilled cavings arises.

It is not possible to correlate with planktonic foraminiferal biozones, although the gross distribution of globotruncanids and marginotruncanids was useful, as has been noted above. The relative persistence and range of certain benthonic forms combine with the marginotruncanids to allow approximate correlation with Cretaceous stages.

The rarity of planktonic forms, the pervasive condition of severe dissolution of all forms, the low taxonomic diversity, and the extent of primitive, quartzose, agglutinated benthos suggest deposition below the foraminiferal lysocline and close to the CCD. The dominance of a few basic, double-keeled forms among both the marginotruncanids and the globotruncanids suggests relatively cold and high latitudinal paleotemperatures of surface waters.

\section{Hole 530B}

Hole 530B was piston-cored from the seafloor to 180.6 $\mathrm{m}$ (Cores 530B-1 through 50). Samples vary from Pleistocene to late Miocene in age. The Transitional Province aspect (Bé, 1977) encountered in Hole 530A continues and is emphasized through the absence of the Globorotalia puncticulata- $G$. inflata sequence and the $G$. miozea plexus (Jenkins, 1978).

\section{Quaternary}

Globorotalia truncatulinoides and, less commonly, G. tosaensis occur through Core 8, below which they are infrequent and rare. However, they persist through Core 29. Globoquadrina altispira, Globigerinoides extremus, and Globorotalia puncticulata occur just below this level, suggesting placement of the Pliocene/Quaternary boundary at Core $30, \mathrm{CC}(116.2 \mathrm{~m})$ and correlation of the interval with the Globorotalia inflata Zone (Jenkins, 1978).

\section{Pliocene}

Below Core 29 foraminiferal occurrence is erratic and contradictory, suggesting repeated reworking. However, Globorotalia inflata was not found below Core 39, suggesting a boundary of the $G$. puncticulata Zone at the horizon of Cores 39-40. Good G. margaritae occur at several horizons, such as Cores $33,36,40$, and 46 . If Core 40 is accepted as the top of the G. puncticulata Zone, the occurrence of $G$. margaritae in Core 46 and below would correspond to the G. margaritae Zone of the early Pliocene and the shallower occurrences would be a result of reworking.

\section{ACCUMULATION RATES}

To calculate accumulation rates, sedimentation rates for stratigraphic intervals of known duration were determined by dividing the thickness of sediment by the time required for its deposition. The proportion of solid phase in each stratigraphic interval was estimated from wet-bulk density data obtained by GRAPE or gravimetric techniques. Multiplying the proportion of solid phase by its density (2.7) yields the total accumulation rate, expressed in $\mathrm{g} / \mathrm{cm}^{2} \mathrm{~m} . \mathrm{y}$. The average proportions of $\mathrm{CaCO}_{3}$, opal, and $\mathrm{C}_{\text {org }}$ within each interval were determined by averaging carbonate bomb measurements, smear slide estimates, and CHN analyzer results, respectively; when multiplied by the total accumulation rate these yield the partial accumulation rates for the biogenic components. The results are given in Table 7.

The most critical part of the calculation of accumulation rates is the determination of the length of time during which a given thickness of sediment was deposited. Errors can be introduced by biostratigraphic uncertainties and by inaccurate calibration of the time scale. The calcareous nannoplankton biostratigraphy has been used to divide the stratigraphic section into intervals, with the magnetic polarity time scale used to determine stage boundaries where the biostratigraphic zonation is poorly defined. The base of a zone is placed in the middle of a core if the defining criterion was found in one core 
catcher and not in the adjacent one. Where biostratigraphic determinations are known from core sections, smaller interpolations have been made.

The age of the base of each calcareous nannofossil zone is that given by Vincent (1977) for the Neogene, and by Hardenbol and Berggren (1978) for the Paleogene. We have used stage boundaries and ages of Obradovich and Cobban (1975) for the Cretaceous. The highest and lowest occurrence levels of calcareous nannofossil species presented by van Hinte (1978) were taken from Roth (1973) and have been significantly revised by Thierstein (1976), Sissingh (1977) and Perch-Nielsen (1979). Thierstein (1976) used the Obradovich and Cobban time scale with the modification that the base of the Turonian was placed at 91 m.y. rather than 89.5 m.y. Perch-Nielsen (1979) followed Thierstein's time scale. We have correlated the highest and lowest occurrences of calcareous nannofossils given by Thierstein (1976), Sissingh (1977), and Perch-Nielsen (1979) with the original Obradovich and Cobban time scale. For calculating sedimentation rates, we have chosen the position of lowest and highest occurrence horizons indicated by PerchNielsen whenever possible, and paleomagnetic boundaries when the nannofossil assemblages are ambiguous.

\section{ORGANIC GEOCHEMISTRY}

One of the major objectives of Leg 75 was to investigate the Cretaceous organic-rich black shales in the Angola Basin. Important aspects of this investigation included identification of the organic-rich layers by $\mathrm{CHN}$ analysis and evaluation of organic matter character by Rock-Eval pyrolysis. In addition, analysis of low-molecular-weight hydrocarbons $\left(\mathrm{C}_{2}-\mathrm{C}_{5}\right)$ was done to provide evidence of biogenic and thermogenic alterations of organic matter.

At Site 530, CHN analyses were done on 157 samples. These data are given in Table 8, which also shows the percentage of carbonates, atomic $\mathrm{C} / \mathrm{N}$ ratios, and averaged values from each of the eight sediment lithologic units at this site. Units 1 and 2 are composed of pelagic clays, turbidites, and debris flows and have relativey high organic carbon contents. The $\mathrm{C} / \mathrm{N}$ ratios of organic matter in these units are fairly uniform and close to values typical of continental margin sediments (Goodell, 1972). Units 3 through 7 are organic-lean. The organic carbon contents of sediments are similar to the $0.2 \%$ found representative of surficial marine sediments by Degens and Mopper (1976). Within Unit 8, black shales averaging $5.17 \%$ organic carbon are interbedded with carbon-poor claystones.

Rock-Eval data are summarized in Table 9 and reflect the concentrations of organic carbon in these sediments. Units 1 and 2 have high $\mathrm{S}_{2}$ values, whereas the values of Units 3 through 7 are low or below detection limits. Black shale layers within Unit 8 have very high $\mathrm{S}_{2}$ values and the intervening organic-lean claystones gave low $\mathrm{S}_{2}$ responses.

In contrast to the marked differences in organic carbon content and Rock-Eval values of the various lithologic units of Site 530, gas concentrations were uniform- ly low throughout these sediments. No methane was detected, indicating little biogenic or thermogenic gas evolution from the organic-rich sediments in Units 1,2, and 8 . Small increases in gas quantities were found in black shale layers.

The sediments from Site 530 indicate that two of the sedimentary intervals merit consideration as potential source rocks: the Pleistocene to uppermost Miocene (Units 1 and 2) and the early Santonian to upper Albian black shales (Unit 8). Although the thermal maturity of both is too low to have generated significant amounts of free hydrocarbons, they are of considerable interest to organic geochemistry.

Within Unit 2 (late Miocene to Pleistocene) organic carbon contents increase from the low values of ca. $0.3 \%$ that typify Units 3 and 7 to ca. $3 \%$, a value characteristic of Unit 1. This increase in the organic carbon content through Unit 2 may reflect a higher input of organic matter arising from the development of high productivity in the overlying water column as a result of the onset of upwelling in the region during the late Miocene. In contrast, the low organic carbon contents of lithologic Units 3 through 7 (late Miocene to early Santonian) probably principally reflect an extended period of low productivity and poor preservation of organic matter.

The overall pattern of organic carbon increase during the Miocene and subsequent decrease from a late Pliocene maximum is shown in Figure 41 . The lack of change in $\mathrm{C} / \mathrm{N}$ ratios indicates little change in character of the organic matter. Considerable fluctuation of organic carbon content occurs throughout Units 1 and 2 at intervals of about 40,000 years. These may reflect short-term changes in upwelling intensity and orientation of the Benguela current, as well as variations in conditions causing organic matter preservation.

Sediments from Units 1 and 2 contain predominantly marine-derived organic matter. Oil potentials are fairly high for such young sediments and are somewhat comparable with the values obtained for Messinian samples from the Mediterranean Sea (Deroo et al., 1978).

In lithologic Units 1 and 2, the organic matter is associated with turbidites and debris-flow deposits. Its marine character and the proximity of the upwelling off Namibia indicate that the organic matter is closely related to the history of this high productivity area. The fact that the organic carbon contents and the $S_{2}$ values increase dramatically in the late Miocene agrees with Siesser (1980), who presents evidence from Site 362 to suggest a late Miocene age for the initiation of the upwelling system.

Detailed study of sedimentary sequences and of different lithologies shows some variability in the distribution of organic matter within these upper units. Units 1 and 2 consist mainly of cyclic interbeds of pelagic foraminifer-nannofossil oozes and diatomaceous turbidites. It appears that most of the organic matter occurs in the turbidite layers.

Little or no gaseous hydrocarbons were found in sediments from either Hole 530A or Hole 530B, indicating either that little generation has occurred or that any gases formed have diffused away. In view of the imma- 
Table 7. Interval sedimentation and accumulation rates at Site 530.

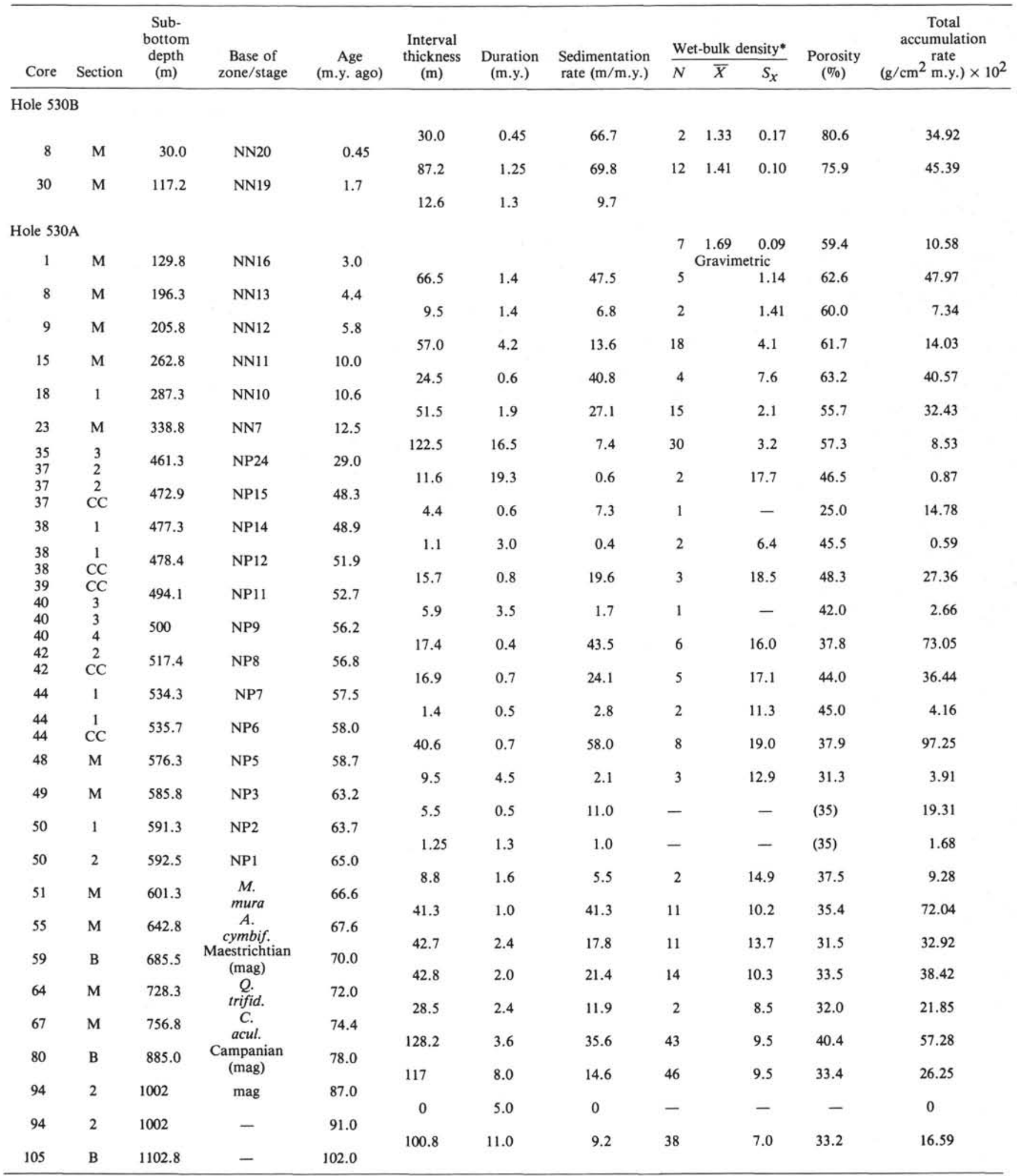

Note: $\mathbf{M}=$ middle; $\mathbf{B}=$ bottom. 
Table 7. (Continued).

\begin{tabular}{|c|c|c|c|c|c|c|c|c|c|c|c|c|}
\hline \multicolumn{3}{|c|}{$\mathrm{CaCO}_{3}(\%)$} & \multirow{2}{*}{$\begin{array}{c}\mathrm{CaCO}_{3} \\
\text { accumulation } \\
\text { rate } \\
\left(\mathrm{g} / \mathrm{cm}^{2} \text { m.y. }\right) \times 10^{2}\end{array}$} & \multicolumn{3}{|c|}{ Opal $(\%)$} & \multirow{2}{*}{$\begin{array}{c}\text { Opal } \\
\text { accumulation } \\
\text { rate } \\
\left(\mathrm{g} / \mathrm{cm}^{2} \text { m.y. }\right) \times 10^{2}\end{array}$} & \multicolumn{3}{|c|}{$\mathrm{C}_{\text {org }}(\%)$} & \multirow{2}{*}{$\begin{array}{c}\mathrm{C}_{\text {org }} \\
\begin{array}{c}\text { accumulation } \\
\text { rate } \\
\left(\mathrm{g} / \mathrm{cm}^{2} \text { m.y. }\right) \times 10^{2}\end{array}\end{array}$} & \multirow{2}{*}{$\begin{array}{c}\begin{array}{c}\text { Nonbiogenic } \\
\text { accumulation } \\
\text { rate }\end{array} \\
\left(\mathrm{g} / \mathrm{cm}^{2} \text { m.y. }\right) \times 10^{2}\end{array}$} \\
\hline$N$ & $\bar{x}$ & $\overline{s_{x}}$ & & $\bar{N}$ & $\bar{x}$ & $\overline{S_{x}}$ & & $\bar{N}$ & $\overline{\bar{X}}$ & $S_{x}$ & & \\
\hline 18 & 38.9 & 21.3 & 13.58 & 33 & 25.2 & 18.2 & 8.80 & 12 & 2.68 & 1.09 & 0.94 & 11.6 \\
\hline 37 & 14.9 & 17.4 & 6.76 & 45 & 43.6 & 20.9 & 19.79 & 17 & 3.64 & 1.11 & 1.65 & 17.2 \\
\hline 15 & 31.3 & 22.0 & 3.31 & 27 & 9.7 & 16.1 & 1.03 & 6 & 1.89 & 0.62 & 0.20 & 6.04 \\
\hline 17 & 34.9 & 23.2 & 16.74 & 22 & 6.6 & 14.5 & 3.17 & 4 & 1.86 & 0.75 & 0.89 & 27.17 \\
\hline 2 & 37.0 & 21.2 & 2.72 & 5 & 3.2 & 6.6 & 0.23 & 2 & 2.03 & 0.37 & 0.01 & 4.38 \\
\hline 27 & 35.8 & 21.2 & 5.02 & 2 & 0.5 & 0.7 & 0.7 & 6 & 0.82 & 0.39 & 0.11 & 8.2 \\
\hline 6 & 22.7 & 22.5 & 9.21 & - & - & - & - & 1 & 0.46 & - & 0.19 & 31.17 \\
\hline 14 & 0.6 & 0.4 & 0.19 & - & - & - & - & 4 & 0.30 & 0.13 & 0.10 & 32.14 \\
\hline 36 & 5.1 & 18.8 & 0.44 & - & - & - & - & 11 & 0.29 & 0.20 & 0.02 & 8.07 \\
\hline 3 & 27.3 & 46.5 & 0.24 & - & - & - & - & 1 & 0.25 & - & 0 & 0.63 \\
\hline 2 & 1.5 & 2.12 & 0.22 & - & - & - & - & - & - & - & - & 14.56 \\
\hline 2 & 77.5 & 13.4 & 0.46 & - & - & - & - & - & - & - & - & 0.13 \\
\hline 1 & 19.0 & - & 5.20 & - & - & - & - & 1 & 0.43 & - & 0.12 & 22.64 \\
\hline 2 & 31.0 & 31.1 & 0.82 & - & - & - & - & - & - & - & - & 1.84 \\
\hline 5 & 56.0 & 35.8 & 40.91 & - & - & - & - & 1 & 0.36 & - & 0.26 & 31.88 \\
\hline 3 & 29.3 & 43.1 & 10.68 & - & - & - & - & - & - & - & - & 25.76 \\
\hline 2 & 8.5 & 10.6 & 0.33 & - & - & - & - & 1 & 0.5 & - & 0.02 & 3.81 \\
\hline 4 & 46.8 & 44.3 & 45.51 & - & - & - & - & 2 & 0.28 & 0 & 0.27 & 51.47 \\
\hline- & - & - & 0.20 & - & - & - & - & 1 & 0.25 & - & 0.01 & 3.70 \\
\hline 1 & 49.0 & - & 9.46 & - & - & - & - & - & - & & - & 9.85 \\
\hline 2 & 28.5 & 21.9 & 0.48 & - & - & - & - & 2 & 0.13 & 0.008 & 0.0 & 1.20 \\
\hline 3 & 27.7 & 26.9 & 2.57 & - & - & - & - & 1 & 0.09 & - & 0 & 6.71 \\
\hline 8 & 24.2 & 30.1 & 17.43 & - & - & - & - & 3 & 0.32 & & 0.23 & 54.38 \\
\hline 10 & 30.0 & 26.5 & 9.88 & - & - & - & - & 2 & 0.3 & 0.17 & 0.10 & 22.94 \\
\hline 11 & 27.3 & 16.0 & 10.49 & - & - & - & - & 3 & 0.19 & 0.07 & 0.07 & 27.86 \\
\hline 1 & 37 & - & 8.08 & - & - & - & - & - & - & - & - & 13.77 \\
\hline 39 & 20.8 & 19.0 & 11.46 & - & - & - & - & 5 & 0.23 & 0.09 & 0.13 & 45.69 \\
\hline 58 & 19.1 & 20.8 & 5.01 & - & - & - & - & 19 & 3.1 & 4.47 & 0.81 & 20.43 \\
\hline- & - & - & 0 & - & - & - & - & - & - & - & - & - \\
\hline 60 & 12.3 & 19.6 & 2.04 & - & - & - & - & 56 & 2.35 & 3.02 & 0.39 & 14.16 \\
\hline
\end{tabular}


Table 8. Organic geochemical measurements, Site 530.

\begin{tabular}{|c|c|c|c|c|c|}
\hline Unit & Age & $\begin{array}{c}\text { Sample } \\
\text { (interval in cm) }\end{array}$ & $\begin{array}{l}\text { Percent } \\
\mathrm{CaCO}_{3}\end{array}$ & $\begin{array}{c}\text { Percent } \\
\mathrm{C}_{\text {org }}\end{array}$ & $\mathrm{C} / \mathrm{N}$ \\
\hline \multicolumn{6}{|c|}{ Hole 530B } \\
\hline & & $1-1,46$ & 62 & 1.33 & 15.2 \\
\hline & & $1-2,52$ & 36 & 2.41 & 10.4 \\
\hline & & $2-1,70$ & 31 & 3.78 & 11.7 \\
\hline & & $2-3,70$ & 55 & 1.99 & 17.5 \\
\hline & & $3-2,85$ & 34 & 1.64 & 12.0 \\
\hline & & $3-3,85$ & 12 & 4.58 & 12.1 \\
\hline & & $4-1,85$ & 14 & 2.77 & 13.1 \\
\hline & & $4-3,110$ & 32 & 3.10 & 13.8 \\
\hline & & $6-1,105$ & 23 & 3.27 & 13.7 \\
\hline & & $7-2,50$ & 76 & 0.79 & 13.7 \\
\hline & & $7-3,20$ & 20 & 3.31 & 14.4 \\
\hline & Holocene to & $8-2,71$ & 31 & 3.21 & 14.4 \\
\hline \multirow[t]{11}{*}{ 1a } & Pleistocene & $9-1,66$ & 13 & 2.51 & 13.3 \\
\hline & & $9-3,14$ & 14 & 3.85 & 13.4 \\
\hline & & $10-1,87$ & 21 & 3.43 & 13.6 \\
\hline & & $10-3,74$ & 6 & 3.82 & 13.9 \\
\hline & & $11-1,70$ & 13 & 3.97 & 13.9 \\
\hline & & $11-2,61$ & 7 & 4.54 & 13.8 \\
\hline & & $11-3,30$ & 4 & 3.69 & 13.8 \\
\hline & & $12-2,78$ & 7 & 4.53 & 13.9 \\
\hline & & $12-3,29$ & 11 & 4.81 & 13.6 \\
\hline & & $14-3,27$ & 53 & 1.67 & 12.9 \\
\hline & & $18-1,100$ & $<1$ & 3.4 & 13.9 \\
\hline \multirow[t]{11}{*}{$1 \mathrm{~b}$} & Pleistocene & $20-2,40$ & $<1$ & 4.48 & 13.9 \\
\hline & & $21-2,9$ & 12 & 2.1 & 11.8 \\
\hline & & $23-1,103$ & $<1$ & 6.21 & 14.0 \\
\hline & & $25-1,95$ & $<1$ & 2.86 & 12.4 \\
\hline & & $26-2,126$ & $<1$ & 2.62 & 12.1 \\
\hline & & $27-2,40$ & 3 & 3.39 & 13.7 \\
\hline & Mean values & 9 samples & & 3.24 & 13.4 \\
\hline & & $33-2,118$ & 43 & 1.62 & 13.4 \\
\hline & & $43-2,112$ & 13 & 1.80 & 12.7 \\
\hline & & $44-1,145$ & 5 & 1.51 & 11.4 \\
\hline & & 44, CC 27 & 9 & 1.30 & 9.8 \\
\hline \multicolumn{6}{|c|}{ Hole 530} \\
\hline & & $2-2,52-54$ & 5 & 2.24 & 12.3 \\
\hline \multicolumn{6}{|c|}{ Hole 530A } \\
\hline \multirow{14}{*}{2} & & $1-1,92-94$ & 47 & 2.08 & 24.1 \\
\hline & & $5-5,27-29$ & 15 & 1.95 & 10.9 \\
\hline & & $6-2,128-130$ & 5 & 1.98 & 13.4 \\
\hline & Pleistocene to & $7-2,5-8$ & 1 & 0.84 & 11.1 \\
\hline & late Miocene & $7-6,54-56$ & 16 & 2.63 & 13.2 \\
\hline & & $8-5,12-14$ & 6 & 1.76 & 9.5 \\
\hline & & $9-1,102-104$ & 22 & 1.02 & 11.8 \\
\hline & & $10-1,27-29$ & 28 & 2.29 & 13.4 \\
\hline & & $11-5,95-97$ & 9 & 0.92 & 9.6 \\
\hline & & $12-5,52-54$ & 5 & 1.10 & 10.3 \\
\hline & & $13-2,67-69$ & 34 & 1.23 & 12.8 \\
\hline & & $14-1,91-93$ & 34 & 0.30 & 8.2 \\
\hline & & $14-3,91-93$ & 46 & 0.36 & 8.0 \\
\hline & & $15-4,45-47$ & 1 & 0.46 & 5.8 \\
\hline \multicolumn{4}{|c|}{ Mean values, 19 samples } & 1.79 & 11.8 \\
\hline \multirow{16}{*}{3} & & $18-3,42-44$ & $<1$ & 0.27 & 4.4 \\
\hline & & $19-4,30-32$ & $<1$ & 0.26 & 4.3 \\
\hline & & $21-4,24-26$ & $<1$ & 0.19 & 4.2 \\
\hline & & $22-6,81-83$ & $<1$ & 0.49 & 7.0 \\
\hline & & $25-3,87-89$ & $<1$ & 0.21 & 6.1 \\
\hline & & $26-3,48-50$ & $<1$ & 0.25 & 4.8 \\
\hline & & $27-7,35-37$ & $<1$ & 0.23 & 4.3 \\
\hline & & $28-1,90-92$ & $<1$ & 0.22 & 4.5 \\
\hline & & $24-3,75-77$ & $<1$ & 0.07 & 2.1 \\
\hline & late Miocene to & $30-4,124-126$ & $<1$ & 0.53 & 10.4 \\
\hline & Oligocene & $31-2,76-78$ & $<1$ & 0.26 & 5.5 \\
\hline & & $33-2,5-7$ & $<1$ & 0.12 & 3.1 \\
\hline & & $34-2,90-92$ & $<1$ & 0.22 & 4.8 \\
\hline & & $34-2,49-51$ & $<1$ & 0.79 & 11.3 \\
\hline & & $35-1,7-9$ & $<1$ & 0.30 & 6.4 \\
\hline & \multicolumn{2}{|c|}{ Mean values, 15 samples } & & 0.29 & 5.5 \\
\hline
\end{tabular}

Table 8. (Continued).

\begin{tabular}{|c|c|c|c|c|c|}
\hline Unit & Age & $\begin{array}{c}\text { Sample } \\
\text { (interval in } \mathrm{cm} \text { ) }\end{array}$ & $\begin{array}{l}\text { Percent } \\
\mathrm{CaCO}_{3}\end{array}$ & $\begin{array}{l}\text { Percent } \\
\text { C }_{\text {org }}\end{array}$ & $\mathrm{C} / \mathrm{N}$ \\
\hline \multicolumn{6}{|c|}{ Hole 530A (Cont.) } \\
\hline \multirow{11}{*}{4} & \multirow{11}{*}{$\begin{array}{l}\text { Eocene to } \\
\quad \text { Maestrichtian }\end{array}$} & $37-3,67-69$ & $<1$ & 0.25 & 7.7 \\
\hline & & $40-1,42-43$ & 9 & 0.43 & 10.2 \\
\hline & & $41-1,100-101$ & $<1$ & 0.36 & 12.4 \\
\hline & & $42, \mathrm{CC}$ & 2 & 0.27 & 8.1 \\
\hline & & $44-2,44-45$ & 1 & 0.50 & 7.7 \\
\hline & & $47-1,103-105$ & 11 & 0.28 & 7.8 \\
\hline & & $48-2,19-20$ & 5 & 0.28 & 10.1 \\
\hline & & $49-1,49-50$ & 12 & 0.25 & 7.7 \\
\hline & & $50-2,12-14$ & 13 & 0.19 & 7.4 \\
\hline & & $50-2,55-57$ & 44 & 0.07 & 5.3 \\
\hline & & $50-4,21-22$ & 57 & 0.09 & 7.7 \\
\hline \multicolumn{3}{|c|}{ Mean values, 11 samples } & & 0.27 & 8.4 \\
\hline \multirow{13}{*}{5} & & $51-5,119-121$ & 8 & 0.35 & 6.0 \\
\hline & & $52-1,60-61$ & 1 & 0.30 & 14.4 \\
\hline & & $53-2,70-71$ & 12 & 0.32 & 9.1 \\
\hline & & $55-3,26-27$ & 29 & 0.14 & 7.6 \\
\hline & & $57-2,84-85$ & 9 & 0.42 & 15.0 \\
\hline & Maestrichtian to & $58-1,89-90$ & 4 & 0.16 & 10.8 \\
\hline & late Cam- & $59-2,24-25$ & 3 & 0.18 & 13.2 \\
\hline & panian & $60-2,112-114$ & 26 & 0.24 & 15.1 \\
\hline & & $61-1,87-88$ & 6 & 0.24 & 5.4 \\
\hline & & $63-3,62-64$ & 11 & 0.11 & 8.2 \\
\hline & & $64-1,53-54$ & 24 & 0.22 & 9.1 \\
\hline & & $68-2,95-96$ & $<1$ & 0.26 & 15.2 \\
\hline & \multicolumn{2}{|c|}{ Mean values, 12 samples } & & 0.25 & 10.8 \\
\hline \multirow[t]{2}{*}{6} & Campanian & $71-2,50-52$ & 19 & 0.15 & 15.5 \\
\hline & Campanian to & $75-4,22-23$ & 1 & 0.37 & 21.2 \\
\hline \multirow[t]{18}{*}{7} & Coniacian & $76-1,70-71$ & 1 & 0.15 & 15.3 \\
\hline & & $77-3,134-135$ & 23 & 0.24 & 17.3 \\
\hline & & $84-2,117$ & 41 & 0.19 & 13.7 \\
\hline & & $85-2,6-7$ & 8 & 0.21 & 9.0 \\
\hline & & $86-4,145-147$ & 4 & 0.28 & 14.6 \\
\hline & & $86-5,31-32$ & $<1$ & 1.28 & 20.6 \\
\hline & & $86-5,33$ & $<1$ & 2.02 & 21.3 \\
\hline & & $86-5,36$ & $<1$ & 0.25 & 10.4 \\
\hline & Mean values, & samples & & 0.55 & 15.9 \\
\hline & & $87-1,37$ & $<1$ & 5.37 & 24.0 \\
\hline & & $87-1,83$ & $<1$ & 1.31 & 20.2 \\
\hline & & $87-3,83-85$ & $<1$ & 0.25 & 9.4 \\
\hline & & $87-4,105$ & $<1$ & 6.22 & 23.2 \\
\hline & & $87-4,118$ & $<1$ & 0.16 & 7.3 \\
\hline & & $88-1,65-66$ & 78 & 0.11 & 13.4 \\
\hline & & $88-3,33$ & $<1$ & 9.7 & 24.7 \\
\hline & & $88-3,90$ & $<1$ & 2.84 & 24.9 \\
\hline & Coniacian to & $89-1,34$ & 15 & 9.6 & 28.9 \\
\hline \multirow[t]{25}{*}{8} & Albian & $90-3,86-87$ & 3 & 16.5 & 36.5 \\
\hline & & $90-3,99-100$ & 11 & 0.62 & 18.6 \\
\hline & & $91-4,45$ & $<1$ & 1.19 & 15.9 \\
\hline & & $93-1,40$ & $<1$ & 0.95 & 14.1 \\
\hline & & $93-2,35$ & $<1$ & 0.18 & 10.1 \\
\hline & & $93-3,45$ & $<1$ & 0.11 & 7.0 \\
\hline & & $93-3,83-84$ & 4 & 0.83 & 32.5 \\
\hline & & $94-1,42-43$ & $<1$ & 12.27 & 34.5 \\
\hline & & $94-2,11-12$ & $<1$ & 0.35 & 18.6 \\
\hline & & $95-4,101-102$ & $<1$ & 0.22 & 6.0 \\
\hline & & $95-5,28-29$ & $<1$ & 1.73 & 30.4 \\
\hline & & $96-2,118-119$ & 34 & 0.11 & 10.8 \\
\hline & & $96-4,29-30$ & $<1$ & 1.79 & 25.9 \\
\hline & & $96-4,40-41$ & 9 & 0.39 & 28.4 \\
\hline & & $96-4,61-62$ & $<1$ & 5.82 & 26.4 \\
\hline & & $96-6,88$ & $<1$ & 2.10 & 27.9 \\
\hline & & $97-3,59-60$ & $<1$ & 7.29 & 32.1 \\
\hline & & $97-4,56$ & $<1$ & 8.04 & 31.6 \\
\hline & & $97-4,87$ & $<1$ & 0.17 & 8.7 \\
\hline & & $97, \mathrm{CC}$ & $<1$ & 7.66 & 30.9 \\
\hline & & $98-2,60$ & $<1$ & 0.28 & 10.7 \\
\hline & & $98-2,69$ & $<1$ & 1.44 & 24.1 \\
\hline & & $98-3,92$ & 2 & 8.57 & 30.2 \\
\hline & & $98-3,110$ & $<1$ & 0.47 & 18.0 \\
\hline & & $99-1,107$ & $<1$ & 0.23 & 13.0 \\
\hline
\end{tabular}


Table 8. (Continued).

\begin{tabular}{|c|c|c|c|c|c|}
\hline Unit & Age & $\begin{array}{c}\text { Sample } \\
\text { (interval in } \mathrm{cm} \text { ) }\end{array}$ & $\begin{array}{l}\text { Percent } \\
\mathrm{CaCO}_{3}\end{array}$ & $\begin{array}{c}\text { Percent } \\
\text { C }_{\text {org }}\end{array}$ & $\mathrm{C} / \mathrm{N}$ \\
\hline \multicolumn{6}{|c|}{ Hole 530A (Cont.) } \\
\hline & & $99-2,67$ & 76 & 0.08 & 10.6 \\
\hline & & $99-5,70$ & $<1$ & 1.73 & 23.3 \\
\hline & & $99-5,86$ & $<1$ & 0.38 & 10.2 \\
\hline & & $100-1,85$ & $<1$ & 0.28 & 11.3 \\
\hline & & $100-1,99$ & $<1$ & 1.92 & 23.1 \\
\hline & & $101-2,8$ & $<1$ & 0.93 & 14.2 \\
\hline & & $101-2,17$ & 26 & 0.48 & 17.2 \\
\hline & & $101-2,21$ & $<1$ & 5.08 & 28.5 \\
\hline & & $101-4,36$ & 21 & 1.31 & 37.1 \\
\hline & & $101-4,55$ & 40 & 0.08 & 10.4 \\
\hline & & $102-1,149$ & $<1$ & 1.16 & 18.5 \\
\hline & & $102-3,120$ & $<1$ & 1.73 & 22.8 \\
\hline & & $102-3,130$ & 11 & 0.45 & 20.4 \\
\hline & & $103-4,85$ & $<1$ & 7.70 & 30.2 \\
\hline & & $103-6,22$ & $<1$ & 0.16 & 10.5 \\
\hline & & $104-2,141$ & 3 & 0.41 & 11.7 \\
\hline & & $104-3,0-1$ & $<1$ & 5.21 & 29.0 \\
\hline & & $104-4,91$ & $<1$ & 0.47 & 17.1 \\
\hline & & $104-4,123$ & $<1$ & 0.18 & 11.3 \\
\hline & & $104-5,61$ & 3 & 0.57 & 23.1 \\
\hline & & $105-1,23-24$ & $<1$ & 0.23 & 12.4 \\
\hline & & $105-2,139-140$ & $<1$ & 5.28 & 28.2 \\
\hline & & $105-4,9-10$ & 6 & 3.60 & 30.0 \\
\hline & & $105-4,35-36$ & $<1$ & 0.16 & 9.4 \\
\hline & & $105, \mathrm{CC}(3-4)$ & $<1$ & 0.15 & 8.3 \\
\hline \multicolumn{4}{|c|}{ Mean values, 26 black shales } & 5.17 & 25.9 \\
\hline & & \multicolumn{2}{|c|}{$16 \mathrm{~N}_{2}$ black shales } & 7.13 & 27.1 \\
\hline & & \multicolumn{2}{|c|}{$10 \mathrm{~N}_{3}-\mathrm{N}_{6}$ black shales } & 2.55 & 24.1 \\
\hline & & \multicolumn{2}{|c|}{23 green claystones } & 0.41 & 15.7 \\
\hline & & \multicolumn{2}{|l|}{8 red claystones } & 0.38 & 10.6 \\
\hline
\end{tabular}

ture character of the sedimentary organic matter, it is likely that gas generation has not yet become important. The low-level bacterial activity in the sediments from Hole 530B may result from a combination of water depth $(4600 \mathrm{~m})$ and sediment disruption resulting from slumping and turbidity flows.

Sediments rich in organic matter containing up to $16.5 \%$ organic carbon are present within Unit 8. These high values of organic carbon occur in black shale layers (average $5.2 \%$ organic carbon). Coniacian-early Santonian black shales (those above $1005 \mathrm{~m}$ ) appear to be usually richer in carbon than are those of Albian-Cenomanian age (Fig. 42).

There is a marked contrast between the organic carbon contents of black shales and the other lithologies (green claystones, red claystones, etc.), which generally contain less than $1 \%$ organic carbon. The darker black shales (color $\mathrm{N}_{2}$ ) possess markedly higher organic carbon contents than do their lighter counterparts (color $\mathrm{N}_{3}, \mathrm{~N}_{4}$, etc), suggesting a relationship between the organic richness of these shales and their color.

Considerable scatter exists in the $\mathrm{C} / \mathrm{N}$ data in Unit 8. In general the higher values are associated with the black shales (mean 26.7) whereas the other lithologies possess $\mathrm{C} / \mathrm{N}$ ratios with averages between 10 and 15 . Such variation suggests that the fluctuations in the carbon content of these sediments are the dominant factor determining the $\mathrm{C} / \mathrm{N}$ ratio, with their nitrogen contents markedly less influential.

Where $S_{2}$ and $S_{3}$ Rock-Eval values were available with organic carbon data, the hydrogen index $(\mathrm{HI})$ and
Table 9. Rock-Eval data, Site 530.

\begin{tabular}{|c|c|c|c|c|c|c|c|}
\hline \multirow{2}{*}{$\begin{array}{c}\text { Sample } \\
\text { (interval in cm) }\end{array}$} & $\underline{s_{1}}$ & $s_{2}$ & $\mathrm{~S}_{3}$ & \multirow[b]{2}{*}{$\mathrm{T}\left({ }^{\circ} \mathrm{C}\right) \mathrm{S}_{2}$} & $\mathrm{HI}$ & $\mathrm{OI}$ & \multirow{2}{*}{$\begin{array}{c}\text { Percent } \\
\mathrm{C}_{\text {org }}\end{array}$} \\
\hline & \multicolumn{3}{|c|}{$\overline{(\mathrm{mg} / 100 \mathrm{~g} \text { sed. })}$} & & $(\mathrm{mg} / 100$ & g sed.) & \\
\hline Hole 530 & & & & & & & \\
\hline $1, \mathrm{CC}$ & - & 180 & 467 & 396 & & & \\
\hline $2-2,53$ & - & 571 & 276 & 406 & 255 & 123 & 2.24 \\
\hline $2-3,87$ & - & 324 & 346 & 402 & & & \\
\hline $2-6,34$ & - & 45 & 204 & 397 & & & \\
\hline $2, \mathrm{CC}$ & - & 548 & 360 & 402 & & & \\
\hline Hole $530 \mathrm{~A}$ & & & & & & & \\
\hline $1-1,92-94$ & - & 184 & 280 & 399 & 88 & 134 & 208 \\
\hline $1, \mathrm{CC}$ & - & 475 & 254 & 406 & & & \\
\hline $2, \mathrm{CC}$ & - & 316 & 299 & 405 & & & \\
\hline $4, \mathrm{CC}$ & - & 82 & 268 & 395 & & & \\
\hline $5-5,26$ & - & 395 & 360 & 393 & 202 & 184 & 1.95 \\
\hline $5, \mathrm{CC}$ & - & 85 & 213 & 397 & & & \\
\hline $6-2,128-130$ & - & 533 & 240 & 409 & 268 & 121 & 1.98 \\
\hline $6, \mathrm{CC}$ & - & 47 & 181 & 403 & & & \\
\hline $7-2,3$ & - & 248 & 145 & 414 & 295 & 173 & 0.84 \\
\hline $7, \mathrm{CC}$ & - & 156 & 239 & 405 & & & \\
\hline $8-5,12-14$ & - & 372 & 242 & 399 & 162 & 106 & 2.29 \\
\hline $8, C C$ & - & 183 & 258 & 398 & & & \\
\hline $9-1,105$ & - & 344 & 334 & 414 & & & \\
\hline $9, \mathrm{CC}$ & - & 176 & 405 & 403 & & & \\
\hline $10-1,30$ & - & 174 & 375 & 400 & 170 & 368 & 1.02 \\
\hline $10-2,5$ & - & 135 & 174 & 396 & & & \\
\hline $10, \mathrm{CC}$ & - & 88 & 381 & 394 & & & \\
\hline $11, \mathrm{CC}$ & - & 101 & 282 & 396 & & & \\
\hline $12-4,143$ & - & 184 & 217 & 397 & & & \\
\hline $12-5,52-54$ & - & 148 & 205 & 399 & 135 & 186 & 1.10 \\
\hline $12, \mathrm{CC}$ & - & 111 & 352 & 395 & & & \\
\hline $13-2,67-69$ & - & 168 & 285 & 398 & 137 & 232 & 1.23 \\
\hline $13, \mathrm{CC}$ & - & 127 & 312 & 398 & & & \\
\hline $14-1,91-93$ & - & 34 & 179 & 394 & 113 & 597 & 0.30 \\
\hline $14-3,91$ & - & 46 & 140 & 395 & 126 & 386 & 0.36 \\
\hline $15-4,45$ & - & 68 & 174 & & & & \\
\hline $16, \mathrm{CC}$ & - & 47 & 130 & 396 & & & \\
\hline $17, \mathrm{CC}$ & - & 57 & 176 & 396 & & & \\
\hline $18, \mathrm{CC}$ & - & 33 & 79 & 398 & & & \\
\hline $19, \mathrm{CC}$ & - & 27 & 53 & 399 & & & \\
\hline $20, \mathrm{CC}$ & - & 38 & 54 & 401 & & & \\
\hline $21, \mathrm{CC}$ & - & 31 & 55 & 397 & & & \\
\hline $22, \mathrm{CC}$ & - & 17 & 135 & 400 & & & \\
\hline $24-3,62$ & - & 11 & 25 & 457 & & & \\
\hline $24, \mathrm{CC}$ & - & 29 & 54 & 410 & & & \\
\hline $25, \mathrm{CC}$ & - & 35 & 45 & 410 & & & \\
\hline $26-5,50$ & - & 49 & 38 & 401 & & & \\
\hline $27, \mathrm{CC}$ & - & 44 & 46 & 396 & & & \\
\hline $28-6,62$ & - & 39 & 37 & 403 & & & \\
\hline $30, \mathrm{CC}$ & - & 35 & 31 & 410 & & & \\
\hline $31, \mathrm{CC}$ & - & 105 & 20 & 405 & & & \\
\hline $32, \mathrm{CC}$ & - & 105 & 24 & 410 & & & \\
\hline $33, \mathrm{CC}$ & - & 90 & 13 & 408 & & & \\
\hline $34, \mathrm{CC}$ & - & 37 & 27 & 412 & & & \\
\hline $35, \mathrm{CC}$ & - & 82 & 42 & 405 & & & \\
\hline $37, \mathrm{CC}$ & - & - & 105 & - & & & \\
\hline $38, \mathrm{CC}$ & - & - & 120 & - & & & \\
\hline $39, \mathrm{CC}$ & - & - & 102 & - & & & \\
\hline $40-1,43$ & - & 5 & 23 & - & 12 & 53 & 0.43 \\
\hline $40, \mathrm{CC}$ & - & - & 120 & - & & & \\
\hline $41, \mathrm{CC}$ & - & - & 117 & - & & & \\
\hline $42, \mathrm{CC}$ & - & - & 117 & - & & & \\
\hline $43-2$ & - & - & 112 & - & & & \\
\hline $43, \mathrm{CC}$ & - & - & 127 & - & & & \\
\hline $44-1,100$ & - & 42 & 40 & - & & & \\
\hline $44-2,44-45$ & - & 43 & 39 & - & & & \\
\hline $44, C C$ & - & 45 & 30 & 399 & & & \\
\hline $45, \mathrm{CC}$ & - & 67 & 32 & 420 & & & \\
\hline $46-1,10$ & - & 14 & 35 & - & & & \\
\hline $46, \mathrm{CC}$ & - & - & 102 & - & & & \\
\hline $47, \mathrm{CC}$ & - & - & 55 & - & & & \\
\hline $48-1,60$ & - & - & 96 & - & & & \\
\hline $48-2,51$ & - & 18 & 127 & - & & & \\
\hline $48, \mathrm{CC}$ & - & 30 & 92 & - & & & \\
\hline $49, \mathrm{CC}$ & - & - & 50 & - & & & \\
\hline $50, \mathrm{CC}$ & - & - & 20 & - & & & \\
\hline $51-5,119-121$ & - & - & 110 & - & - & 314 & 0.35 \\
\hline $51, C C$ & - & - & 152 & - & & & \\
\hline $52, \mathrm{CC}$ & - & - & 149 & - & & & \\
\hline $53, \mathrm{CC}$ & - & - & 133 & - & & & \\
\hline $54, \mathrm{CC}$ & - & - & 166 & - & & & \\
\hline $55, \mathrm{CC}$ & - & - & 137 & - & & & \\
\hline $56, \mathrm{CC}$ & - & - & 130 & - & & & \\
\hline
\end{tabular}


Table 9. (Continued).

\begin{tabular}{|c|c|c|c|c|c|c|c|}
\hline \multirow{2}{*}{$\begin{array}{c}\text { Sample } \\
\text { (interval in cm) }\end{array}$} & $\underline{s_{1}}$ & $s_{2}$ & $\mathrm{~S}_{3}$ & \multirow[b]{2}{*}{$\mathrm{T}\left({ }^{\circ} \mathrm{C}\right) \mathrm{S}_{2}$} & $\mathrm{HI}$ & OI & \multirow{2}{*}{$\begin{array}{l}\text { Percent } \\
\text { Corg }\end{array}$} \\
\hline & \multicolumn{3}{|c|}{$\overline{(\mathrm{mg} / 100 \mathrm{~g} \text { sed. })}$} & & \multicolumn{2}{|c|}{ (mg/100 g sed.) } & \\
\hline \multicolumn{8}{|l|}{ Hole 530 (Cont.) } \\
\hline $57-2,84-85$ & - & - & 150 & - & & & \\
\hline $57, \mathrm{CC}$ & - & - & 163 & - & & & \\
\hline $58, \mathrm{CC}$ & - & - & 197 & - & & & \\
\hline $59, \mathrm{CC}$ & - & 11 & 90 & 416 & & & \\
\hline $60, \mathrm{CC}$ & - & - & 158 & - & & & \\
\hline $61-1,87-88$ & - & - & 130 & - & & & \\
\hline $61, \mathrm{CC}$ & - & - & 110 & - & & & \\
\hline $62, \mathrm{CC}$ & - & - & 37 & - & & & \\
\hline $63, \mathrm{CC}$ & - & - & 94 & - & & & \\
\hline $64-1,53-54$ & - & - & 60 & - & - & 272 & 0.22 \\
\hline $64, \mathrm{CC}$ & - & - & 41 & - & & & \\
\hline $65, \mathrm{CC}$ & - & - & 43 & - & & & \\
\hline $67, \mathrm{CC}$ & - & - & 45 & - & & & \\
\hline $68, \mathrm{CC}$ & - & - & 93 & - & & & \\
\hline $69, \mathrm{CC}$ & - & - & 140 & - & & & \\
\hline $70, \mathrm{CC}$ & - & - & 45 & - & & & \\
\hline $71, \mathrm{CC}$ & - & - & 61 & - & & & \\
\hline $72, \mathrm{CC}$ & - & - & 32 & - & & & \\
\hline 73-4 Bottom & - & - & 38 & - & & & \\
\hline 74-2 Top & - & - & 45 & - & & & \\
\hline $75-4,22-23$ & - & - & 51 & - & - & 138 & 0.37 \\
\hline $75, \mathrm{CC}$ & - & - & 64 & - & & & \\
\hline $\begin{array}{l}76, \mathrm{CC} \\
77, \mathrm{CC}\end{array}$ & $\bar{z}$ & $\bar{z}$ & $\begin{array}{l}54 \\
88\end{array}$ & $\overline{-}$ & & & \\
\hline $78, \mathrm{CC}$ & - & - & 69 & - & & & \\
\hline $79, \mathrm{CC}$ & - & - & 79 & - & & & \\
\hline $80, \mathrm{CC}$ & - & - & 119 & - & & & \\
\hline $81, \mathrm{CC}$ & - & - & 130 & - & & & \\
\hline $82, \mathrm{CC}$ & - & - & 57 & - & & & \\
\hline $83, \mathrm{CC}$ & - & - & 41 & - & & & \\
\hline $84, \mathrm{CC}$ & - & - & 84 & - & & & \\
\hline 86 Top & - & - & 39 & - & & & \\
\hline $86, \mathrm{CC}$ & - & - & 34 & - & & & \\
\hline $87-1,60$ & 80 & 10430 & 392 & 411 & & & \\
\hline $87-3,122$ & - & 2374 & 208 & 417 & & & \\
\hline $87-4,105$ & - & 1272 & 197 & 423 & 205 & 32 & 6.20 \\
\hline $87, \mathrm{CC}$ & - & - & 66 & - & & & \\
\hline $88, \mathrm{CC}$ & - & - & 120 & - & & & \\
\hline $89, \mathrm{CC}$ & - & - & 58 & - & & & \\
\hline $90-3,86-87$ & 20 & 14445 & 296 & 404 & 875 & 18 & 16.5 \\
\hline $90, \mathrm{CC}$ & 3 & 906 & 79 & 422 & & & \\
\hline $91, \mathrm{CC}$ & - & - & 38 & - & & & \\
\hline $92, \mathrm{CC}$ & - & - & 41 & - & & & \\
\hline $94, \mathrm{CC}$ & - & - & 51 & - & & & \\
\hline $95, \mathrm{CC}$ & 18 & 2596 & 108 & 418 & & & \\
\hline $96-6,88$ & 18 & 213 & 78 & - & 101 & 37 & 2.10 \\
\hline $96, \mathrm{CC}$ & 3 & 619 & 58 & 423 & & & \\
\hline $97-4,56-57$ & - & 3363 & 490 & - & 418 & 61 & 8.04 \\
\hline $97, \mathrm{CC}$ & 14 & 4376 & 163 & 417 & 571 & 21 & 7.66 \\
\hline $98-1,92-93$ & 6 & 1115 & 364 & 407 & & & \\
\hline $98-3,92-93$ & - & 3481 & 227 & - & 406 & 26 & 8.57 \\
\hline $98-3,110-111$ & - & 6 & 75 & - & 13 & 160 & 0.47 \\
\hline $98, \mathrm{CC}$ & - & - & 51 & - & & & \\
\hline $99, \mathrm{CC}$ & - & 32 & 51 & - & & & \\
\hline $100-1,99-100$ & - & 260 & 79 & - & 135 & 41 & 1.92 \\
\hline $100-2,107-108$ & - & 45 & 123 & 407 & & & \\
\hline $100, \mathrm{CC}$ & - & 133 & & - & & & \\
\hline $101-3,24-25$ & 6 & 116 & & 428 & & & \\
\hline 102-2, Top & 19 & 2326 & 118 & 417 & & & \\
\hline $102-3,124$ & 21 & 392 & 182 & 427 & & & \\
\hline $\begin{array}{l}102, \mathrm{CC} \\
103-4,85-86\end{array}$ & $\bar{z}$ & $\overline{3709}$ & $\begin{array}{r}48 \\
402\end{array}$ & $\bar{z}$ & 522 & 57 & 7.10 \\
\hline $103, \mathrm{CC}$ & - & - & 188 & - & & & \\
\hline $104-3,0-1$ & - & 2241 & 214 & - & 430 & 41 & 5.21 \\
\hline $104-5,62$ & 2 & 35 & 70 & 420 & 59 & 119 & 0.57 \\
\hline $104, \mathrm{CC}$ & - & - & 24 & - & & & \\
\hline $105-2,139-140$ & $\overline{0}$ & 2581 & 257 & - & 489 & 49 & 5.28 \\
\hline $105-3,103$ & 37 & 3592 & 212 & 413 & & & \\
\hline $105-4,3-5$ & 29 & 1457 & 95 & 423 & & & \\
\hline $105, \mathrm{CC}$ & - & 15 & 55 & 408 & 100 & 367 & 0.15 \\
\hline
\end{tabular}

Note: $-=$ response below detection limits.

oxygen index (OI) were determined and the results plotted in an HI versus OI diagram (Fig. 43). These results show that the black shales from Unit 8 possess predominantly type II organic matter, reflecting a dominant contribution of marine-derived organic material. This

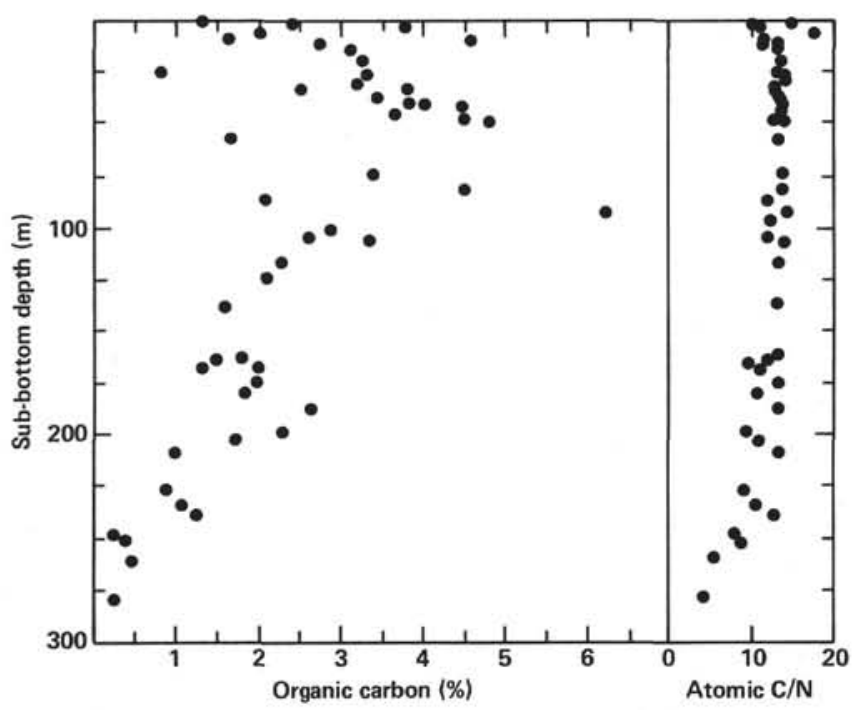

Figure 41. Downhole profiles of organic carbon contents and $\mathrm{C} / \mathrm{N}$ ratios for upper $300 \mathrm{~m}$ of Site 530 sediments.

predominantly marine origin for the organic matter associated with the black shales has been verified by subsequent lipid and kerogen analysis. However, there is a wide diversity in the hydrogen index (100 to 850 ) of the black shale samples, an observation verified by shorebased analyses. At present, it is unclear whether this diversity reflects multiple sources of organic matter or depositional environment fluctuations. The interbedded green claystones lie in the range of hydrogen-poor type III, suggesting a detrital origin for their organic matter.

The temperatures of the $\mathrm{S}_{2}$ maximum from Rock-Eval pyrolysis (Fig. 44) indicate that none of the sediments has attained the temperature-time requirements for significant petroleum generation. The temperature of the $\mathrm{S}_{2}$ maximum increases with depth from $395^{\circ}$ to $410^{\circ} \mathrm{C}$ in the uppermost part of the hole up to $405^{\circ}$ to $425^{\circ} \mathrm{C}$, but does not reach values of $425^{\circ}$ to $440^{\circ} \mathrm{C}$, which are considered to be the limit of oil generation (Espitalié et al., 1977). As a consequence of this low degree of thermal maturity, and despite the richness in organic matter and its high hydrocarbon potential $\left(\mathrm{S}_{2}\right)$, the $\mathrm{S}_{1}$ peak (free hydrocarbons) was generally insignificant, and only small amounts of gaseous hydrocarbons were found. The minor quantities of $\mathrm{C}_{2}-\mathrm{C}_{5}$ hydrocarbons detected in various samples, combined with variability of vacutainer blanks, makes these gas shows poor indicators of the diagenesis of organic matter at this site. Despite this caveat, two significant differences between the gas content of samples from the black shale sequence and that of other samples from Site 530 were observed. First, the amounts of gas were higher in the black shales. Second, the black shale ethane/propane ratios were consistently in the range 1.2 to 2.1 , rather than markedly less than unity. Given the higher gas content of the black shales this ratio may be genuine, and therefore indicate the onset of gaseous hydrocarbon generation in these immature sediments. Although possible, it seems unlikely that these gaseous hydrocarbons represent migrated components. 


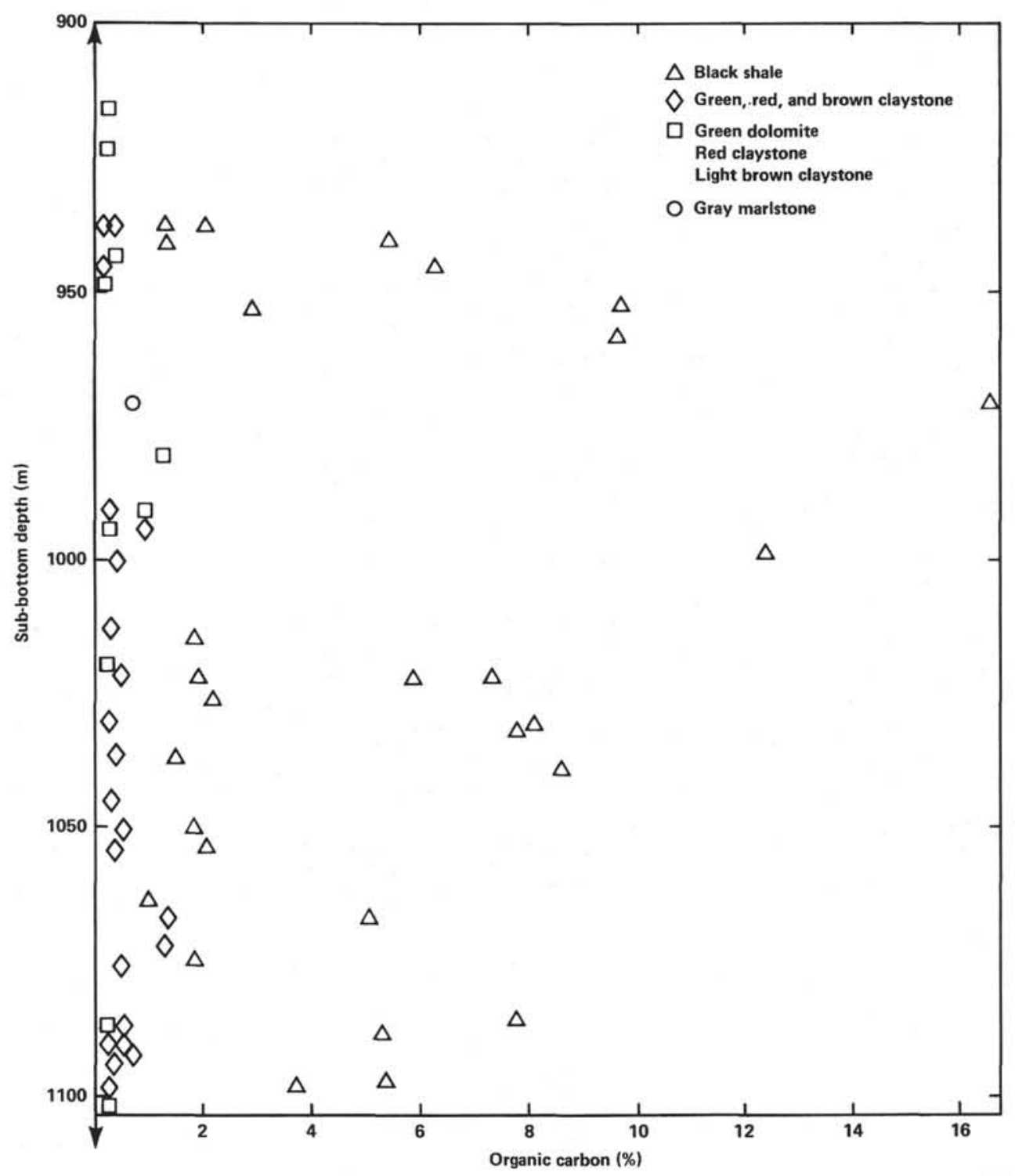

Figure 42. Organic carbon contents of Unit 8 sediments from Hole 530A.

\section{IGNEOUS PETROLOGY}

\section{Megascopic Description}

The deepest sediment recorded-Sample 530A-105, CC $(10-20 \mathrm{~cm})$-consists of red mudstone with few signs of bioturbation or lamination. The mudstone is baked or altered and intruded with white calcite veins having a dendroid pattern. These veins extend $6 \mathrm{~cm}$ into the mudstones. The surface of the basalt is white and altered (Fig. 45).

The basement rock (Unit 9) recovered in this hole is hypocrystalline, fine-grained, amygdaloidal phyric basalt. It is characterized by a groundmass of randomly oriented plagioclase microlites with intergranular pyroxene. White veins and vugs are filled with megacrystalline calcite. Occasionally red veins (baked or altered sediments) are present.

A red, baked, or altered sediment contact is preserved at the top of Section 530A-108-1. The fine-grained hypocrystalline basalt has a glassy upper margin which is overlain by rounded fragments of red clay and calcite. Only two sediment contacts were recovered in Cores 106-108 of Hole 530A. Based upon the magnetic observations it is likely that several extrusive units were encountered within Cores 106-108. However, no attempt was made to differentiate igneous subunits onboard.

\section{PALEOMAGNETICS}

Paleomagnetic studies were conducted on Cores 7 through 47 from Hole 530B and 35 through 108 from Hole 530A. Cores 530B-7 through 47 contain Holocene to upper Miocene sediments which were obtained using the hydraulic piston corer. Cores 530A-35 through 108 contain Paleocene to Albian sediments and basalts. All of the cores were sampled and measured on the Digico spinner magnetometers aboard the vessel. The long core spinner magnetometer measures the direction and intensity of the horizontal component of magnetization of the core sections while in the core liner and unopened and was used to measure core sections from Hole 530A. 


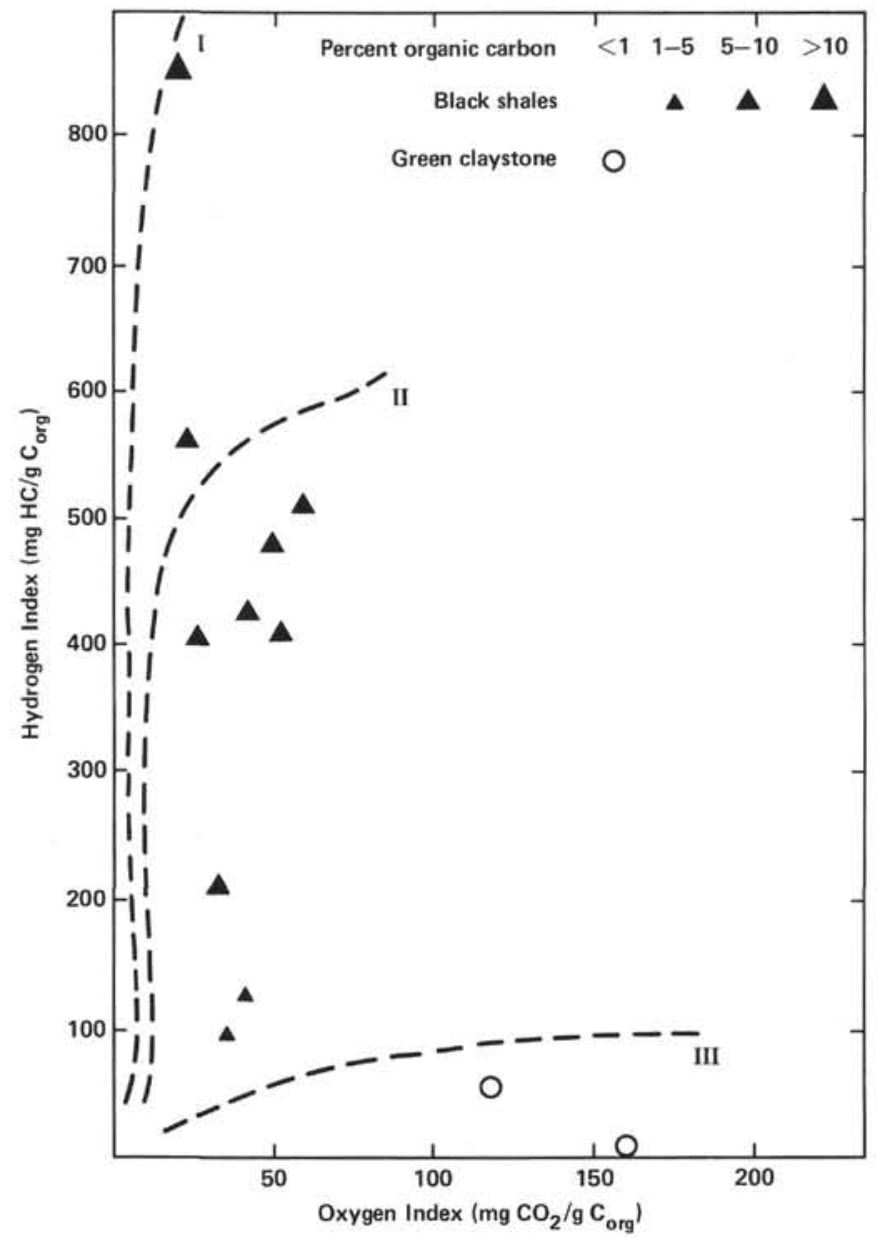

Figure 43. Plot of HI versus OI for samples from Unit 8, Hole 530A.

\section{Holocene to Miocene Sediments (hydraulic piston cored)}

As with the studies of sediments from Holes 512A and 514 on Leg 71, the cores from Hole 530B were found to have a record of magnetization which appeared to be random. The only exception to this observation was Core 530B-8, Sections 2 and 3, which did give consistent paleomagnetic directions. The distribution of magnetic directions is shown in Figure 46, a histogram, and in Figure 47, a stratigraphic plot. The paleomagnetic studies of these cores failed for three reasons:

1) Much of the sediment in these cores consists of debris flows and turbidites. These rock types are sometimes unsuitable for paleomagnetic studies since much of the rock is reoriented detritus. In addition, the coarse-grained portions of such flows are usually unstably magnetized. Because the cores were measured on the magnetometer prior to being split and described, the nature of the rock was unknown during the course of measurement.

2) Most of the sediments from these cores were so weakly magnetized that they were within the noise levels of the magnetometer. Noise tests of the magnetometer indicated that the noise level, on the long core spinner, at $2^{6}$ spins, ranged from $3 \times 10^{-8}$ to $1.2 \times 10^{-7}$ e.m.u. The majority of the sediments had a magnetic moment

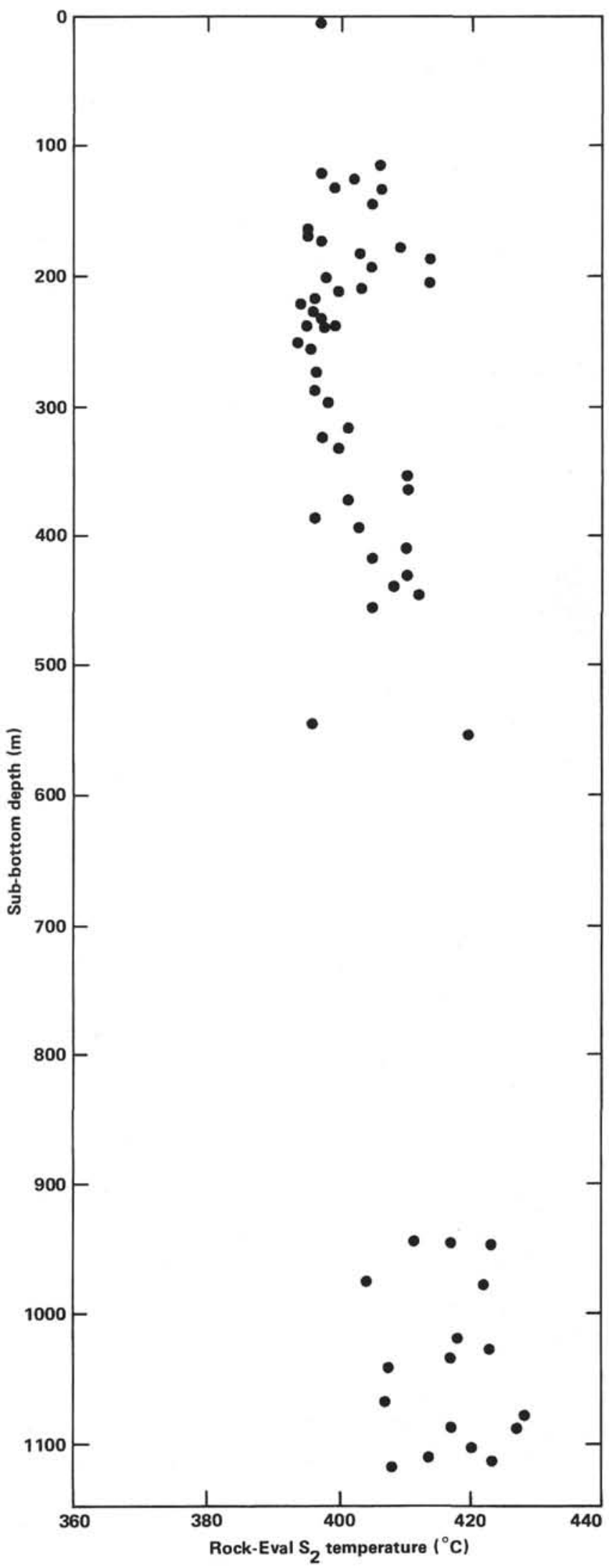

Figure 44. Downhole profile of Rock-Eval S 2 temperatures at Site 530. 


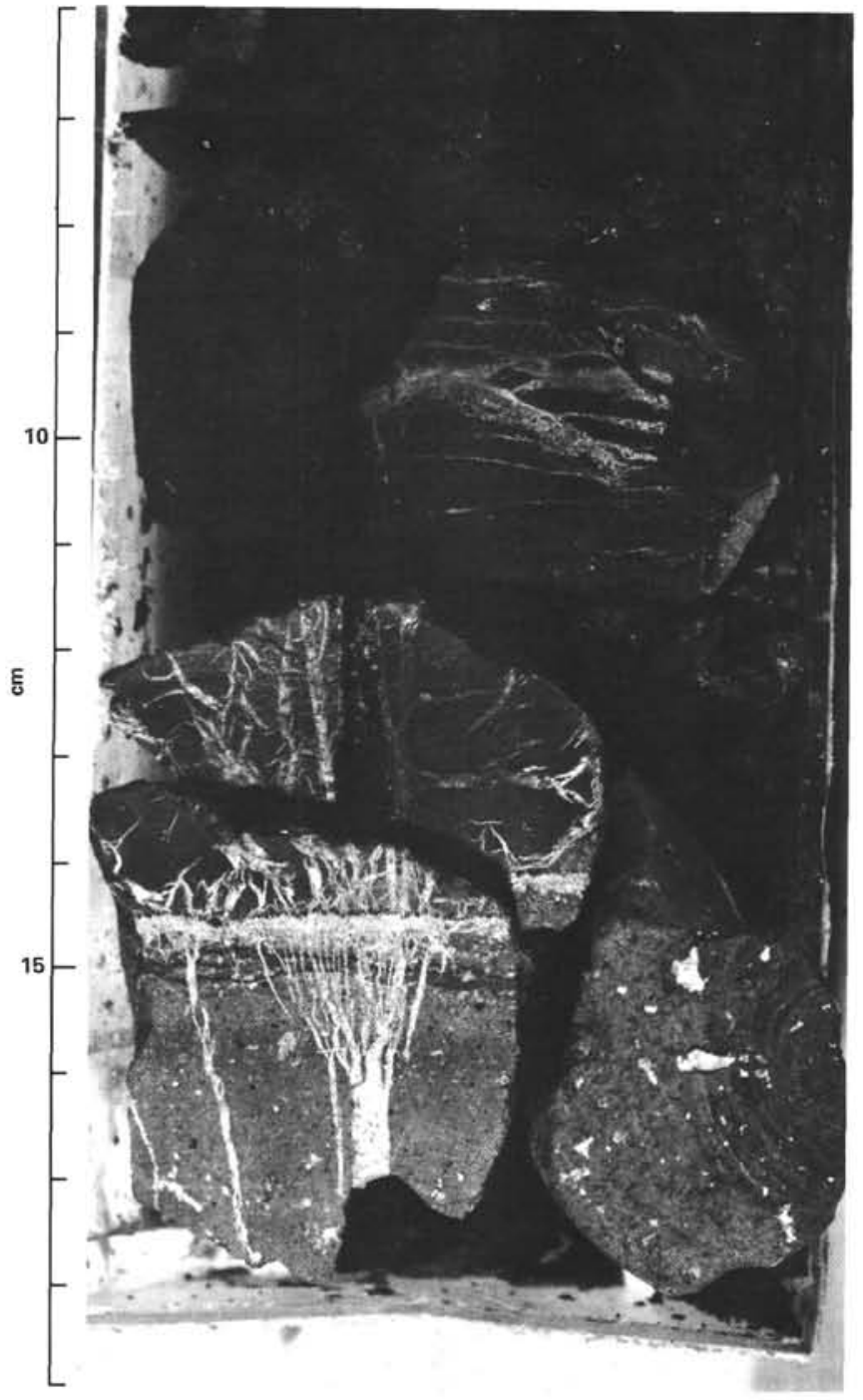

Figure 45. Contact between red mudstone of lithologic Unit 8 and basalt, Unit 9; Sample 530A-105,CC (10-19 cm).

on the order of $1.0 \times 10^{-7}$ e.m.u. Thus, it appears that in many cases the noise level is greater than or equal to the sample magnetization. The low intensity of magnetization in these sediments and the noise level of the magnetometer combine to produce inconsistent indications of directions of magnetization in these cores.

3. Large and abrupt changes in the intensity found in many core sections are related to contamination of the cores with rust from the drill string. Subsequent examination of the split core sections revealed fragments of rusted drill pipe up to $1.5 \mathrm{~cm}$ in length within the sediments, most often at the tops of the core and around the margins of the core liners.

On the previous leg, Chave (pers. comm.) also encountered a rust-contamination problem and found that long core spinning of sediments for paleomagnetic studies was fruitless. The contamination found in this hole was much less than that on Leg 74 , however, since the prior hole, 530A, had been drilled to a depth of $1120 \mathrm{~m}$ and was plugged with three cement plugs; the drilling and cementing should have cleared the drill string of much of its rust.

Successful paleomagnetic studies had been made using the long core spinner on hydraulic piston cores during Leg 72. However, this leg used drill pipe free of rust and, in addition, the intensity of the magnetization of the sediments was in general two to three orders of magnitude greater than that found during Legs 71 and 75 .

Individual, oriented samples were collected from Cores 16 to 63 in Hole 530B, after the cores had been split and described. The objective of this sampling was to allow us to compare the magnetic directions for individual samples to those derived from the long core spinner. However, because the data from the long core spinner cannot be used, the measurements do not tell much about the reversal sequence in Hole 530B. Based upon the biostratigraphy and the limited polarity data available, however, the sampled interval appears to represent portions of the Matuyama and Gauss polarity epochs.

\section{Paleocene-Albian Sediments}

Paleomagnetic studies of Cretaceous sediments from Site 530A were conducted on board using the single specimen vertical Digico magnetometer. Because the sediments were lithified and often friable, the samples were collected by cutting $1.5 \mathrm{~cm}$ cubes from the center of the sediment cores, oriented relative to vertical. The samples were then placed in cubic plastic sample boxes and sealed to retain their moisture content.

The intensity of magnetization within the sediments varied according to lithology (from $8.0 \times 10^{-8}$ to $2.6 \times$ $10^{-4}$ e.m.u.). The most strongly magnetized sediments were the red shales, while the black and green shales were very weakly magnetized. Pyrite nodules were often found in the cores, and where pyrite was found the magnetization was weak. Pyrite formation is a result of diagenesis; it would appear that this form of diagenesis acts to decrease the overall magnetization without changing magnetic directions.

The natural remanent magnetization (NRM) of each sample was measured. The majority of the samples display high paleoinclinations and suggest an overall site paleolatitude of $35-40^{\circ}$.

Because the NRM intensities of many of the shale units do not exceed the noise level of the shipboard magnetometer, the samples were measured at the University of Hawaii using a ScT cryogenic magnetometer. The NRM was remeasured, and a set of samples having representative lithologies was selected in order to conduct detailed alternating-current demagnetization studies. The pilot study samples were then demagnetized at 25 and 50 Oe steps up to $300 \mathrm{Oe}$. On the basis of the pilot study behavior, all of the samples were demagnetized in alternating fields of 100 and $150 \mathrm{Oe}$. The results from the three steps were compared in order to eliminate samples that were not stably magnetized. Those samples displaying in excess of $15^{\circ}$ of motion on demagnetization were rejected as being unstably magnetized. The results of the paleomagnetic studies are displayed stratig- 


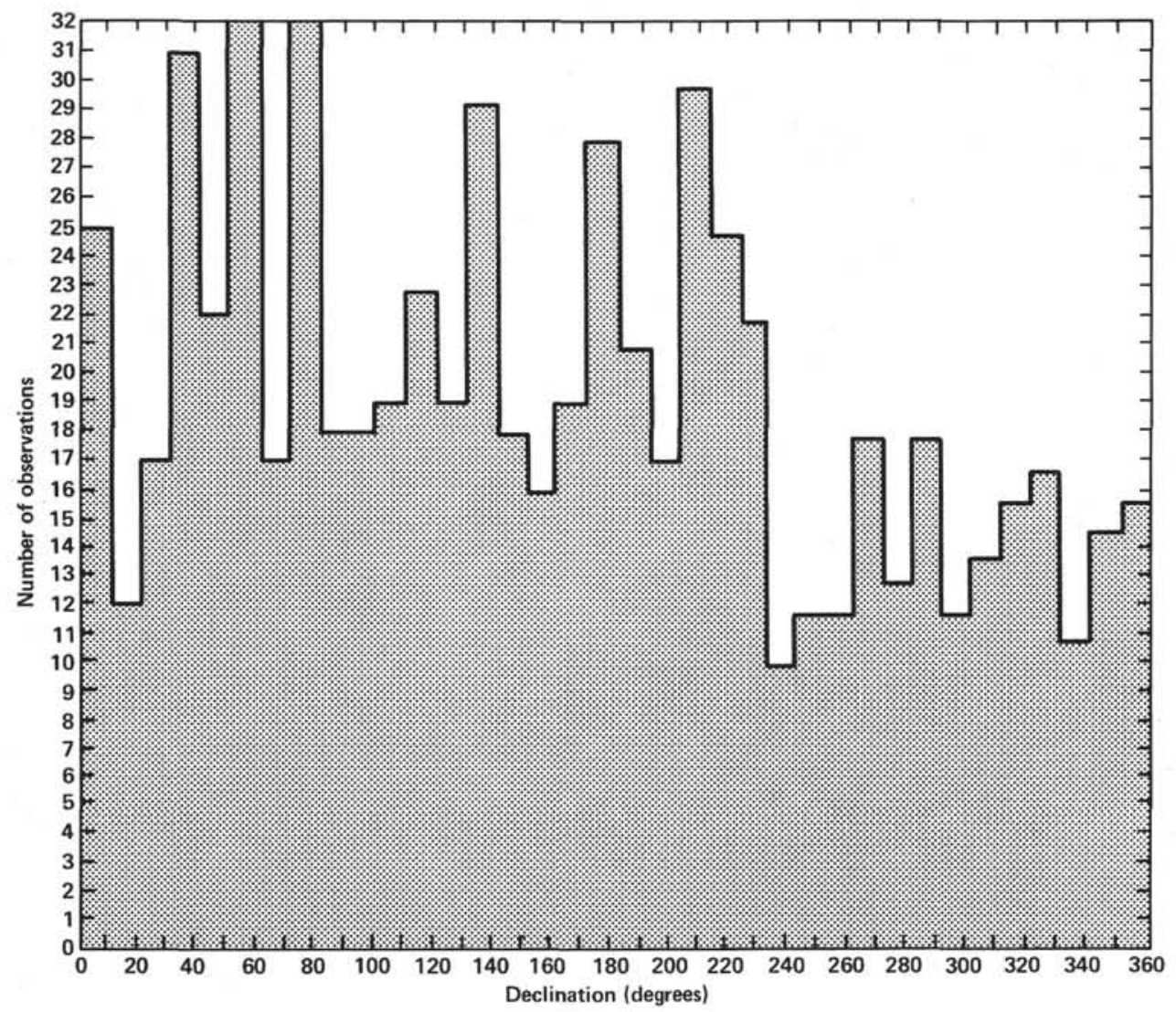

Figure 46. Histogram of magnetic declinations from Hole 530A.

raphically in Figure 48, a stratigraphic plot of sample inclinations. Because this site was situated south of the paleomagnetic equator, the negative inclinations indicate normal polarity. Single-point polarity changes have been omitted from this diagram since they most likely represent undetected inversions of samples occurring during sampling.

Cores $35-59$ and $68-80$ were characterized by mixed polarity. Two intervals, those between Cores 60 and 68 and 81 and 105 , were found to be characterized by normal polarity. Sediments from Cores $35-50$ are characterized by mixed polarity and are assigned a Cenozoic age based upon biostratigraphic studies. Thus the observation of mixed polarity is consistent with reports of mixed polarity in this interval of time (Ness et al., 1980). Mixed polarity was also observed in Cores 50-59. Magnetostratigraphically, this interval appears to correlate with the mixed polarity intervals of the Maestrichtian reported by Keating (1976), Alvarez et al. (1977), and Keating and Helsley (in press). Cores 59-68 are characterized by normal polarity and appear to be Campanian because most of that stage is characterized by normal polarity. Cores $68-80$ are characterized by mixed, but predominantly reversed polarity. If the magnetostratigraphic correlations are correct to this point, the only remaining mixed polarity interval in the Upper Cretaceous occurs in the lower Campanian, and this would be the correlation for Cores 68-80. The remainder of the cores from this hole are characterized by normal polarity and appear to correlate with at least a portion of the Cretaceous Quiet Interval (Fig. 49). Because reversed polarity intervals are absent near the base of the section sampled at Site 530A, it would appear that we have not sampled M-sequence magnetic anomalies or the M-minus sequence anomalies of Albian and Aptian age reported by Keating and Helsley (1978b; 1978). Based upon the magnetostratigraphy the lowermost samples collected at Site 530A can be no older than late Albian.

The correlation of polarity changes with seafloor magnetic anomalies (Ness et al., 1980), polarity sequences derived on land (Alvarez et al., 1977), or marine cores (Keating and Helsley, 1978a, b; 1978; Keating and Helsley, in press), is very poor for the sequence of Cores $68-80$, where three brief normal polarity intervals were recorded. Only one normal polarity interval separating two reversed polarity intervals has been recorded previously (Keating et al., 1975). The reason for this discrepancy is unclear. Most of the stratigraphic interval (Cores 68-80) is characterized by reversed polarity as would be expected. This interval is characterized by thick turbidite sequences. Since the turbidite deposition is episodic and represents geologically instantaneous deposition, the apparent normal polarity intervals may represent secular variation of the magnetic field, possible geomagnetic excursions, or previously undetected brief polarity events.

\section{Igneous Rocks}

Cores 106-108 from Hole 530A contained igneous rocks. One or two specimens were collected per core section. The orientation was marked on the core using a 


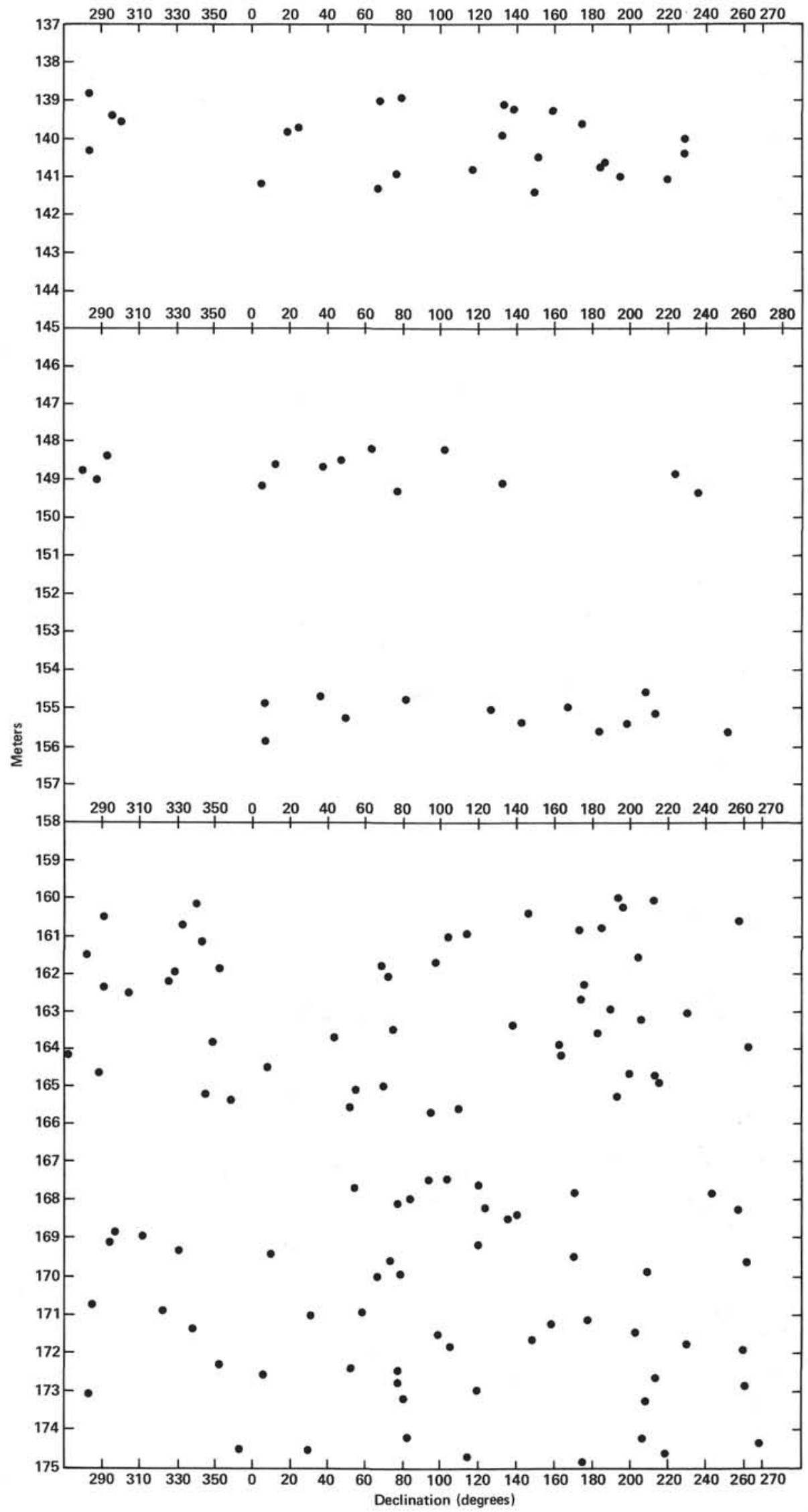

Figure 47. Stratigraphic plot of declination from a portion of the hydraulic piston core samples, Hole 530B, Cores 35-47, 137-175 m sub-bottom. 

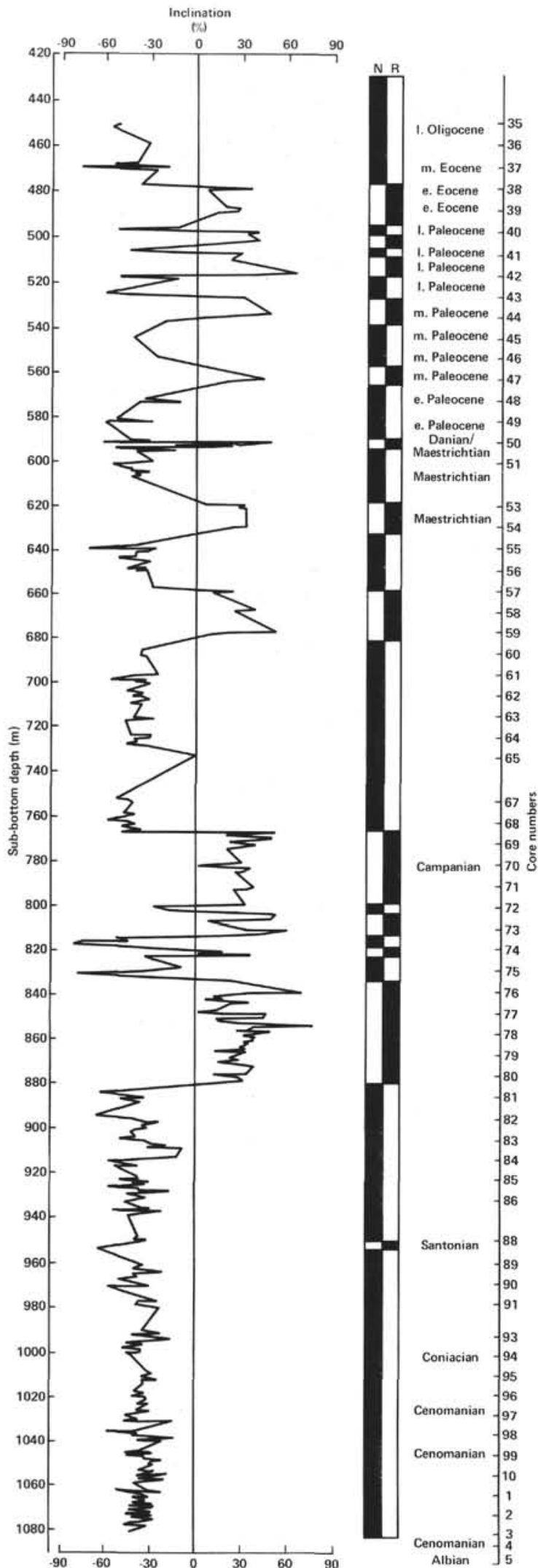

Figure 48. Stratigraphic plot of individual sample inclinations for samples from Site 530A. Magnetic polarity is summarized in the double columns at right. The column marked $\mathrm{N}$ indicates normal polarity by black intervals and reversed polarity by white intervals. The column marked $\mathrm{R}$ indicates normal polarity by white intervals and reversed polarity by black. (Demagnetization intensity, 150 Oe.) (See Steinmetz et al. for revised age scale.)

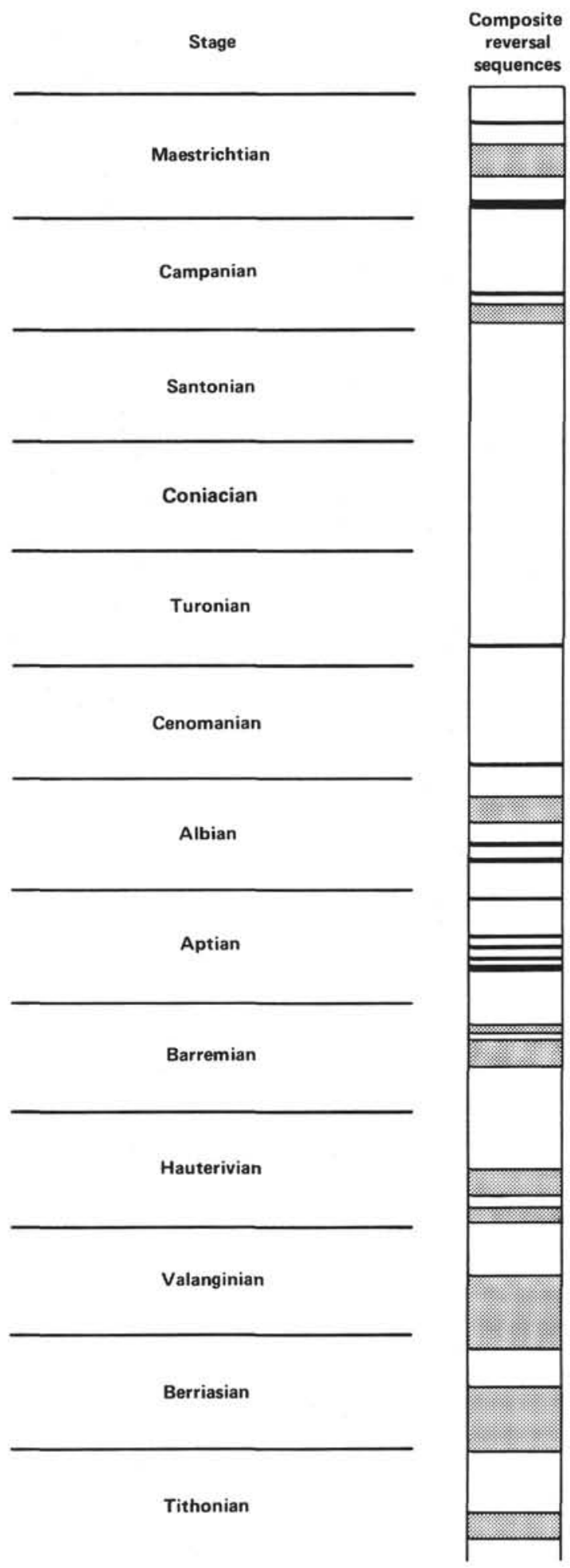

Figure 49. Summary of paleomagnetic studies of Cretaceous sediments from DSDP Legs 40, 41, 43, and 44 and those reported by Keating (1976). Within the polarity summary column, black represents reversed polarity and white represents normal polarity.

diamond scribe, and a $2.5 \mathrm{~cm}$ cylinder was cut from the core centered upon the orientation mark. These minicores were then cut to $2.5 \mathrm{~cm}$ in length and measured on the single specimen spinner shipboard magnetometer.

Core samples were strongly magnetized and ranged in intensity from $7.4 \times 10^{-5}$ to $1.6 \times 10^{-4}$ e.m.u. The di- 
rections (inclinations) were not consistent, however, suggesting that several extrusive units were sampled.

\section{PHYSICAL PROPERTIES}

\section{METHODS}

Sound velocity (compressional), 2-minute GRAPE wet-bulk density (ratio of the wet sediment weight to its volume), and continuous GRAPE wet-bulk density measurements were performed using methods described by Boyce (1976a). To calculate the wet-bulk density $\left(\mathrm{g} / \mathrm{cm}^{3}\right)$ of sediments by the GRAPE technique, a grain density and an Evans (1965) "corrected" grain density of 2.7 was assumed. Basalt densities were calculated using a grain density and "corrected" grain density of $2.9 \mathrm{~g} / \mathrm{cm}^{3}$ (see Boyce, this volume).

Cohesion or shear strength $\left(\mathrm{g} / \mathrm{cm}^{2}\right)$ of clayey sediment was measured using the techniques described by Boyce (1977) using $1.28 \mathrm{~cm}$ (diameter) $\times 1.26 \mathrm{~cm}$ (height) vane size. The vane was rotated with axis parallel to bedding on a split core.

Gravimetric wet-bulk density, wet water content (ratio of the "weight of pore water" to "weight of the wet saturated sediment or rock," expressed as a percent), and porosity (ratio of "pore volume" to the "volume of the wet-saturated rock," expressed as percent) were also determined by traditional gravimetric techniques. These measurements were done by Meyer on board ship on 20-gram samples, using weight in air and weight in water to determine volume. The sample was then dried at $105^{\circ}$ for $24 \mathrm{hr}$. and cooled in a desiccator for at least two hr. before weighing (Ohaus Triple Beam Balance; Rocker, 1974). Before being processed, the samples were wrapped in plastic, placed in plastic vials with damp tissue and sealed; the vials were stored in a refrigerator at a temperature above freezing. The gravimetric data are salt-corrected for $35 \mathrm{ppt}$ interstitial water salinity. The density data, with good firm samples ${ }^{3}$, have an accuracy and precision of $<0.01$ $\mathrm{g} / \mathrm{cm}^{3}$. However, shipboard gravimetric determinations of density may be less accurate with softer samples, which may crumble or flake off during measurement or which are simply too soft to handle properly.

To avoid these problems in softer sediment, "cylinder technique" $\left(15 \mathrm{~cm}^{3}\right)$ samples were taken and stored under seawater; gravimetric porosity and density were determined by Bode at DSDP headquarters in $\mathrm{La}$ Jolla. Precision is $\pm 1 \%$ relative error. The "cylinder technique" uses a $2 \mathrm{~cm}$ high and $\sim 3 \mathrm{~cm}$ diameter metal cylinder that is inserted in the sediment, then carefully removed and cleaned; the sediment is carefully scraped flush to the top of the cylinder. Then two plastic plates are placed over the cylinder ends.

Before the plates are placed on the cylinder, a 2-minute GRAPE count is made through them. Another 2-minute count is made through the same plates plus the sediment (through the axis of the cylinder), so that a 2-minute GRAPE density value can be calculated for the sediment. Almost all data on HPC cores were acquired using this technique.

In general, sound velocity samples were allowed to reach room temperature (four hr. in unsplit core) before sampling. Because of curatorial procedures required for basalt and because drying seriously affects basalt velocities, the velocity of the basalts was measured across the diameter of the core as soon as they arrived on deck $\left(\sim 10^{\circ} \mathrm{C}\right.$, cold $)$. If the basalt samples are slightly air dried, errors as great as $0.3 \mathrm{~km} / \mathrm{s}(<8 \%)$ may occur; the error caused by temperature differences is less than $1 \%$ for $24^{\circ}$ to $2^{\circ} \mathrm{C}$. The error of the shipboard measurements is chiefly the product of temperature and is $<1 \%$, because the core is as fully water saturated as is possible at the time the measurement is made. See Boyce (this volume) for more detail.

\section{Results}

All sound velocity, wet-bulk density, porosity, water content, vane shear strength, and impedance measure-

\footnotetext{
${ }^{3}$ Gravimetric density and GRAPE 2-minute densities do not match well above Core 530A-35, where the sample that was cut from the core may have been a combination of drilling paste and firm rock. Thus, the two samples may not have been homogeneous. Below Core 530A-35 the cores were split using the "super-saw." This tool affects the drilling paste in such a manner that when sampling for velocity and density, the undisturbed rock is easily distinguished. A more "homogeneous pure-rock sample" can be selected, and sample splits are more identical. Thus, below Core 530A-35, the GRAPE 2-minute density and gravimetric density data agree better than data above Core 530A-35. The imprecision of data above Core $530 \mathrm{~A}-35$ may be in part due to the crumbling of the samples during the measurements.
}

ments are listed in Tables 10 and 11, and all except vane shear strength are plotted in Figures 50-53. Vane shear strength versus depth is shown in Figure 54. All analog GRAPE data for each core appear in Appendix B.

The significance of most of these data can best be appreciated in the plots versus depth and the tables and will not be discussed further here. (See Boyce, this volume, for further discussion and interpretation.)

Interval velocities were estimated (see techniques of Boyce, 1976b) using laboratory velocity values and are presented in Table 12 in terms of average velocity at laboratory conditions and at theoretical in situ conditions. If Hamilton's (1976) porosity rebound for sediments is not true, then the in situ velocities would be only slightly greater than those of "laboratory condition," with a small correction for hydrostatic pressure and temperature (see footnotes of Table 12).

Averaging only the softest, uncemented mudstones at laboratory conditions, average velocity between the seafloor and $468 \mathrm{~m}$ is $1.55 \mathrm{~km} / \mathrm{s}$; between $468 \mathrm{~m}$ and $700 \mathrm{~m}$ it is $1.82 \mathrm{~km} / \mathrm{s}$; and between $700 \mathrm{~m}$ and $1099 \mathrm{~m}$ it is 2.03 $\mathrm{km} / \mathrm{s}$. These velocities should be minimum values unless gas is present in situ.

\section{DOWNHOLE MEASUREMENTS}

\section{Temperature Measurements}

A first heat-flow attempt was done in Site 530 at a sub-bottom depth of $125 \mathrm{~m}$. Unfortunately, the probe of the heat-flow tool bent and could not be retrieved. The drill string was pulled to clear the bit; the probe had to be cut off with a blow torch. Other temperature measurements were suspended because of the presence of basalt fragments at this level of the hole and to avoid risk to delaying the geological program. When the drilling of Hole 530A was completed, another heat-flow probe was used to obtain temperature measurements at four levels outside the pipe, at $112 \mathrm{~m}$ depth, at 700 and $300 \mathrm{~m}$ depth, and at the mudline. A summary of the runs given in Tables 13 and 14. Figure 55 shows the recorded temperature curve as a function of time. Because surface water was pumped to push the tool down, the temperatures measured at the bottom of the hole were far from the equilibrium temperature. The temperature recorded at the mudline was too high (about $9^{\circ} \mathrm{C}$ ) because warm water was pulled up with the tool during the ascent.

As a result of the loss of the Density Log part of the Temperature Log-absolute and Density Log tool, the Temperature Log-absolute was run only once at the end of the logging operations. Consequently, the temperature evolution could not be followed through time. Temperature measurements were collected in the open hole between 859 and $625 \mathrm{~m}$ and inside of the pipe. Figure 56 shows logging temperatures and the previous measurements. The five-minute temperature record at $859 \mathrm{~m}$ depth does not allow extrapolation of an equilibrium temperature. Using the $28.4^{\circ} \mathrm{C}$ and $2.6^{\circ} \mathrm{C}$ temperatures recorded at $859 \mathrm{~m}$ depth and at the mudline, respectively, the gradient is $0.303^{\circ} \mathrm{C} / 10 \mathrm{~m}$; this is too low to be valid and indicates that these temperatures were recorded before the hole had come to thermal equilibrium. 


\begin{tabular}{|c|c|c|c|c|c|c|c|c|c|c|c|c|c|c|c|}
\hline \multirow[b]{3}{*}{$\begin{array}{l}\text { Core-Section } \\
\text { (interval in } \mathrm{cm} \text { ) }\end{array}$} & \multirow[b]{3}{*}{$\begin{array}{l}\text { Depth in } \\
\text { hole } \\
\text { (m) }\end{array}$} & \multicolumn{5}{|c|}{ Compressional-sound velocity } & \multirow{2}{*}{\multicolumn{2}{|c|}{$\begin{array}{l}\text { GRAPE "special" } \\
\text { wet-bulk density" } \\
\text { (2-minute count) } \\
\left(\mathrm{g} / \mathrm{cm}^{3}\right)\end{array}$}} & \multirow{2}{*}{\multicolumn{3}{|c|}{ Gravimetric $^{b, c}$}} & \multirow[b]{3}{*}{$\begin{array}{c}\text { Acoustic } \\
\text { impedance } \\
\left(\mathrm{g} \cdot 10^{5} / \mathrm{cm}^{2} \cdot \mathrm{s}\right)\end{array}$} & & & \multirow[b]{3}{*}{ Lithology (G.S.A. color number) } \\
\hline & & \multirow{2}{*}{$\begin{array}{c}1 \\
\text { Beds } \\
(\mathrm{km} / \mathrm{s})\end{array}$} & \multirow[b]{2}{*}{$\begin{array}{c}\frac{1}{\text { Beds }} \\
(\mathrm{km} / \mathrm{s})\end{array}$} & Ani & tropy & & & & & & & & Vane & shear & \\
\hline & & & & $\frac{1-1}{(\mathrm{~km} / \mathrm{s})}$ & $\frac{(1-1) / 1}{(\%)}$ & $\begin{array}{l}\text { Temp. } \\
\left({ }^{\circ} \mathrm{C}\right)\end{array}$ & $\begin{array}{c}1 \\
\text { Beds }\end{array}$ & $\frac{1}{\text { Beds }}$ & $\begin{array}{l}\text { bulk } \\
\text { density } \\
\left(\mathrm{g} / \mathrm{cm}^{3}\right)\end{array}$ & $\begin{array}{c}\text { content } \\
\text { (salt corr.) } \\
(\%)\end{array}$ & $\begin{array}{l}\text { (salt } \\
\text { corr.) } \\
(\%)\end{array}$ & & $\begin{array}{l}\text { Original } \\
\left(\mathrm{g} / \mathrm{cm}^{2}\right)\end{array}$ & $\begin{array}{c}\text { Remolded } \\
\left(\mathrm{g} / \mathrm{cm}^{2}\right)\end{array}$ & \\
\hline $3, \mathrm{CC}-$ & 144.10 & 4.810 & 4.672 & - & - & 9 & - & - & & - & - & - & - & & Vesicular-vuggy basalt pebble. Velocity orientation(?). \\
\hline $4-4,91-93$ & 158.91 & 1.520 & - & - & - & 20 & - & - & $1.65^{\mathrm{b}}$ & $39.5^{\mathrm{b}}$ & $63.7^{b}$ & - & - & & Nannofossil ooze (5Y $5 / 2$ ) \\
\hline $4-5,81-82$ & 160.31 & 1.476 & 1.545 & -0.069 & -4.4 & 20 & - & 1.68 & - & - & - & 2.60 & - & & Mottled clay $(5 Y 3 / 2)$ \\
\hline $4-5,89-90$ & 160.39 & - & - & - & - & - & - & - & $1.64^{\mathrm{b}}$ & $40.4^{\mathrm{b}}$ & $64.7^{\mathrm{b}}$ & - & 1580 & 224 & Mottled clay (5Y 3/2) \\
\hline $7-1,131-135$ & 183.31 & 1.561 & 1.531 & 0.030 & 2.0 & 20 & 1.75 & - & $1.68^{\mathrm{b}}$ & $37.9^{\mathrm{b}}$ & $62.1 \mathrm{~b}$ & 2.68 & - & 224 & Nannofossil ooze (5Y $5 / 2$ ) \\
\hline $7-3,49-51$ & 185.49 & 1.523 & - & - & - & 20 & - & - & $1.65^{\mathrm{b}}$ & $39.4^{\mathrm{b}}$ & $63.5^{\mathrm{b}}$ & - & - & & Laminated nannofossil ooze (5Y $5 / 2$ ) \\
\hline $7-6,43-44$ & 189.93 & 1,020 & - & - & - & - & - & $=$ & & & & $=$ & 743 & 24 & Clay (5Y 3/2) \\
\hline $7-6,46-48$ & 189.96 & 1.560 & - & - & $\overline{-}$ & 20 & 1.65 & $\overline{-}$ & $1.70^{\mathrm{b}} ?$ & $37.7^{\mathrm{b}} ?$ & $62.5^{b} ?$ & $\bar{z}$ & - & & Clay (5Y 3/2) \\
\hline $8-5,17-19$ & 197.67 & - & - & - & - & - & - & $=$ & - & - & - & - & 1604 & 236 & Clay (5Y $3 / 2)$ \\
\hline $8-5,23-25$ & 197.72 & 1.553 & 1.537 & $\overrightarrow{0.016}$ & $\overline{1.0}$ & $\overline{20}$ & $\overline{-}$ & $1 . \overline{52}$ & $=$ & $43.6^{\mathrm{b}}$ & $=$ & $2 . \overline{34}$ & 1004 & 236 & $\begin{array}{l}\text { Clay (5Y 33/2) } \\
\text { Clay (5Y } 3 / 2 \text { ) }\end{array}$ \\
\hline $8-6,135-137$ & 200.35 & 1.577 & - & - & - & 20 & $=$ & - & $1 . \overline{7} 5^{\mathrm{b}}$ & $\begin{array}{l}46.3^{\mathrm{b}} \\
36 \mathrm{a}\end{array}$ & $61 . \overline{8^{b}}$ & 2.34 & $\overline{-}$ & & Nannofossil ooze (5Y $5 / 2$ ) \\
\hline $8-7,51-53$ & 201.01 & - & 1.505 & - & $=$ & 20 & $z$ & - & $1.73^{\mathrm{b}}$ & $\begin{array}{l}35.7 \mathrm{~b} \\
35 \mathrm{~b}\end{array} \mathrm{~b}$ & $60.1^{\mathrm{b}}$ & $2 . \overline{60}$ & $\bar{z}$ & & Nannofossil ooze (5Y $5 / 2)$ \\
\hline $10-2,26-27$ & 212.26 & 1.534 & - & - & - & 20 & - & 1.66 & $1.60^{\mathrm{b}}$ & $45.8^{\mathrm{b}}$ & $71.7^{b}$ & - & - & & Nannofossil marl (5Y 4/2) \\
\hline $10-3,0-3$ & 213.50 & 1.507 & 1.502 & 0.005 & 0.3 & 20 & - & 1.57 & $1.61^{\mathrm{b}}$ & $43.1^{\mathrm{b}}$ & $67.7^{\mathrm{b}}$ & 2.42 & - & & Nannofossil ooze (5Y 5/2) \\
\hline $10-6,5-7$ & 218.05 & $\overline{0}$ & - & - & - & & - & - & - & - & - & - & 1014 & 153 & Clay (5Y 3/2) \\
\hline $10-6,10-12$ & 218.10 & 1.568 & - & - & - & 20 & - & - & $1.67^{\mathrm{b}}$ & $39.9^{\mathrm{b}}$ & $64.9^{\mathrm{b}}$ & - & - & & Clay (5Y $3 / 2)$ \\
\hline $11-1,29-31$ & 220.29 & 1.620 & 1.572 & 0.048 & 3.1 & 20 & - & 1.71 & $1.69^{\mathrm{b}}$ & $37.3^{\mathrm{b}}$ & $61.5^{\mathrm{b}}$ & 2.66 & - & & Clay (5Y $3 / 2$ ) \\
\hline $11-2,135-137$ & 222.85 & 1.626 & 1.613 & 0.013 & 0.8 & 20 & - & 1.71 & $1.71^{\mathrm{b}}$ & $37.2^{\mathrm{b}}$ & $62.1^{\mathrm{b}}$ & 2.76 & - & & Sandy nannofossil ooze (5Y 4/2) \\
\hline $11-4,0-4$ & 224.97 & - & - & - & - & - & - & - & $1.73^{\mathrm{b}}$ & $36.3^{\mathrm{b}}$ & $61.3^{\mathrm{b}}$ & - & - & & Nannofossil ooze (5Y 5/2) \\
\hline $11-6,88-90$ & 228.38 & - & - & - & - & - & - & - & $1.83^{\mathrm{b}}$ ? & $35.6^{\mathrm{b}}$ ? & $63.7^{\mathrm{b}} ?$ & - & 908 & (cracked) & Clay $(5 Y 3 / 2)$ \\
\hline $12-4,97-100$ & 234.97 & 1.492 & 1.578 & -0.086 & -5.4 & 20 & 1.61 & - & $1.66^{\mathrm{b}}$ & $37.7^{\circ}$ & $61.0^{\mathrm{b}}$ & 2.62 & - & & Nannofossil ooze (5Y 5/2) \\
\hline $12-5,0-3$ & 235.50 & 1.573 & - & - & - & 20 & - & - & $1.70^{\mathrm{b}}$ & $37.9^{\mathrm{b}}$ & $62.9^{\mathrm{b}}$ & - & - & & Clay $(5 Y 3 / 2)$ \\
\hline $12-5,135-137$ & 236.85 & 1.566 & 1.593 & -0.027 & -1.7 & 20 & 1.70 & - & $1.72^{\mathrm{b}}$ & $35.4 \mathrm{~b}$ & $59.2^{\mathrm{b}}$ & 2.74 & 1368 & & Nannofossil marl (5Y 5/2) \\
\hline $13-2,135-137$ & 241.85 & 1.596 & - & - & - & 20 & - & - & $1.70^{\mathrm{b}}$ & $35.8^{\mathrm{b}}$ & $59.3^{\mathrm{b}}$ & - & 1085 & 141 & Clay (5Y 3/2) \\
\hline $13-3,140-142$ & 243.40 & 1.562 & - & - & - & 20 & - & - & $2.00^{\mathrm{b}}$ & $34.0^{\mathrm{b}}$ & $66.2^{\mathrm{b}}$ & $=$ & - & 141 & Nannofossil ooze (5Y 5/2) \\
\hline $13-5,104-106$ & 246.04 & - & - & - & - & - & - & 1.74 & $1.73^{\mathrm{b}}$ & $34.5^{\mathrm{b}}$ & $58.2^{\mathrm{b}}$ & $=$ & $\overline{-}$ & & Nannofossil marl (5Y $4 / 2)$ \\
\hline $14-1,110-112$ & 249.60 & 1.589 & - & - & - & 20 & - & - & $1.70^{\mathrm{b}}$ & $37.8^{\mathrm{b}}$ & $62.7^{\mathrm{b}}$ & $=$ & $=$ & & Clay (SY 5/2) \\
\hline $14-2,46-48$ & 250.46 & 1.536 & $=$ & $=$ & - & 20 & $=$ & $=$ & $1.82^{\mathrm{b}}$ ? & $34.8^{\mathrm{b}}$ ? & $61.9^{b} ?$ & $=$ & - & & Clay (5Y $3 / 2$ ) \\
\hline $14-2,98-100$ & 250.98 & 1.579 & 1.554 & $\overline{0.025}$ & $\overline{1.6}$ & 20 & $\overline{-}$ & $1 . \overline{75}$ & $1.72^{\mathrm{b}^{\mathrm{t}}}$ & 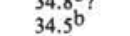 & $57.9^{\mathrm{b}}$ & $2 . \overline{67}$ & $\bar{z}$ & & $\begin{array}{l}\text { Clay (5Y 3/2) } \\
\text { Nannofossil marl (5Y } 4 / 2)\end{array}$ \\
\hline $14-3,55-57$ & 252.05 & & - & - & 1.0 & - & $\overline{-}$ & - & & 34. & & 2.07 & 1297 & 523 & Nannofossil marl or ooze (5Y $6 / 2$ ) \\
\hline $15-2,6-8$ & 259.56 & $1 . \overline{641}$ & $1 . \overline{581}$ & 0.060 & $\overline{3.8}$ & $\overline{20}$ & $1 . \overline{69}$ & $=$ & $1 . \overline{80} \mathrm{~b} ?$ & $32.6^{\mathrm{b}} \mathrm{l}$ & $57.1^{\mathrm{b}} ?$ & 2.84 ? & - & & Clay $(5 Y 3 / 2)$ \\
\hline $15-2,10-12$ & 259.60 & & - & 0.000 & -0 & - & 1.09 & $=$ & 1.00 & - & - & 2.0+1: & 849 & (Cracked) & Clay (5Y $3 / 2$ ) \\
\hline $15-4,144-146$ & 263.92 & 1.565 & $=$ & $\bar{z}$ & $=$ & $\overline{20}$ & $\overline{-}$ & $\bar{z}$ & - & Bad sample & 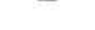 & 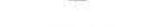 & & & Nannofossil marl (5Y $5 / 1$ ) \\
\hline $15-6,93-95$ & 266.43 & 1.589 & 1.574 & 0.015 & $\overline{1.0}$ & 20 & $1 . \overline{72}$ & $=$ & & Bad sample & & $3.07 ?$ & - & & Nannofossil ooze (5Y $6 / 1$ \\
\hline $16-1,77-78$ & 268.27 & 1.634 & 1.609 & 0.025 & 1.6 & 20 & - & $1 . \overline{81}$ & $1.79^{\mathrm{b}}$ & $32.3^{3}$ & $56.4^{\mathrm{b}}$ & 2.88 & $\overline{-}$ & & Clay (5Y 3/2) \\
\hline $16-1,78-90$ & 268.29 & - & - & - & - & - & - & - & $\overline{-}$ & - & - & - & 1274 & (Cracked) & Clay (5Y 3/2) \\
\hline $17-1,6-7$ & 277.06 & 1.626 & 1.525 & 0.101 & 6.6 & 20 & - & - & $1.88^{\mathrm{b}}$ ? & $34.0^{\mathrm{b}}$ ? & $62.3^{\mathrm{b}}$ ? & $2.87 ?$ & - & & Clay (5Y $3 / 2)$ \\
\hline $18-2,25-27$ & 288.25 & 1.638 & 1.629 & 0.009 & 0.6 & 20 & - & 1.88 & $1.87^{\mathrm{b}}$ & $28.3^{\mathrm{b}}$ & $51.5^{b^{\mathrm{b}}}$ & 3.05 & - & & Nannofossil marl (5Y 4/3) \\
\hline $18-3,146-150$ & 290.96 & 1.639 & 1.625 & 0.014 & 0.9 & 20 & - & 1.84 & $1.82^{\mathrm{b}}$ & $30.2^{\mathrm{b}}$ & $53.8^{\mathrm{b}}$ & 2.96 & - & & Clay (5Y 5/3) \\
\hline $18-5,102-104$ & 293.52 & 1.623 & 1.599 & 0.024 & 1.5 & 20 & - & 1.89 & $1.80^{\mathrm{b}}$ & $31.5^{\mathrm{b}}$ & $55.3^{\mathrm{b}}$ & 2.88 & - & & Clay (SY $5 / 3$ ) \\
\hline $18-5,106-108$ & 293.54 & - & - & - & - & 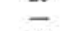 & - & - & & & & - & 2235 & (Cracked) & Clay (SY $5 / 3$ ) \\
\hline $19-1,140-150$ & 297.40 & 1.634 & 1.592 & 0.042 & 2.6 & 20 & - & - & $1.74^{\mathrm{b}}$ & $33.5^{\mathrm{b}}$ & $57.1^{b}$ & 2.77 & - & & Clay $(5 Y 3 / 2)$ \\
\hline $19-4,143-145$ & 301.97 & 1.622 & 1.601 & 0.021 & 1.3 & 20 & - & 1.80 & $1.77^{\mathrm{b}}$ & $31.8^{\mathrm{b}}$ & $54.8^{\mathrm{b}}$ & 2.83 & - & & Clay (5Y $3 / 2$ ) \\
\hline $19-6,134-136$ & 304.84 & 1.625 & 1.599 & 0.029 & 1.8 & 20 & - & 1.81 & $1.75^{\mathrm{b}}$ & $33.9^{\mathrm{b}}$ & $58.0^{\mathrm{b}}$ & 2.80 & - & & Clay $(5 \mathrm{Y} 3 / 2)$ \\
\hline $19-6,146-148$ & 304.96 & - & - & - & - & 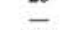 & - & . & & & & 0.00 & 2111 & 82 & Clay (5Y 3/2) \\
\hline $20-1,143-145$ & 306.93 & 1.617 & 1.603 & 0.014 & 0.9 & 20 & $=$ & $1 . \overline{82}$ & $1 . \overline{78^{\mathrm{b}}}$ & $32.6^{\mathrm{b}}$ & $56.7^{\mathrm{b}}$ & 2.85 & - & & Claystone (5Y 3/2) \\
\hline $20-3,143-147$ & 309.93 & 1.582 & 1.593 & -0.011 & -0.7 & 20 & - & 1.71 & $1.76^{\mathrm{b}}$ & $33.4^{\mathrm{b}}$ & $57.4^{\mathrm{b}}$ & 2.80 & - & & Claystone (5Y 3/2) \\
\hline $20-5,133-136$ & 312.87 & 1.582 & 1.590 & -0.008 & -0.5 & 20 & - & 1.78 & $1.74^{\mathrm{b}}$ & $34.2^{\mathrm{b}}$ & $58.2^{\mathrm{b}}$ & 2.77 & - & & Claystone (5Y 3/2) \\
\hline $21-1,145-147$ & 316.45 & 1.617 & 1.587 & 0.030 & -1.9 & 20 & - & 1.78 & $1.76^{\mathrm{b}}$ & $32.9^{\mathrm{b}}$ & $56.5^{\mathrm{b}}$ & 2.79 & - & & Claystone (5Y 3/2) \\
\hline $21-3,132-134$ & 319.32 & 1.598 & 1.613 & -0.015 & -0.9 & 21 & - & 1.93 & $1.77^{\mathrm{b}}$ & $32.2 \mathrm{~b}$ & $55.6^{\mathrm{b}}$ & 2.86 & - & & Claystone (5Y $2 / 2$ ) \\
\hline $21-5,149-150$ & 322.49 & 1.612 & 1.591 & 0.021 & +1.3 & 21 & $=$ & 1.82 & $1.79^{\mathrm{b}}$ & $32.1^{\mathrm{b}}$ & $56.0^{\mathrm{b}}$ & 2.85 & - & & Claystone (5Y 3/2) \\
\hline $22-2,130-132$ & 327.30 & 1.602 & 1.587 & 0.015 & +0.9 & 21 & $=$ & 1.71 & $1.70^{\mathrm{b}}$ & $35.9^{\mathrm{b}}$ & $59.5^{\mathrm{b}}$ & 2.70 & - & & Clay $(10 \mathrm{Y} 4 / 2)$ \\
\hline $22-4,90-93$ & 329.90 & 1.621 & - & - & -8 & 21 & $=$ & 1.82 & $1.76^{\mathrm{b}}$ & $33.7^{\mathrm{b}}$ & $57.8^{\mathrm{b}}$ & - & $=$ & & Clay (5Y 5/2) \\
\hline $22-6,11-12$ & 332.11 & 1.670 & $1 . \overline{720}$ & -0.050 & $-\overline{2} .9$ & 21 & $\beth$ & 1.80 & $1.80^{\mathrm{b}}$ & $32.8^{\mathrm{b}}$ & 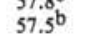 & 3.10 & $=$ & & Clay (5Y 5/2) \\
\hline $23-1,10-15$ & 334.10 & $2.807 ?$ & - & - & - & 21 & $=$ & - & 1.00 & - & - & 3.10 & $=$ & & Breccia (chert with $\mathrm{CO}_{3}$ cement) \\
\hline $24-2,0-3$ & 345.00 & 1.529 & $1 . \overline{573}$ & $-0 . \overline{0} 44$ & $-\overline{2.8}$ & 21 & $\bar{z}$ & $1 . \overline{64}$ & $=$ & $\overline{-}$ & $\overline{-}$ & $2 . \overline{61}$ & $=$ & & Nannofossil foraminifer ooze (disturbed) (12YR $5 / 2$ ) \\
\hline $24-2,60-63$ & 345.60 & 1.607 & 1.589 & 0.018 & $\begin{array}{r}-2.8 \\
1.1\end{array}$ & 21 & $\overline{-}$ & 1.78 & $1 . \overline{72^{\mathrm{b}}}$ & $34.9^{\mathrm{b}}$ & $58 . \overline{7^{\mathrm{b}}}$ & 2.73 & $\bar{z}$ & & 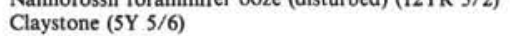 \\
\hline $24-3,145-147$ & 347.95 & 1.658 & 1.623 & 0.035 & 2.2 & ${ }_{21}^{21}$ & 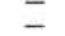 & 1.81 & $1.77^{\mathrm{b}}$ & $33.3^{\mathrm{b}}$ & $57.5^{\mathrm{b}}$ & 2.87 & $=$ & & Clay (10Y 4/4) \\
\hline $25-3,75-77$ & 356.75 & $\begin{array}{l}1.038 \\
\text { gassy }\end{array}$ & 1.609 & 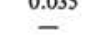 & -2 & 20 & $\overline{-}$ & 1.81 & $1.65^{\mathrm{b}}$ ? & $\begin{array}{l}39.9 \mathrm{~b} \text { ? } \\
39 .\end{array}$ & $64.4^{\mathrm{b}}$ ? & $\begin{array}{l}2.81 \\
2.65\end{array}$ & $=$ & & Clay (10Y 4/2) (gassy) \\
\hline $25-6,71-74$ & 361.21 & gassy & gassy & - & - & - & - & 1.74 & - & - & & - & - & & Clay (10Y $4 / 2$ ) (gassy) \\
\hline $25-7,58-60$ & 362.58 & 1.608 & gassy & - & - & 21 & - & - & $1.73^{\mathrm{b}}$ & $35.5^{\mathrm{b}}$ & $59.9^{\mathrm{b}}$ & - & - & & Clay (10Y $4 / 2$ ) (gassy) \\
\hline $26-3,105-107$ & 366.55 & 1.612 & 1.620 & -0.008 & -0.5 & 20 & - & 1.86 & $1.71^{\mathrm{b}}$ & $35.0^{\mathrm{b}}$ & $58.4^{\mathrm{b}}$ & 2.77 & $\bar{z}$ & & Claystone (10Y 4/2) (gassy) \\
\hline
\end{tabular}




\begin{tabular}{|c|c|c|c|c|c|c|c|c|c|c|c|c|c|c|}
\hline $26-4,12-14$ & 367.12 & 1.611 & gassy & - & - & 20 & - & 1.77 & $1.66^{\mathrm{b}}$ & $37.5^{\mathrm{b}}$ & $60.9^{\mathrm{b}}$ & - & - & Claystone (10Y 4/2) \\
\hline $26-5,106-108$ & 369.56 & 1.586 & 1.643 & -0.061 & -3.7 & 20 & - & 1.71 & $1.75^{\mathrm{b}}$ & $34.4^{\mathrm{b}}$ & $58.8^{\mathrm{b}}$ & 2.88 & - & Claystone (10Y $4 / 2)$ \\
\hline $27-4,138-140$ & 377.88 & 1.593 & 1.634 & -0.041 & -2.5 & 20 & - & 1.88 & $1.77^{\mathrm{b}}$ & $32.0^{\mathrm{b}}$ & $55.3^{\mathrm{b}}$ & 2.89 & - & Claystone (10Y 4/2) \\
\hline $27-5,138-140$ & 379.38 & 1.616 & 1.648 & -0.032 & -1.9 & 20 & - & 1.79 & $1.83^{\mathrm{b}}$ & $31.2^{\mathrm{b}}$ & $55.7^{\mathrm{b}}$ & 3.02 & - & Claystone (10Y $4 / 2)$ \\
\hline $27-6,138-140$ & 380.88 & 1.628 & 1.650 & -0.022 & -1.4 & 20 & 1.84 ? & - & $1.69^{\mathrm{b}}$ & $37.3^{\mathrm{b}}$ & $61.5^{\mathrm{b}}$ & 2.79 & - & Claystone (10Y $4 / 2)$ \\
\hline $28-6,105-107$ & 390.07 & 1.583 & 1.619 & -0.036 & -2.2 & 20 & - & $=$ & $1.80^{\mathrm{b}}$ & $34.1^{\mathrm{b}}$ & $59.8^{\mathrm{b}}$ & 2.91 & $=$ & Claystone (10Y 4/2) (gassy) \\
\hline $29-2,75-77$ & 393.25 & $1.711 ?$ & $2.065 ?$ & -0.354 & -17.1 & 20 & $1 . \overline{76}$ & $\bar{z}$ & $1.84^{\mathrm{b}}$ & $30.1^{b}$ & $54.1^{\mathrm{b}}$ & $\begin{array}{l}2.91 \\
3.80 ?\end{array}$ & $\bar{z}$ & Claystone (10Y 4/2) (gassy) \\
\hline $29-4,75-77$ & 396.25 & 1.651 & 1.601 & 0.050 & 3.1 & 20 & 1.88 & $=$ & $1.81^{\mathrm{b}}$ & $32.1 \mathrm{~b}$ & $56.7^{\mathrm{b}}$ & 2.90 & $=$ & Claystone (10Y $4 / 2$ ) (gassy) \\
\hline $29-6,73-75$ & 399.24 & 1.669 & 1.616 & 0.053 & 3.3 & 20 & - & $1 . \overline{77}$ & $1.76^{\mathrm{b}}$ & $35.6^{\mathrm{b}}$ & $61.2^{\mathrm{b}}$ & 2.84 & $\bar{z}$ & Claystone (10Y $4 / 2$ ) (gassy) \\
\hline $30-2,38-40$ & 402.38 & 1.685 & 1.625 & 0.060 & 3.7 & 20 & - & - & $1.83^{\mathrm{b}}$ & $31.6^{\mathrm{b}}$ & $56.4^{\mathrm{b}}$ & $\begin{array}{l}2.94 \\
2.97-10\end{array}$ & $=$ & Claystone $(10 \mathrm{Y} 4 / 2)$ (gassy) \\
\hline $30-3,38-40$ & 403.88 & gassy & gassy & - & - & - & - & - & $1.78^{\mathrm{b}}$ & $33.3^{\mathrm{b}}$ & $57.8^{\mathrm{b}}$ & - & $\bar{z}$ & Claystone (10Y 4/2) (gassy) \\
\hline $30-5,38-40$ & 406.88 & 1.738 & - & - & - & 20 & - & - & $1.74^{\mathrm{b}}$ & $34.3^{\mathrm{b}}$ & $58.2 \mathrm{~b}$ & $\bar{z}+1+x$ & 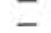 & $\begin{array}{l}\text { Claystone (10Y } 3 / 2) \\
\text { Cassy) }\end{array}$ \\
\hline $31-3,18-20$ & 413.18 & 1.633 & 1.585 & 0.048 & 3.0 & 20 & - & - & $1.65^{b}$ & $40.7^{b}$ & $65.4^{\mathrm{b}}$ & $\overline{2.62}$ & $\bar{z}$ & $\begin{array}{l}\text { Claystone (10Y 4/2) } \\
\text { Claystone (IOY) }\end{array}$ \\
\hline $31-5,18-20$ & 416.18 & 1.705 & 1.644 & 0.061 & 3.7 & 20 & 1.85 & - & $1.70^{\mathrm{b}}$ & $36.9^{\mathrm{b}}$ & $61.2^{\mathrm{b}}$ & $\begin{array}{l}2.02 \\
2.79\end{array}$ & $=$ & Claystone (10Y $4 / 2)$ \\
\hline $31-6,18-20$ & 417.81 & 1.705 & 1.621 & 0.084 & 5.2 & 20 & - & 1.85 & $1.70^{\mathrm{b}}$ & $35.3^{\mathrm{b}}$ & $58.5^{\mathrm{b}}$ & 2.75 & $=$ & Claystone (10Y $4 / 2)$ \\
\hline $32-1,75-77$ & 420.25 & 1.629 & - & - & - & 20 & - & - & & & & - & - & Claystone (10Y 4/2) \\
\hline $32-2,75-77$ & 421.75 & 1.690 & - & - & - & 20 & - & - & $1.71^{\mathrm{b}}$ & $35.1^{\mathrm{b}}$ & $58.5^{\mathrm{b}}$ & - & - & Claystone $(10 \mathrm{Y} 4 / 2)$ \\
\hline $32-3,75-77$ & 423.25 & $1.694 ?$ & $2.100 ?$ & -0.406 & -19.3 & 20 & - & 1.83 & $1.63^{\mathrm{b}}$ ? & $39.2^{\mathrm{b}} \mathrm{r}$ ? & $62.4^{\mathrm{b}}$ ? & $3.42 ?$ & - & Claystone $(10 \mathrm{Y} 4 / 2)$ \\
\hline $33-2,5-7$ & 430.55 & 1.744 & 1.660 & 0.084 & 5.1 & 20 & - & 1.85 & $1.78^{\mathrm{b}}$ & $34.3^{\mathrm{b}}$ & $59.4^{\mathrm{b}}$ & 2.95 & - & Claystone (10Y 4/2) \\
\hline $33-3,5-7$ & 432.05 & 1.681 & 1.655 & 0.026 & 1.6 & 20 & - & - & $1.67^{b}$ & $36.7^{\mathrm{b}}$ & $59.6^{\mathrm{b}}$ & 2.76 & - & Claystone (10Y 4/2) \\
\hline $33-4,5-7$ & 433.55 & 1.761 & 1.657 & 0.104 & 6.3 & 20 & 1.86 & - & $1.83^{\mathrm{b}}$ & $28.9^{\mathrm{b}}$ & $51.6^{\mathrm{b}}$ & 3.03 & - & Claystone (10Y 4/2) \\
\hline $34-3,70-72$ & 442.20 & $1.664 ?$ & 2.053? & $0.389 ?$ & $18.9 ?$ & 20 & - & 1.86 & $1.74^{\mathrm{b}}$ & $35.2^{\mathrm{b}}$ & $59.8^{\mathrm{b}}$ & 3.57 & - & Claystone (10Y $4 / 2)$ (disturbed) \\
\hline $34-5,105-108$ & 445.55 & 1.720 & 1.647 & 0.073 & 4.4 & 20 & - & 1.85 & & - & & 3.05 & - & Claystone (10YR 3/2) \\
\hline $34-7,60-62$ & 448.10 & 1.759 & 1.688 & 0.071 & 4.2 & 20 & - & 1.85 & $1.86^{\mathrm{b}}$ & $29.1^{\mathrm{b}}$ & $52.7^{b}$ & 3.14 & - & Claystone (10Y $4 / 2)$ \\
\hline $35^{\mathrm{e}}-2,7-10$ & 449.57 & 1.684 & $1.626^{\mathrm{e}}$ & 0.058 & 3.6 & 20 & - & - & $1.87 \mathrm{~b}$ & $29.8^{\mathrm{b}}$ & $54.3^{\mathrm{b}}$ & 3.04 & - & Claystone (SYR 3/2) \\
\hline $35-4,63-65$ & 453.13 & 1.775 & 1.695 & 0.080 & 4.7 & 20 & - & 1.93 & $1.89^{\mathrm{b}}$ & $28.5^{\mathrm{b}}$ & $52.4^{\mathrm{b}}$ & 3.20 & - & Claystone (10YR and 5YR $3 / 2$ ) \\
\hline $35-5,32-35$ & 454.32 & 1.794 & 1.634 & 0.160 & 9.8 & 20 & $\overline{-}$ & 1.83 & $1.86^{\mathrm{b}}$ & $30.1^{\mathrm{b}}$ & $54.7^{\mathrm{b}}$ & 3.03 & - & Claystone (10Y $4 / 2)$ \\
\hline $36-1,61-63$ & 458.11 & 1.702 & 1.686 & 0.016 & 0.9 & 20 & - & 1.87 & $1.82^{\mathrm{b}}$ & $31.6^{b}$ & $56.2^{b}$ & 3.07 & - & Claystone (10Y 4/2) \\
\hline $37-1,105-108$ & 468.06 & 1.965 & - & - & - & 20 & - & 2.14 & $2.16^{\mathrm{b}}$ & $16.2^{\mathrm{b}}$ & $34.2^{\mathrm{b}}$ & - & $=$ & Chalk (10YR 8/2) \\
\hline $37-2,102-104$ & 469.52 & 3.900 & - & - & - & 20 & - & - & & - & - & $\overline{-}$ & - & Basalt pebble (5Y 3/2) \\
\hline $37-2,126-128$ & 469.76 & 1.744 & 1.578 & 0.166 & 10.5 & 20 & - & 1.71 & $1.77^{\mathrm{b}}$ & $34.8^{b}$ & $60.0^{\mathrm{b}}$ & $2 . \overline{79}$ & - & Mudstone (10Y 4/2) \\
\hline $37, \mathrm{CC}(0-3)$ & 471.13 & 3.028 & & - & - & 20 & 2.17 & - & & & & - & - & Calcarenite (10YR 3/2) (air?) \\
\hline $38-1,0-3$ & 476.50 & 3.643 & $3 . \overline{468}$ & 0.175 & 5.0 & 20 & - & $2 . \overline{14}$ & $2 . \overline{31^{\mathrm{b}}}$ & $11.1^{\mathrm{b}}$ & $25.0^{\mathrm{b}}$ & $8 \overline{.01}$ & 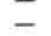 & Coarse $\mathrm{CO}_{3}$ cemented sandstone (10YR $\left.8 / 2\right)$ \\
\hline $38-1,44-46$ & 476.94 & 1.677 & 1.682 & -0.005 & -0.3 & 20 & $\overline{-}$ & 1.67 & $1.63^{\mathrm{b}}$ & $42.0^{\mathrm{b}}$ & $67.0^{\mathrm{b}}$ & 2.74 & $=$ & 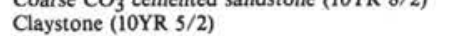 \\
\hline $38-2,28-30$ & 478.28 & 1.901 & 1.699 & 0.202 & 11.9 & 20 & $=$ & - & $1.89^{\mathrm{b}}$ & $\begin{array}{l}27.7^{\mathrm{b}} \\
\mathrm{n}\end{array}$ & $\begin{array}{l}61.0^{\mathrm{b}} \\
5\end{array}$ & $\begin{array}{l}2.74 \\
3.21\end{array}$ & 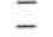 & Nannofossil chalk (10YR $8 / 2$ ) \\
\hline $39-1,8-10$ & 486.08 & 1.734 & 1.629 & 0.105 & 6.4 & 20 & $\bar{z}$ & $1 . \overline{61}$ & $1.71^{b}$ & $36.4^{\mathrm{b}}$ & $60.9^{\mathrm{b}}$ & 2.79 & $=$ & Claystone (10YR 8/2) \\
\hline $39-1,70-72$ & 486.70 & 2.695 & 1.989 & 0.706 & 35.5 & 20 & $1 . \overline{80}$ & - & $1.77^{\mathrm{b}}$ & $30.4 \mathrm{~b}$ & $52.6^{\mathrm{b}}$ & 3.52 & $=$ & $\mathrm{CO}_{3}$ cemented claystone (10YR $8 / 2$ ) \\
\hline $39-2,65-67$ & 488.15 & 3.677 & 2.874 & 0.803 & 27.9 & 20 & - & 2.26 & $2.27^{\mathrm{b}}$ & $12.4^{\mathrm{b}}$ & $27.6^{\mathrm{b}}$ & 6.52 & $=$ & $\mathrm{CO}_{3}$ cemented sandstone (10YR $8 / 2$ ) \\
\hline $40-1,94-97$ & 496.44 & 1.859 & 1.649 & 0.210 & 12.7 & 20 & - & 1.74 & $1.75^{b}$ & $34.6^{b}$ & $59.1 \mathrm{~b}$ & 2.86 & - & $\begin{array}{l}\text { Mudstone }(10 Y 4 / 2)\end{array}$ \\
\hline $40-2,103-107$ & 498.04 & 1.928 & 1.811 & 0.117 & 6.5 & 20 & - & 2.05 & $2.03^{b}$ & $21.4^{\mathrm{b}}$ & $42.2^{\mathrm{b}}$ & 3.68 & - & Foraminifer-nannofossil chalk (10YR 8/2) \\
\hline $40-4,32-35$ & 500.32 & 2.058 & 1.952 & 0.106 & 5.4 & 20 & - & 2.12 & $2.14^{b}$ & $17.4 \mathrm{~b}$ & $36.3^{\mathrm{b}}$ & 4.18 & - & Foraminifer-nannofossil chalk (10YR $8 / 2$ ) \\
\hline $41-1,40-42$ & 505.40 & 4.081 & 3.943 & 0.138 & 3.5 & 20 & 2.29 & - & $2.44^{\mathrm{b}}$ & $8.3^{\mathrm{b}}$ & $19.8^{\mathrm{b}}$ & 9.62 & - & $\mathrm{CO}_{3}$ cemented sandstone $(10 \mathrm{YR} 8 / 2)$ \\
\hline $41-1,105-107$ & 506.05 & 1.596 & 1.599 & -0.003 & -0.2 & 21 & - & 1.61 & $1.66^{\mathrm{b}}$ & $40.0^{\mathrm{b}}$ & $64.7^{\mathrm{b}}$ & 2.65 & - & Mudstone (10YR 8/2) \\
\hline $41-3,39-41$ & 508.39 & 2.021 & $1.494 ?$ & $0.527 ?$ & $35.3 ?$ & 21 & - & 1.99 & $2.07^{\mathrm{b}}$ & $19.4^{\mathrm{b}}$ & $39.1^{\mathrm{b}}$ & 3.09 ? & - & Laminated mudstone (10Y $4 / 2-6 / 2)$ \\
\hline $42-1,42-45$ & 515.96 & 3.990 & - & - & - & 20 & - & - & & - & & - & - & Chert (5Y $5 / 2)$ \\
\hline $42-1,145-147$ & 515.95 & 3.789 & 3.522 & 0.267 & 7.6 & 21 & - & 2.30 & $2.35^{\mathrm{b}}$ & $10.1^{b}$ & $23.0^{\mathrm{b}}$ & 8.28 & - & $\mathrm{CO}_{3}$ cemented sandstone (5Y $6 / 2$ ) \\
\hline $42-2,3-4$ & 516.03 & 1.896 & - & - & - & 21 & - & 1.98 & $1.99^{\mathrm{b}}$ & $23.5^{\mathrm{b}}$ & $45.6^{\mathrm{b}}$ & - & - & Laminated calcareous mudstone $(105 / 2)$ \\
\hline $42, C C(3-7)$ & 517.92 & $1.673 ?$ & 1.849 ? & -0.176 & -9.5 & 21 & - & 1.65 & $1.79^{b}$ & $32.7^{\mathrm{b}}$ & $57.1^{\mathrm{b}}$ & 3.31 ? & - & Mudstone (5Y 3/2) \\
\hline $43-1,64-67$ & 524.64 & 1.878 & 1.781 & 0.097 & 5.4 & 22 & - & 1.97 & $1.98^{b}$ & $23.5^{b}$ & $45.5^{b}$ & 3.51 & - & Lenticular mudstone (5GY 6/1) \\
\hline $43-1,80-83$ & 524.80 & 1.750 & 1.661 & 0.089 & 5.4 & 22 & - & 1.74 & $1.78^{\mathrm{b}}$ & $33.0^{\mathrm{b}}$ & $57.3^{\mathrm{b}}$ & 2.96 & - & Mudstone (10YR 8/2) \\
\hline $43-2,137-140$ & 526.87 & 4.397 & 4.175 & 0.222 & 5.3 & 22 & - & 2.35 & $2.47^{\mathrm{b}}$ & $6.3^{\mathrm{b}}$ & $15.2^{\mathrm{b}}$ & 10.31 & - & $\mathrm{CO}_{3}$ cemented sandstone ( $\left.5 \mathrm{Y} 6 / 2\right)$ \\
\hline $44-1,22-25$ & 533.72 & 1.842 & 1.785 & 0.057 & 3.2 & 22 & - & - & $1.91^{\mathrm{b}}$ & $25.3 \mathrm{~b}$ & $47.2^{\mathrm{b}}$ & 3.41 & - & Mudstone (10Y $8 / 2)$ \\
\hline $44-1,77-79$ & 534.27 & 2.290 ? & 2.512 ? & -0.222 & -8.8 & 22 & - & $2 . \overline{08}$ & $2.05^{\mathrm{b}}$ & $18.1^{\mathrm{b}}$ & $36.2^{\mathrm{b}}$ & 5.15 & $=$ & Coarse $\mathrm{CO}_{3}$ cemented sandstone ( 5 Y $6 / 2$ ) \\
\hline $44-1,143-147$ & 534.93 & 1.811 & 1.670 & 0.141 & 8.4 & 22 & $\overline{-}$ & $\begin{array}{l}2.08 \\
1.81\end{array}$ & $1.83^{\mathrm{b}}$ & $30.0^{\mathrm{b}}$ & $53.7^{\mathrm{b}}$ & 3.06 & $\overline{-}$ & 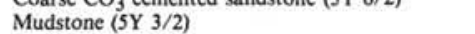 \\
\hline $45-1,20-22$ & 543.20 & 1.767 & 1.676 & 0.091 & 5.4 & 21 & $\overline{-}$ & $\begin{array}{l}1.81 \\
1.79\end{array}$ & $1.83 \mathrm{~b}$ & $31.1^{\mathrm{b}}$ & $55.5^{\mathrm{b}}$ & 3.07 & $=$ & Mudstone (5Y 3/2) \\
\hline $46-1,18-20$ & 552.68 & 1.795 & 1.720 & 0.075 & 4.4 & ${ }_{21}^{21}$ & 1.80 & - & $1.82^{\mathrm{b}}$ & $30.9^{\mathrm{b}}$ & $54.8^{\mathrm{b}}$ & $\begin{array}{l}3.0 t \\
3.13\end{array}$ & $=$ & Mudstone (5Y 3/2) \\
\hline $47-1,0-3$ & 562.00 & 4.518 & - & - & - & 20 & - & $=$ & $2.65^{\mathrm{b}}$ & $0.9^{\mathrm{b}}$ & $2.3 \mathrm{~b}$ & - & - & Chert $(5 Y 3 / 2)$ \\
\hline $47-1,123-124$ & 563.23 & 1.936 & 1.891 & 0.045 & 2.4 & 20 & 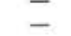 & 2.02 & $2.03^{\mathrm{b}}$ & $21.9^{\mathrm{b}}$ & $43.3^{\mathrm{b}}$ & 3.83 & $=$ & Laminated mudstone (5Y S/2) \\
\hline $47-1,147-150$ & 563.47 & 3.612 & - & - & - & 20 & $=$ & 2.02 & $2.34^{\mathrm{b}}$ & $11.6^{\mathrm{b}}$ & $26.5^{\mathrm{b}}$ & - & $=$ & $\mathrm{CO}_{3}$ cemented sandstone (10YR $\left.8 / 2\right)$ \\
\hline $47-2,18-20$ & 563.68 & 1.866 & 1.705 & 0.161 & 9.4 & 21 & $\bar{z}$ & $1 . \overline{69}$ & $1.88^{\mathrm{b}}$ & $28.7^{\mathrm{b}}$ & $52.5^{\mathrm{b}}$ & $3 . \overline{21}$ & $\overline{-}$ & Mudstone (SYR 3/2) \\
\hline & 571.63 & 3.487 & 3.398 & 0.089 & 2.6 & 20 & - & 2.35 & $2.35^{b}$ & $10.0^{\mathrm{b}}$ & $23.0^{\mathrm{b}}$ & 7.99 & - & $\mathrm{CO}_{3}$ cemented sandstone (10Y $\left.8 / 2\right)$ \\
\hline $48-1,48-50$ & 571.98 & 1.829 & 1.717 & 0.112 & 6.5 & 20 & - & 1.93 & $1.92^{b}$ & $25.9^{\mathrm{b}}$ & $48.6^{\mathrm{b}}$ & 3.30 & - & \\
\hline & 572.73 & 1.872 & 1.736 & 0.136 & 7.8 & 20 & - & 1.93 & $1.97^{b}$ & $24.5^{b}$ & $46.9^{\mathrm{b}}$ & 3.42 & - & Mudstone (5Y 3/2) \\
\hline $49-1,26-28$ & 581.24 & 1.920 & 1.765 & 0.155 & 8.8 & 21 & 1.94 & - & $1.95^{b}$ & $24.7^{\mathrm{b}}$ & $46.9^{\mathrm{b}}$ & 3.44 & - & Mudstone (5Y 3/2) \\
\hline $49-1,41-42$ & 581.41 & 3.342 & 3.060 & 0.282 & 9.2 & 21 & - & 2.32 & $2.26^{\mathrm{b}}$ & $12.0^{\mathrm{b}}$ & $26.4^{\mathrm{b}}$ & 6.92 & - & Laminated, $\mathrm{CO}_{3}$ cemented sandstone (10YR $8 / 2$ ) \\
\hline $49-2,0-3$ & 582.50 & 3.772 & 3.506 & 0.266 & 7.9 & 21 & - & 2.31 & $2.34^{b}$ & $9.9^{\mathrm{b}}$ & $22.6^{\mathrm{b}}$ & 8.21 & - & Coarse $\mathrm{CO}_{3}$ cemented sandstone (10YR $8 / 2$ ) \\
\hline $51-1,50-52$ & 600.50 & 3.500 & 3.337 & 0.163 & 4.9 & 20 & - & 2.35 & $2.24^{\mathrm{b}}$ & $12.6^{\mathrm{b}}$ & $27.6^{\mathrm{b}}$ & 7.47 & - & $\mathrm{CO}_{3}$ cemented sandstone $(10 \mathrm{YR} 8 / 2)$ \\
\hline $51-1,134-136$ & 601.34 & 1.884 & 1.783 & 0.101 & 5.7 & 21 & 1.90 & - & $1.91^{b}$ & $26.1^{\mathrm{b}}$ & $48.6^{\mathrm{b}}$ & 3.41 & - & Mudstone (5Y 3/2) \\
\hline $51-4,134-136$ & 605.84 & 2.001 & 1.842 & 0.159 & 8.6 & 20 & - & - & $2.08^{\mathrm{b}}$ & $17.9^{\mathrm{b}}$ & $36.5^{\mathrm{b}}$ & 3.83 & - & Mudstone (5Y $5 / 2$ ) \\
\hline $52-1,65-67$ & 610.15 & 2.025 & 1.827 & 0.198 & 10.8 & 20 & 1.80 & - & $1.91^{\mathrm{b}}$ & $25.0^{\mathrm{b}}$ & $46.5^{\mathrm{b}}$ & 3.49 & - & Mudstone (5Y $3 / 2$ ) \\
\hline
\end{tabular}




\begin{tabular}{|c|c|c|c|c|c|c|c|c|c|c|c|c|c|c|c|}
\hline \multirow[b]{3}{*}{$\begin{array}{c}\text { Core-Section } \\
\text { (interval in } \mathrm{cm} \text { ) }\end{array}$} & \multirow{3}{*}{$\begin{array}{l}\text { Depth in } \\
\text { hole } \\
\text { (m) }\end{array}$} & \multicolumn{5}{|c|}{ Compressional-sound velocity } & \multirow{2}{*}{\multicolumn{2}{|c|}{$\begin{array}{l}\text { GRAPE "special" } \\
\text { wet-bulk density" } \\
\text { (2-minute count }) \\
\left(\mathrm{g} / \mathrm{cm}^{3}\right)\end{array}$}} & \multicolumn{3}{|c|}{ Gravimetric ${ }^{b, c}$} & \multirow{3}{*}{$\begin{array}{c}\text { Acoustic } \\
\text { impedance } \\
\text {, }\left(\mathrm{g} \cdot 10^{5} / \mathrm{cm}^{2} \cdot \mathrm{s}\right)\end{array}$} & \multirow{2}{*}{\multicolumn{2}{|c|}{$\begin{array}{c}\text { Vane shear } \\
\text { strength }\end{array}$}} & \multirow[b]{3}{*}{ Lithology (G.S.A. color number) } \\
\hline & & \multirow{2}{*}{$\begin{array}{c}\begin{array}{c}\text { Beds } \\
\text { Beds } \\
(\mathrm{km} / \mathrm{s})\end{array}\end{array}$} & & Anis & tropy & & & & $\begin{array}{l}\text { Wet- } \\
\text { bulk }\end{array}$ & $\begin{array}{c}\text { Wet-water } \\
\text { content }\end{array}$ & $\begin{array}{c}\text { Porosity } \\
\text { (salt }\end{array}$ & & & & \\
\hline & & & $\begin{array}{c}\text { Beds } \\
(\mathrm{km} / \mathrm{s})\end{array}$ & 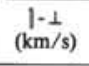 & $\underset{(\%)}{(1-1) / 1}$ & $\begin{array}{l}\text { Temp. } \\
\left({ }^{\circ} \mathrm{C}\right)\end{array}$ & $\begin{array}{c}\mathrm{T} \\
\text { Beds }\end{array}$ & $\frac{1}{\text { Beds }}$ & $\begin{array}{l}\text { density } \\
\left(\mathrm{g} / \mathrm{cm}^{3}\right)\end{array}$ & $\begin{array}{c}\text { (salt corr.) } \\
(\%)\end{array}$ & $\begin{array}{c}\text { corr. }) \\
(\%)\end{array}$ & & $\begin{array}{l}\text { Original } \\
\left(\mathrm{g} / \mathrm{cm}^{2}\right)\end{array}$ & $\begin{array}{l}\text { Remolded } \\
\left(\mathrm{g} / \mathrm{cm}^{2}\right)\end{array}$ & \\
\hline $52-1,100-102$ & 610.50 & - & - & - & - & - & - & - & $2.33^{\mathrm{b}}$ & $6.0^{\mathrm{b}}$ & $13.8^{\mathrm{b}}$ & - & - & & Chert (5Y 5/2) \\
\hline & 610.60 & 2.653 & - & - & - & 20 & - & - & $2.05^{b}$ & $18.7^{\mathrm{b}}$ & $37.5^{\mathrm{b}}$ & - & - & & $\mathrm{CO}_{3}$ cemented sandstone $(10 \mathrm{YR} 8 / 2)$ \\
\hline $53-1,16-18$ & 619.16 & 3.292 & 2.363 & 0.929 & 39.3 & 20 & - & - & $1.98^{\mathrm{b}}$ & $18.4^{\mathrm{b}}$ & $35.6^{\mathrm{b}}$ & $\overline{4.68}$ & - & & Laminated calcareous mudstone ( $5 Y 3 / 2$ to $7 / 2$ ) \\
\hline & 620.33 & 2.703 & - & - & - & 20 & - & 2.14 & $2.24 \mathrm{~b}$ & $12.3^{\mathrm{b}}$ & $27.0^{\mathrm{b}}$ & -0.00 & - & & $\mathrm{CO}_{3}$ cemented sandstone (5Y $\left.8 / 1-5 \mathrm{GY} 3 / 2\right)$ \\
\hline $53-2,37-40$ & 620.87 & 2.030 & 1.855 & 0.175 & 9.4 & 20 & 1.88 & - & $1.88^{\mathrm{b}}$ & $26.0^{\mathrm{b}}$ & $47.7^{\mathrm{b}}$ & 3.49 & - & & Mudstone (SGY 4/1) \\
\hline $54-1,36-38$ & 628.86 & 2.856 & 2.756 & 0.100 & 3.6 & 20 & - & 2.22 & $2.226^{\mathrm{b}}$ & $11.4^{\mathrm{b}}$ & $25.2^{\mathrm{b}}$ & 6.23 & - & & $\mathrm{CO}_{3}$ cemented sandstone ( $\left.5 \mathrm{GY} 3 / 2\right)$ \\
\hline $54-1,95-97$ & 629.45 & 2.543 & 2.290 & 0.253 & 11.0 & 20 & - & 2.11 & $2.07^{\mathrm{b}}$ & $18.3^{\mathrm{b}}$ & $36.9^{\mathrm{b}}$ & 4.74 & - & & Lenticular, calcareous mudstone ( $5 G 4 / 1$ to $6 / 1$ ) \\
\hline $55-1,93-95$ & 638.93 & 4.108 & 3.782 & 0.326 & 8.6 & 20 & - & 2.25 & & Bad sample? & & 8.51 & - & & Coarse $\mathrm{CO}_{3}$ sandstone $(5 \mathrm{GY} 3 / 2)$ \\
\hline $55-2,90-92$ & 640.40 & 2.062 & 1.967 & 0.095 & $\begin{array}{l}8.0 \\
4.8\end{array}$ & 20 & 2.06 & - & $2.05^{\mathrm{b}}$ & $19.7^{\mathrm{b}}$ & $39.3^{\mathrm{b}}$ & 4.03 & - & & $\mathrm{CO}_{3}$ mudstone $(5 \mathrm{G} 6 / 1)$ \\
\hline $55-3,36-38$ & 641.36 & 3.606 & 3.256 & 0.350 & 10.7 & 20 & - & - & $2.33^{\mathrm{b}}$ & $9.5^{\mathrm{b}}$ & $21.5^{b}$ & 7.59 & - & & Laminated $\mathrm{CO}_{3}$ cemented sandstone (5Y $8 / 1$ ) \\
\hline $55-4,76-78$ & 643.26 & 2.175 & 1.950 & 0.225 & 11.5 & 20 & - & - & $1.98^{\mathrm{b}}$ & $23.1^{\mathrm{b}}$ & $44.5^{\mathrm{b}}$ & 3.86 & - & & Calcareous mudstone ( $5 \mathrm{GY} 3 / 2$ to $2 / 2$ ) \\
\hline $56-1,31-33$ & 647.82 & 4.333 & 4.461 & -0.128 & -2.9 & 20 & - & 2.60 & $2.47^{\mathrm{b}}$ & $5.8^{\mathrm{b}}$ & $13.9^{\mathrm{b}}$ & 11.02 & - & & Laminated $\mathrm{CO}_{3}$ cemented sandstone (N8) \\
\hline $56-1,74-76$ & 648.26 & 2.289 & 2.051 & 0.238 & 11.6 & 20 & - & 2.04 & $2.04^{\mathrm{b}}$ & $20.9^{\mathrm{b}}$ & $41.4^{\mathrm{b}}$ & 4.18 & - & & Mudstone (5GY 4/1) \\
\hline $56-2,96-98$ & 649.96 & 2.328 & 2.078 & 0.250 & 12.0 & 20 & 2.16 & - & $2.02^{\mathrm{b}}$ & $18.5^{\mathrm{b}}$ & $36.6^{\mathrm{b}}$ & 4.20 & - & & Calcareous mudstone (5GY $6 / 1 ; 5 \mathrm{G} 4 / 1$ ) \\
\hline $57-1,39-40$ & 657.39 & 2.335 & 2.004 & 0.331 & 16.5 & 20 & - & 1.83 & $1.95^{\mathrm{b}}$ & $24.3^{\mathrm{b}}$ & $46.2^{\mathrm{b}}$ & 3.91 & - & & Mudstone (5GY $4 / 1)$ \\
\hline $57-1,65-67$ & 657.65 & 4.011 & 3.182 & 0.829 & 26.1 & 20 & - & 2.40 & $2.40^{\mathrm{b}}$ & $7.7^{\mathrm{b}}$ & $18.0^{\mathrm{b}}$ & 7.64 & - & & $\mathrm{CO}_{3}$ cemented sandstone (NS) \\
\hline $57-2,66-68$ & 659.16 & 2.581 & 2.397 & 0.184 & 7.7 & 20 & - & 2.13 & $2.14^{\mathrm{b}}$ & $16.5^{\mathrm{b}}$ & $34.4^{\mathrm{b}}$ & 5.13 & - & & $\mathrm{CO}_{3}$ cemented sandstone $(5 \mathrm{Y} 7 / 2)$ \\
\hline $58-1,110-112$ & 667.60 & 2.351 & 2.021 & 0.330 & 16.3 & 20 & - & 1.98 & $2.03^{\mathrm{b}}$ & $20.6^{\mathrm{b}}$ & $40.9^{b}$ & 4.10 & - & & Calcareous mudstone ( $(5 Y 7 / 2)$ \\
\hline $59-1,98-100$ & 676.98 & 5.478 & 5.300 & 0.178 & 3.4 & 20 & - & 2.63 & $2.57^{\mathrm{b}}$ & $3.4^{\mathrm{b}}$ & $8.4^{\mathrm{b}}$ & 13.62 & - & & $\mathrm{CO}_{3}$ cemented sandstone (NS) \\
\hline $59-2,43-45$ & 677.93 & - & 2.620 & - & - & 20 & - & - & $1.89^{\mathrm{b}}$ & $24.9^{\mathrm{b}}$ & $46.0^{\mathrm{b}}$ & 4.95 & - & & Mudstone $(5 G Y 4 / 1)$ \\
\hline $60-1,3-5$ & 685.53 & 4.943 & 4.495 & 0.448 & 10.0 & 20 & - & $2 . \overline{48}$ & $2.47^{\mathrm{b}}$ & $5.9^{\mathrm{b}}$ & $14.1^{\mathrm{b}}$ & 11.10 & - & & Coarse $\mathrm{CO}_{3}$ cemented sandstone (N5) \\
\hline $60-1,18-20$ & 685.68 & 2.261 & 2.177 & 0.084 & 3.9 & 20 & - & 2.04 & $2.03^{\mathrm{b}}$ & $20.3 \mathrm{~b}$ & $40.3^{\mathrm{b}}$ & 4.42 & - & & Calcareous mudstone ( $(5 Y 7 / 2)$ \\
\hline $60-1,50-52$ & 686.01 & 2.561 & 2.473 & 0.088 & 3.6 & 20 & - & 2.12 & $2.14^{\mathrm{b}}$ & $16.5^{\mathrm{b}}$ & $34.3^{\mathrm{b}}$ & 5.29 & - & & Mudstone (5GY 4/1) \\
\hline $61-1,22-25$ & 695.22 & 3.324 & 2.311 & 1.013 & 43.8 & 20 & - & 1.96 & $2.12^{\mathrm{b}}$ & $17.8^{\mathrm{b}}$ & $36.8 \mathrm{~b}$ & 4.90 & - & & Calcareous mudstone ( $5 Y 7 / 7$ ) \\
\hline $61-2,144-147$ & 697.94 & 2.044 & 1.878 & 0.166 & 8.8 & 20 & - & - & & $24.0^{\mathrm{b}}$ & $46.0^{\mathrm{b}}$ & 3.70 & $=$ & & Mudstone (5GY $4 / 1 ; 5 Y 4 / 1)$ \\
\hline $61-3,43-45$ & 698.43 & 2.060 & 1.892 & 0.168 & 8.9 & 20 & - & 1.84 & $2.02^{\mathrm{b}}$ & $21.6^{\mathrm{b}}$ & $42.6^{\mathrm{b}}$ & 3.82 & - & & $\begin{array}{l}\text { Mudstone (5Y 4/1) } \\
\text { Mis } 4 / 1)\end{array}$ \\
\hline $62-1,50-52$ & 705.00 & 2.422 & 1.853 & 0.569 & 30.7 & 20 & - & 2.13 & $2.18^{\mathrm{b}}$ & $15.5^{\mathrm{b}}$ & $32.8 \mathrm{~b}$ & 4.03 & $=$ & & Calcareous mudstone (5Y $4 / 1$ ) \\
\hline $62-3,97-99$ & 708.47 & 2.657 & 2.491 & 0.166 & 6.7 & 20 & - & 1.92 & $2.24^{\mathrm{b}}$ ? & $13.8^{\mathrm{b}}$ ? & $30.0^{\mathrm{b}}$ ? & 5.57 & $\overline{-}$ & & Sandstone grading to mudstone (5GY $4 / 1$ ) \\
\hline $62-4,10-12$ & 709.10 & 3.678 & 2.808 & 0.870 & 31.0 & 20 & 2.29 & - & $2.16^{\mathrm{b}}$ ? & $15.8^{\mathrm{b}}$ ? & $33.3^{\mathrm{b}}$ ? & 6.07 & - & & Sandstone grading to mudstone (5GY 4/1) \\
\hline $63-1,12-14$ & 714.12 & 3.823 & 3.359 & 0.464 & $\begin{array}{l}13.8 \\
13.8\end{array}$ & 20 & - & 2.43 & $2.40^{\mathrm{b}}$ & $9.4^{\mathrm{b}}$ & $22.0^{\mathrm{b}}$ & 8.06 & - & & Laminated sandstone (N5) \\
\hline $63-2,31-33$ & 715.81 & 3.303 & 2.245 & 1.058 & $\begin{array}{l}15.8 \\
47.1\end{array}$ & 20 & 2.15 & - & $2.10^{\mathrm{b}}$ & $18.5^{\mathrm{b}}$ & $37.8^{\mathrm{b}}$ & 4.71 & - & & Calcareous mudstone ( $5 Y / 4 / 1)$ \\
\hline $63-3,73-75$ & 717.73 & 2.259 & 1.904 & 0.355 & $\begin{array}{l}4.1 \\
18.6\end{array}$ & 20 & - & 2.03 & $1.97^{\mathrm{b}}$ & $23.5^{\mathrm{b}}$ & $45.3^{\mathrm{b}}$ & 3.85 & - & & Mudstone (5G 4/1) \\
\hline $64-1,18-20$ & 723.68 & 4.948 & 4.372 & 0.576 & $\begin{array}{l}10.0 \\
13.2\end{array}$ & 20 & - & 2.29 ? & $2.47 \mathrm{~b}$ & $5.7^{\mathrm{b}}$ & $13.7^{\mathrm{b}}$ & 10.80 & - & & Laminated $\mathrm{CO}_{3}$ cemented sandstone (NS) \\
\hline $64-1,52-55$ & 724.02 & $\begin{array}{l}4.9480 \\
2.095\end{array}$ & 1.943 & $\begin{array}{l}0.576 \\
0.152\end{array}$ & $\begin{array}{r}13.2 \\
7.8\end{array}$ & 20 & $\overline{-}$ & 2.01 & $2.03^{\mathrm{b}}$ & $20.9^{\mathrm{b}}$ & $41.5^{\mathrm{b}}$ & 3.94 & - & & Mudstone $(5 \mathrm{G} 4 / 1 ; 5 \mathrm{Y} 4 / 1)$ \\
\hline $64-2,65-67$ & 725.65 & 3.361 & - & - & - & 20 & - & 2.29 & $2.19^{\mathrm{b}}$ & $16.7^{\mathrm{b}}$ & $35.7^{\mathrm{b}}$ & - & - & & Laminated sandstone (N5) \\
\hline $67-1,60-62$ & 752.60 & 2.963 & 2.962 & 0.001 & 0.0 & 20 & - & - & $2.37^{\mathrm{b}}$ & $11.3^{\mathrm{b}}$ & $26.0^{\mathrm{b}}$ & 7.02 & - & & Laminated sandstone $(5 Y 4 / 1)$ \\
\hline $67-2,56-58$ & 754.06 & 2.336 & 2.044 & 0.292 & 14.3 & 20 & $=$ & - & $2.09^{\mathrm{b}}$ & $18.7^{\mathrm{b}}$ & $38.2^{\mathrm{b}}$ & 4.27 & - & & Mudstone (5Y 4/1) \\
\hline $67-3,107-109$ & 756.07 & 2.370 & 1.951 & 0.419 & 21.5 & 20 & $\overline{-}$ & 2.01 & $2.03^{\mathrm{b}}$ & $21.4^{\mathrm{b}}$ & $42.4^{\mathrm{b}}$ & 3.96 & - & & Mudstone (5G 4/1) \\
\hline $68-1,23-25$ & 761.73 & 3.011 & 2.718 & 0.293 & 10.8 & 20 & $\overline{-}$ & 1.97 & $2.00^{\mathrm{b}}$ & $21.8^{\mathrm{b}}$ & $45.5^{\mathrm{b}}$ & 5.44 & - & & Mudstone (5G 4/1) \\
\hline $68-1,60-63$ & 762.10 & 2.208 & 1.975 & 0.233 & 11.8 & 20 & - & 2.07 & $2.03^{\mathrm{b}}$ & $21.1^{\mathrm{b}}$ & $41.9^{\mathrm{b}}$ & 4.01 & - & & Mudstone (5Y 4/1) \\
\hline $68-2,109-112$ & 764.09 & 2.671 & 2.652 & 0.019 & 0.7 & 20 & - & 2.23 & $2.21^{\mathrm{b}}$ & $16.2^{\mathrm{b}}$ & $35.0^{\mathrm{b}}$ & 5.86 & - & & Laminated size-graded sandstone (5Y $4 / 1$ ) \\
\hline $69-1,43-45$ & 771.43 & 3.488 & 3.420 & 0.068 & 2.0 & 20 & - & 2.43 & $2.38^{\mathrm{b}}$ & $10.5^{\mathrm{b}}$ & $24.5^{\mathrm{b}}$ & 8.14 & - & & Laminated sandstone (5Y $4 / 1$ ) \\
\hline $69-2,101-103$ & 773.51 & 2.316 & 2.094 & 0.222 & 10.6 & 20 & - & 2.10 & $2.04^{\mathrm{b}}$ & $19.9^{\mathrm{b}}$ & $40.0^{\mathrm{b}}$ & 4.27 & - & & Mudstone (5Y 4/1) \\
\hline $69-3,27-30$ & 774.27 & 2.532 & 2.322 & 0.210 & 9.0 & 20 & - & 2.14 & $2.14^{\mathrm{b}}$ & $16.9 \mathrm{~b}$ & $34.9^{\mathrm{b}}$ & 4.97 & - & & Laminated calcareous mudstone ( $5 \mathrm{Y} 4 / 1)$ \\
\hline $70-1,123-127$ & 781.73 & 2.286 & 1.995 & 0.291 & 14.6 & 20 & - & 2.09 & $2.01^{\mathrm{b}}$ & $20.1^{\mathrm{b}}$ & $39.3^{\mathrm{b}}$ & 4.01 & $=$ & & Laminated mudstone $(5 \mathrm{G} 4 / 1)$ \\
\hline $70-2,0-3$ & 782.00 & 2.647 & 2.484 & 0.163 & 6.6 & 20 & - & 2.12 & $2.14^{\mathrm{b}}$ & $17.1^{b}$ & $35.6^{\mathrm{b}}$ & 5.32 & $\bar{z}$ & & Laminated sandstone (5GY 3/1) \\
\hline $70-3,141-143$ & 784.91 & 2.467 & 2.277 & 0.190 & 8.3 & 20 & - & 2.24 & $2.19^{\mathrm{b}}$ & $14.2^{b}$ & $30.3^{\mathrm{b}}$ & 4.99 & $\overline{-}$ & & Calcareous mudstone ( $5 \mathrm{G} 5 / 1)$ \\
\hline $71-1,3-4$ & 790.03 & 3.160 & 3.129 & 0.031 & 1.0 & 20 & - & $2.19 ?$ & $2.64 \mathrm{~b}^{\mathrm{b}}$ ? & $2.9^{\mathrm{b}}$ ? & $7.6^{\mathrm{b}}$ ? & $8.26 ?$ & $=$ & & Coarse sandstone (5GY $3 / 1)$ \\
\hline $71-2,59-61$ & 792.09 & 2.093 & 1.854 & 0.239 & 12.9 & 20 & - & 1.99 & $1.90^{\mathrm{b}}$ & $23.4^{\mathrm{b}}$ & $43.3^{\mathrm{b}}$ & 3.52 & - & & Mudstone (5G 5/1) \\
\hline $71-2,112-114$ & 792.62 & 2.253 & 1.994 & 0.259 & 13.0 & 20 & - & 2.13 & $2.08^{\mathrm{b}}$ & $18.2^{\mathrm{b}}$ & $37.1^{\mathrm{b}}$ & 4.15 & - & & Calcareous mudstone (5GY 6/1) \\
\hline $71-3,16-18$ & 793.16 & 2.527 & 2.401 & 0.126 & 5.2 & 20 & - & 1.96 & $1.93^{\mathrm{b}}$ & $23.3^{\mathrm{b}}$ & $43.4 \mathrm{l}^{\mathrm{b}}$ & 4.63 & - & & Sandstone (5G 4/1) \\
\hline $72-1,65-67$ & 800.15 & 2.532 & 2.113 & 0.419 & 19.8 & 20 & 2.04 & - & $1.95^{b}$ & $24.0^{\mathrm{b}}$ & $45.7^{6}$ & 4.12 & & & Sandstone $(5 \mathrm{G} 2 / 1)$ \\
\hline $72-2,16-18$ & 801.16 & 3.172 & 2.443 & 0.729 & 29.8 & 20 & - & - & $2.18^{\mathrm{b}}$ & $14.9^{\mathrm{b}}$ & $31.6^{\mathrm{b}}$ & 5.33 & - & & Mudstone (5GY 4/1) \\
\hline $72-5,131-133$ & 806.81 & 2.591 & 2.427 & 0.164 & $\begin{array}{r}99.8 \\
6.8\end{array}$ & 20 & - & - & $2.03^{\mathrm{b}}$ & $20.0^{\mathrm{b}}$ & $39.64^{b}$ & 4.93 & - & & Laminated sandstone (5GY 4/1) \\
\hline $73-1,134-136$ & 810.34 & 2.452 & 2.427 & -104 & -0 & 20 & - & 1.92 & $1.94^{\mathrm{b}}$ & $23.0^{\mathrm{b}}$ & $43.6^{\mathrm{b}}$ & - & & & Laminated sandstone $(5 \mathrm{G} 4 / 1)$ \\
\hline $\begin{array}{l}73-2,87-90 \\
73-1,130\end{array}$ & 811.37 & 2.547 & $2 . \overline{418}$ & 0.129 & $\overline{5.3}$ & 20 & 1.96 & - & $1.99^{\mathrm{b}}$ & $21.1^{\mathrm{b}}$ & $41.0^{\mathrm{b}}$ & 4.81 & - & & Sandstone $(5 \mathrm{G} 4 / 1)$ \\
\hline $\begin{array}{l}73-2,8,118-120 \\
73-5\end{array}$ & $\begin{array}{l}811.37 \\
816.18\end{array}$ & 2.748 & $\begin{array}{l}2.418 \\
2.736\end{array}$ & 0.012 & 0.4 & 20 & - & 2.02 & $2.03^{\mathrm{b}}$ & $21.9^{\mathrm{b}}$ & $43.3^{\mathrm{b}}$ & 5.55 & - & & Spotted sandstone (5G 4/1) \\
\hline $74-1,79-81$ & $\begin{array}{l}810.18 \\
819.29\end{array}$ & 2.489 & 2.454 & 0.035 & 1.4 & 20 & - & 2.02 & $2.03^{\mathrm{b}}$ & $24.3^{\mathrm{b}}$ & $48.1^{\mathrm{b}}$ & 4.98 & - & & Spotted sandstone (5G 4/1) \\
\hline $74-2,20-22$ & 820.20 & & $\begin{array}{l}2.434 \\
2.388\end{array}$ & $\begin{array}{l}0.043 \\
0.047\end{array}-150$ & $\begin{array}{l}1.4 \\
2.0\end{array}$ & 20 & - & 2.07 & $2.01^{\mathrm{b}}$ & $23.2^{\mathrm{b}}$ & $45.6^{\mathrm{b}}$ & 4.80 & - & & Spotted sandstone (5G $4 / 1)$ \\
\hline $74-4,102-104$ & 824.02 & 2.256 & $\begin{array}{l}2.388 \\
2.163\end{array}$ & 0.093 & 4.3 & 20 & - & 1.91 & $2.02^{\mathrm{b}}$ & $25.1^{\mathrm{b}}$ & $49.6^{\mathrm{b}}$ & 4.37 & - & & Sandstone $(5 \mathrm{G} 6 / 1)$ \\
\hline $75-1,10-12$ & 828.10 & 2.207 & 1.886 & 0.321 & 17.0 & 20 & - & 1.98 & $1.99^{\mathrm{b}}$ & $23.2^{\mathrm{b}}$ & $45.0^{\mathrm{b}}$ & 3.75 & - & & Mudstone (5YR 3/1) \\
\hline $75-2,34-36$ & 829.84 & 2.214 & 2.093 & 0.121 & 5.8 & 20 & - & 1.98 & $2.01^{\mathrm{b}}$ & $24.6^{\mathrm{b}}$ & $48.3^{\mathrm{b}}$ & 4.21 & - & & Sandstone ( $5 \mathrm{G} 6 / 1$ ) \\
\hline
\end{tabular}




\begin{tabular}{|c|c|c|c|c|c|c|c|c|c|c|c|c|c|c|}
\hline $75-3,77-79$ & 831.77 & 2.157 & 1.885 & 0.272 & 14.4 & 20 & - & 1.88 & $2.01 \mathrm{~b}$ & $23.6^{\mathrm{b}}$ & $46.2^{\mathrm{b}}$ & 3.79 & - & Calcareous, size-graded mudstone (5G $4 / 1$ ) \\
\hline $76-1,26-28$ & 837.76 & 2.057 & 2.071 & -0.014 & -0.7 & 20 & - & 1.79 & $1.83^{\mathrm{b}}$ & $30.8^{\mathrm{b}}$ & $54.9 \mathrm{~b}$ & 3.79 & - & $\begin{array}{l}\text { Sandstone (5G } 6 / 1 \text { ) } \\
\text { (1) }\end{array}$ \\
\hline $\begin{array}{l}76-2,110-112 \\
76-45-57\end{array}$ & 840.10 & 2.289 & 2.389 & -0.100 & -4.2 & 20 & - & 2.08 & $2.05^{\mathrm{b}}$ & $20.8^{\mathrm{b}}$ & $41.6^{\mathrm{b}}$ & 4.90 & - & Mudstone (SGY 2/1) \\
\hline & $\begin{array}{l}842.55 \\
847.08\end{array}$ & 2.183 & 1.953 & 0.230 & 11.8 & 20 & - & 2.04 & $1.97^{\mathrm{b}}$ & $25.0^{\mathrm{b}}$ & $48.2_{\mathrm{b}}^{\mathrm{b}}$ & 3.85 & - & Mudstone (5YR 3/1) \\
\hline $77-2,52-54$ & $\begin{array}{l}847.08 \\
849.02\end{array}$ & $\begin{array}{l}2.477 \\
2.315\end{array}$ & 2.096 & $\begin{array}{l}0.381 \\
0.239\end{array}$ & 18.2 & 20 & - & 2.06 & $2.09^{\mathrm{b}}$ & $19.7^{\mathrm{b}}$ & $40.1 \mathrm{l}_{\mathrm{b}}^{\mathrm{b}}$ & 4.38 & - & Laminated mudstone (5G 6/1; SYR 3/1) \\
\hline $77-4,2-3$ & 851.52 & 2.073 & 1.967 & 0.106 & $\begin{array}{r}11.5 \\
5.4\end{array}$ & 20 & - & 2.05 & $2.05^{\circ}$ & $21.8^{\circ}$ & $43.5^{\mathrm{b}}$ & 4.26 & - & Spotted calcareous mudstone ( $5 \mathrm{G} 6 / 1 ; 5 \mathrm{Y} 5 / 2)$ \\
\hline $77-5,70-72$ & 853.70 & 2.073 & 1.955 & 0.118 & $\begin{array}{l}.4 .4 \\
6.0\end{array}$ & ${ }_{20}^{20}$ & $-\overline{196}$ & 2.00 & $1.91^{\mathrm{b}}$ & $27.2^{\circ} \mathrm{b}$ & $50.8^{\circ}$ & 3.76 & $=$ & Cross-bedded sandstone (5G 3/1) \\
\hline $78-1,61-63$ & 857.11 & 2.119 & 2.045 & 0.074 & 3.6 & 20 & 1.96 & $1 . \overline{94}$ & $1.91^{\mathrm{b}}$ & $28.3^{\mathrm{b}}$ & $52.7^{\mathrm{b}}$ & $\begin{array}{l}3.68 \\
3.91\end{array}$ & 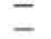 & $\begin{array}{l}\text { Sandstone }(5 \mathrm{G} \mathrm{6} / 1) \\
\text { Massive sandstone }(5 \mathrm{GY} 2 / 1)\end{array}$ \\
\hline $78-2,75-77$ & 858.75 & 2.242 & 1.959 & 0.283 & 14.4 & 20 & - & 2.07 & $2.06^{\mathrm{b}}$ & $22.6^{\mathrm{b}}$ & $45.5^{b}$ & 4.04 & - & Laminated-lenticular mudstone (5YR $2 / 1$ ) \\
\hline $78-3,78-80$ & 860.24 & 2.204 & 1.984 & 0.220 & 11.1 & 20 & - & 2.03 & $2.01^{\mathrm{b}}$ & $24.1^{\mathrm{b}}$ & $47.4^{b}$ & 3.99 & - & Cross-bedded mudstone (5Y $2 / 1 ; 5 \mathrm{Y} 4 / 1)$ \\
\hline $78-4,147-149$ & 862.47 & 2.327 & 2.021 & 0.306 & 15.1 & 20 & - & 2.08 & $2.10^{\mathrm{b}}$ & $19.7^{b}$ & $40.2^{\mathrm{b}}$ & 4.24 & - & Mudstone (5YR 4/1) \\
\hline $79-1,138-140$ & 867.39 & 1.978 & 2.063 & -0.085 & -4.3 & 20 & - & 2.14 & $1.80^{\mathrm{b}}$ ? & $18.6^{6^{b}}$ ? & $32.7^{\mathrm{b}}$ ? & 3.56 & - & Mudstone (SYR 4/1) \\
\hline $79-3,56-58$ & 869.56 & 4.616 & 4.496 & 0.012 & 2.7 & 20 & - & 2.52 & $2.49^{\mathrm{b}}$ & $5.7^{\mathrm{b}}$ & $13.9^{\mathrm{b}}$ & 11.20 & - & $\mathrm{CO}_{3}$ cemented sandstone ( $5 \mathrm{GY} 6 / 1$ ) \\
\hline $79-4,75-77$ & 871.25 & 2.040 & 1.934 & 0.106 & 5.5 & 20 & - & 1.89 & $1.85^{\mathrm{b}}$ & $31.0^{\mathrm{b}}$ & $56.0^{\mathrm{b}}$ & 3.58 & - & Sandstone $(5 \mathrm{Y} 7 / 1)$ \\
\hline $79-5,98-100$ & 872.98 & 2.160 & 1.902 & 0.258 & 13.5 & 20 & - & 2.01 & $1.96^{\mathrm{b}}$ & $25.2^{\mathrm{b}}$ & $48.3^{\mathrm{b}}$ & 3.73 & - & Mudstone (5Y 2/1) \\
\hline $80-1,128-130$ & 876.78 & 2.533 & 2.101 & 0.432 & 20.6 & 20 & - & 2.17 & $2.14^{\mathrm{b}}$ & $17.4^{\mathrm{b}}$ & $36.4^{\mathrm{b}}$ & 4.50 & - & Mudstone (5YR 4/1; 5G 2/1) \\
\hline $80-1,141-142$ & 876.91 & 2.610 & 2.324 & 0.286 & 12.4 & 20 & - & 2.17 & $2.17^{\mathrm{b}}$ & $16.1^{\mathrm{b}}$ & $34.2^{\mathrm{b}}$ & 5.04 & - & Laminated sandstone (SYR $6 / 1$ ) \\
\hline $80-3,1-3$ & 878.51 & 2.419 & 2.210 & 0.209 & 9.5 & 20 & - & 2.19 & $2.14^{\mathrm{b}}$ & $17.1^{\mathrm{b}}$ & $35.7^{\mathrm{b}}$ & 4.73 & - & Lenticular mudstone (SYR 4/1) \\
\hline $81-1,134-136$ & 886.34 & 2.464 & 2.270 & 0.194 & 8.5 & 20 & - & 2.24 & $2.20^{\mathrm{b}}$ & $16.4^{\mathrm{b}}$ & $35.3^{\mathrm{b}}$ & 4.99 & $=$ & Mudstone (5R 4/3) \\
\hline $81-2,19-21$ & 886.69 & 2.364 & 2.133 & 0.231 & 10.8 & 20 & - & 2.17 & $2.14^{\mathrm{b}}$ & $18.2^{\mathrm{b}}$ & $38.1^{\mathrm{b}}$ & 4.56 & - & Mudstone (SR 4/3) \\
\hline $81-3,70-72$ & 888.70 & 2.776 & 2.560 & 0.216 & 8.4 & 20 & - & 2.21 & $2.25^{\mathrm{b}}$ & $13.7^{\mathrm{b}}$ & $30.1^{b}$ & 5.76 & - & Laminated $\mathrm{CO}_{3}$ cemented sandstone (5Y $4 / 1$ ) \\
\hline $82-1,3-4$ & 894.53 & 4.544 & 4.477 & 0.067 & 1.5 & 20 & - & 2.55 & $2.54^{\mathrm{b}}$ & $4.4^{\mathrm{b}}$ & $10.8^{\mathrm{b}}$ & 11.37 & $\overline{-}$ & Laminated $\mathrm{CO}_{3}$ cemented sandstone ( $5 \mathrm{Y} 4 / 1$ ) \\
\hline $82-1,34-36$ & 894.84 & 2.395 & 2.241 & 0.154 & 6.9 & 20 & 2.12 & & $2.14^{\mathrm{b}}$ & $17.9^{\mathrm{b}}$ & $37.4^{\mathrm{b}}$ & 4.80 & $\overline{-}$ & Laminated sandstone (SY 4/1) \\
\hline $82-2,75-77$ & 896.75 & 2.559 & 2.313 & 0.246 & 10.6 & 20 & - & 2.19 & $2.22^{\mathrm{b}}$ & $14.3^{\mathrm{b}}$ & $31.0^{\mathrm{b}}$ & 5.13 & $\overline{-}$ & Lenticular mudstone (5YR $4 / 4$ ) \\
\hline $82-3,120-123$ & 898.71 & 2.393 & 2.049 & 0.344 & 16.8 & 20 & - & 2.10 & $2.18^{\mathrm{b}}$ & $19.3^{\mathrm{b}}$ & $40.9^{b}$ & 4.47 & $\overline{-}$ & $\begin{array}{l}\text { Mudstone (5YR 3/4) } \\
\text { (Y) } / 4 \text { ) }\end{array}$ \\
\hline $83-1,48-50$ & 904.48 & 2.402 & 2.103 & 0.299 & 14.2 & 20 & $\overline{-}$ & 2.16 & $2.12^{\mathrm{b}}$ & $17.7 \mathrm{~b}$ & $36.6^{\mathrm{b}}$ & $\begin{array}{l}4.47 \\
4.46\end{array}$ & $\overline{-}$ & Lenticular mudstone (5YR 4/4) \\
\hline $83-2,132-133$ & 906.83 & 2.056 & 1.908 & 0.148 & 7.8 & 20 & $=$ & 2.09 & $2.08^{\mathrm{b}}$ & $19.0^{\mathrm{b}}$ & $38.6^{\mathrm{b}}$ & 3.97 & $\overline{-}$ & Laminated sandstone (5Y $4 / 1$ ) \\
\hline $83-3,24-26$ & 907.24 & 2.422 & 2.121 & 0.301 & 14.2 & 20 & $=$ & 2.15 & $2.12^{\mathrm{b}}$ & $17.9^{\mathrm{b}}$ & $37.0^{\mathrm{b}}$ & $\begin{array}{l}3.91 \\
4.50\end{array}$ & $\overline{-}$ & Mudstone (5Y 4/4) \\
\hline $83-4,66-68$ & 909.16 & 3.951 & - & - & - & 20 & $=$ & - & $2.18^{\mathrm{b}}$ & $13.6^{\mathrm{b}}$ & $28.9^{\mathrm{b}}$ & 4.50 & $\overline{-}$ & Laminated $\mathrm{CO}_{3}$ cemented sandstone $(5 \mathrm{Y} 4 / 1)$ \\
\hline $84-1,30-32$ & 913.30 & 2.388 & $2 . \overline{191}$ & 0.197 & 9.0 & 20 & $\overline{-}$ & $2 . \overline{14}$ & $2.19^{\mathrm{b}}$ & $15.5^{\mathrm{b}}$ & $33.2 \mathrm{~b}$ & $\overline{4.80}$ & $\bar{z}+\mathrm{r}+\mathrm{r}+\mathrm{r}+\mathrm{r}+\mathrm{r}$ & Lenticular mudstone ( $(5 \mathrm{YR} 3 / 4$ ) \\
\hline $84-1,115-117$ & 914.15 & 2.268 & 2.012 & 0.256 & 12.7 & 20 & $\overline{-}$ & 2.11 & $2.06^{\mathrm{b}}$ & $20.5^{\mathrm{b}}$ & $41.1^{\mathrm{b}}$ & 4.14 & $=$ & $\begin{array}{l}\text { Mudstone (SYR 4/4) } \\
\text { MyK 3/4) }\end{array}$ \\
\hline $84-2,142-144$ & 915.92 & 4.728 & 4.389 & 0.339 & 7.7 & 20 & - & 2.56 & $2.48^{\mathrm{b}}$ & $5.5^{\mathrm{b}}$ & $13.2^{\mathrm{b}}$ & 10.88 & $\overline{-}$ & Laminated $\mathrm{CO}_{3}$ cemented sandstone $(5 \mathrm{Y} 4 / 1)$ \\
\hline $84-3,147-149$ & 917.42 & 2.975 & 2.104 & 0.871 & 41.4 & 20 & - & 2.21 & $2.27 \mathrm{~b}$ & $12.6^{\mathrm{b}}$ & $27.8^{\mathrm{b}}$ & 4.78 & - & Laminated sandstone (5Y $4 / 1)$ \\
\hline $85-1,3-4$ & 922.03 & 2.653 & 2.465 & 0.188 & 7.6 & 20 & - & 2.43 & $2.35^{\mathrm{b}}$ & $11.4 \mathrm{~b}$ & $26.2^{\mathrm{b}}$ & 5.79 & - & Mudstone (5YR 3/4) \\
\hline $85-1,38-40$ & 922.38 & 4.450 & 4.628 & -0.178 & -3.8 & 20 & - & Bad data & $2.57^{\mathrm{b}}$ & $3.3^{\mathrm{b}}$ & $8.3^{\mathrm{b}}$ & 11.89 & - & $\mathrm{CO}_{3}$ cemented sandstone (5Y $\left.4 / 1\right)$ \\
\hline $85-2,14-17$ & 923.64 & 2.532 & 2.176 & 0.356 & 16.4 & 20 & - & Bad data & $2.23 \mathrm{~b}$ & $13.8^{\mathrm{b}}$ & $30.0^{\mathrm{b}}$ & 4.85 & - & Lenticular mudstone (5YR 4/4) \\
\hline $85-3,1-3$ & 925.01 & 2.114 & 1.915 & 0.199 & 10.4 & 20 & - & 1.92 & $1.96^{\mathrm{b}}$ & $23.8^{\mathrm{b}}$ & $45.5^{\mathrm{b}}$ & 3.75 & - & Laminated sandstone (5Y $4 / 1)$ \\
\hline $86-1,138-140$ & 932.38 & 2.373 & 2.090 & 0.283 & 13.5 & 20 & - & 2.24 & $2.16^{\mathrm{b}}$ & $17.2^{\mathrm{b}}$ & $36.2^{b}$ & 4.51 & - & Mudstone (5YR 3/4) \\
\hline $86-2,146-148$ & 932.94 & 2.507 & 2.155 & 0.352 & 16.3 & 20 & - & 2.22 & $2.19^{\mathrm{b}}$ & $15.1^{\mathrm{b}}$ & $32.4^{\mathrm{b}}$ & 4.72 & - & Lenticular mudstone (SYR 3.5/4) \\
\hline $86-4,146-148$ & 936.96 & 2.425 & 2.257 & 0.168 & 7.4 & 20 & - & 2.17 & $2.20^{\mathrm{b}}$ & $16.0^{\mathrm{b}}$ & $34.2^{\mathrm{b}}$ & 4.97 & - & Lenticular mudstone (SGY 3/2) \\
\hline $87-1,95-98$ & 940.95 & 1.801 & 1.833 & -0.032 & -1.7 & 20 & - & 2.03 & $2.03^{\mathrm{b}}$ & $21.0^{\mathrm{b}}$ & $41.7^{\mathrm{b}}$ & 3.72 & - & Mudstone (5G 5/1) \\
\hline $87-1,128-130$ & 941.28 & 2.211 & 2.036 & 0.175 & 8.6 & 20 & - & 2.19 & $2.19^{\mathrm{b}}$ & $16.0^{\mathrm{b}}$ & $34.2^{\mathrm{b}}$ & 4.46 & - & Lenticular mudstone (5YR 4/1) \\
\hline $87-2,118-120$ & 942.68 & 2.045 & 1.858 & 0.195 & 10.5 & 20 & - & 2.01 & $2.04^{\mathrm{b}}$ & $21.9^{\mathrm{b}}$ & $43.8^{\mathrm{b}}$ & 3.79 & - & Mudstone (5YR 3/4) \\
\hline $88-1,18-20$ & 949.18 & 2.029 & - & - & - & 20 & - & 2.13 & $2.07^{\mathrm{b}}$ & $20.9^{\mathrm{b}}$ & $42.2^{b}$ & - & - & Mudstone (5YR 3/2) \\
\hline $88-1,70-72$ & 949.70 & 3.675 & 2.812 & 0.863 & 30.7 & 20 & - & 2.75 & $2.59^{\mathrm{b}}$ & $6.6^{\mathrm{b}}$ & $16.7^{\mathrm{b}}$ & 7.28 & - & Dolomitic mudstone (5YR 3/2) \\
\hline $88-1,128-130$ & 950.28 & 2.469 & 2.411 & 0.058 & 2.4 & 20 & 2.36 & - & $2.44^{\mathrm{b}}$ & $9.4^{\mathrm{b}}$ & $22.4^{\mathrm{b}}$ & 5.88 & - & Sandstone (SY $5 / 1$ ) \\
\hline $88, \mathrm{CC}(2-4)$ & 953.48 & 2.219 & 2.084 & 0.135 & 6.5 & 20 & - & 2.21 & $2.24^{\mathrm{b}}$ & $15.5^{b}$ & $33.9^{\mathrm{b}}$ & 4.67 & - & Lenticular mudstone (5G $5 / 1$ ) \\
\hline $89-1,78-80$ & 958.78 & 2.107 & 1.949 & 0.158 & 8.1 & 20 & - & 2.13 & $2.12^{\mathrm{b}}$ & $18.1^{\mathrm{b}}$ & $37.4^{\mathrm{b}}$ & 4.13 & - & Lenticular mudstone (5GY $6 / 1 ; 5 G 5 / 1$ ) \\
\hline $89-2,105-107$ & 960.55 & 2.058 & 1.841 & 0.217 & 11.8 & 20 & - & - & $2.06^{\mathrm{b}}$ & $21.5^{\mathrm{b}}$ & $43.2^{\mathrm{b}}$ & 3.79 & - & Mudstone (5YR 3/2) \\
\hline $89-3,130-132$ & 962.30 & 2.094 & 1.948 & 0.146 & 7.5 & 20 & - & 2.18 & $2.13^{\mathrm{b}}$ & $17.9^{\mathrm{b}}$ & $37.2^{\mathrm{b}}$ & 4.15 & - & Calcareous mudstone (10YR 4/2) \\
\hline $89-4,50-52$ & 963.00 & 2.047 & 1.857 & 0.190 & 10.2 & 20 & - & - & $2.08^{\mathrm{b}}$ & $20.7^{b}$ & $42.1^{b}$ & 3.86 & - & Mudstone (SYR 3/4) \\
\hline $90-1,45-47$ & 967.45 & 2.394 & 2.219 & 0.175 & 7.9 & 20 & $=$ & 2.31 & $2.27^{\mathrm{b}}$ & $14.5^{\mathrm{b}}$ & $32.0^{\mathrm{b}}$ & 5.04 & - & Mudstone (5Y 3/4) \\
\hline $90-3,30-32$ & 970.30 & 1.951 & 1.813 & 0.138 & 7.6 & 20 & - & - & $2.01^{\mathrm{b}}$ & $22.3^{\mathrm{b}}$ & $43.8^{\mathrm{b}}$ & 3.64 & - & Mudstone (5GY $6 / 1$ ) \\
\hline $91-1,140-142$ & 977.46 & 1.734 & 1.788 & -0.054 & -3.0 & 20 & $\overline{-}$ & 2.08 & $2.03^{\mathrm{b}}$ & $22.0^{\mathrm{b}}$ & $43.6^{\mathrm{b}}$ & 3.63 & 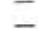 & Mudstone (SYR 4/1) \\
\hline $91-2,94-96$ & 978.44 & 2.137 & 1.990 & 0.147 & 7.4 & 20 & - & 2.17 & $2.13^{\mathrm{b}}$ & $17.8^{\mathrm{b}}$ & $37.0^{b}$ & 4.24 & - & Lenticular mudstone (5G 6/1) \\
\hline $91-3,98-100$ & 979.98 & 2.772 & 2.310 & 0.462 & 20.0 & 20 & $\overline{-}$ & 2.32 & $2.35^{\mathrm{b}}$ & $12.3^{\mathrm{b}}$ & $28.3^{\mathrm{b}}$ & 5.43 & - & Calcareous mudstone (5YR 3/4) \\
\hline $91-4,12-14$ & 980.62 & 4.288 & 3.692 & 0.596 & 16.1 & 20 & - & 2.78 & $2.69^{\mathrm{b}}$ & $5.5^{\mathrm{b}}$ & $14.4^{\mathrm{b}}$ & 9.93 & $=$ & Laminated $\mathrm{CO}_{3}$ cemented sandstone ( $\left.5 \mathrm{Y} 4 / 1\right)$ \\
\hline 93-1, 133-135 & 991.33 & 2.056 & 1.905 & 1 & & & - & & $2.21^{\mathrm{b}}$ ? & $\begin{array}{l}\text { Bad sample } \\
5.1^{b} \text { ? }\end{array}$ & $11.0^{b}$ & $4.21 ?$ & - & \\
\hline $93-2,72-74$ & $\begin{array}{ll}991.33 \\
992.22\end{array}$ & 2.395 & $\begin{array}{l}1.903 \\
2.191\end{array}$ & $\begin{array}{l}0.151 \\
0.204\end{array}$ & 9.3 & 20 & $=$ & 2.25 & $2.23 \mathrm{~b}^{\mathrm{q}}$ & $14.6^{\mathrm{b}}$ & $31.7^{\mathrm{b}}$ & $\begin{array}{l}4.217 \\
4.89\end{array}$ & $=$ & $\begin{array}{l}\text { Mudstone (SYK } 3 / 2) \\
\text { Lenticular calcareous mudstone (SYR 4/4) }\end{array}$ \\
\hline $93-3,60-62$ & 993.60 & 2.232 & 2.063 & 0.169 & $\begin{array}{l}9.3 \\
8.2\end{array}$ & 20 & 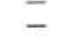 & 2.22 & $2.16^{\mathrm{b}}$ & $17.5^{\mathrm{b}}$ & $36.9^{\mathrm{b}}$ & 4.46 & $=$ & Calcareous mudstone (5YR $4 / 4)$ \\
\hline $93-5,3-5$ & 996.03 & 2.111 & 1.927 & 0.184 & 9.5 & 20 & - & 2.08 & $2.04^{\mathrm{b}}$ & $20.9^{\mathrm{b}}$ & $41.6^{\mathrm{b}}$ & 3.93 & - & Lenticular mudstone (SG $4 / 1 ; \mathrm{N} 8$ ) \\
\hline $94-1,11-13$ & 999.11 & 2.750 & 2.084 & 0.666 & 32.0 & 20 & - & 2.02 & $2.02^{b}$ & $22.0^{b}$ & $43.4^{b}$ & 4.21 & - & Laminated mudstone $(5 \mathrm{G} 4 / \mathrm{I})$ \\
\hline $94-1,30-32$ & 999.30 & $2.081 ?$ & 2.283 & -0.202 & -8.8 & 20 & - & 2.37 & $2.37^{\mathrm{b}}$ & $13.7^{\mathrm{b}}$ & $31.5^{\mathrm{b}}$ & 5.41 & - & Lenticular calcareous mudstone (SG 6/1) \\
\hline $94-2,140-142$ & 1001.90 & 2.063 & 1.891 & 0.172 & 9.1 & 20 & - & 2.14 & $2.07^{\mathrm{b}}$ & $21.1^{\mathrm{b}}$ & $42.5^{\mathrm{b}}$ & 3.91 & - & Mudstone (5YR 3/2) \\
\hline $95-1,102-104$ & 1009.02 & 2.186 & 1.933 & 0.253 & 13.1 & 20 & - & 2.06 & $2.11^{\mathrm{b}}$ & $19.3^{\mathrm{b}}$ & $39.8^{\mathrm{b}}$ & 4.08 & - & Mudstone (SYR 3/2) \\
\hline $95-2,137-139$ & 1010.88 & 2.181 & 1.999 & 0.182 & 9.1 & 20 & - & 2.10 & $2.20^{\mathrm{b}}$ & $16.7^{b}$ & $35.8^{\mathrm{b}}$ & 4.40 & - & Laminated mudstone ( $5 \mathrm{G} 4 / 1 ; N 3)$ \\
\hline $95-3,118-120$ & 1012.12 & 2.360 & 2.201 & 0.159 & 7.2 & 20 & - & 2.22 & $2.22^{\mathrm{b}}$ & $14.7^{\mathrm{b}}$ & $31.7^{\mathrm{b}}$ & 4.89 & - & Laminated calcareous mudstone (SYR $2 / 1$ to $4 / 1$ ) \\
\hline $96-1,73-77$ & 1017.73 & 1.881 & 2.115 & -0.234 & -12.4 & 20 & - & - & $2.05^{\mathrm{b}}$ & $20.8^{\mathrm{b}}$ & $41.6^{\mathrm{b}}$ & 4.34 & - & Lenticular calcareous mudstone ( $5 \mathrm{GY} 8 / 1$ to $4 / 1$ ) \\
\hline
\end{tabular}


Table 10. (Continued).

\begin{tabular}{|c|c|c|c|c|c|c|c|c|c|c|c|c|c|c|c|}
\hline \multirow[b]{3}{*}{$\begin{array}{c}\begin{array}{c}\text { Core-Section } \\
\text { (interval in cm) }\end{array} \\
\end{array}$} & \multirow[b]{3}{*}{$\begin{array}{c}\text { Depth in } \\
\text { hole } \\
\text { (m) }\end{array}$} & \multicolumn{5}{|c|}{ Compressional-sound velocity } & \multirow{2}{*}{\multicolumn{2}{|c|}{$\begin{array}{c}\text { GRAPE "special" } \\
\text { wet-bulk density" } \\
\text { (2-minute count) } \\
\left(\mathrm{g} / \mathrm{cm}^{3}\right) \\
\end{array}$}} & \multicolumn{3}{|c|}{ Gravimetric $^{b, c}$} & \multirow[b]{3}{*}{$\begin{array}{c}\text { Acoustitic } \\
\text { impedance } \\
\left(\mathrm{g} \cdot 10^{\mathrm{d}} / \mathrm{cm}^{2} \cdot \mathrm{s}\right)\end{array}$} & & & \multirow[b]{3}{*}{ Lithology (G.S.A. color number) } \\
\hline & & \multirow[b]{2}{*}{ 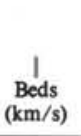 } & \multirow[b]{2}{*}{$\begin{array}{c}\text { Beds } \\
(\mathrm{km} / \mathrm{s})\end{array}$} & \multicolumn{2}{|c|}{ Anisotropy } & \multirow[b]{2}{*}{$\begin{array}{l}\text { Temp. } \\
\left({ }^{\circ} \mathrm{C}\right)\end{array}$} & & & \multirow{2}{*}{$\begin{array}{c}\text { Wet. } \\
\text { bulk } \\
\text { density } \\
\left(\mathrm{g} / \mathrm{cm}^{3}\right)\end{array}$} & \multirow{2}{*}{$\begin{array}{c}\text { Wet-water } \\
\text { content } \\
\text { (salt corr.) } \\
\text { (\%) }\end{array}$} & \multirow{2}{*}{$\begin{array}{c}\text { Porosity } \\
\text { (salt } \\
\text { corr.) } \\
(\%)\end{array}$} & & \multicolumn{2}{|c|}{$\begin{array}{l}\text { Vane shear } \\
\text { strength }\end{array}$} & \\
\hline & & & & $\begin{array}{c}1-1 \\
(\mathrm{~km} / \mathrm{s})\end{array}$ & $\underset{(\%)}{\left(1-\frac{1}{(\%) / 1}\right.}$ & & $\begin{array}{c}1 \\
\text { Beds }\end{array}$ & $\frac{1}{\text { Beds }}$ & & & & & $\begin{array}{l}\text { Original } \\
\left(\mathrm{g} / \mathrm{cm}^{2}\right)\end{array}$ & $\begin{array}{c}\text { Remolded } \\
\left(\mathrm{g} / \mathrm{cm}^{2}\right)\end{array}$ & \\
\hline 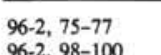 & 1019.25 & 2.276 & 2.198 & 0.078 & 3.5 & 20 & & 2.20 & $2.19^{\mathrm{b}}$ & $15.1^{\mathrm{b}}$ & $32.2^{\mathrm{b}}$ & 4.81 & - & & Lenticular calcareous mudstone $(5 \mathrm{GY} 6 / 1$ to $4 / 1)$ \\
\hline $\begin{array}{l}96-2,98-100 \\
97-1,26-28\end{array}$ & $\begin{array}{l}1019.48 \\
102.26\end{array}$ & $\begin{array}{l}2.045 \\
4.421\end{array}$ & $\begin{array}{l}1.899 \\
4.382\end{array}$ & 0.146 & 7.7 & 20 & 2.05 & 255 & $2.0 \mathrm{~g}^{\mathrm{b}}$ & $\begin{array}{c}20.2^{\mathrm{b}} \\
3 \mathrm{~b}\end{array}$ & $40.9^{\mathrm{b}}$ & 3.95 & - & & \\
\hline $\begin{array}{l}97-1,26-28 \\
97-3,5-7\end{array}$ & $\begin{array}{l}1022.626 \\
1029.05\end{array}$ & $\begin{array}{l}4.421 \\
2.079\end{array}$ & $\begin{array}{l}4.382 \\
1.869\end{array}$ & $\begin{array}{l}0.039 \\
0.210\end{array}$ & $\begin{array}{r}0.9 \\
11.2\end{array}$ & ${ }_{20}^{20}$ & $\bar{z}+x+r+x+10$ & $\begin{array}{l}2.55 \\
2.05\end{array}$ & 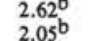 & 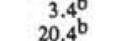 & $\begin{array}{c}8.6^{6} \\
40.8\end{array}$ & $\begin{array}{r}11.48 \\
3.83\end{array}$ & 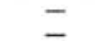 & & $\begin{array}{l}\text { Lenticular calcareous mudstone ( }(5 \mathrm{GY} 4 / 1 ; \mathrm{N} 3) \\
\text { Mudstone (5GY } 2 / 1)\end{array}$ \\
\hline $98-1,18-20$ & 1035.18 & 1.976 & 1.893 & 0.083 & 4.4 & 20 & 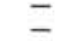 & 2.11 & 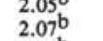 & $201^{\mathrm{b}}$ & 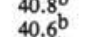 & $\begin{array}{l}3.83 \\
3.92\end{array}$ & 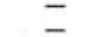 & & 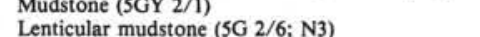 \\
\hline $98-2,20-22$ & 1036.70 & 2.100 & 1.906 & 0.194 & 10.2 & 20 & $\overline{-}$ & 2.07 & $2.08^{\mathrm{b}}$ & $18.8^{\mathrm{b}}$ & $\begin{array}{l}40.2^{\mathrm{b}} \\
\mathrm{b}\end{array}$ & 3.96 & 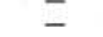 & & Laminated mudstone (SG $2 / 6)$ \\
\hline $\begin{array}{l}98-3,10-12 \\
99-1,18-140\end{array}$ & $\begin{array}{l}1038.10 \\
10458\end{array}$ & 2.165 & 1.974 & 0.191 & 9.7 & 20 & - & 2.12 & $2.00^{\mathrm{b}}$ & $19.2^{\mathrm{b}}$ & $39.1 \mathrm{~b}$ & 4.13 & - & & Laminated mudstone $(5 \mathrm{G} 2 / 6)$ \\
\hline $\begin{array}{l}99-1,138-140 \\
99-2,40-42\end{array}$ & $\begin{array}{l}1045.38 \\
1045.90\end{array}$ & $\begin{array}{l}1.863 \\
2.089\end{array}$ & $1 . \overline{910}$ & 0.179 & 9.4 & 20 & 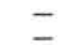 & $\begin{array}{l}2.13 \\
2.07\end{array}$ & $\begin{array}{l}2.07^{\mathrm{b}} \\
2.0^{\mathrm{b}}\end{array}$ & $\begin{array}{l}19.6^{\mathrm{b}} \\
19 \mathrm{~b}^{\mathrm{b}}\end{array}$ & $\begin{array}{c}39.5^{\mathrm{b}} \mathrm{b} \\
3.5 \mathrm{~b}\end{array}$ & $\overline{3.95}$ & 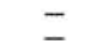 & & $\begin{array}{l}\text { Mudstone }(5 \mathrm{Y} 2 / 1) \\
\text { Lenticular }(5 \mathrm{G})\end{array}$ \\
\hline $99-2,68-70$ & $\begin{array}{l}1046.18 \\
10430\end{array}$ & 3.841 & 2.908 & $\begin{array}{l}0.933 \\
0.933\end{array}-3-179$ & $\begin{array}{l}9.4 \\
32.1\end{array}$ & 20 & $\bar{z}+x+r+x+10$ & $\begin{array}{l}2.07 \\
2.52\end{array}$ & 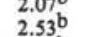 & $5.9^{\mathrm{b}}$ & 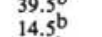 & 7.36 & $\Xi$ & & $\begin{array}{l}\text { Lenticular ( (G G 4 /1, ; N3) } \\
\text { Nannofossil limestone (SY } 4 / 1 \text { ) }\end{array}$ \\
\hline $99-4,135-137$ & 1049.85 & 2.170 & 1.924 & 0.246 & $\begin{array}{l}32.1 \\
12.8\end{array}$ & 20 & 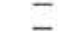 & $\begin{array}{l}2.32 \\
2.09\end{array}$ & $2.08^{\mathrm{b}}$ & $19.1^{\circ}$ & $\begin{array}{l}14.9 \mathrm{~b} \\
38.7 \mathrm{~b}\end{array}$ & $\begin{array}{l}7.36 \\
4.00\end{array}$ & $\overline{-}$ & & $\begin{array}{l}\text { Nannootossil limimestone ( }(9 Y 4 / 1) \\
\text { Mudstone }(5 Y 2 / 1)\end{array}$ \\
\hline $100-1,140-142$ & 1054.40 & 2.258 & 2.030 & 0.228 & 11.2 & 20 & - & 2.07 & $2.11^{\mathrm{b}}$ & $19.0^{\mathrm{b}}$ & $39.0^{\mathrm{b}}$ & 4.28 & - & & Lenticular mudstone $(5 \mathrm{G} 4 / 1 ; \mathrm{N} 3)$ \\
\hline $\begin{array}{l}100-2,94-96 \\
100-3,34-36\end{array}$ & $\begin{array}{l}1055.44 \\
105.34\end{array}$ & $\begin{array}{l}2.201 \\
2.34\end{array}$ & $1.677 ?$ & $0.524 ?$ & $31.2 ?$ & 20 & - & 2.10 & $2.09^{\mathrm{b}}$ & $\begin{array}{ll}18.6^{\mathrm{b}} \\
15 \mathrm{~b}\end{array}$ & $37.9 \mathrm{~b}$ & 3.50 ? & - & & Laminated mudstone $(5 \mathrm{G} 4 / 1)$ \\
\hline $100-4,36-38$ & 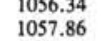 & $\begin{array}{l}2.2344 \\
2.271\end{array}$ & 2.073 & $\begin{array}{l}0.165 \\
0.198\end{array}-30$ & $\begin{array}{l}7.6 \\
9.6\end{array}$ & ${ }_{20}^{20}$ & $\overline{-}$ & $\begin{array}{l}2.12 \\
2.16\end{array}$ & $2.199^{\circ}$ & $\begin{array}{l}15.2^{\circ} \mathrm{b} \\
16 . \mathrm{b}^{\mathrm{b}} \mathrm{a}\end{array}$ & 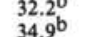 & $\begin{array}{l}4.75 \\
4.42\end{array}$ & $\overline{-}$ & & $\begin{array}{l}\text { Laminated mudstone }(5 \mathrm{Y} 4 / 3) \\
\text { Laminated calcaracous mudstone }(5 \mathrm{GY} 5 \mathrm{~s})\end{array}$ \\
\hline $\begin{array}{ll}101-1, & 22-24 \\
1012 & 32,35\end{array}$ & 1062.22 & 2.248 & 2.030 & 0.218 & $\begin{array}{l}9.6 \\
10.7\end{array}$ & ${ }_{20}^{20}$ & $\bar{z}+x+x+x+10$ & 2.11 & $2.09 \mathrm{~b}$ & $19.2^{\mathrm{b}}$ & 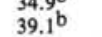 & $\begin{array}{l}4.42 \\
4.24\end{array}$ & $\overline{-}$ & & 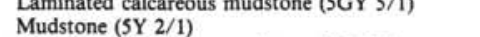 \\
\hline $\begin{array}{l}101-2,33-35 \\
1012-3486\end{array}$ & 1063.83 & 2.295 & 2.137 & 0.158 & 7.4 & 20 & $\bar{z}$ & 2.16 & & & & & $\overline{-}$ & & Laminated calcareous mudstone (5G 6/1) \\
\hline $\begin{array}{l}101-3,84-86 \\
101-5,13-138\end{array}$ & 1065.84 & 2.414 & 2.199 & 0.215 & 9.8 & 20 & - & 2.12 & $2.14^{\mathrm{b}}$ & $16.2^{\mathrm{b}}$ & $33.8^{\mathrm{b}}$ & 4.71 & - & & Calcareous mudstone (SY 5/1) \\
\hline $\begin{array}{l}\text { lof } \\
102-1,15-17\end{array}$ & $\begin{array}{l}1069.36 \\
1071.15\end{array}$ & 2.253 & 1.752 & 0.501 & 28.6 & 20 & 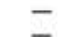 & 2.17 & $\begin{array}{l}2.15^{5} \\
2.1 \mathrm{~b}^{\mathrm{b}}\end{array}$ & $\begin{array}{ll}17.0^{6} \\
15.3\end{array}$ & $\begin{array}{l}35.77^{7} \\
3,28\end{array}$ & 3.77 & $\overline{-}$ & & Mudstone (5YR 3/1) \\
\hline $102-2,47-49$ & ${ }_{1072.97}^{10113}$ & 2.246 & $\begin{array}{l}2.089 \\
2.089\end{array}$ & $\begin{array}{l}0.232 \\
0.157\end{array}$ & $\begin{array}{c}10.8 \\
7.5\end{array}$ & ${ }_{20}^{20}$ & $\overline{-}$ & $\begin{array}{l}2.18 \\
2.16\end{array}$ & $\begin{array}{l}2.1 .16^{6} \\
2\end{array}$ & $16.4^{\mathrm{b}}$ & $\begin{array}{l}32.88^{\mathrm{b}} \\
34 . \mathrm{b}^{2} \mathrm{l}\end{array}$ & $\begin{array}{l}4.722 \\
4.51\end{array}$ & - & & 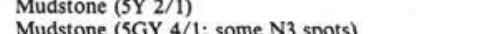 \\
\hline $102-4,2-4$ & 1075.52 & 2.406 & 2.175 & 0.231 & 10.6 & ${ }_{20}^{20}$ & $=$ & $\begin{array}{l}2.16 \\
2.17\end{array}$ & $2.18^{\mathrm{b}}$ & $15.2^{\mathrm{b}}$ & 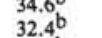 & $\begin{array}{l}4.31 \\
4.74\end{array}$ & $\overline{-}+x+x+x+10$ & & 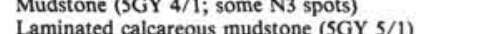 \\
\hline $102-5,2-5$ & $\begin{array}{l}1077.02 \\
102-32\end{array}$ & 2.369 & 1.871 & 0.498 & 26.6 & 20 & $=$ & 2.26 & $2.19^{\mathrm{b}}$ & $15.3^{\mathrm{b}}$ & 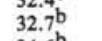 & 4.10 & 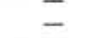 & & Mudstone $(5 Y 2 / 1)$ \\
\hline $103-1,46-48$ & 1080.46 & & 2.096 & - & - & 20 & - & 2.16 & $2.11^{\mathrm{b}}$ & $16.5^{\mathrm{b}}$ & $34.6^{\mathrm{b}}$ & - & - & & Mudstone $(5 Y 3 / 1)$ \\
\hline $\begin{array}{l}103-2,102-103 \\
103-3,40-42\end{array}$ & $\begin{array}{l}1082.52 \\
108340\end{array}$ & 2.420 & $\begin{array}{l}2.227 \\
2200\end{array}$ & 0.193 & 8.7 & 20 & 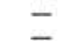 & 2.16 & ${ }_{2.11^{\mathrm{b}}}^{2}$ & $15.1^{\mathrm{b}}$ & $\begin{array}{l}32.3 \mathrm{~b} \\
32.7 \mathrm{~b}\end{array}$ & 4.88 & - & & Lenticular calcareous mudstone $(5 \mathrm{G} 6 / 1)$ \\
\hline $\begin{array}{l}103-3,4,40-42 \\
103-4,2-4\end{array}$ & $\begin{array}{l}1083.40 \\
1084.50\end{array}$ & $\begin{array}{l}2.608 \\
2.444\end{array}$ & $\begin{array}{l}2.299 \\
2.226\end{array}$ & $\begin{array}{l}0.309 \\
0.218\end{array}$ & 13.4 & ${ }_{20}^{20}$ & $\overline{-}$ & $\begin{array}{l}2.19 \\
2.17\end{array}$ & $\begin{array}{l}2.11^{\circ}{ }^{\circ} \\
2.6^{6}\end{array}$ & $\begin{array}{l}14.8^{\circ} \mathrm{b} \\
157^{\mathrm{b}}\end{array}$ & $\begin{array}{l}31.77^{\circ} \\
33.1 \mathrm{~b}\end{array}$ & $\begin{array}{l}5.03 \\
4.81\end{array}$ & $\overline{-}$ & & $\begin{array}{l}\text { Mudstone (SY } 331 \text { ) } \\
\text { Calcareous mudstone ( } 5 \mathrm{G} 61: \text { N3 lenses) }\end{array}$ \\
\hline $\begin{array}{l}103-4,2-4 \\
104-1,120-122\end{array}$ & $\begin{array}{l}1084.40 \\
1086.20\end{array}$ & $\begin{array}{l}2.444 \\
3.072\end{array}$ & $\begin{array}{l}2.226 \\
2.861\end{array}$ & 0.211 & $\begin{array}{l}9.8 \\
7.4\end{array}$ & 20 & $\overline{-}$ & 2.28 & $2.29^{\mathrm{b}}$ & $11.4^{\mathrm{b}}$ & 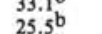 & 6.55 & $\bar{z}+x+x+1+x$ & & 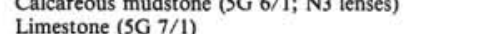 \\
\hline $104-2,100-102$ & $\begin{array}{l}1087.50 \\
1007-20\end{array}$ & 2.370 & 2.120 & 0.250 & 11.8 & 20 & - & 2.07 & $2.12^{\mathrm{b}}$ & $17.3^{\mathrm{b}}$ & $35.8^{\mathrm{b}}$ & 4.49 & - & & Mudstone (5G 4/1; N3 lenses) \\
\hline $104-3,38-40$ & 1088.38 & 2.463 & 2.194 & 0.269 & 12.3 & 20 & - & 2.12 & $2.16^{\mathrm{b}}$ & $15.2^{\mathrm{b}}$ & $31.9 \mathrm{~b}$ & 4.74 & - & & Laminated siltstone (5Y 9/1) \\
\hline $\begin{array}{l}104-5,144-146 \\
105-1,48-50\end{array}$ & $\begin{array}{l}1092.15 \\
1094.48\end{array}$ & $\begin{array}{l}2.417 \\
2.363\end{array}$ & $\begin{array}{l}2.089 \\
2.027\end{array}$ & $\begin{array}{l}0.328 \\
0.336\end{array}$ & 15.7 & 20 & $\overline{-}$ & $\begin{array}{l}2.11 \\
2.08\end{array}$ & $2.13 \mathrm{~b}^{\mathrm{b}}$ & $\begin{array}{l}16.8 \mathrm{~b} \\
15.9 \mathrm{~b}\end{array}$ & $34.9^{\circ} \mathrm{b}$ & $\begin{array}{l}4.45 \\
4.36\end{array}$ & 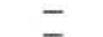 & & $\begin{array}{l}\text { Mudstone (SY 2/1) } \\
\text { lenticulare }\end{array}$ \\
\hline $\begin{array}{l}105-1,48-50 \\
105-3,18-20\end{array}$ & 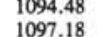 & $\begin{array}{l}2.3 .33 \\
3.252\end{array}$ & 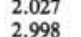 & $\begin{array}{l}0.336 \\
0.254\end{array}$ & $\begin{array}{l}16.6 \\
18.5\end{array}$ & ${ }_{20}^{20}$ & $\overline{-}$ & $\begin{array}{l}2.08 \\
2.44\end{array}$ & $2.15^{\circ}$ & $\begin{array}{l}11.9^{\circ} \text {. } \\
\text { Bad sample }\end{array}$ & ${ }^{333.3^{\circ}}$ & 7.31 & $\bar{z}+x+x+1+x$ & & 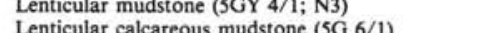 \\
\hline $\begin{array}{l}105-4,115-117 \\
105\end{array}$ & 1099.65 & $\begin{array}{l}3.053 \\
3.053-1250\end{array}$ & 2.832 & 0.221 & 7.8 & 20 & 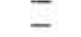 & 2.47 & $2.32^{\mathrm{b}}$ & $10.9 b^{6}$ & $24.8^{\mathrm{b}}$ & 6.57 & 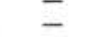 & & Lenticular calcareous mudstone ( $5 \mathrm{G} 6 / 1)$ \\
\hline $105-5,115-117$ & 1101.15 & 2.319 & 2.092 & 0.227 & 10.9 & 20 & - & 2.15 & $2.20^{\mathrm{b}}$ & $14.9^{\mathrm{b}}$ & $32.0^{\mathrm{b}}$ & 4.60 & - & & Mudstone (SYR 3.5/2) \\
\hline $106-1,8-10$ & 1103.08 & $\begin{array}{l}3.813^{f} \\
3.774^{f}\end{array}$ & & -0 & -2.2 & Cold $\left(15^{\circ} \mathrm{C}\right)$ & 247 & $=$ & $2 \overline{50 \mathrm{~b}}$ & $\overrightarrow{7^{b} \mathrm{~b}}$ & $1 \overline{6}^{\mathrm{b}}$ & 9.54 & $\bar{z}+x+r+10$ & & Basalt (velocity of whole core) \\
\hline $\begin{array}{l}106-1,8-10 \\
107-1,12-14\end{array}$ & $\begin{array}{ll}1103.08 \\
1110.12\end{array}$ & $\begin{array}{l}3.784^{1} \\
4.803 \\
\end{array}$ & ${ }_{-}^{3.858^{7}}$ & -0.084 & -2.2 & 20 & 2.47 & - & $2.50^{\circ}$ & $\frac{7.2^{\circ}}{-}$ & $17.6^{\circ}$ & & $\bar{z}+x+1+x$ & & Basalt (vein) (velocity of mini-core) \\
\hline $\begin{array}{l}1 \\
107-1,12-14 \\
107-14\end{array}$ & $\begin{array}{l}11105.12 \\
1105.12\end{array}$ & $\begin{array}{l}4.403 \\
4.693\end{array}$ & $4 . \overline{829}$ & $-\overline{0.136}$ & $-\overline{2.8}$ & $\begin{array}{l}\text { Cold } \\
20\end{array}-1-100$ & $2 . \overline{69}$ & $\overline{-}$ & $2 . \overline{74^{\mathrm{b}}}$ & $4.0^{\mathrm{b}}$ & $10 \overline{7^{b}}$ & 12.9 & - & & $\begin{array}{l}\text { Gasalat (velocty) of whole core) } \\
\text { Basalt (vein) (velocity of mini-core) }\end{array}$ \\
\hline $107-2,24-26$ & 1106.74 & 4.727 & & & & Cold & & & & & & 12.6 & $=$ & & Basalt (velocity of whole core) \\
\hline $107-2,24-26$ & 1106.74 & 4.711 & 4.678 & 0.033 & 0.7 & 20 & 2.67 & - & $2.65^{\mathrm{b}}$ & $5.2^{\mathrm{b}}$ & $13.5^{\mathrm{b}}$ & & - & & Basalt (velocity of mini-core) \\
\hline $\begin{array}{l}107-3,44-1-33 \\
107-3,41-43\end{array}$ & 1108.41 & $\begin{array}{l}4.924 \\
5.013\end{array}$ & & $-\overline{0.017}$ & $-\overline{0.3}$ & Cold & $2 \overline{70}$ & $\overline{-}$ & $2 . \overline{73} \mathrm{~b}$ & $3.4^{b}$ & $9 . \overline{2}^{\mathrm{b}}$ & $\stackrel{13.43}{-}$ & - & & Basalt (velocity of whole core) \\
\hline $\begin{array}{l}107-3,4,-43 \\
108-1,19-21\end{array}$ & $\begin{array}{l}1108.24 \\
112.14\end{array}$ & $\begin{array}{l}5.013 \\
4.857 \\
-157\end{array}$ & 5.030 & & & 20 & 2.10 & & & & & $13 . \overline{21}$ & & & 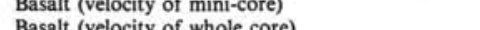 \\
\hline $\begin{array}{l}108-1,19-21 \\
108-1,19\end{array}$ & ${ }_{1112.14}^{11214}$ & $\begin{array}{l}4.887 \\
4.962\end{array}$ & $4 . \overline{846}$ & $\overline{0.116}$ & $\overline{2.4}$ & ${ }_{20}^{C O A}$ & $2 . \overline{68}$ & $\bar{z}+x+3+1$ & $2 . \overline{72^{\mathrm{b}}}$ & $44^{\mathrm{b}}$ & $11 \overline{8^{b}}$ & 13.21 & & & Basalt (velocity of mini-core) \\
\hline $108-2,58-60$ & 1114.08 & 4.678 & & & & Cold & & & & & & 12.44 & - & & Basalt (velocity of whole core) \\
\hline $108-2,58-60$ & 1114.08 & 4.583 & 4.659 & -0.076 & -1.6 & 20 & 2.65 & 2.68 & $2.66^{6}$ & $5.0^{\mathrm{b}}$ & $12.9^{\mathrm{b}}$ & & - & & Basalt (velocity of mini-core) \\
\hline $\begin{array}{l}108-3,388-1-83 \\
108-3,81-83\end{array}$ & 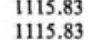 & $\begin{array}{l}4.497 \\
4.764\end{array}$ & 4.495 & $\overline{0.269}$ & 6.0 & Cold & $\overline{2.48 ?}$ & (Fracture) & $2 . \overline{7^{\mathrm{b}}}$ & $5 . \bar{b}^{\mathrm{b}}$ & $13.6^{\mathrm{b}}$ & $\stackrel{12.54}{-1}$ & $\overline{-}$ & & $\begin{array}{l}\text { Basalal (telocity of hhole core) } \\
\text { Basalt (vein) (velocity of mini-core) }\end{array}$ \\
\hline
\end{tabular}

a The calculation used the following parameters: $\mathrm{eg}, \mathrm{egc}=2.7 \mathrm{~g} / \mathrm{cm}^{3}$ for sediments and $3.0 \mathrm{~g} / \mathrm{cm}^{3}$ for basalt; ef $=1.025 \mathrm{~g} / \mathrm{cm}^{3}$; and $\mathrm{efc}=1.128 \mathrm{~g} / \mathrm{cm}^{3}$. There was a linear interpolation between $0.10126 \mathrm{~cm} 2 / \mathrm{g}$, for the $6.61 \mathrm{~cm}$ aluminum standard, and $0.10056 \mathrm{~cm}^{2} / \mathrm{g}$, for the $2.54 \mathrm{~cm}$ aluminum standard, based on the sample's own diameter.

cravimetric data were done on ship by weight in air and weight in water ssing 0 us centrogram balance; these were done by $W$. Meyers.

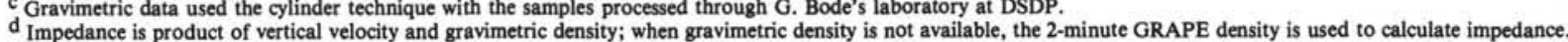

${ }^{\text {e }}$ Core 35 and the core below were split using the "super-saw." This saw affects (erodes) the drilling paste such that when sampling for velocity and density the undisturbed rock is more easily distinguished. Thus, a more homogeneous pure-rock

f Use the velocities measured through the whole basalt core for any velocity-related geophysical calculations. The velocities measured on the basalt mini-cores are used only to determine anisotropy, since these are not as accurate as the whole basalt core velocities. 
Table 11. Physical property data, Hole 530B (hydralic piston cores).

\begin{tabular}{|c|c|c|c|c|c|c|c|c|c|c|c|c|c|c|c|}
\hline \multirow[b]{3}{*}{$\begin{array}{l}\text { Core-Section } \\
\text { (interval in } \mathrm{cm} \text { ) }\end{array}$} & \multirow{3}{*}{$\begin{array}{l}\text { Depth in } \\
\text { hole } \\
\text { (m) }\end{array}$} & \multicolumn{5}{|c|}{ Compressional-sound velocity } & \multirow{2}{*}{\multicolumn{2}{|c|}{$\begin{array}{c}\text { GRAPE "special" } \\
\text { wet-bulk density } \\
\text { (2-minute count) } \\
\left(\mathrm{g} / \mathrm{cm}^{3}\right)\end{array}$}} & \multicolumn{3}{|c|}{ Gravimetric $^{b, c}$} & \multirow{3}{*}{$\begin{array}{c}\text { Acoustic } \\
\text { impedançe } \\
\left(8 \cdot 10^{-5} / \mathrm{cm}^{2} \cdot \mathrm{s}\right)\end{array}$} & \multirow{2}{*}{\multicolumn{2}{|c|}{$\begin{array}{c}\text { Vane shear } \\
\text { strength }\end{array}$}} & \multirow[b]{3}{*}{ Lithology (G.S.A. color numbers) } \\
\hline & & & $\perp$ & & otropy & & & & \multirow{2}{*}{ 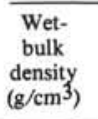 } & \multirow{2}{*}{$\begin{array}{c}\text { Wet-water } \\
\text { content } \\
\text { (salt corr.) } \\
(\%)\end{array}$} & \multirow{2}{*}{ 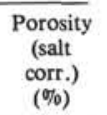 } & & & & \\
\hline & & $\begin{array}{c}\text { Beds } \\
(\mathrm{km} / \mathrm{s})\end{array}$ & $\begin{array}{c}\text { Beds } \\
(\mathrm{km} / \mathrm{s})\end{array}$ & $\begin{array}{c}1-1 \\
(\mathrm{~km} / \mathrm{s})\end{array}$ & $\begin{array}{c}(1-1) / 1 \\
(\%)\end{array}$ & $\begin{array}{l}\text { Temp. } \\
\left({ }^{\circ} \mathrm{C}\right)\end{array}$ & $\begin{array}{c}1 \\
\text { Beds }\end{array}$ & $\begin{array}{c}1 \\
\text { Beds }\end{array}$ & & & & & $\begin{array}{l}\text { Original } \\
\left(\mathrm{g} / \mathrm{cm}^{2}\right)\end{array}$ & $\begin{array}{c}\text { Remolded } \\
\left(\mathrm{g} / \mathrm{cm}^{2}\right)\end{array}$ & \\
\hline $3-2,110-112$ & 10.90 & - & - & - & - & - & - & - & - & - & - & - & 91 & (Cracked) & Clay $(5 Y 2 / 1)$ \\
\hline $3-2,113-115$ & 10.93 & 1.506 & - & - & - & 21 & 1.20 & - & $1.22^{\mathrm{c}}$ & $72.1^{\mathrm{c}}$ & $86.0^{c}$ & 1.84 & $\overline{-}$ & & Clay $(5 Y 2 / 1)$ \\
\hline $7-3,80-82$ & 27.20 & - & - & - & - & - & - & - & - & - & - & - & 130 & 1 & Clay $(5 \mathrm{GY} 4 / 1)$ \\
\hline $7-3,83-85$ & 27.23 & 1.489 & - & - & - & 21 & 1.45 & - & $1.44^{\mathrm{c}}$ & $53.1^{\mathrm{c}}$ & $74.6^{\mathrm{c}}$ & 2.14 & - & & Clay $(5 \mathrm{GY} 4 / 1)$ \\
\hline $9-2,130-132$ & 35.00 & - & - & - & - & - & - & - & - & - & - & - & 149 & 9 & Clay $(5 G Y 4 / 1)$ \\
\hline $9-2,133-135$ & 35.03 & 1.585 & - & - & - & 21 & 1.60 & - & & Bad sample & & 2.54 & - & & Clay $(5 \mathrm{GY} 4 / 1)$ \\
\hline $10-1,138-140$ & 37.98 & - & - & - & - & - & - & - & - & - & - & - & 248 & 48 & Nannofossil ooze (5Y 6/1) \\
\hline $10-1,140-141$ & 38.00 & 1.482 & - & - & - & 20 & 1.52 & - & $1.47^{c} ?$ & $51.0^{c}$ ? & $73.0^{c}$ ? & 2.18 & - & & Nannofossil ooze $(5 Y$ 6/1) \\
\hline $11-2,140-142$ & 43.90 & 1.505 & - & - & - & 20 & 1.36 & - & $1.33^{\mathrm{c}}$ & $62.7^{\mathrm{c}}$ & $81.2^{\mathrm{c}}$ & 2.00 & - & & Clayey diatom ooze (5Y $3 / 1)$ \\
\hline $11-2,145-147$ & 43.95 & - & - & - & - & - & - & - & - & - & - & - & 414 & (Cracked) & Clayey diatom ooze (5Y 3/1) \\
\hline $12-3,10-12$ & 48.50 & 1.495 & - & - & - & 20 & 1.34 & - & $1.32^{\mathrm{c}}$ & $63.4^{c}$ & $81.9^{c}$ & 1.97 & - & & Clayey diatom ooze (SY 3/1) \\
\hline $12-3,13-15$ & 48.53 & - & - & - & - & - & - & - & - & - & - & - & 405 & (Cracked) & Clayey diatom ooze (5Y $3 / 1)$ \\
\hline $14-2,10-12$ & 55.80 & 1.513 & - & - & - & 20 & 1.48 & - & $1.46^{\mathrm{C}}$ & $52.9^{\mathrm{c}}$ & $75.2^{\mathrm{c}}$ & 2.21 & - & & Diatom nannofossil ooze (5G $6 / 1)$ \\
\hline $14-2,15-17$ & 55.85 & - & - & - & - & - & - & - & - & - & - & - & 412 & 58 & Diatom nannofossil ooze $(5 \mathrm{G} 6 / 1)$ \\
\hline $16-2,130-132$ & 65.80 & 1.503 & - & - & - & 20 & 1.24 & - & $1.24^{\mathrm{c}}$ & $70.6^{\mathrm{c}}$ & $85.7^{\mathrm{c}}$ & 1.86 & - & & Clayey diatom ooze (SY 4/1) \\
\hline $16-2,133-135$ & 65.83 & - & - & - & - & - & - & - & - & - & - & - & 463 & (Cracked) & Clayey diatom ooze (5Y $4 / 1)$ \\
\hline $17-2,119-121$ & 70.09 & - & - & - & - & - & - & - & - & - & - & - & 889 & 140 & Clayey diatom ooze (5Y $3 / 1)$ \\
\hline $17-2,125-127$ & 70.15 & 1.517 & - & - & - & 20 & 1.35 & - & $1.32^{\mathrm{c}}$ & $62.4^{\mathrm{c}}$ & $80.5^{\mathrm{c}}$ & 2.00 & - & & Clayey diatom ooze (5Y $3 / 1)$ \\
\hline $18-1,130-133$ & 73.10 & - & - & - & - & - & - & - & - & - & - & $\bar{m}$ & 498 & (Cracked) & Clayey diatom ooze (5Y 3/1) \\
\hline $18-1,135-136$ & 73.15 & 1.497 & - & - & - & 20 & 1.32 & - & $1.34^{\mathrm{c}}$ & $61.6^{\mathrm{c}}$ & $80.3^{\mathrm{c}}$ & 2.00 & - & & Clayey diatom ooze (5Y $3 / 1)$ \\
\hline $20-3,20-22$ & 83.80 & - & - & - & - & - & - & - & - & - & - & - & 705 & (Cracked) & Clayey diatom ooze (5Y $3 / 1)$ \\
\hline $20-3,25-27$ & 83.85 & 1.505 & - & - & - & 20 & 1.34 & - & $1.36^{\mathrm{C}}$ & $59.7^{\mathrm{c}}$ & $79.2^{\mathrm{c}}$ & 2.05 & - & & Clayey diatom ooze (5Y 3/1) \\
\hline $21-2,25-27$ & 86.75 & 1.499 & - & - & $=$ & 20 & 1.36 & - & $1.35^{\mathrm{c}}$ & $61.0^{c}$ & $80.3^{\mathrm{c}}$ & 2.02 & - & & Clayey diatom ooze (5Y $3 / 1)$ \\
\hline $21-2,30-33$ & 86.80 & - & - & - & - & - & - & - & - & - & - & - & 708 & 153 & Clayey diatom ooze (5Y 3/1) \\
\hline $25-2,125-127$ & 102.55 & - & - & - & - & - & - & - & - & - & - & - & 1097 & 159 & Clayey diatom ooze (marl) $(5 \mathrm{G} 4 / 1)$ \\
\hline $25-2,130-133$ & 102.60 & $1 . \overline{500}$ & $\bar{z}$ & $=$ & - & $\overline{20}$ & $1 . \overline{38}$ & - & $1.41^{\mathrm{c}}$ & $58.4^{c}$ & $80.5^{\mathrm{C}}$ & $2 . \overline{12}$ & - & & Clayey diatom ooze (marl) $(5 \mathrm{G} 4 / 1)$ \\
\hline $27-2,10-13$ & 108.80 & 1.507 & - & - & - & 20 & 1.50 & - & $1.50^{\mathrm{c}}$ ? & $53.4^{\mathrm{c}}$ ? & $78.0^{\mathrm{c}}$ ? & 2.26 & - & & Mottled clayey diatom ooze $(5 \mathrm{Y} 4 / 1)$ \\
\hline $33-1,70-75$ & 118.90 & - & - & - & - & - & - & - & - & - & - & - & 719 & (Cracked) & Mud flow clast: diatomaceous clay (5YR $3 / 1$ ) \\
\hline $33-1,75-77$ & 118.95 & 1.586 & - & - & - & 20 & 1.56 & - & $1.58^{\mathrm{c}} ?$ & $47.1^{c}$ ? & $72.5^{c}$ ? & 2.51 & - & & Mud flow clast: diatomaceous clay (SYR $3 / 1$ ) \\
\hline $35-2,120-122$ & 137.10 & - & - & - & - & - & - & - & - & - & - & - & 778 & (Cracked) & Mud flow clast: nannofossil ooze (5Y $6 / 1)$ \\
\hline $35-2,125-127$ & 137.15 & 1.560 & - & - & - & 20 & 1.85 & - & $1.84^{\mathrm{c}}$ & $31.4^{\mathrm{c}}$ & $56.4^{\mathrm{c}}$ & 2.87 & - & & Mud flow clast: nannofossil ooze (5Y $6 / 1)$ \\
\hline $36-3,15-17$ & 141.95 & - & - & - & - & - & - & - & - & & - & - & 2082 & & Mud flow clast: mottled clayey \\
\hline $36-3,20-22$ & 142.00 & 1.578 & - & - & - & 20 & - & - & $1.64^{\mathrm{c}}$ & $39.6^{\mathrm{c}}$ & $63.6^{\mathrm{C}}$ & $2.59^{\mathrm{b}}$ & - & & Nannofossil ooze $(5 Y$ Y $6 / 1)$ \\
\hline $37-1,50-52$ & 142.70 & - & - & - & - & - & - & - & - & - & - & - & 566 & (Cracked) & Nannofossil ooze (5Y $6 / 1)$ \\
\hline $37-1,55-57$ & 142.75 & 1.535 & - & - & - & 20 & 1.62 & - & $1.67^{\mathrm{c}}$ & $40.5^{\mathrm{c}}$ & $66.2^{\mathrm{c}}$ & 2.56 & - & (C) & Nannofossil ooze (5Y $6 / 1)$ \\
\hline $41-3,70-72$ & 158.30 & - & - & - & - & - & - & - & - & - & - & - & 1522 & 71 & Nannofossil ooze (5Y $6 / 1)$ \\
\hline $41-3,75-77$ & 158.35 & 1.524 & - & - & - & 20 & 1.72 & - & $1.65^{\mathrm{c}}$ & $39.2^{c}$ & $64.8^{\mathrm{c}}$ & 2.58 & - & & Nannofossil ooze (5Y $6 / 1)$ \\
\hline $44-2,80-83$ & 165.30 & - & - & - & - & - & - & - & - & - & - & - & 1297 & (Cracked) & Laminated nannofossil ooze (5Y 6/1) \\
\hline $44-2,85-87$ & 165.35 & 1.534 & $=$ & $\overline{-}$ & $\overline{-}$ & 20 & 1.68 & - & $1.68^{\mathrm{c}}$ & $40.0^{c}$ & $65.5^{\mathrm{C}}$ & 2.57 & - & & Laminated nannofossil ooze (5Y $6 / 1$ ) \\
\hline $46-2,10-12$ & 172.40 & 1.500 & - & - & - & 20 & 1.65 & - & $1.65^{\mathrm{c}}$ ? & $43.8^{\mathrm{C}}$ ? & $70.6^{\mathrm{C}}$ ? & 2.48 & - & & Mud flow clast: clay (disturbed) (5Y $2 / 1$ ) \\
\hline $47-2,62-64$ & 176.32 & 1.538 & - & $\overline{-}$ & - & 20 & - & - & $1.81^{\mathrm{b}}$ & $35.0^{\mathrm{b}}$ & $61.6^{\mathrm{b}}$ & 2.78 & - & & Mud flow matrix: nannofossil ooze (disturbed) (5G 6/1) \\
\hline $48-1,130-132$ & 178.90 & - & - & - & - & - & - & - & - & - & - & - & 920 & 413 & Layered nannofossil ooze $(5 \mathrm{G} 6 / 1)$ \\
\hline $48-1,135-138$ & 178.95 & 1.520 & - & - & - & 20 & 1.77 & - & $1.73^{\mathrm{c}}$ & $37.6^{\mathrm{c}}$ & $63.5^{\mathrm{c}}$ & 2.63 & - & & Layered nannofossil ooze ( $5 \mathrm{G} 6 / 1)$ \\
\hline
\end{tabular}

a The calculation used the following parameters: $e_{g}, e_{g c}=2.7 \mathrm{~g} / \mathrm{cm}^{3}$ for sediments and $3.0 \mathrm{~g} / \mathrm{cm}$ for basalt; $e f=1.025 \mathrm{~g} / \mathrm{cm}^{3}$, and $e f c=1.128 \mathrm{~g} / \mathrm{cm}^{3}$. There was a linear interpolation between $0.10126 \mathrm{~cm} / \mathrm{g}$ for the $6.61 \mathrm{~cm}$ aluminum standard, and $0.10056 \mathrm{~cm}^{2} / \mathrm{g}$ for the $2.54 \mathrm{~cm}$ aluminum standard, based on the sample's own diameter.

Gravimetric data were done on ship by weight in air and weight in water using Ohaus centrogram balance; these were done by W. Meyers.

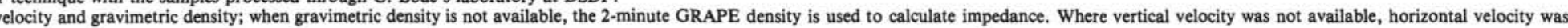
used to calculate impedance. 

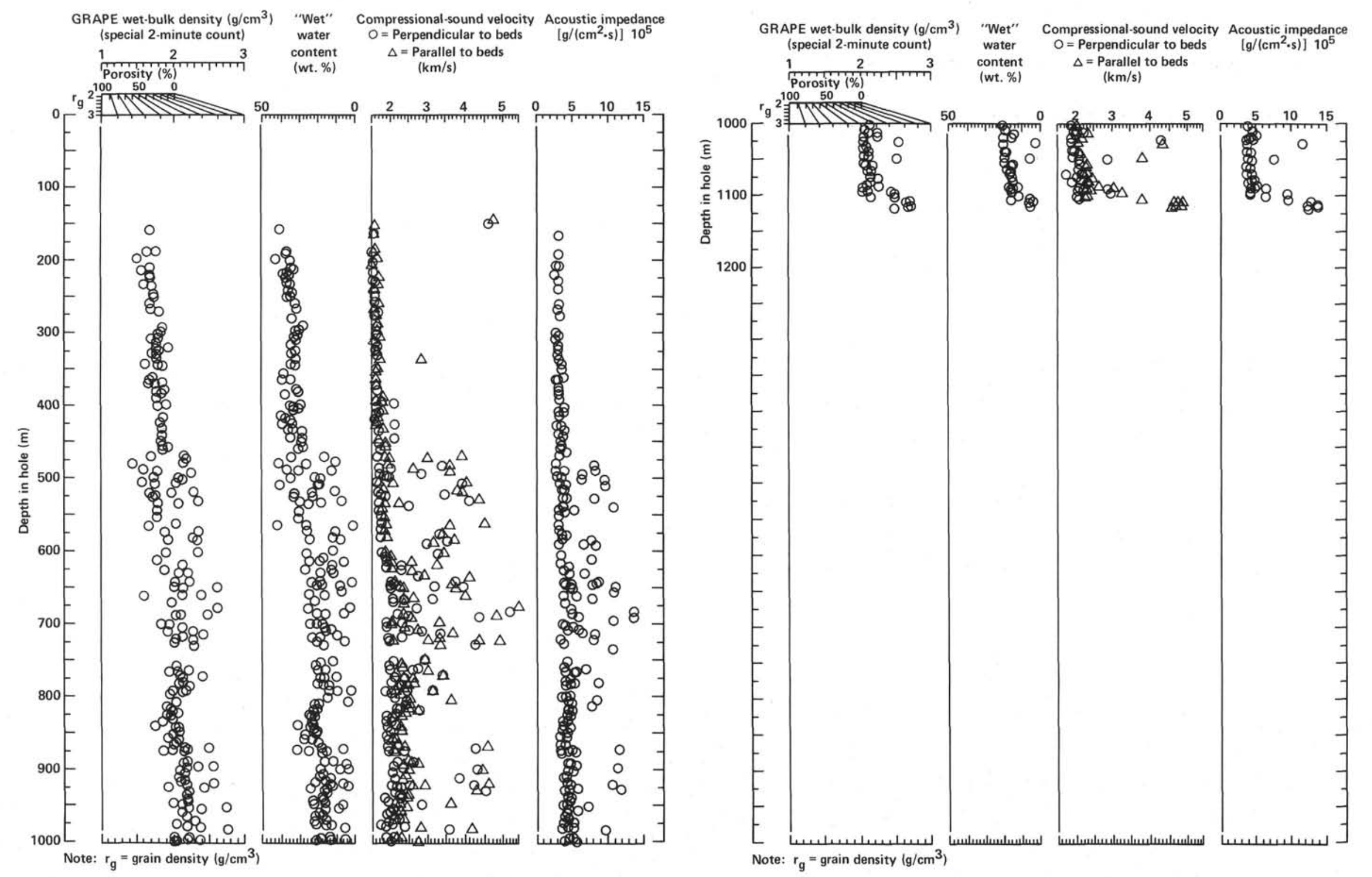

Figure 50. Laboratory velocity and associated laboratory data from Hole 530A, at a condensed vertical scale. The data were taken at laboratory temperatures and pressures. 

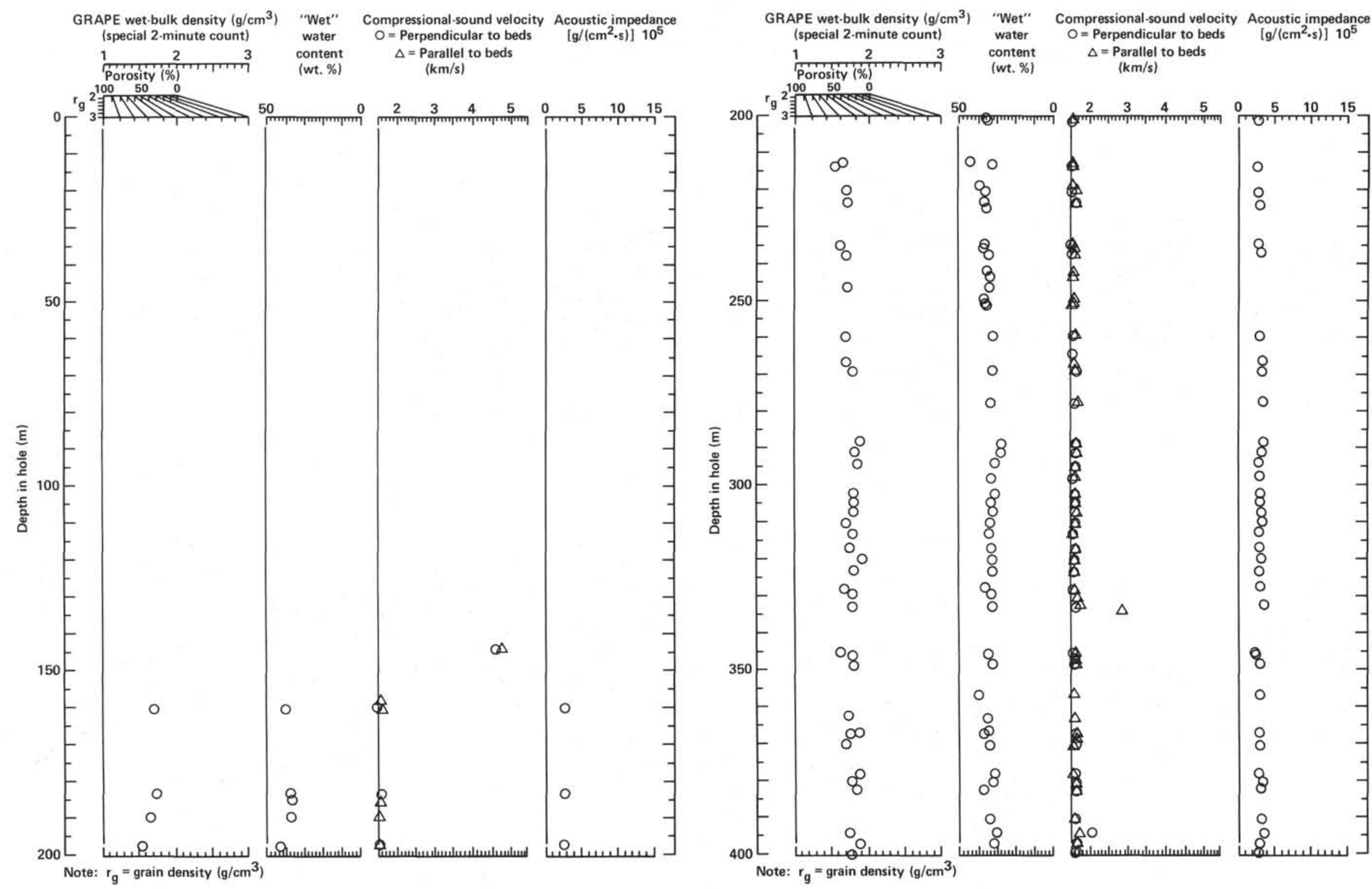

Figure 51. Laboratory velocity and associated laboratory data from Hole 530A, at an expanded vertical scale. The data were taken at laboratory temperatures and pressures. 

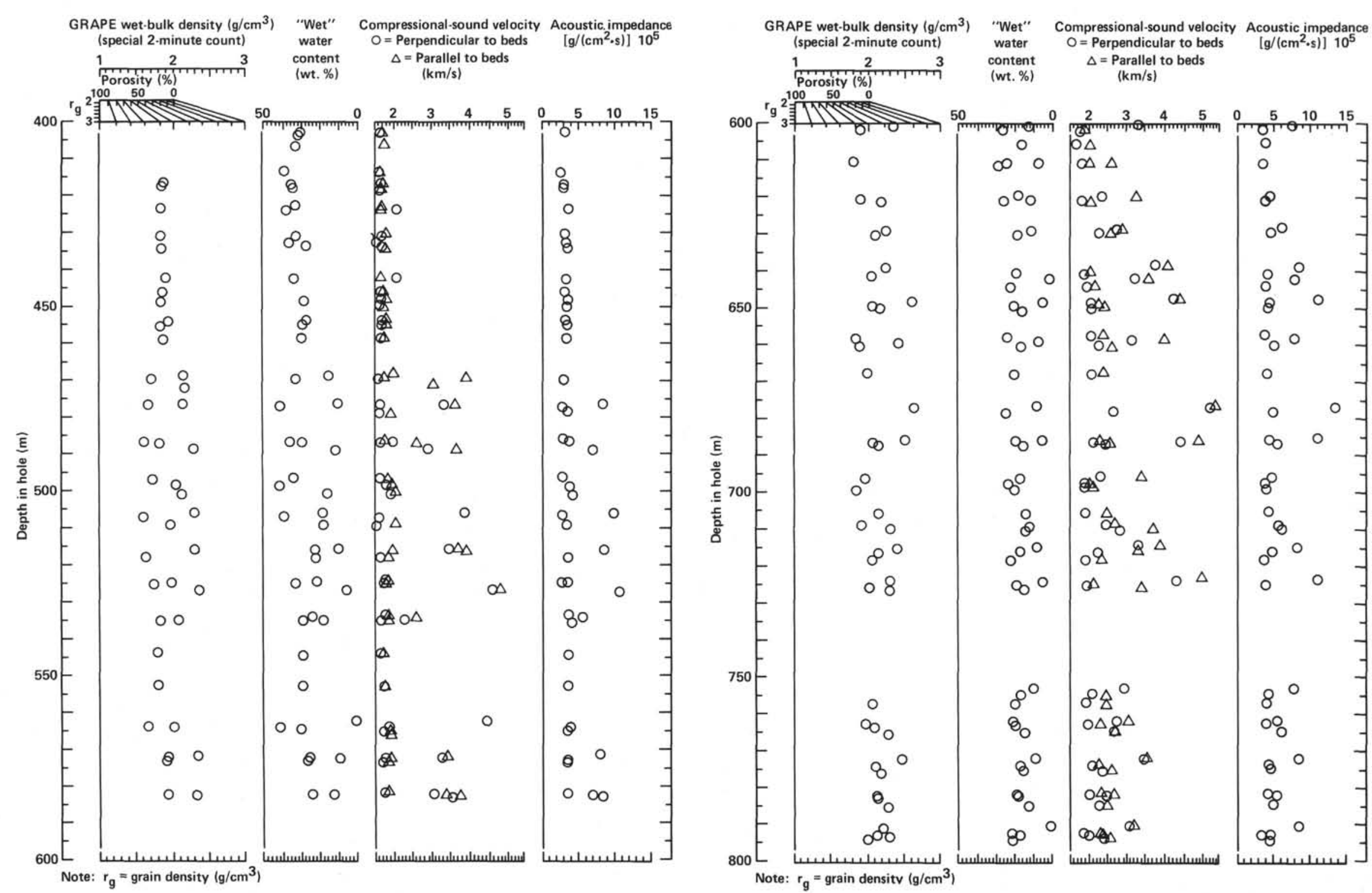

Figure 51. (Continued). 

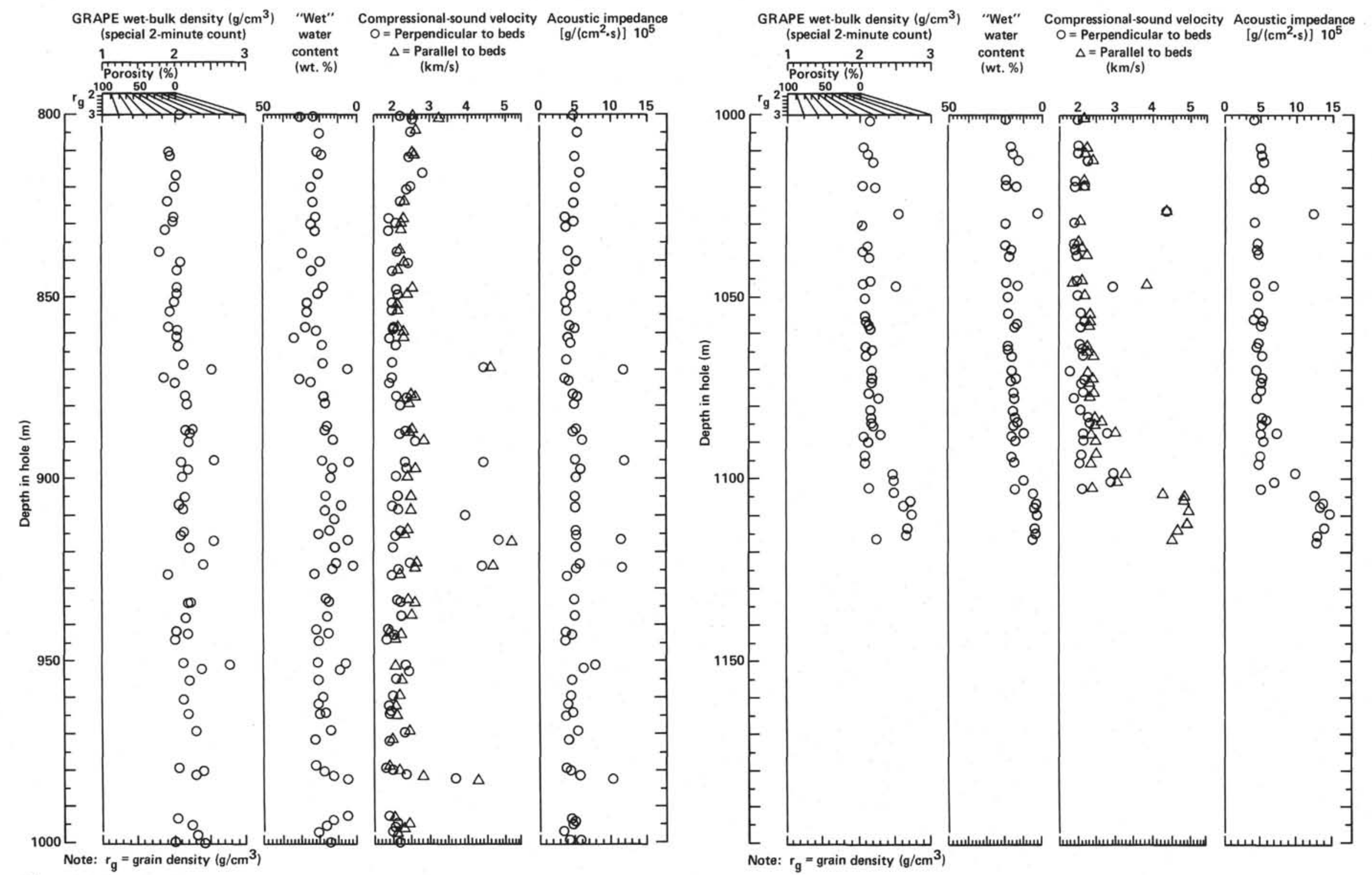

Figure 51. (Continued). 


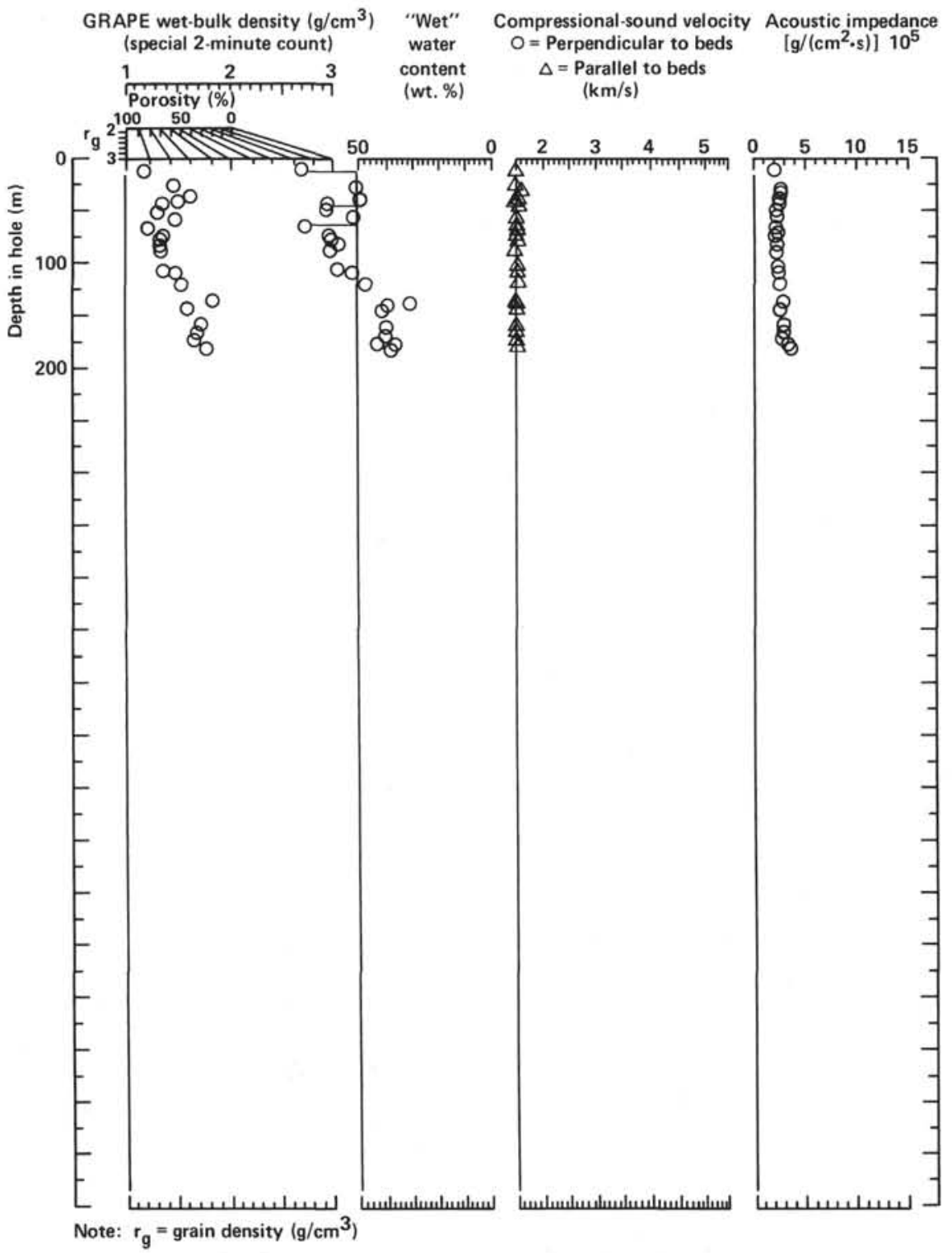

Figure 52. Laboratory velocity and associated laboratory data from Hole 530B, at a condensed vertical scale. The data were taken at laboratory temperatures and pressures.

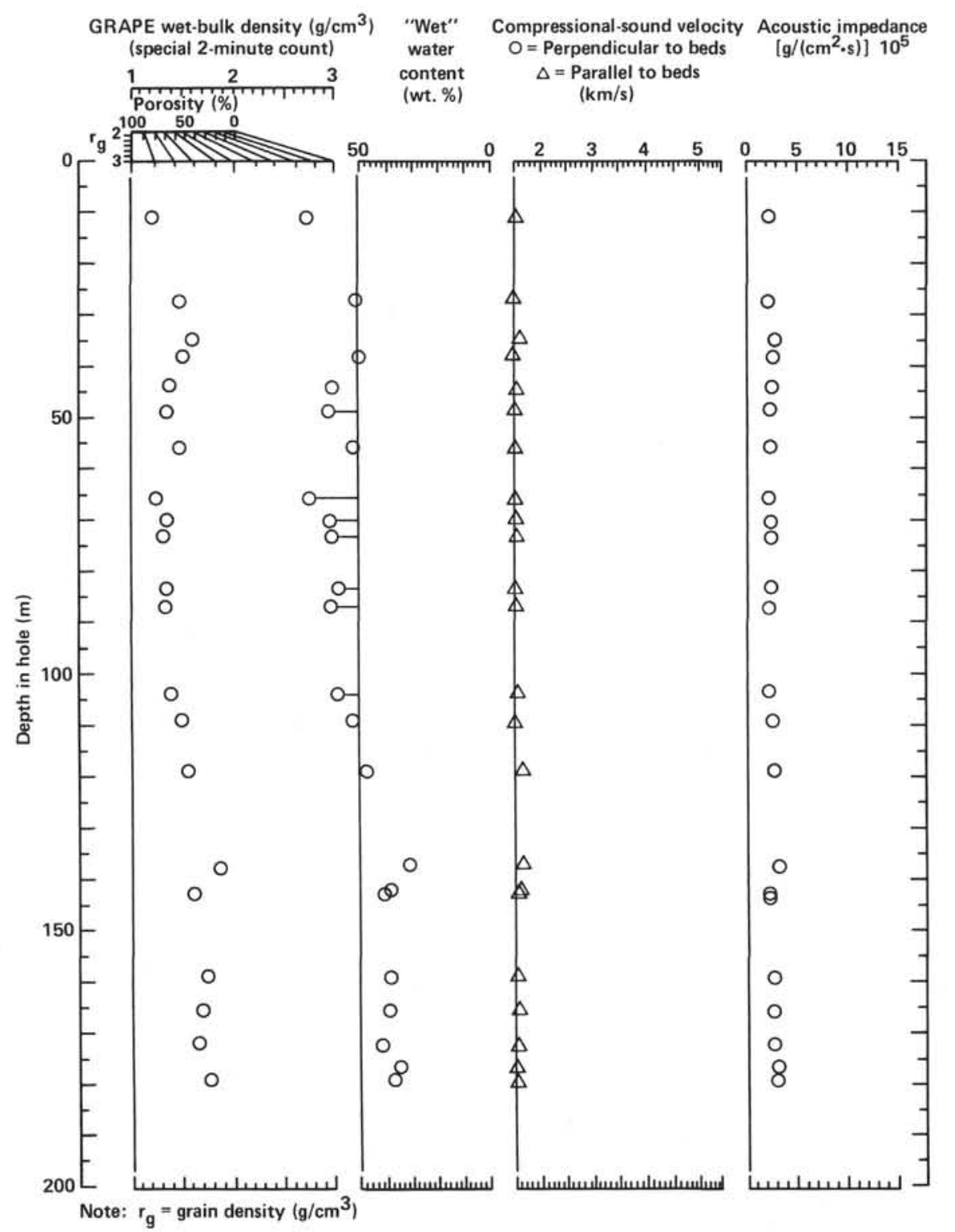

Figure 53. Laboratory velocity and associated laboratory data from Hole 530B, at an expanded vertical scale. The data were taken at laboratory temperatures and pressures. 


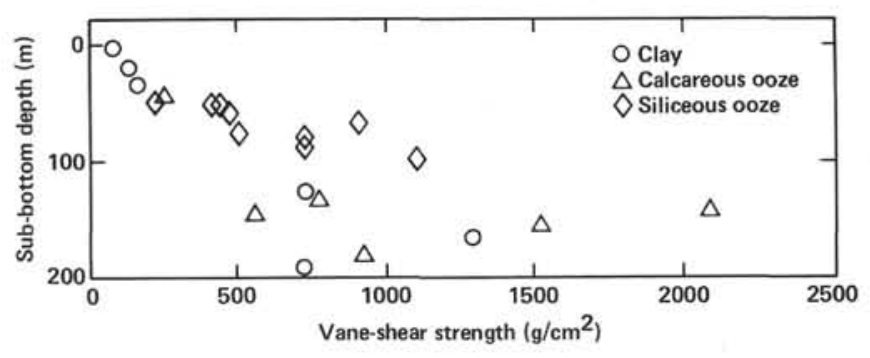

Figure 54. Vane shear strength at Hole 530B.

Table 12. Calculation of in situ velocity from laboratory data, Site 530.

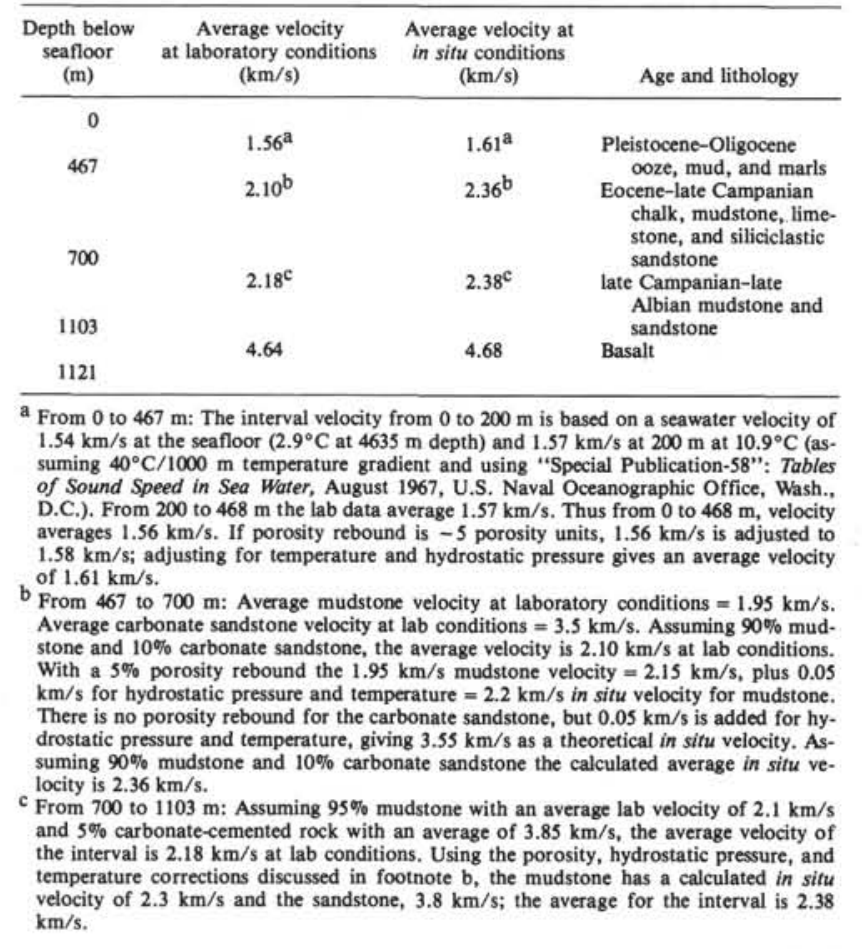

Table 13. Heat-flow, Hole 530A.

\begin{tabular}{lc}
\hline \multicolumn{1}{c}{ Tool movement } & Minutes/seconds \\
\hline Start timer on deck & 00.00 .00 \\
Start down pipe & 9.30 \\
On bottom, 1112 m & 56.00 \\
Turn off pump & 57.00 \\
Stay at bottom, 30 min. & 56.00 to 86.00 \\
Tool at first stop, 700 m & 89.25 \\
Stay at first stop, 20 min. & 89.25 to 109.25 \\
Tool at second stop, 300 m & 115.35 \\
Stay at second stop 20 min. & 115.35 to 135.35 \\
Tool at mudline & 139.25 \\
Stay at mudline, 20 min. & 139.25 to 159.25 \\
Tool on deck & 183.00 \\
Tool off & 194.00 \\
\hline
\end{tabular}

Table 14. Temperature data, Hole 530A (measurement $75-2$, thermistor 6 ).

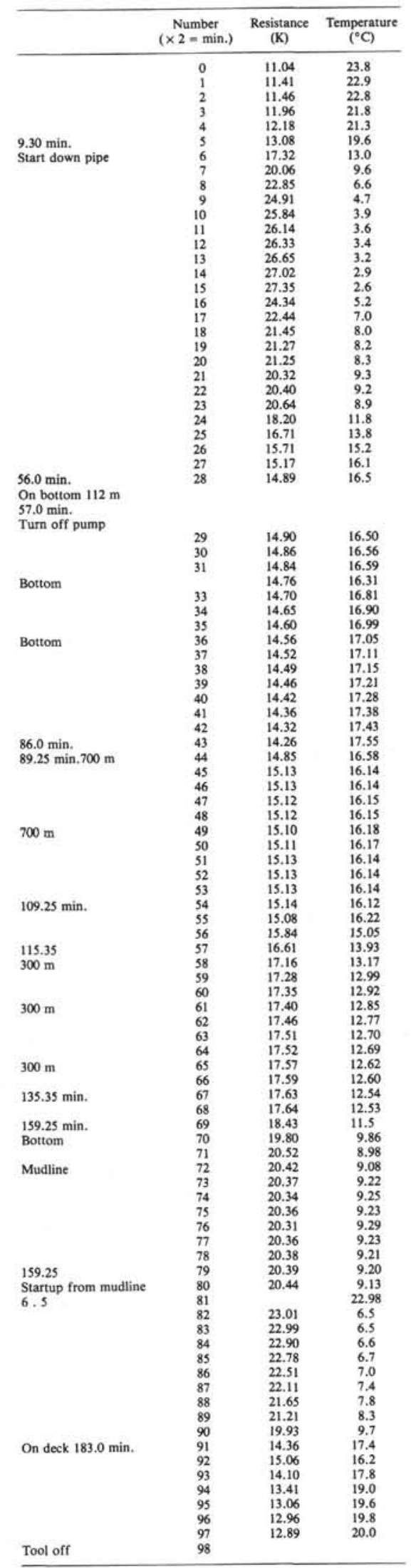




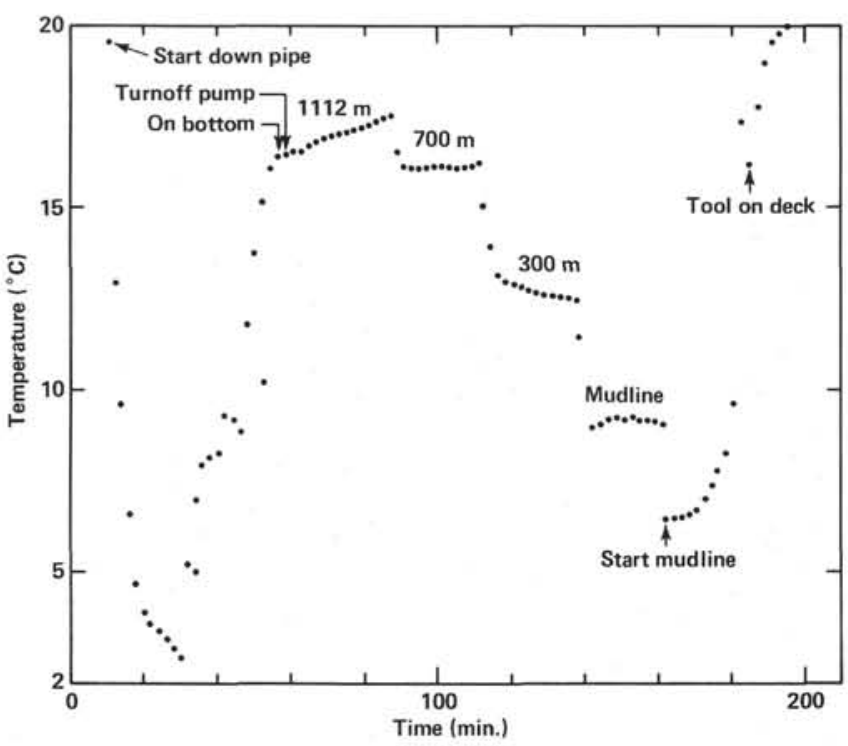

Figure 55. Temperature versus time as the Uyeda Temperature Probe descends and ascends Hole 530A.

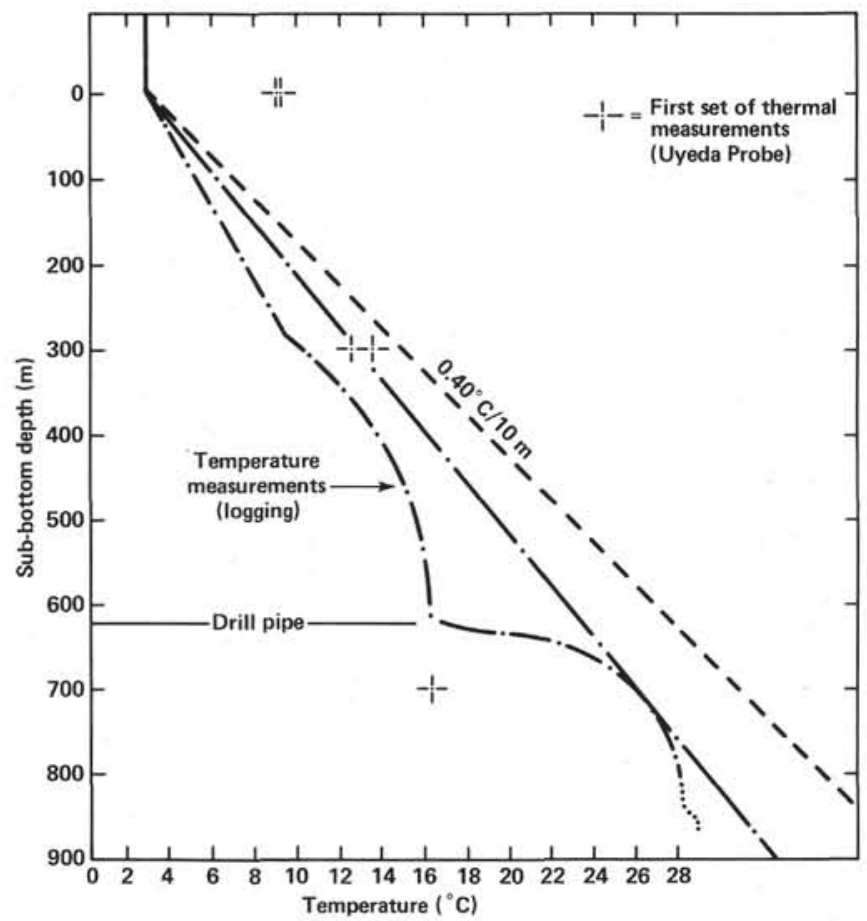

Figure 56. Temperature profile of Hole 530A using results of the Uyeda Temperature Probe and Gearhart-Owen Temperature Log.

\section{Gearhart-Owen Well Logs}

\section{Logging Program in Sedimentary Rock Based on Gearhart-Owen Equipment}

\section{METHODS AND EQUIPMENT}

The logging program was intended to provide data for interpretation of several geophysical and geological problems. First, in situ geophysical measurements, such as sound velocity, density, porosity, electrical conductivity, and temperature, would allow an integrated geophysical section to be determined. This integrated geophysical section would be at in situ conditions, which are very difficult, if not im- possible in some cases, to duplicate from laboratory measurements and would allow interpretation of the results of remote-sensing techniques, such as seismic reflection and refraction data, gravity surveys, electrical resistivity surveys, and surface geothermal data. Second, the density (gamma-ray backscatter) and porosity (neutron) logging data provide an index to other physical parameters and allow the bulk mineral density (grain or matrix density) of the formation to be estimated statistically; with the aid of sound velocity these data permit identification of certain sedimentary strata, some "potential ore deposits," gas, and some igneous and metamorphic rocks. Third, natural gamma radiation will generally distinguish shale (high count) from nonshale sediments. In basalt, the natural gamma radiation may be related to the $\mathrm{K}_{2} \mathrm{O}$ content or to the presence of some alteration minerals. Fourth, if the porosity derived from the density log (assuming a 2.7 $\mathrm{g} / \mathrm{cm}^{3}$ grain density) does not match the porosity from the electric logs, the anomalies may be the result of (1) the presence of minerals of extremely high or low grain density (significantly different from $\mathbf{2 . 7}$ $\left.\mathrm{g} / \mathrm{cm}^{3}\right),(2)$ anomalous interstitial water salinities, (3) the presence of metallic minerals that are electrical conductors, (4) anomalous temperatures, or (5) hydrocarbons. The two continuous temperature logging runs are to assist interpretation of the electric logs and to provide more accurate estimation of in situ temperature. Even with continuous coring, the entire interval cored is never recovered, and logging should provide data in the missing gaps, so that a more complete geologic section, not biased by core recovery, is available.

The following suite of Gearhart-Owen logging tools were attempted in Hole 530A:

1) Gamma Ray-Neutron (thermal) Single Detector, unpositioned, semi-qualitative, $3.65 \mathrm{~cm}$ in diameter. This tool was run in the pipe and bottom-hole assembly from 0 to $1050 \mathrm{~m}$ in Hole 530A. (Successful)

2) Temperature Log (thermocouple), $3.65 \mathrm{~cm}$ in diameter (absolute and differential temperature, $\pm 0.05^{\circ} \mathrm{C}$ ); plus Density Log (Borehole Compensated) (CDL), $6.99 \mathrm{~cm}$ in diameter, Caliper, and Gamma-Ray (GR) Log. These tools could not be lowered past a bridge in the hole. (Unsuccessful)

3) Sonic Log (Borehole Compensated System) $9.21 \mathrm{~cm}$ diameter, Caliper, and GR Log. The tool was run from 628 to $940 \mathrm{~m}$ in the bare hole. (Successful)

4) Induction Log and 16-in. (40 cm) Normal Resistivity, $9.21 \mathrm{~cm}$ in diameter, and Gr. Log. The tool was run from 628 to $855 \mathrm{~m}$ in the bare hole. (Successful)

5) Deep Laterolog (LL-3), (poor data), $8.9 \mathrm{~cm}$ diameter, and Neutron Log (thermal neutron, single detector and unpositioned, therefore, semi-qualitative), Gr. Log. The tool was run from 628 to $855 \mathrm{~m}$ in the bare hole. (Partially successful)

6) Temperature Log. The tool was run from 628 to $855 \mathrm{~m}$ in the bare hole; and from 0 to $628 \mathrm{~m}$ within the pipe and bottom-hole assembly, with cool water being circulated. This tool measured temperature on the way down. (Successful)

\section{Gamma-Ray Tool}

The Gamma-Ray Tool detects natural gamma radiation $(0.0$ to $3.0 \mathrm{MeV})$ emitted primarily from potassium, thorium, and uranium contained in the sediment and rock. Commonly, carbonates and sandstones (without potassium feldspar) emit very little radiation compared to clayey and shaley sediments because the clay minerals have varying ion-exchange capacities which may absorb varying amounts of radioactive isotopes. Natural gamma-ray emitters include organic-rich black shales, hydrothermal deposits, authigenic minerals deposited during slow sedimentation rates, biotite, K-feldspars, and glauconite. Problems of gamma-ray interpretation and data characteristics, such as time constants and logging speed, etc. have been discussed by Lynch (1962) and Kokesh (1951). Gamma-ray data collected through the pipe contain these artifacts: (1) all signals are attenuated (low) by the pipe, and pipe connections; (2) drill collars, which are very thick at the bottom of the string, atten- 
uate the signals even more than the thinner drill pipe; and (3) open bumper subs may act as windows permitting relatively high gamma counts. Gamma radiation is also affected by the borehole diameter, which can be corrected by using Gearhart-Owen International (GOI) charts.

\section{Sonic Tool}

The Sound-Velocity (compressional) Log is a "compensated system" with two sets of receivers $61 \mathrm{~cm}$ apart; the velocity is measured both up and down the hole so that the tool cancels out most but not all of the effect of variations in borehole diameter. Where sediments and rock of differing velocities are differentially washed out, anomalous velocities may be recorded. General principles of the compensated system have been described by Kokesh et al. (1965) and Morris et al. (1963). "Noises" are high-velocity artifacts and "cycle skipping"' is a lowvelocity artifact; these have been discussed by Lynch (1962). The tool has a $60 \mathrm{~cm}$ vertical resolution and a very shallow $(5-10 \mathrm{~cm})$ depth of investigation. Lowvelocity and borehole-diameter limitations, derived from equations in Lynch (1962), are given in Figure 57.

\section{Density Tool}

The Density Tool is a borehole compensated system. The tool emits gamma rays which are detected by two receivers. The source and detectors are held against the side of the hole, and a caliper measures hole diameter. This system automatically corrects for borehole diameter, mudcake thickness, and density. The technique assumes that all materials except water have the gammaray attenuation coefficient of quartz. The tools are empirically calibrated for wet-bulk density in fresh water and limestone matrix. The technique, interpretation characteristics, assumptions, and precautions have been discussed by Wahl et al. (1964), and Sherman and Locke (1975). Discussions of general principles have been presented by Baker (1957) and Lynch (1962). Resolution

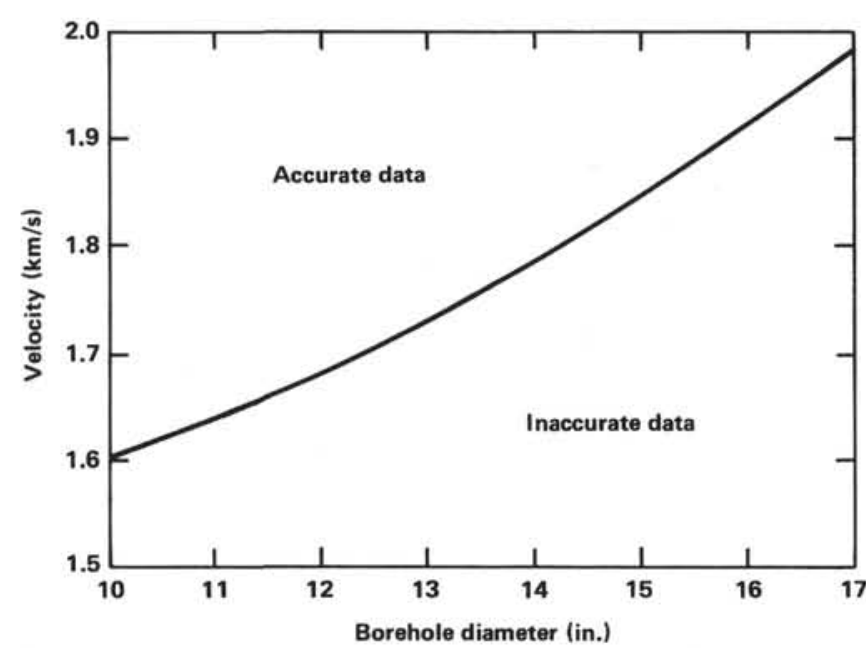

Figure 57. Diagram showing the minimum possible velocity that can be accurately measured for a given hole diameter. Curve derived from Lynch (1962). and penetration are about $30 \mathrm{~cm}$ depending on formation density, logging speed, and time constant.

\section{Neutron Tool}

The Neutron Tool has a single detector which is unpositioned in the hole, so that this is a semi-qualitative log. It emits thermal neutrons which are mostly (but not completely-e.g., Cl) attenuated by collisions with $\mathrm{H}^{+}$ protons, which have the same mass as a neutron, in the pore water. With the proper correction for formation type and hole diameter, the tool can be used qualitatively to infer porosity. Principal assumptions and precautions in the use of the tool have been discussed by Lynch (1962). Resolution and penetration are about 53 $\mathrm{cm}$, depending on logging speed, porosity, type of sediment or rock, and time constant.

\section{Electric Logging Tools}

The Induction $\mathrm{Log}$ has a $100 \mathrm{~cm}$ resolution and penetration of $\sim 254 \mathrm{~cm}$, but its data are not precisely quantitative where the hole is washed out more than 13 in. It is designed to measure electrical conductivity in highporosity sediment and rock having resistivities less than $100 \mathrm{ohm}-\mathrm{m}$. The 16-Inch Normal Resistivity Tool has an approximate $40.6 \mathrm{~cm}$ (16-in.) resolution and penetration and is normally used to indicate whether invasion of fresh drilling water has occurred; however, seawatermud was the drilling fluid here. The Deep-Laterolog is a focused electrical resistivity tool designed with a $15 \mathrm{~cm}$ vertical resolution and $254 \mathrm{~cm}$ penetration. It is designed to measure electrical resistivity of hard rocks such as basalt, with greater than 100 ohm-m resistivity. All of these electrical tools are affected by the resistivity of the formations and geometry of the borehole; caliper data from the Density Log must be used to correct the electric logs to true formation resistivities by using GOI charts. Lynch (1962), Doll (1949, 1951), Moran and Kunz (1962), and Keller and Frischknecht (1966) have presented detailed discussions of these techniques.

\section{Miscellaneous}

The Gamma-Ray (GR) Tool is included with each logging run for stratigraphic control. It allows the logs made on different logging runs to be related to the formation and to be correlated because the depths indicated by the tools are neither precise nor accurate, which is in part a result of the ship's motions.

Before interpreting any of the logs, the GearhartOwen manual should be consulted to determine whether data corrections are necessary and how to make them.

\section{Results-Gearhart-Owen Well Logs}

Logs were attempted in Hole 530A in the following order:

1) There was a successful attempt through the drill string with the Gamma Ray-Neutron Tool from 0 to $1050 \mathrm{~m}$ below the seafloor (Figs. 58 and 59).

2) There were two unsuccessful attempts to enter the bare hole from the end of the drill string, at $200 \mathrm{~m}$ and at $300 \mathrm{~m}$, with the Density, Temperature, Caliper, and Gamma-Ray suites. At $300 \mathrm{~m}$ the logging suite was 


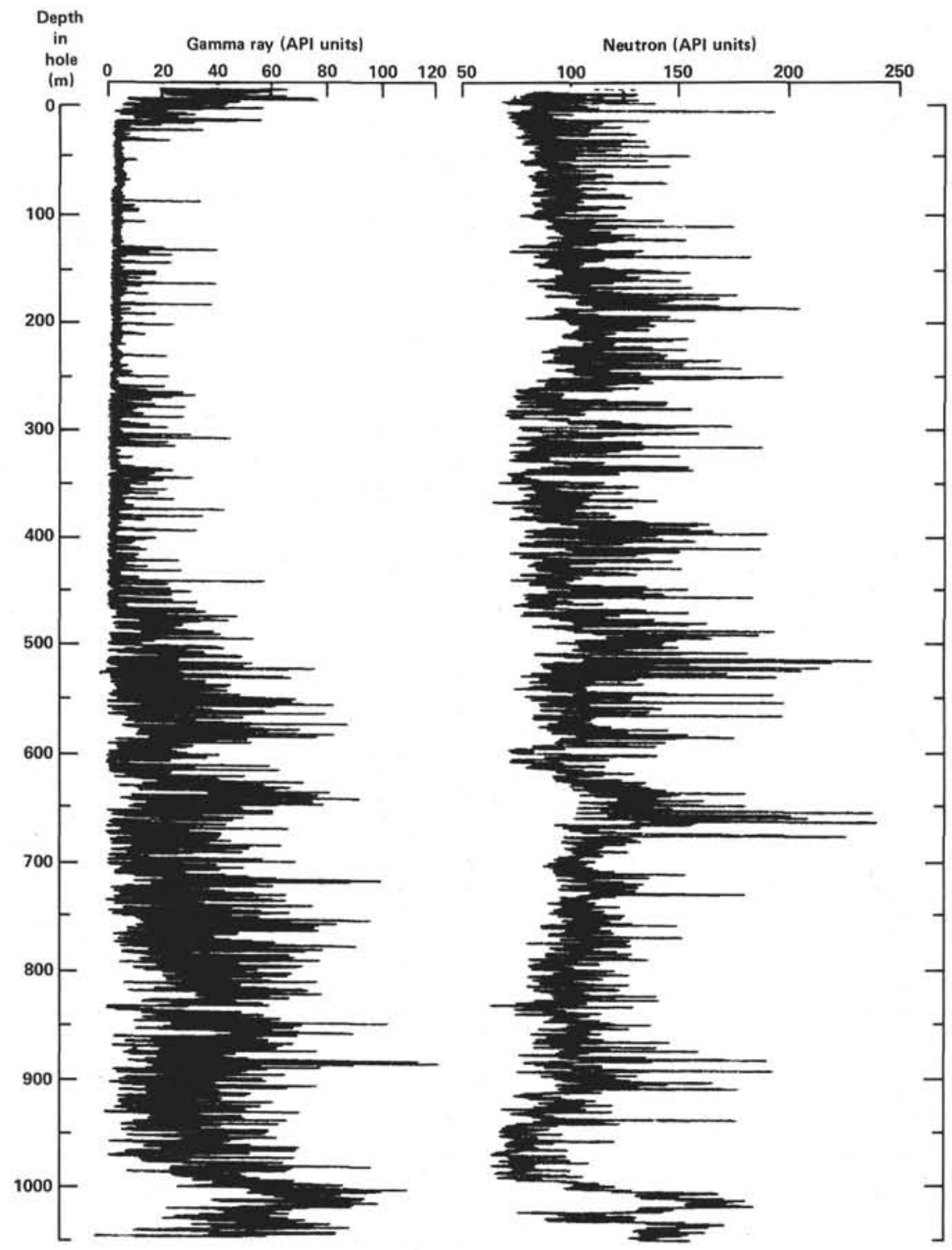

Figure 58. Neutron-Gamma Ray Tools, Hole 530A. These tools were collecting data through a pipe and bottom-hole assembly from 0 to $1050 \mathrm{~m}$ Condensed vertical scale.

caught, and we lost the Cs source from the Density Log; no spare source was available, precluding further density logging on this leg.

3) Another attempt to enter the bare hole was made at $628 \mathrm{~m}$, where the sides of the hole were more firm. The pipe was lowered and raised, while circulating, to clean the hole. We placed the end of the drill pipe at 628 $\mathrm{m}$ and successfully ran the following suite of tools in the bare hole from $\sim 630$ to $\sim 900 \mathrm{~m}$ :

a. Sonic Log, Caliper, and Gamma Ray (Figs. 60, 61).

b. Induction Log, 16-Inch Normal Resistivity, and Gamma Ray (Figs. 60, 61).

c. Deep-Laterolog (poor data, not quantitative), Neutron Log, and Gamma Ray Log (Figs. 62, 63).

d. Temperature Log (Figs. 62, 63).

We obtained only one temperature log; therefore, calculation of in situ temperature by the Keller et al. (1979) method was not possible.

\section{Interpretation of Neutron-Gamma Ray Data from 0-1050 $\mathrm{m}$ through Drill String (Figs. 59, 60)}

Larry Axline (a Gearhart-Owen logging engineer) was not certain whether or not the Gamma-Ray Tool was working properly because the gamma-ray response above the seafloor appeared to be anomalously high.

The Neutron-Gamma Ray Log data were measured through the drill string as follows: (1) from 0-991 m, through the 7 -in. $(17.8 \mathrm{~cm})$ diameter drill pipe; (2) from 991-1050 m, through 7-10 in. (17.8-25.4 cm) diameter drill collars, with diameter increasing gradually downward. Bumper sub openings were located at 1035 and $1045 \mathrm{~m}$

The pipe causes attenuation of the GR counts and may create anomalously low porosity indications on the Neutron Log. The pipe is joined together at $\sim 9.5 \mathrm{~m}$ intervals, and these thicker joints cause decreasing GR 


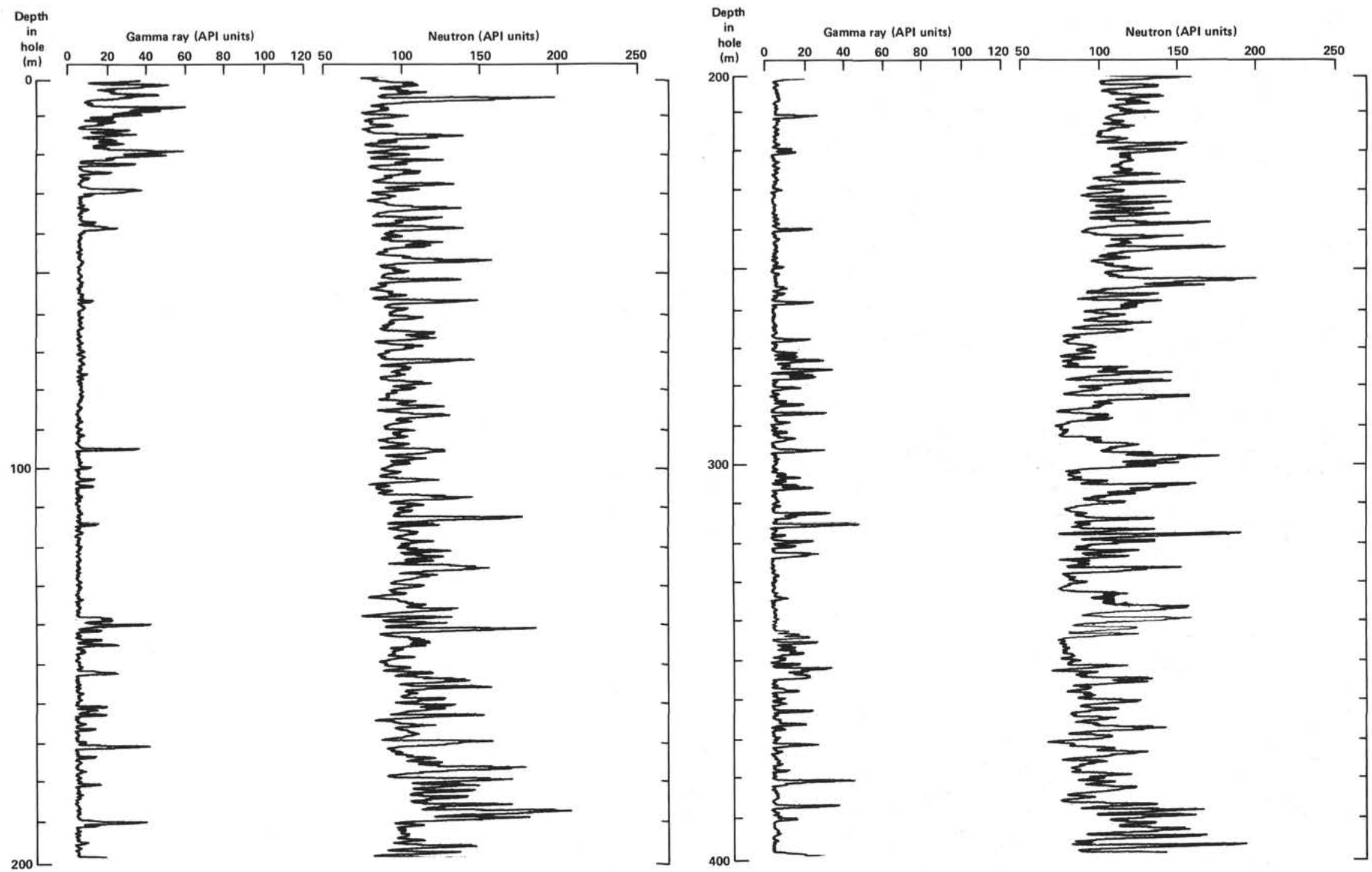

Figure 59. Gamma Ray and Neutron Tools (single detector, thus only qualitative) unpositioned in Hole 530A. These tools were collecting data through a pipe and bottom-hole assembly from 0 to $1050 \mathrm{~m}$. Expanded vertical scale. 

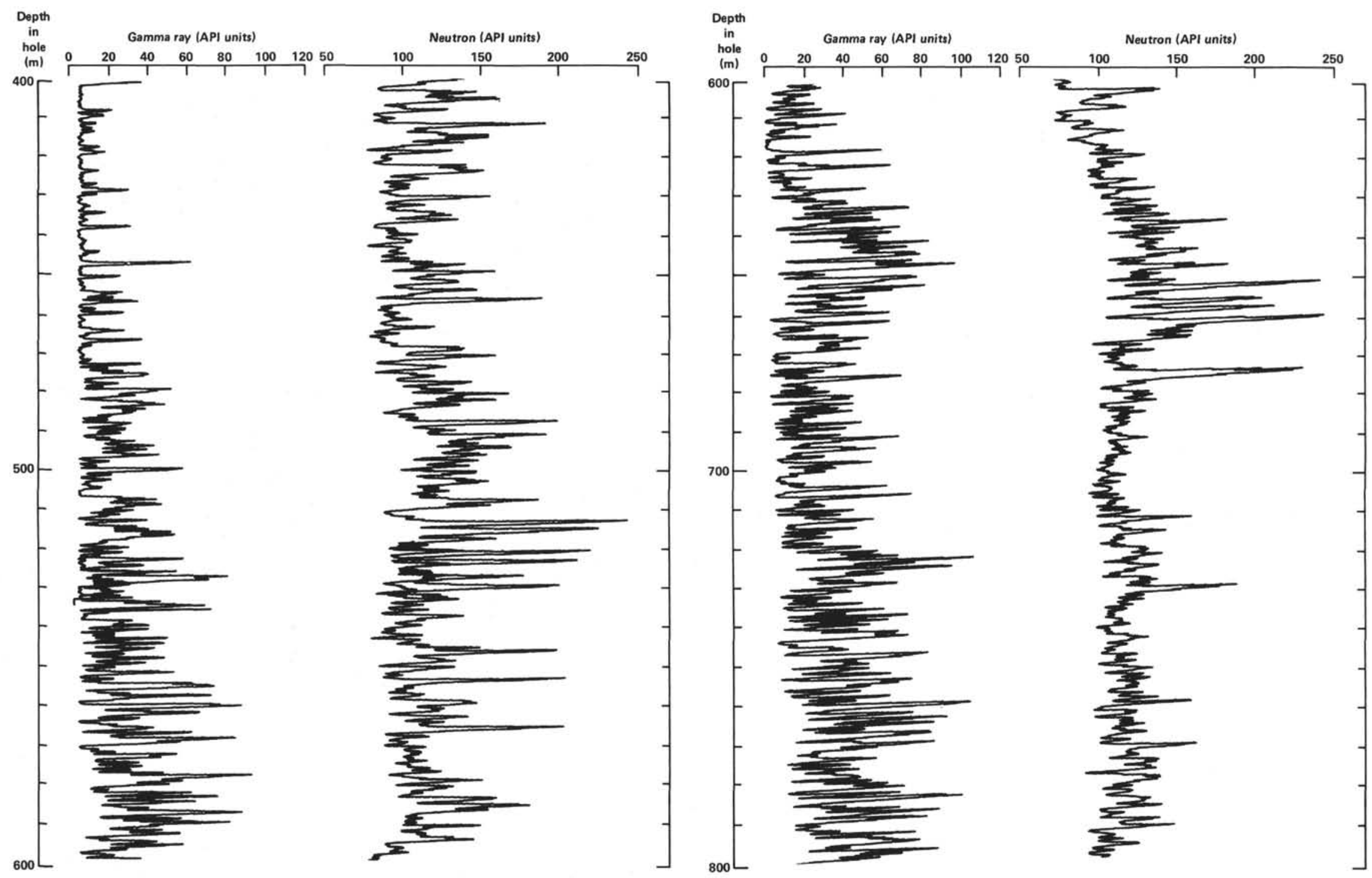

Figure 59. (Continued). 

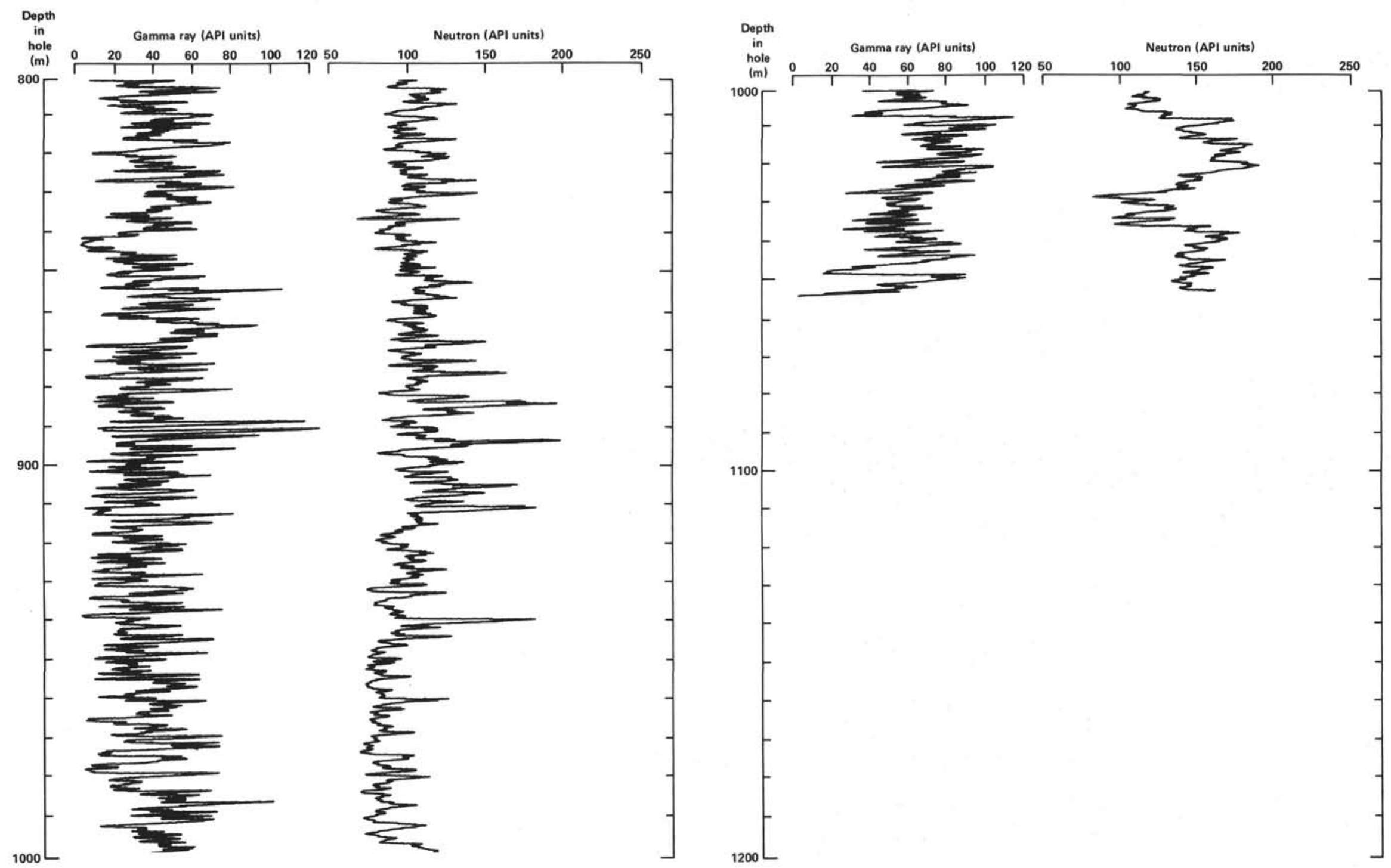

Figure 59. (Continued). 


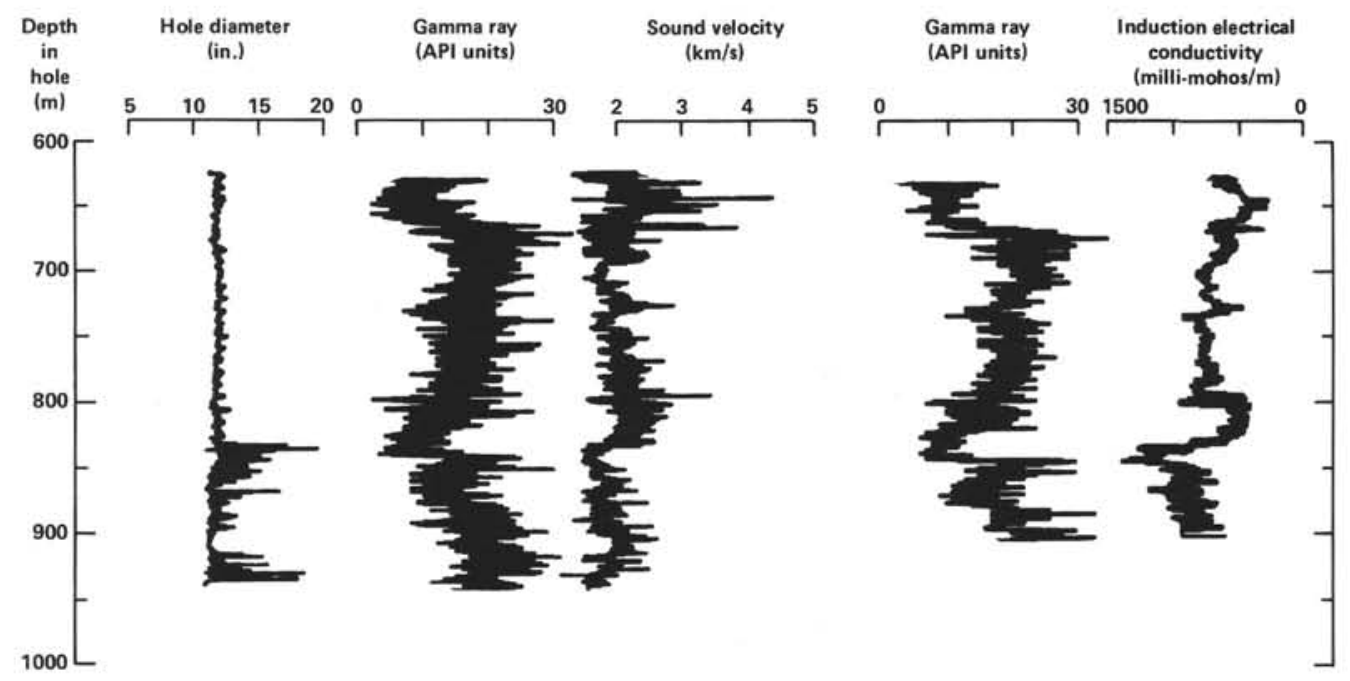

Figure 60. Hole diameter from Caliper Tool with Sonic Tool; gamma-ray with Sonic Tool; compressional sound velocity from Sonic Tool; gamma ray with Induction Tool; and electrical conductivity from the Induction Logging Tool, Hole 530A. See Figure 57 to determine which velocity values are accurate. The Sonic Tool was centered in the hole. Vertical scale is condensed.

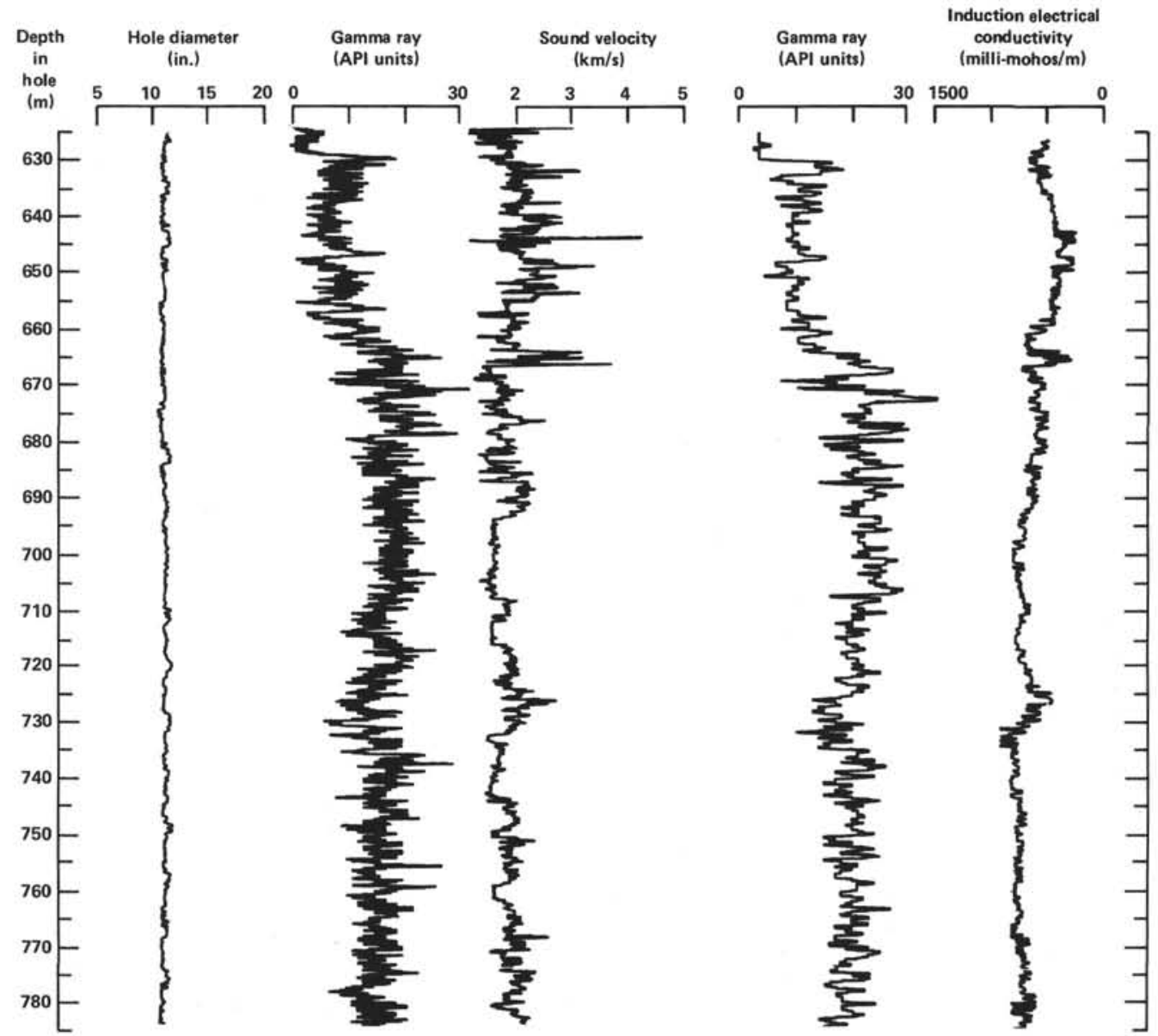

Figure 61. Hole diameter from Caliper Tool with Sonic Tool; gamma ray from Sonic Tool; compressional sound velocity from Sonic Logging Tool; gamma ray from Induction Tool; and electrical conductivity from the Induction Logging Tool, Hole 530A. See Figure 57 to determine which velocity values are accurate. The Sonic Tool was centered in the hole. Vertical scale is expanded. 


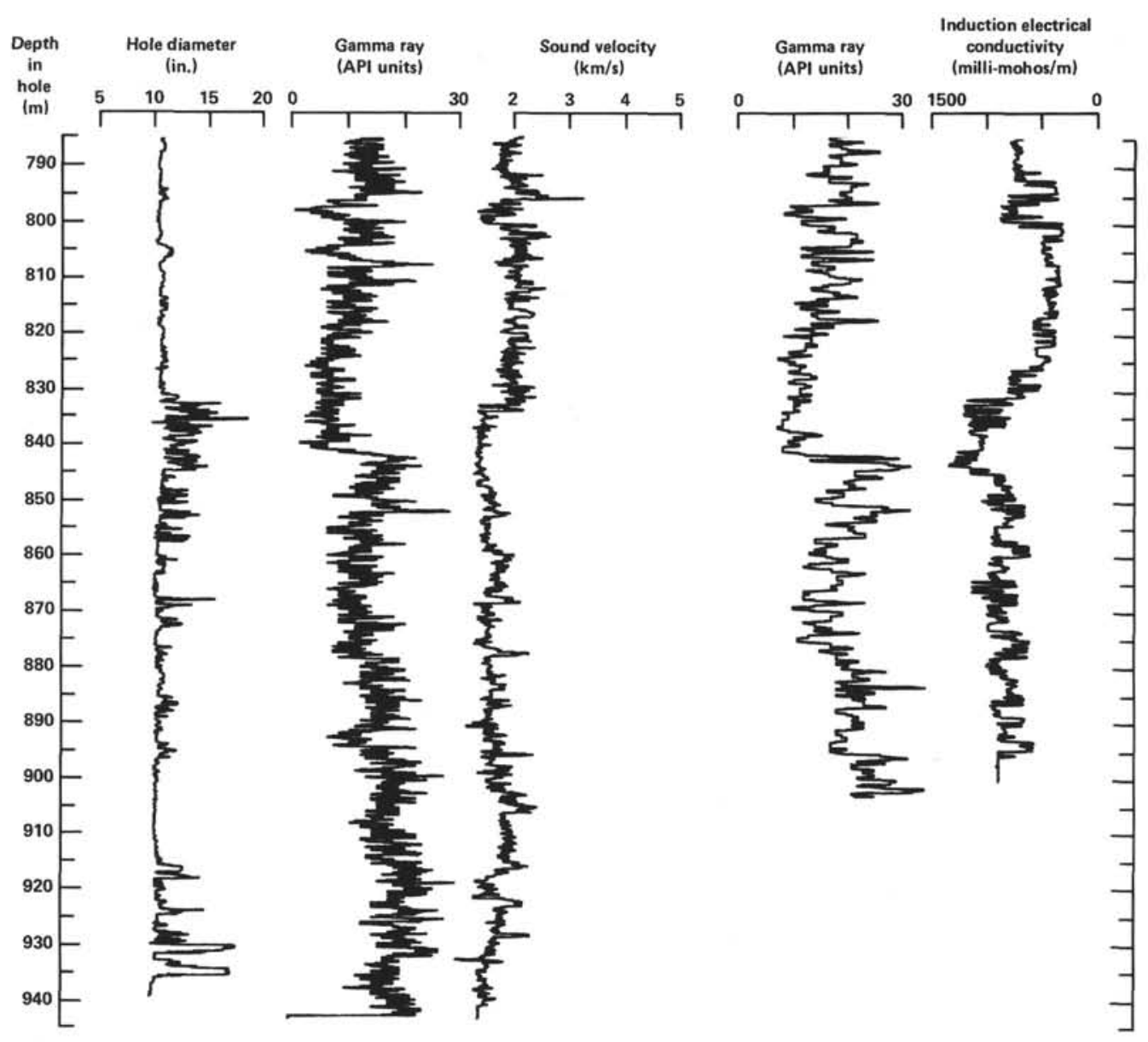

Figure 61. (Continued).

spikes and decreasing neutron porosity spikes in the logging data.

The thicker drill collars attenuate the GR and Neutron logs more than does the seven-in. pipe. However, the thin walls of the bumper subs cause relatively high counts in the low attenuated background data of the drill collars. The following interpretation of these data assumes that the hole is not washed out.

The Neutron-Gamma Ray Log has a high GR count from 0 to $25 \mathrm{~m}$ below seafloor. However, these data could also be anomalous if the tool was not working correctly, since the GR count is similar above the seafloor. The soft upper portion of this hole is probably washed out, because of the drill pipe's being moved back and forth (horizontally) during drilling. If the hole is washed out, it may also be filled in part with radioactive drill-cuttings while drilling is done deeper in the hole. It is also possible that the high GR counts represent a formation with high clay content or one with a large number of thin clayey beds, and that either the clay content or the number of thin clayey beds irregularly decrease down to $25 \mathrm{~m}$; however, this is not what is found in the cores.

From 25 to $477 \mathrm{~m}$, the GR count is very low and should indicate nonclayey sediments. This is correct for the upper part of the section, but below $277 \mathrm{~m}$ the sedi- ment is a red and green mud virtually devoid of $\mathrm{CaCO}_{3}$. High GR spikes, probably representing thin clayey beds ( $<2 \mathrm{~m}$ thick), occur in greater number with increasing depth. Porosity appears to decrease very slightly, assuming the borehole is not washed out.

From 477 to $590 \mathrm{~m}$, the gamma radiation increases irregularly with increasing depth. This should indicate a higher clay content or increasing frequency of thin clayey beds, but the sediments of this interval are actually more carbonate rich. The Neutron Log suggests an overall porosity lower than that above $477 \mathrm{~m}$, assuming uniform borehole conditions. The GR and neutron data suggest that there are some beds of low porosity and low clay content, and many beds of higher porosity and higher clay content.

From 590 to $650 \mathrm{~m}$, the GR decreases irregularly, with a corresponding increase in porosity with depth, and then increases, with a corresponding decrease in porosity. This suggests first decreasing then increasing clay content or that the number of thin clay beds decrease then increase with increasing depth, but these do not correspond to the observed changes in lithology.

From 650 to $675 \mathrm{~m}$, the Neutron-Gamma Ray Log data indicate beds of distinctive low porosity 2-3 meters thick and low GR counts interlayered with others having high counts. The levels with higher counts may cor- 


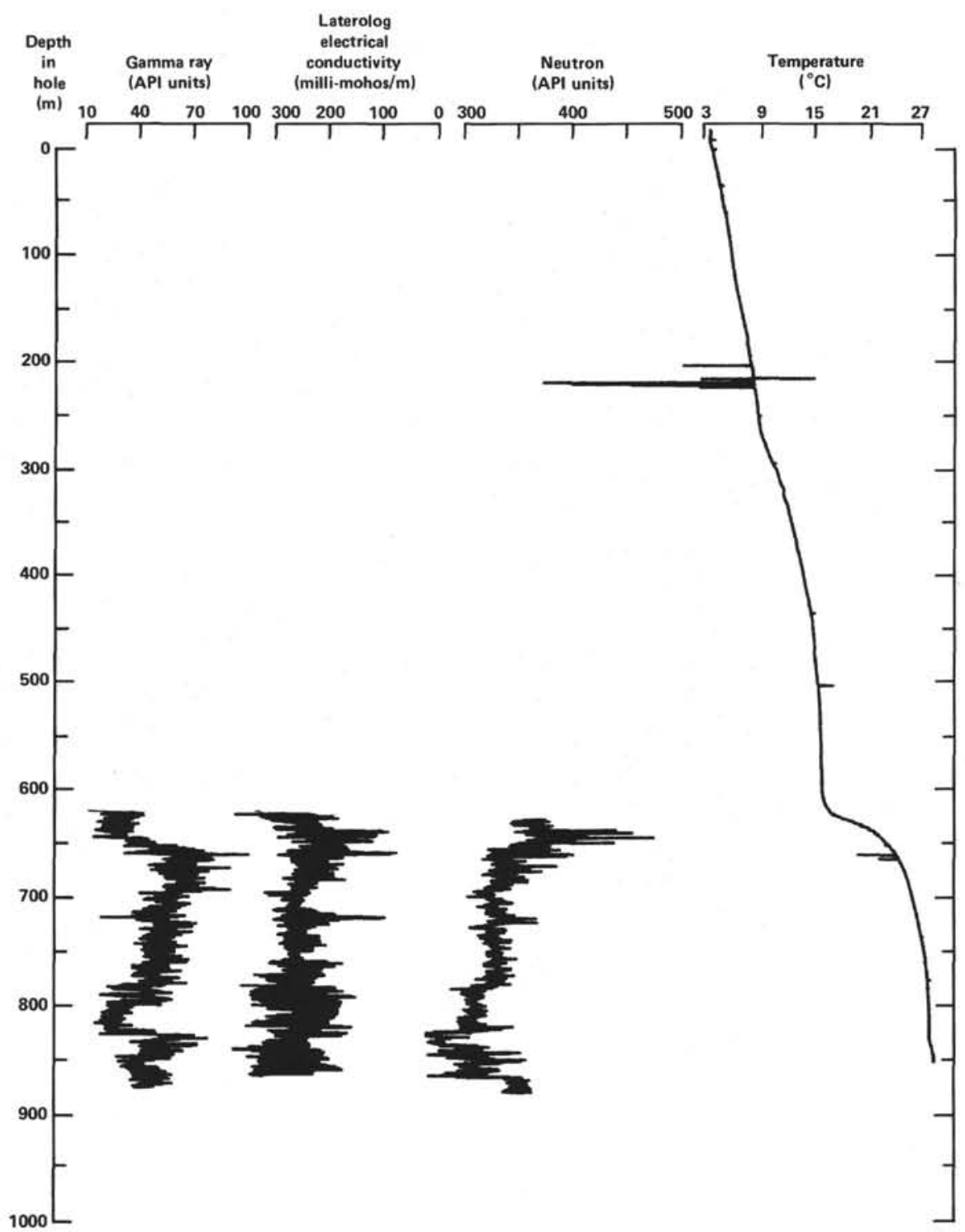

Figure 62. Gamma ray-Neutron Log run with Laterolog tool. The Laterolog tool was not working properly, thus its electrical conductivity values are too small. The Neutron Log is a single unpositioned detector, thus providing only qualitative information. The Temperature Log was run within the drill pipe and bottom-hole assembly from 0 to $625 \mathrm{~m}$; cool water had been circulating through the pipe to pump the Temperature Tool down. The negative temperature spikes probably represent places where the Temperature Tool was caught in the hole and then fell more rapidly. The vertical scale is condensed.

respond to the siliciclastic sandstones containing feldspar, glauconite, and heavy minerals which are characteristic of lithologic Subunit $5 \mathrm{~b}$.

From 675 to $1000 \mathrm{~m}$, the formation appears to be of medium to high GR intensity and porosity, corresponding to the observed high clay content. There are a few $(5 \%)$ low porosity and low clay content (low GR intensity) beds. At $717,552,854,886$, and $891 \mathrm{~m}$, and perhaps at 1004-1025 m, extremely high GR counts suggest thin claystone beds or organic-rich black-shale beds as indicated by core recovery. In general, porosity from 927 to $975 \mathrm{~m}$ shows a slight increase.

From 1000 to $1050 \mathrm{~m}$, there is a significant decrease in porosity and an increase in GR intensity. There is an apparent higher porosity zone from $1035-1045 \mathrm{~m}$ with a slightly lower GR intensity, but this is an artifact of the presence of the bottom-hole assembly, which causes an anomalously low GR count. The high GR intensity is unusual and could be produced by the abundant black shales, but it may also be related to the thin-walled bumper subs.

Time-stratigraphic units cannot be clearly identified from the neutron-Gamma Ray Log. The boundaries of the lithologic units are recognizable only as subtle changes in the GR intensity and in all cases would be difficult to pick by logging data alone:

1) The boundary between siliceous ooze of lithologic Unit 1 above and nannofossil marl of lithologic Unit 2 


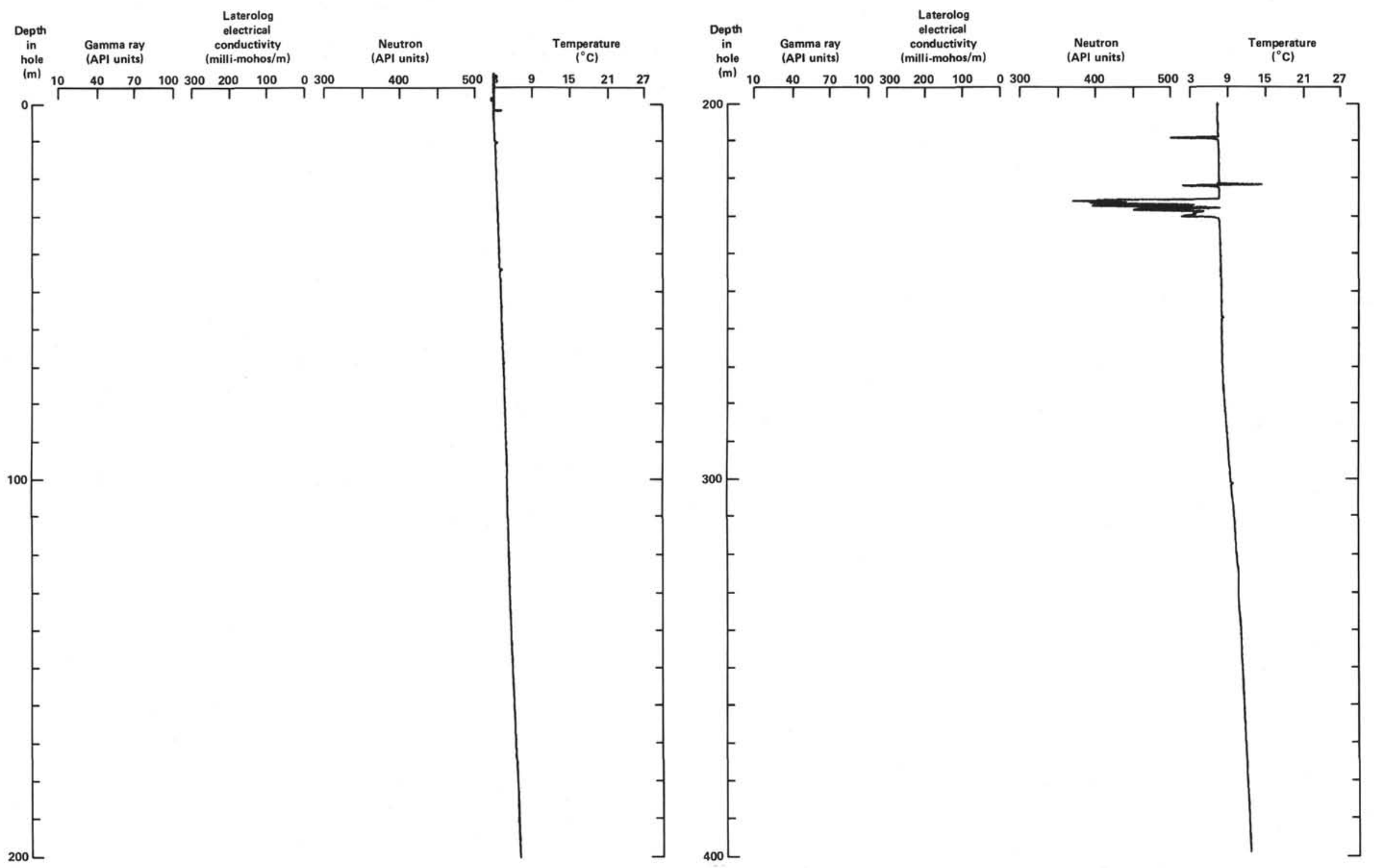

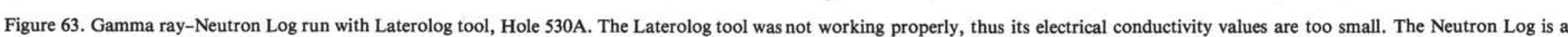
single unpositioned detector, thus providing only qualitative information. The Temperature Log was run within the drill pipe and bottom-hole assembly from 0 to $625 \mathrm{~m}$; cool water had been circulating through the pipe to pump the Temperature Tool down. The negative temperature spikes probably represent places where the Temperature Tool was caught in the hole and then fell more rapidly. The vertical scale is expanded. 


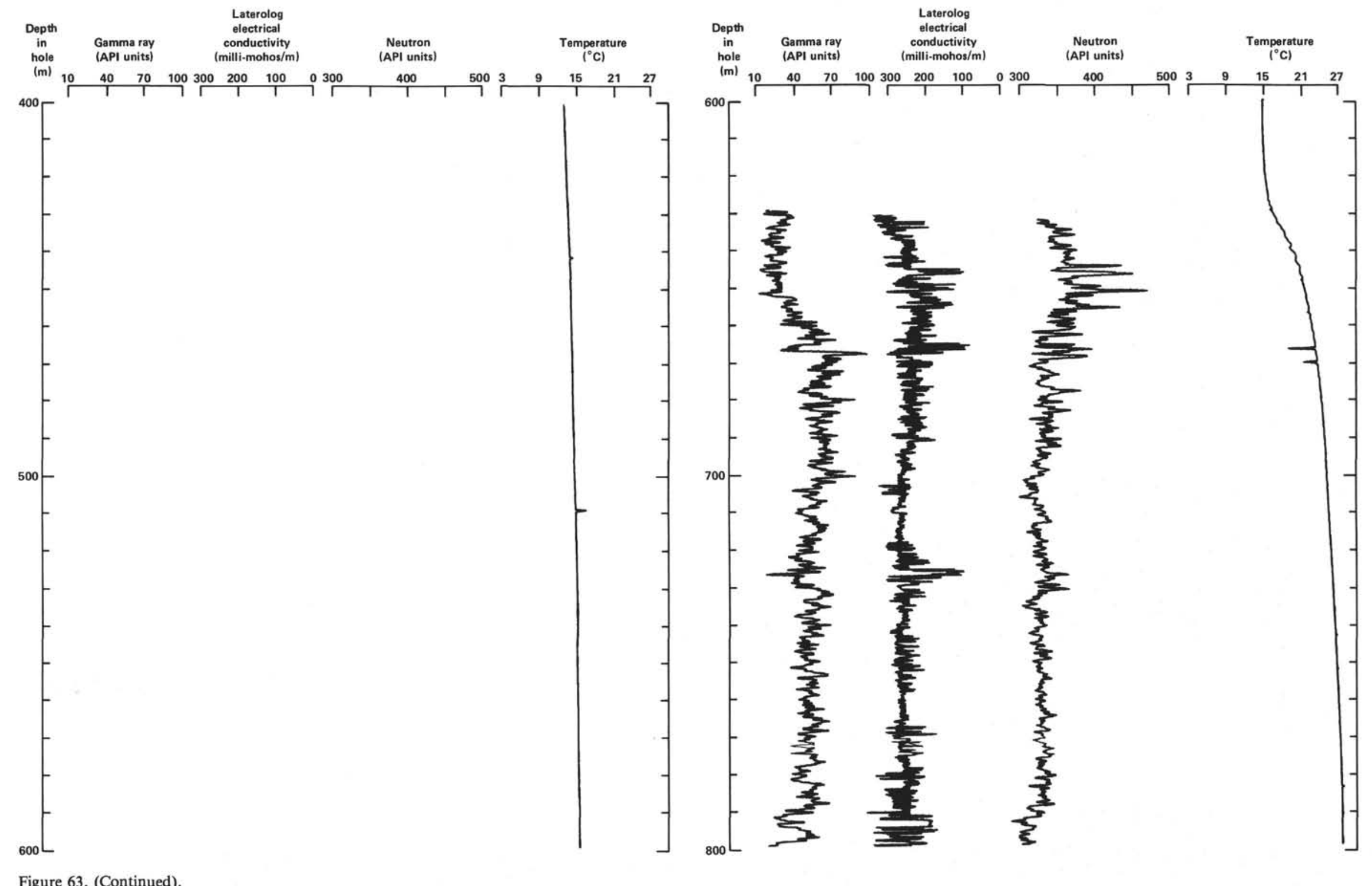




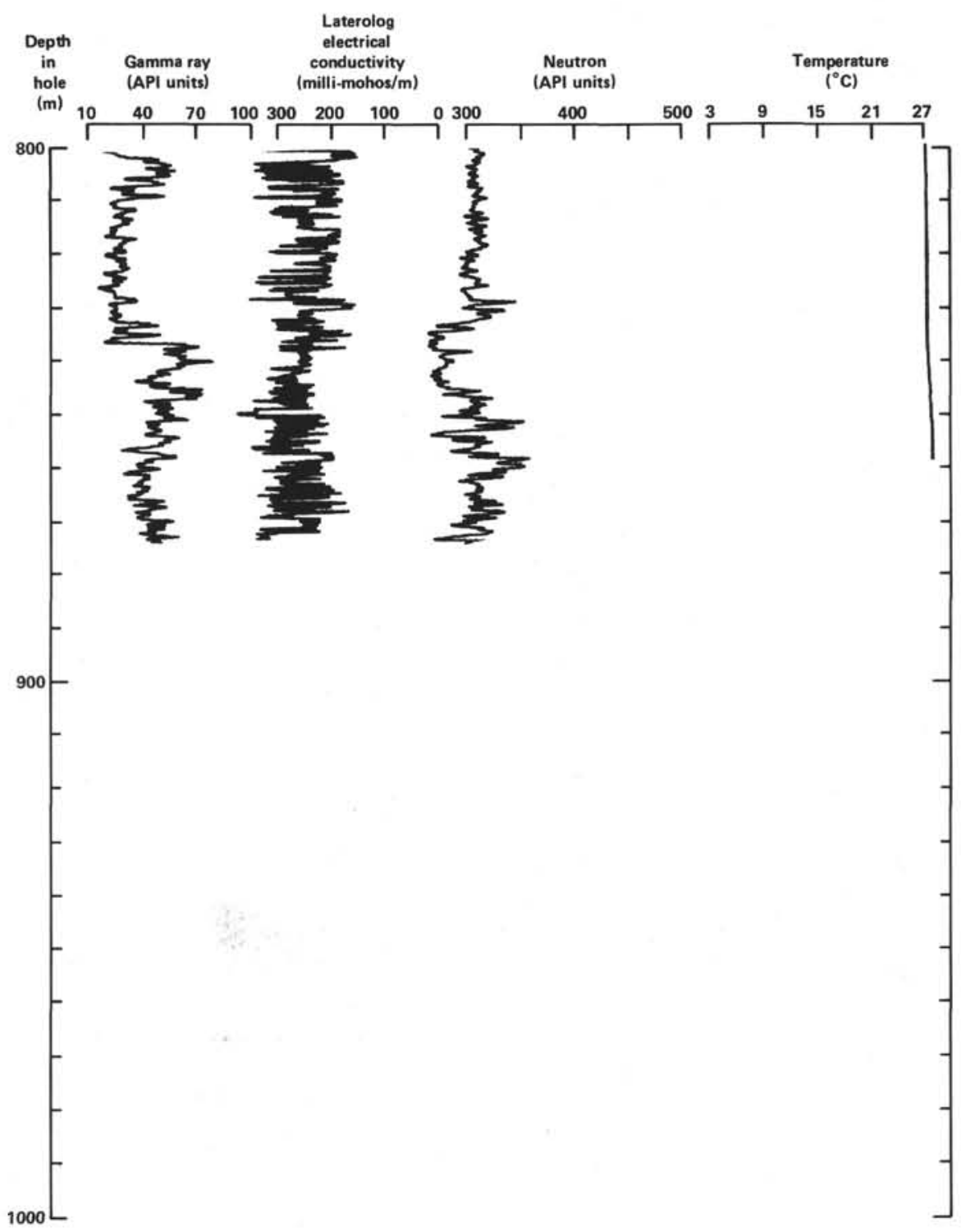

Figure 63. (Continued).

below is at $110 \mathrm{~m}$. The gamma radiation is very uniform above $110 \mathrm{~m}$; below the boundary the intensity is slightly greater, with a greater frequency of high GR spikes.

2) The boundary between nannofossil marl of Unit 2 above and muds of lithologic Unit 3 below, at $277 \mathrm{~m}$, shows a subtle GR change, with slightly greater intensity and greater frequency of higher GR spikes below.

3) The boundary between muds of Unit 3 above and mud alternating with marls and chalks of Unit 4 below, could be that indicated to be at $473 \mathrm{~m}$ on the GR log; below this horizon there is in general a higher GR intensity.

4) The Gr intensity is lower below the boundary between alternating marl, chalk, and mud of Unit 4 above and muds, siliceous clastics, and clastics of Unit 5 below, at $600 \mathrm{~m}$.

5) The boundary between volcanogenic sandstone of lithologic Unit 6 above and claystone of Unit 7 below is at $831 \mathrm{~m}$. On the GR $\log$ this boundary may be indicated $10 \mathrm{~m}$ deeper, at $841 \mathrm{~m}$. In the 10 -m interval above $841 \mathrm{~m}$ is a low GR intensity layer $5 \mathrm{~m}$ thick, but it is not particularly distinctive and would be difficult to identify using only logging data.

\section{Interpretation of Gamma-Ray Data from the Sonic Log Run from 630 to $940 \mathrm{~m}$ in the Bare Hole}

(Figs. 60, 61)

From 630 to $655 \mathrm{~m}$, the GR count is relatively low, indicating predominantly nonclayey rock. This corresponds to lithologic Units 4 and 5a which are characterized by the presence of clastic limestones in a mudstone sequence.

From 655 to $680 \mathrm{~m}$, the GR increases irregularly. This increase probably represents either increasing clay content or an increase in the frequency of thin clayey layers.

From 680 to 805 , m, the GR remains high and constant, suggesting that clay content (or frequency of thin clayey beds) is high and uniform, except for low GR ( $\sim 5 \mathrm{~m}$ thick) counts at $715,725-735,797$, and $800 \mathrm{~m}$. 
From 805 to $840 \mathrm{~m}$, the GR count gradually decreases, suggesting that the rock becomes less clay rich; a sharp contact with low GR count above and high GR count below occurs at $840 \mathrm{~m}$.

Below $840 \mathrm{~m}$, the high GR count gradually decreases with increasing depth to $866 \mathrm{~m}$, and then gradually increases to $940 \mathrm{~m}$. In general, the high GR suggests a formation with high clay content or a large number of thin clay layers. Some of the highest GR counts appear to be thin layers and could be indications of the organic-rich black shales.

Geologic time boundaries are not evident on the GR Log from 630 to $940 \mathrm{~m}$. Lithologic unit boundaries can be observed on the GR Log as follows:

1) The lithologic boundary at $647.5 \mathrm{~m}$ separates the mudstones, marlstones, and clastic limestones of lithologic Subunit 5a above from mudstone, clastic limestone, and siliciclastic sandstone of Subunit $5 \mathrm{~b}$ below; the GR is generally higher below this contact.

2) The lithologic boundary at $790 \mathrm{~m}$ separates mudstone, marlstone, and calcareous siliciclastic sandstone of Subunit $5 \mathrm{c}$ above from the volcanogenic sandstone of Unit 6 below. The GR is high and uniform above $790 \mathrm{~m}$ and then gradually decreases below $790 \mathrm{~m}$.

3) The lithologic boundary at $831 \mathrm{~m}$ separates the volcanogenic sandstone of lithologic Unit 6 above from the claystone of lithologic Unit 7 below. The GR is high above $840 \mathrm{~m}$ and low below $841 \mathrm{~m}$, and this may represent the contact on the log.

\section{Future Results of Gamma-Ray Data}

With proper borehole corrections the GR can be calibrated to estimate percentage of clay, frequency of thin clay beds, or percentage of other minerals which may emit natural gamma radiation. If $G R_{L}=$ average GR intensity of the nonclayey material (e.g., pure $100 \%$ $\mathrm{CaCO}_{3}$, chalk, or limestone); $G R_{H}=$ average GR intensity of the "clayey" material (e.g., 100\% claystone, shale, etc.); and $G R_{c}=$ measured GR, then the estimated percent clayey material is:

$$
\frac{G R_{H}-G R_{c}}{G R_{H}-G R_{L}} \times 100
$$

In reality, this relationship may not be linear (as in this equation), and a more accurate, curved, empirical relationship might be developed with experience.

\section{Results of the Temperature Logging Attempts} (Figs. 62, 63)

In order to understand the temperature data, the drilling and circulation history must be known. This was as follows:

1) Normal drilling circulation was stopped at 0000 hr., 11 August 1980, and a wiper run was made at 0948 hr.

2) Mud and seawater were introduced into the hole at 1522 to $1650 \mathrm{hr}$., 11 August 1980 (80 barrels Guar mud).

3) At $1548 \mathrm{hr}$., 12 August 1980, another wiper run was made, and the hole recirculated with seawater and
40 barrels of Guar mud. Circulation stopped at 2024 hr., 12 August 1980.

4) The bare hole was logged from 625 to $855 \mathrm{~m}$. The upper part of the hole was chilled by the circulating seawater used to pump the tool down the pipe. The times, minute tick marks, and dates are printed on the log.

In the bare hole, temperatures reached a maximum of $28.3^{\circ} \mathrm{C}$ at $855 \mathrm{~m}$ when the probe first arrived. After 10 minutes on the bottom, the temperature was $29.5^{\circ} \mathrm{C}$. True in situ temperatures must be 50 to $200 \%$ greater, and the determined temperature gradient $\left(29.7^{\circ} \mathrm{C} / 1000\right.$ $\mathrm{m})$ is a minimum value. The true temperature gradient should be closer to $40^{\circ} \mathrm{C} / 1000 \mathrm{~m}$, but the gradient could vary as much as $100 \%$ depending on the thermal conductivity of the formation-e.g., a high porosity surface sediment would have a larger gradient than low porosity rock deeper in the hole. Knowledge of the heat flow and of the interval thermal conductivities of the sediments allows one to calculate a temperature profile by extrapolating from the seafloor temperature of $2.9^{\circ} \mathrm{C}$. The thermal conductivity can be estimated from porosity and formation type.

The Uyeda Temperature Probe data are not directly comparable with Gearhart-Owen's continuous temperature $\log$, but both read $2.9^{\circ} \mathrm{C}$ for the bottom water.

\section{Comparison of the Electric Log and Laboratory Density Data}

As a check on the electrical conductivity log at a level where the hole was not washed out, the porosity derived from the laboratory density data was compared to the Induction Log at $855 \mathrm{~m}$ below the seafloor, with the following results:

1) The formation electrical resistivity $\left(R_{o}\right)$ after borehole correction was $1.30 \mathrm{ohm}-\mathrm{m}$. The interstitial water ( $\sim 35 \mathrm{ppt}$ salinity) has an electrical resistivity $\left(R_{w}\right)$ of $0.175 \mathrm{ohm}-\mathrm{m}$ at $28.3^{\circ} \mathrm{C}$ (after Thomas et al., 1934, and pressure corrections of Horne and Frysinger, 1963). Applying Archie's (1942) equation

$$
F=R_{o} / R_{w}=\phi^{-2}=7.43
$$

gives a porosity $(\phi)$ of $36 \%$.

2) The laboratory GRAPE density data give a wetbulk density of $2.06 \mathrm{~g} / \mathrm{cm}^{3}$; assuming a grain density of $2.7 \mathrm{~g} / \mathrm{cm}^{3}$, this represents a porosity of $38 \%$.

The results compare closely, so that one can conclude that the Induction Log is giving good quantitative data.

The good comparison of the Electric Log and density data also suggests that the Temperature Log data can be used to quantitatively interpret the Electric Log. Boyce (this volume) compares the entire Electric Log porosity data suite to that derived from the Sonic Log data, which may identify metallic deposits, oil-gas, hydrothermal anomalies, or salinity anomalies (using an $R_{w}$ plot). A cursory inspection of the conductivity curve does not indicate any unusual anomalies in the logged section.

\section{Laterolog-Neutron Log}

The Laterolog tool was not working properly, indicating electrical resistivities about two times too high. 
However, the log data are presented here as a qualitative indicator of bed thickness and so forth, along with the data from the qualitative Neutron tool.

Minor high resistivity anomalies in these data, corresponding to higher porosity indications or to the Neutron Log, suggest one of the following: (1) hydrocarbon oil, (2) fresher interstitial water, or (3) changes in clay content (which give false high-porosity indications on the Neutron Log). The anomalies were as follows:

725-727 m (medium anomaly);

$769 \mathrm{~m}$ (small anomaly);

$800 \mathrm{~m}$ (small anomaly);

879-830 m (small anomaly);

$835 \mathrm{~m}$ (small anomaly).

These anomalies are so small that they are probably only noise in the data.

\section{Sonic Log}

The Sonic Log was run from 630 to $940 \mathrm{~m}$ in Hole 530A. The log-velocity data are generally lower than the velocities measured in the laboratory. By deleting all log velocities too low to be measured for a given hole diameter (Fig. 58), we were able to determine the following average interval velocities:

$630-695 \mathrm{~m}:=1.97 \mathrm{~km} / \mathrm{s}$

$695-745 \mathrm{~m}:=1.90 \mathrm{~km} / \mathrm{s}$

$745-835 \mathrm{~m}:=2.04 \mathrm{~km} / \mathrm{s}$

$835-940 \mathrm{~m}:=1.91 \mathrm{~km} / \mathrm{s}$

The overall average equals $1.89 \mathrm{~km} / \mathrm{s}$.

These Sonic Log average velocities appear to be too low, and probably they do not represent in situ conditions. For example, if we average laboratory measurements on low velocity mudstone only and do not include any high velocity data or make corrections from laboratory temperatures and pressures, we obtain an average velocity of $2.03 \mathrm{~km} / \mathrm{s}$ between 700 and $1099 \mathrm{~m}$, which is $7 \%$ higher than the $1.89 \mathrm{~km} / \mathrm{s} \log$ average. The average velocity on the log in the interval from 745 to $835 \mathrm{~m}$, where the hole is relatively good, is $2.04 \mathrm{~km} / \mathrm{s}$, which compares well to the laboratory mudstone average. However, this zone also contains higher-velocity carbonate cemented mudstone and marlstones, which should give a significantly higher $(10 \%)$ interval velocity, so that even the interval from 745 to $835 \mathrm{~m}$ has a velocity which is too low.

The probable causes of the lower log velocities are (1) a borehole whose walls are physically disturbed by drilling, or (2) gas in the sediment in situ. It is much more probable that the borehole is physically disturbed; because the Sonic Log has a shallow $(5 \mathrm{~cm})$ depth of investigation away from the borehole, and the velocity-log sample also includes disturbed soft clayey material. The presence of gas in the sediments was not verified by direct observations on the cores or Neutron and Electric logs.

\section{CORRELATIONS WITH SEISMIC PROFILES}

Site 530 was located on the Glomar Challenger profile at 0817 (GMT) on 29 July 1980, about 2.5 miles from the position of SAI-1C. This was a result of the fact that during our approach to the proposed site, the basement topography could not be observed with the standard procedure, using a $40 \mathrm{c}$.i. air gun at full speed ( $\sim 9$ knots). Leaving the site, a seismic profile was shot with two air guns of 100 and 60 c.i. chamber sizes, running at 6 knots. The line was perpendicular to the strike of the Walvis Ridge, and we passed over Site 530 at 1357 on 18 August 1980 (Fig. 8). A weak reflection of the basaltic basement appears at $1.20 \mathrm{~s}$ at Site 530 . Based on correspondence of the shape of the upper reflectors between the BGR-41 and the Glomar Challenger approach line, and on the earlier estimate of basement depth, the projection of the position of Site 530 on the processed BGR-41 profile would be near shot point 3275 (Figs. 64, $65)$. The correspondence between Site 530 data and the acoustic stratigraphy based on the BGR-41 profile should be good except for the lowermost part of the sedimentary sequence, from the acoustic basement to the first discontinuity, which is 0 to $150 \mathrm{~m}$ above basement.

The acoustic reflectors and discontinuities have sufficient lateral continuity on the existing seismic profiles to permit them to be traced through the southeastern part of the Angola Basin, along a $150 \mathrm{~km}$ wide band north of the Frio Ridge, including the base of the continental margin.

\section{Definition of Acoustic Units}

Using seismic acoustic stratigraphic techniques (Payton, 1977), at least eight discontinuities can be traced in the southeastern Angola Basin (Fig. 66). Four acoustic units separated by major discontinuities form the main sequences (Figs. 66, 67). Their thicknesses at Site 530 appear in Table 15. Acoustic Unit 1 is characterized by discontinuous and hatched reflectors, which indicate the occurrence of slumps and flows. Two minor discontinuities, at 0.07 and $0.19 \mathrm{~s}$, can be traced within this unit. The presence of a large disturbed zone between shot points 800 and 1200 on the BGR-41 profile parallel to the Walvis Ridge and the presence of minor prograding series on UTMSI Profile 33, shot perpendicularly to the Walvis Ridge, suggest an origin on the Ridge for these flow deposits. Acoustic Unit 2 is a transparent layer within which a minor discontinuity can be followed. The base of Unit 2 corresponds to a major discontinuity, which is well defined on the Glomar Challenger profile. The degree of stratification seen in the acoustic records decreases from the top of acoustic Unit 3 to the base of Unit 4. A major discontinuity can be identified within Unit 3. Acoustic Unit 4 is a slightly layered unit. In its lowermost part, a discontinuity is present in the depressions of the basement. At the projection of Site 530 , it is very close to the basement.

\section{Identification of Key Discontinuities}

The major discontinuity at $0.60 \mathrm{~s}$ corresponds to the Eocene-middle Oligocene condensed section or hiatus and to the boundary between lithologic Units 3 and 4 at $467 \mathrm{~m}$. The basaltic basement at $1.20 \mathrm{~s}$ was reached at $1103 \mathrm{~m}$. Using these horizons as constraints, other discontinuities and acoustic units have been matched with hiatuses, lithologic changes, and differences in the phys- 
SW

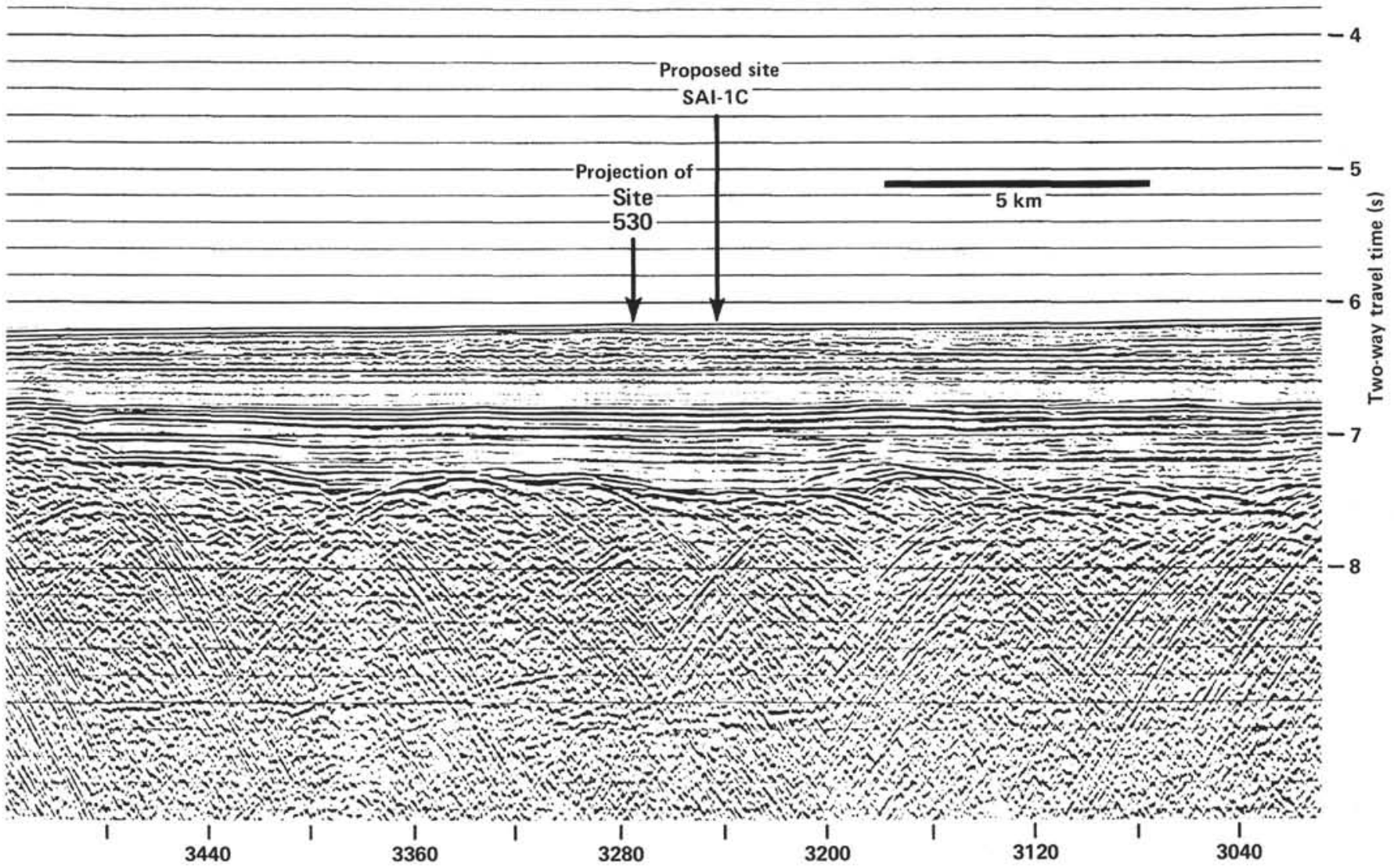

Figure 64. BGR-41 processed seismic profile showing the projection of Site 530 .

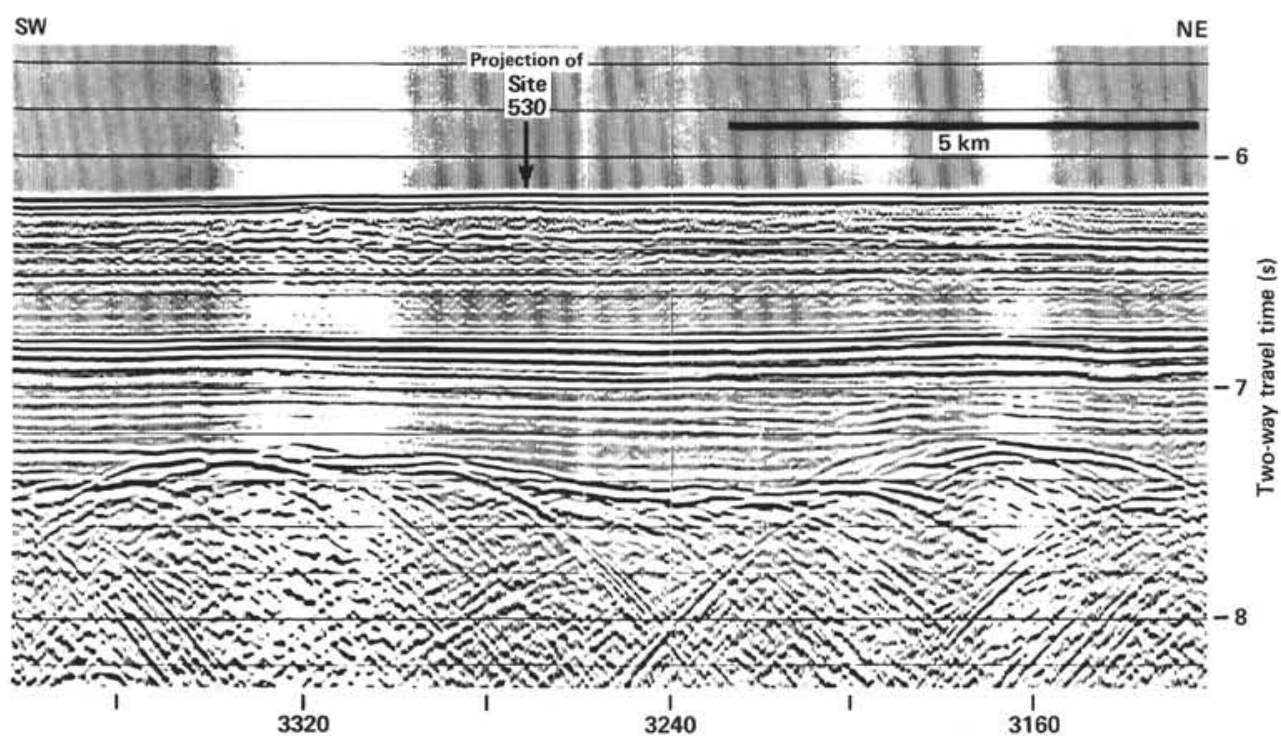

Figure 65 . BGR-41 processed seismic profile showing the projection of Site 530. Enlargement of central part of Figure 64

ical properties. The major acoustic units correspond well with both lithologic units and stratigraphic hiatuses.

\section{Identification of the Main Acoustic Units}

Acoustic Unit $1(0-0.35 \mathrm{~s} ; 0-277 \mathrm{~m})$ corresponds to lithologic Units 1 (nannofossil and diatom smarl, marl, and ooze; diatom ooze and debris-flow deposits) and 2 (nannofossil clay, marl, and ooze, and debris-flow deposits) of Recent to late Miocene age (0-10 m.y.). The acoustic discontinuities at 0.07 and $0.20 \mathrm{~s}$ do not correspond to obvious hiatuses or changes in lithology. On the $3.5-\mathrm{kHz}$ records, the top of the debris-flow deposits 
SW

NE

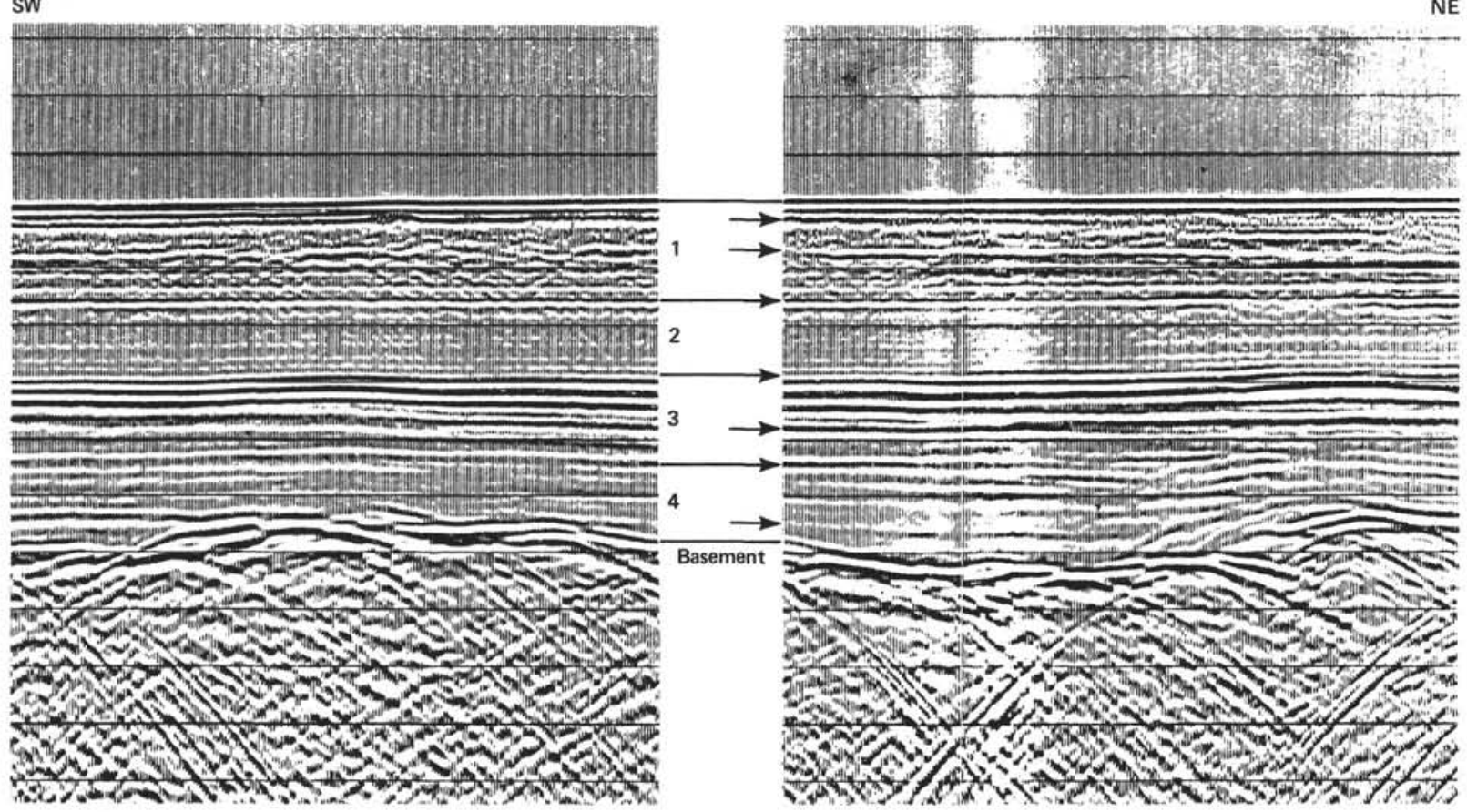

Figure 66. Definition of acoustic units on BGR-41 processed seismic profile. Arrows show the main unconformities followed in the southeastern Angola Basin.

Table 15. Definition of acoustic units, Site 530.

\begin{tabular}{lccccc}
\hline $\begin{array}{l}\text { Acoustic } \\
\text { units }\end{array}$ & $\begin{array}{c}\text { Lithologic } \\
\text { units }\end{array}$ & $\begin{array}{c}\text { Thickness } \\
(\mathrm{m})\end{array}$ & $\begin{array}{c}\text { Two-way } \\
\text { penetration } \\
\text { depth }(\mathrm{s})\end{array}$ & $\begin{array}{c}\text { Sub-bottom } \\
\text { depth }(\mathrm{m})\end{array}$ & $\begin{array}{c}\text { Velocity } \\
(\mathrm{km} / \mathrm{s})\end{array}$ \\
\hline 1 & 1,2 & 277 & 0 & 0 & 1.526 \\
2 & 3 & 190 & 0.35 & 277 & 1.600 \\
3 & $\left\{\begin{array}{l}4,5 \mathrm{a} \\
5 \mathrm{~b}, \mathrm{c}\end{array}\right.$ & 183 & 0.60 & 467 & 1.839 \\
4 & $6,7,8$ & 313 & 0.80 & $650 ?$ & 2.154 \\
Basalt & 9 & & 1.20 & 1103 & 2.311 \\
\hline
\end{tabular}

can be seen to extend from Site 530 to the foot of the Walvis Ridge and parallel to the Ridge. At Site 530, the highest occurrence of debris-flow deposits is at a depth of $25 \mathrm{~m}$ on both the $3.5 \mathrm{kHz}$ record and in Hole 530B. The geometry of the top of these debris-flow deposits suggests the existence of submarine fans at the foot of the Walvis Ridge, with a sediment supply from the slopes or from the basin on the top of the Ridge through channels across the northern basement ridge.

Acoustic Unit $2(0.35-0.60 \mathrm{~s} ; 277-467 \mathrm{~m})$ corresponds to lithologic Unit 3, a red and green mud sequence of earliest late Miocene, middle and early Miocene, and Oligocene age (10-37 m.y.). The acoustic discontinuity at the top of acoustic Unit 2 may represent a short stratigraphic hiatus in the early late Miocene, but this cannot be confirmed by biostratigraphic studies. A change in horizontal velocities and density also mark this boundary. The major discontinuity at the base of acoustic Unit 2 corresponds to the contact be- tween the red and green mud of lithologic Unit 3 and the lower multicolored mudstone, marlstone, chalk, and clastic limestone of lithologic Unit 4. A major change in the physical properties occurs at this level. The Eocene and early Oligocene are represented by possible lower Oligocene strata devoid of calcareous fossils (451-469 $\mathrm{m})$, upper Eocene with calcareous nannoplankton of Zones NP19/20 $(469.3 \mathrm{~m})$, a possible hiatus in which Zones NP16-18 are missing, lower middle Eocene with calcareous nannoplankton Zone NP15 at $475.5 \mathrm{~m}$, lower Eocene with calcareous nannoplankton Zone NP12 at 486-495 m, and a possible hiatus with Zone NP10 missing above upper Paleocene strata, with Zone NP9 at $505 \mathrm{~m}$.

A discontinuity of $0.5 \mathrm{~s}$ is not associated with any change in lithology or physical properties but could correspond to a hiatus at about $390 \mathrm{~m}$, within upper Oligocene strata barren of calcareous microfossils between 350 and $450 \mathrm{~m}$.

Acoustic Unit 3 (0.6-0.93 s; 467-790 m) corresponds to lithologic Units 4 (multicolored mudstone, marlstone, chalk, and clastic limestone) and 5 (mudstone, marlstone, clastic limestone, and siliclastic sandstone), which represent the interval from Eocene to early Campanian (37-77 m.y.). The discontinuity at the base of Unit 3 corresponds to a rapid change in velocity and is associated with the early Oligocene-Eocene condensed section or hiatuses. The strong stratification seen in acoustic Unit 3 is related to the occurrence of thin beds of limestone, chert, and siliciclastic sandstone characterized by high velocities, up to $5.3 \mathrm{~km} / \mathrm{s}$, and high acoustic impedance.

Acoustic Unit $4(0.93-1.20 \mathrm{~s} ; 790-1103 \mathrm{~m})$ corresponds to lithologic Units 6 (volcanogenic sandstone), 7 


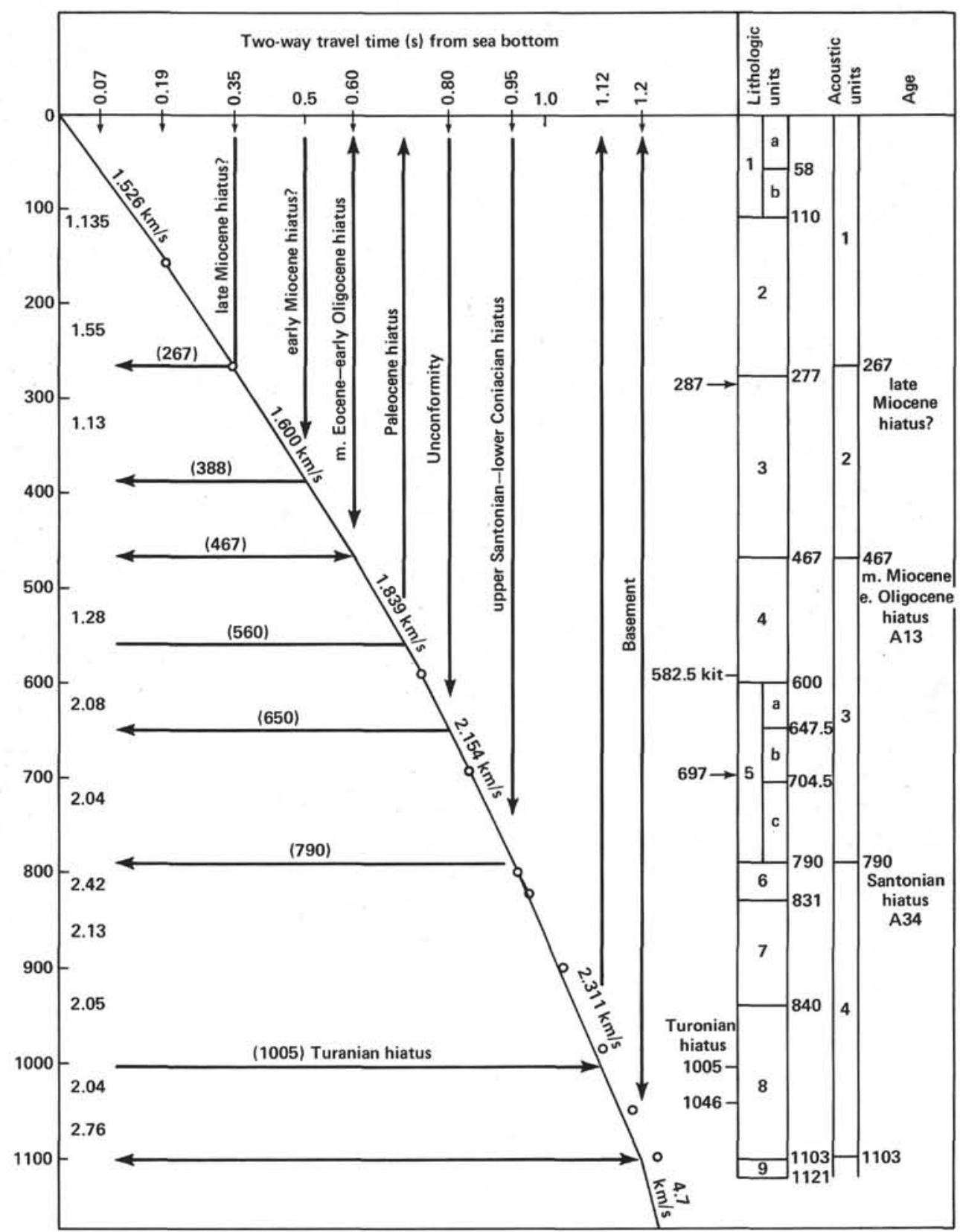

Figure 67. Velocity depth profile for Site 530 showing main reflectors; acoustic and lithologic units are identified.

(variegated red, green, and purple claystone, siltstone, and sandstone) and 8 (red and green claystone and marlstone with interbedded black shales), which are of early Campanian to late Albian age (77.5-102.5 m.y.). The lowermost discontinuity lies at about 1.12 to $1.20 \mathrm{~s}$ on the BGR-41 seismic profile. Although this discontinuity cannot be seen on the Glomar Challenger profile, and Site 530 is not located on the BGR-41 profile, this discontinuity may correspond to the Coniacian-Cenomanian hiatus in Hole 530A. No contrast in physical properties and lithology marks this boundary.

The acoustic basement is highly diffractive, thus suggesting that the $19 \mathrm{~m}$ cored could be massive basalt rather than a sill.

\section{Velocity Measurements}

The Gamma-Ray Log (compensated) and Sonic Log (Borehole Compensated) recorded between 940 and 625 $\mathrm{m}$ sub-bottom depth. Units for the Sonic Log, in microseconds per foot, were converted to kilometers per second to produce a mean curve. Since the compensated Sonic Log is a two-layer refraction measurement, the lateral investigation penetration is a few centimeters and velocities below 1.7 to $1.8 \mathrm{~km} / \mathrm{s}$ are strongly affected by the hole diameter (Boyce, this volume). Figure 68 shows the mean sonic velocity and the velocities deduced from the seismic discontinuities (Figs. 66, 67) for the logged interval. Seismic velocities are always higher than veloc- 


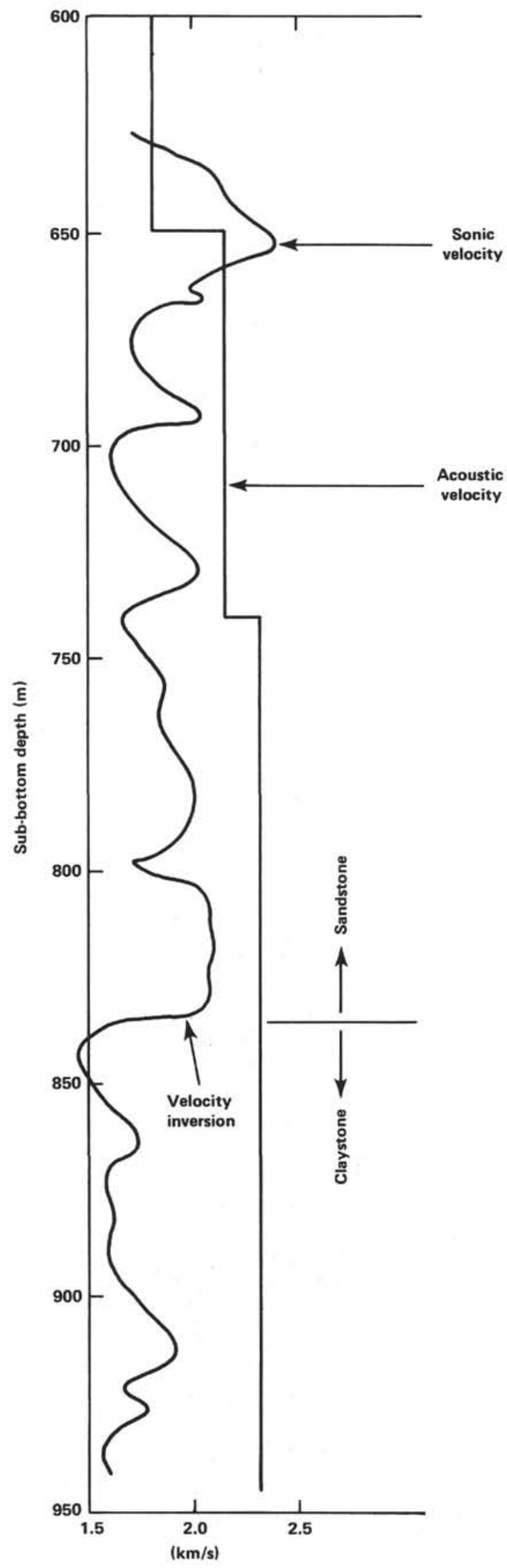

Figure 68. Comparison between Sonic Log and calculated acoustic velocities. ities measured by the sonic log by 0.2 to $0.3 \mathrm{~km} / \mathrm{s}$. Velocities measured on samples also show a systematic shift with respect to those recorded on the sonic log. At $837 \mathrm{~m}$ the log shows an abrupt decrease in the sonic velocities at the transition from volcanogenic sandstone of lithologic Unit 6 to claystone of lithologic Unit 7. The velocities below $830 \mathrm{~m}$ are in part artificially low because the hole is washed out (see Figs. 57 and 61). This discontinuity does not appear on the seismic profile because it corresponds to a speed inversion.

\section{Nature of Main Unconformities}

Seismic discontinuities in the deep sea may be related to tectonic events and/or paleoceanographic events which may or may not be linked to fluctuations of sea level. The limit between acoustic Units 2 and 3, associated with the Eocene-lower Oligocene condensed section, corresponds to: a tectonic readjustment in plate motion at the time of Anomaly 13 (late Eocene); volcanic events registered in South Africa (Moore, 1976); the highest elevation of the CCD in the South Atlantic (van Andel et al., 1977); and high stands of sea level (Vail et al., 1977).

The limit between acoustic Units 3 and 4 corresponds to the time of Anomaly 34. This corresponds to a major change of position of the pole of rotation during the evolution of the South Atlantic (e.g., Ladd, 1974; Sibuet and Mascle, 1978). Volcanic activity is recorded all around the South Atlantic at this time (e.g., Moore, 1976; Almeida et al., 1968).

Seismic discontinuities may also reflect the main transgression and regression cycles which appear in the Vail et al. (1977) sea-level curve. Within the errors on the preliminary age determinations, the intervals barren of carbonate fossils (the early Eocene, late middle Eocene, and early Oligocene) occur during high stands of sea level; the intervals with carbonate fossils (the early middle Eocene and late Eocene) correspond to relatively low stands of sea level.

\section{SUMMARY AND CONCLUSIONS}

\section{Introduction}

Site 530 is located in the southeastern corner of the Angola Basin, about $20 \mathrm{~km}$ north of the Walvis Escarpment, near the eastern end of the Walvis Ridge (Fig. 1). It lies on the abyssal floor of the Angola Basin in an area with a seismic stratigraphic sequence typical for the entire deep part of the basin.

Magnetic lineations of the basement are not distinct at Site 530. The M-sequence (M0 to M11) has been clearly identified in the Cape Basin south of Walvis Ridge by Rabinowitz (1976). Cande and Rabinowitz (1978) have published an interpretation of the Angola Basin anomalies in which they suggest that a ridge jump occurred approximately at the time of Anomaly M0 or later, so that the basement at Site 530 would be early Aptian or younger. One of the objectives of drilling at this site was, therefore, to determine the basement age to establish whether the hypothesis of a ridge jump in the southern Angola Basin is correct. 
Extensive multichannel seismic surveys of the area had been carried out by the University of Texas Marine Science Institute and the Bundesanstalt für Geowissenschaften und Rohstoffe. Correlating the results of drilling at DSDP Sites 362 and 363 with the processed multichannel seismic profile (BGR-36) allowed three main sequences bounded by discontinuities to be identified on the adjacent Walvis Ridge: (1) the lowest surface of discontinuity was thought to be a paraconformity where the Cenomanian and much or all of the Turonian would be missing, as at Site 363 ; (2) the middle discontinuity was expected to be early Oligocene, the top of the Braarudosphaera chalk as noted at Site 362 and 363; (3) the upper discontinuity was expected to be middle Miocene, corresponding to strata which had been drilled at Site 362 . Because of the water depth difference and probable differences in sedimentary facies, it was considered speculative to extend this seismic stratigraphy to the deep Angola Basin, except for the lowest discontinuity which could be recognized throughout the area and was thought to correspond to a Cenomanian-Turonian hiatus known to occur near the base of the upper blackshale sequence at Site 364 . Prior to drilling, seismic stratigraphic interpretation was limited to tracing the lower discontinuity and to studying the basal onlap of the sequence above it.

Arriving on 29 July, we spent 21 days at Site 530 . Hole 530 was spudded in just before midnight of the 29 th. A seafloor core ( $4645.0 \mathrm{~m}$ water depth) was taken. The interval from 1.5 to $115.5 \mathrm{~m}$ sub-bottom was washed in, and a second core cut. The heat-flow tool was then dropped but could not be retrieved. The drill string was pulled, and the bit with the heat-flow tool arrived on deck at $2000 \mathrm{hr}$. on 30 July. The probe of the tool was broken off at the bottom of the bit and crushed. It could not be recovered until the bent edges had been cut off with a torch.

Hole $530 \mathrm{~A}$ was spudded in on 31 July and washed to a depth of $125 \mathrm{~m}$ sub-bottom. Coring proceeded continuously until 10 August, when basalt was encountered at the base of Core 105, at about $1103 \mathrm{~m}$ sub-bottom. Three cores were drilled in basalt, but the last required 745 min. to cut; it was decided to terminate the hole on 11 August.

The heat-flow probe was run in an attempt to take measurements of the water temperature near the bottom of the hole just outside the bit, at two intermediate levels inside the pipe, and at the mudline inside the pipe, but the results were not meaningful.

The Gamma Ray-Neutron Log was run inside the pipe 12 August. Open-hole logging was attempted first with a rig of the Temperature Density Logs, but was stopped by a bridge in the hole a short distance below the pipe. We made several attempts to clear the bridge, cleaning and flushing the hole and setting the bottom of the pipe deeper. After an attempted logging run on 13 August, it was found that the Density Log part of the tool with its source had been left in the hole. The hole was again flushed with mud and the pipe set at $625 \mathrm{~m}$ sub-bottom. The Gamma-Ray Log, Sonic Log, Induction Log, Laterolog, Neutron Log, and Temperature
Log were all run in the bottom of the hole. The drill bit was dropped without tripping the string, and Hole 530A was plugged with cement.

Hole 530B was offset a short distance and spudded in on 15 August. Hydraulic piston coring continued to a sub-bottom depth of $180.6 \mathrm{~m}$, reached after 48 cores, on 18 August.

\section{Age of the Southeastern Part of the Angola Basin}

At Site 530, the age of the oldest sediments is late Albian. Using the Obradovich and Cobban (1975) time scale and extrapolating the previous sedimentation rate, an age of $102.5 \mathrm{~m} . \mathrm{y}$. is proposed. Assuming a constant seafloor spreading rate for the creation of the oceanic crust older than Anomaly 34 (79 m.y.), an age of 106 to 108 m.y. (i.e., early Albian) is predicted for the oldest oceanic crust at the ocean/continent boundary. This is in agreement with the hypothesis of a ridge-crest jump in latest Aptian as proposed by Cande and Rabinowitz (1978), just after the salt deposition. This ridge jump was indicated both by the lack of salt deposits in the southeastern Angola Basin and by the relative eastward shift of the Anomaly 34 lineation with respect to the axis of symmetry of the South Atlantic. Magnetic lineations west of Site 530 could correspond to M minus 2 and 3 anomalies of Albian age (Ryan et al., 1978).

\section{An Empirical Curve for Seafloor Subsidence in the Angola and Brazil Basins}

According to the present plans of the Deep Sea Drilling Project, Site 530 is the last site to be drilled to basement in the South Atlantic; thus, the data base for an empirical subsidence curve for the Angola and Brazil basins will not be expanded in the near future. Hole 530A sampled oceanic basement much older than any previous drilling in the Angola and Brazil basins, and is critical in defining an empirical subsidence curve.

Table 16 gives age and depth relations for sites in the Angola and Brazil basins that have reached or closely approached basement. Figure 69 presents relationships of calculated depth to basement after removal of the sediment and isostatic adjustment plotted against age.

There is a scatter of points, but some are obviously much closer to alignment along a subsidence curve than others. Assuming that the subsidence curve has the form $h_{t}=-a t^{b}$, where $h_{t}$ is the depth of basement below sea level, at age $t$, an empirical curve can be fit as a linear regression if the equation is written $1 \mathrm{n} h_{t}=-(b 1 \mathrm{n} t+$ $1 n a)$. The closeness of fit is expressed by the coefficient of determination:

$$
r^{2}=\frac{\left[\Sigma\left(\ln t_{i}\right)\left(\ln h_{i}\right)-\frac{\left(\Sigma 1 \mathrm{n} t_{i}\right)\left(\Sigma 1 \mathrm{n} h_{i}\right)}{\mathrm{n}}\right]^{2}}{\left[\Sigma\left(1 \mathrm{n} t_{i}\right)^{2}-\frac{\left(\Sigma 1 \mathrm{n} t_{i}\right)^{2}}{\mathrm{n}}\right]\left[\Sigma\left(1 \mathrm{n} h_{i}\right)^{2}-\frac{\left(\Sigma 1 \mathrm{n} h_{i}\right)^{2}}{\mathrm{n}}\right]}
$$

For all of the Angola Basin sites, the equation is

$$
h_{t}=-3.2435 t^{0.0954}
$$

but $r^{2}$ is only 0.7776 . 
Table 16. Age and depth of basement in the Angola and Brazil basins.

\begin{tabular}{|c|c|c|c|c|c|c|}
\hline Angola Basin & $\begin{array}{l}\text { Water depth } \\
\text { (m) }\end{array}$ & Basement age & $\begin{array}{c}\text { Age } \\
\text { (m.y.) }\end{array}$ & $\begin{array}{l}\text { Sediment } \\
\text { thickness } \\
(\mathrm{m})\end{array}$ & $\begin{array}{l}\text { Depth of unloaded } \\
\text { basement } \\
\text { (m) }\end{array}$ & Basalt reached \\
\hline 519 & 3778 & late Miocene & 6 & 151.5 & 3879 & Yes \\
\hline 520 & 4217 & $\begin{array}{l}\text { Langhian } \\
\text { mid-Miocene }\end{array}$ & 15 & 458 & 4522 & Yes \\
\hline 521 & 4141 & mid-Miocene & 16 ? & 84 & 4197 & No, but very close \\
\hline 522 & 4456 & late Eocene & 39 & 156 & 4560 & Yes \\
\hline 523 & 4572 & mid-Eocene & 50 & 193 & 4701 & No, but very close \\
\hline 527 & 4437 & mid-Maestrichtian & 68 & 384 & 4693 & Yes \\
\hline 530 & 4645 & late Albian & 102.5 & 1103 & 5380 & Yes \\
\hline 17 & 4266 & late Oligocene & $31.5^{\mathrm{a}}$ & $\begin{array}{c}92.7 \\
124\end{array}$ & 4348 & Yes \\
\hline 18 & 4022 & earliest Miocene & 24 & 178 & $\begin{aligned} 4141 & \\
\Sigma_{11} a & =3.2435 \\
b & =0.0954 \\
r^{2} & =0.7776\end{aligned}$ & Yes \\
\hline \multicolumn{7}{|l|}{ Brazil Basin } \\
\hline 16 & 3526 & late Miocene & 9 & 175 & 3643 & Yes \\
\hline 15 & 3938 & early Miocene & 20 & 141 & 4032 & Yes \\
\hline 14 & 4346 & Eocene/Oligocene boundary & 37 & 107 & 4417 & Yes \\
\hline 19 & 4685 & middle Eocene & 46 & 140 & 4778 & Yes \\
\hline \multirow[t]{3}{*}{20} & $4447-4484$ & late Maestrichtian & 66 & 65 & 4509 & Yes \\
\hline & & & & & $\Sigma_{5} \begin{aligned} a & =2.7761 \\
b & =0.1270 \\
r^{2} & =0.8767\end{aligned}$ & \\
\hline & & & & & $\begin{aligned} \Sigma_{14 a} a & =3.0892 \\
b & =0.2047 \\
T^{2} & =0.7513\end{aligned}$ & \\
\hline
\end{tabular}

a van Andel used $35, \mathrm{~m} / \mathrm{m} . \mathrm{y}$.

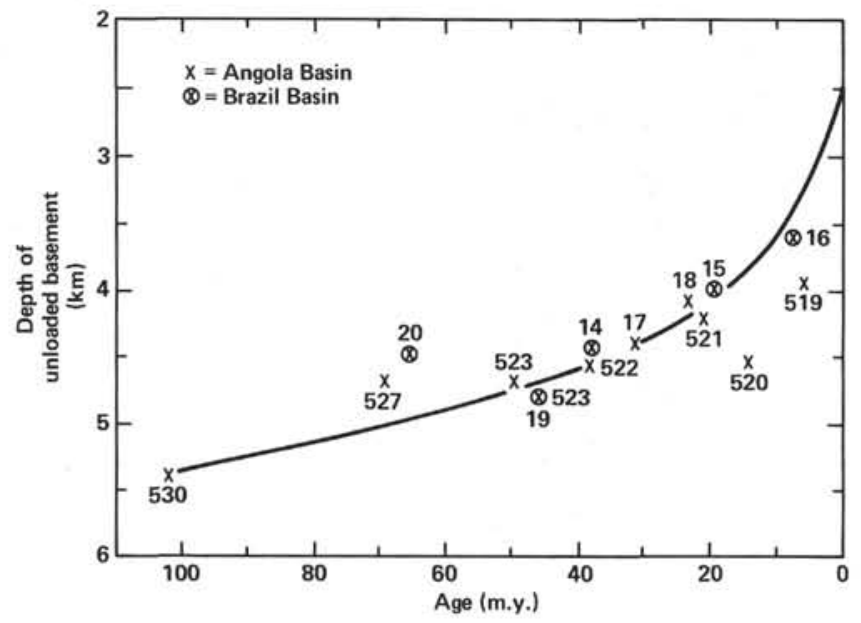

Figure 69. Depth of unloaded basement versus age for Angola and Brazil basin sites.

As shown on Table 16, for all five of the Brazil Basin sites, the equation is:

$$
h_{t}=-2.7761 t^{0.1270}
$$

and $r^{2}=0.8767$. is:

For all 14 Angola and Brazil basin sites, the equation

$$
h_{t}=-3.0892 t^{0.2047}
$$

and $r^{2}=0.7513$.

From the low values of $r^{2}$ it is evident that no single subsidence curve can estimate depth of basement at all of the sites to closer than $400 \mathrm{~m}$.

However, using only those sites that appear to lie along a curve, and testing different combinations, we found an empirical curve based on seven sites $(15,16$, $17,18,522,523$, and 530) which has $r^{2}=0.9978$ :

$$
h_{t}=0.23644 t^{0.1773}
$$

An even closer fit exists for the five sites 15, 17, 18, 522, and 530, as follows:

$$
h_{t}=-2.3568 t^{0.1785}
$$

with $r^{2}=0.9987$, but the close fit with seven sites is not significantly poorer as an estimator of subsidence with age.

For backtracking other sites, the preferred equation can be written

$$
h_{t}^{\prime}=-2.3644 t^{0.1773}+\left(h_{R}-h_{R}{ }^{\prime}\right)
$$

where $h_{R}{ }^{\prime}$ is the present depth of unloaded basement at a given site, $h_{R}$ the depth of basement predicted by the subsidence curve, and $h_{t}{ }^{\prime}$ is the depth of unloaded basement at the given site at any age $t$.

Because the fractional root of numbers less than $1 \rightarrow$ $\infty$ the equation cannot be used to estimate the elevation of the Ridge at its time of origin. The term $a$ in the equation is the elevation of the Ridge crest predicted for an age of $1 \mathrm{~m} . \mathrm{y}$.

Table 17 is an empirical prediction of average unloaded basement depths and water depths assuming a constant sedimentation rate of $10 \mathrm{~m} / \mathrm{m} . \mathrm{y}$.

\section{Interpretation of the Sediments and Rocks Recovered}

The increase in abundances of nannofossils and foraminifers in Subunit 1a records the deepening of the CCD during the Pliocene, probably associated with the maximum extent of upwelling conditions off the coast 
Table 17. Empirical age depth curve for Angola and Brazil basins.

\begin{tabular}{cccc}
\hline $\begin{array}{c}\text { Age } \\
(\mathrm{m} . \mathrm{y})\end{array}$ & $\begin{array}{c}\text { Unloaded } \\
\text { basement } \\
(\mathrm{km})\end{array}$ & $\begin{array}{c}\text { Sediment } \\
\text { thickness } \\
(\mathrm{km})\end{array}$ & $\begin{array}{c}\text { Depth of } \\
\text { water }^{\mathrm{a}} \\
(\mathrm{km})\end{array}$ \\
\hline 1 & 2.3644 & 0.01 & 2.3577 \\
5 & 3.1452 & 0.05 & 3.1119 \\
10 & 3.5565 & 0.10 & 3.4898 \\
20 & 4.0216 & 0.20 & 3.8882 \\
30 & 4.2213 & 0.30 & 4.1213 \\
40 & 4.5474 & 0.40 & 4.2808 \\
50 & 4.7309 & 0.50 & 4.3976 \\
60 & 4.8864 & 0.60 & 4.0864 \\
70 & 5.0218 & 0.70 & 4.5551 \\
80 & 5.1421 & 0.80 & 4.6087 \\
90 & 5.2506 & 0.90 & 4.6506 \\
100 & 5.3496 & 1.00 & 4.6829 \\
110 & 5.4408 & 1.10 & 4.7074 \\
120 & 5.5253 & 1.20 & 4.7253 \\
130 & 5.6043 & 1.30 & 4.7377 \\
140 & 5.6784 & 1.40 & 4.7451 \\
150 & 5.7483 & 1.50 & 4.7483 \\
160 & 5.8145 & 1.60 & 4.7478 \\
170 & 5.8773 & 1.70 & 4.7440 \\
180 & 5.9372 & 1.80 & 4.7372 \\
190 & 5.9944 & 1.90 & 4.7277 \\
200 & 6.0491 & 2.00 & 4.7158 \\
\hline
\end{tabular}

${ }^{\text {a }}$ Assumes average bulk density of sediment to be 2.2 .

of southwest Africa. Shoaling of the CCD, as indicated by low concentrations of carbonate and high diatom productivity, resulted in the accumulation of diatomrich, carbonate-poor sediments interbedded with debrisflow deposits to form Subunit 1b. They were probably derived from approximately contemporaneous sediments on the Walvis Ridge, and the larger flows can be seen on seismic reflection profiles to have moved downslope 15 to $20 \mathrm{~km}$. Thick $(20-100 \mathrm{~cm})$ clay-diatom turbidites are approximately equal in abundance to pelagic ooze and marl in Unit 1a. The turbidites were also probably derived from Walvis Ridge, where similar materials of the same age were recovered at Sites 362 and 532.

Unit 2 comprises mainly calcareous biogenic sediments interbedded with thick debris-flow deposits and thin mud turbidites. The marked increase in carbonate accumulation (nannofossil marls and oozes) beginning in the late Miocene was probably the result of a combination of rapid deepening of the CCD and increased productivity as the Benguela upwelling system came into being. Turbidity currents supplied fine-grained clastics that formed the clay-marl-ooze cycles, but most of the sediment that accumulated was pelagic calcareous nannoplankton skeletal remains. The thickness of the largest debris-flow deposit near the top of this unit is at least $32 \mathrm{~m}$. As in Unit 1, the clasts include at least seven or eight multicolored mud, marl, and ooze lithologies derived from the Walvis Ridge, as well as rare basalt pebbles. The base of this unit coincides with a change in density and sonic velocity of the sediment.

Unit 3 contains thin-bedded basinal turbidites, pelagic clay, and volcanic-palagonitic silt deposited from the late Oligocene to the late Miocene, following a period of much reduced sedimentation during middle Eo- cene through early Oligocene time. Seismic reflection profiles show that the equivalent of this unit extends over much of the Angola Basin and was dominated by sediment input from the African continental margin.

The lower Oligocene may be represented at the base of the unit by a condensed section with hiatuses. The base of Unit 3 corresponds to the widespread lower seismic discontinuity at which we had anticipated a Cenomanian-Turonian hiatus.

Unit 4 consists of minor red and dominant green mudstone, calcareous mudstone, and marlstone, with common interbeds of nannofossil chalk and clastic limestone. The clastic limestone beds contain many shallowwater carbonate debris mixed with volcanic rock fragments. Both the chalk and limestone beds were deposited by turbidity currents, which probably originated on the African continental shelf or upper slope.

Obtaining a section across the Cretaceous/Tertiary boundary was one of the objectives of Leg 75. The Cretaceous/Tertiary boundary (65 m.y.) is well documented by moderately to well preserved, common to abundant nannofossils in Core 50, Section $2(593.0 \mathrm{~m})$. The boundary, as far as can be judged by calcareous nannoplankton, is between 14 and $53 \mathrm{~cm}$ in this section. The boundary is not a sharp break between Maestrichtian and Paleocene assemblages, and there may be some interlayering or mixing. Paleomagnetic studies show a shift from normal to reverse polarity at $62 \mathrm{~cm}$, just below the paleontologic boundary.

In Unit 5 there are no beds of chalk, but interbeds of clastic limestone are still present. These become less common downward until the carbonate clastic debris is replaced by dark-colored siliciclastics and, near the base of the unit, by volcanogenic sandstone.

There are several irregular thickening and thinning sequences of turbidites in Units 4 and 5, suggesting that these sediments may have been deposited on fan lobes and small channels. Unit $5 \mathrm{c}$ is interpreted as a channelfill sequence overlying the thick turbidites of Unit 6 .

The base of Unit 5 is marked by a decrease in density but an increase in sonic velocity, reflecting the fact that the volcanogenic sandstone of Unit 6 has a relatively high velocity but a low density.

The dominant lithology of Unit 6 is carbonate-cemented, greenish-black volcanogenic sandstone that occurs as thin $(5-10 \mathrm{~cm})$ to thick $(1-3 \mathrm{~m})$ graded turbidites. These were probably derived from one or more volcanic islands or seamounts on the Walvis Ridge, although there is little bathymetric evidence for these features, and were deposited in an upper fan channel setting.

The dominant lithology of Unit 7 is red claystone with interbeds of green, red, and purple siltstone and claystone and green sandstone in numerous repeated turbidite sequences. These were probably deposited on the lower to middle portions of a prograding fan sequence.

Unit 8 comprises red, green, and black mudstones, marlstones, and rare limestones. The interpretation of these interbedded lithologies is complex.

The red mudstones and marlstones make up about $44 \%$ of the unit and were deposited in a relatively deep $(3.5 \mathrm{~km})$, narrow, ocean basin by pelagic, hemipelagic, 
and turbiditic processes under oxygenated bottom water. The green mudstones and marlstones, composing about $47 \%$ of the unit, are closely associated with the black shales and were deposited in the same manner as the red sediments. There are two possible interpretations for the green coloration: either it results from diagenetic reduction of iron in red muds around layers rich in organic matter or it results from iron reduction during deposition in reducing sediments under poorly oxygenated or anoxic bottom waters. These two interpretations are not mutually exclusive, and both may have operated. The common interbedding of red, green, and black layers, and the bioturbation of much of the sediment but its absence in parts of the black shales, suggests that there was a delicate balance between oxidizing and reducing conditions in the Angola Basin and sediments at this time.

Following are several important aspects to a blackshale model for Site 530:

1) Factors acting to reduce seawater oxygen content include restricted circulation, salinity stratification, warm bottom waters, high productivity, increased evaporation, and high input of organic matter via turbidity currents.

2) Factors acting to increase seawater oxygenation include wind-forced advection of water masses, geothermal heating of the basin, and circulation resulting from movement of oxygenated density currents.

3) Factors affecting oxygen content of sediments include the oxygen content of the overlying seawater and the rate of supply, burial, and conservation of organic material.

Black shales in the South Atlantic accumulated during two distinct periods, the Aptian to early Albian and late Albian to early Santonian. These periods probably represent a coincidence of several factors acting to produce and preserve organic matter. The earlier event was widespread: it had been observed in the Angola Basin (Site 364), the Cape Basin (Site 361), and on the Falkland Plateau (Site 327, 330, and 511). The later event is of more limited occurrence and is known only from the Angola Basin (Sites 363, 364, and 530) and the northern slope of the Rio Grande Rise (Site 516).

The Angola Basin was sufficiently oxygenated during most of the Late Cretaceous to support an active benthic infauna. There were periods of shorter and longer duration when several of the factors previously noted combined to produce bottom-water conditions that fluctuated between mildly oxic and slightly anoxic. Pelagic, hemipelagic, and turbiditic processes continued as normal during these periods, but the sediments deposited contained and preserved a higher concentration of organic matter, remained unbioturbated or at least less bioturbated, and subsequently formed the black and gray-black shales.

We cored $19 \mathrm{~m}$ of medium gray, fine-grained basalt (Unit 9), containing veins and vugs filled with calcite. White veins and veinlets of calcite extend from the basalt into the overlying reddish mudstone for a distance of about $5 \mathrm{~cm}$; the mudstone above the basalt appears to be hydrothermally altered or baked for a distance of about $1 \mathrm{~m}$ above the contract.

\section{Seismic Units in the Southeastern Angola Basin}

\section{Main Acoustic Units}

Four main acoustic units separated by major discontinuities can be followed in the southeastern Angola Ba$\sin$. Their thicknesses and nature are defined at Site 530 .

Acoustic Unit 1 (0-277 m), characterized by discontinuous and hatched reflectors, corresponds to lithologic Units 1 and 2 and is Recent to late Miocene.

Acoustic Unit $2(277-467 \mathrm{~m})$ is a transparent layer of late Miocene to late Oligocene age, which corresponds to lithologic Unit 3.

Between acoustic Units 2 and 3 a major seismic discontinuity corresponds to the $20 \mathrm{~m}$.y. condensed section representing the late Oligocene to middle Eocene.

Acoustic Unit $3(467-790 \mathrm{~m})$ is a highly stratified sequence of early Eocene to early Campanian age which corresponds to lithologic Units 4 and 5 .

Acoustic Unit 4 (790-1103 m), in which the stratification decreases downward, corresponds to lithologic Units 6,7 , and 8 and is early Campanian to late Albian.

\section{Main Discontinuities}

The major discontinuity on the seismic records is the boundary between acoustic Units 2 and 3 . It corresponds to the $20 \mathrm{~m} . \mathrm{y}$. condensed section from middle Eocene to late Oligocene and is associated with both the late Eocene change in plate motions (Anomaly 13) and a $150-\mathrm{m}$ rise of sea level. Acoustic Unit 2 consists of a red and green pelagic mud section with turbidites. Regional onlap of the lower part of this sequence is shown on Fig. 4. Clearly, the turbidites come through channels from the African margin and not from the Walvis Ridge. During the $20 \mathrm{~m}$.y. of middle Eocene to late Oligocene condensed section with hiatuses, a slight warping of the ocean floor could have occurred as a result of late Eocene tectonic movements, or the $50 \mathrm{~m}$ difference in subsidence between the ridge and the oceanic crust may be because of the difference in age of the ridge and the adjacent basin. This could explain the continuous belts of onlap in the Angola Basin just north of the ridge.

Another important seismic discontinuity is in the early Campanian and is associated with a significant change in plate motions at the time of Anomaly 34 .

\section{Depth of the Seafloor through Time at Site 530}

Using the new empirical curve for seafloor subsidence in the Angola and Brazil basins and sediment accumulation rates, the depth of the seafloor beneath present sea level at Site 530 has been calculated and is presented in Table 18.

\section{Calcium Carbonate Compensation Depth}

Figure 70 shows the depth of the seafloor at Site 530 through time. Sediments with less than $10 \% \mathrm{CaCO}_{3}$ are indicated by a heavy line. The sea level curve of Vail et al. (1977) with isostatic adjustment for sea level in the ocean basins is shown at the same vertical scale. If the prime control of carbonate compensation is sea level changes, the sea level falls of the Vail et al. curve might be recognized in the carbonate/noncarbonate sediments 


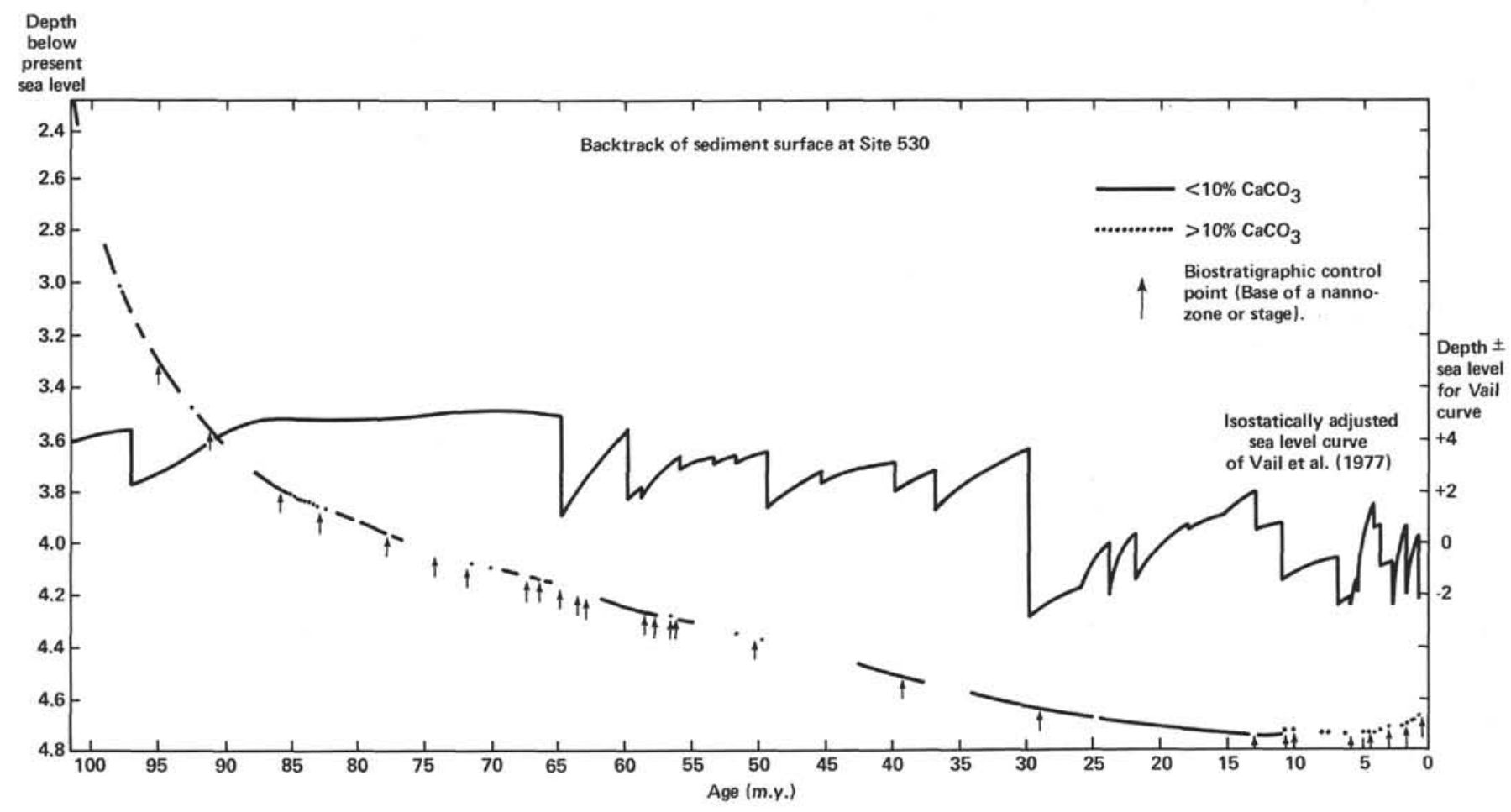

Figure 70. Backtrack of sediment surface at Site 530.

Table 18. Depth of seafloor below present sea level at Site 530 .

\begin{tabular}{rccc}
\hline $\begin{array}{c}\text { Age } \\
(\mathrm{m} . \mathrm{y})\end{array}$ & $\begin{array}{c}\text { Depth of seafloor } \\
\text { below present sea level } \\
(\mathrm{km})\end{array}$ & $\begin{array}{c}\text { Age } \\
(\mathrm{m} . \mathrm{y} .)\end{array}$ & $\begin{array}{c}\text { Depth of seafloor } \\
\text { below present sea level } \\
(\mathrm{km})\end{array}$ \\
\hline 0 & 4.645 & 25 & 4.671 \\
1 & 4.680 & 30 & 4.631 \\
2 & 4.705 & 35 & 4.577 \\
3 & 4.702 & 40 & 4.506 \\
4 & 4.724 & 45 & 4.437 \\
5 & 4.730 & 50 & 4.371 \\
6 & 4.726 & 55 & 4.299 \\
7 & 4.725 & 60 & 4.249 \\
8 & 4.724 & 65 & 4.156 \\
9 & 4.723 & 70 & 4.106 \\
10 & 4.722 & 75 & 4.026 \\
11 & 4.735 & 80 & 3.913 \\
12 & 4.743 & 85 & 3.821 \\
13 & 4.744 & 90 & 3.624 \\
14 & 4.739 & 92 & 3.512 \\
15 & 4.733 & 95 & 3.307 \\
16 & 4.727 & 97 & 3.126 \\
17 & 4.721 & 98 & 3.010 \\
18 & 4.716 & 99 & 2.866 \\
19 & 4.709 & 100 & 2.672 \\
20 & 4.703 & 101 & 2.369 \\
\hline
\end{tabular}

Note: Assumes age of basement is 102.5 m.y.; present water depth is $4.645 \mathrm{~km}$; thickness of sediment is $1.103 \mathrm{~km}$; average density of sediment is $2.2 \mathrm{~g} / \mathrm{cm}^{3}$.

at Site 530. Sea level falls should appear as boundaries, separating older sediments with less than $10 \%$ carbonate from younger sediments with more than $10 \%$ carbonate. The following third-order sea-level cycle boundaries may be represented at Site 530: top Q2, Q2/Q1, TP3/ Q1, TP2/TP3, TM3.1/TM3.2, TM2.3/TM3.1, T01/02.1 (indicated at 34 m.y. on our diagram, but biostrati-

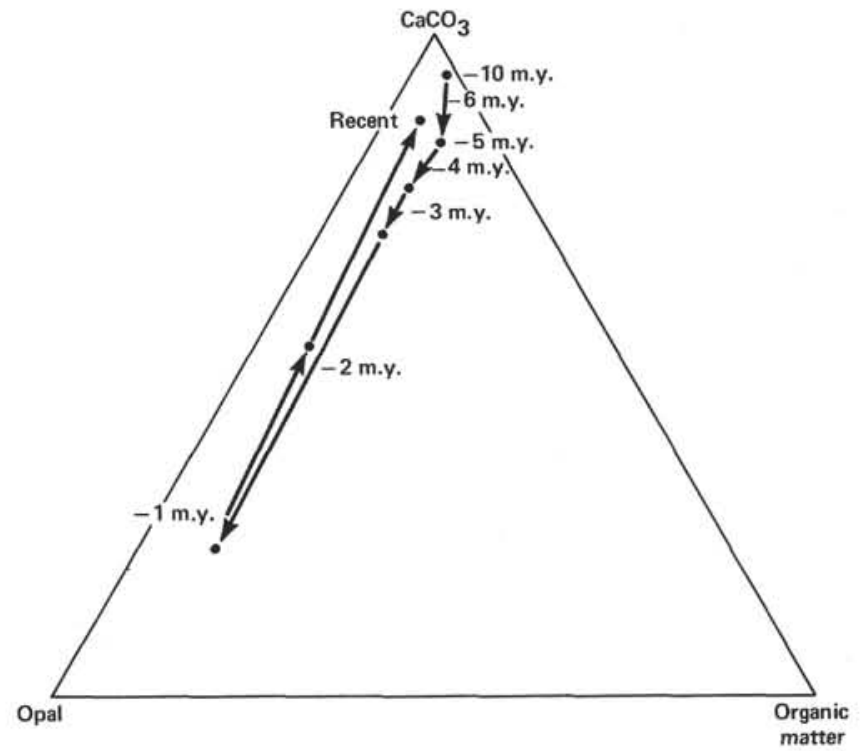

Figure 71. Development of the Benguela upwelling system.

graphic control in this part of the section is very poor), TE2-2/TE3, TE1.2/TE2.1, TE1.1/TE1.2, TP2.2/TP2.3, and TP1/TP2 (shown at $62 \mathrm{~m} . \mathrm{y}$. on our diagram but without close biostratigraphic control). Except for those discussed above, the correlations are very close, within 1 m.y. The discrepancy for T01/T02.1 is only 4 m.y. and occurs in the condensed section with poor biostratigraphic control; the discrepancy for TP1/TP2.1 is apparently 2 m.y. but the age assignment of Vail et al. (1977) is within the same nannofossil zone as is the $>10 \%<$ carbonate boundary at Site 530 . 


\section{Development of the Benguela Upwelling System}

The development of the upwelling system can be followed in Figure 71, which shows the changing proportions of the biogenic components of the sediment.

\section{REFERENCES}

Almeida, F. F. M. de, 1968. Radiometric age determinations from northeastern Brazil. Bol. Soc. Bras. Geol., 17:3-14.

Alvarez, W., Arthur, M. A., Fischer, A. G., Lowrie, W., Napoleone, G., Premoli Silva, I., and Roggenthen, W. M., 1977. Upper Cretaceous-Paleocene geomagnetic reversal time scale. Geol. Soc. Am. Bull., 88:383-389.

Archie, G. E., 1942. The electrical resistivity log as an aid in determining some reservoir characteristics. Am. Inst. Mining Metall. Pet. Engineers Trans., 146:54.

Arthur, M. A., and Natland, J. H., 1979. Carbonaceous sediments in the North and South Atlantic: The role of salinity in stable stratification of Early Cretaceous basins. In Talwani, M., Hay, W., and Ryan, W. B. F. (Eds.), Deep Drilling Results in the Atlantic Ocean: Continental Margins and Paleoenvironment: Washington (Am. Geophys. Union), Series 3, pp. 375-401.

Baker, P. E., 1957. Density logging with gamma rays. Trans. AIME, 210:280-291.

Bé, A. W. H., 1977. An ecological, zoogeographic and taxonomic review of Recent planktonic foraminifera. In Ramsey, A. T. S. (Ed.), Oceanic Micropaleontology: New York (Academic Press) 1: $1-100$, pl. 2-12.

Bolli, H. M., Ryan, W. B. F., et al., 1978. Init. Repts. DSDP, 40: Washington (U.S. Govt. Printing Office).

Bouma, A. H., 1962. Sedimentology of some flysch deposits: A graphic approach to facies interpretation: Amsterdam (Elsevier).

Boyce, R. E., 1976a. Definitions and laboratory techniques of compressional sound velocity parameters and wet-water content, wetbulk density, and porosity parameters by gravimetric and gamma ray attenuation techniques. In Schlanger, S. O., Jackson, E. D., et al., Init. Repts. DSDP, 33: Washington (U.S. Govt. Printing Office), 931-958.

1976b. Sound velocity-density parameters of sediment and rock from DSDP drill Sites $315-318$ on the Line Islands Chain, Manihila Plateau, and Tuamota Ridge in the Pacific Ocean. In Schlanger, S. O., Jackson, E. D., et al., Init. Repts. DSDP, 33: Washington (U.S. Govt. Printing Office), 695-728.

1977. Deep sea drilling procedures for shear strength measurements of clayey sediment using modified Wykeham Farrance laboratory vane apparatus. In Barker, P., and Dalziel, W. D., et al., Init. Repts. DSDP, 36: Washington (U.S. Govt. Printing Office), 1059-1068.

Brass, G., Salzman, E., Sloan, J. R., II, Southam, J. R., Hay, W. W., Holser, W., and Peterson, W. H., 1982. Ocean circulation, plate tectonics and climate. Climate in Earth History: Washington (National Academy Press) (N.R.C. Geophysics Study Comm.).

Cande, S., and Rabinowitz, P. D., 1978. Mesozoic seafloor spreading bordering conjugate continental margins of Angola and Brazil. Proc. Offshore Tech. Conf.: Houston (Rept. OTC, Paper 3268), pp. $1869-1876$.

Cornford, C., Rullkötter, J., and Welte, D. H., 1979. Organic geochemistry of DSDP Leg 47A, Site 397, eastern North Atlantic: Organic petrography and extractable hydrocarbons. In von Rad, U., Ryan, W. B. F., et al., Init. Repts. DSDP, 47, Pt. 2: Washington (U.S. Govt. Printing Office), 511-522.

Degens, E. T., and Mopper, K., 1976. Factors controlling the distribution and early diagenesis of organic material in marine sediments. In Riley, J. P., and Chester, R. (Eds.), Chemical Oceanography (Vol. 6): New York (Academic Press), 59-113.

Degens, E. T., and Stoffers, P., 1976. Stratified waters as a key to the past. Nature: 263:22-27.

Deroo, G., Herbin, J. P., and Roucaché, J., 1978. Organic geochemistry of some Neogene cores from Sites 374, 375, 377 and 378: Leg 42A eastern Mediterranean Sea. In Ross, D. A., Neprochnov, Y. P., et al., Init. Repts. DSDP, 42, Pt. 2: Washington (U.S. Govt. Printing Office), 465-472.
Detrick, R., and Watts, A. B., 1979. An analysis of isostasy in the world's oceans: Aseismic ridges. J. Geophys. Res., 84:3637-3653.

Doll, H. G., 1949. Introduction of induction logging and application logging of wells drilled with oil base mud. Trans. AIME, 186: $148-164$.

1951. The Laterolog: A new resistivity logging method with electrodes using an automatic focusing system. Trans. AIME, 192: 305-316.

Espitalié, J., Madec, M., and Tissot, B., 1977. Source rock characterization method for petroleum exploration. Proc. Offshore Technology Conf.: Houston, (Rept. OTC, Paper 2935), pp. 439-444.

Evans, H. B., 1965. GRAPE-A device for continuous determination of material density and porosity. Trans. 6th Ann. SPWIA Logging Symp. (Dallas), 2:B1-B25.

Fischer, A. G., and Arthur, M. A., 1977. Secular variation in the pelagic realm. In Cook, H. E., and Enos, P. (Eds.), Deep Water Carbonate Environments (SEPM Spec. Publ.) 25:19-50.

Gallois, R. W., 1976. Coccolith blooms in the Kimmeridgian and the origin of North Sea oil. Nature, 259:473-475.

Goodell, H. G., 1972. Carbon/nitrogen ratio. In Fairbridge, R. W. (Ed.), Encyclopedia of Geochemistry and Environmental Science: New York (Van Nostrand Reinhold), pp. 136-142.

Goslin, J., Mascle, J., Sibuet, J-C., and Hoskins, H., 1974. Geophysical study of the easternmost Walvis Ridge, South Atlantic: Morphology and shallow structure. Geol. Soc. Am. Bull., 85: 619-632.

Goslin, J., and Sibuet, J-C., 1975. Geophysical study of the easternmost Walvis Ridge, South Atlantic: Deep structure. Geol. Soc. Am. Bull., 86:1713-1724.

Hallam, A., 1967. An environmental study of the upper Domerian and lower Toarcian in Great Britain. Phil. Trans. R. Soc., 252: 393-445.

Hallam, A., and Bradshaw, M. J., 1979. Bituminous shales and eolitic ironstones as indicators of transgressions and regressions. $J$. Geol. Soc. London, 136:157-164.

Hamilton, E. L., 1976. Variations of density and porosity within deepsea sediments. J. Sed. Petrol., 46:280-300.

Hardenbol, J., and Berggren, W. A., 1978. A new Paleogene numerical time scale. In Cohee, G. U., Glaessner, M. F., and Hedberg, H. D. (Eds.), The Geologic Time Scale. (Am. Assoc. Petrol. Geol., Studies in Geology), 6:213-234.

Hékinian, R., 1972. Volcanics from the Walvis Ridge. Nature, 239: 91-93.

Horne, R. A., and Frysinger, G. R., 1963. The effect of pressure on the electrical conductivity of sea water. J. Geophys. Res., 68:1967.

Jenkins, D. G., 1978. Neogene planktonic foraminifers from DSDP Leg 40, Sites 360 and 362 in the southeastern Atlantic. In Bolli, H. M., Ryan, W. B. F., et al., Init. Repts. DSDP, 40: Washington (U.S. Govt. Printing Office), 723-739.

Jenkyns, H. C., 1980. Cretaceous anoxic events: From oceans to continents. J. Geol. Soc, London, 137:171-188.

Keating, B., 1976. Contributions to paleomagnetism [Ph.D. dissert.]. University of Texas at Dallas.

Keating, B. H., and Helsley, C. E. 1978a. Magnetostratigraphic studies of Cretaceous sediments from DSDP Site 369. In Lancelot, Y., Seibold, E., et al., Init. Repts. DSDP, 41: Washington (U.S. Govt. Printing Office), 498.

$1978 \mathrm{~b}$. Magnetostratigraphy of Cretaceous sediments from DSDP Sites 361, 363, and 364. In Bolli, H. M., Ryan, W. B. F., et al., Init. Repts. DSDP, 40: Washington (U.S. Govt. Printing Office), 459-467.

1978c. Paleomagnetic results from DSDP Hole 391C and the magnetostratigraphy of Cretaceous sediments from Atlantic Ocean floor. In Benson, W. E., Sheridan, R. E., et al., Init. Repts. DSDP, 44: Washington (U.S. Govt. Printing Office), 523-528. 1979. Magnetostratigraphy of Cretaceous sediments from DSDP Site 386. In Tucholke, B., Vogt, P., et al., Init. Repts. DSDP, 43: Washington (U.S. Govt. Printing Office), 781-784.

, in press. Cretaceous magnetostratigraphy. In Kauffman, E., and Haite (Eds.), The Temperate and Boreal Cretaceous. (N. Am. Paleon. Conv.).

Keating, B. H., Helsley, C. E., and Pessagno, E. A., Jr., 1975. Late Cretaceous reversal sequence. Geology, 2:73. 
Keller, G. V., and Frischknecht, F. C., 1966. Electrical Methods in Geophysical Prospecting: New York (Pergamon Press).

Keller, G. V., Grose, L. T., Murray, J. C., Skokan, C. K., 1979. Results of an experimental drill hole at the summit of Kilauea Volcano, Hawaii. J. Volc. Geoth. Res., 5:345-385.

Kogan, M. G., 1979. Gravity anomalies and origin of the Walvis Ridge. J. Geophys. Res., 84:6019-6025.

Kokesh, F. P., 1951. Gamma ray logging. Oil Gas J., 50:284-290.

Kokesh, F. P., Schwartz, R. J., Wall, W. B., and Morris, R. L., 1965. A new approach to sonic logging and other acoustic measurements. J. Petrol. Tech., 17:282-286.

Krasheninnikov, V. A., 1973. Cretaceous benthic foraminifera, Leg 20, Deep Sea Drilling Project, In Heezen, B. C., MacGregor, I. D., et al., Init. Repts. DSDP, 20: Washington (U.S. Govt. Printing Office), 205-219.

1974. Upper Cretaceous benthonic agglutinated foraminifera, Leg 27 of the Deep Sea Drilling Project. In Veevers, J. J., Heirtzler, J. R., et al., 27: Init. Repts. DSDP, Washington (U.S. Govt. Printing Office), 631-661.

Ladd, J. W., 1974. South Atlantic sea floor spreading and Caribbean tectonics [Ph.D. dissert.]. Columbia Univ., New York.

Lynch, E. J., 1962. Formation Evaluation: New York (Harper \& Row).

McNulty, C. L., 1979. Smaller Cretaceous Foraminifera of Leg 43, Deep Sea Drilling Project. In Tucholke, B. E., Vogt, P. R., et al., 43: Init. Repts. DSDP, Washington (U.S. Govt. Printing Office), 487-505.

Moore, A. E., 1976. Controls of post-Gondwanaland alkaline volcanism in southern Africa. Earth Planet. Sci. Lett., 31:291-296.

Moran, J. H., and Kunz, J. S., 1962. Basic theory of induction logging and application to study of two-coil sondes. Geophysics, 27: 829-858.

Morris, R. L., Grine, D. R., and Arkfeld, T. E., 1963. The use of compressional and shear acoustic amplitudes for the location of fractures: 38th Ann. Mtg. Soc. Petrol. Eng. AIME (Paper SPE 723), pp. 1-13.

Ness, G., Levi, S., and Couch, R., 1980. Marine magnetic anomaly time scale, for the Cenozoic and Late Cretaceous: A precis, critique and synthesis. Rev. Geoph. Sp. Physics, 18:753-770.

Neumann, G., and Pierson, W. J., Jr., 1966. Principles of Physical Oceanography: Englewood (Prentice-Hall).

Obradovich, J. D., and Cobban, W. A., 1975. A time scale for the Late Cretaceous of the western interior of North America. Geol. Assoc. Canada, (Spec. Paper No. 13), pp. 31-54.

Olausson, E., 1960. Description of cores from the Mediterranean Sea and the Red Sea. Rept. Swedish Deep Sea Expedition, 1947-48, $8:(5): 287-334 ;(6): 337-391$.

Pastouret, L., and Goslin, J., 1974. Middle Cretaceous sediments from the eastern part of Walvis Ridge. Nature, 248:495-496.

Payton, C. E., 1977. Seismic stratigraphy-Applications to hydrocarbon exploration. Am. Assoc. Petrol. Geol. Mem., 26.

Perch-Nielsen, K., 1979. Calcareous nannofossils from the Cretaceous between the North Sea and the Mediterranean. In Wiedmann, J. (Ed.), Aspekte der Kreide Europas (IUGS, Series A, No. 6), pp. 223-272.

Rabinowitz, P. D., 1976. A geophysical study of the continental margins of southern Africa. Geol. Soc. Am. Bull., 27:1643-1653.

Rocker, K., 1974. Physical properties measurements and test procedures for Leg 27. In Veevers, J. J., Heirtzler, J. R., et al. Init. Repts. DSDP, 27: Washington (U.S. Govt. Printing Office), 433-443.
Roth, P. H., 1973 Calcareous nannofossils, Leg 17, Deep Sea Drilling Project. In van Andel, Tj. H., Heath, G. R., et al., Init. Repts. $D S D P, 17$ : Washington (U.S. Govt. Printing Office), 695-795.

Ryan, W. B. F., et al., 1978. Objectives, principal results, operations, and explanatory notes of Leg 40 . In Bolli, H. B., Ryan, W. B. F., et al., Init. Repts. DSDP, 40: Washington (U.S. Govt. Printing Office), 5-28.

Sherman, H., and Locke, S., 1975. Effect of porosity on depth of investigation of neutron and density sondes. 50th Ann. Mtg. Soc. Petrol. Eng. AIME, (Pap. SPE 5510), pp. 1-12.

Sibuet, J.-C., and Mascle, J., 1978. Plate kinematic implications of Atlantic equatorial fracture zone trends. J. Geophys. Res., 83: 3401-3421.

Siesser, W. G., 1980. Late Miocene origin of the Benguela upwelling system off northern Namibia. Science, 208:283-285.

Sissingh, H. W., 1977. Biostratigraphy of Cretaceous calcareous nannoplankton. Geol. en Mijnb., 56(1):37-56.

Sliter, W. V., 1977. Cretaceous benthic foraminifers from the western South Atlantic Leg 39, Deep Sea Drilling Project. In Supko, P. R., Perch-Nielsen, K., et al., Init. Repts. DSDP, 39: Washington (U.S. Govt. Printing Office), 657-697.

Thiede, J., and Dinkelman, M. G., 1976. Occurrence of Inoceramus remains in late Mesozoic pelagic and hemipelagic sediments. In Perch-Nielsen, K., Supko, P., et al., Init. Repts. DSDP, 34: Washington (U.S. Govt. Printing Office), 899-910.

Thiede, J., and van Andel, Tj. H., 1977. The deposition of anaerobic sediments in the late Mesozoic Atlantic Ocean. Earth Planet. Sci. Lett., 33:301-309.

Thierstein, H. R., 1976. Mesozoic calcareous nannoplankton biostratigraphy of marine sediments. Mar. Micropaleontology, 1: 325-362.

Thomas, B. D., Thompson, T. G., and Utterback, C. L., 1934. The electrical conductivity of sea water. Jour. Conseil. Internat. Explor. Mer., 9:28-35.

Tyson, R. V., Wilson, R. C. L., and Downie, C., 1979. A stratified water column environmental model for the type Kimmeridge clay. Nature, 277:377-380.

Vail, P. R., Mitchum, R. M., Todd, R. G., Widmier, J. M., Thompson, III, S., Sangree, J. B., Bubb, J. N., and Hatlelid, W. G., 1977. Seismic stratigraphy and global changes of sea level. In Payton, C. E. (Ed.), Seismic Stratigraphy-Applications to Hydrocarbon Exploration. Am. Assoc. Petrol. Geol. Mem., 26: 49-212.

van Andel, Tj. H., Thiede, J., Sclater, J. G., and Hay, W. W., 1977. Depositional history of the South Atlantic Ocean during the last 125 m.y. J. Geol., 85:651-698.

Van Hinte, J. E., 1978. A Cretaceous time scale. In Cohee, G. H., Glaessner, M. F., and Hedberg, H. D. (Eds.), The Geologic Time Scale. (Am. Assoc. Petrol. Geol., Studies in Geology), 6:269-288.

Vincent, E., 1977. Indian Ocean Neogene planktonic foraminiferal biostratigraphy and its paleoceanographic implications. In Heirtzler, J. R., Bolli, H. M., Davies, T. A., Saunders, J. B., and Sclater, J. G. (Eds.), Indian Ocean Geology and Biostratigraphy. (Am. Geophys. Union), pp. 469-584.

Wahl, J. S., Tittman, J., and Johnstone, C. W., 1964. The dual spacing formation density log. J. Petrol. Technol., 16:1411-1416.

Welte, D. H., Cornford, C., and Rullkotter, D., 1979. Hydrocarbon source rocks in deep sea sediments, Proc. Offshore Technology Conf., (Report OTC, Pap. 3408), pp. 457-464.

Date of Initial Receipt: August 22, 1982 


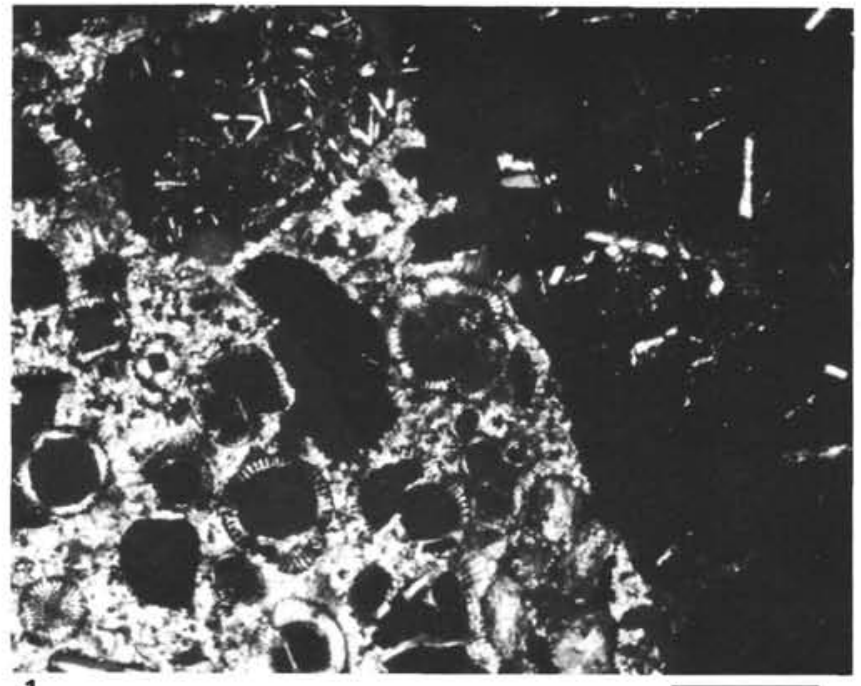

1

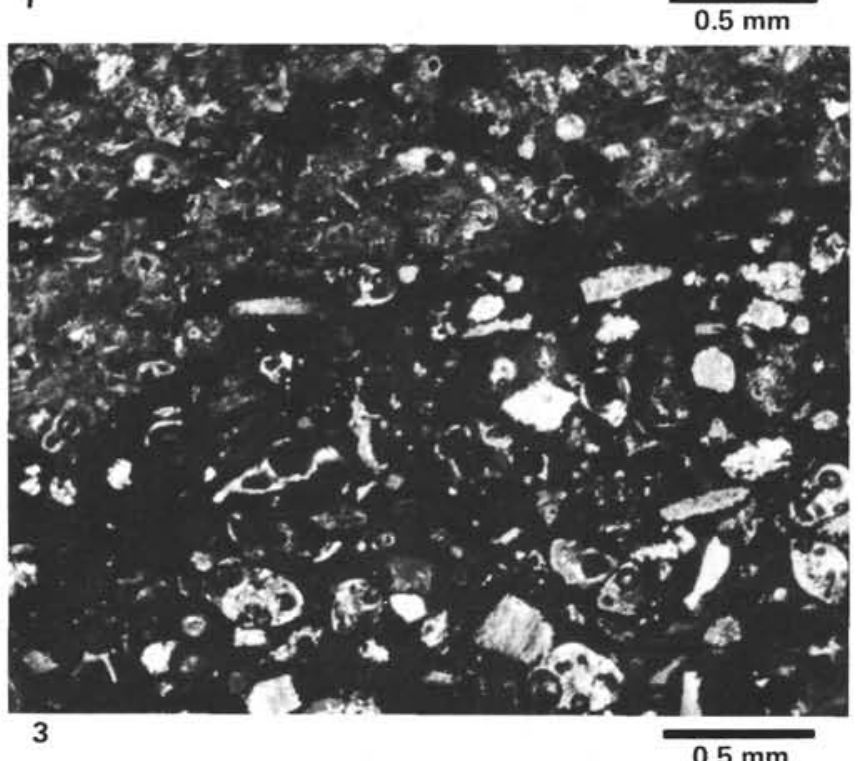

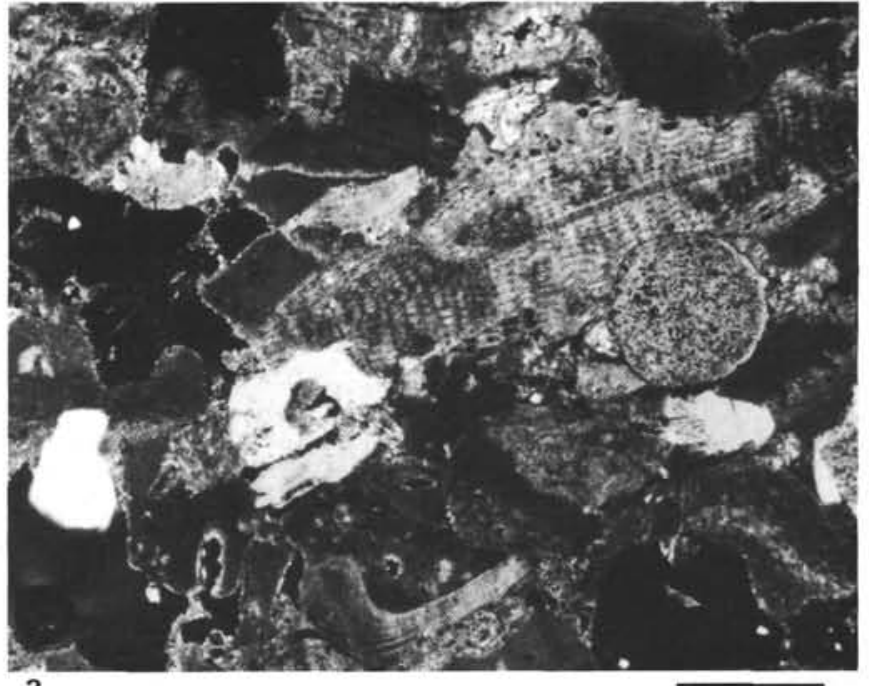

2

$0.5 \mathrm{~mm}$

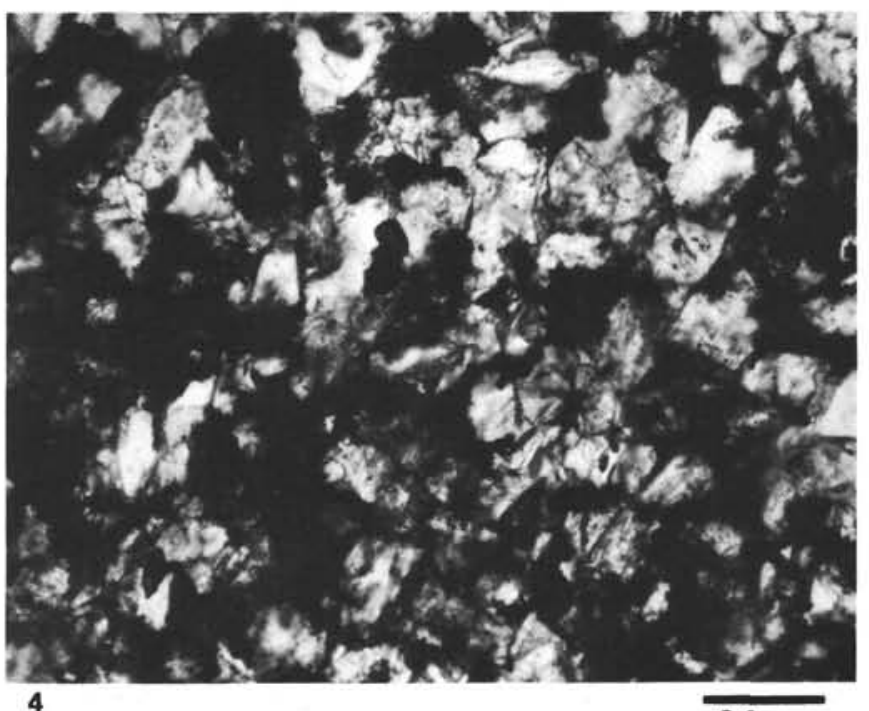

$0.1 \mathrm{~mm}$

Plate 1. Representative lithologies, Site 530. 1. Foraminifers and volcanic rock fragments with sparry calcite cement forming a volcanic breccia (Sample 530A-23-1, 0-20 cm; cross-polarized light). 2. Silicified lithic and bioclastic limestone containing shallow-water benthic foraminifers, glauconite, volcanic glass, and feldspar; lithologic Unit 4 (Sample 530A-39-2, 56-60 cm; cross-polarized light). 3. Detrital bioclastic limestone (darker) that has been partly silicified (lighter); lithologic Unit 5a. (Sample 530A-51-4, 68-70 cm; cross-polarized light). 4. Carbonate-cemented quartz sandstone; lithologic Unit $5 \mathrm{~b}$. (Sample 530A-59-1, $120 \mathrm{~cm}$; cross-polarized light). 5. Carbonate and volcanic sandstone. Carbonate-cemented volcanic rock fragment; lithologic Unit 5c (Sample 530A-70-4, 39-42 cm; plane polarized light). 6. Fragments of prismatic layers of the mollusk Inoceramus with borings filled with silica. Also shown are benthic foraminifers and volcanic rock fragments; lithologic Unit 6 (Sample 530A-82-1, 96-98 cm; cross-polarized light). 7. Veins of calcite in red mudstone (lithologic Unit 8) at contact with basalt (lithologic Unit 9) (Sample 530A-105,CC; cross-polarized light). 
SITE 530
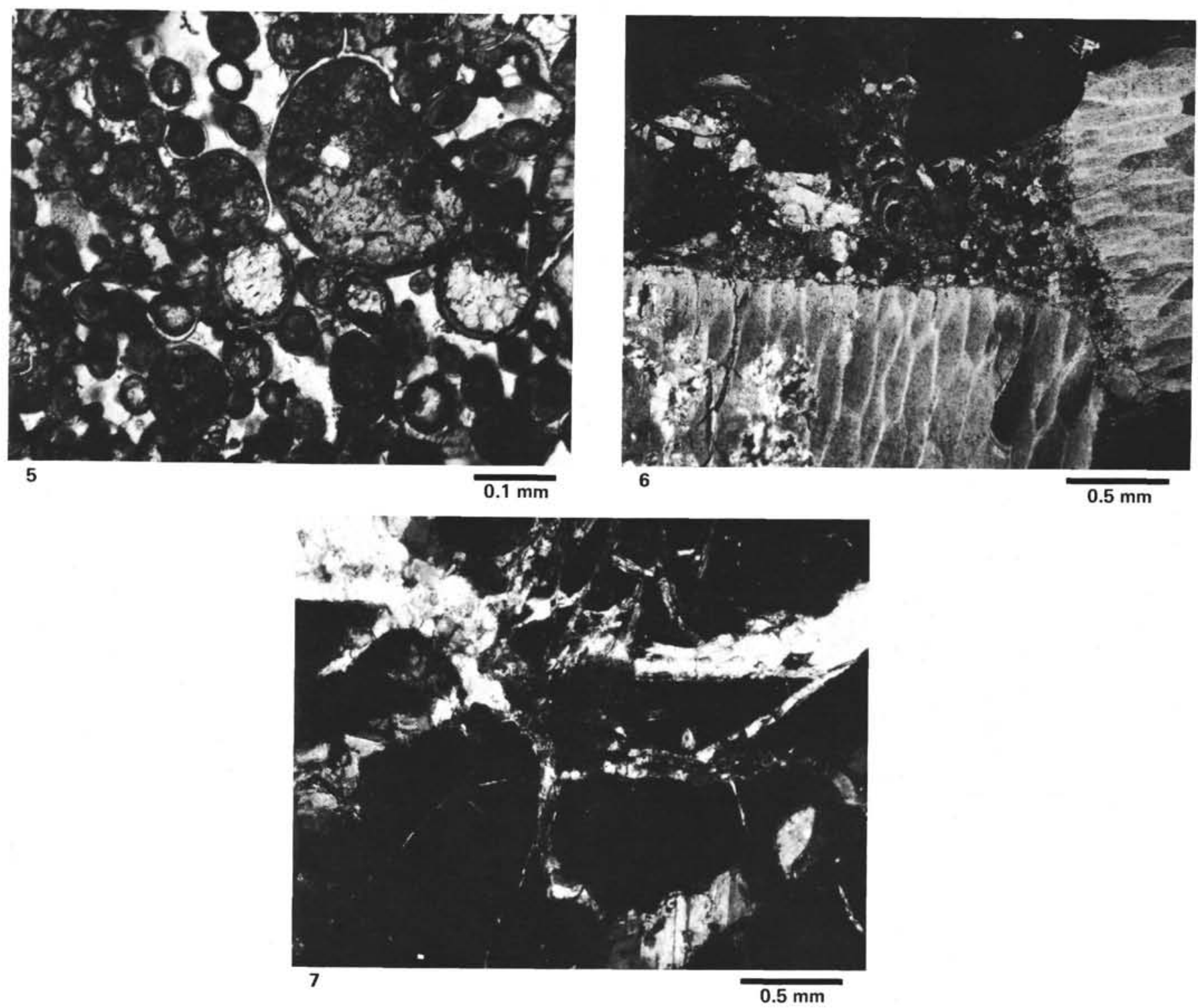

Plate 1. (Continued). 
APPENDIX A

Summary of Smear Slide Results for Holes 530, 530A, and 530B

Hole 530

\begin{tabular}{|rl} 
& TRACE \\
$<5 \%$ & RARE \\
$5-25 \%$ & COMMON \\
$25-50 \%$ & ABUNDANT \\
$>50 \%$ & DOMINANT
\end{tabular}

* = minor lithology

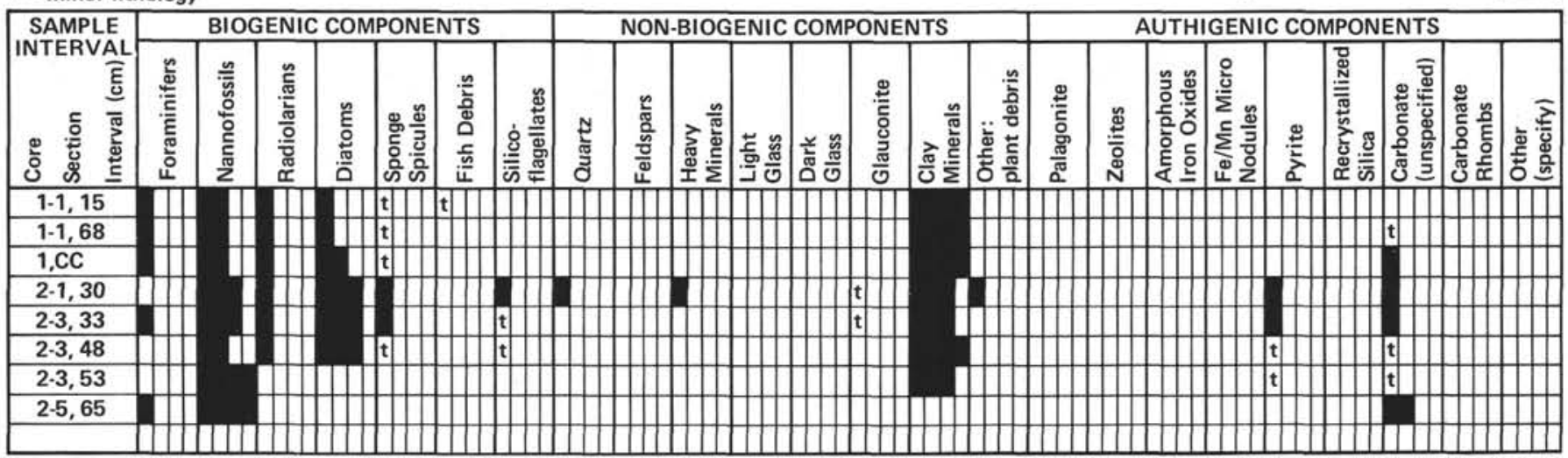

Hole 530A

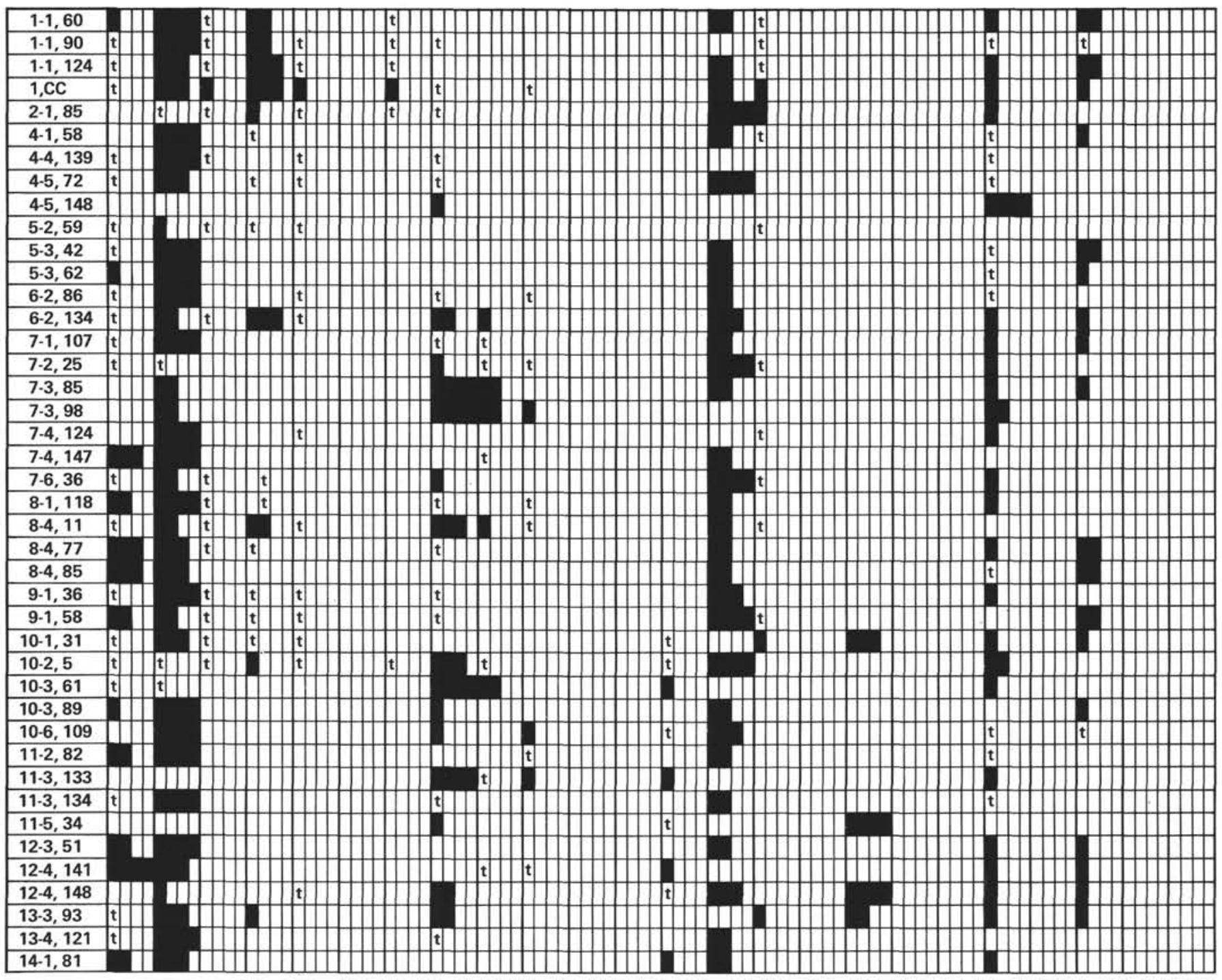


Appendix A. (Continued).

SMEAR SLIDE SUMMARY

Hole 530A
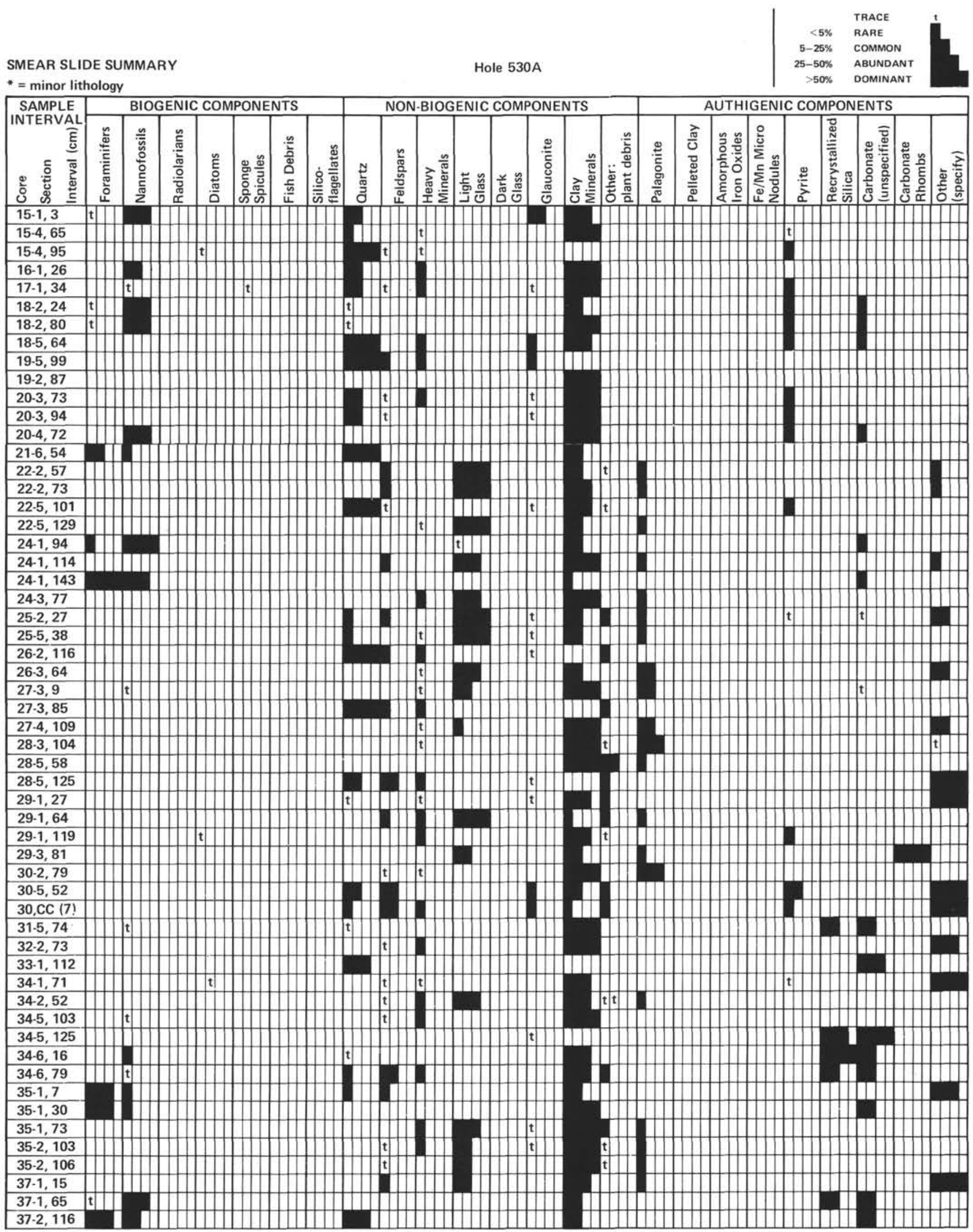
Appendix A. (Continued).

SMEAR SLIDE SUMMARY

Hole 530A

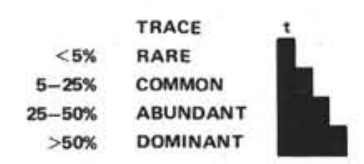

* = minor lithology

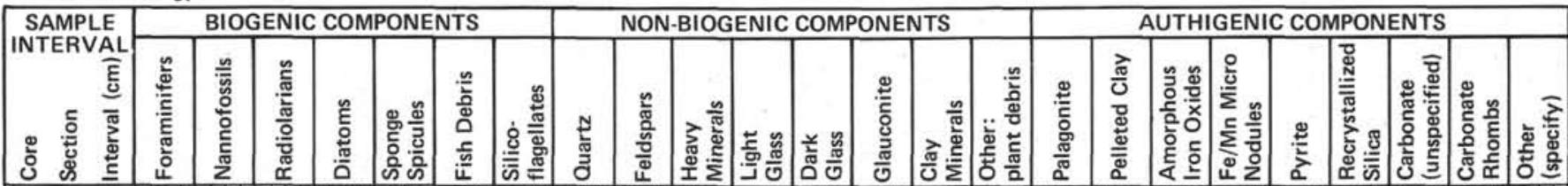

61-1, 57

$61-1,59$

$61-3,57$

$61-3,122$

$62-1,82$

62-2, 30

63-3, 72

63-3, 87

64-2, 64

$64-3,4$

67-1, 72

78-1, 121

78-2, 107

78-3, 113

$79-1,63$

79-2, 33

$79 \cdot 3,110$

$79-4,5$

$79-5,13$

79-5, 136

$80-1,100$

$81-1,19$

$81-2,50$

$81-2,56$

$82-2,72$

$82-5,48$

$82-5,148$

$83-2,12$

83-2, 39

83-4, 39

$84-1,56$

$84-1,103$

$84-2,117$

85-1, 4

$85-1,55$

$85 \cdot 3,49$

85-4, 123

86-1, 37

86-2, 37

$86-4,123$

86-5, 34

$87.4,23$

\begin{tabular}{|l}
$87.4,26$ \\
\hline $87.4,31$
\end{tabular}

87-4, 31

87.5, 36

88-3, 89

$88-3,113$

88-3, 122

$88, \mathrm{CC}(5)$

\begin{tabular}{|l}
\hline $89-1,64$ \\
\hline $89-1,73$ \\
\hline $89-1,80$ \\
\hline
\end{tabular}

89-1, 80

89-2, 120

90-1, 48

90-3, 75

90-3, 84
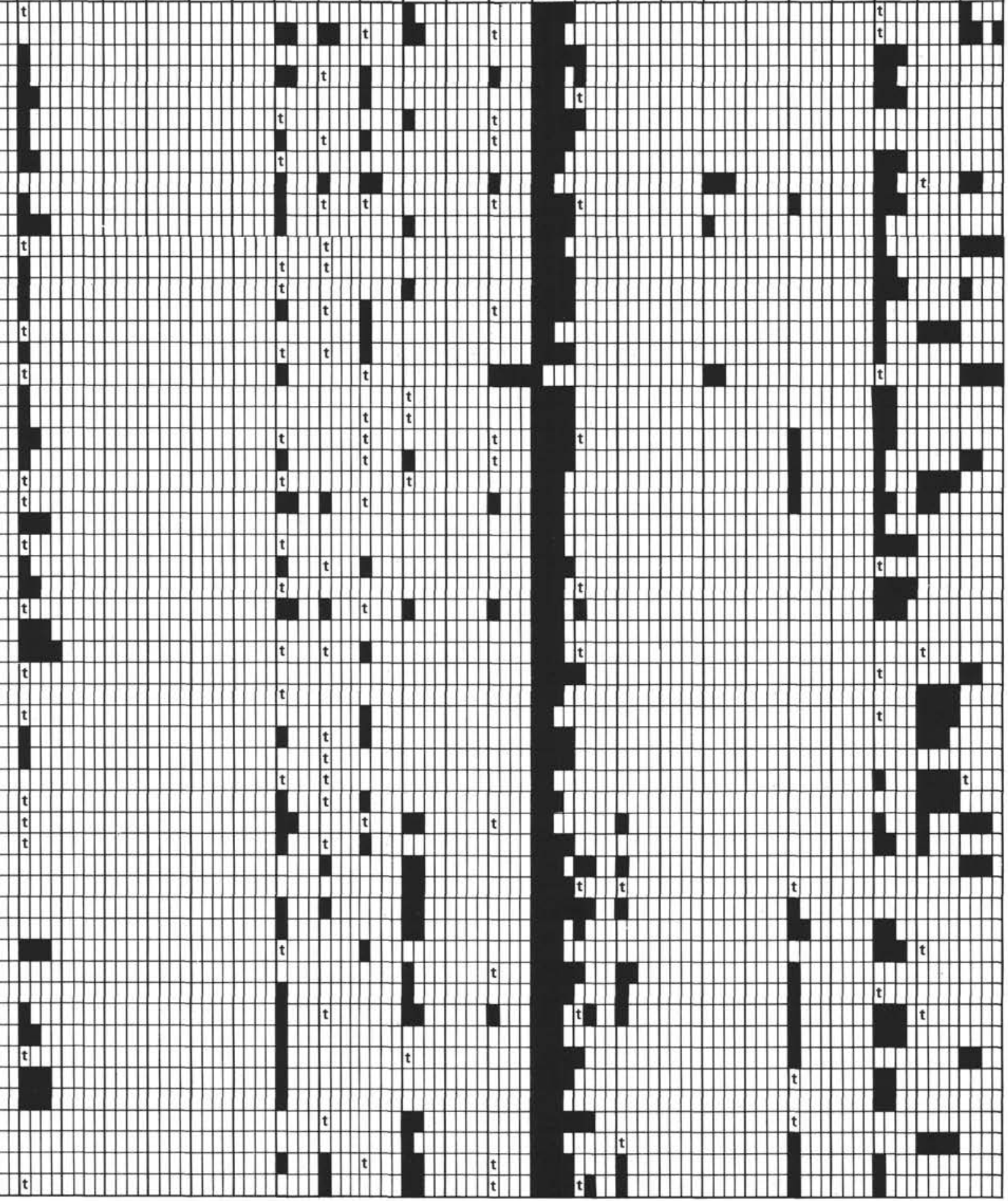
Appendix A. (Continued).

SMEAR SLIDE SUMMARY

Hole 530A

* = minor lithology

SAMPLE

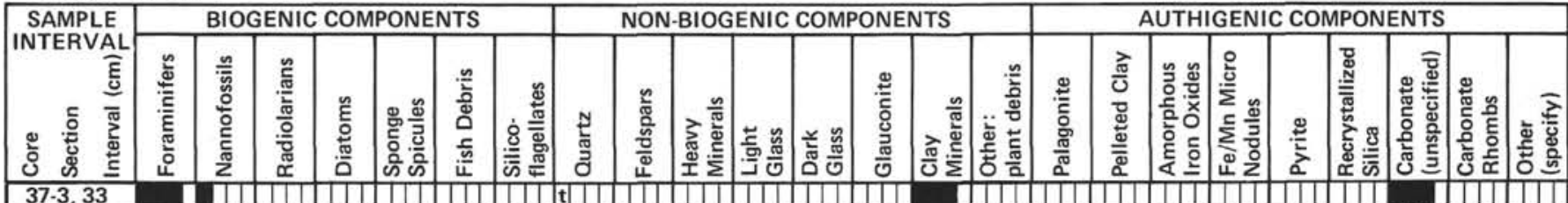

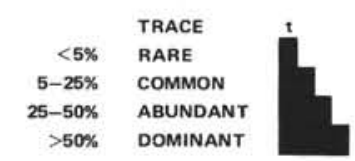

\begin{tabular}{|l|}
\hline $37-3,33$ \\
\hline $37-3,43$ \\
\hline $38-1,78$ \\
\hline
\end{tabular}

$37-3,43$
$38-1,78$

38-1, 89

$39-1,63$

39-1, 137

39-2, 54

39-2, 70

41-1, 106

$41, \mathrm{CC}(8)$

$41-3,146$

$42-1,13$

$42, \mathrm{CC}(8)$

43-1, 82

43-2, 91

$43, \mathrm{CC}$ (5)

4-2, 109

45-1, 37

$47-1,71$

$48-1,35$

48-1, 37

$48-1,98$

$49-1,49$

49-1, 89

$49 \cdot 1,108$

$49, \mathrm{CC}$ (12)

50-1, 24

$50-1,30$

50-2, 31

$50-2,104$

50-3, 68

50-4, 16

$50-4,126$

$51-1,62$

$51-2,25$

$51-2,29$

$52-1,65$

53-1, 55

53-1, 108

$53, \mathrm{CC}(5)$

54-1, 56

54-1, 69

55-1, 42

$55-5,67$

$55-5,122$

$55-5,126$

$56-1,122$

\begin{tabular}{l}
$57-2,85$ \\
\hline $57-2,38$
\end{tabular}

$57-2,38$

$58-1,13$

$59-1,42$

$59-1,94$

60-1, 97

$60-2,113$

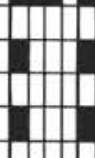
$10 \mathrm{t} t \mathrm{t}$

TII
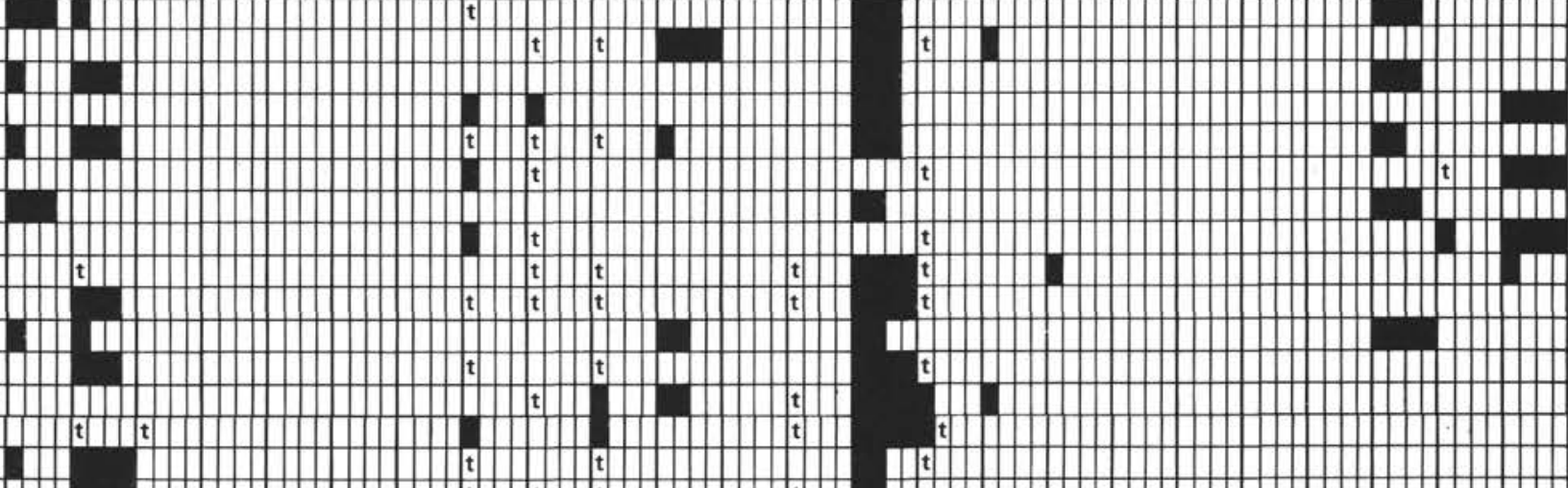

10

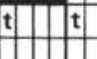

$1+1 \mid$
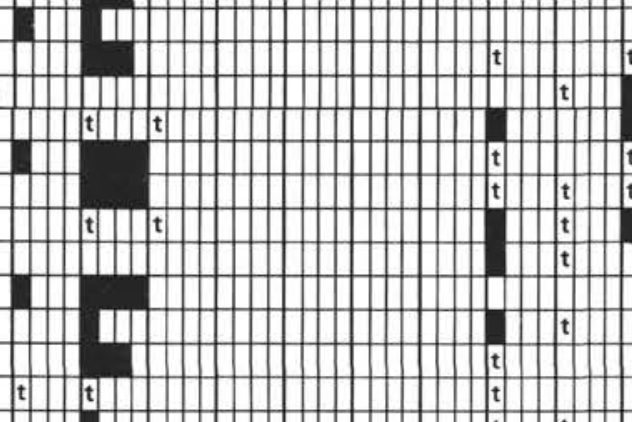
Appendix A. (Continued).

SMEAR SLIDE SUMMARY

Hole 530A

\begin{tabular}{|rl|r|} 
& TRACE \\
$<5 \%$ & RARE \\
$5-25 \%$ & COMMON \\
$25-50 \%$ & ABUNDANT \\
$>50 \%$ & DOMINANT
\end{tabular}

* = minor lithology

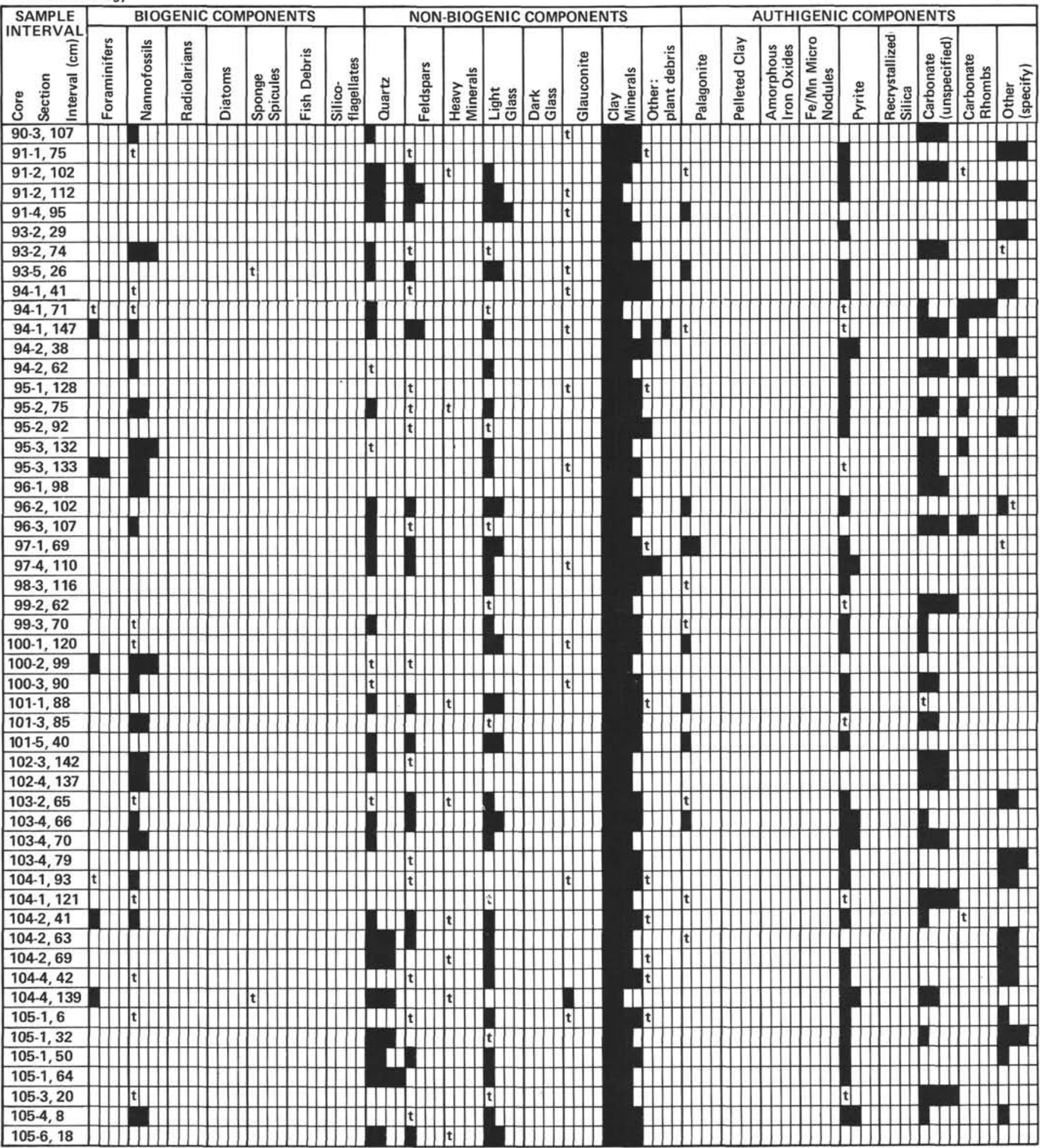


Appendix A. (Continued).

Hole 530B

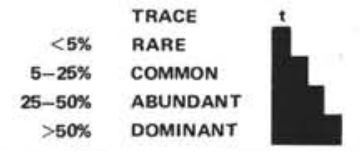

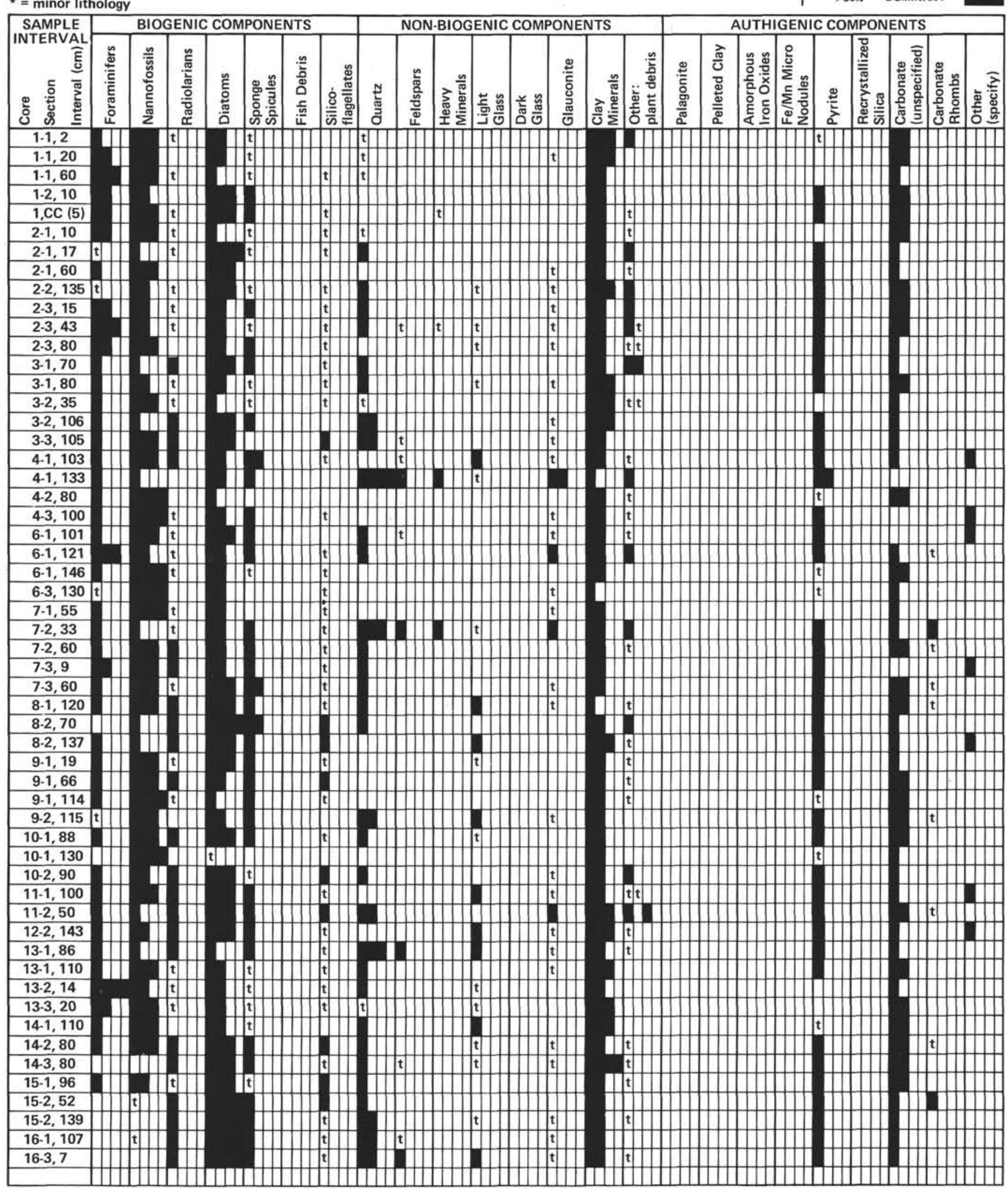


Appendix A. (Continued).

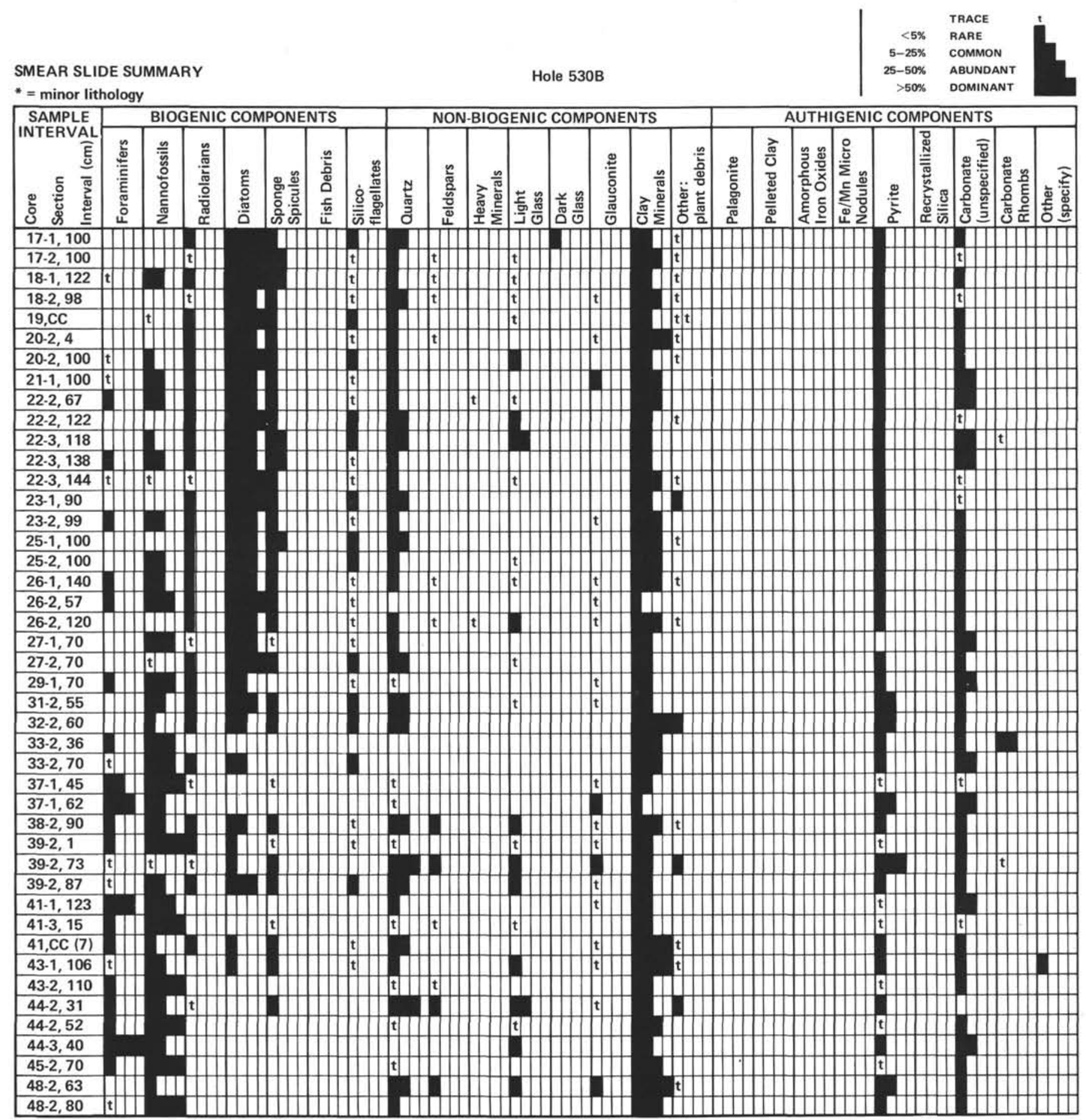




\section{APPENDIX B}

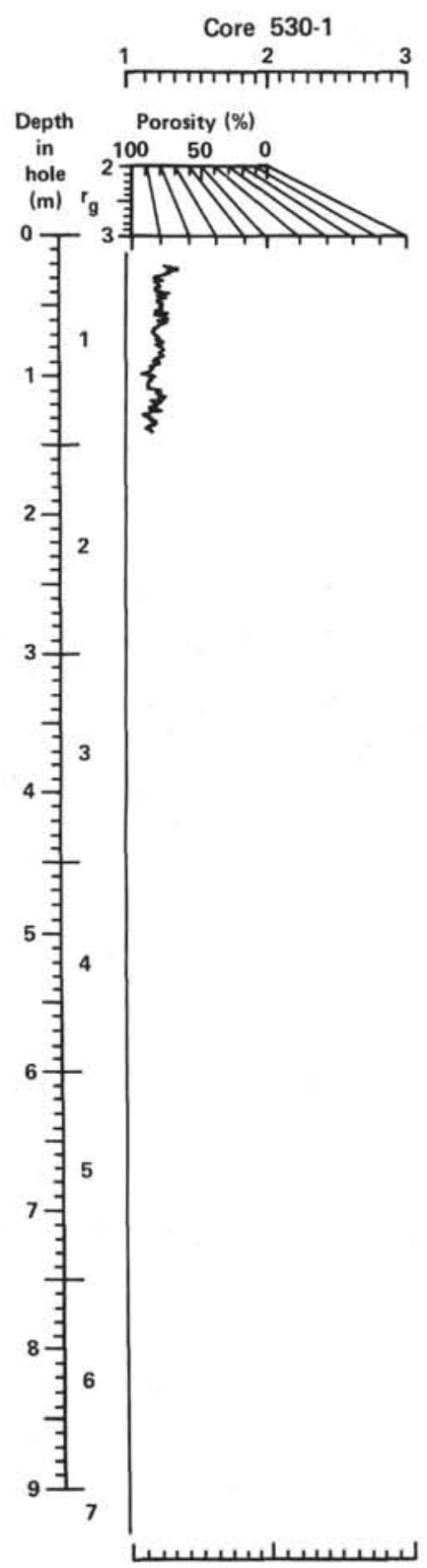

Core $530 \mathrm{~A}-1$

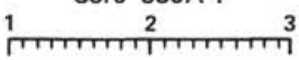

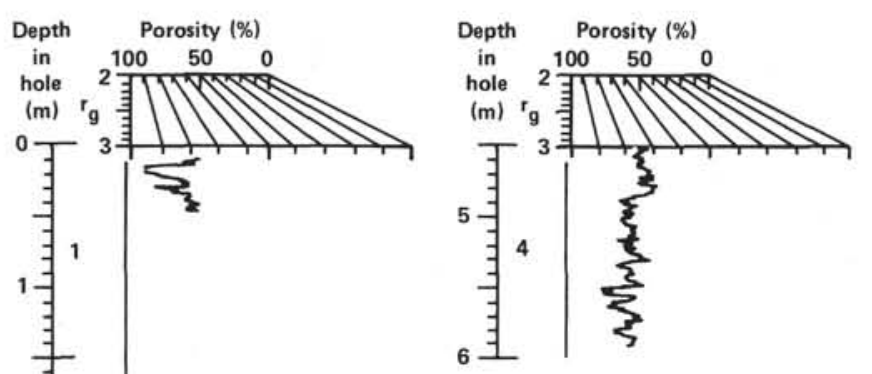

Core $530 \mathrm{~A}-2$

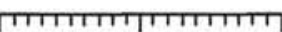

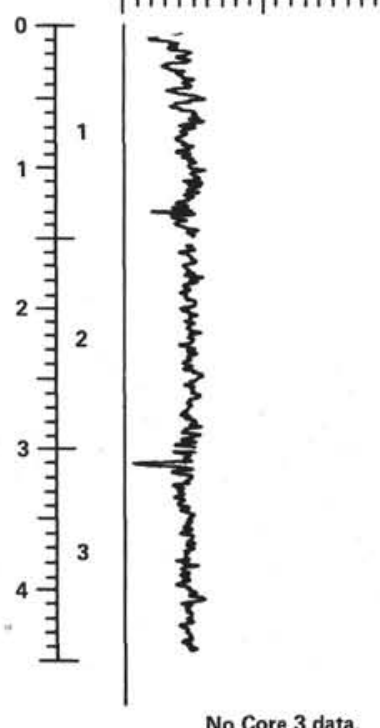

\section{GRAPE Analog Computer Dat}

The analog GRAPE data contain disturbed and undisturbed portions of the consult core forms and photographs in order to distinguish valid and invalid data.

These data have been severely edited for publication. All rock diameters were measured by hand, usually one measurement per $5 \mathrm{~cm}$ of core segment. The core segments are very rough and irregular, therefore, when these diameters (and assuming offset from the gamma-ray beam as described by Equation 36 in Boyce, 1976a) are applied to the raw GRAPE data, the resulting adjusted data (dotted lines) are subject to huge errors, particularly when core segments offset is incort, thus cour are

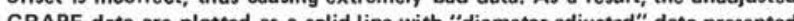
as a dotced line. This allawed the abvious erors to be corrected by hand using white correction fluid and an ink pen. More importantly, this presentation allows investigators to manipulate the data Investigators interested in the density of a specific layer or rock piece, should check the sample dismeter from the core photographs and make the appropriate diameter corrections as discussed in Boyce (1976a).

Note: The upper scale is GRAPE wet-bulk density $\left(1.0\right.$ to $\left.3.0 \mathrm{~g} / \mathrm{cm}^{3}\right)$; solid lines (- ) are GRAPE analog data assuming a $6.61 \mathrm{~cm}$ core diameter; dotted lines $(\ldots)$ are GRAPE analog data adjusted for actual core diameter; circled tionary sample; the porosity nomogram allows a porosity scale to be determined by selecting the proper grain density $\left(\mathrm{r}_{\mathrm{g}}\right)$ and extrapolating horizontally. 


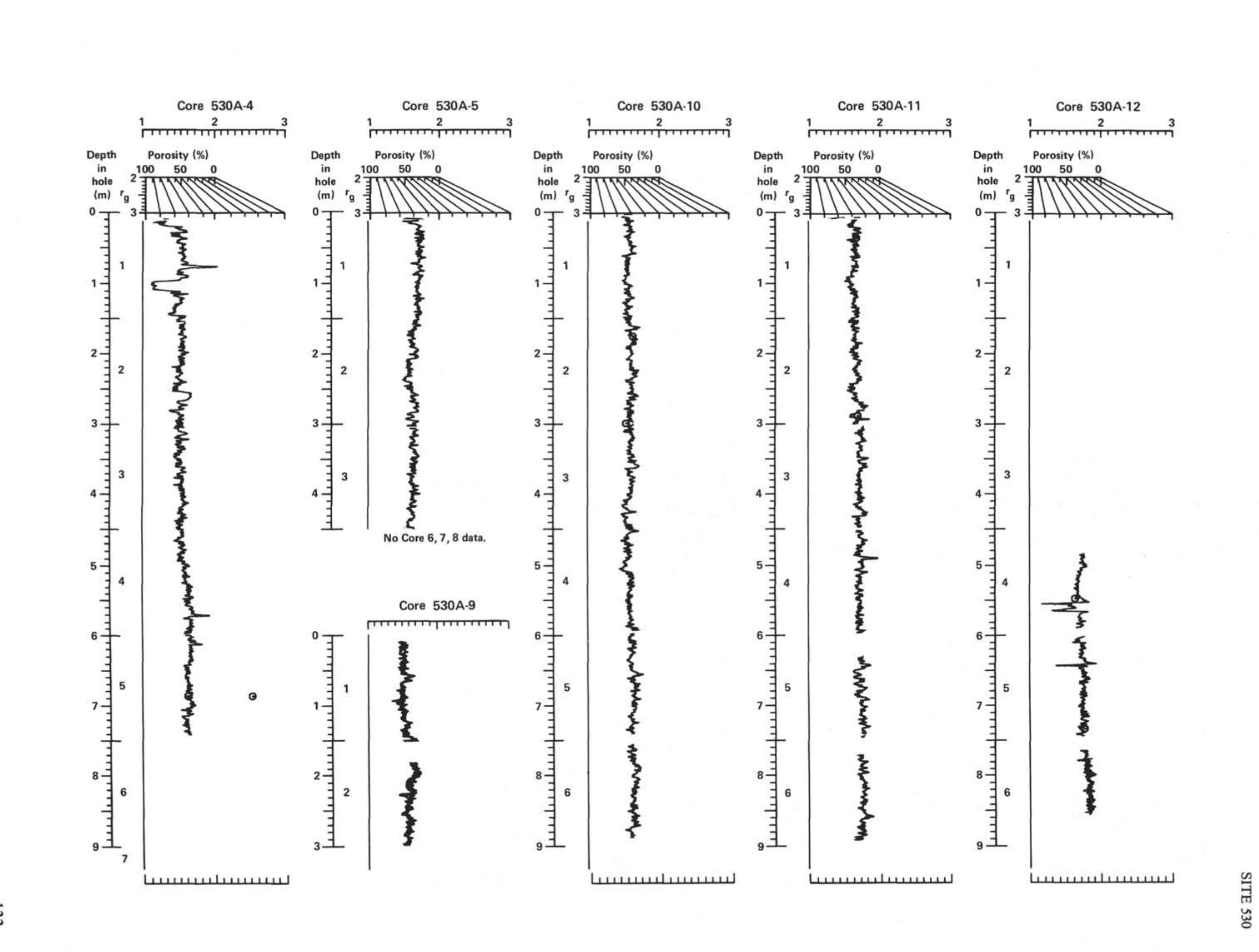


Appendix B. (Continued).

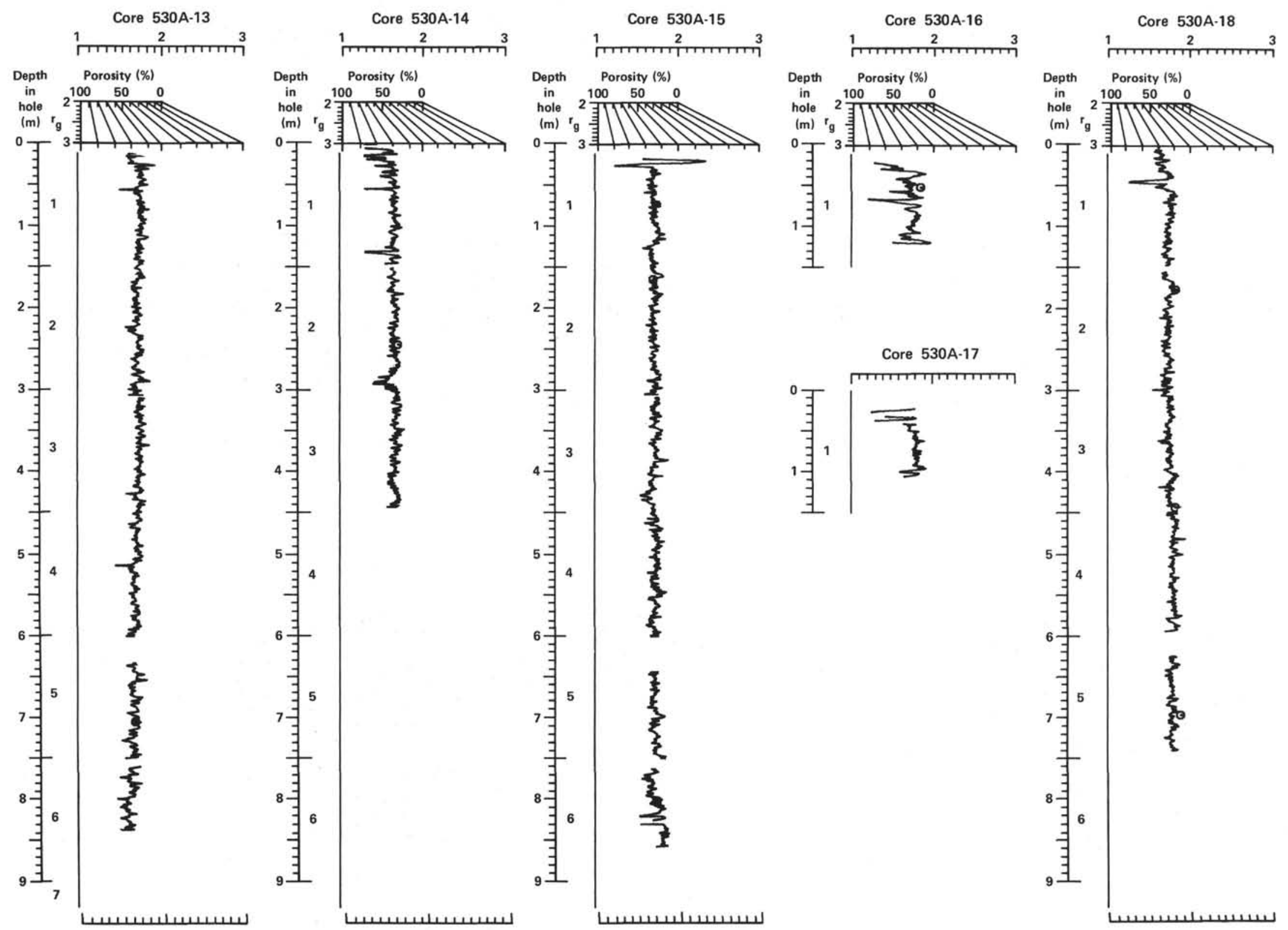




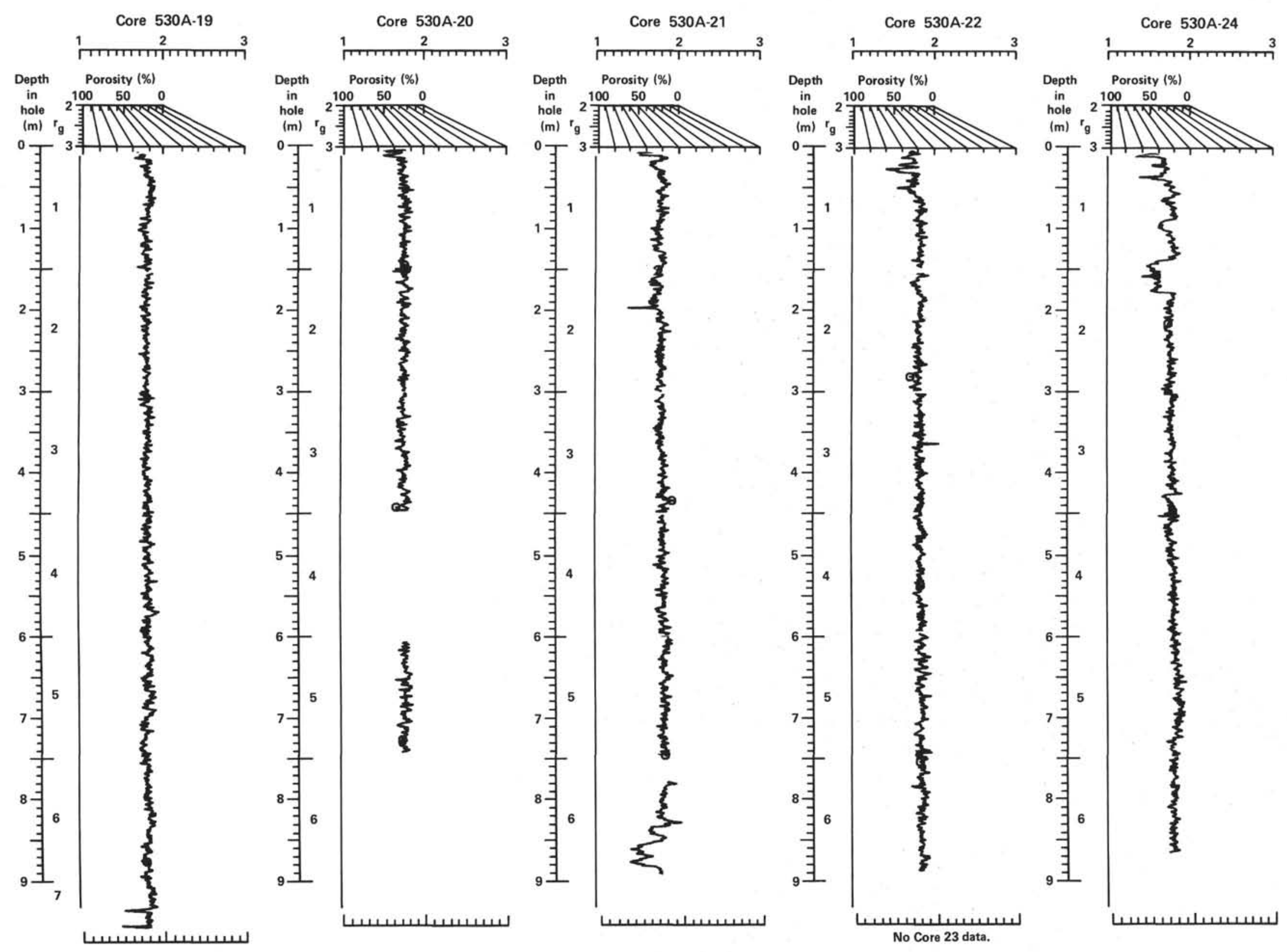




$$
\text { Iffffl }
$$



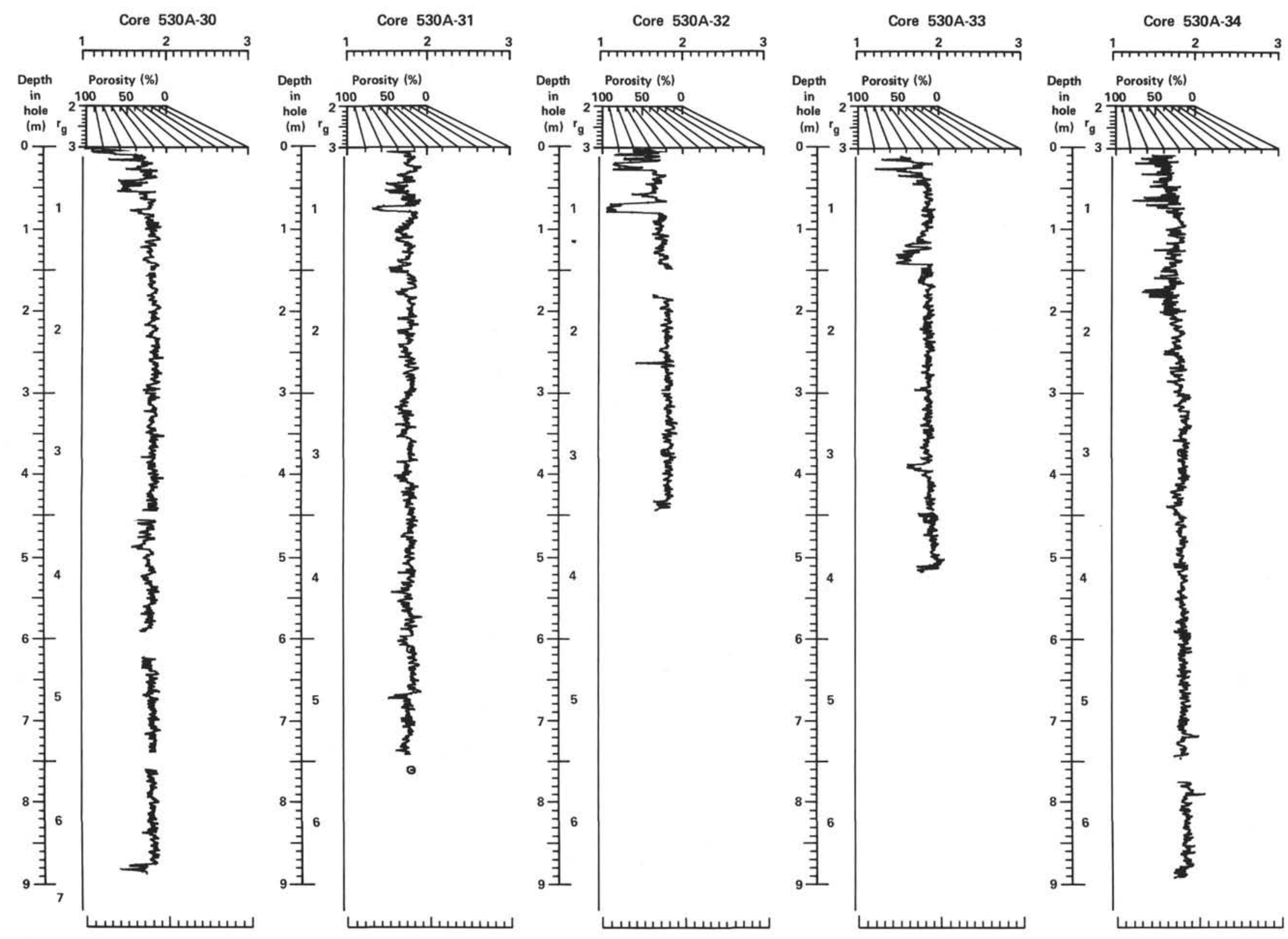

in
hole
(m)
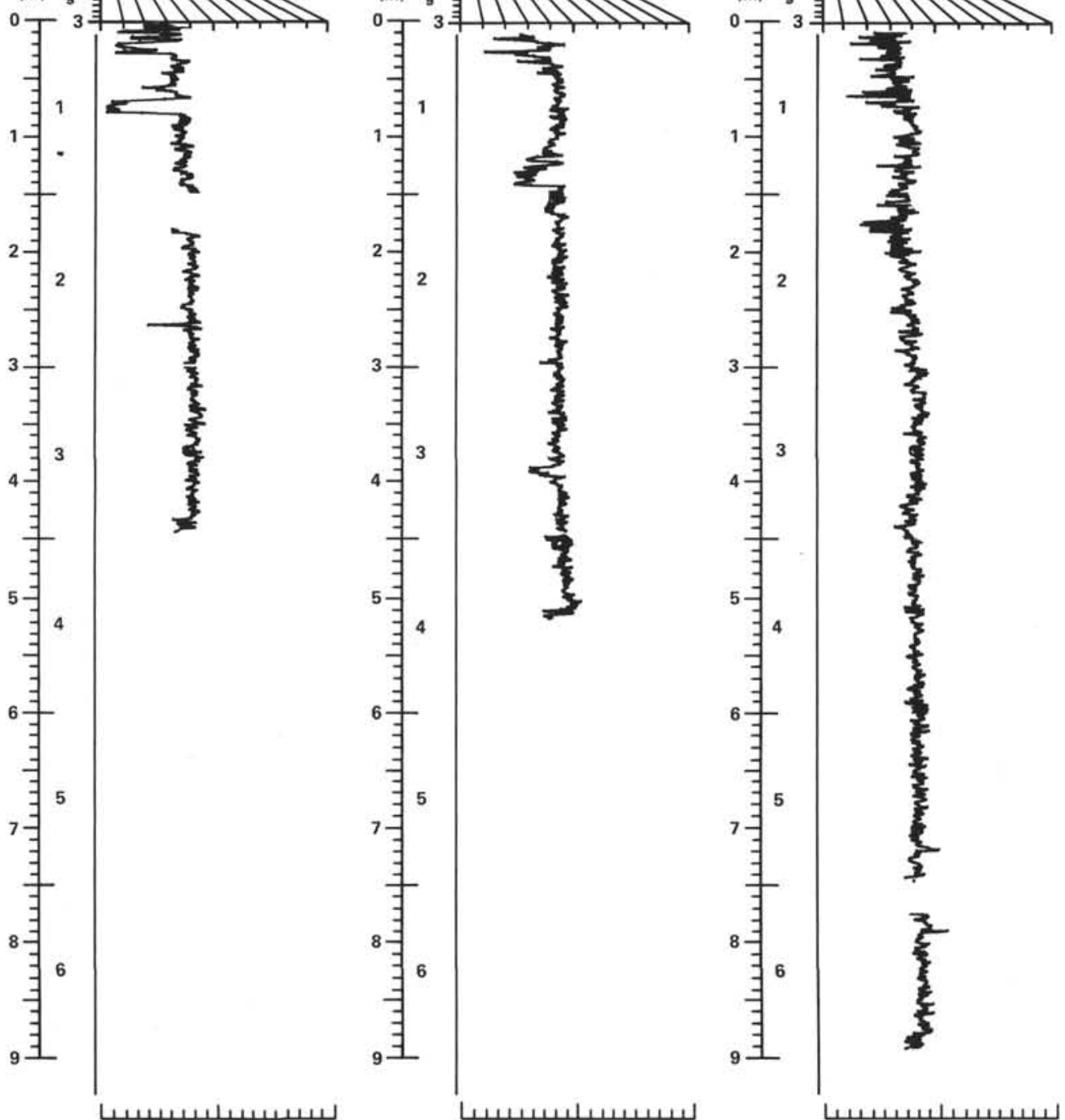
Appendix B. (Continued).

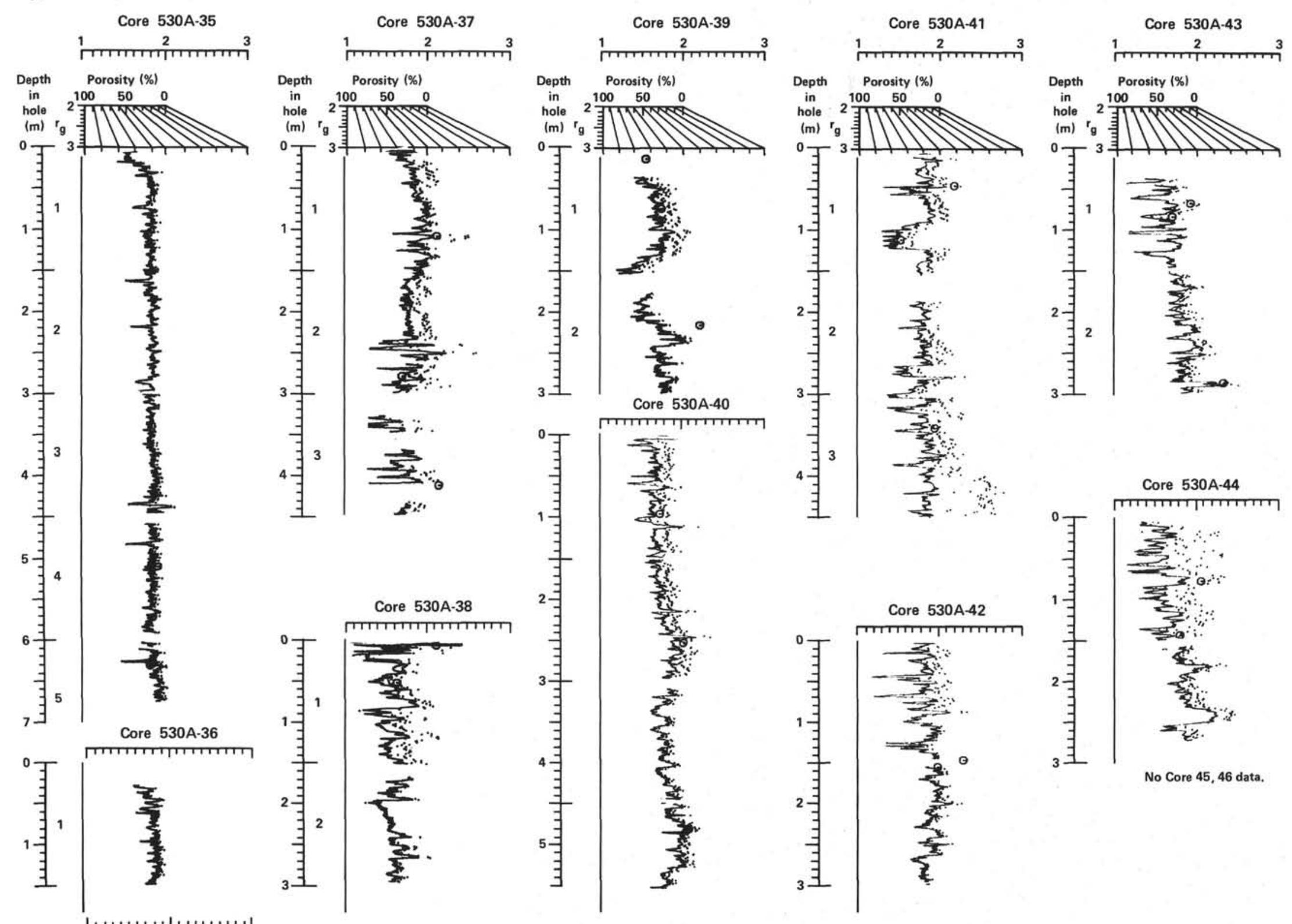




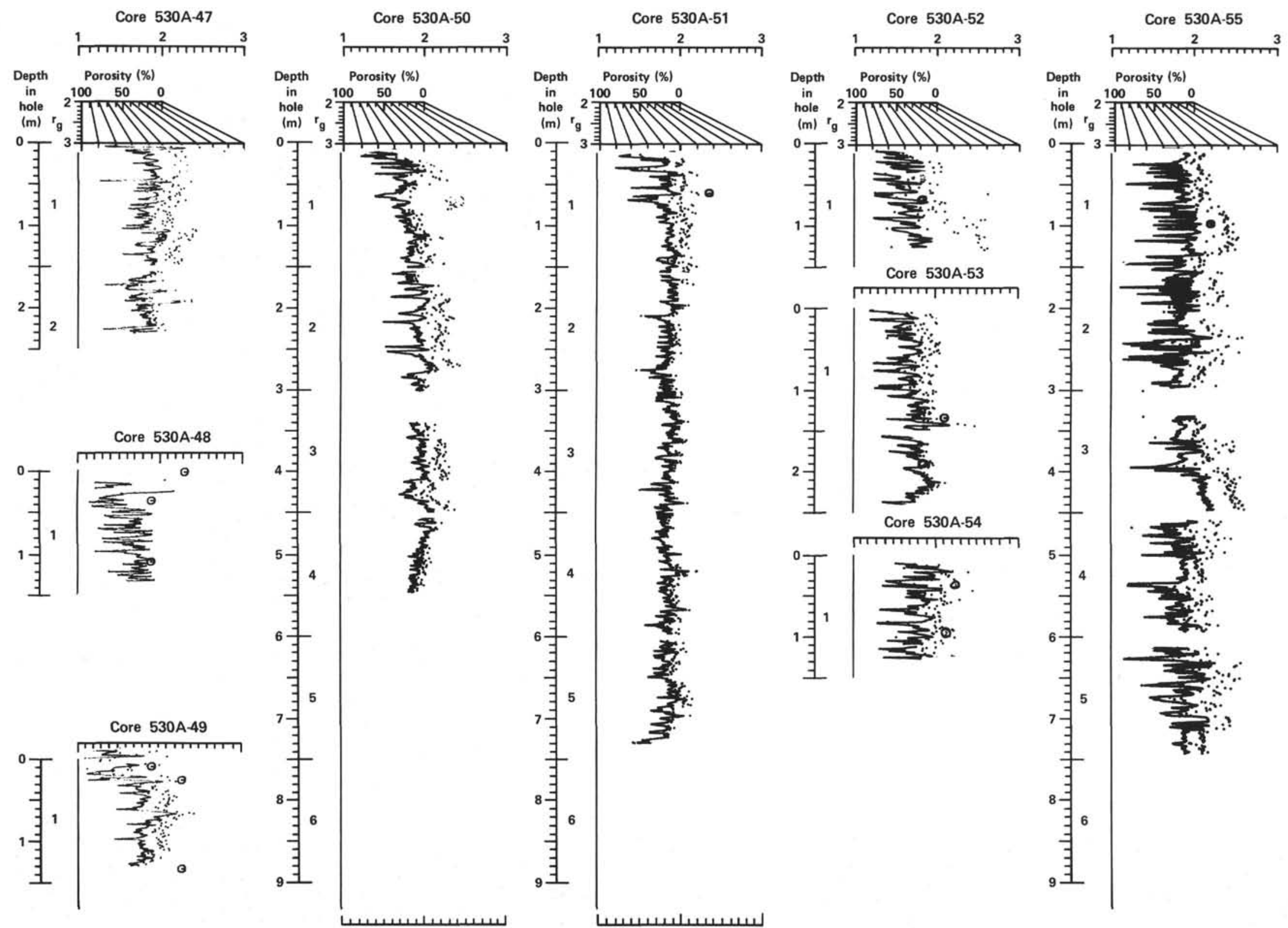


Appendix B. (Continued).
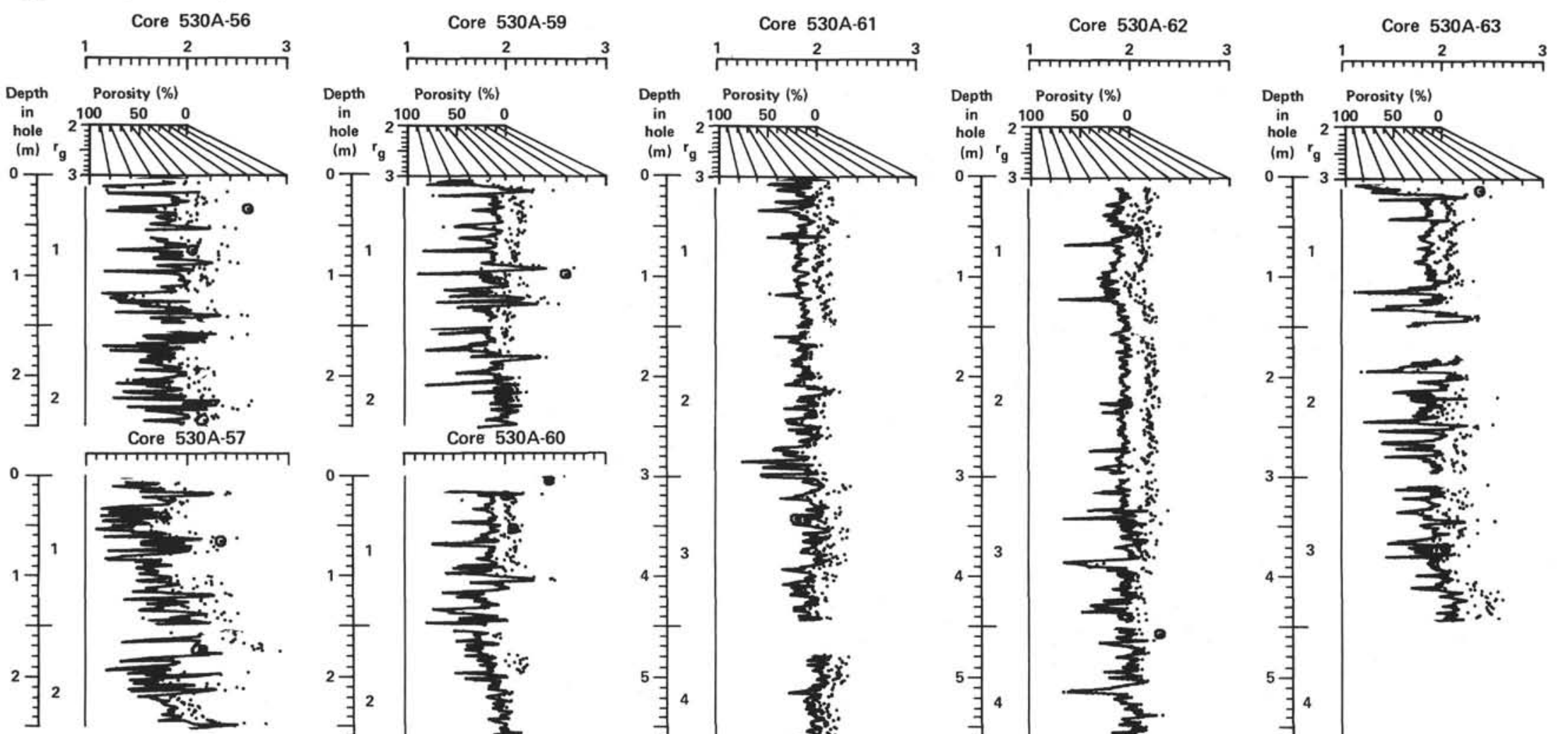

Core 530A-60
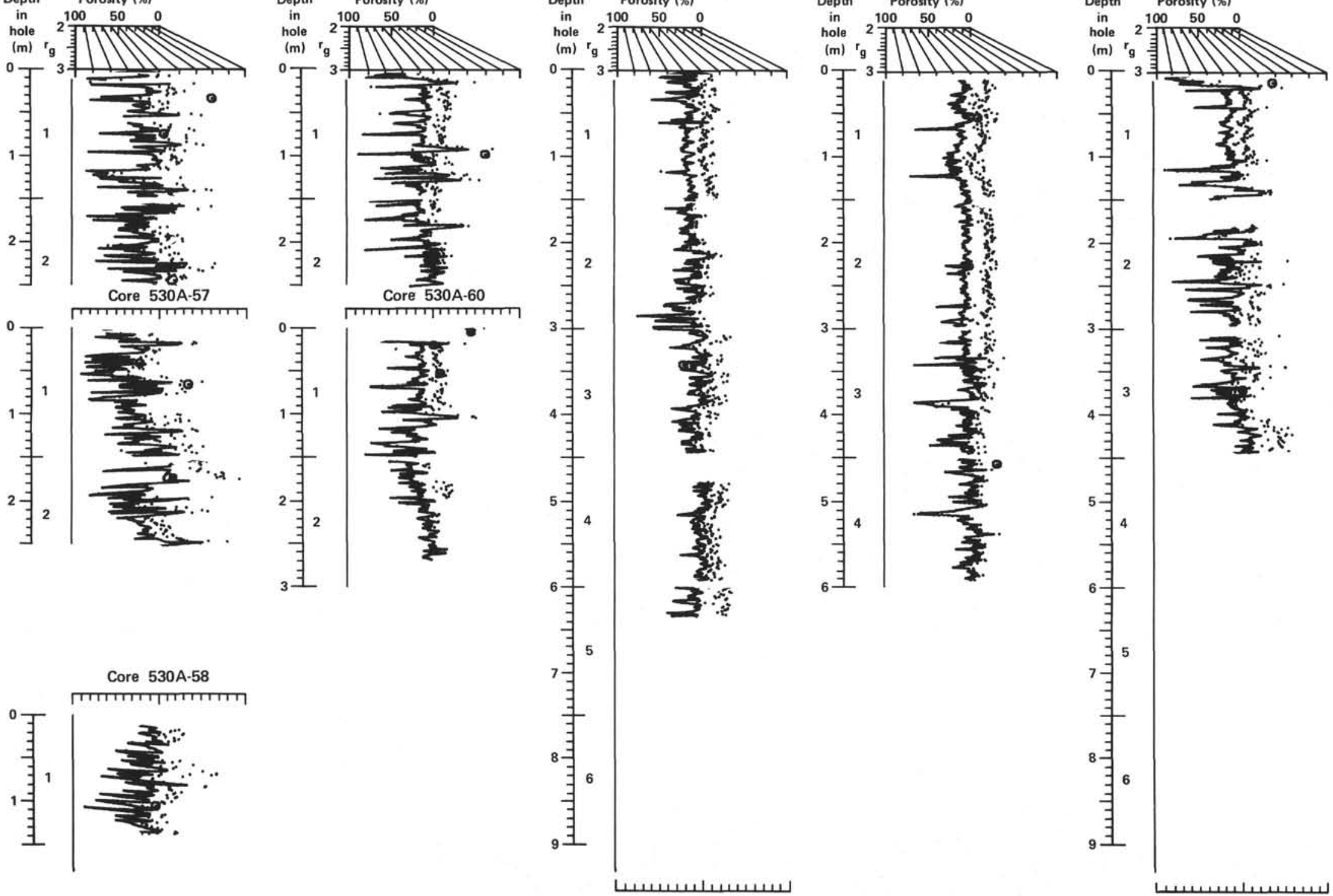


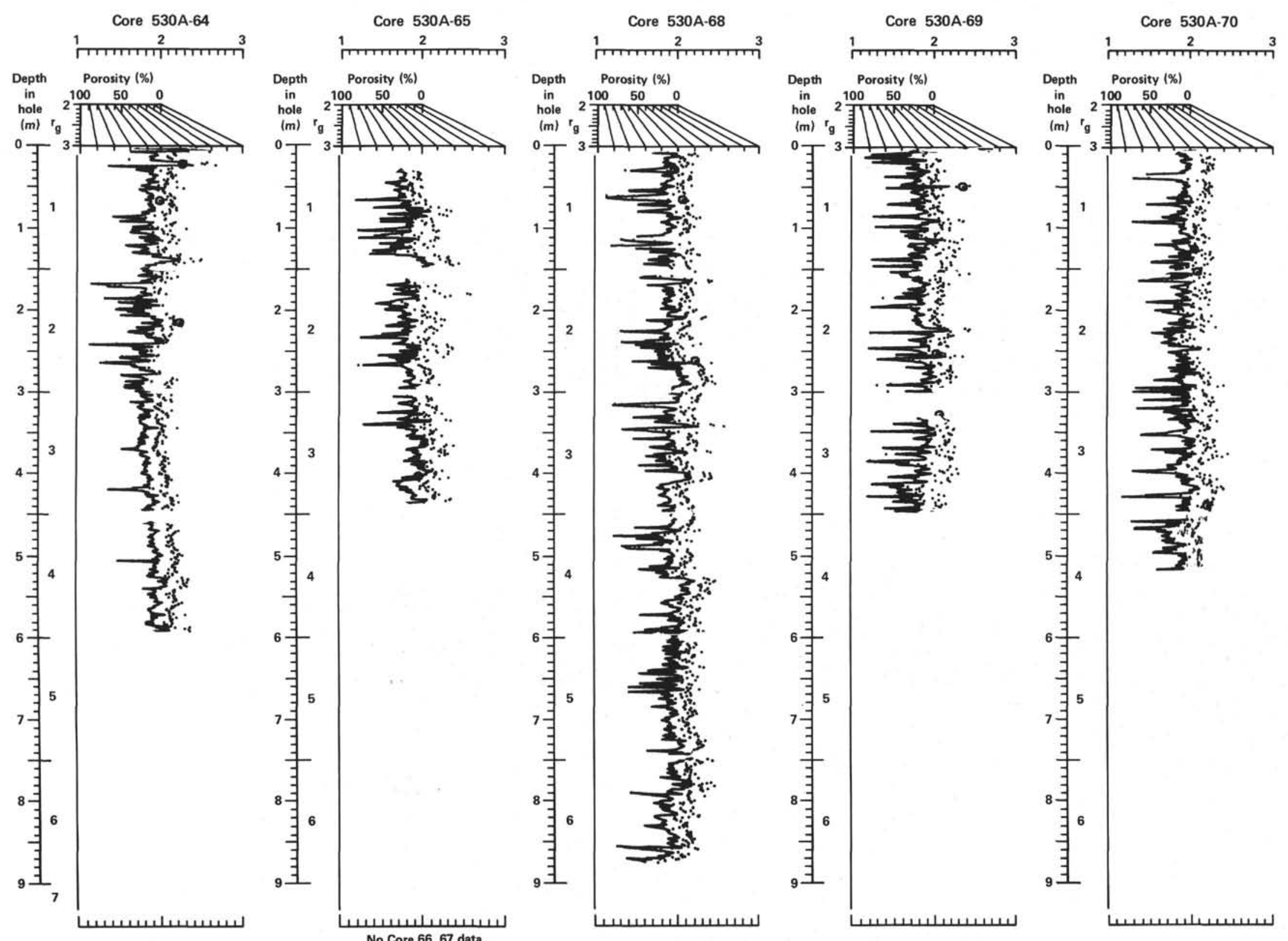


Appendix B. (Continued).

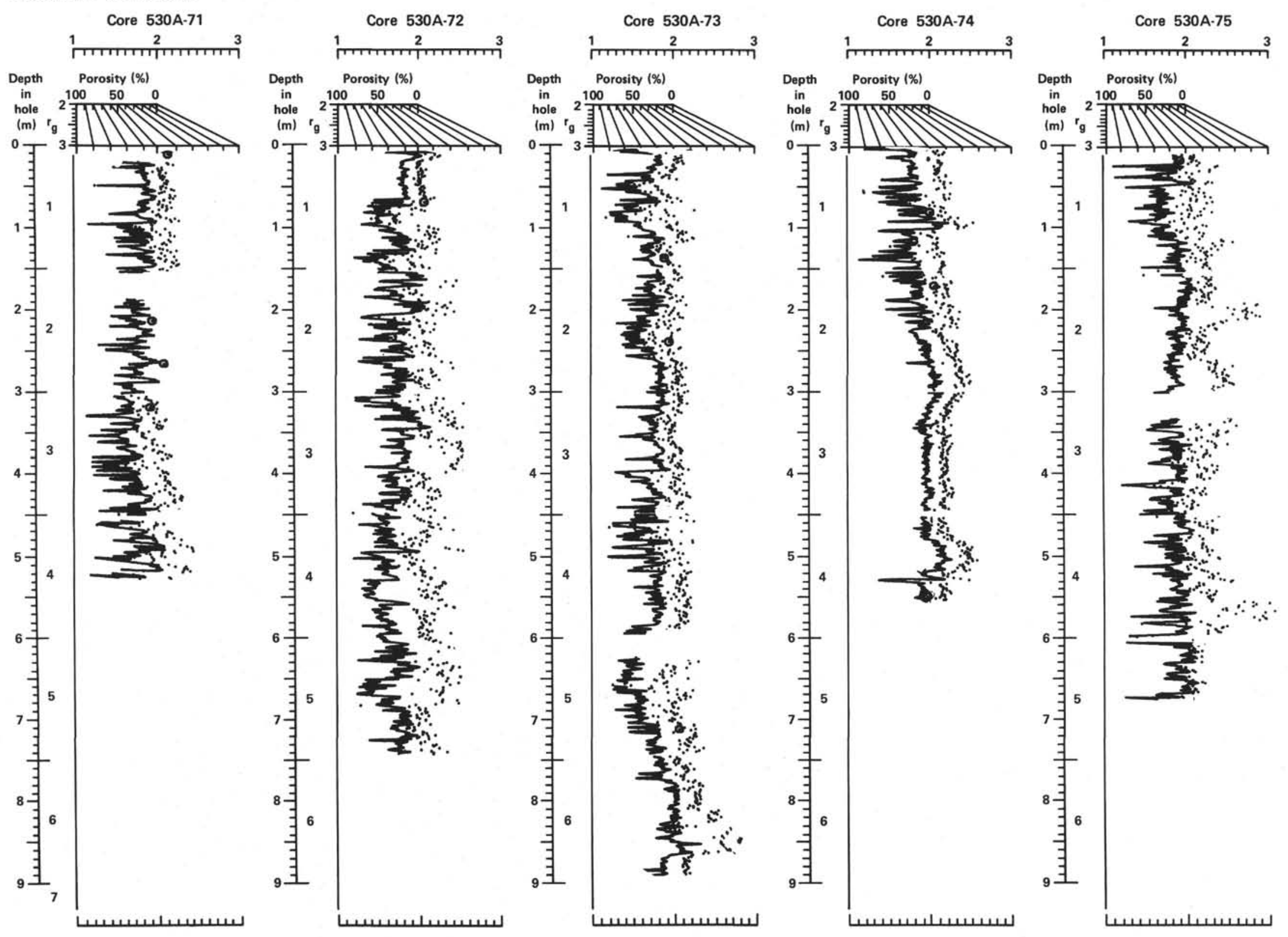




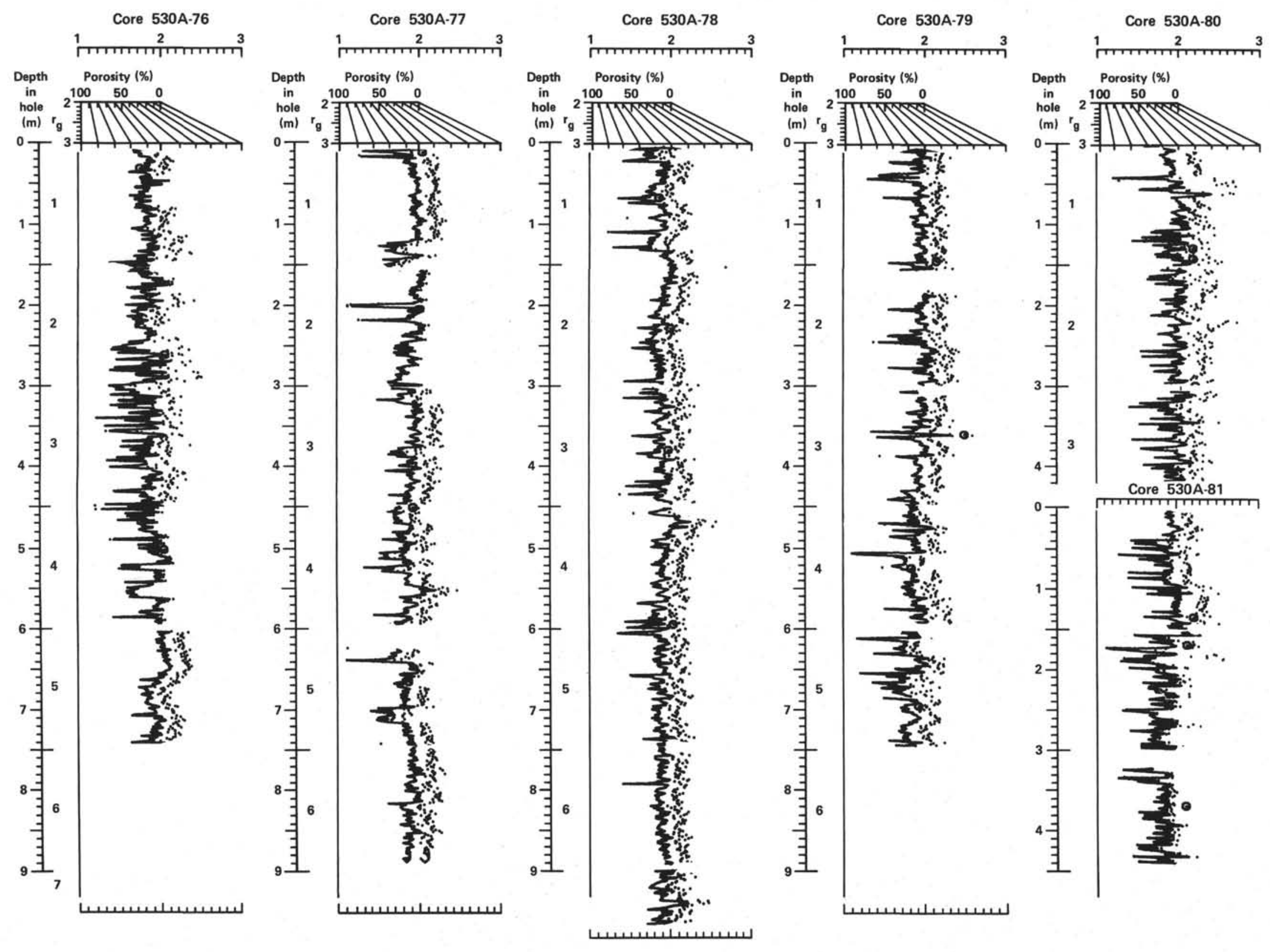


Appendix B. (Continued).

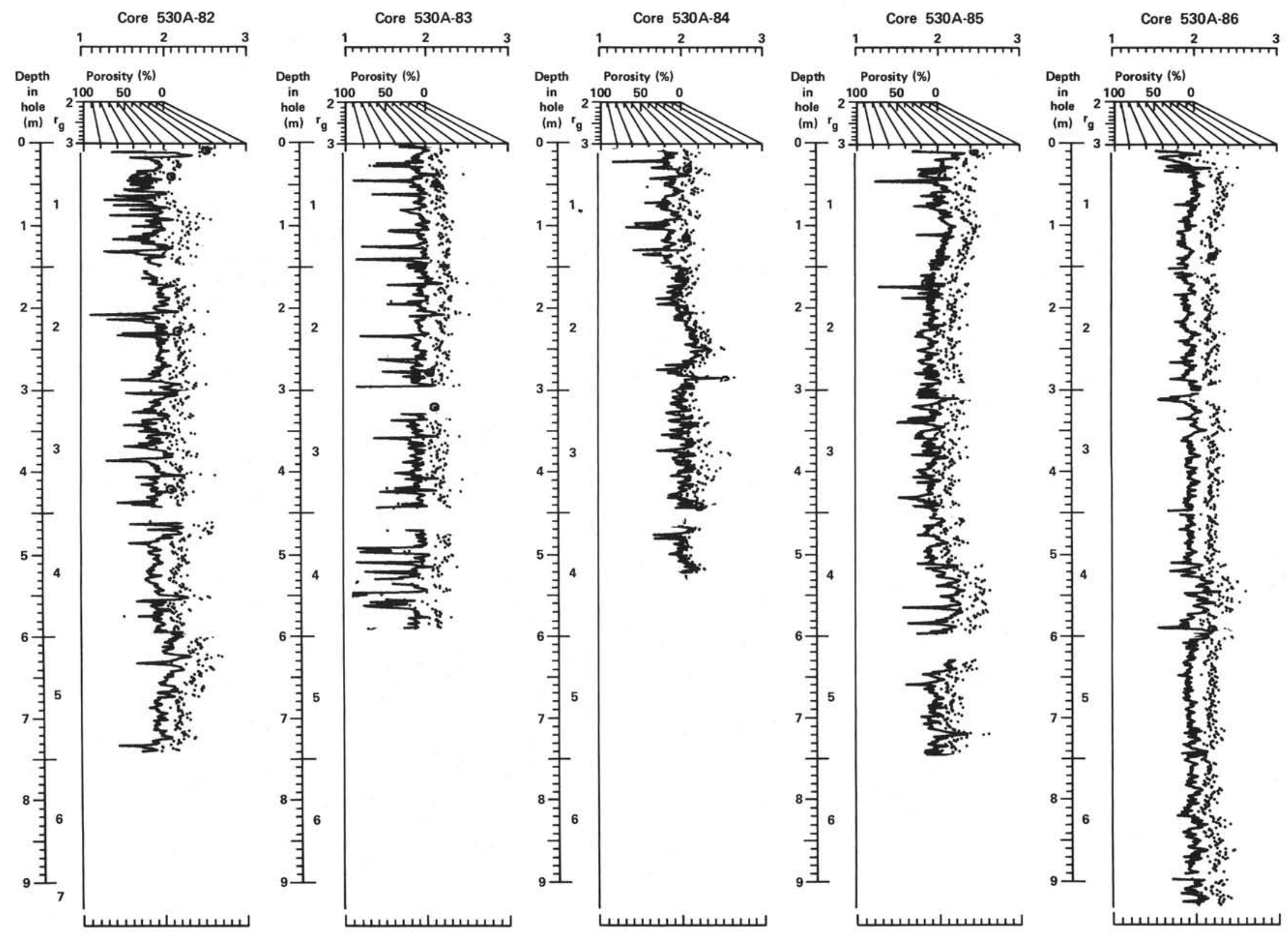




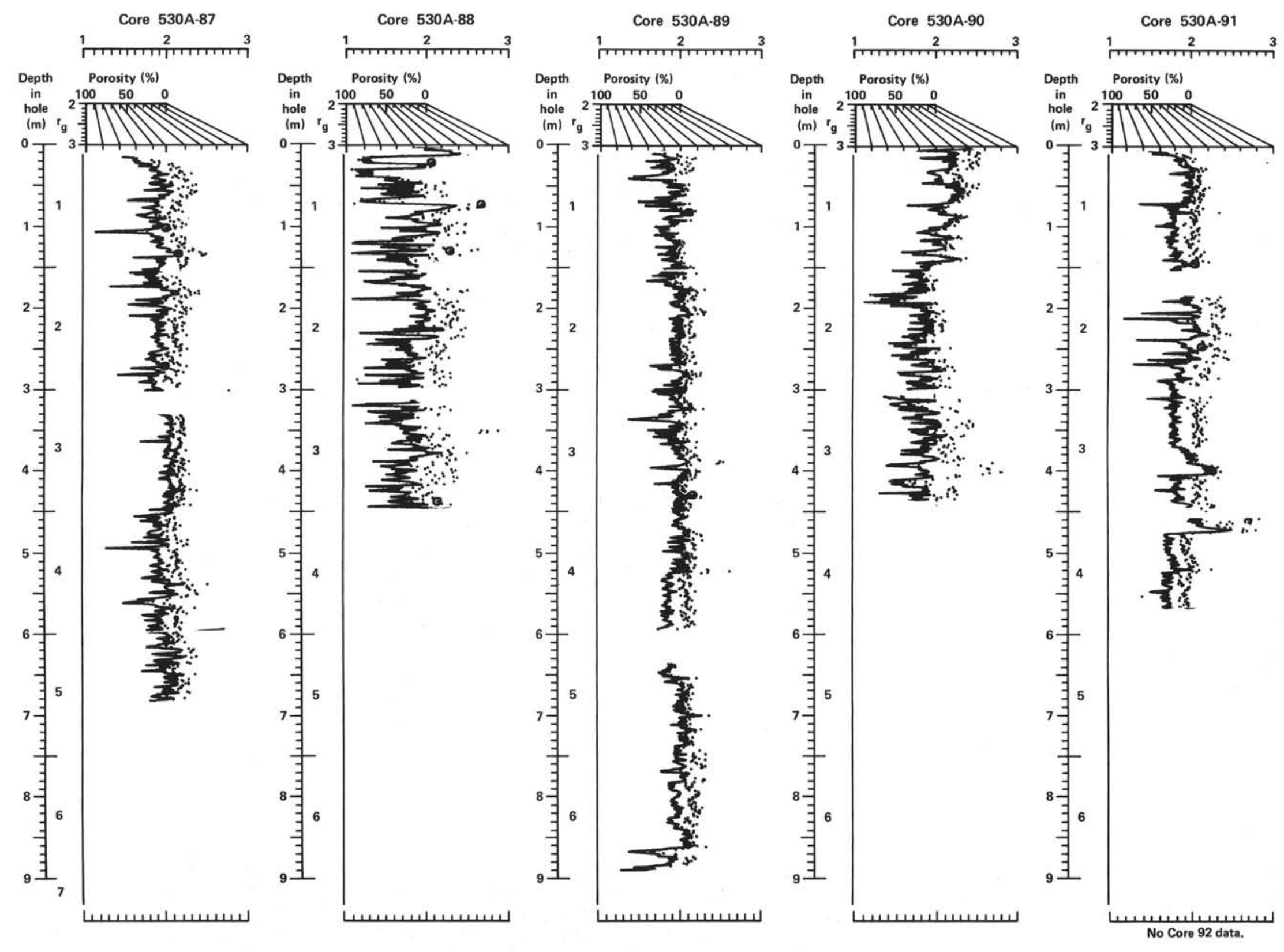




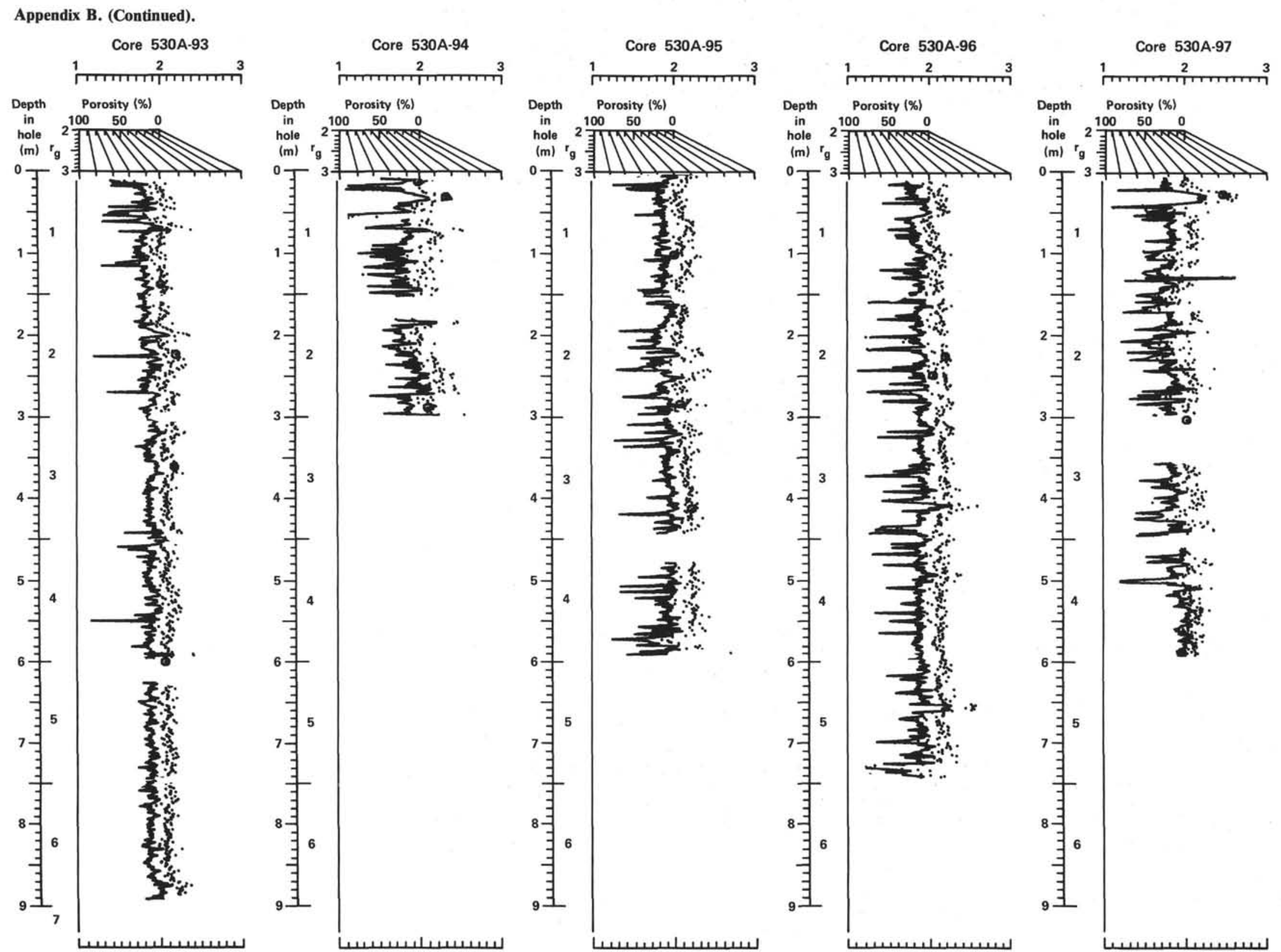



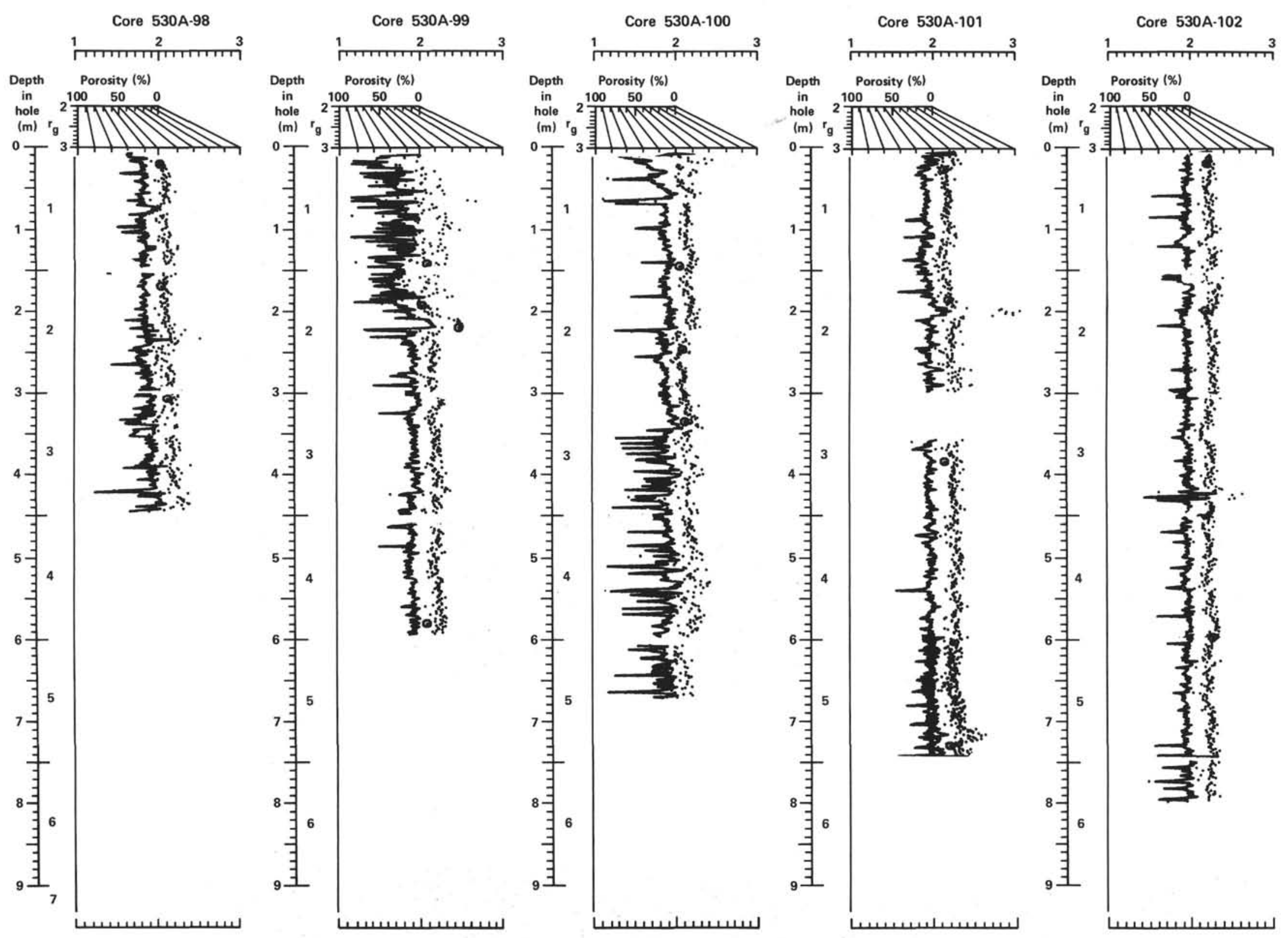
Appendix B. (Continued)

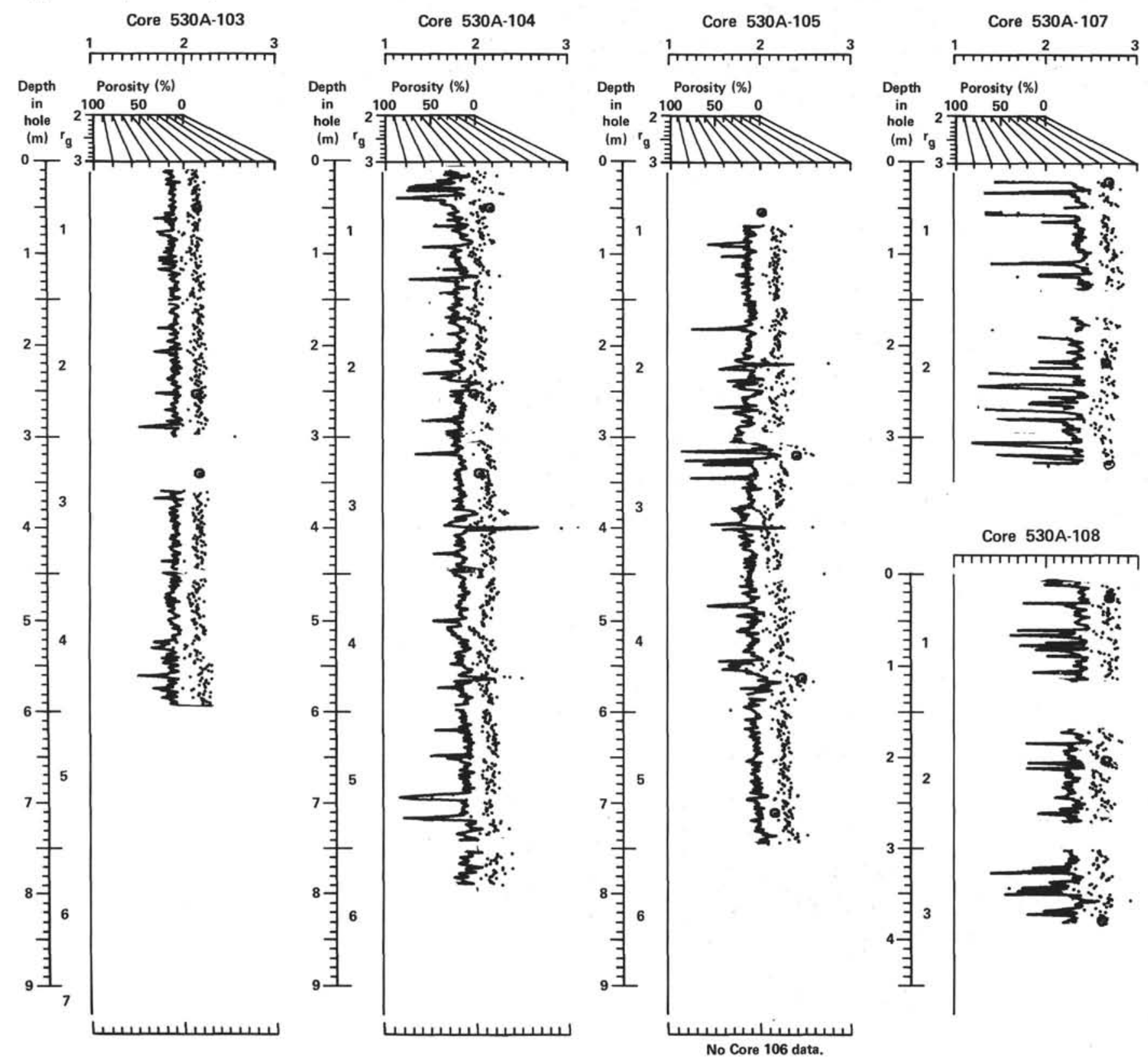



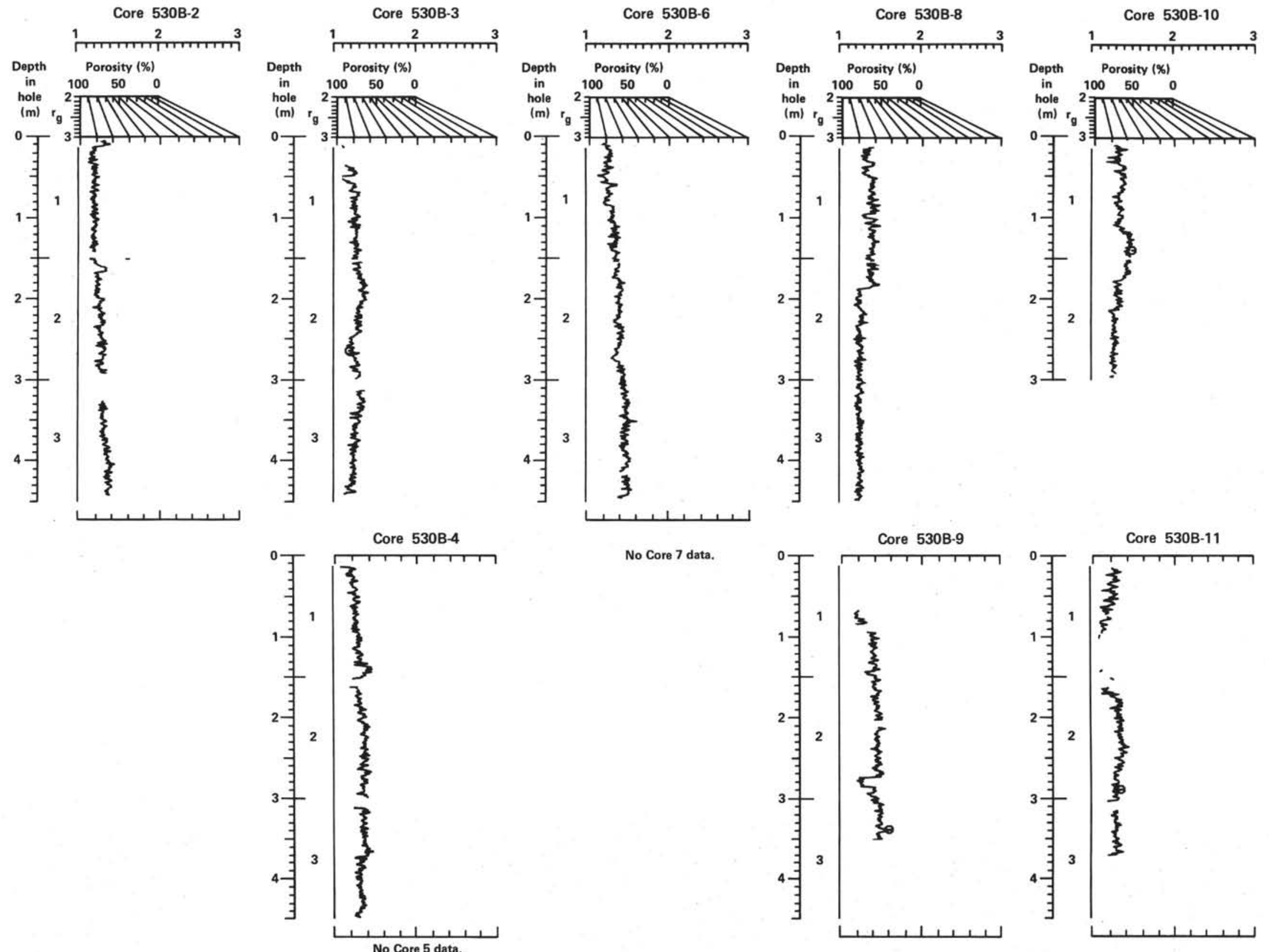

No Core 7 data.
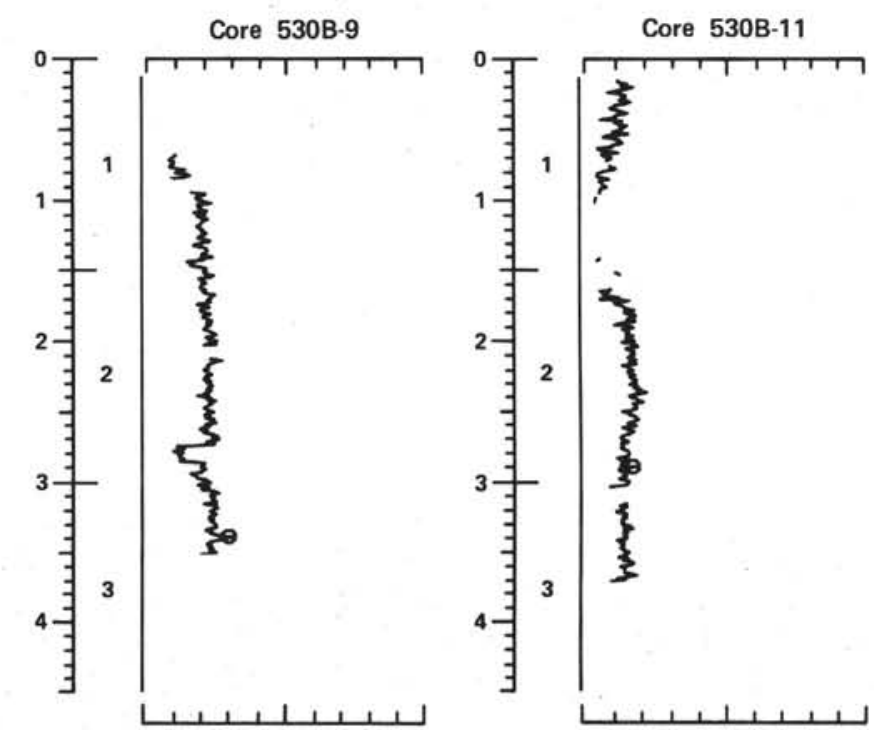
Appendix B. (Continued).
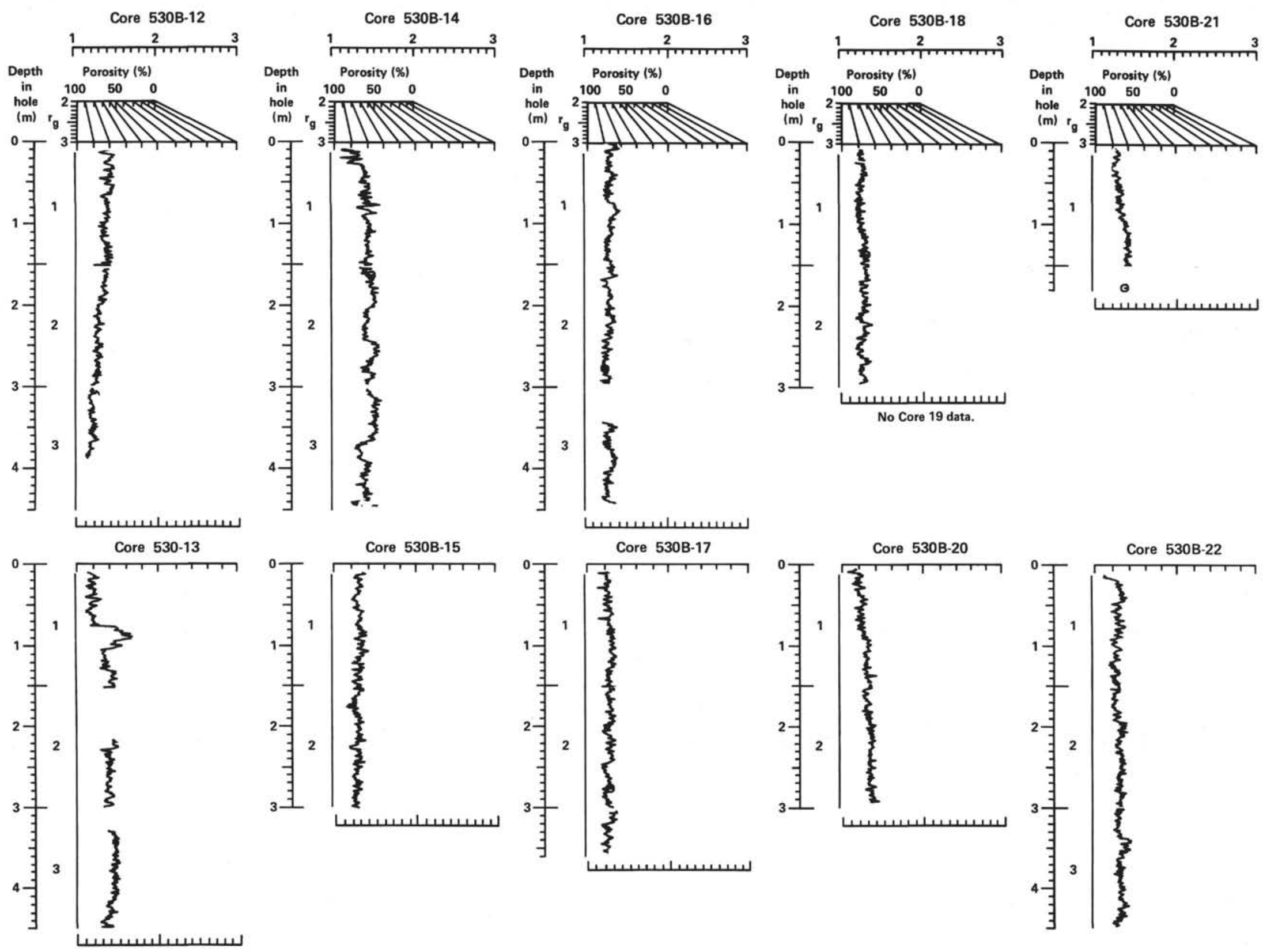

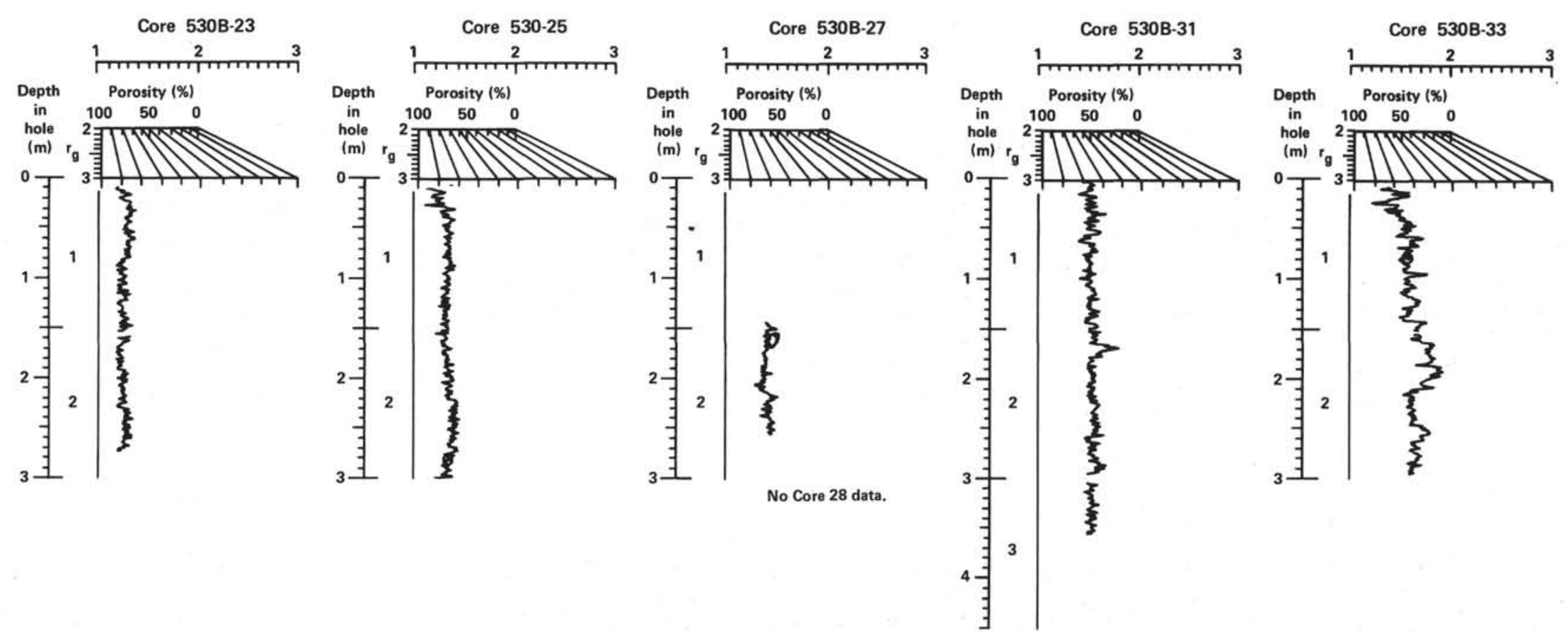

No Core 28 data.
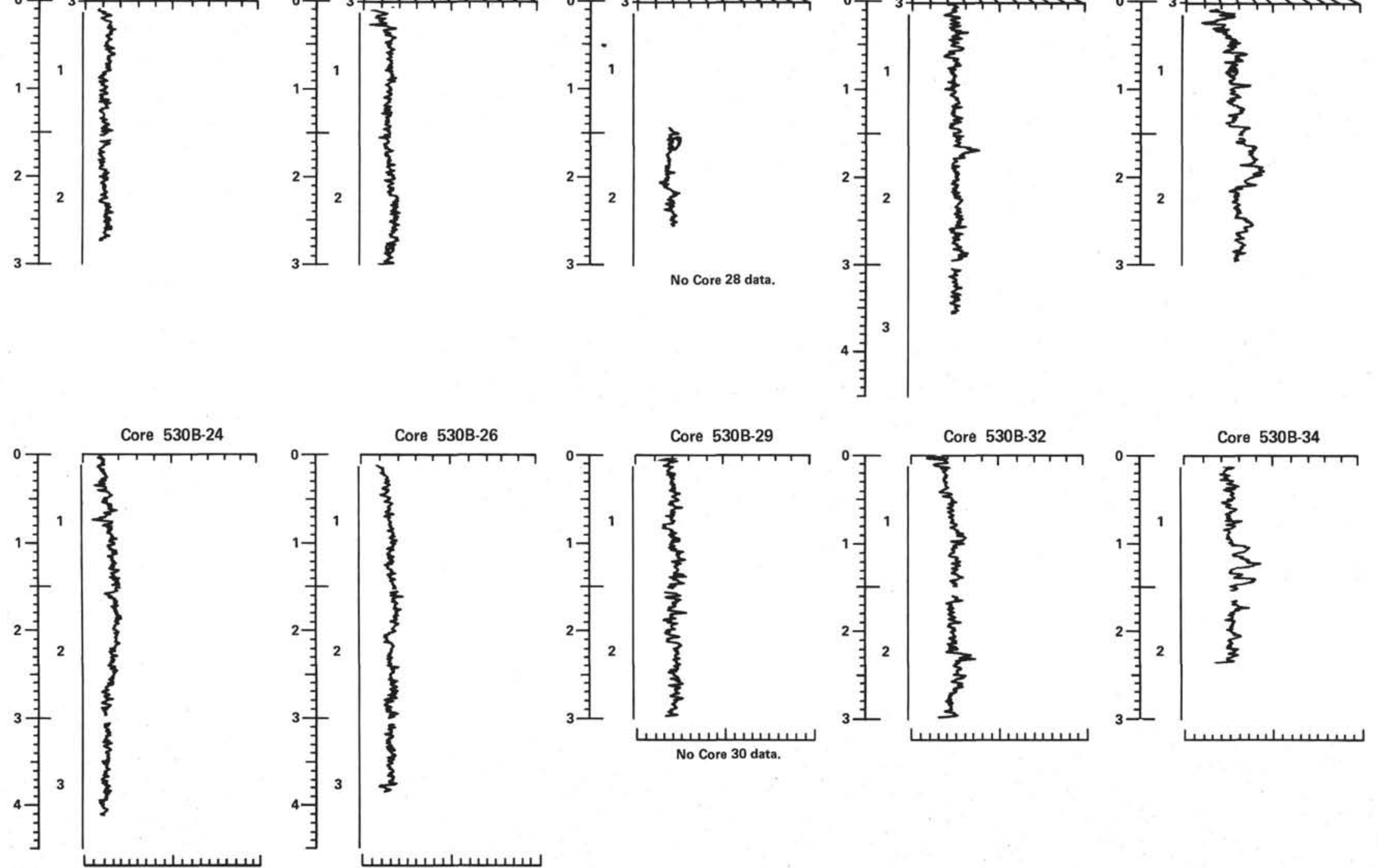
Appendix B. (Continued).
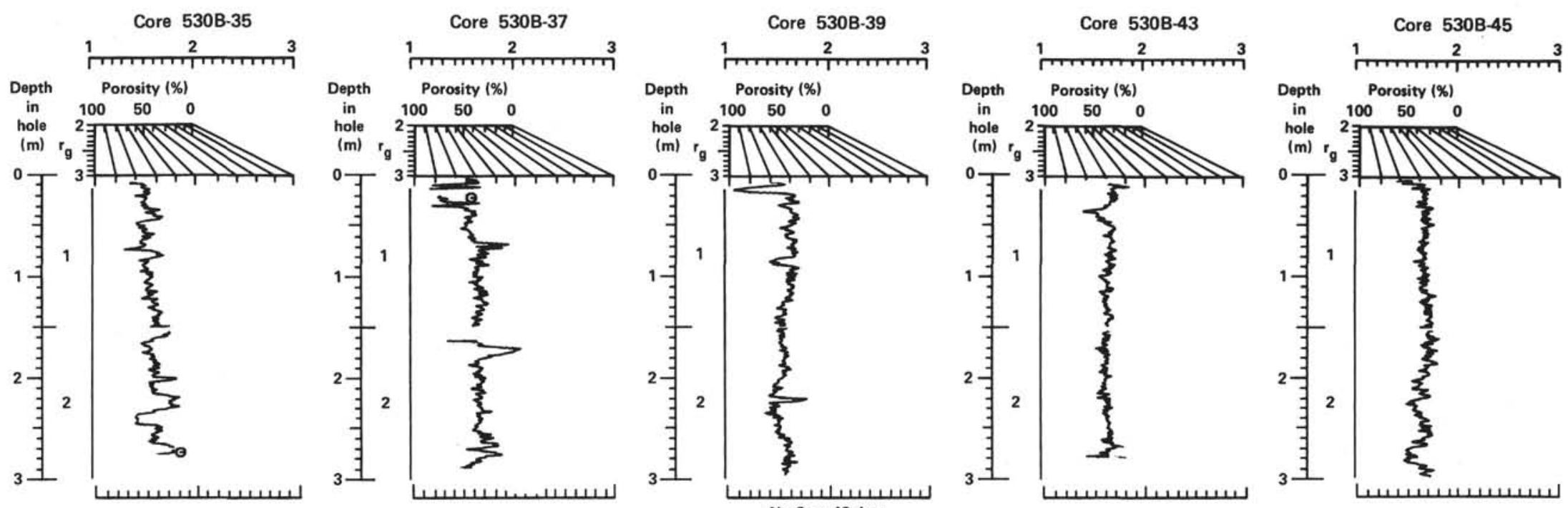

No Core 40 data.
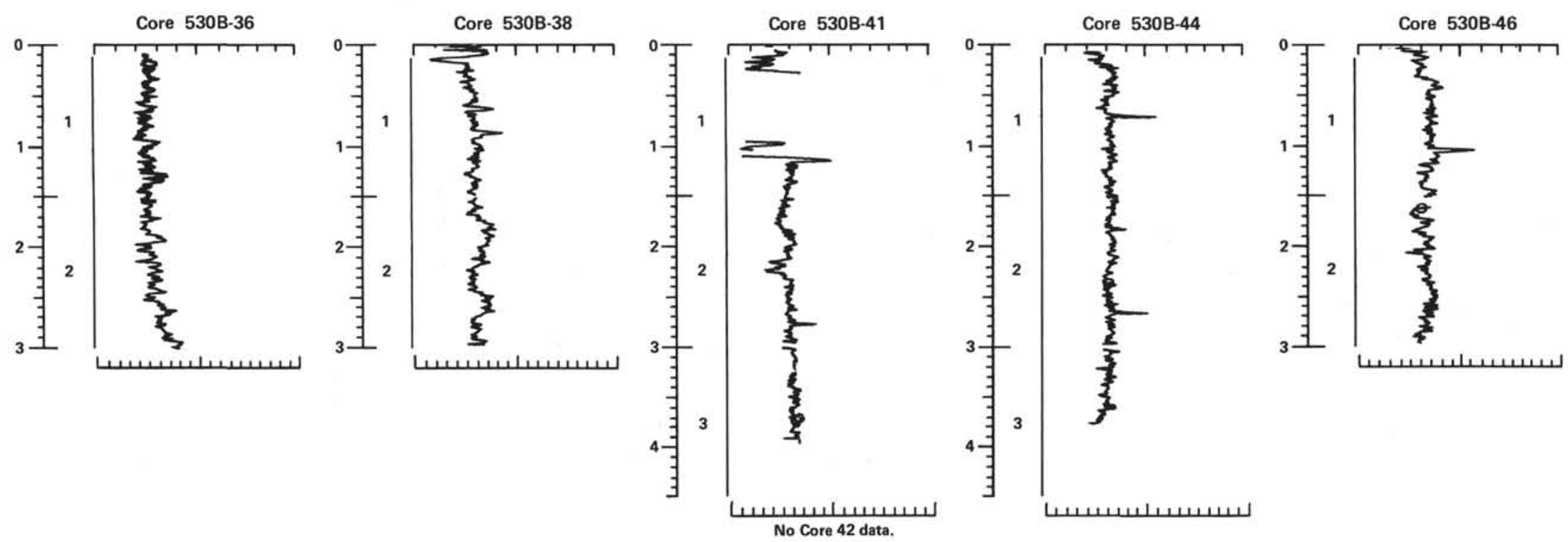

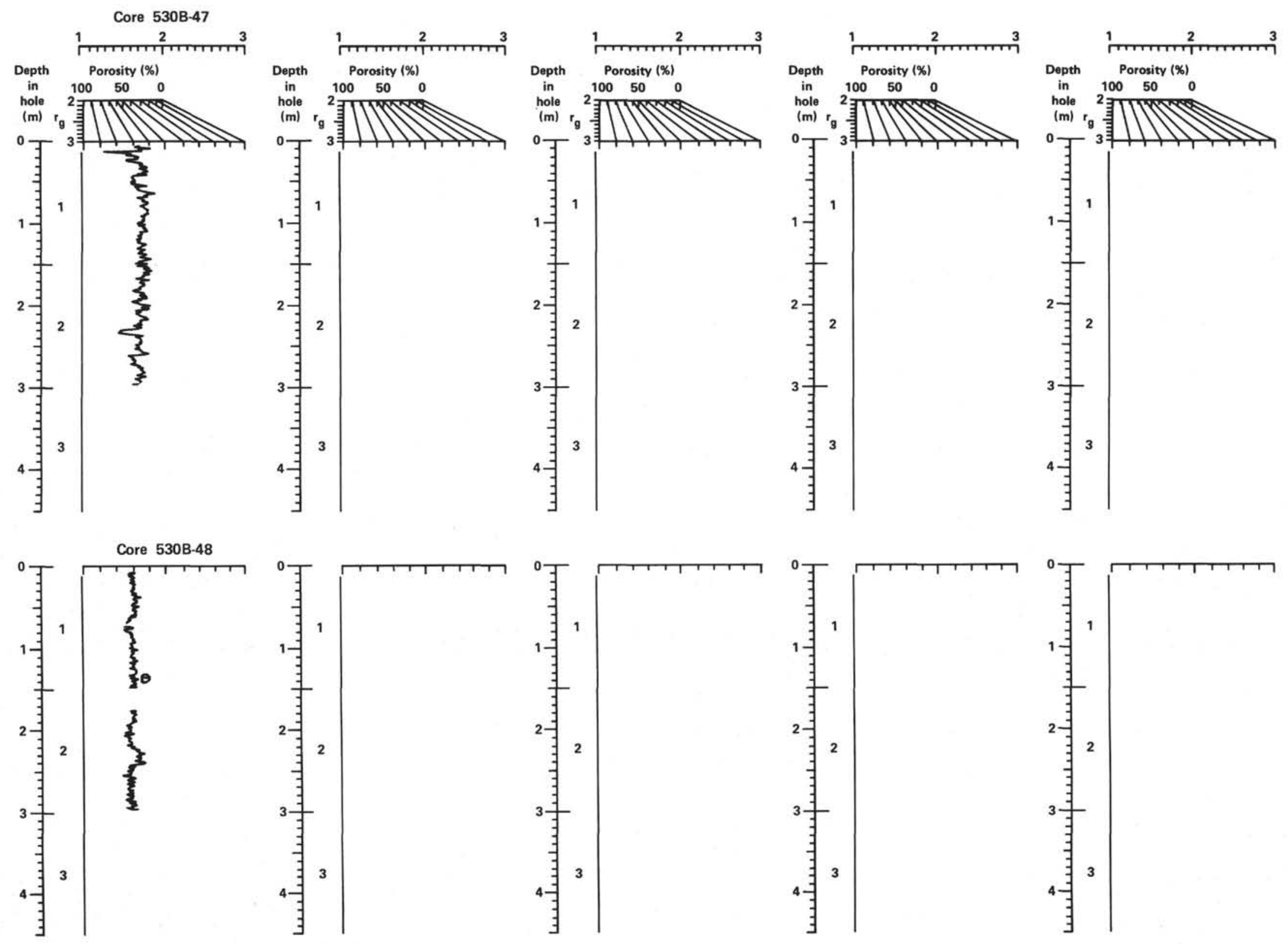


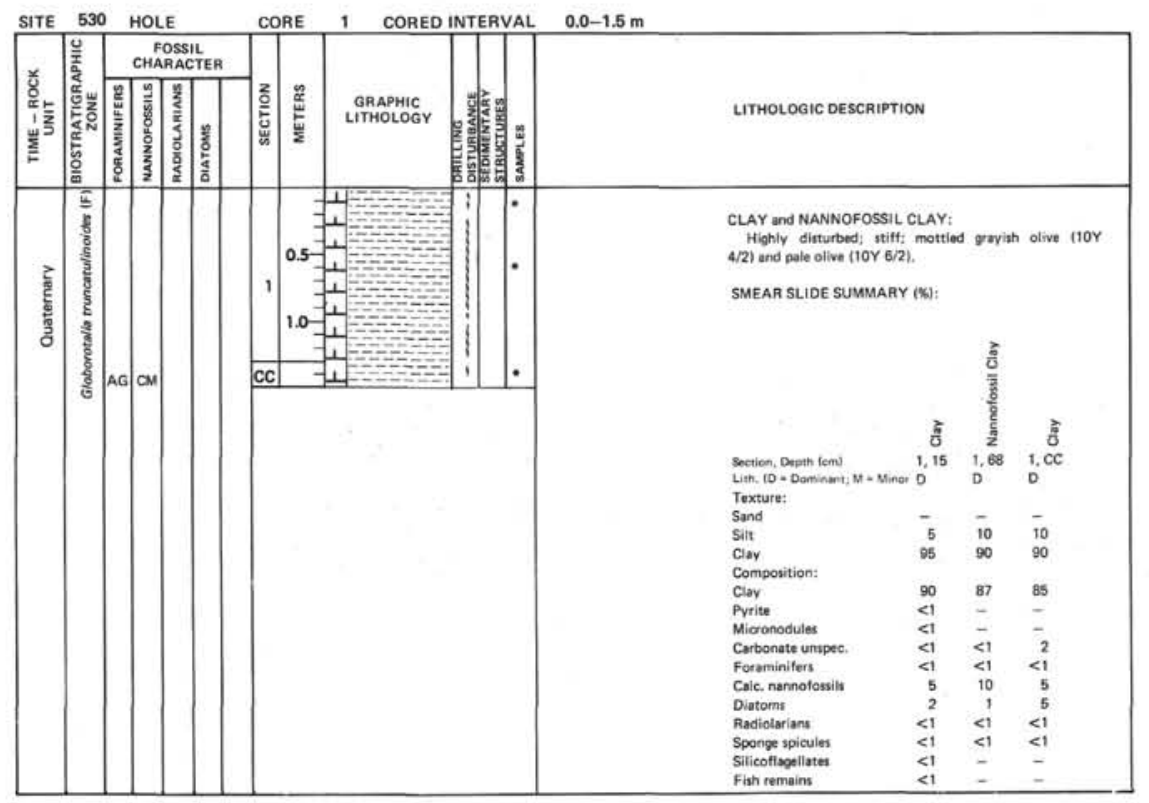

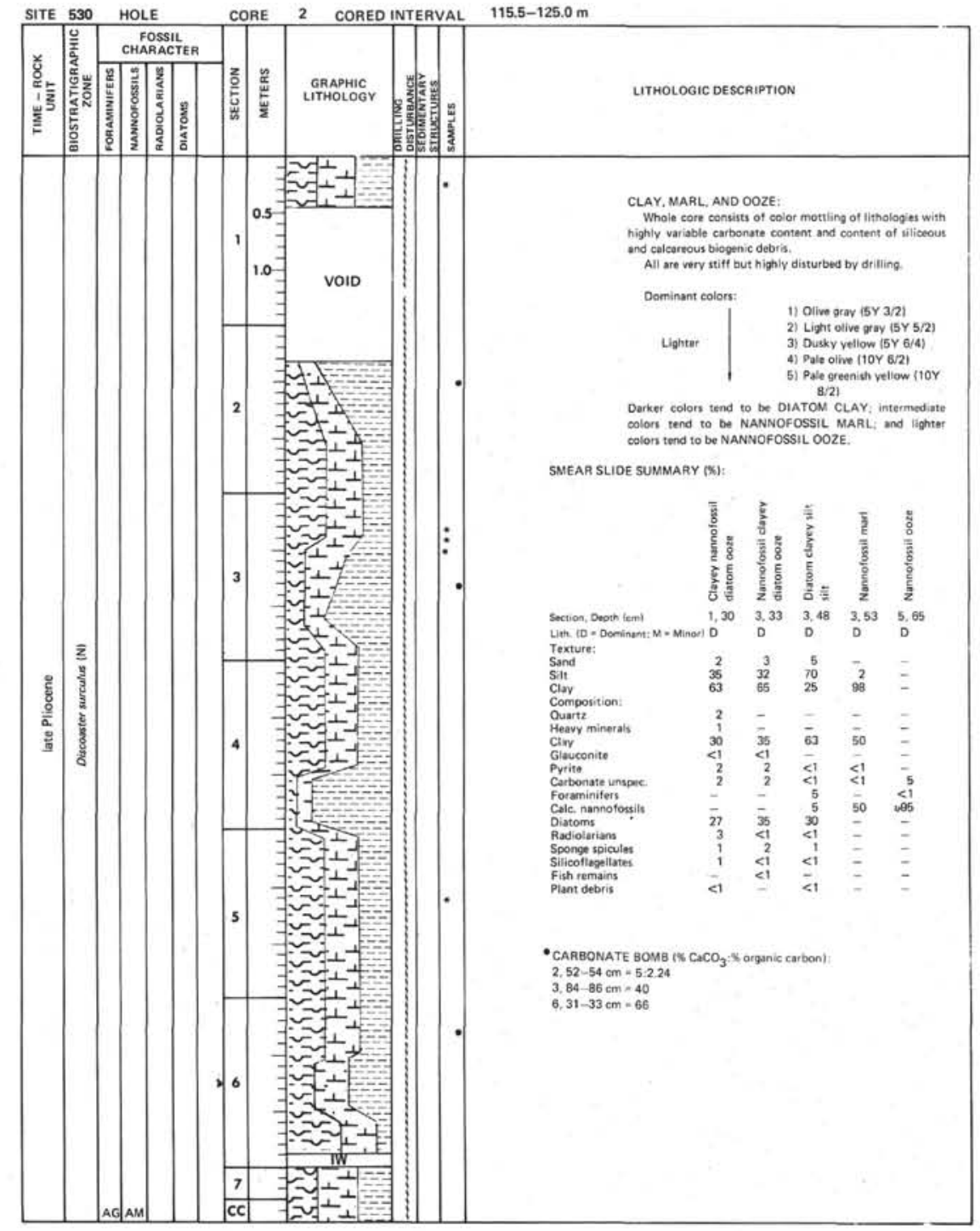

Information on core description sheets, for ALL sites, represents field notes taken aboard ship under time pressure. Some of this information has been refined in accord with postcruise findings, but production schedules prohibit definitive correlation of these sheets with subsequent findings. Thus the reader should be alerted to the occasional ambiguity pancy. 

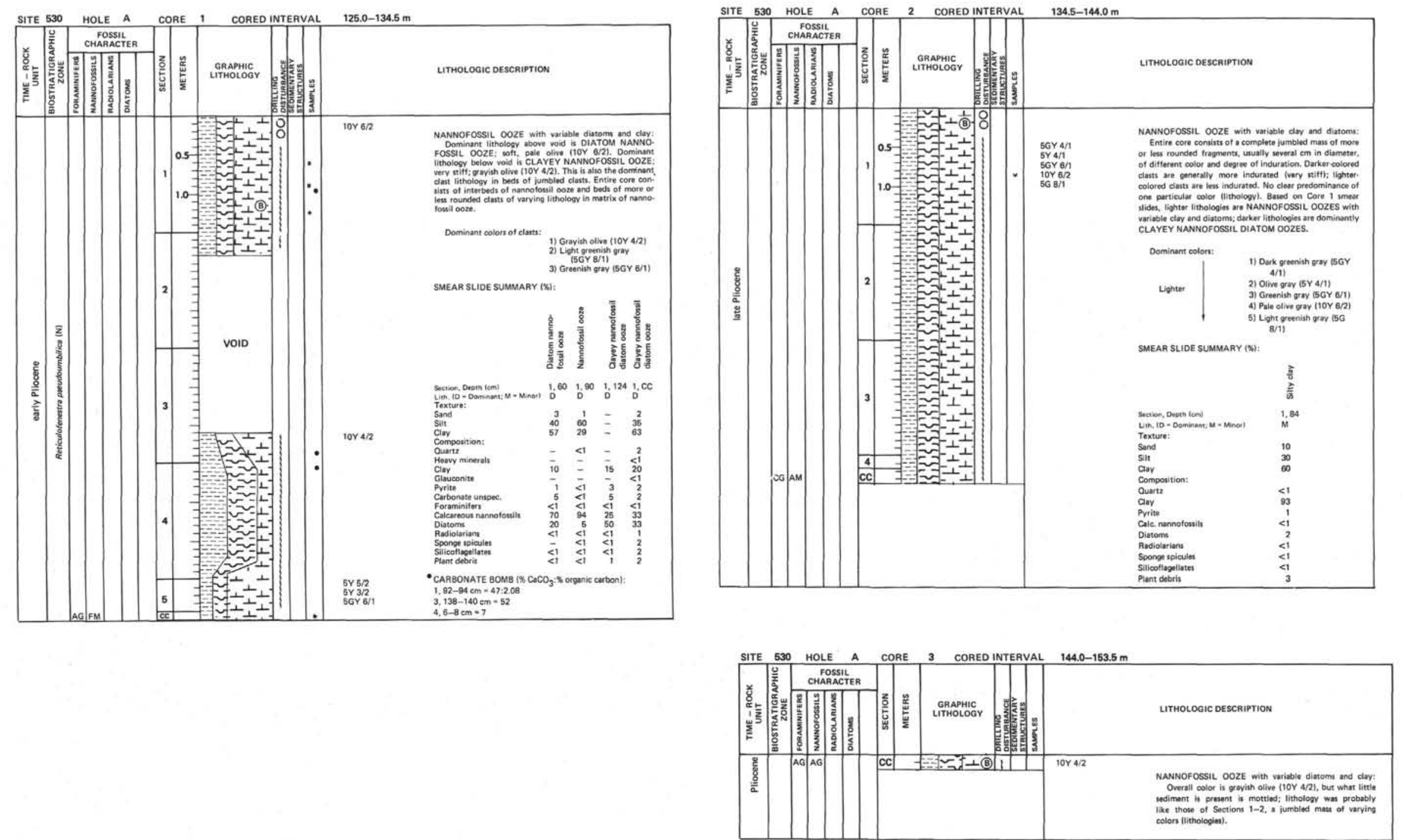

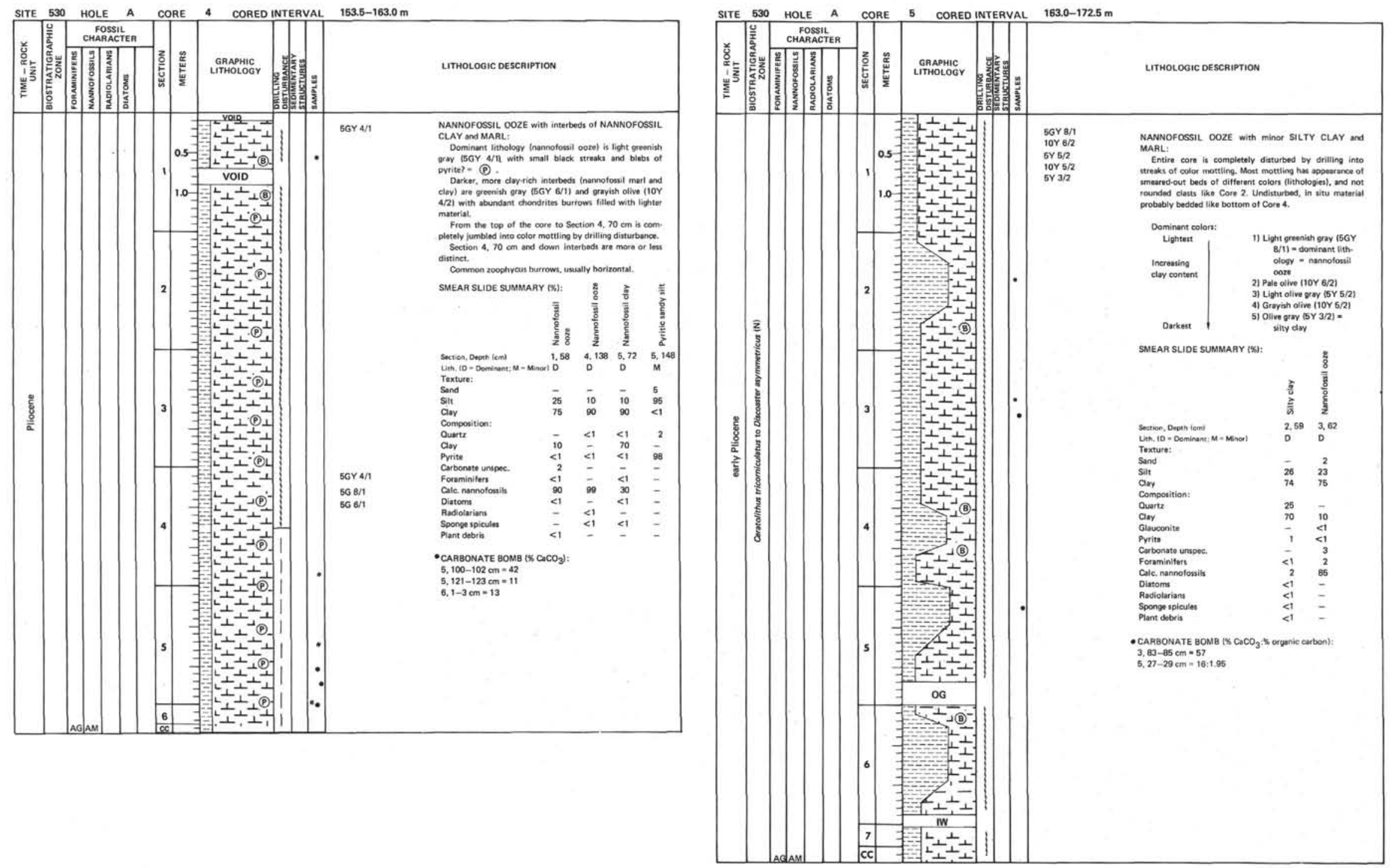


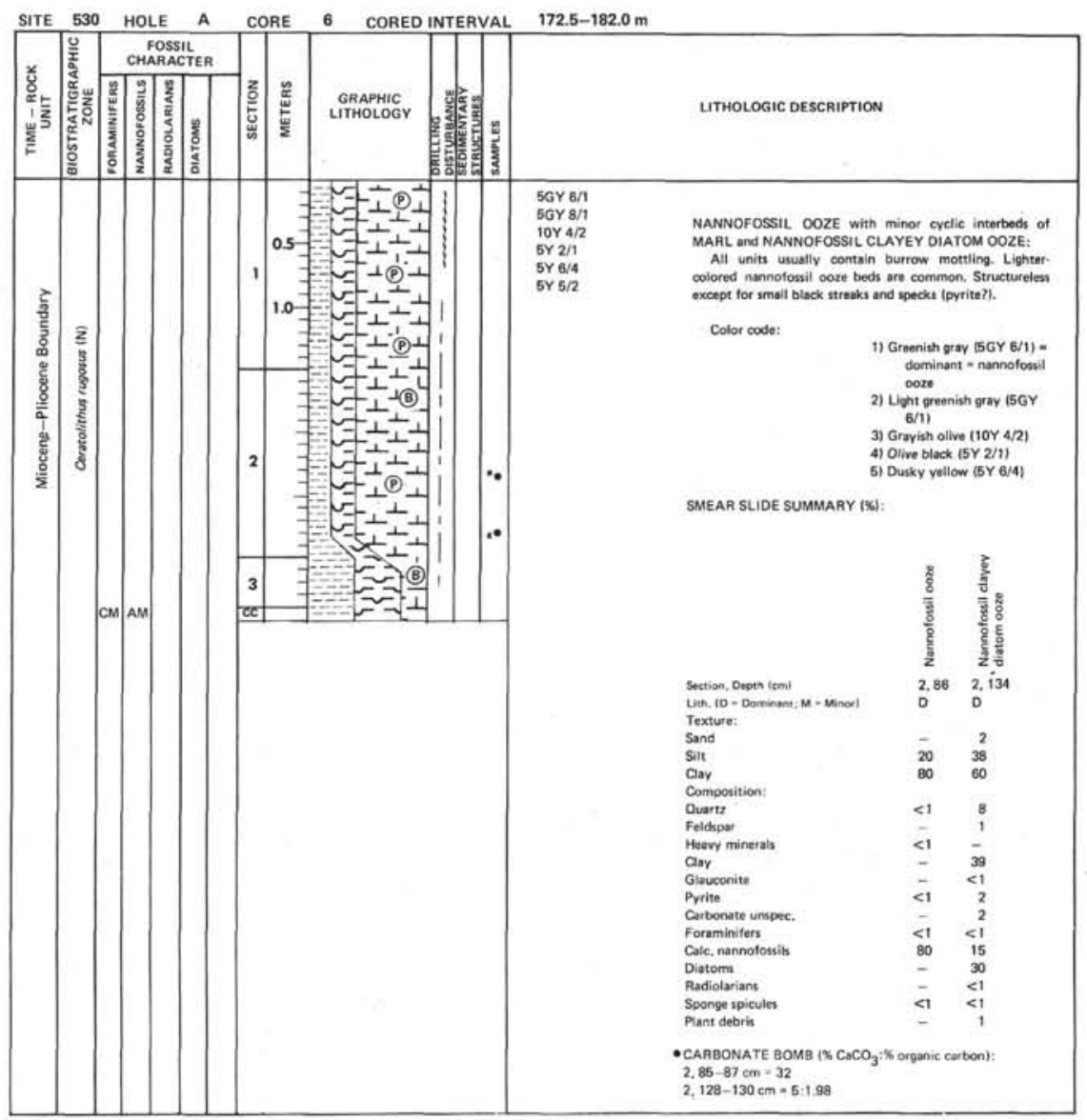

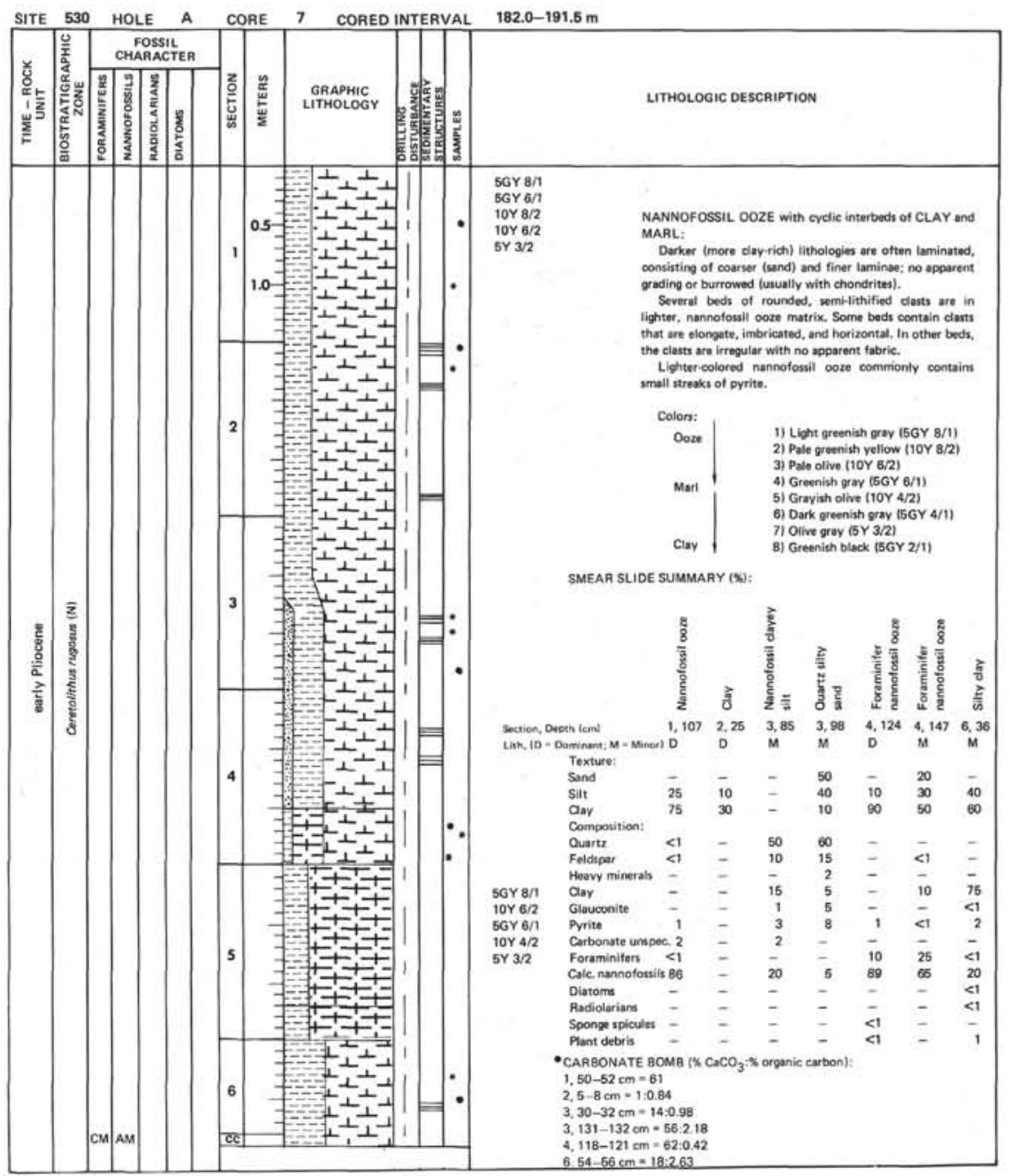



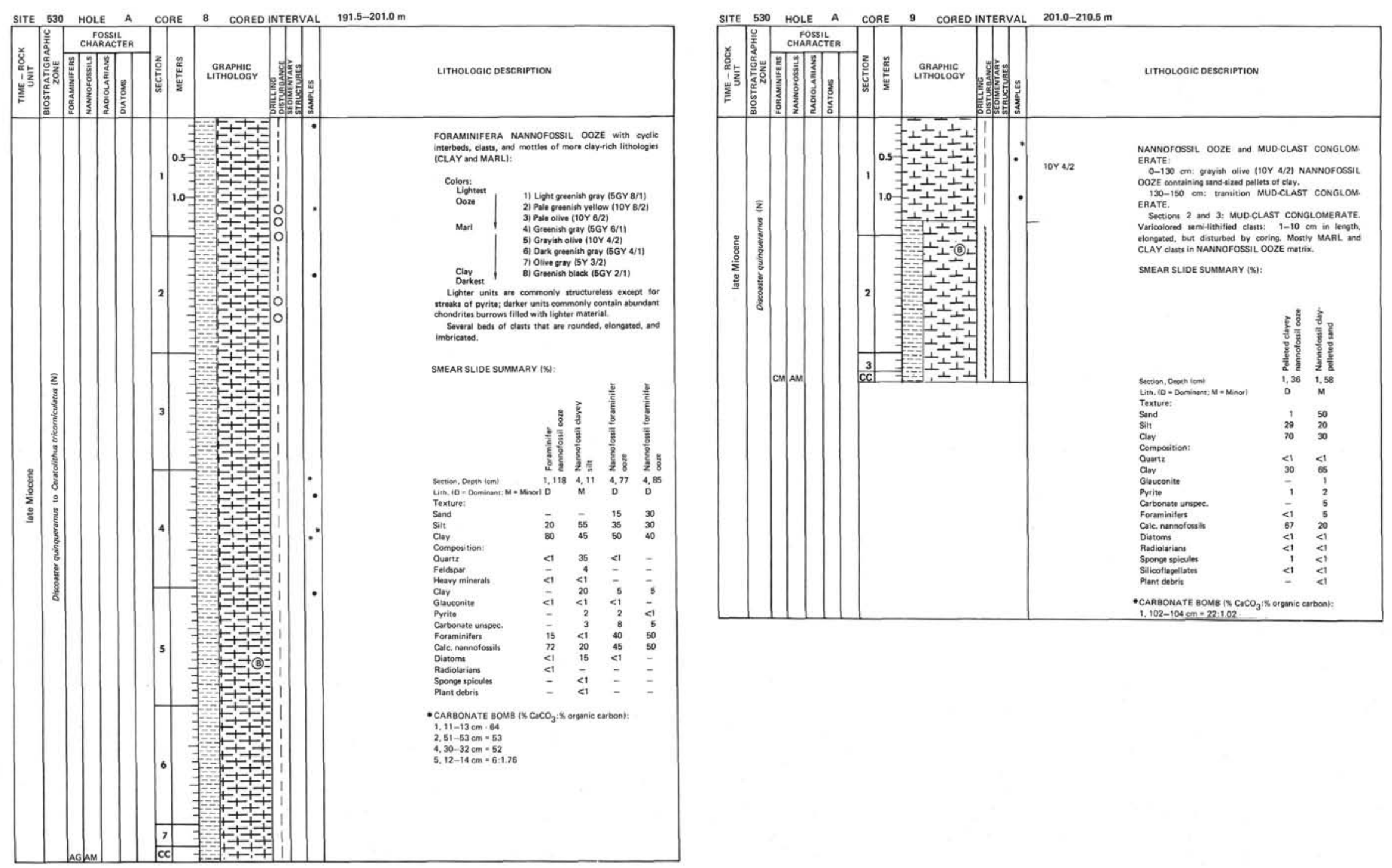

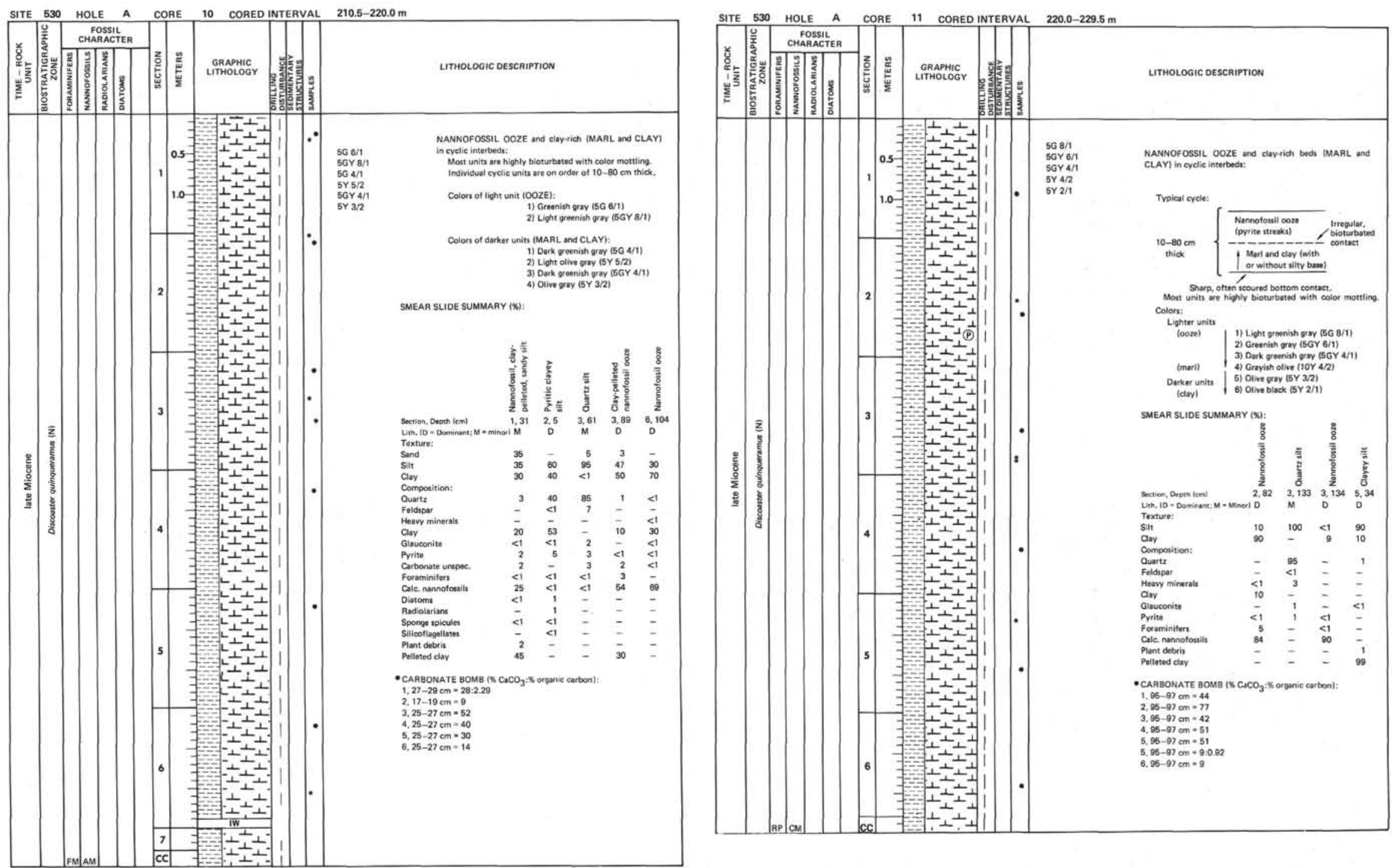

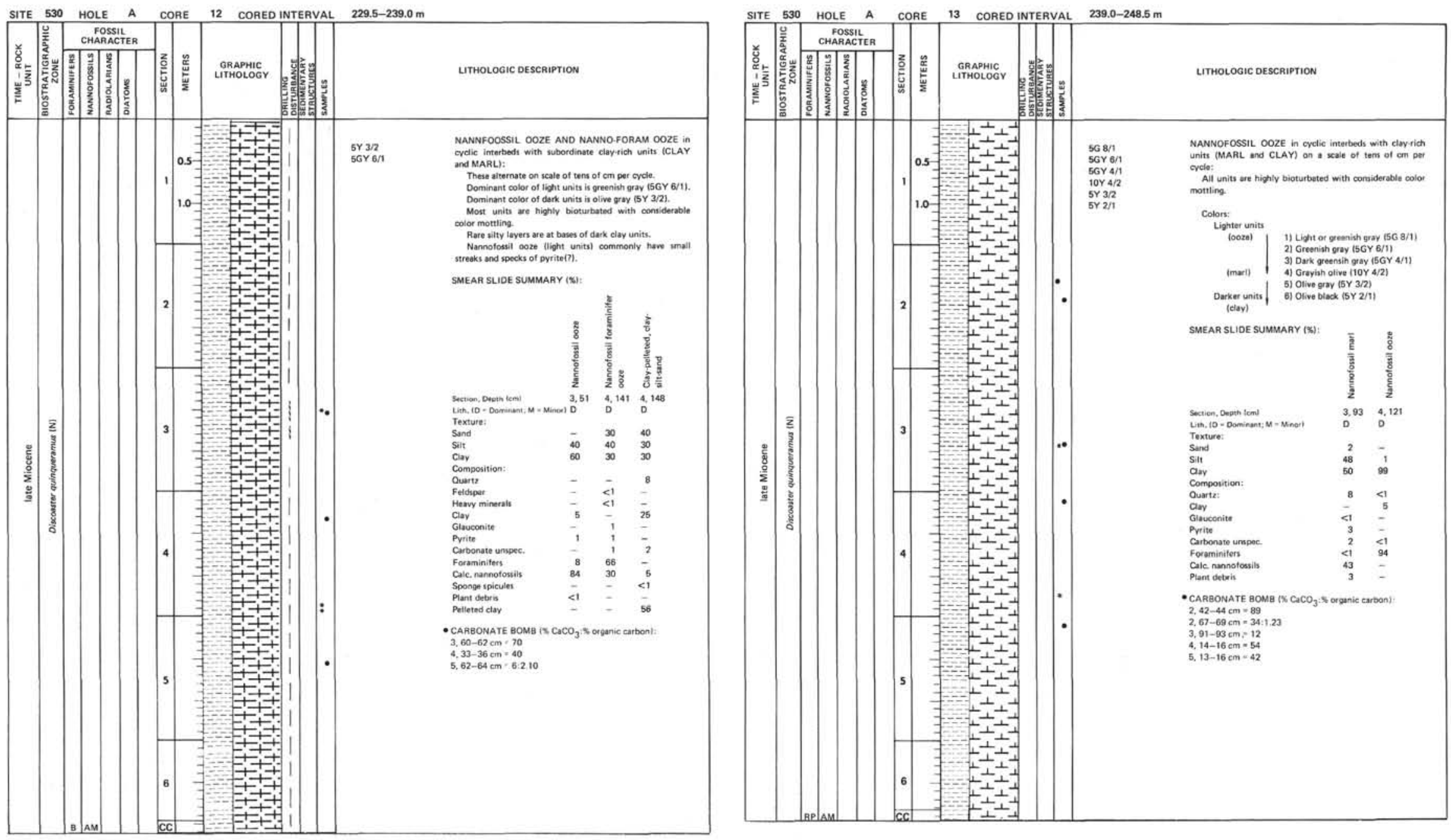


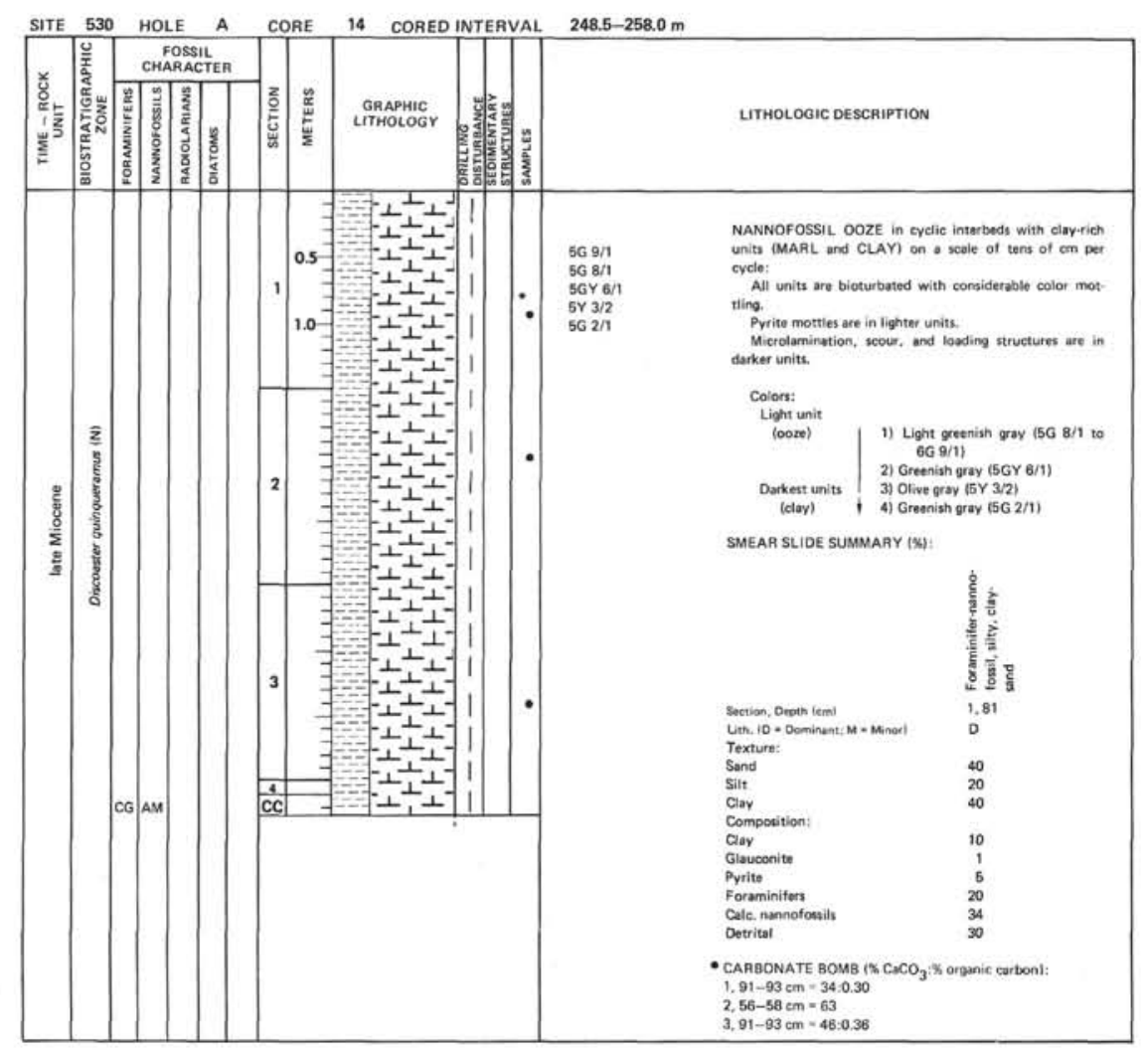

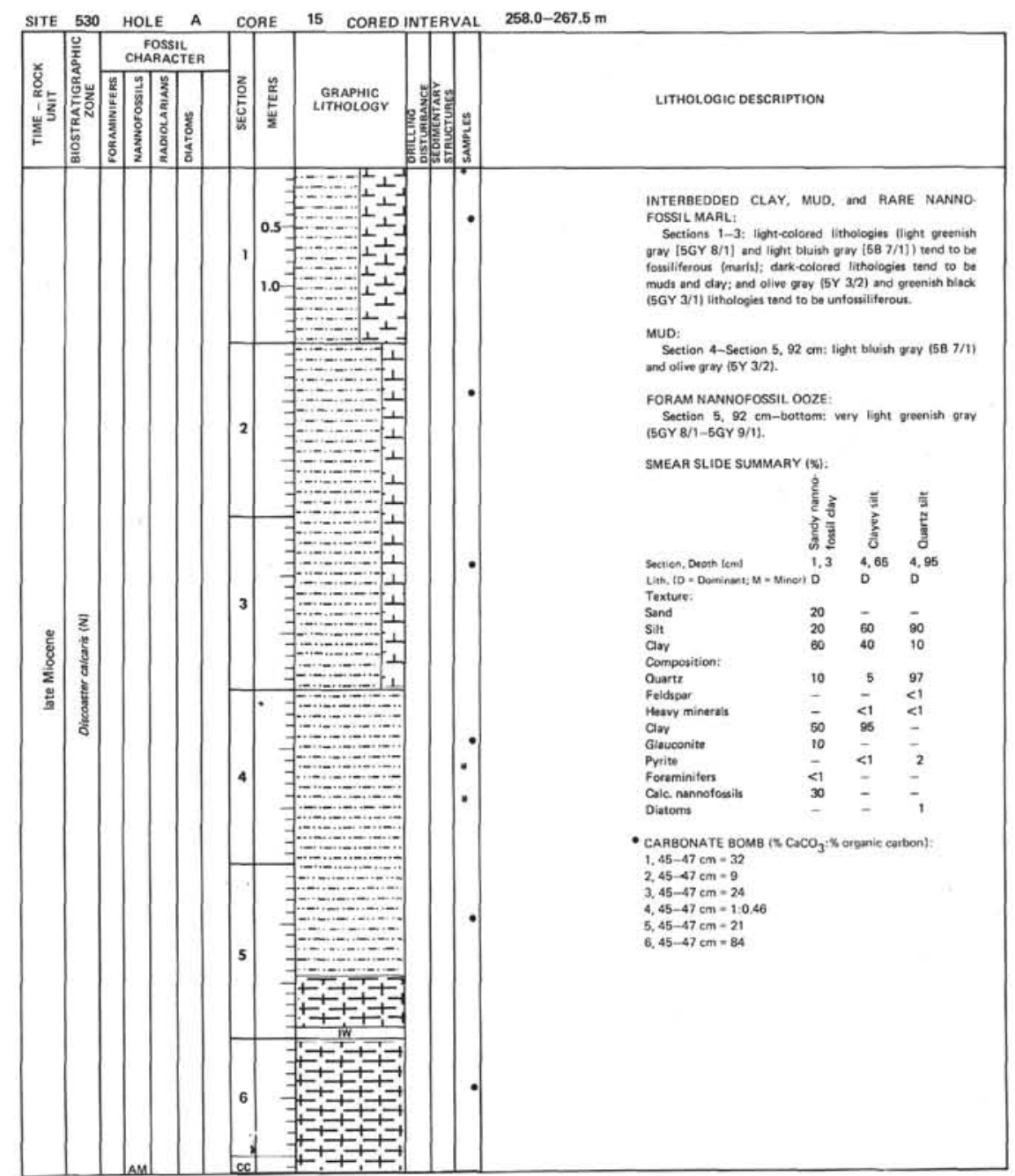



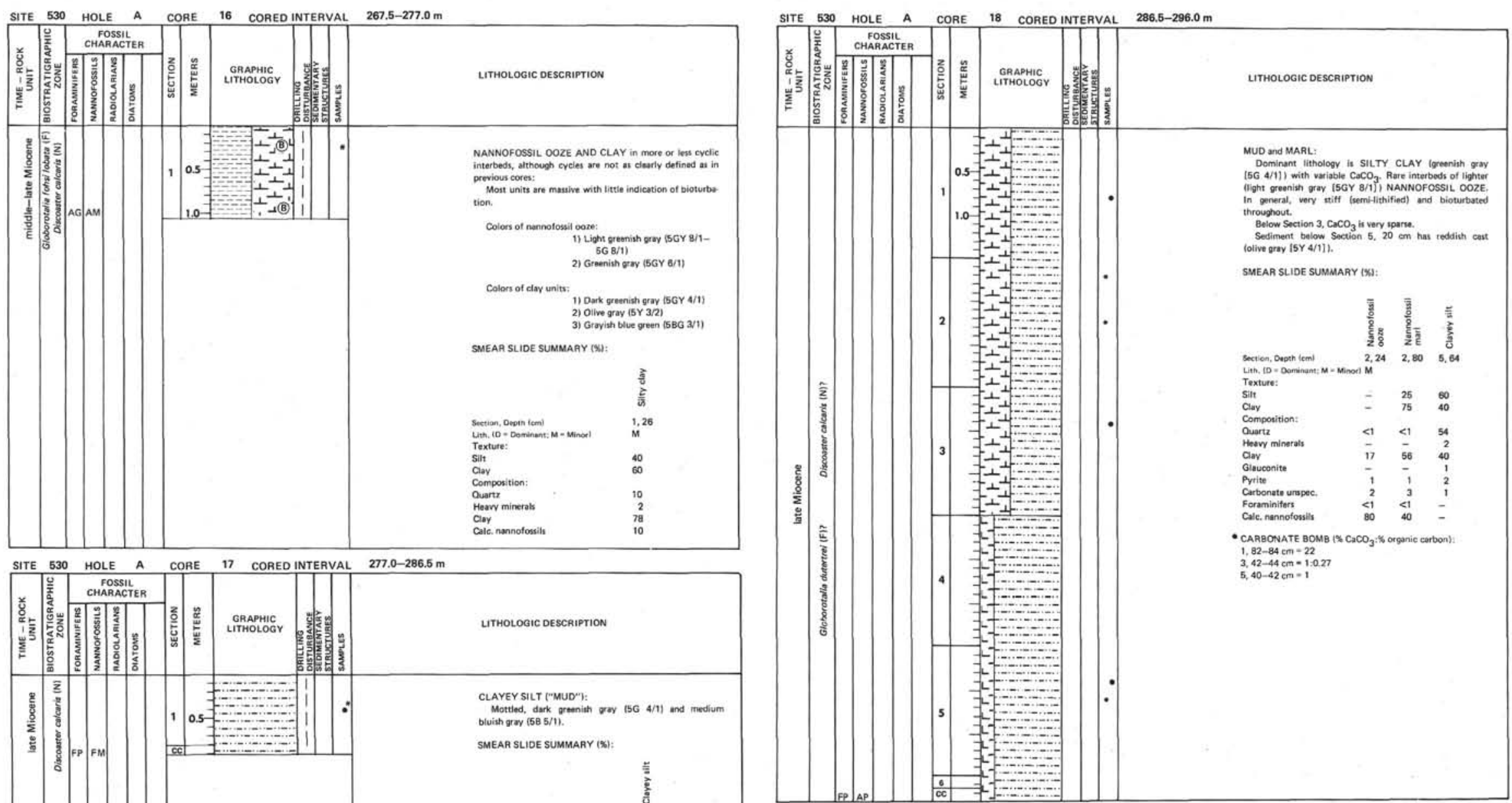

\begin{tabular}{|c|c|c|c|c|c|}
\hline SITE & 30 \\
\hline
\end{tabular}



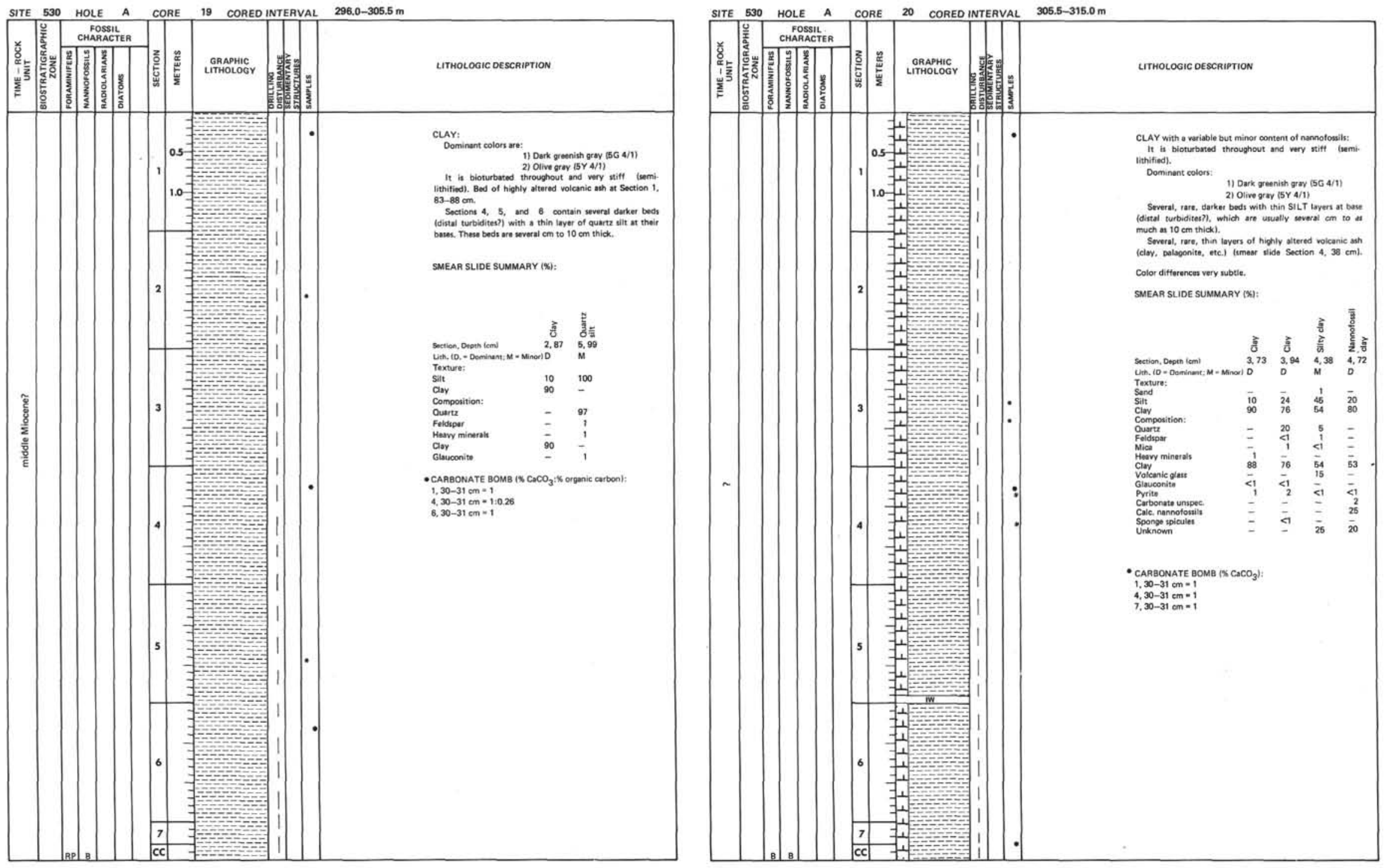

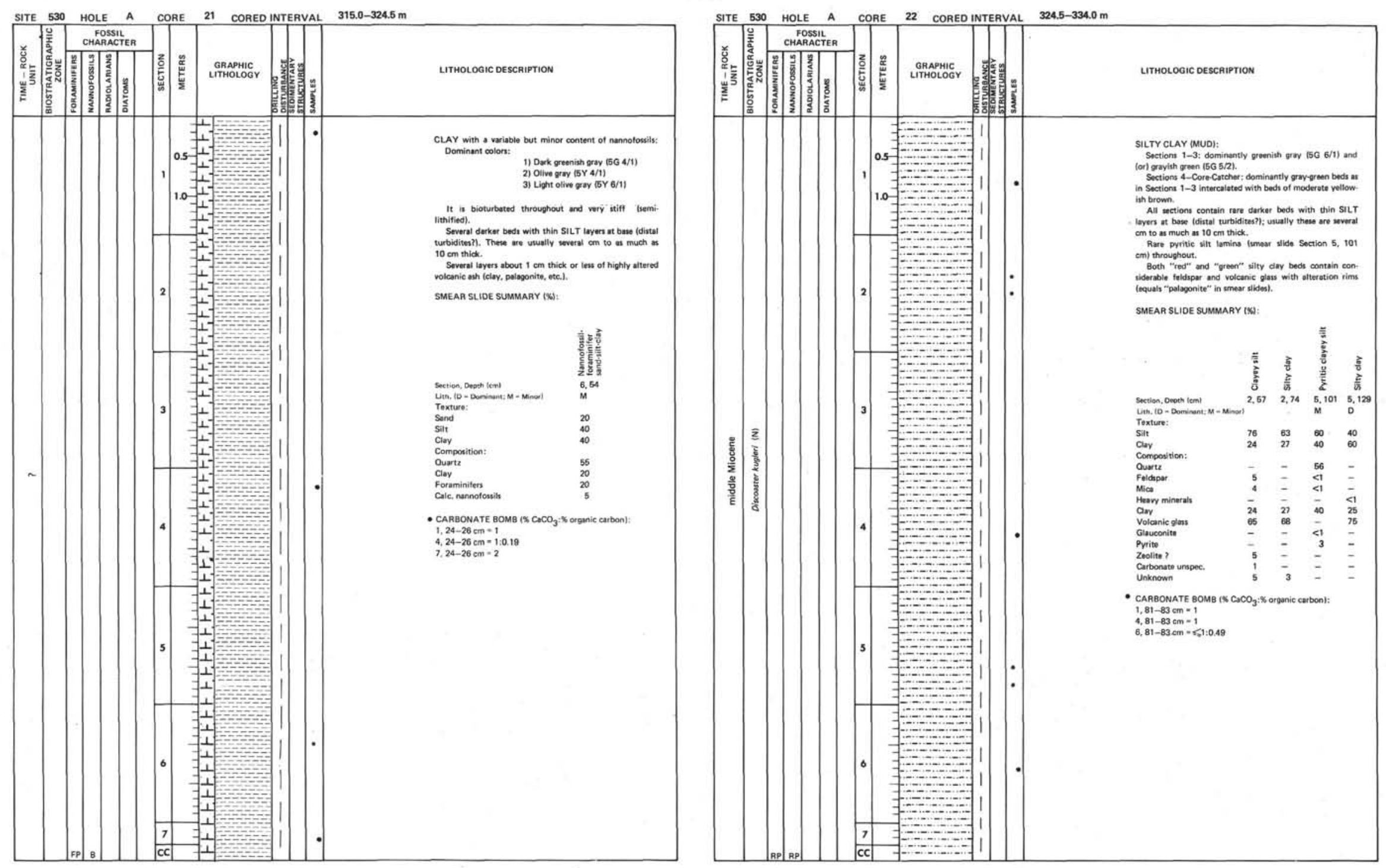


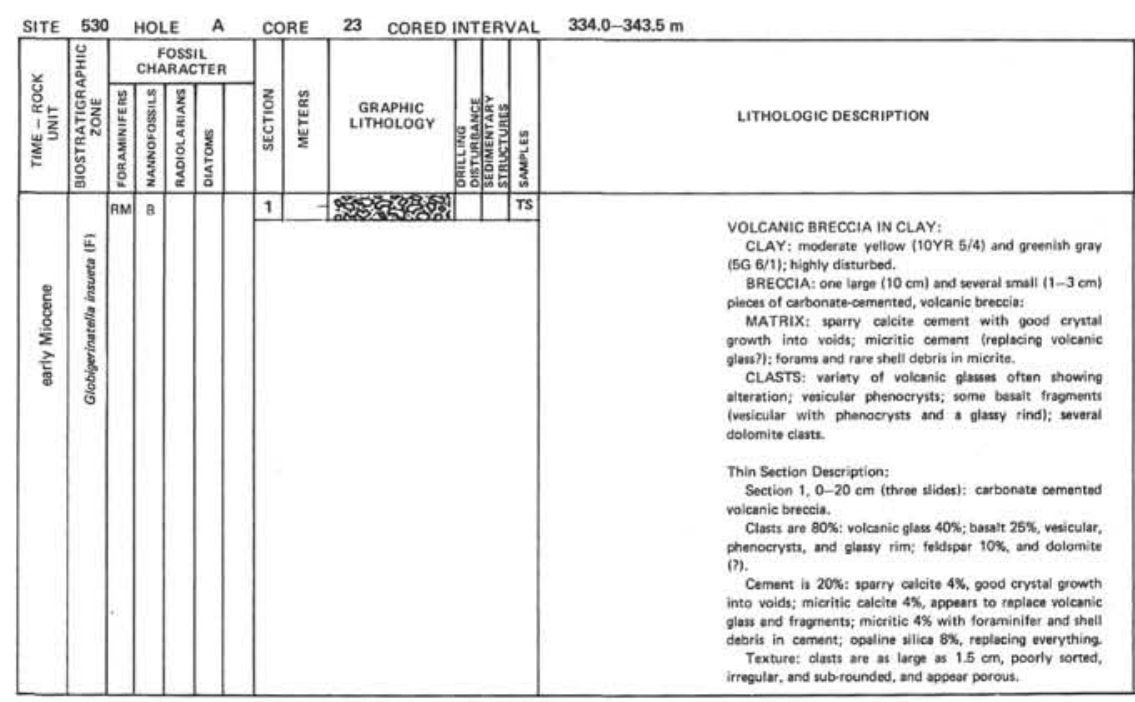

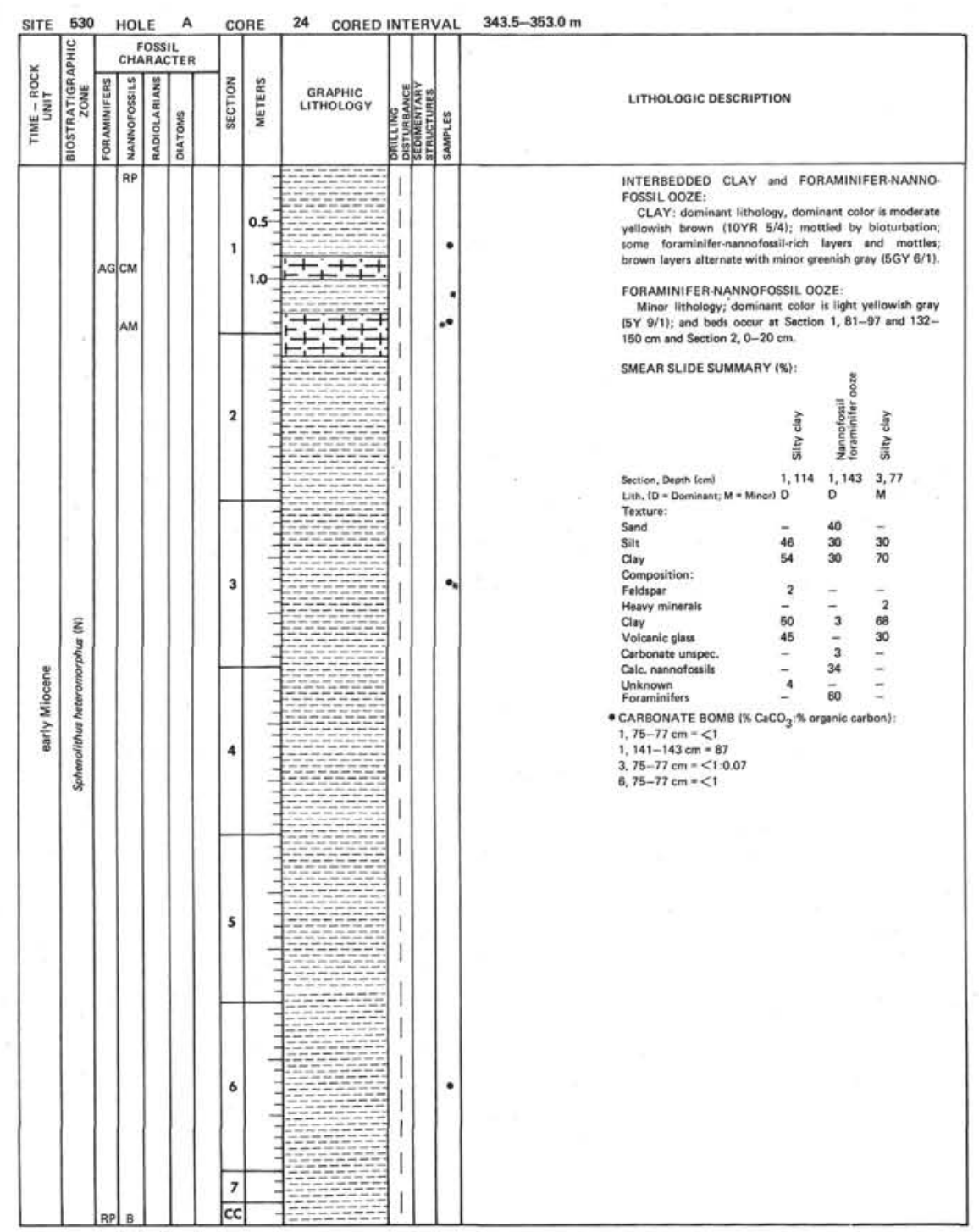



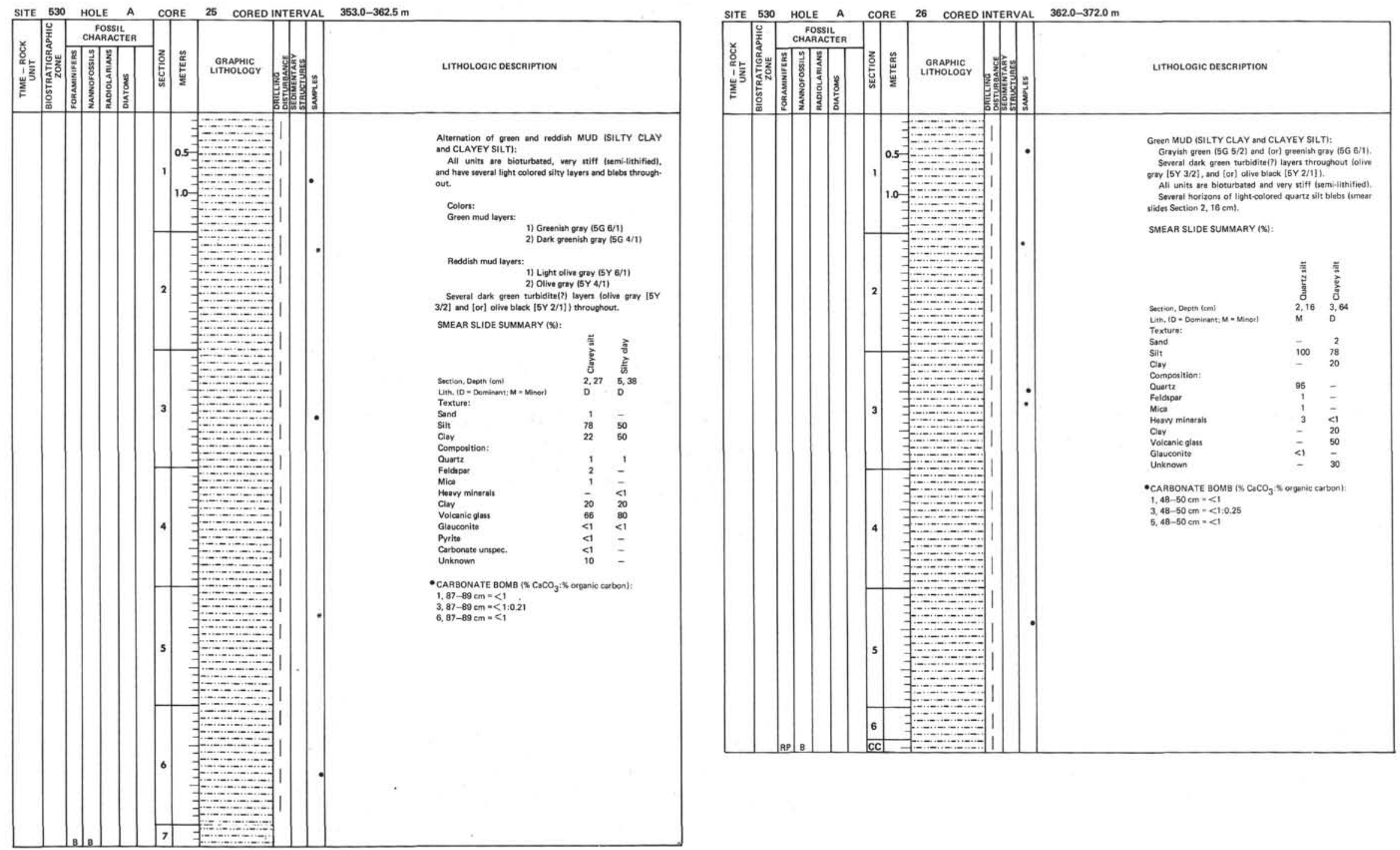

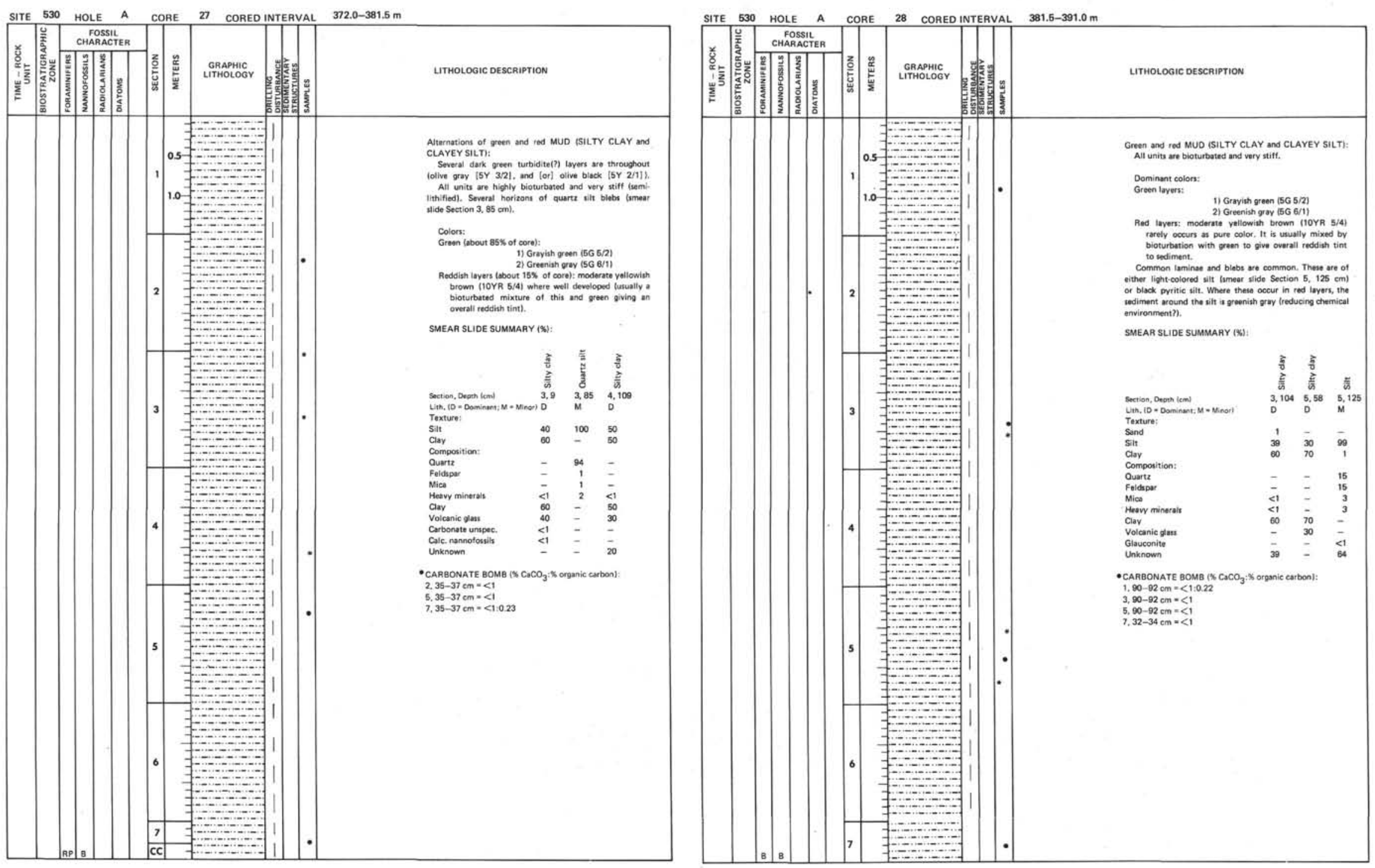

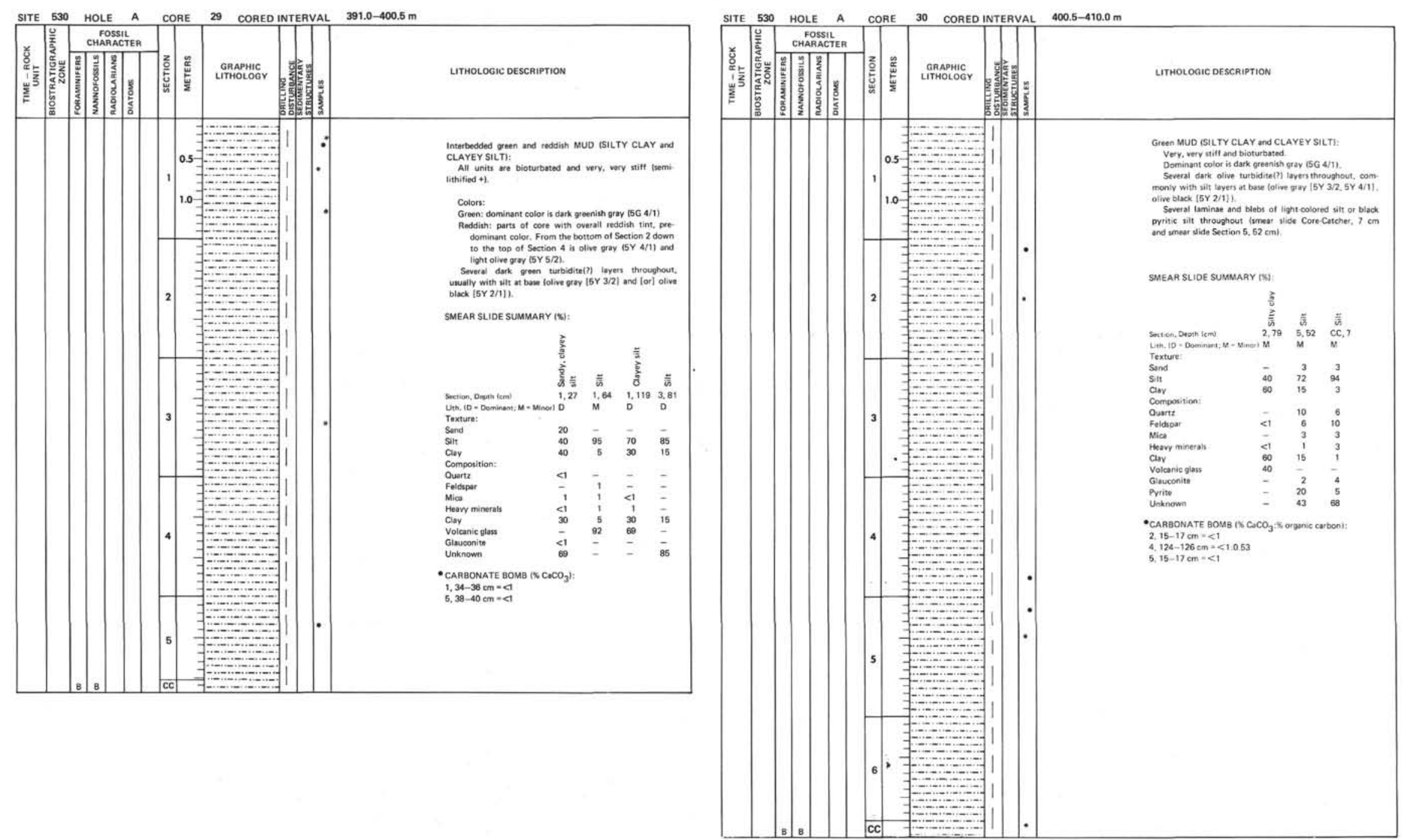


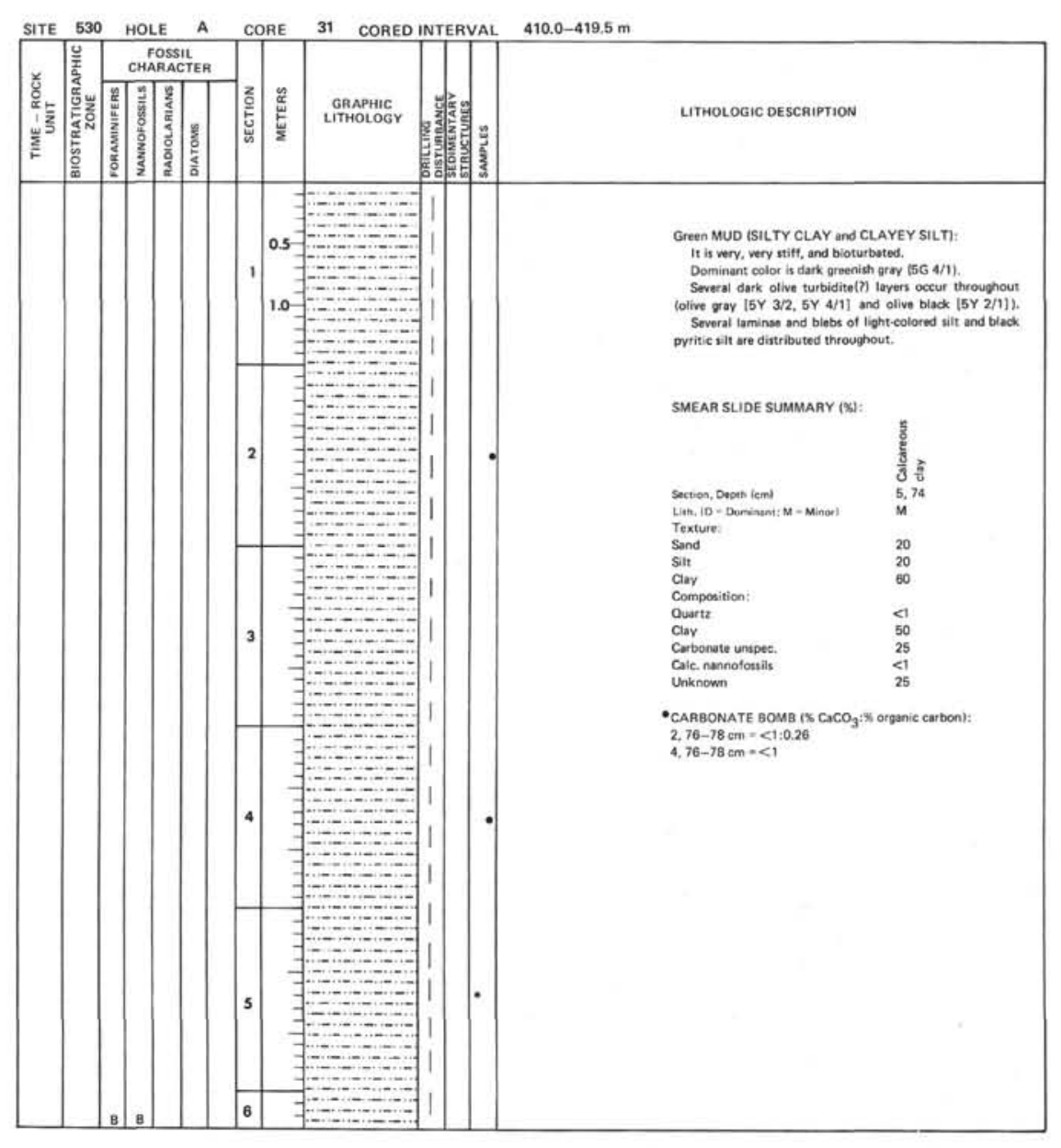

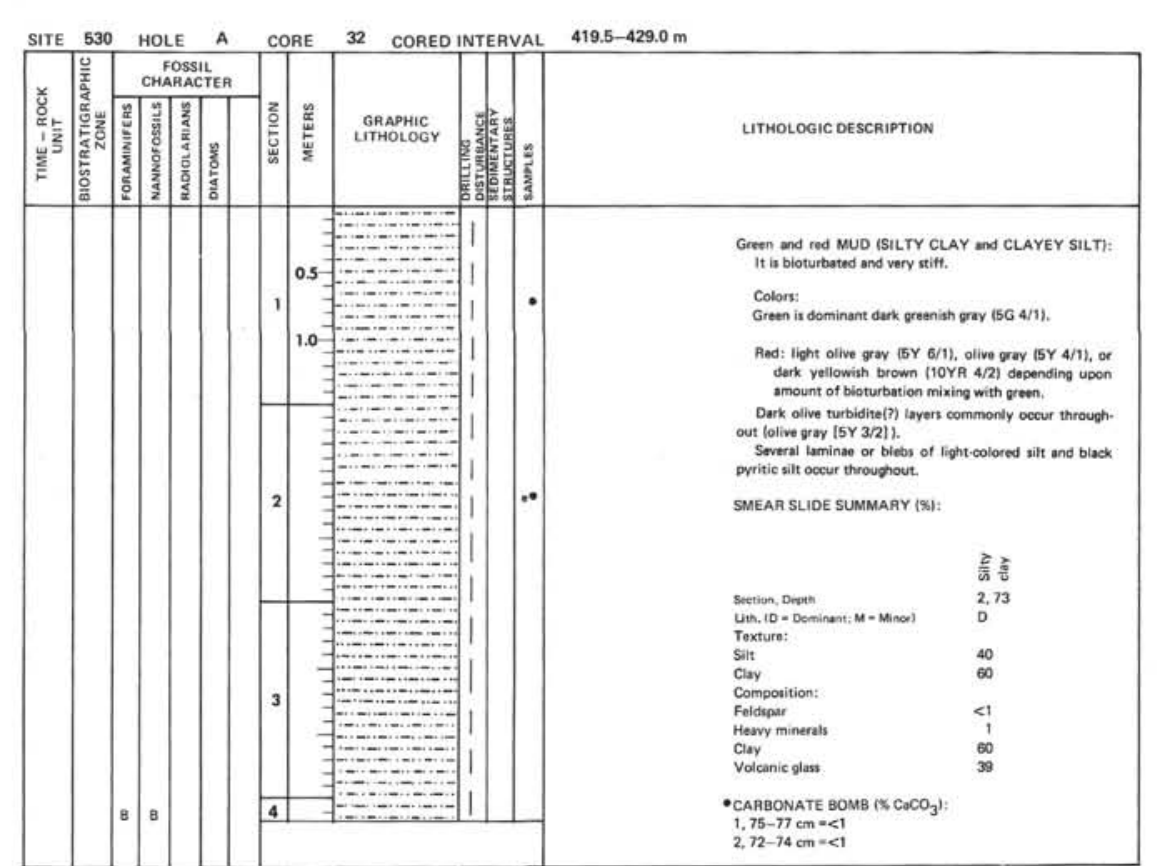

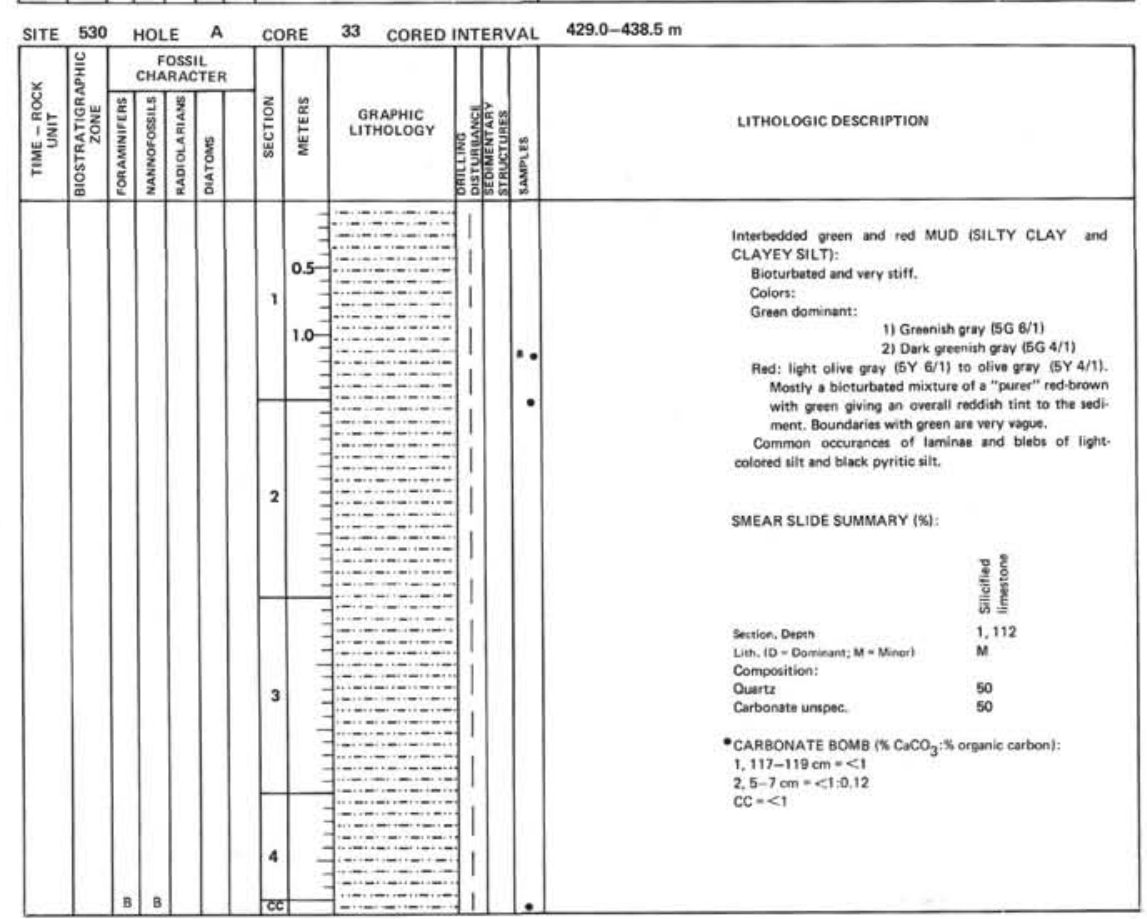



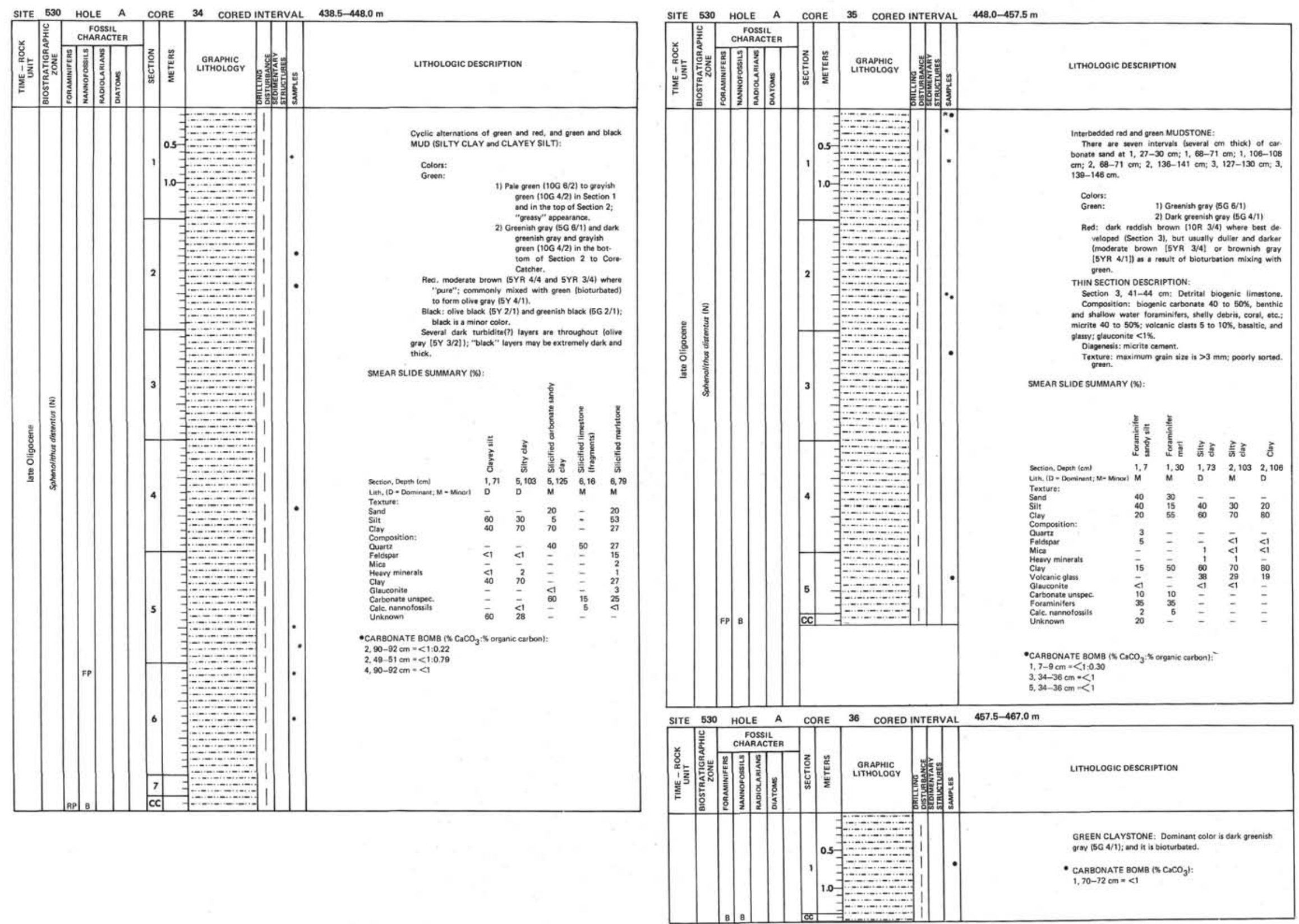


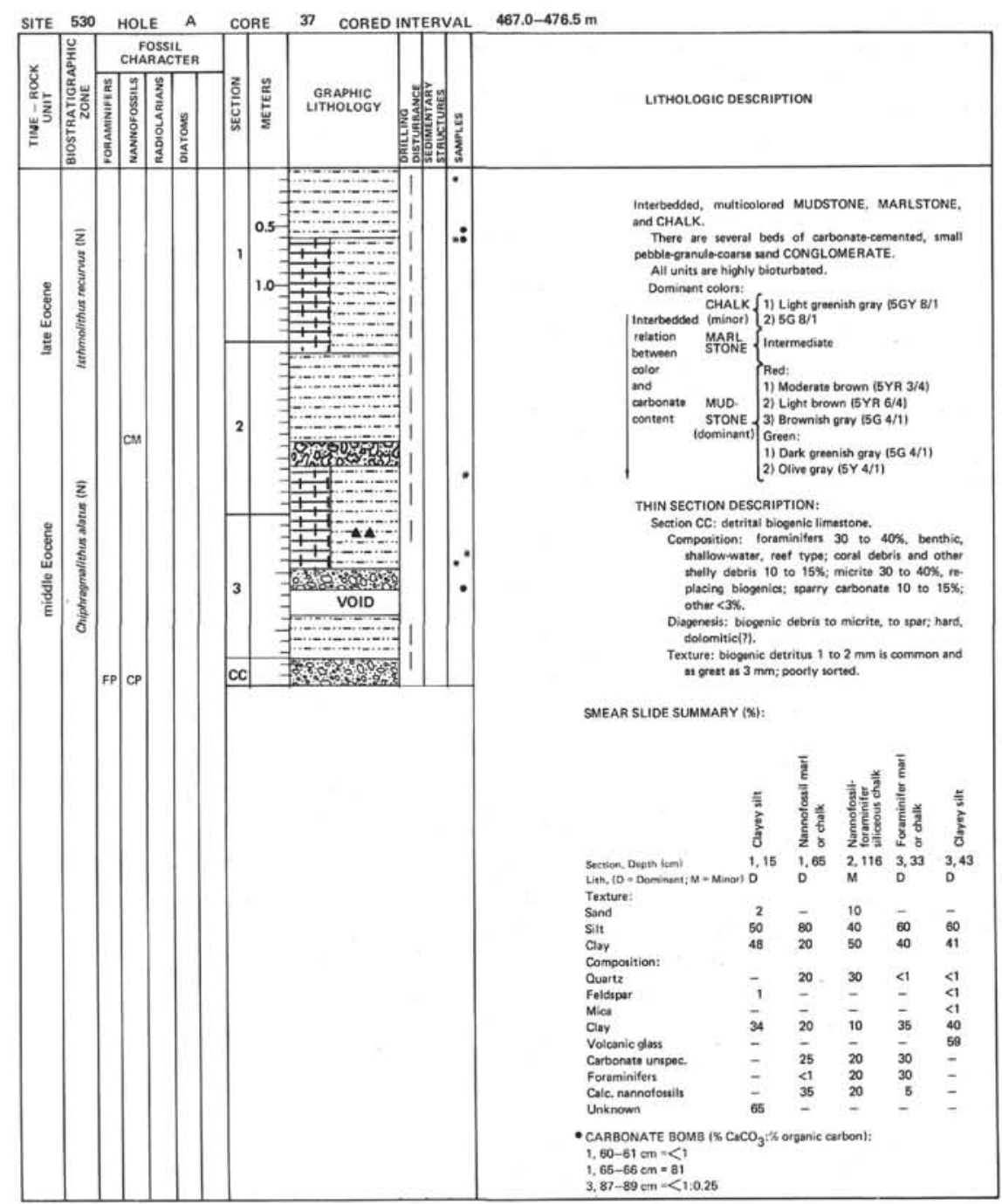

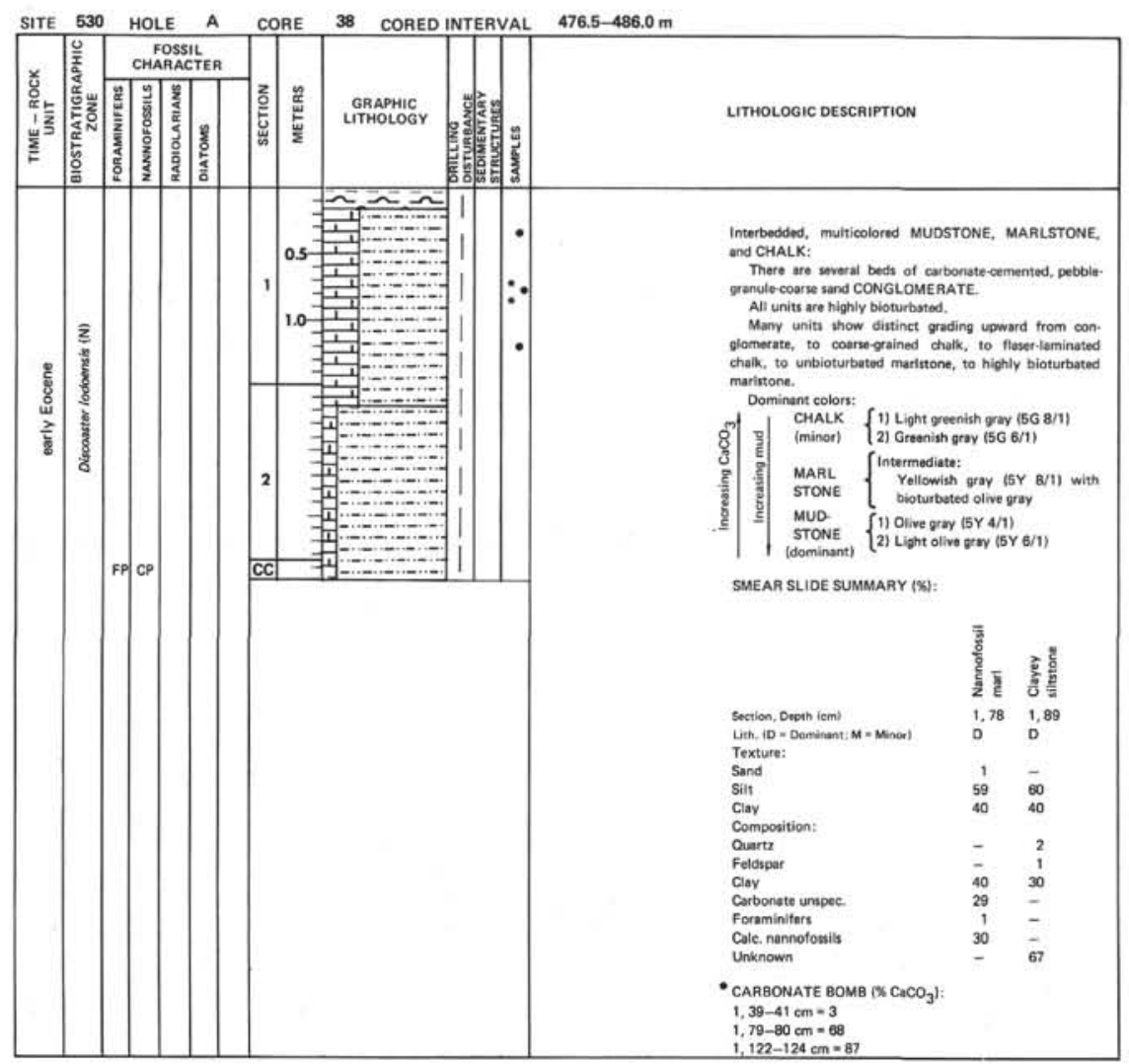



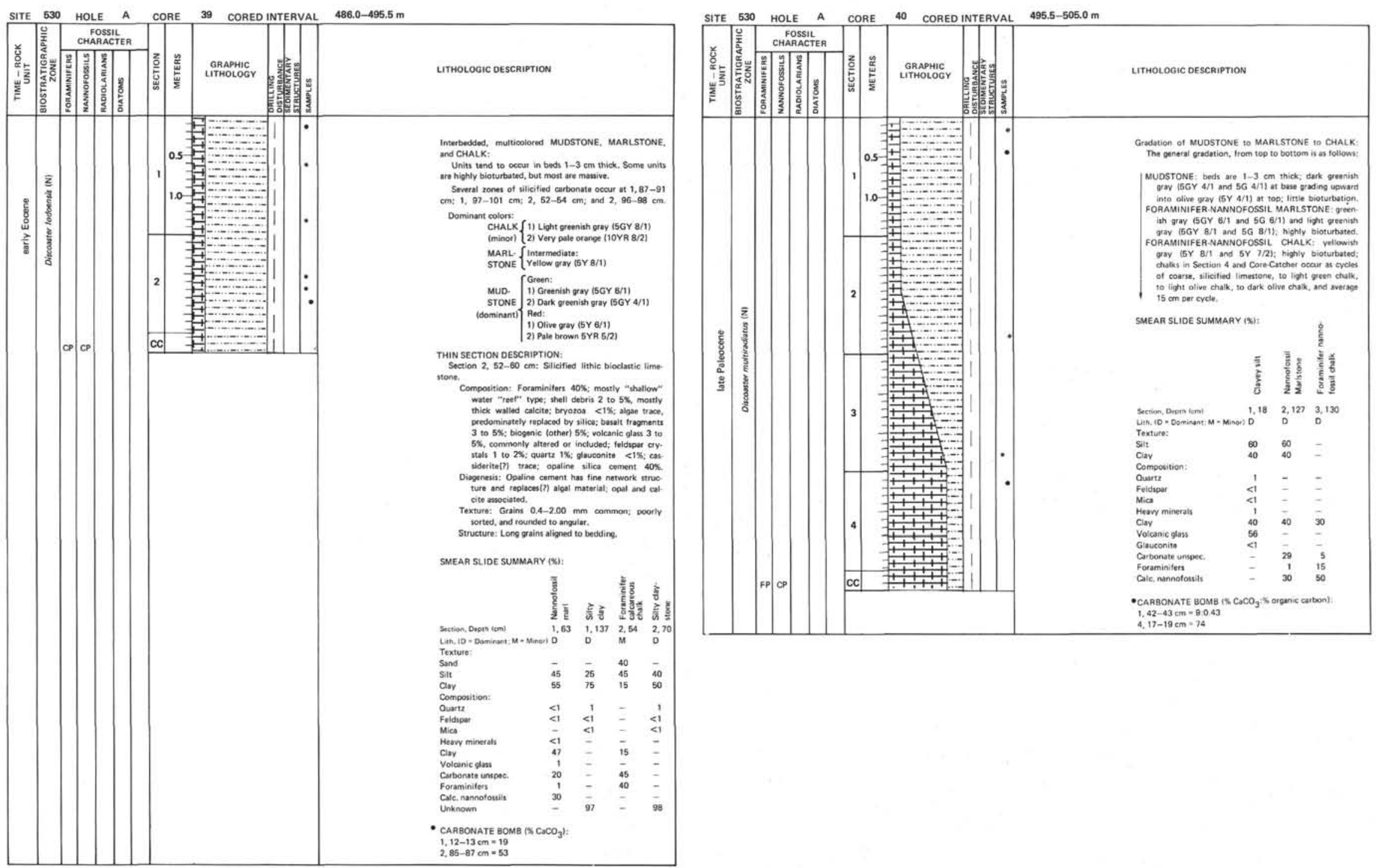

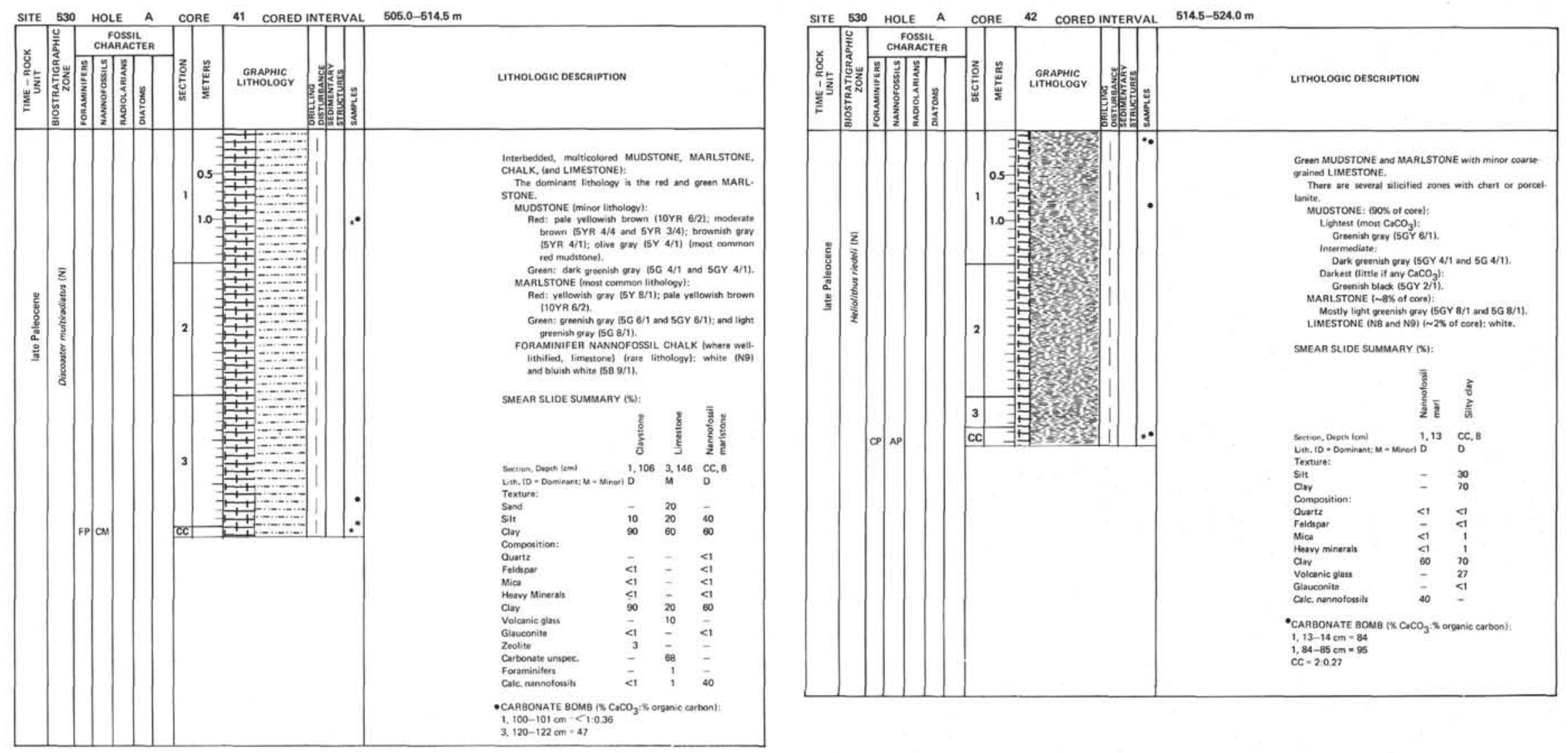

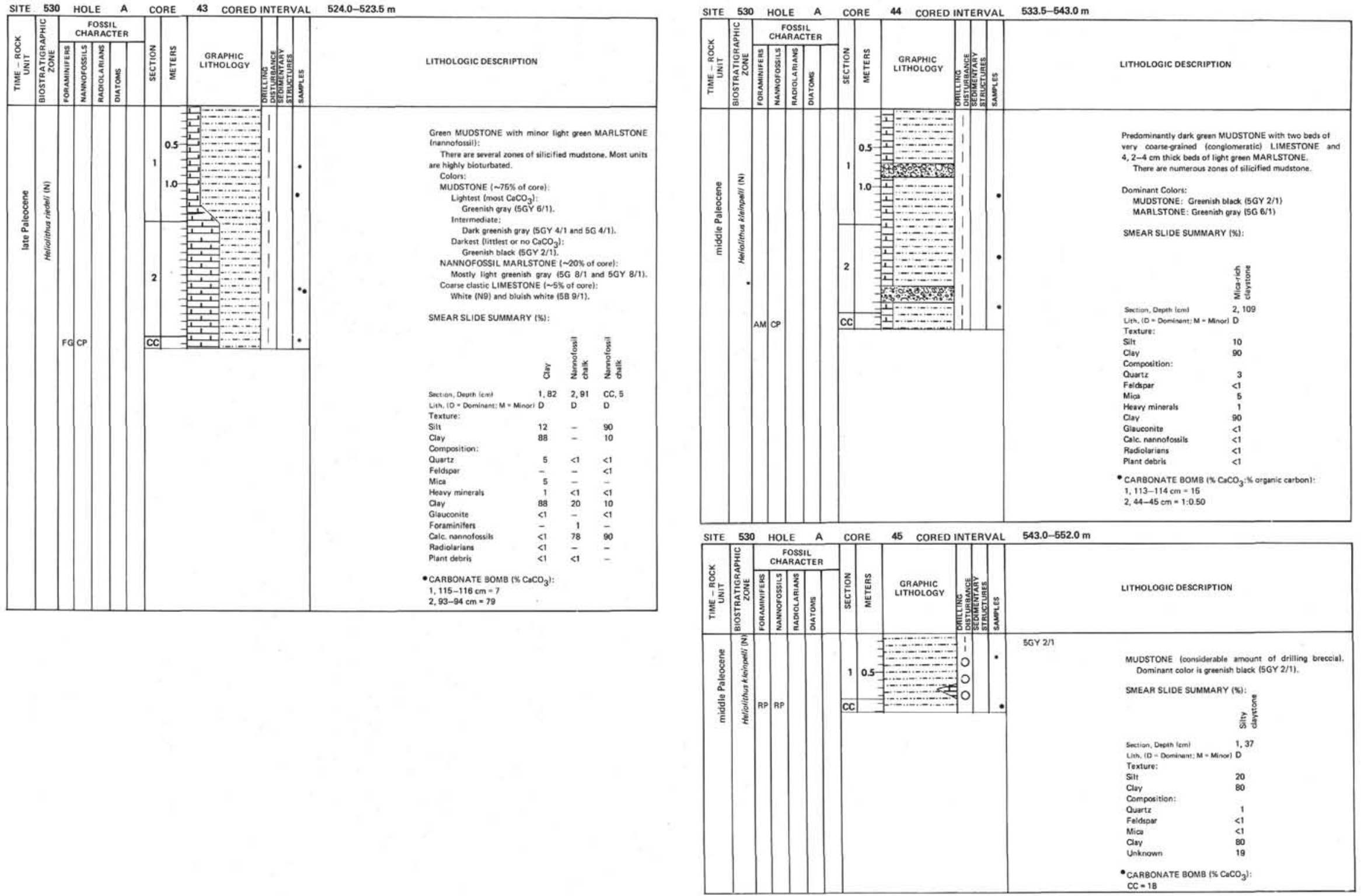


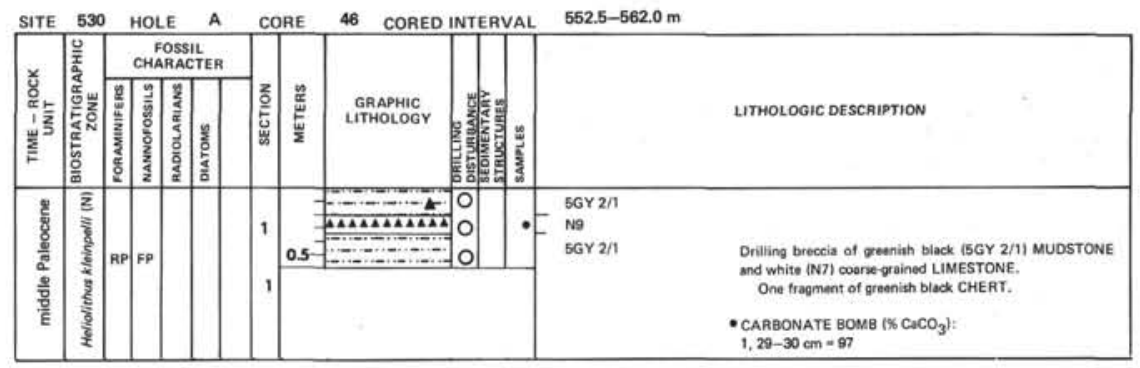

SITE 530 HOLE A CORE 47 CORED INTERVAL $5620-571.5 \mathrm{~m}$

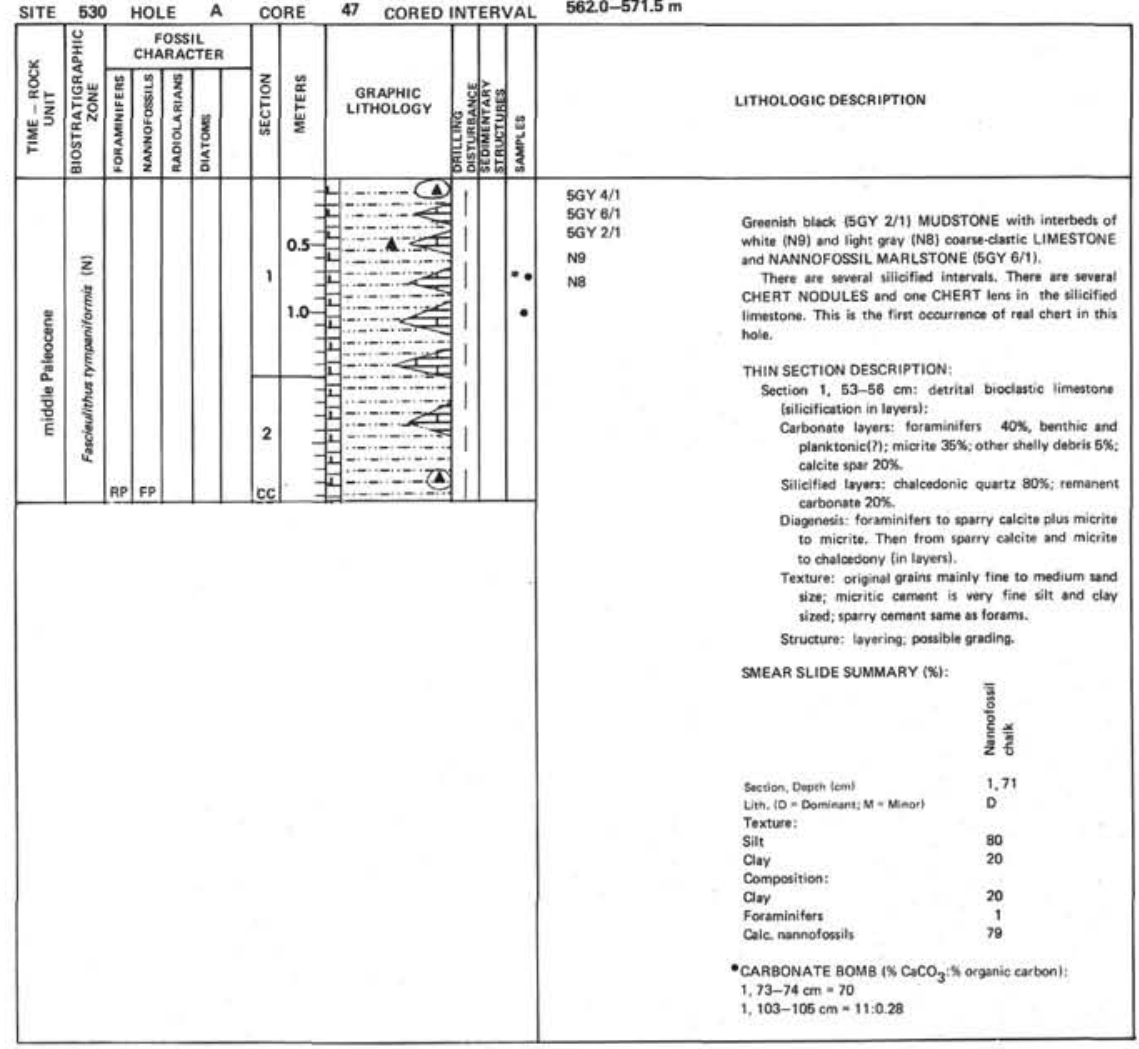

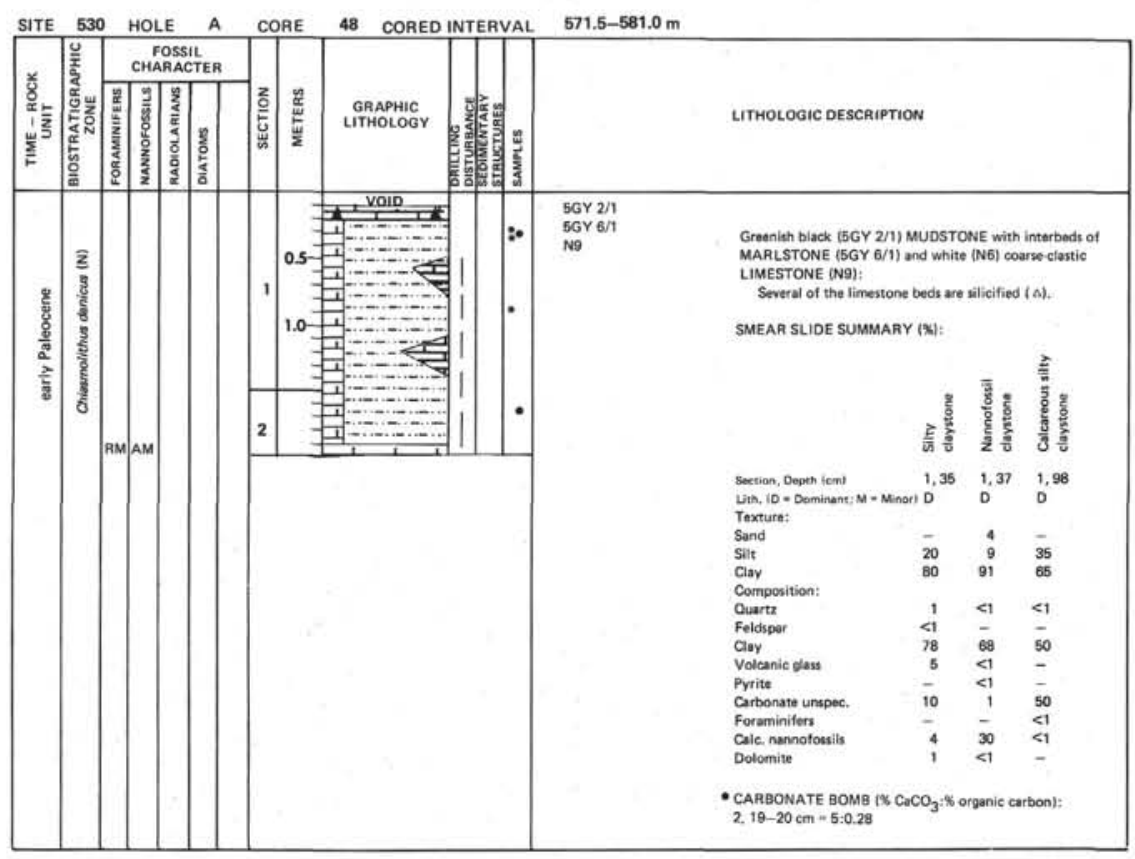



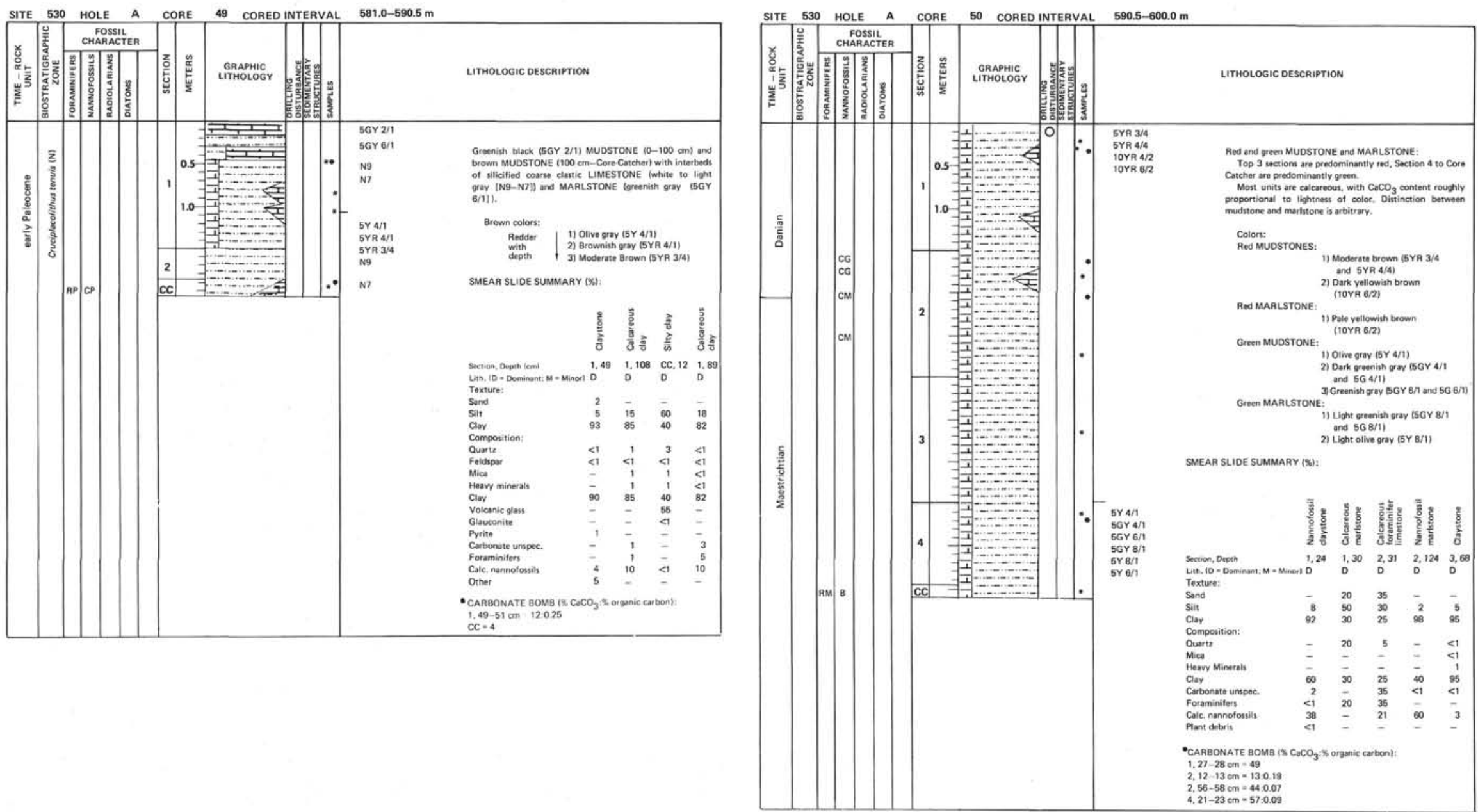


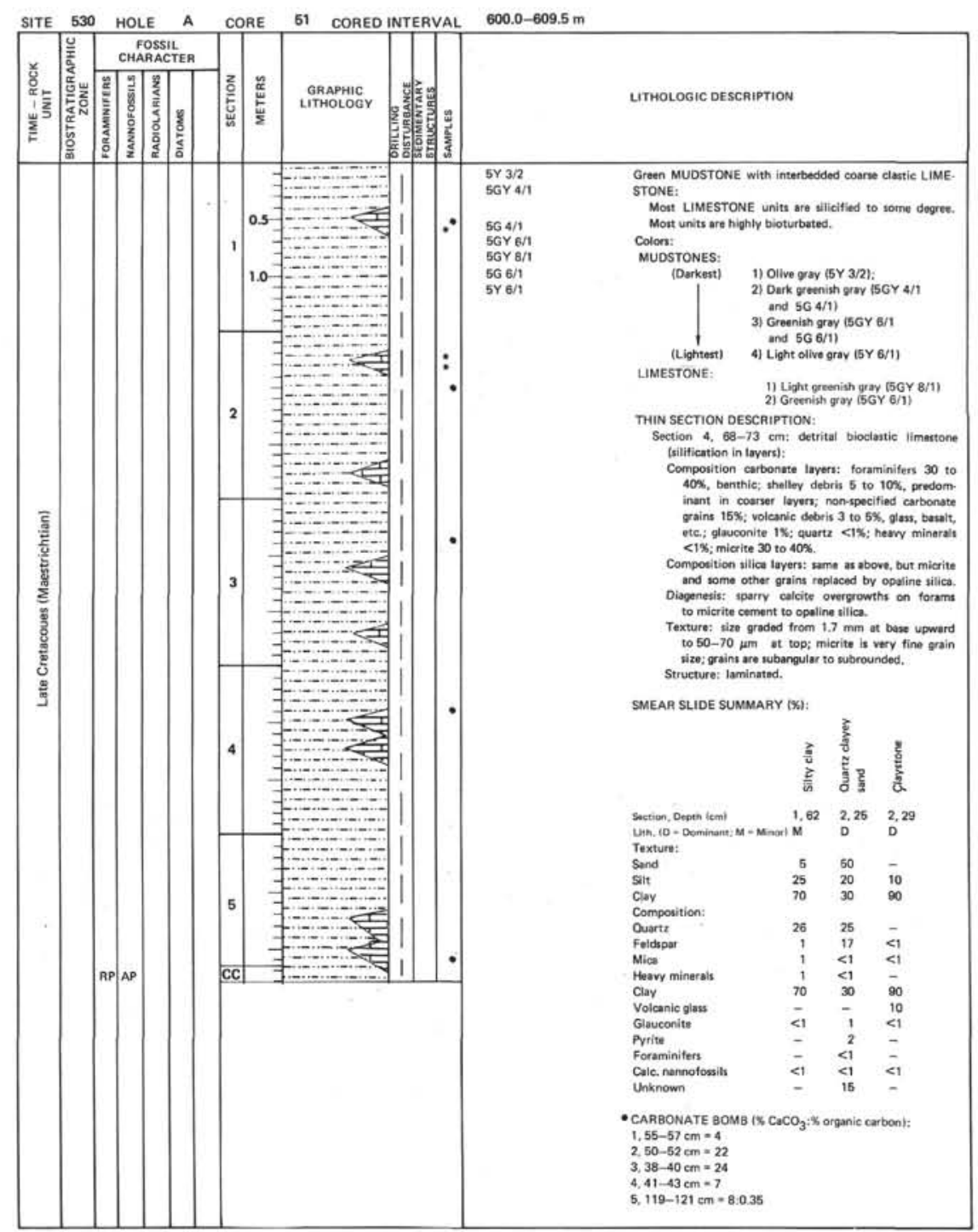

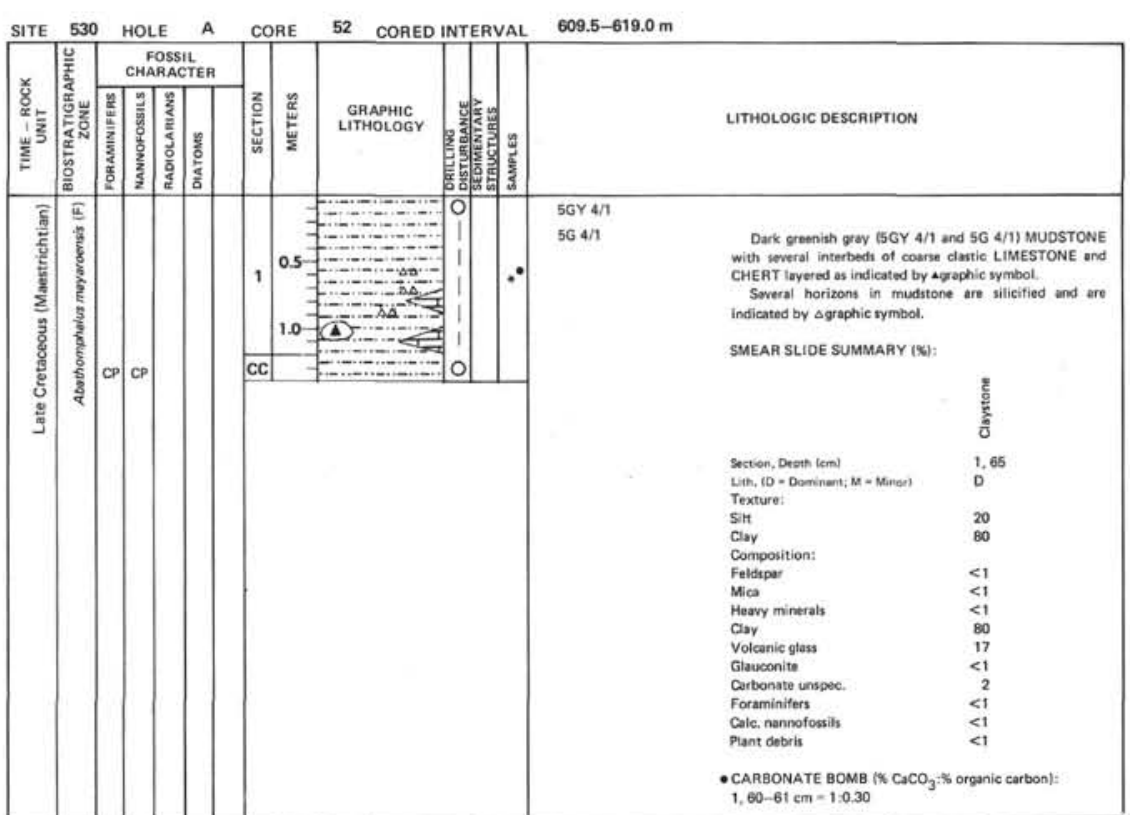

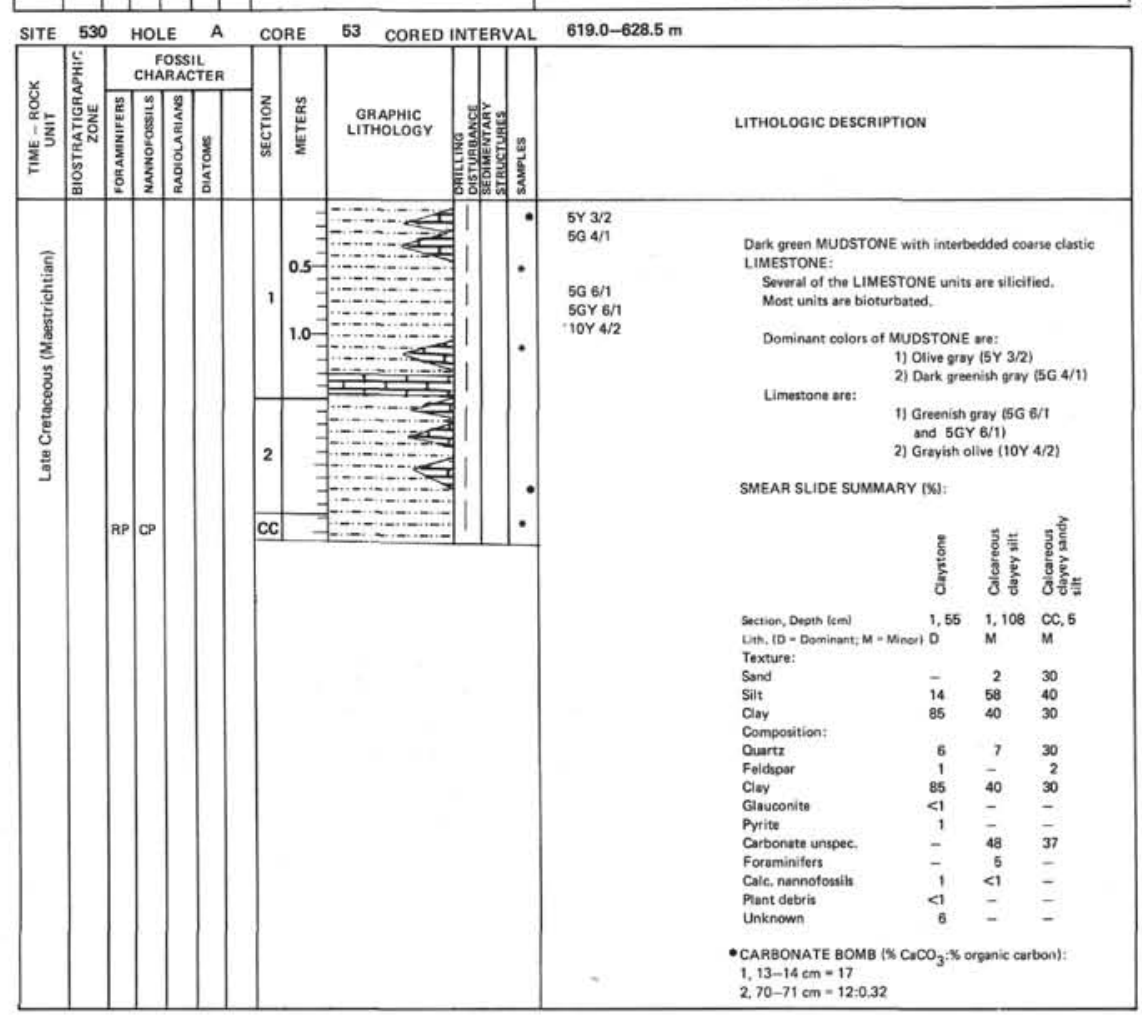



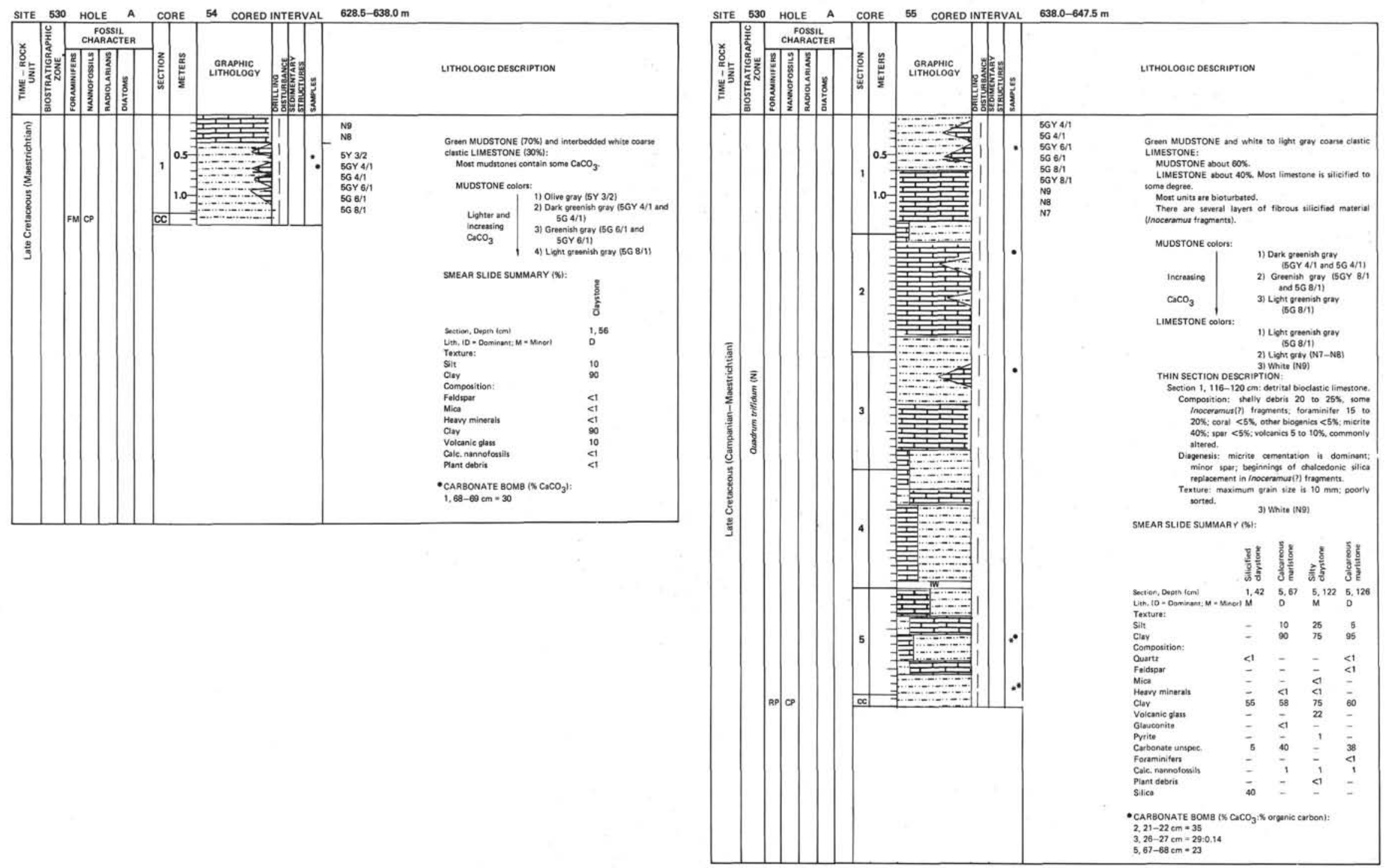


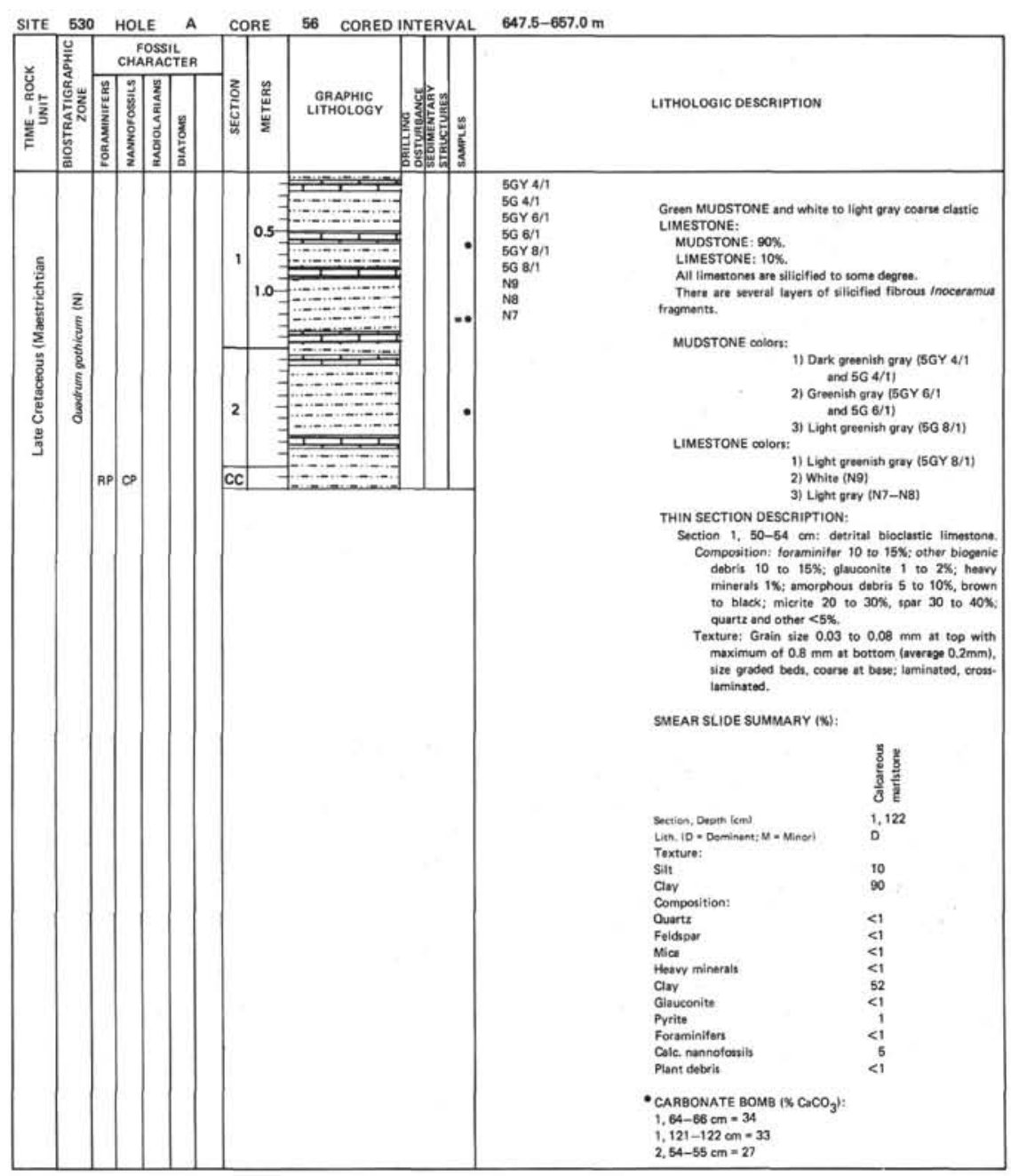

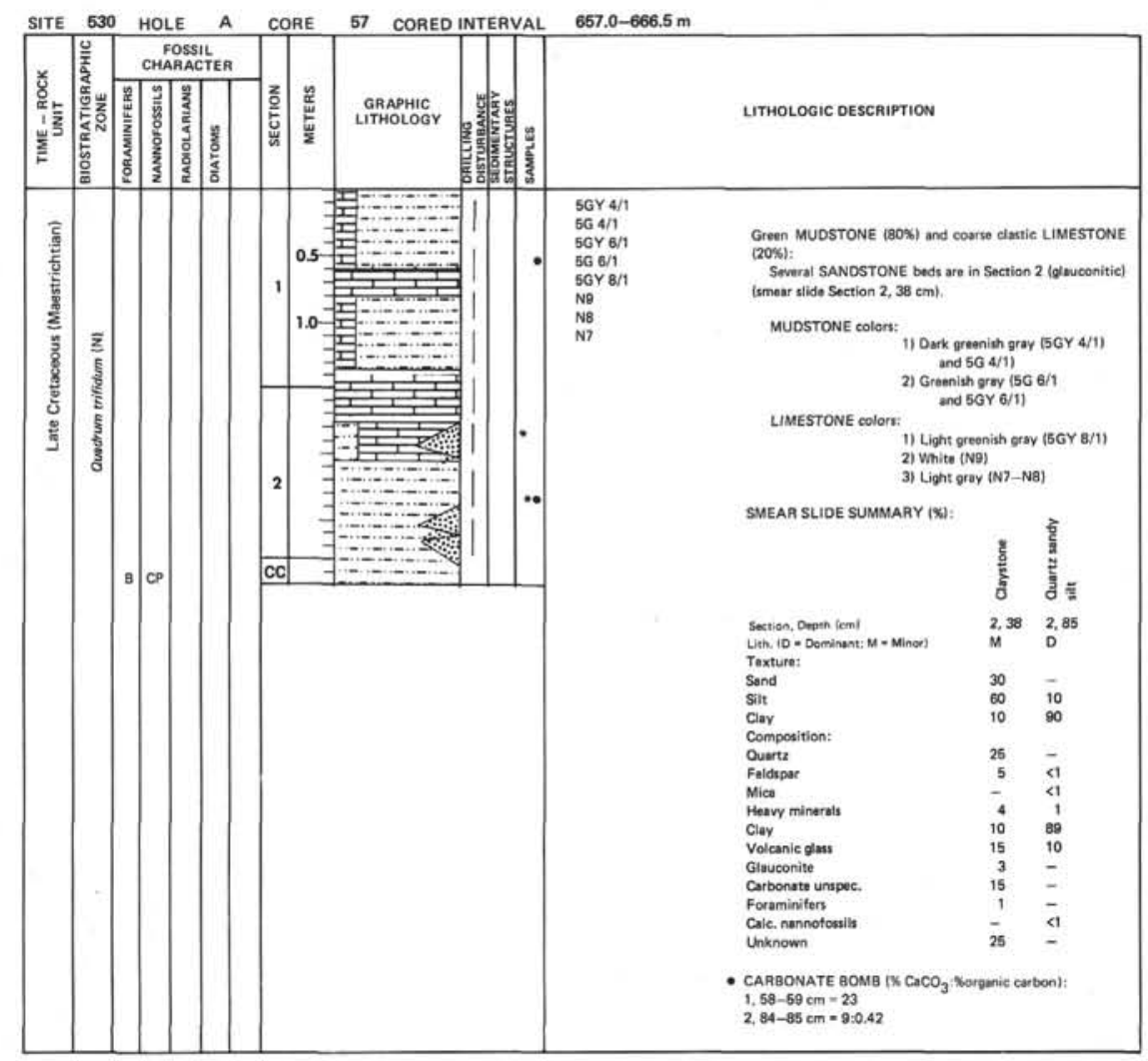



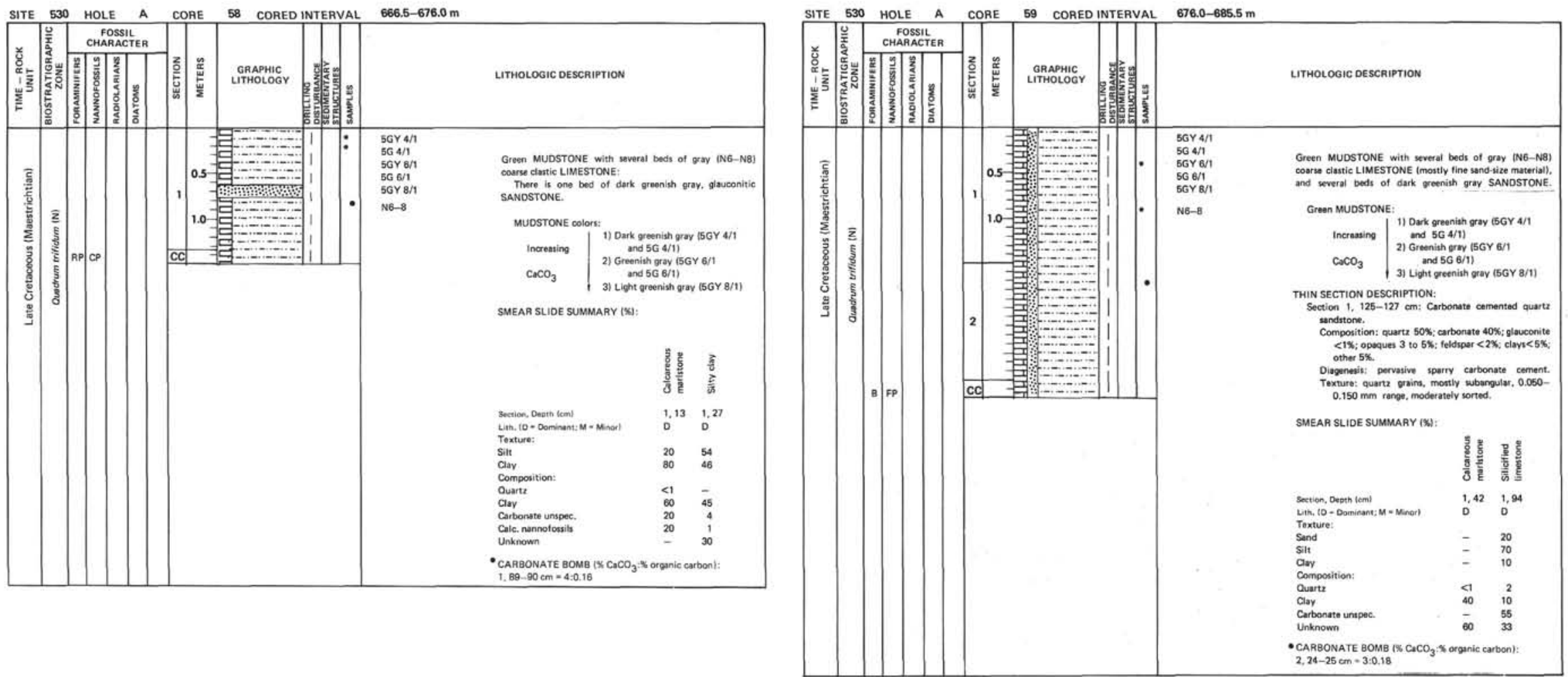

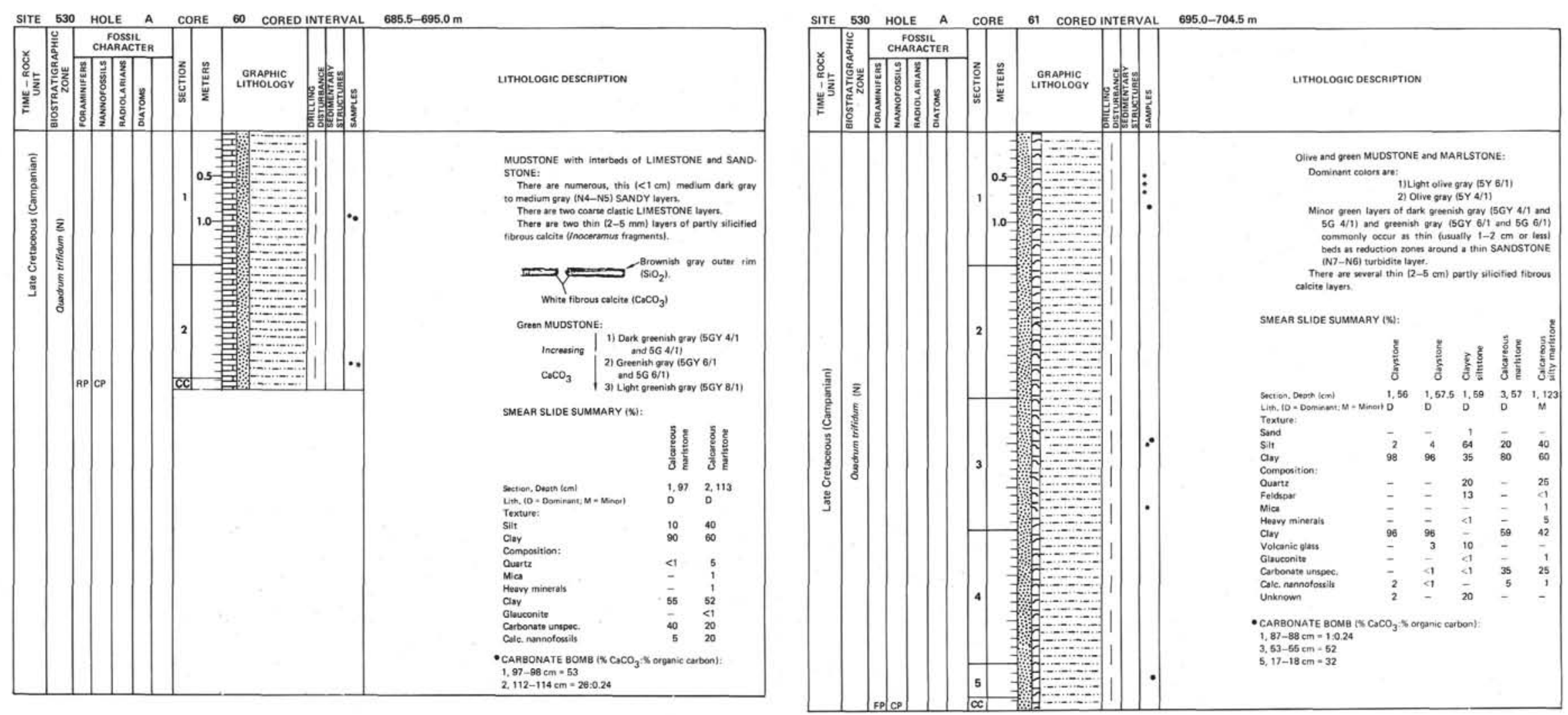


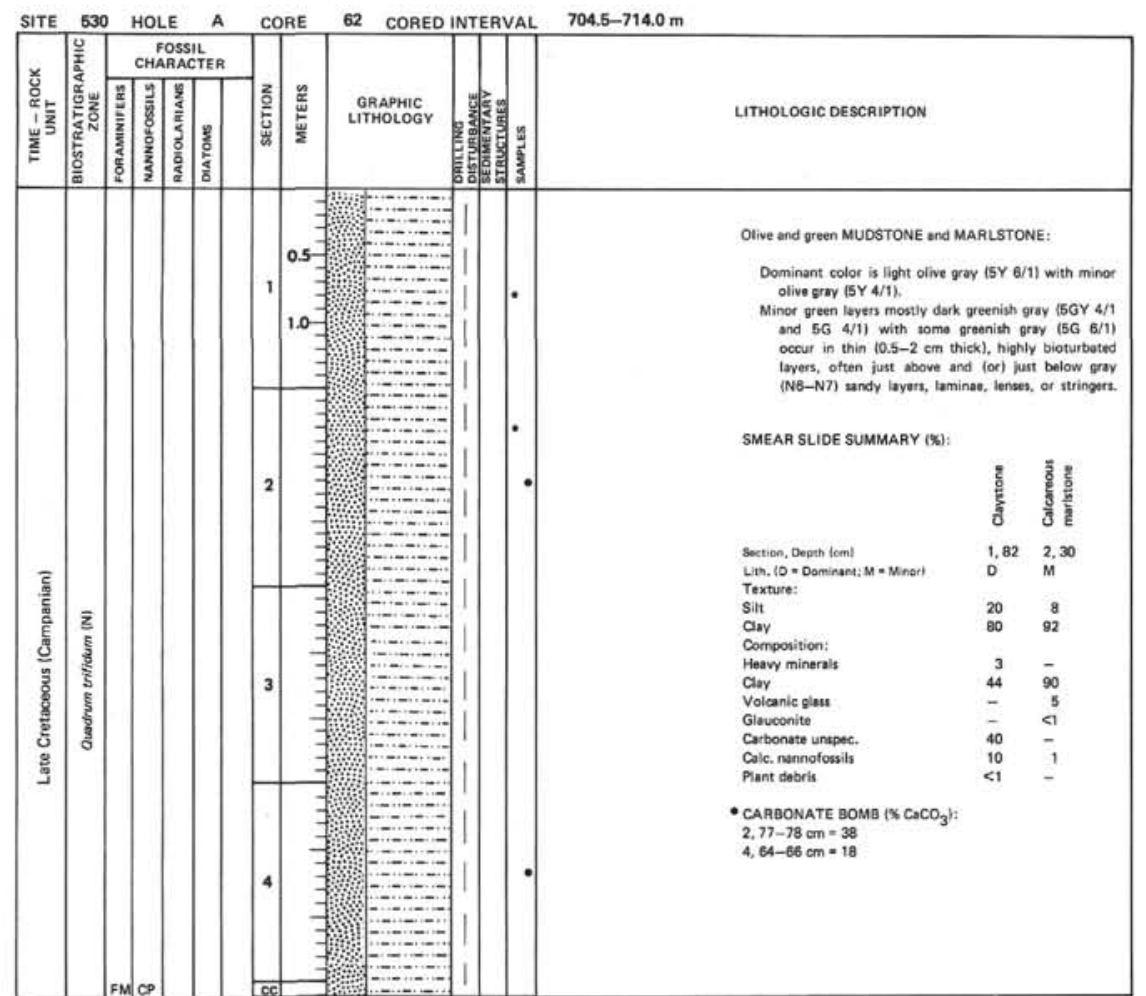

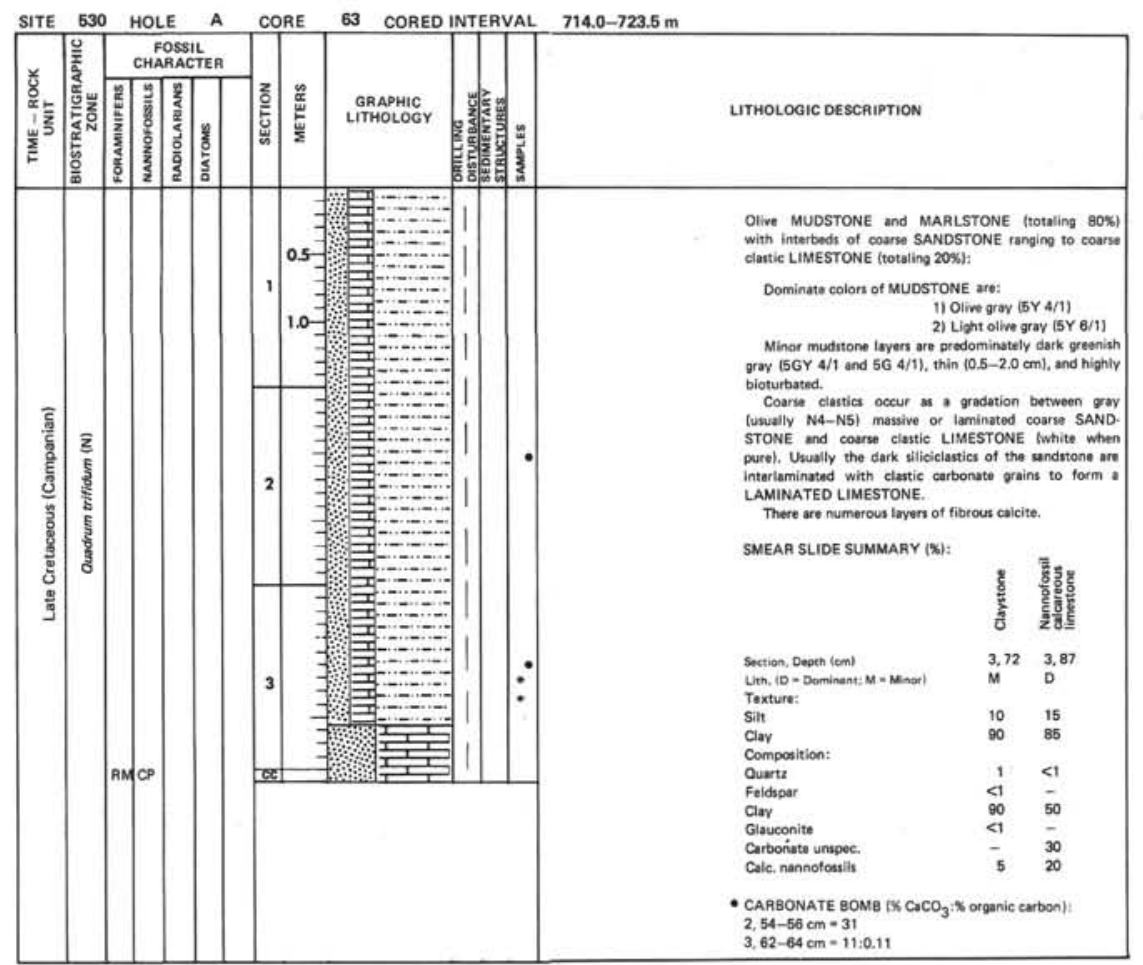




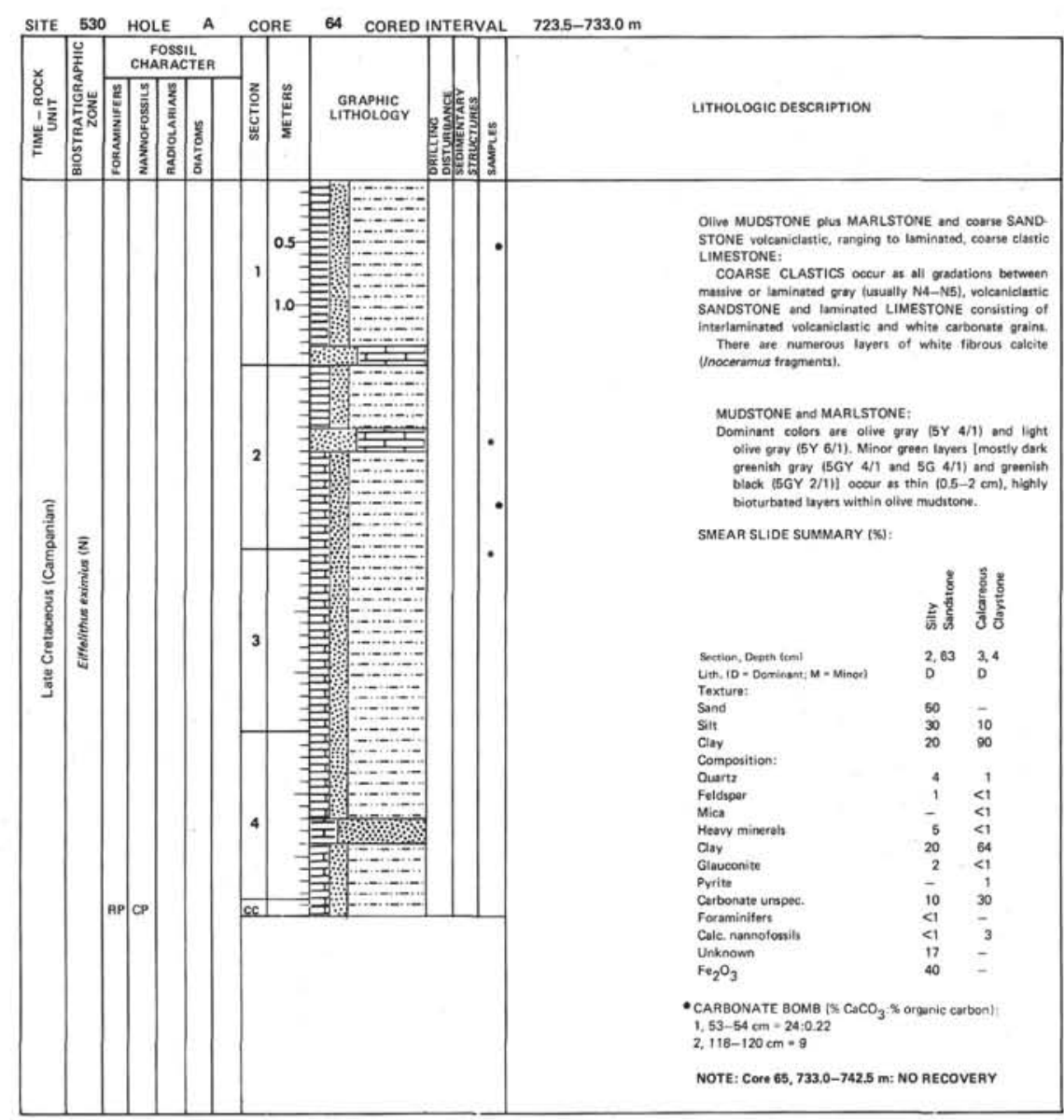

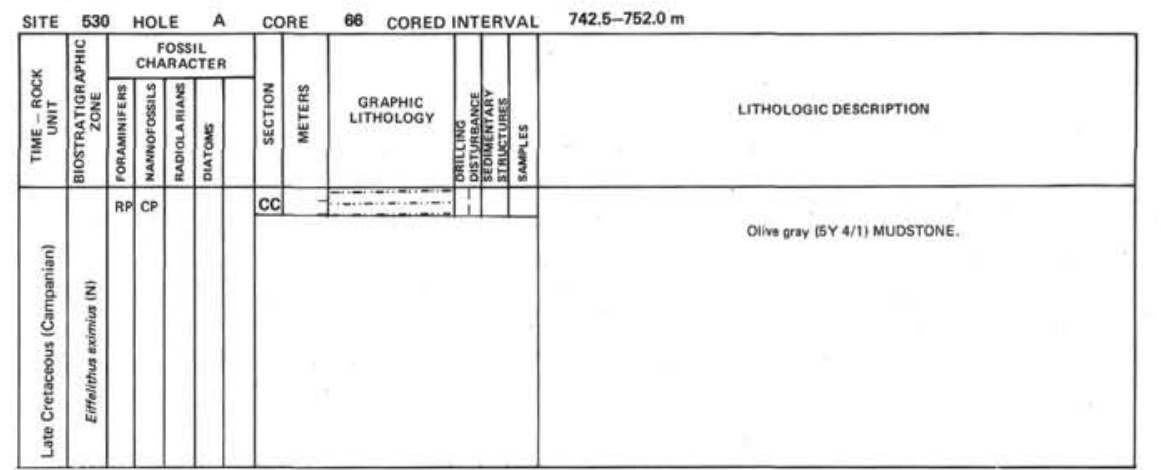

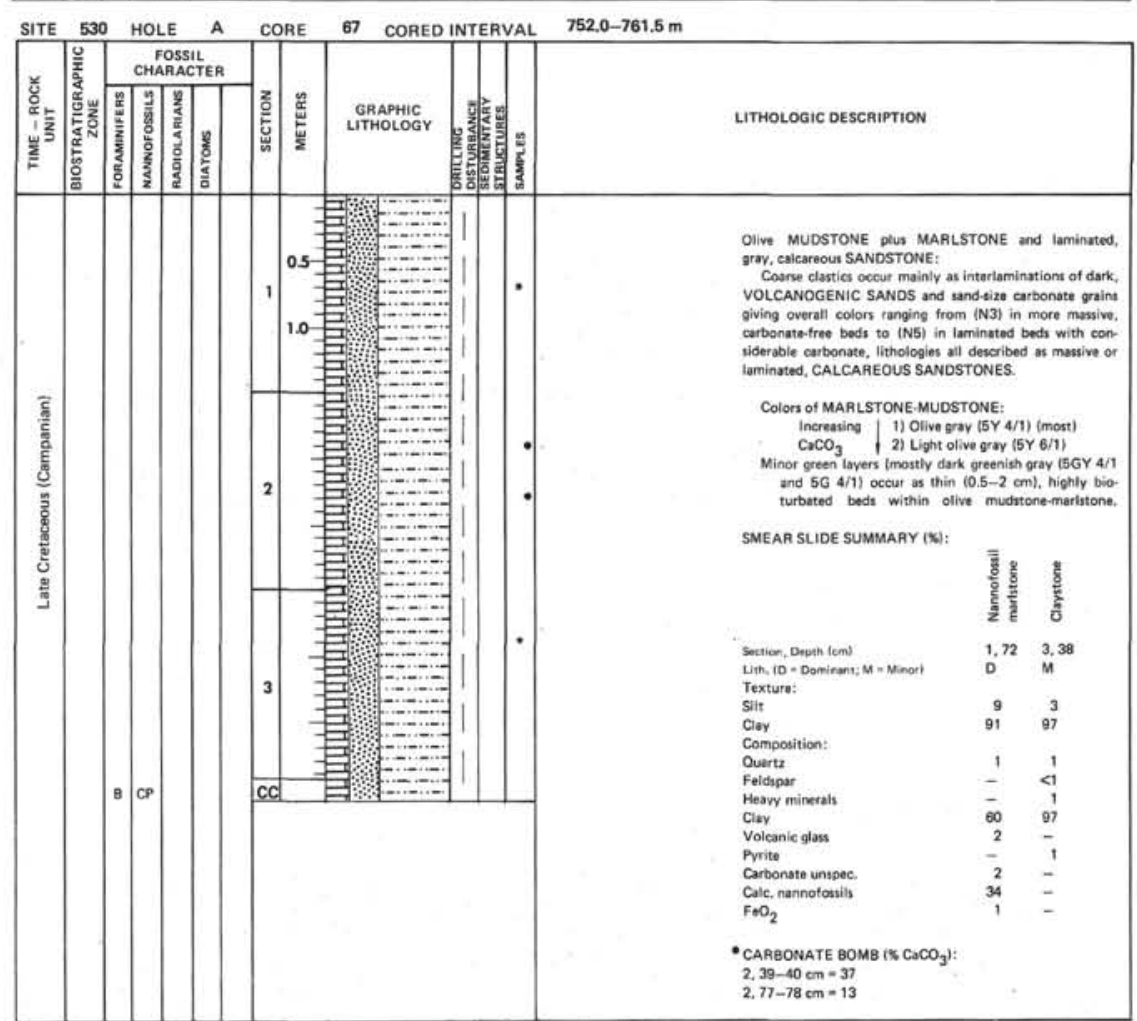




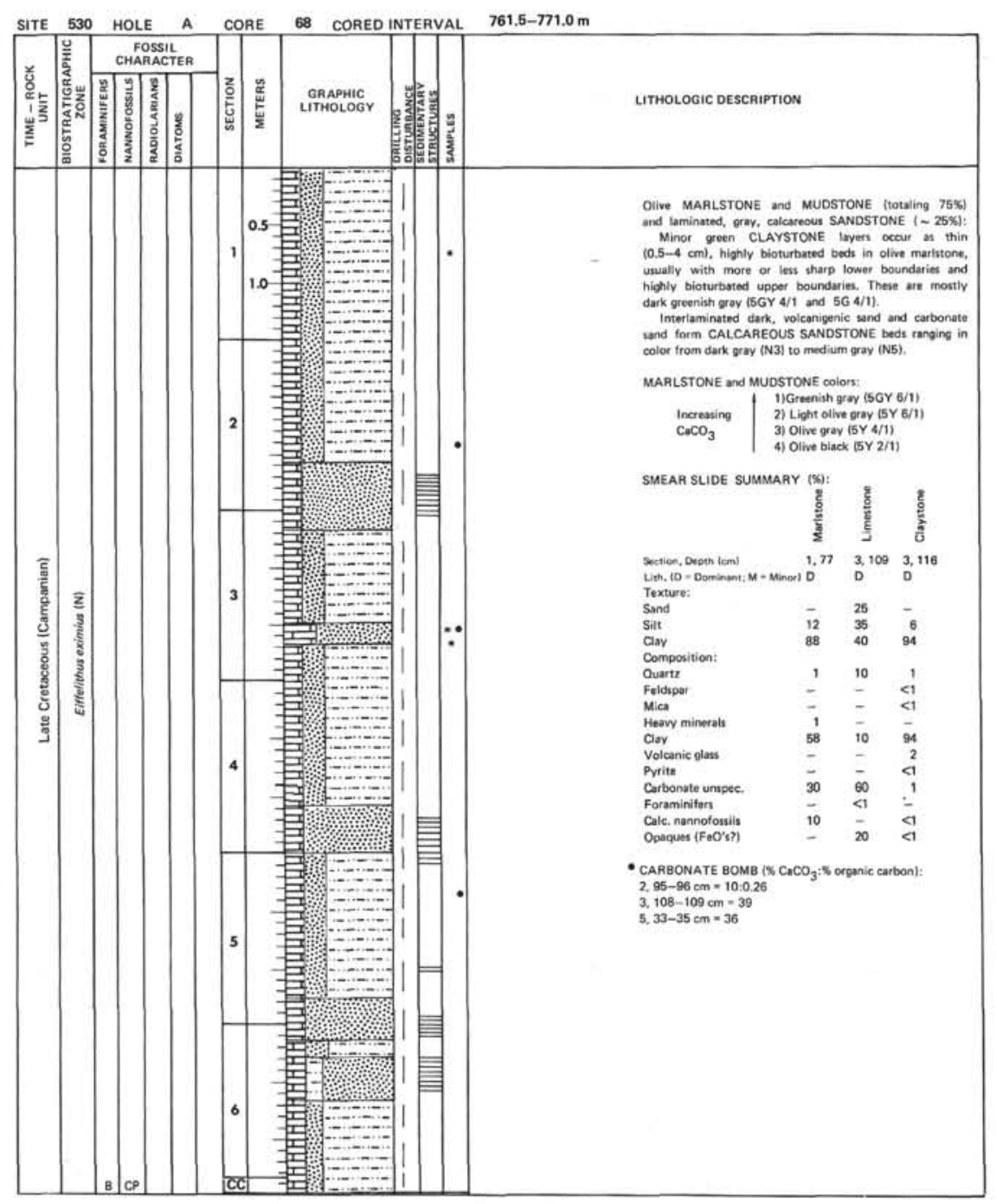

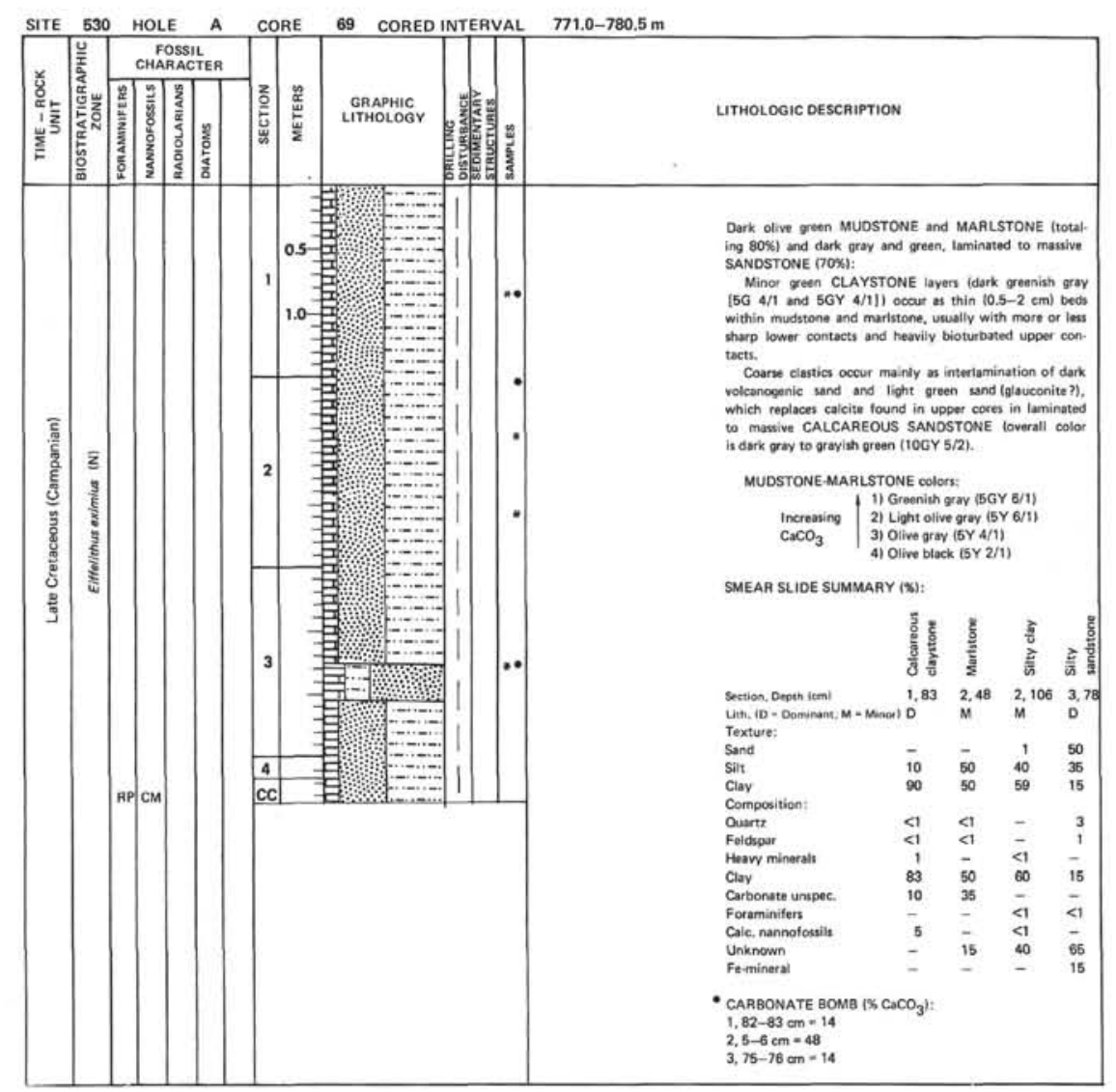




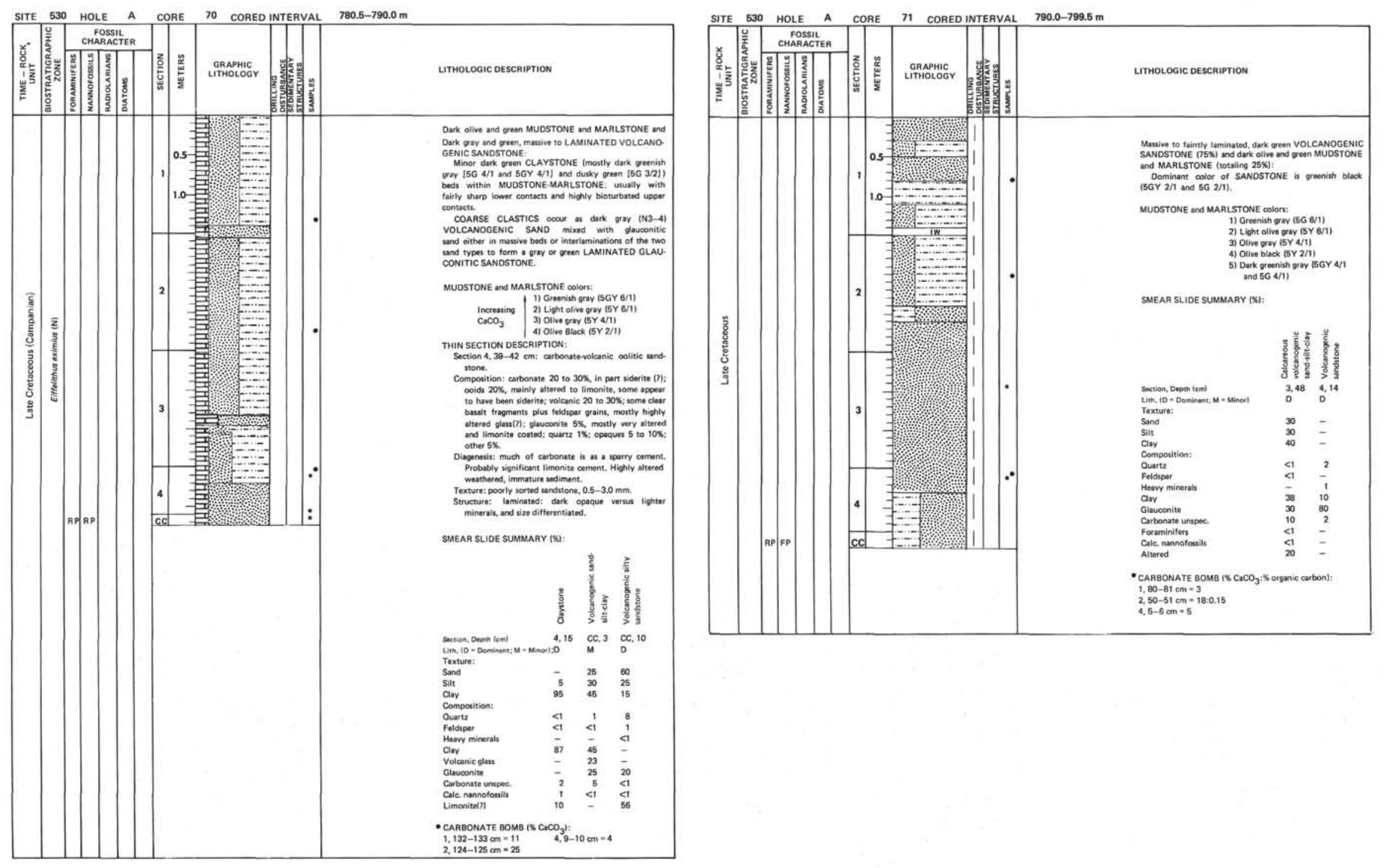



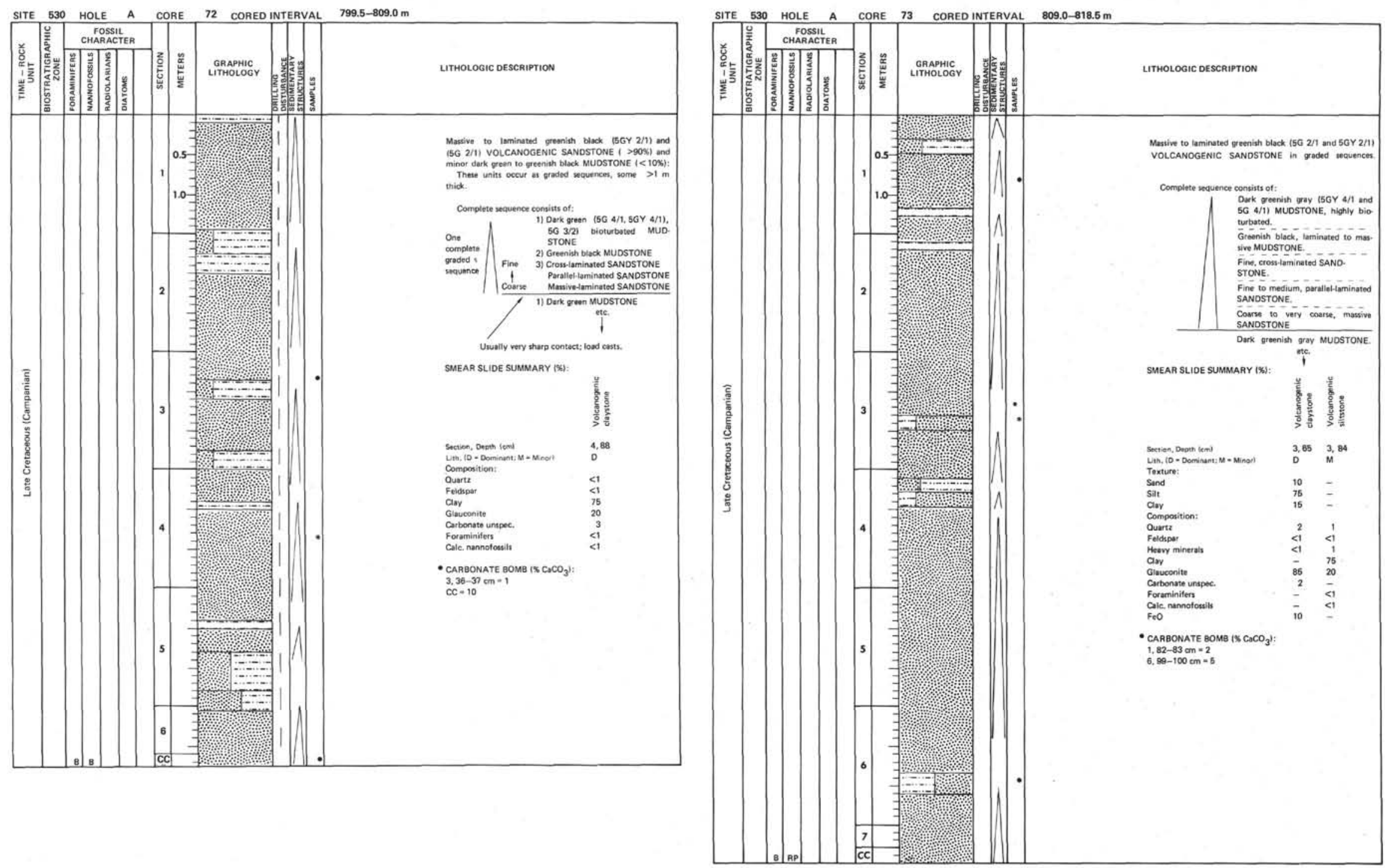


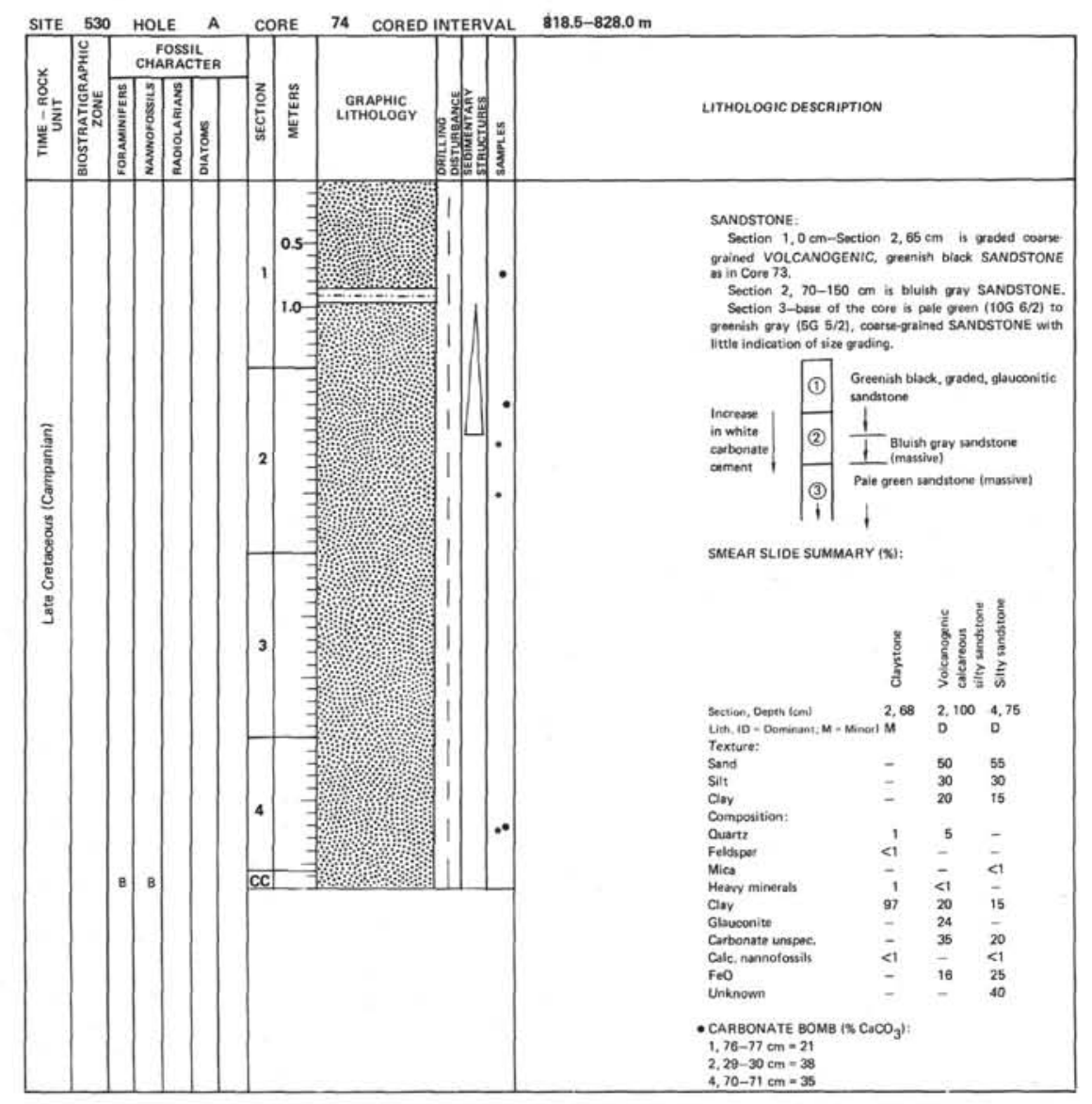

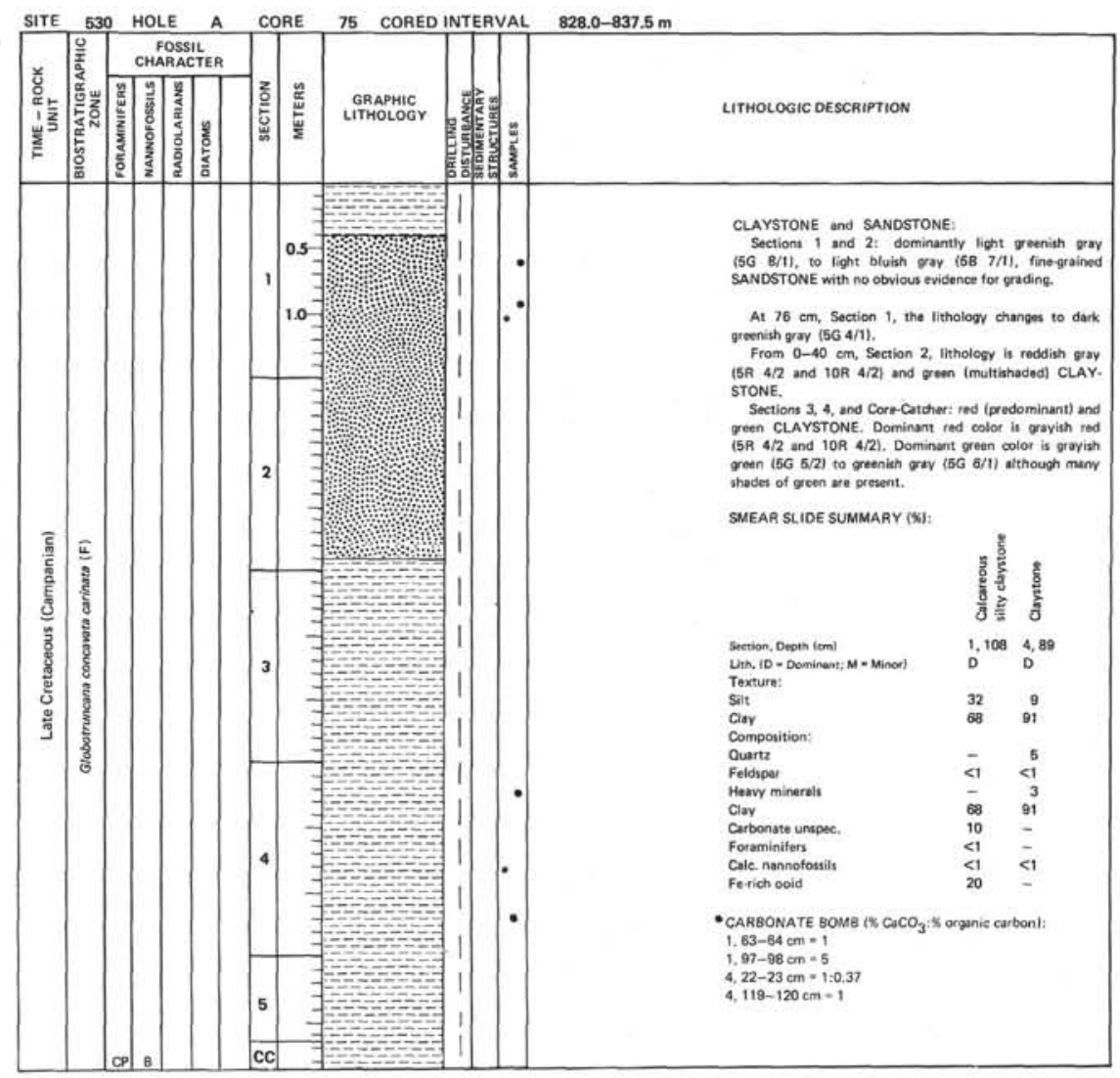



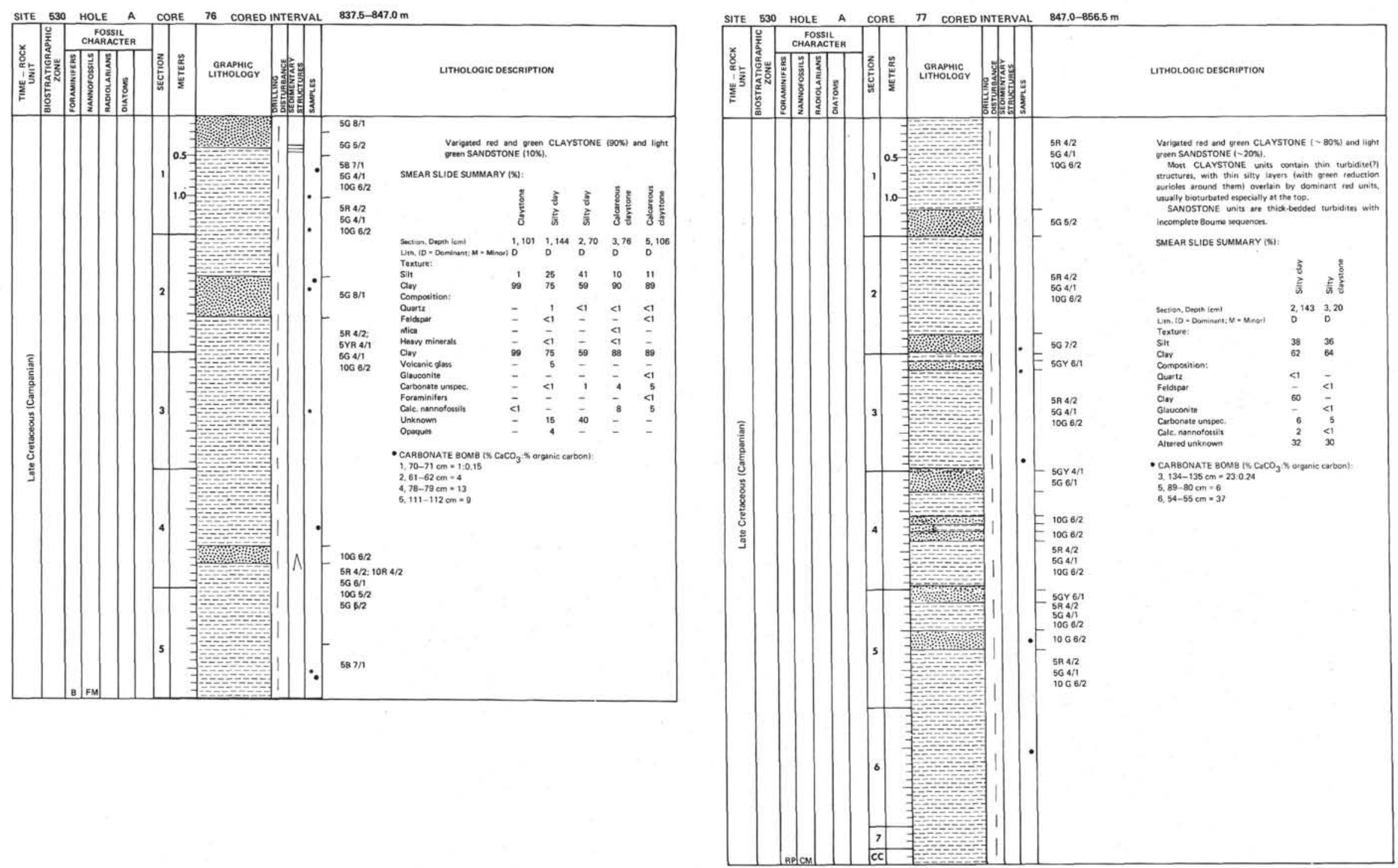

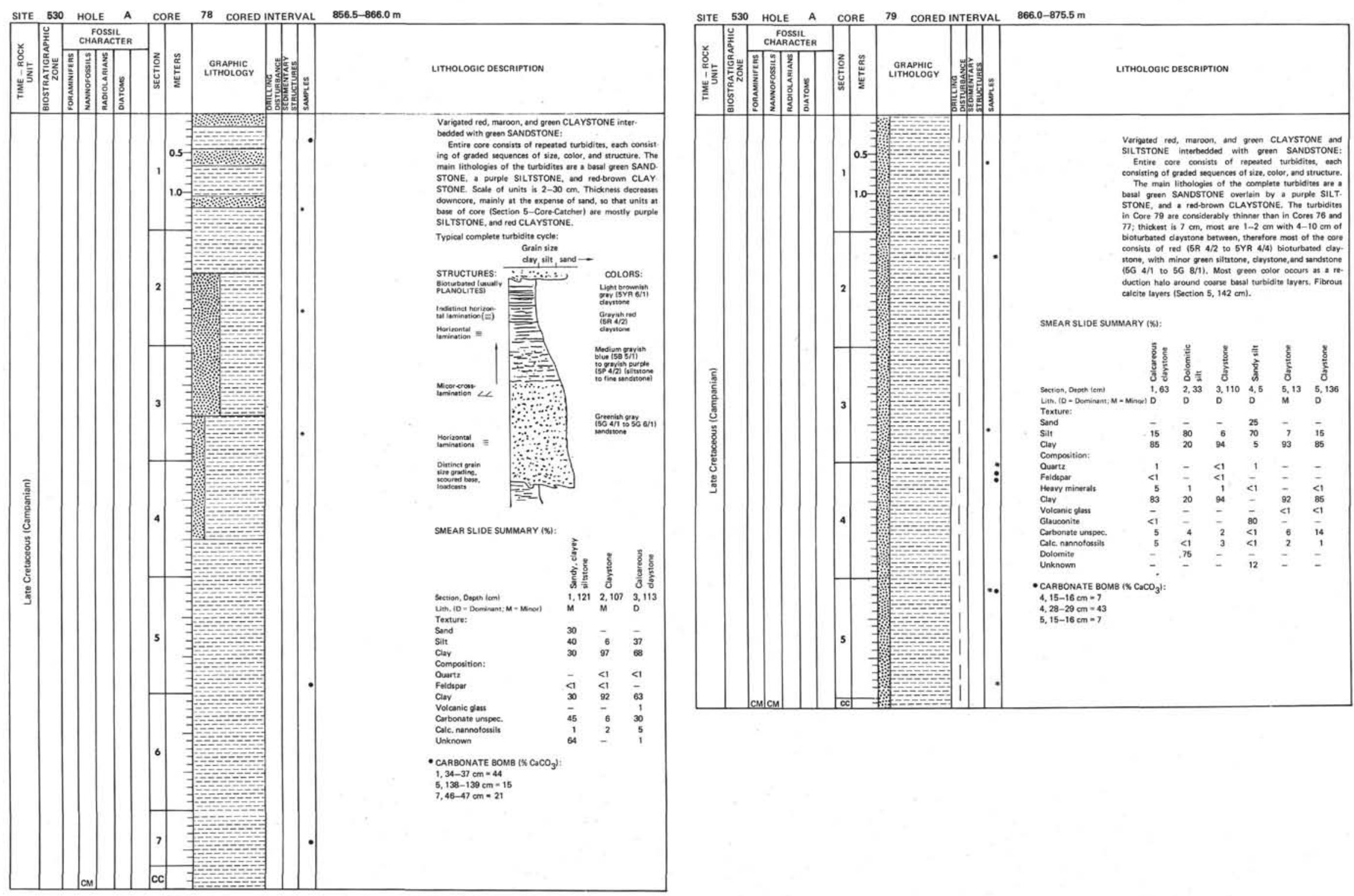

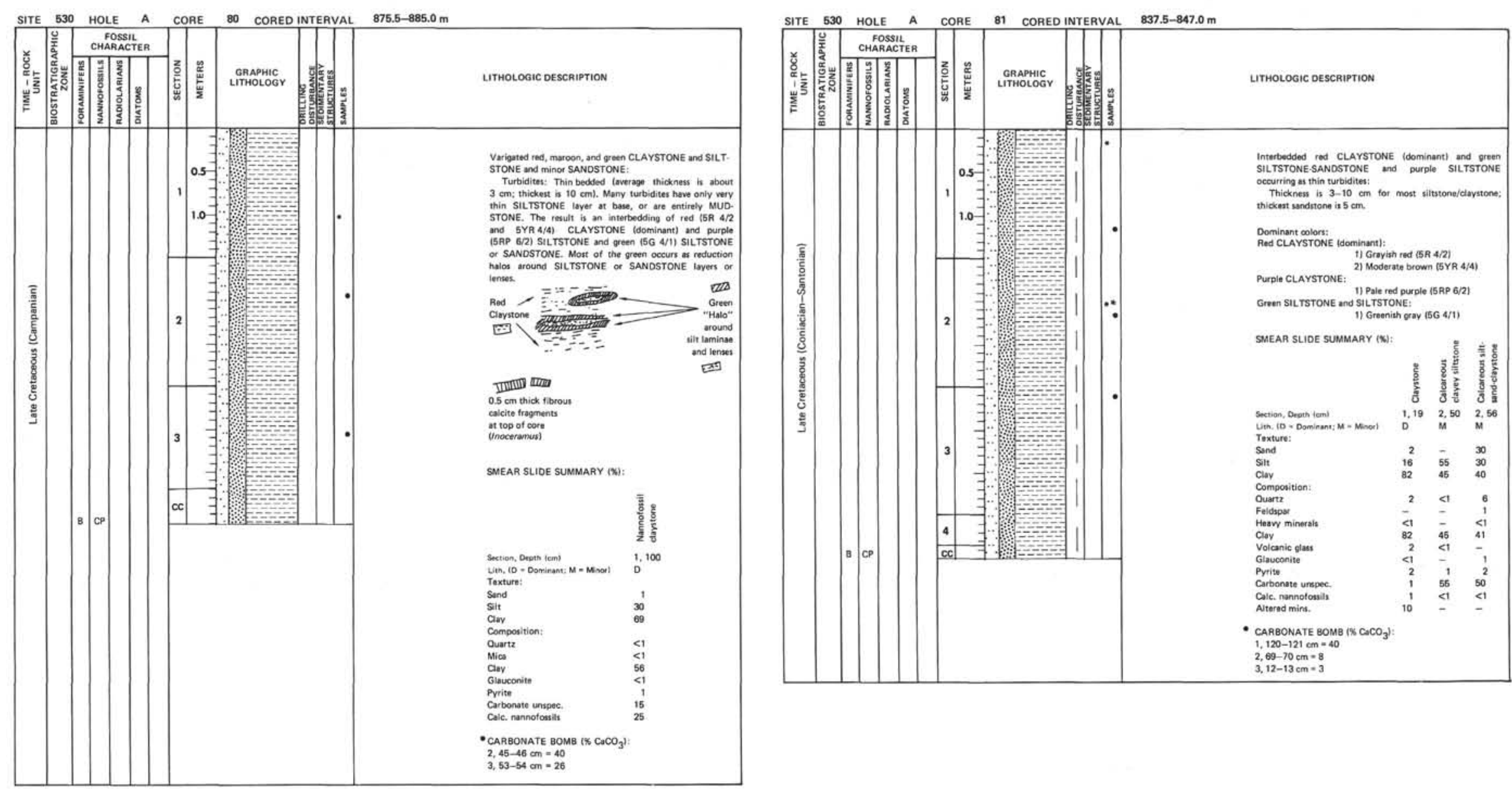


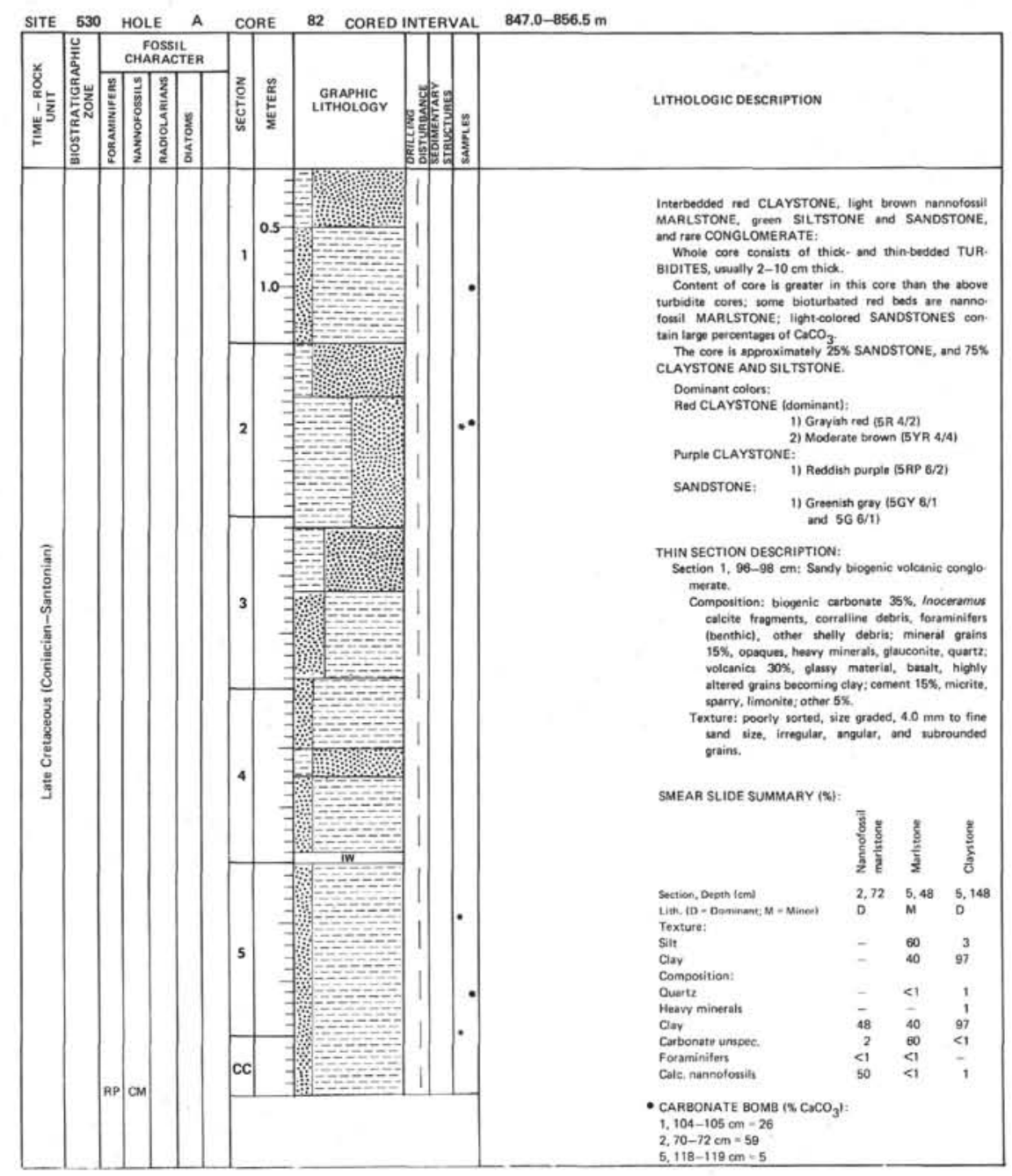

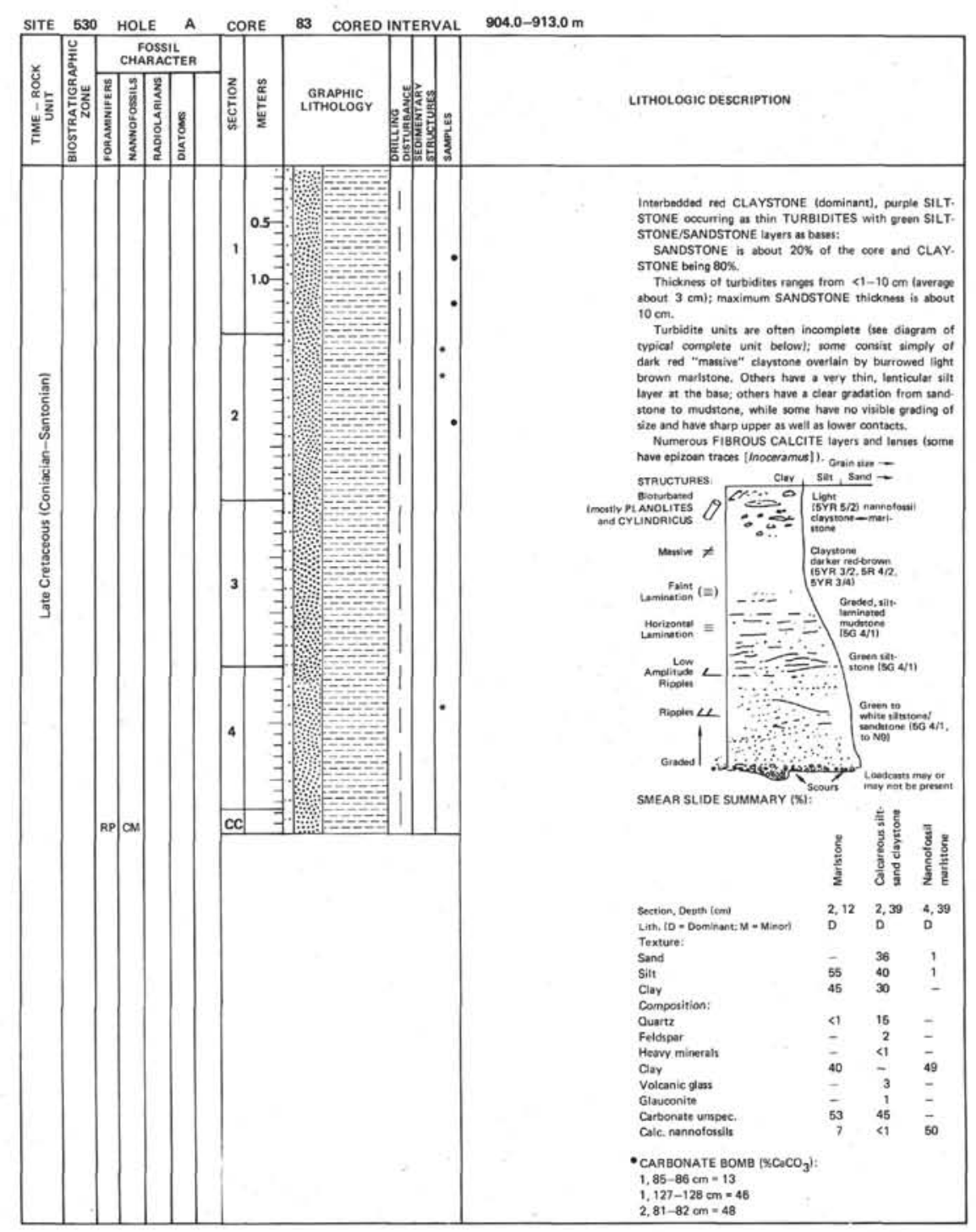




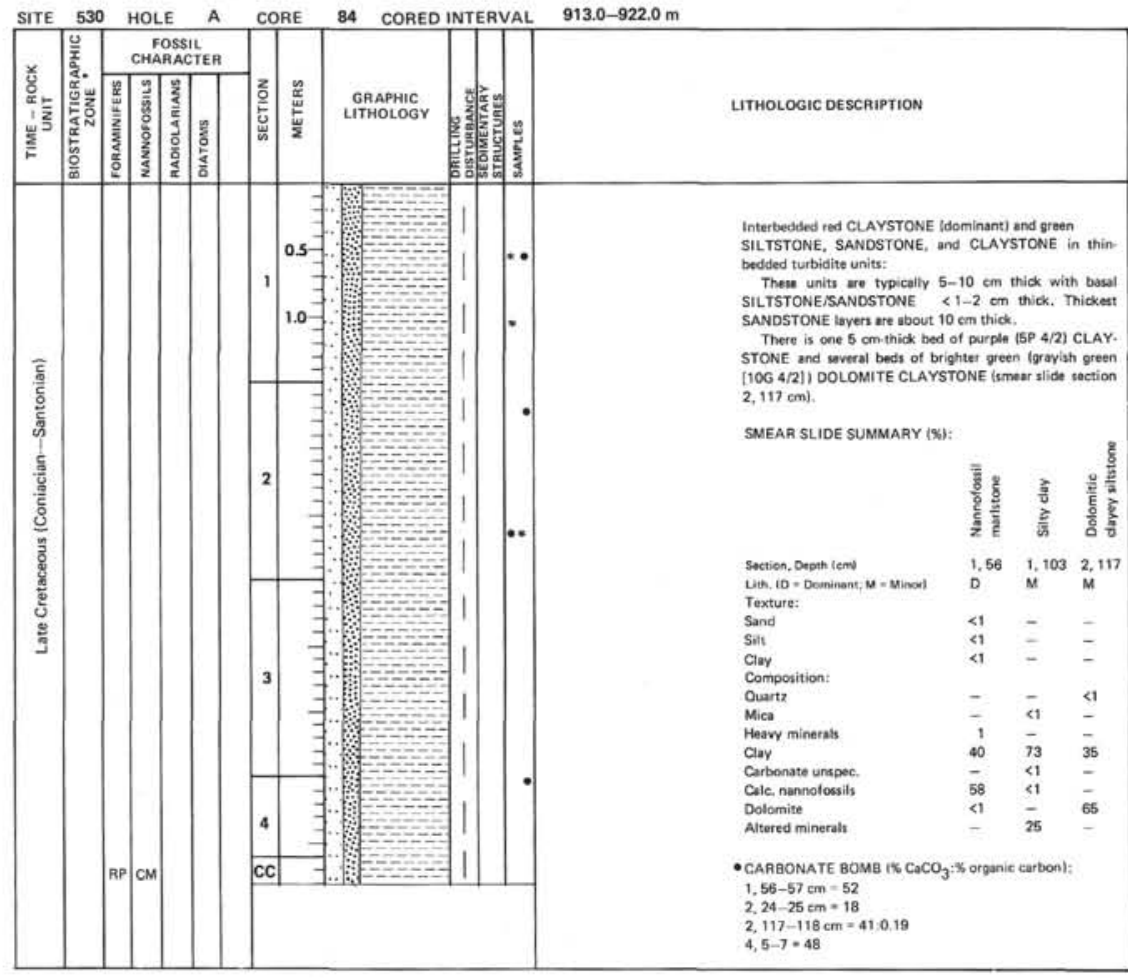

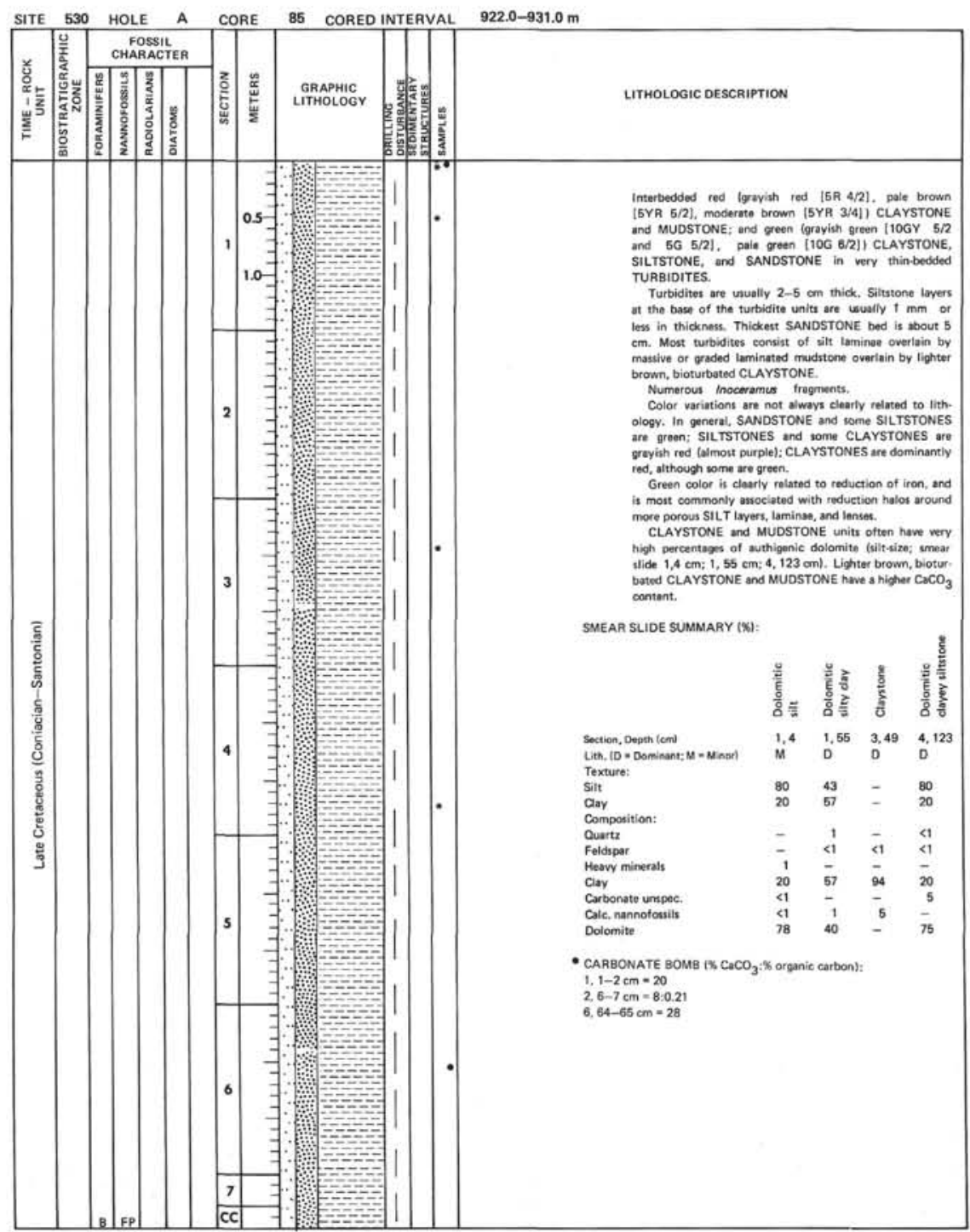



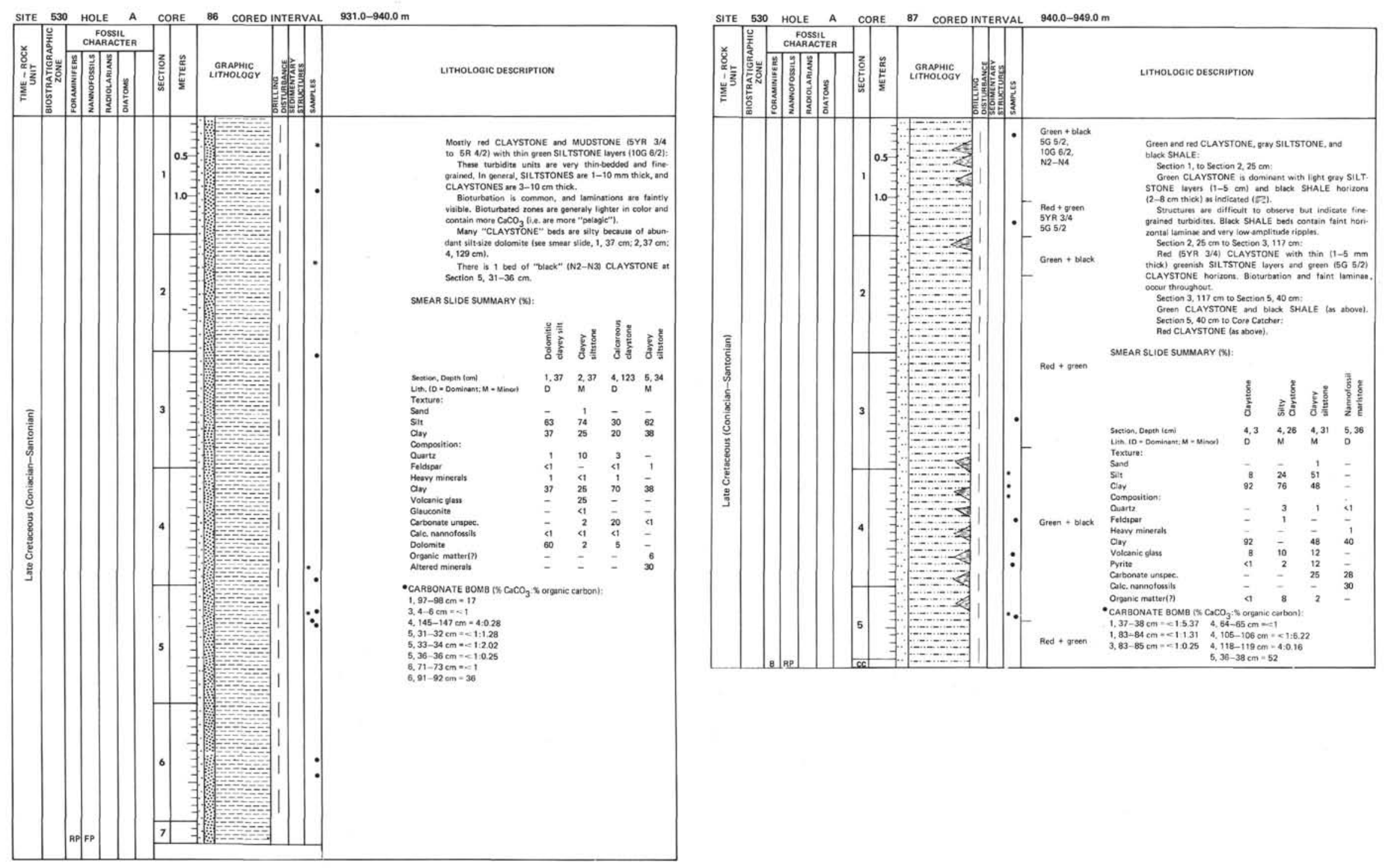

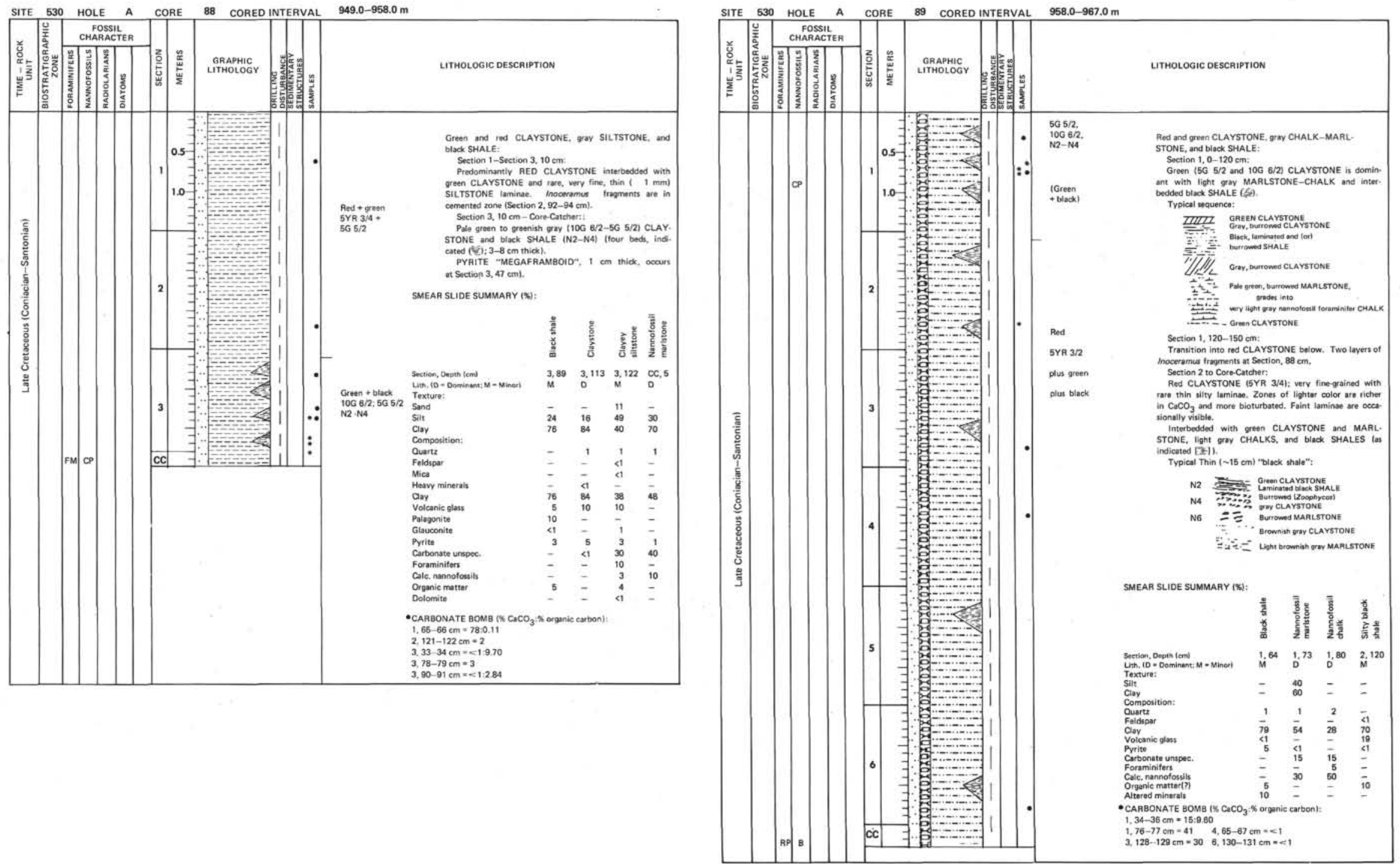

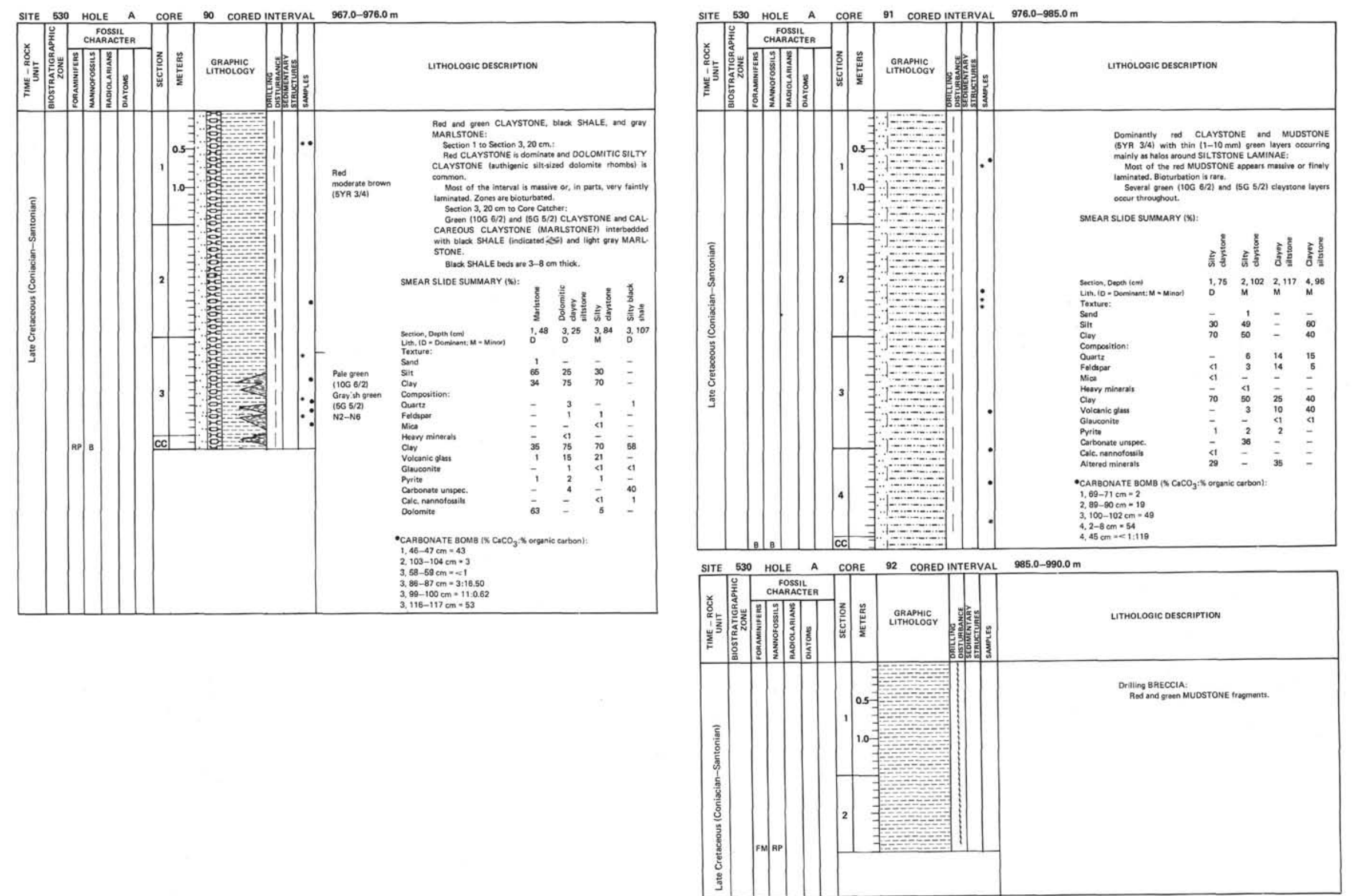

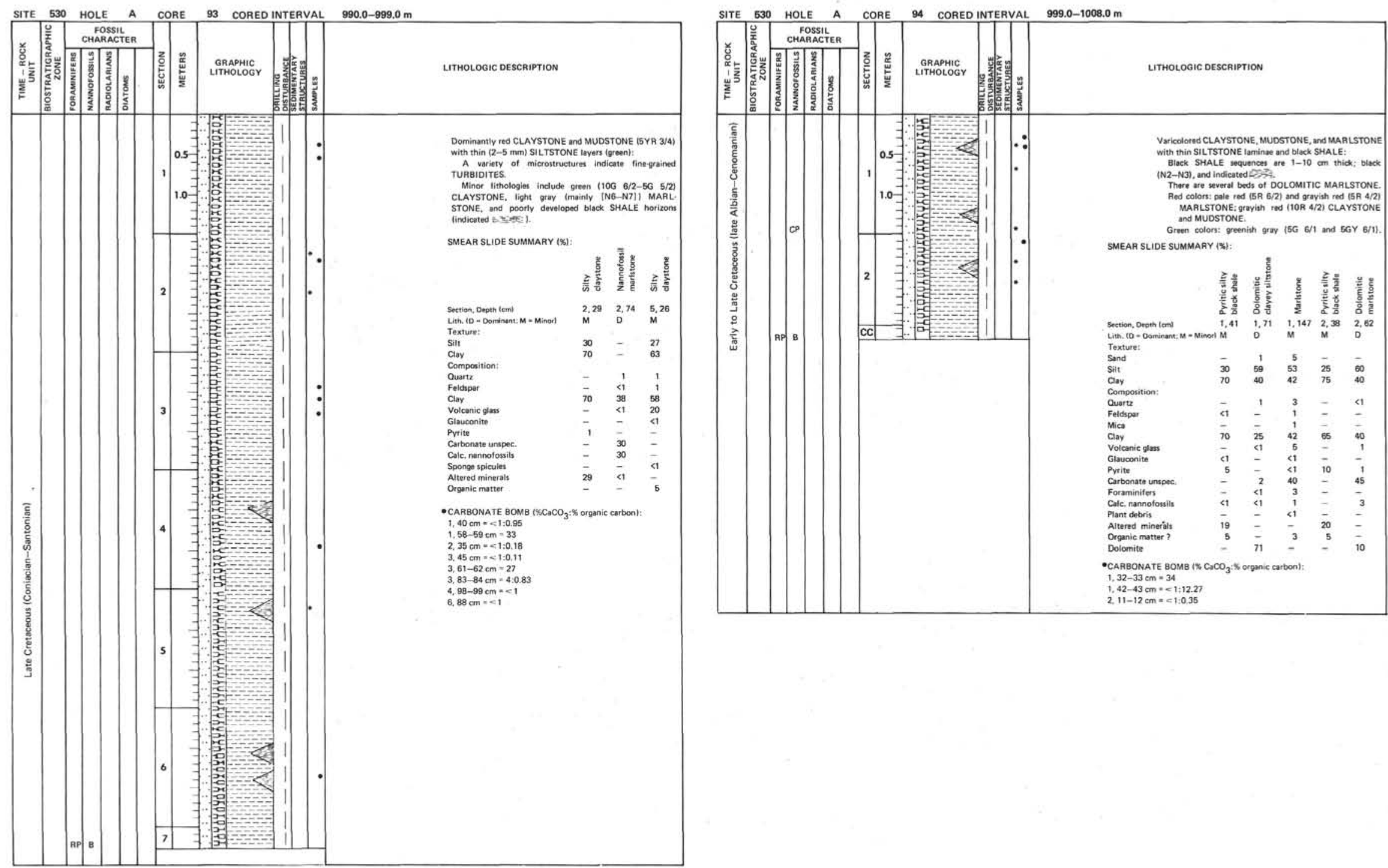


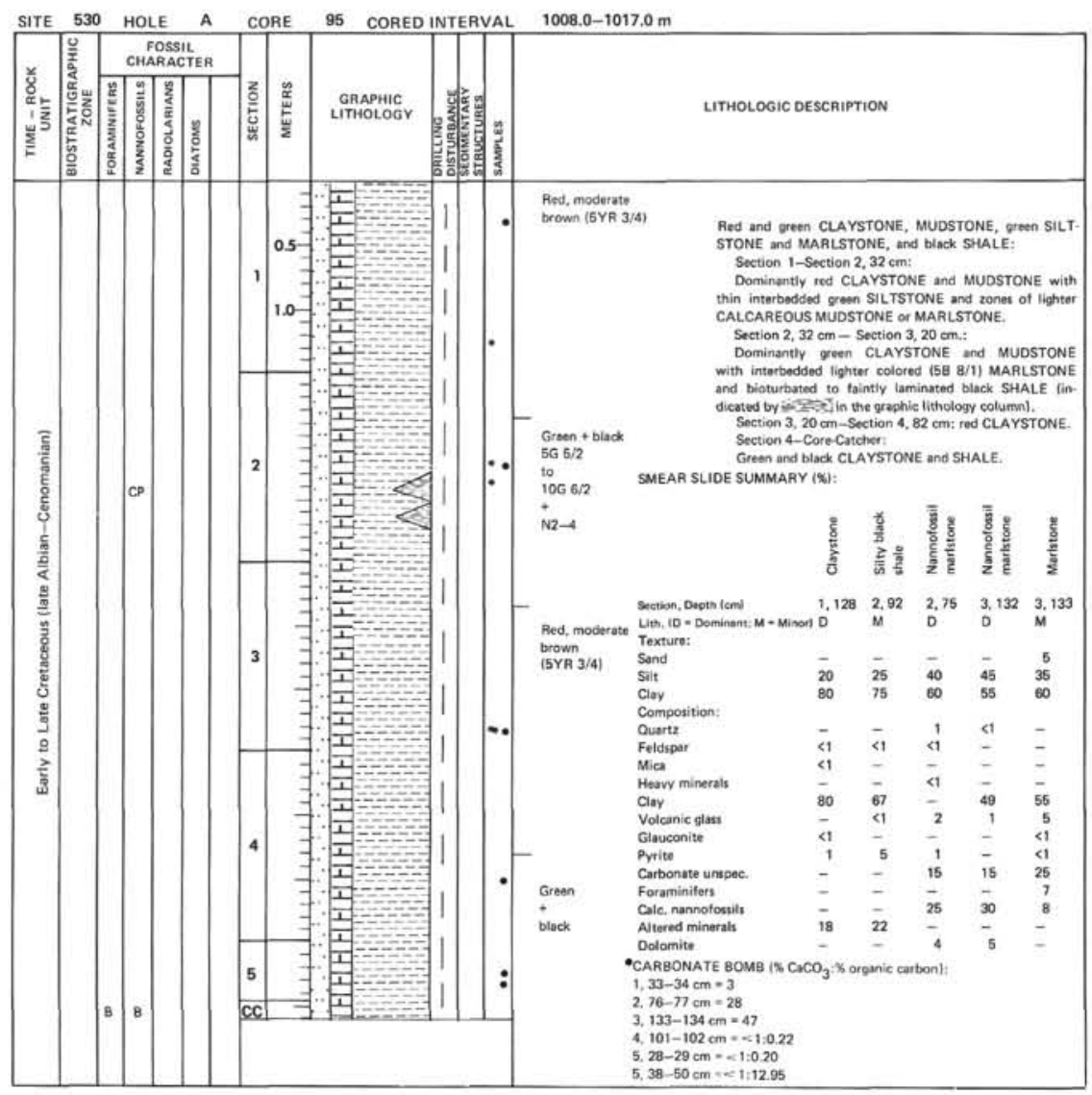

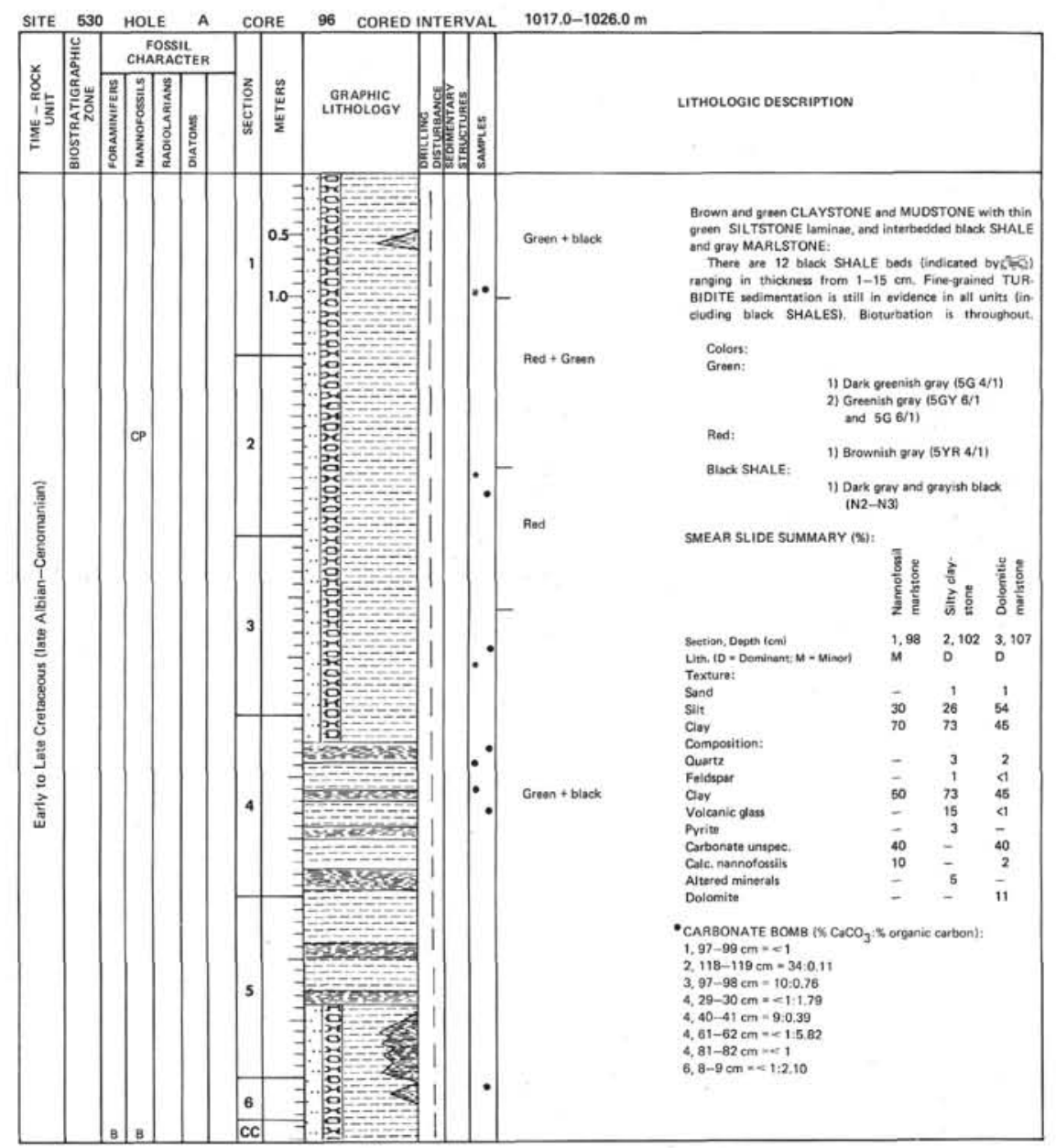



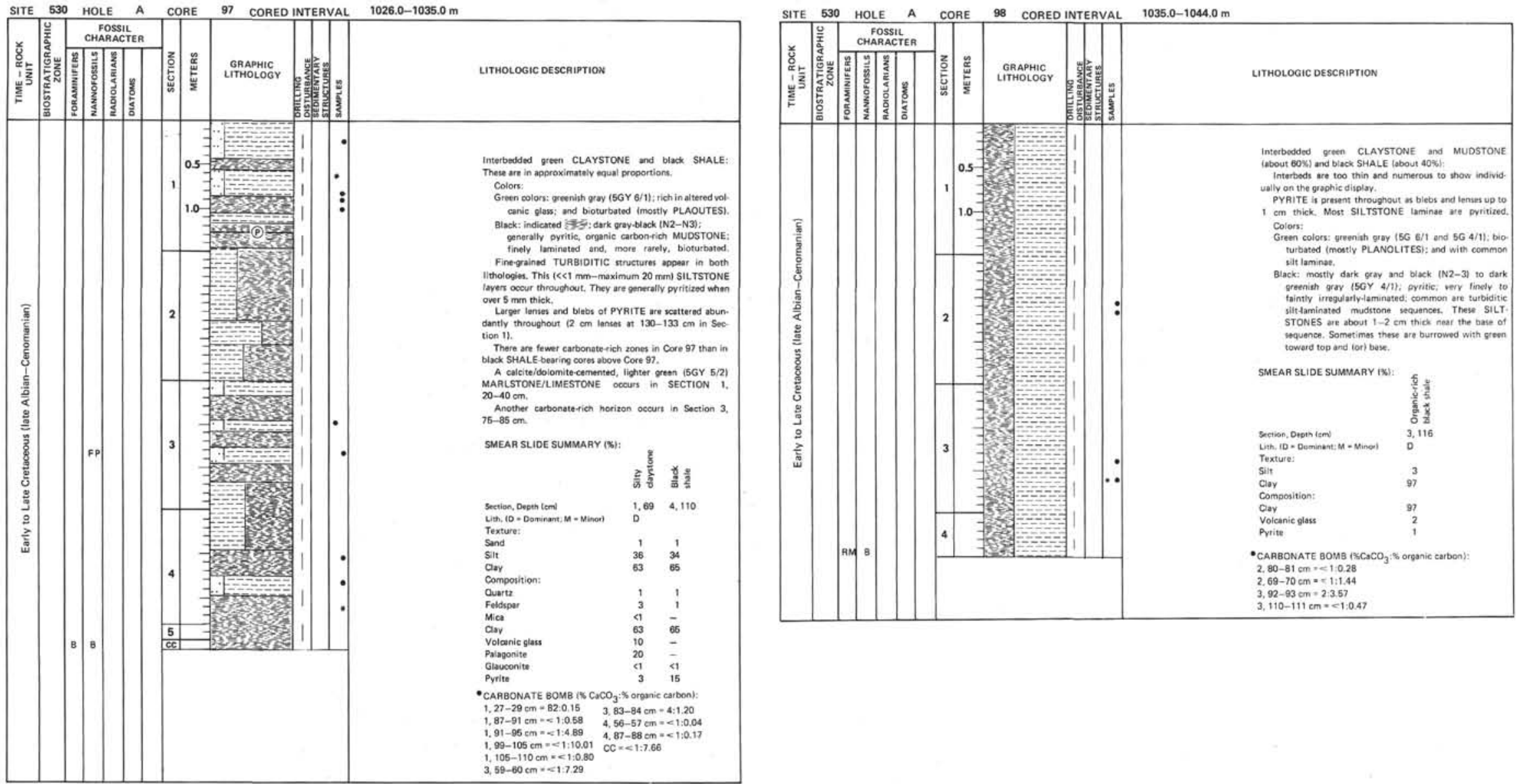


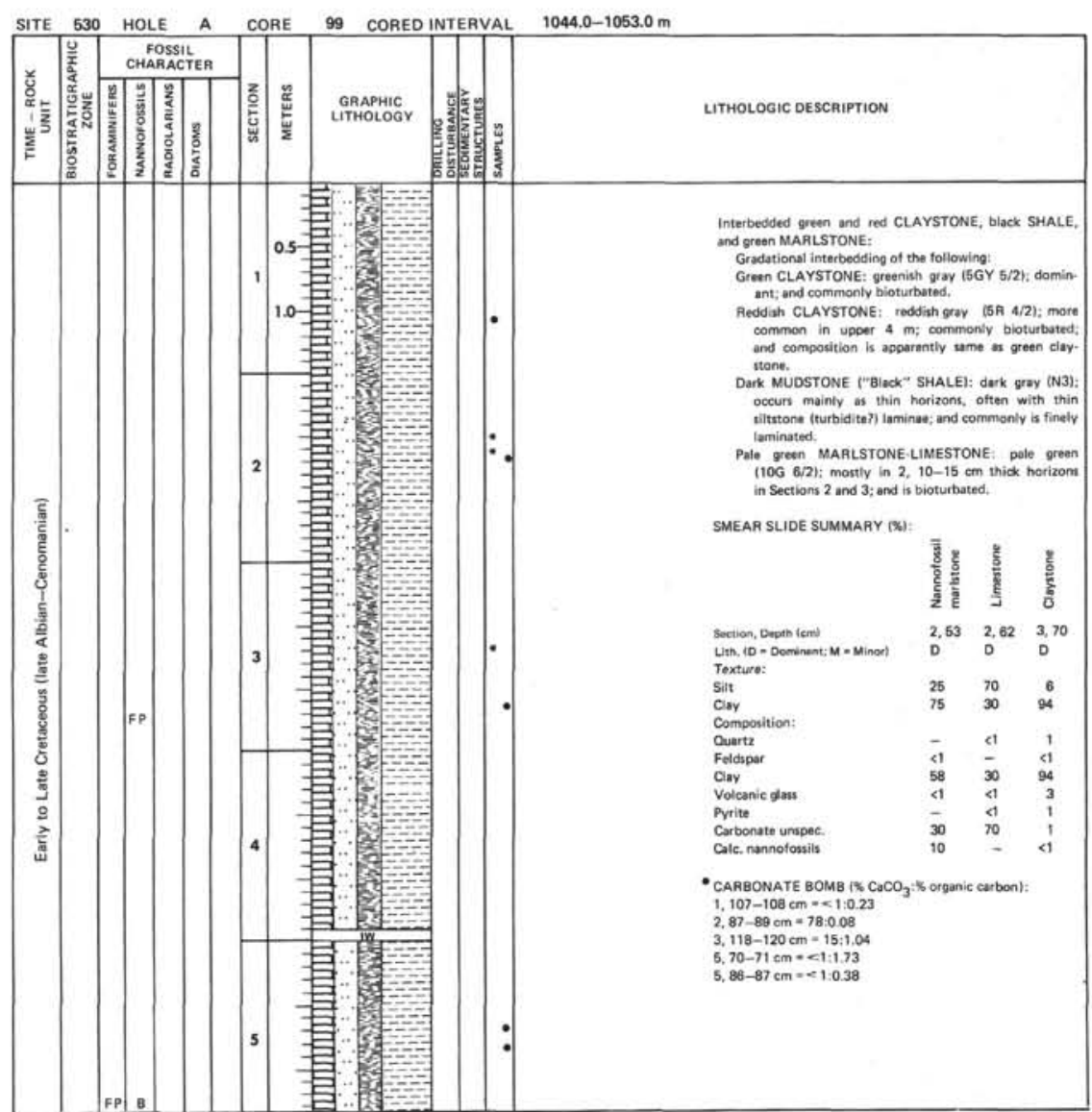

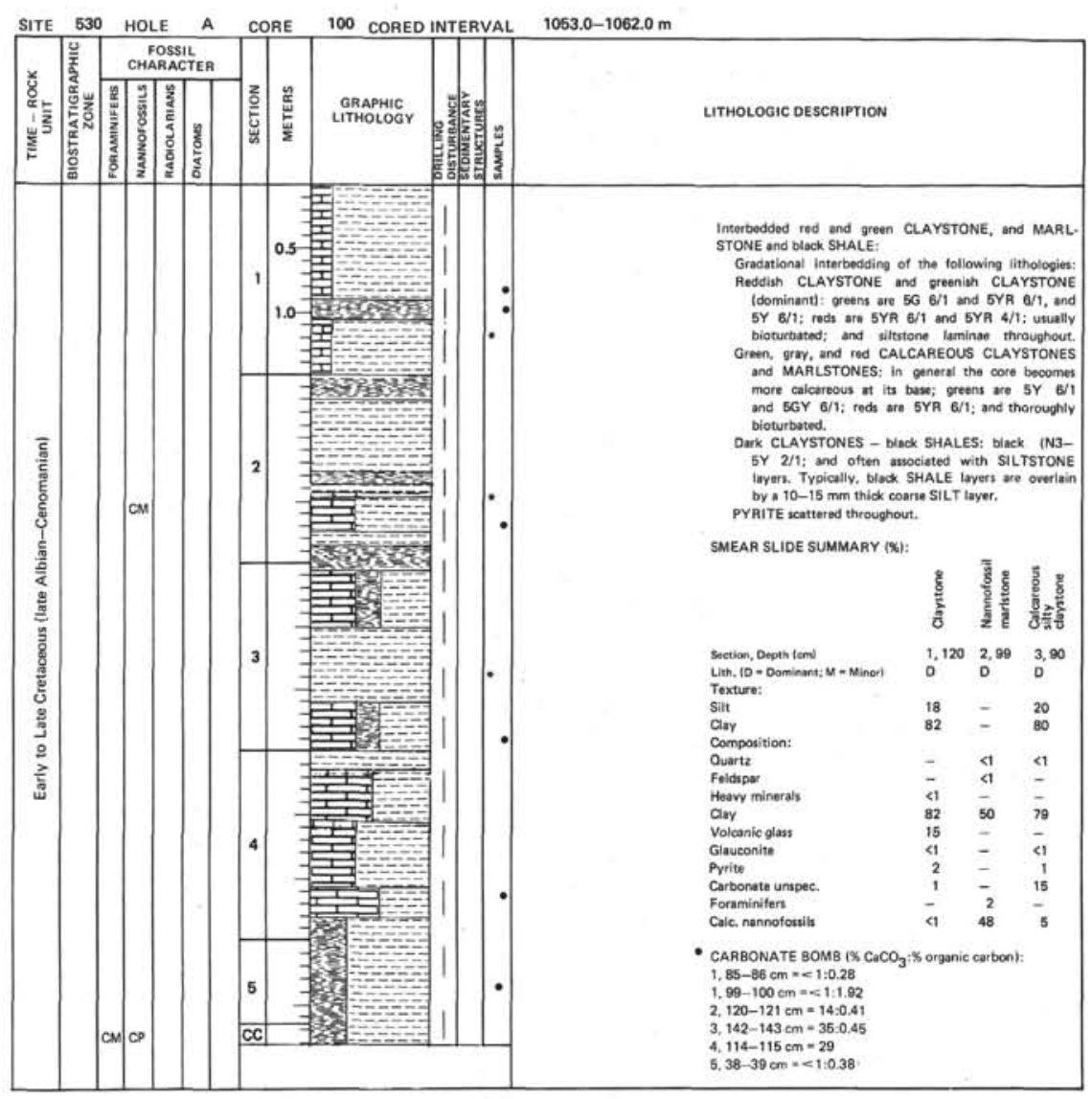



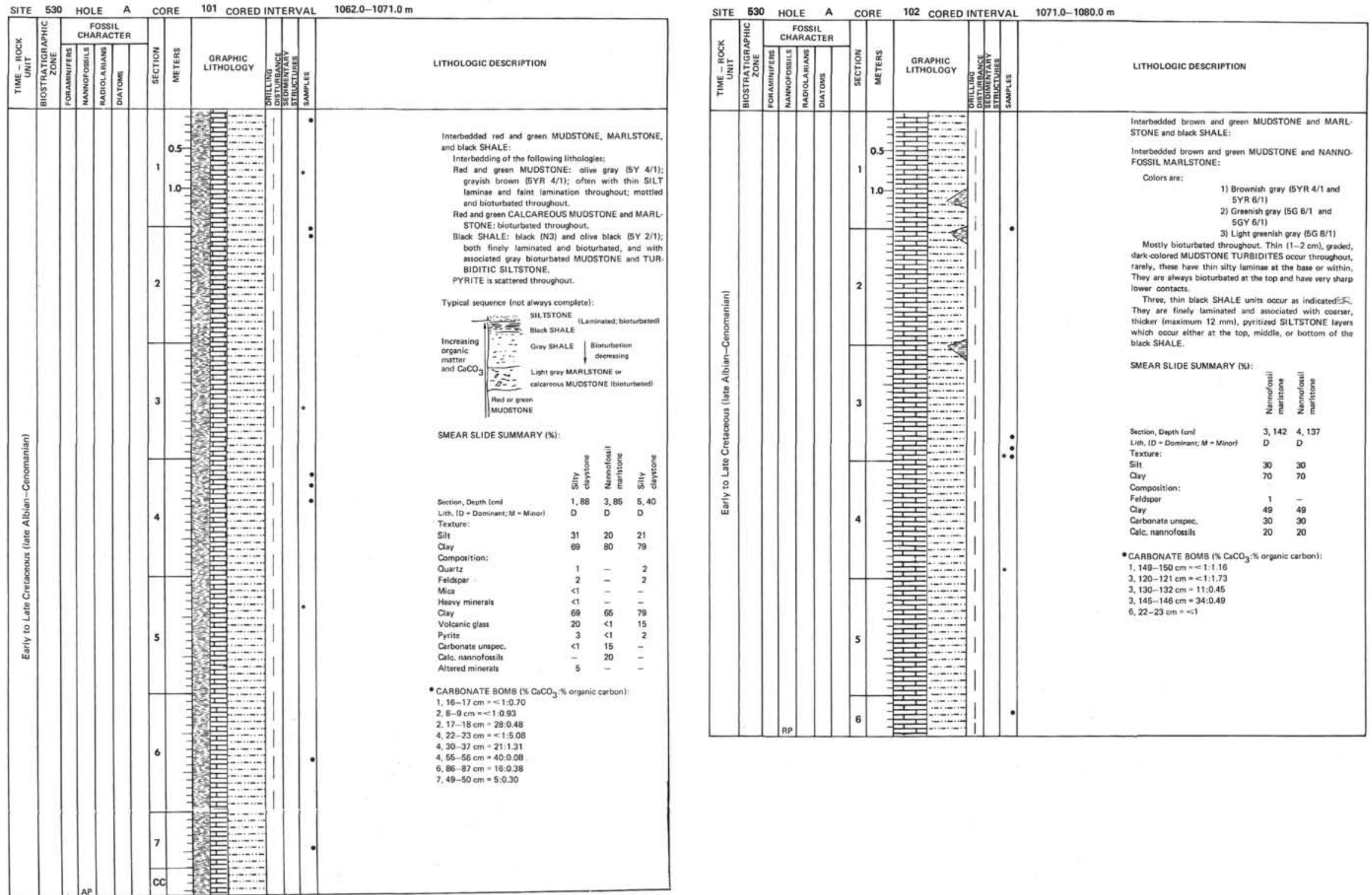


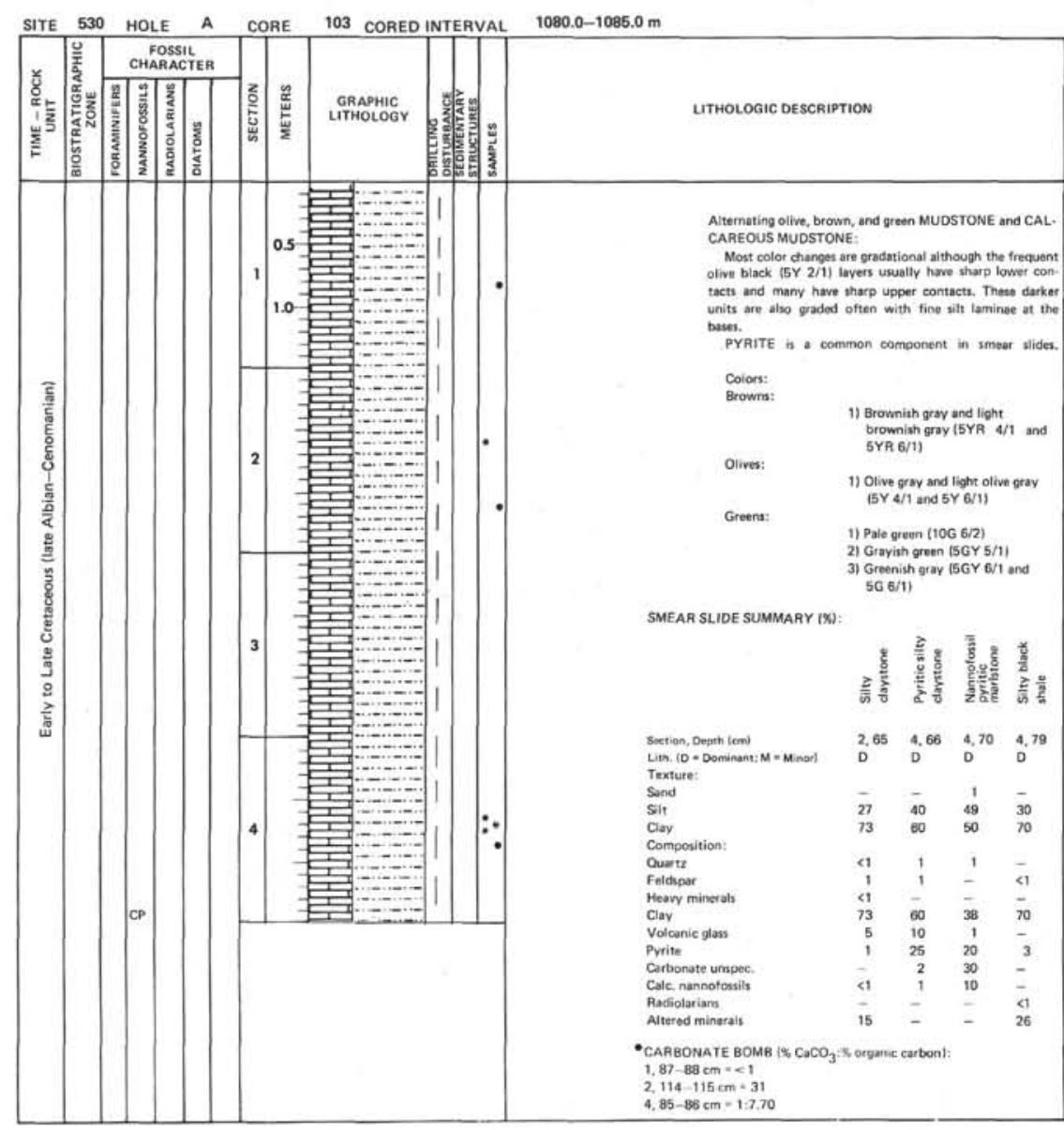

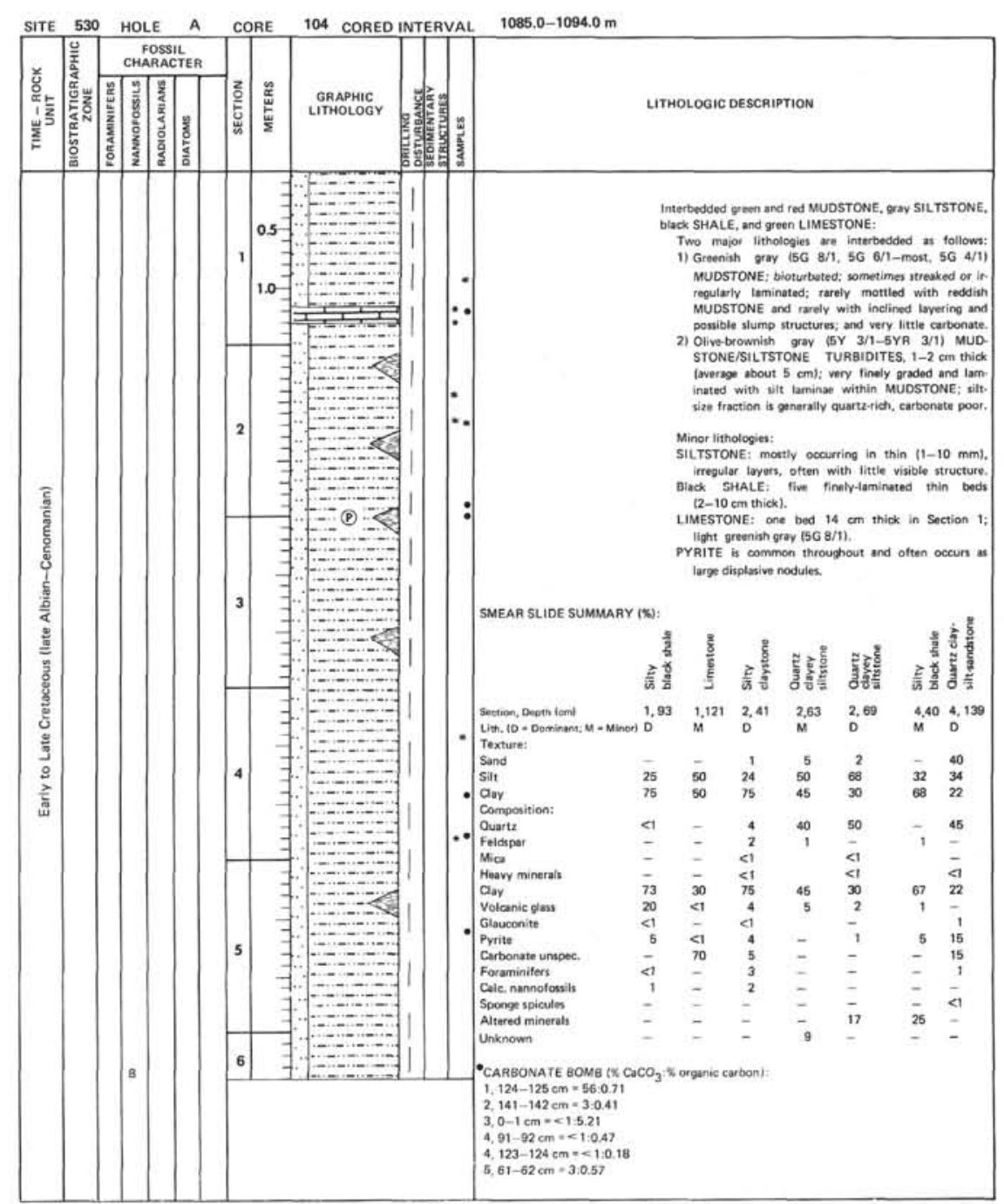




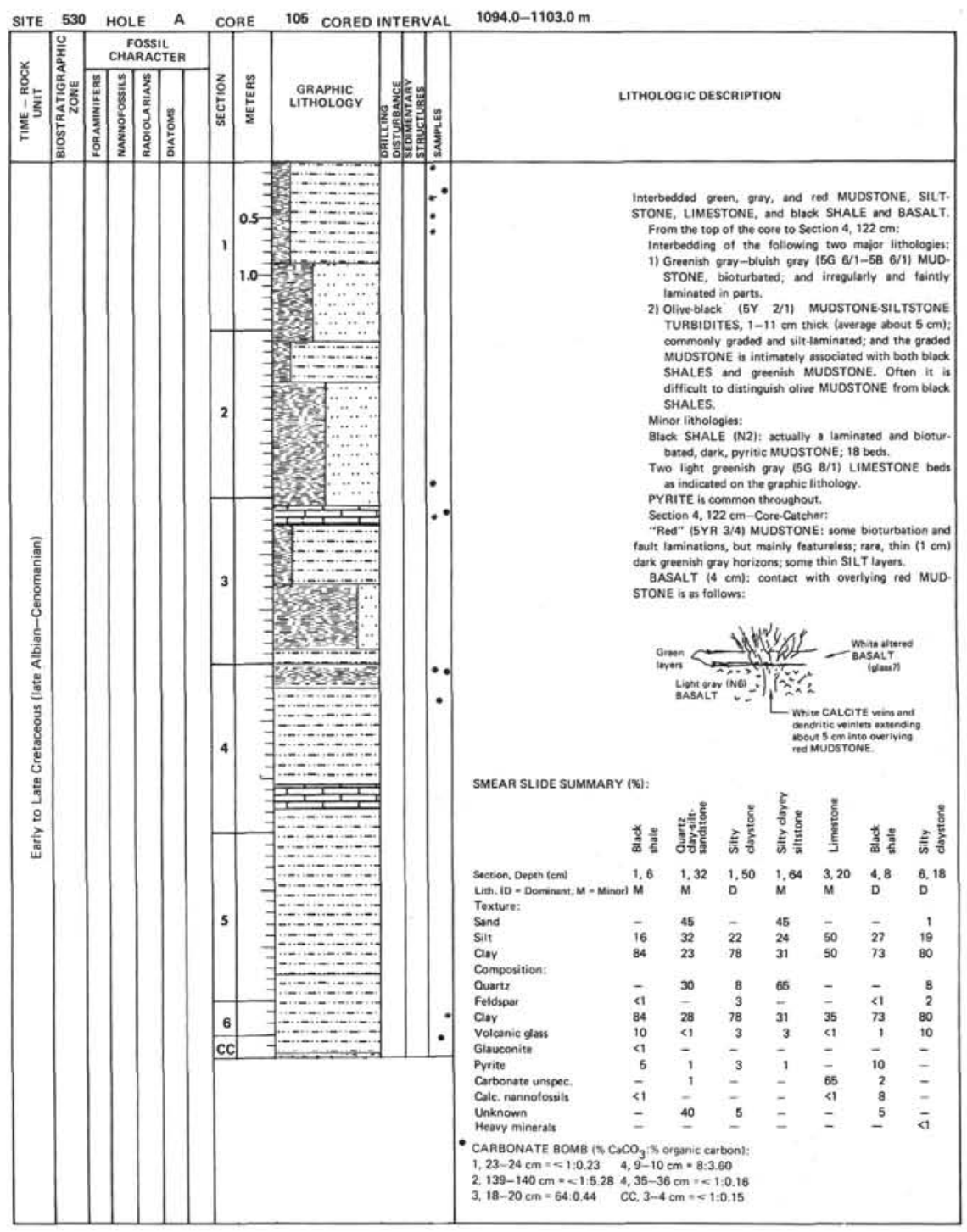



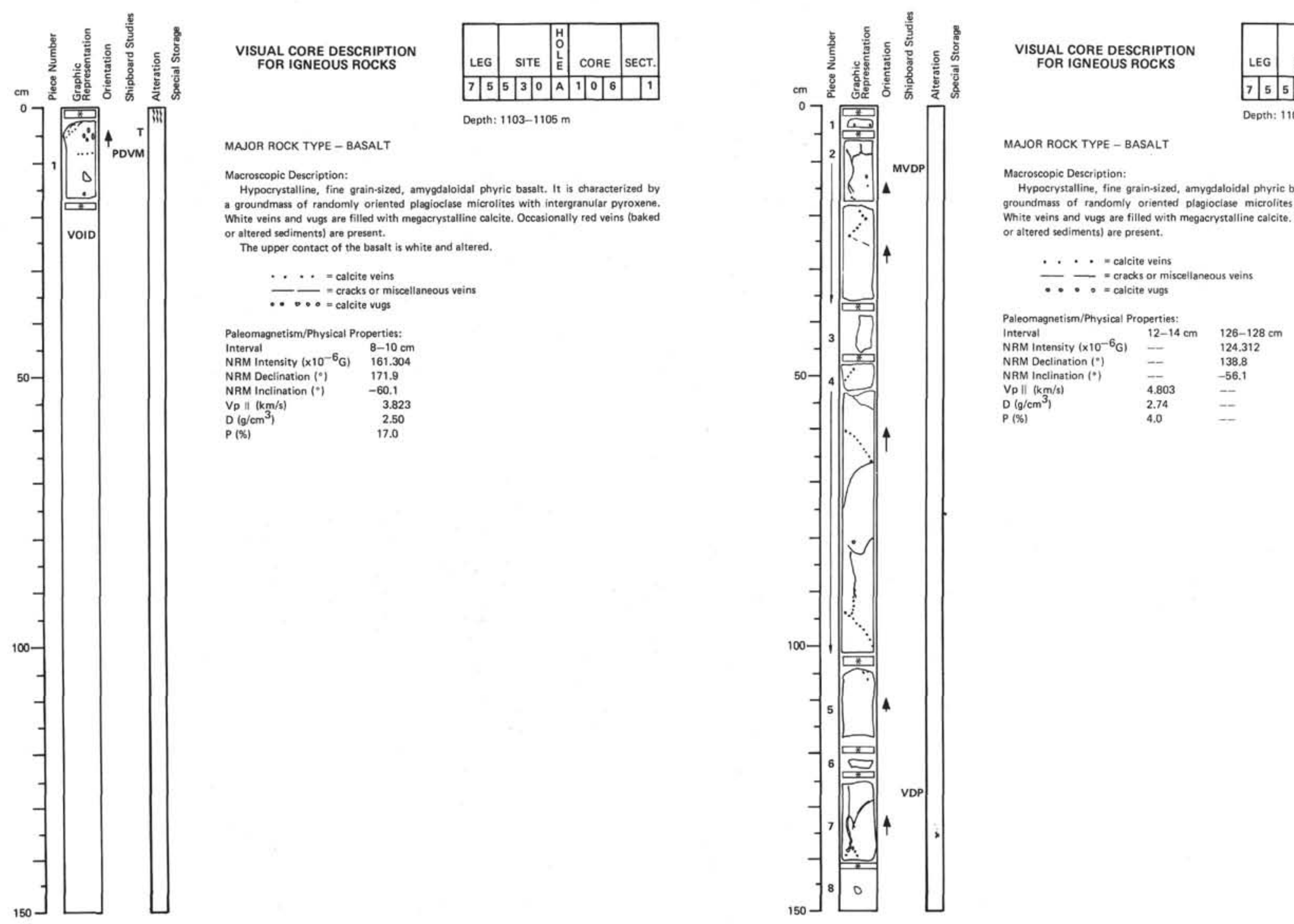


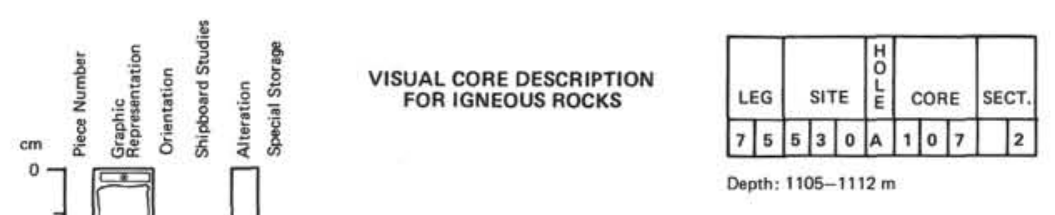

MAJOR ROCK TYPE - BASALT

Macroscopic Description

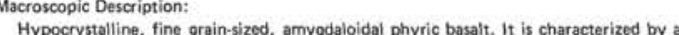
groundmass of randomly oriented plagioclase microlites with interoranular pyroxene. White veins and vugs are filled with megacrystalline calcite. Occassionally red veins (baked or altered sediments) are present.

$$
\ldots . .=\text { calcite veins }
$$$$
\ldots \ldots=\text { cracks or mis }
$$

Paleomagnetism/Physical Properties:
IItrerval
NPM

NRM Intensity $\left(\times 10^{-6} \mathrm{G}\right) \quad-\quad \begin{array}{rrr}77.971 & 119.901\end{array}$

$\begin{array}{llrr}\text { NRM Declination ( } & - & & 71 \\ \text { NRM Inclination (") } & - & 242.8 & 118.8 \\ V & - & 21.5 & -32.2\end{array}$

D $\left(g / \mathrm{cm}^{3}\right)$

4.65
2.65
13.0

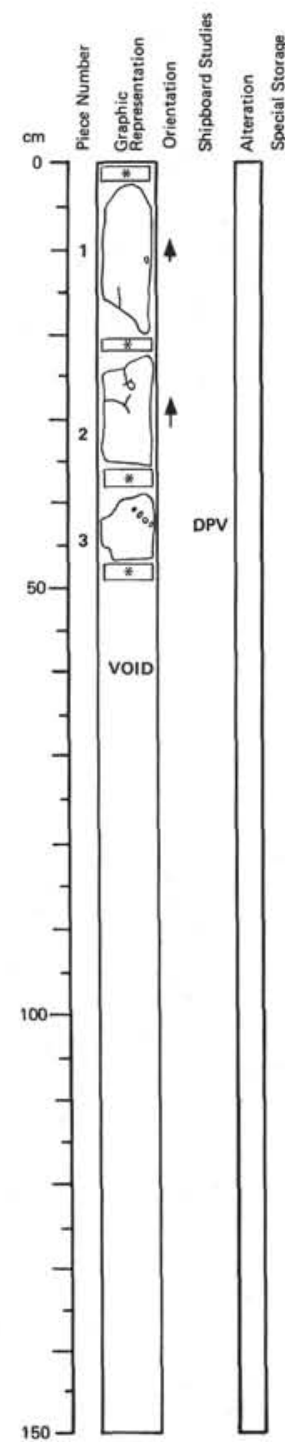

VISUAL CORE DESCRIPTION

FOR IGNEOUS ROCKS

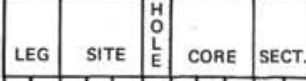

\begin{tabular}{|l|l|l|l|l|l|l|l|l|l|}
\hline 7 & 5 & 5 & 3 & 0 & $A$ & 1 & 0 & 7 & \\
\hline
\end{tabular} Depth: $1105-1112 \mathrm{~m}$

MANOR ROCK TYPE - BASALT

Macroscopic Description

Hypocrystalline, fine grain-sized, amygdaloidal phyric basalt. It is characterized by iy oriented plagioclase microlites White veins and vugs are filled with megacrystalline calcite. Occasionally red veins (baked

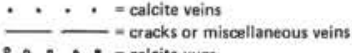

$\cdots \cdots=$ calcite vugs

Physical Properties:

\begin{tabular}{lc} 
Physical Properties: & $41-43 \mathrm{~cm}$ \\
Interval \\
Vo $\mid l(\mathrm{~km} / \mathrm{s})$ & 4.924 \\
\hline
\end{tabular}

$V_{p} \| l(k m / 2)$
$D\left(g / \mathrm{cm}^{3}\right)$

$P(x)$

2.72
12.0 


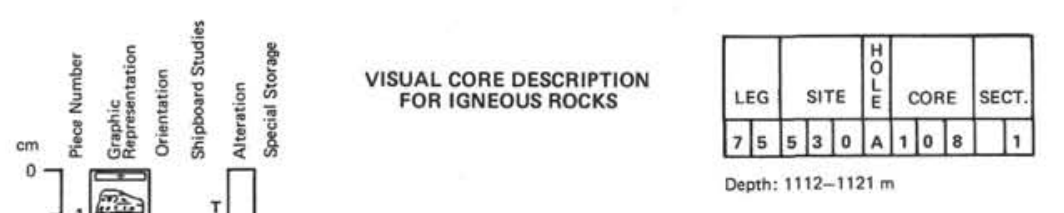

MANOR ROCK TYPE - BASALT

Macroscopic Description

A red, baked or altered sediment occurs at the top of section. The fine-grained hypo. Wer margin which is overlain by rounded fragments of White veins and vugs are filled with megacrystalline calcite. Occa .

$$
\begin{aligned}
& \text { … - calcite veins } \\
& \text {.... - calcite vugh } \\
& \begin{array}{l}
\text { Paleomagnetism/Physical Properties: } \\
\text { Interval } \\
14-16 \mathrm{~cm} \quad 104 \mathrm{~cm}
\end{array} \\
& \begin{array}{l}
\text { NRM Intensity }\left(\times 10^{-6} \mathrm{G}\right) \quad-\quad 109.905 \\
\text { NRM Declination }\left(0^{\circ}\right)
\end{array} \\
& \text { NRM Inclination (") - } \\
& \begin{array}{lll}
V_{p} \|(\mathrm{km} / \mathrm{s}) & 4.850 & - \\
\mathrm{D}\left(\mathrm{g} / \mathrm{cm}^{3}\right) & 2.72
\end{array}
\end{aligned}
$$

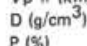

$$
\begin{aligned}
& \begin{array}{c}
2.72 \\
12.0
\end{array}
\end{aligned}
$$

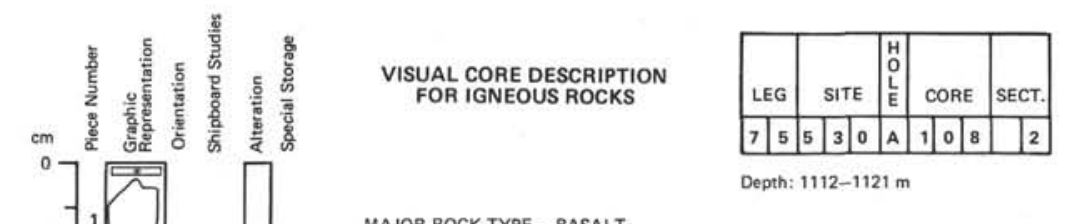

MANOR ROCK TYPE - BASALT

Macroscopic Description:

the

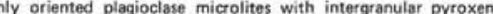
White veins and vugs are filled with megacrystalline calcite. Occasionally red veins (baked or altered sediments) are present.

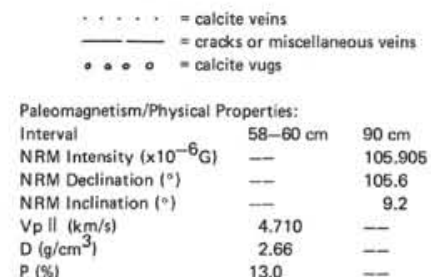

NRM Inclination ( $\left.{ }^{\circ}\right)$

$V_{p} \|(k m / s)$

$p(q) / \mathrm{cm} /$
$p(s)$ 


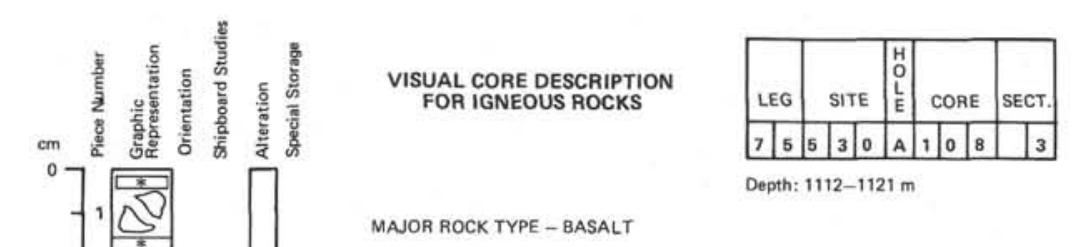

MANOR ROCK TYPE - BASALT

Macrosoopic Description:

thporystanthe, fine grain-sized, amygdaloidal phyric basalt. It is characterized by a

groundmass of randomly oriented plagioclase microlites with intergranular pyroxene.

$$
\text { .... - calcite veins }
$$



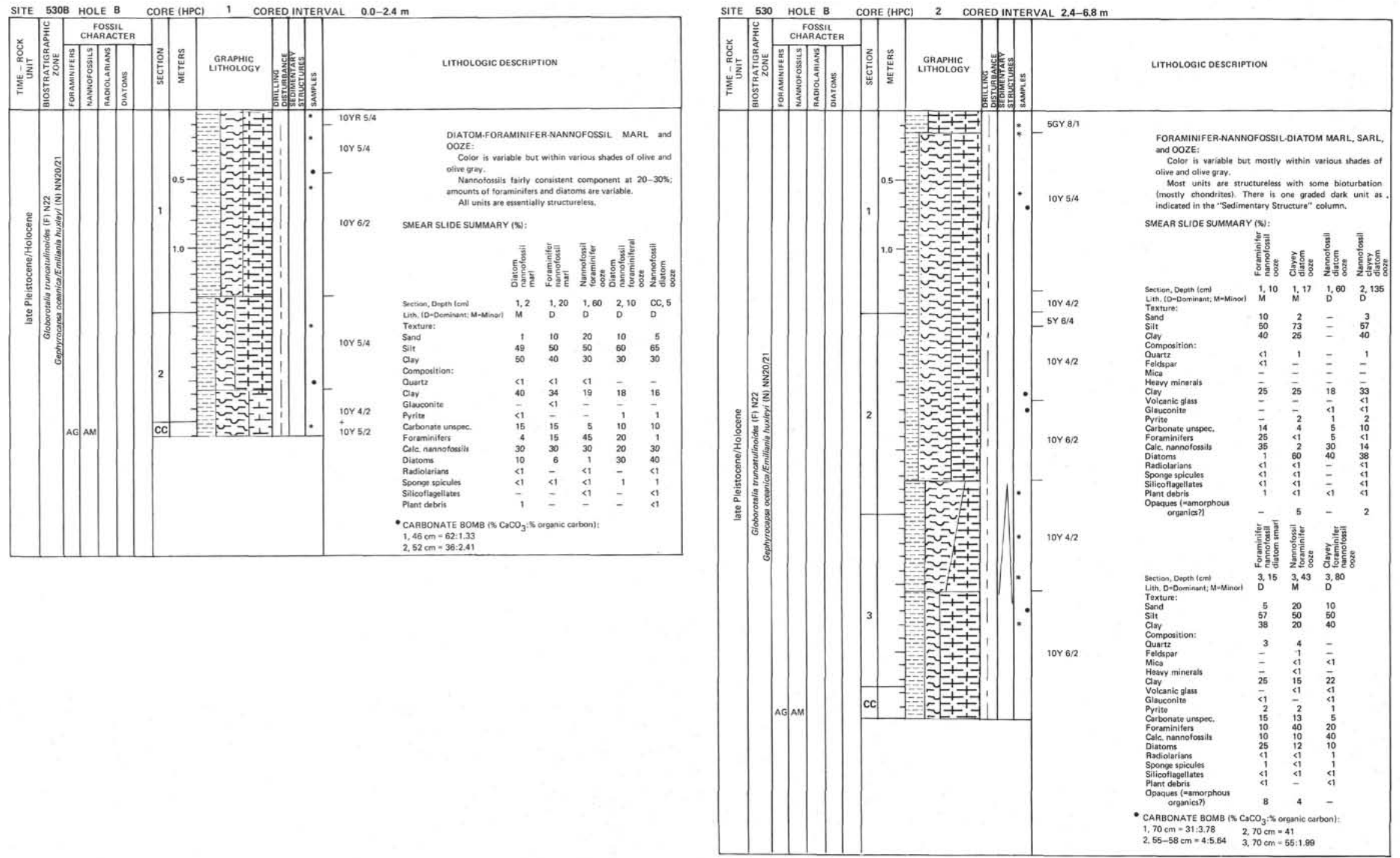

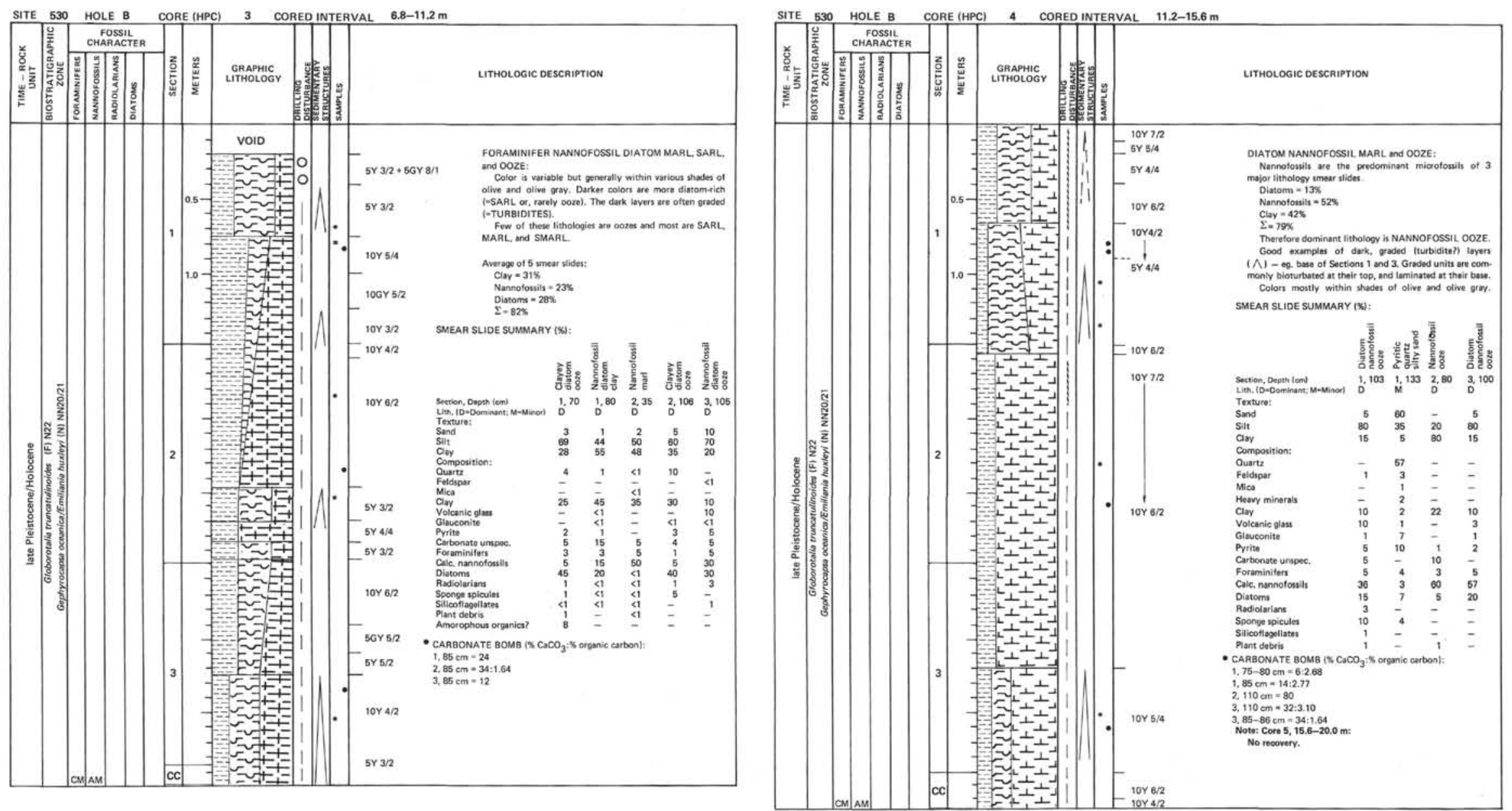


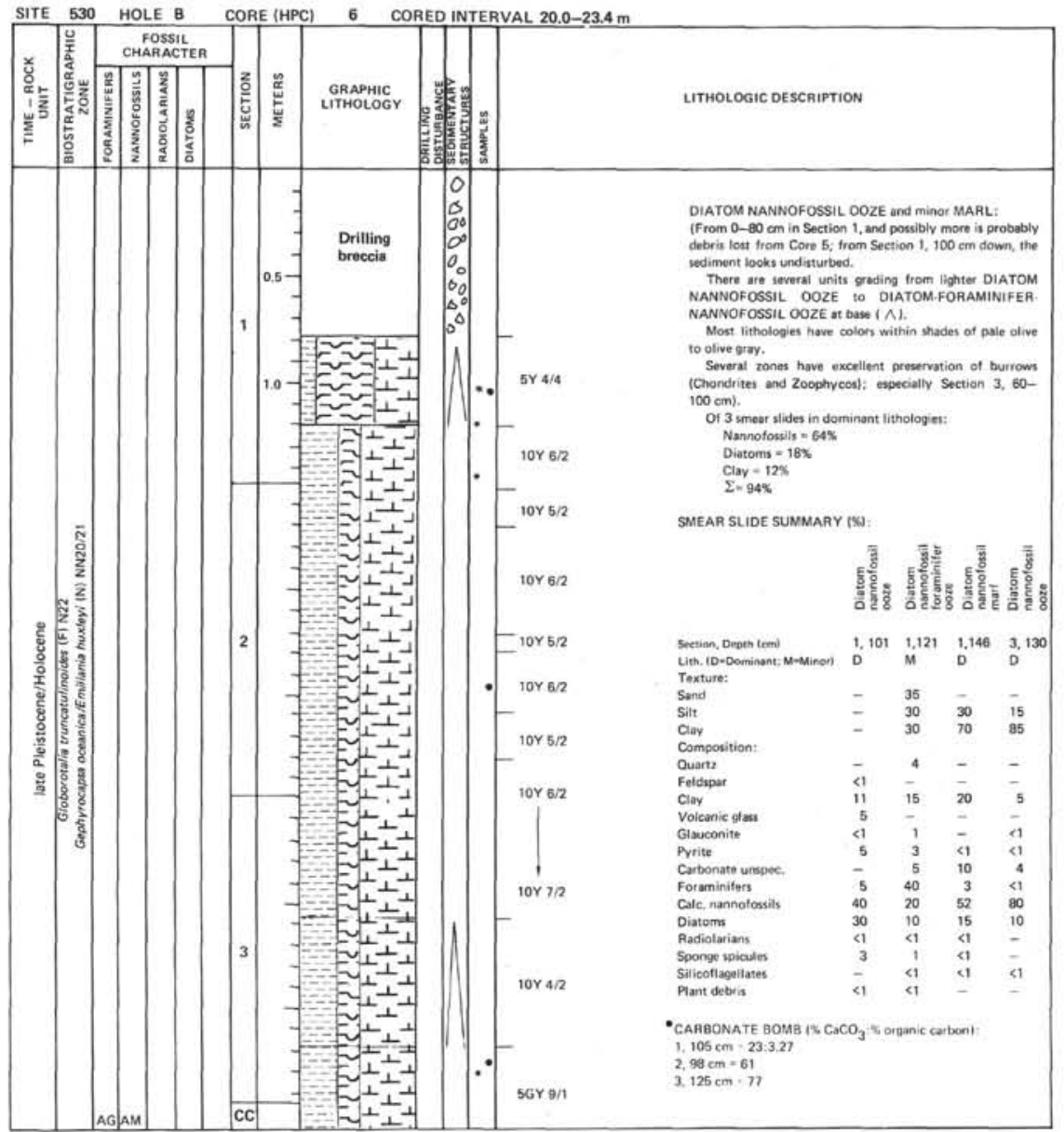

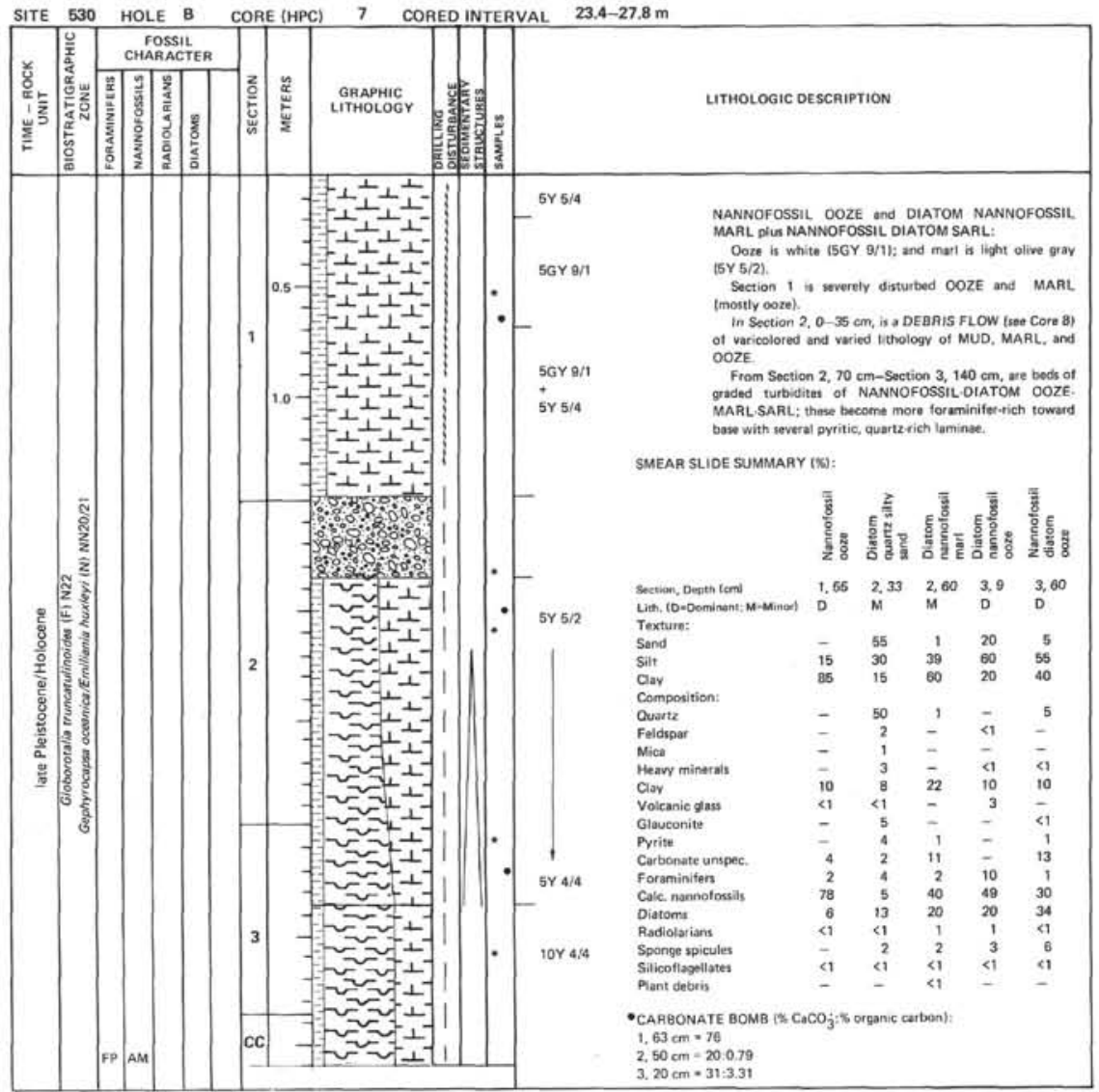



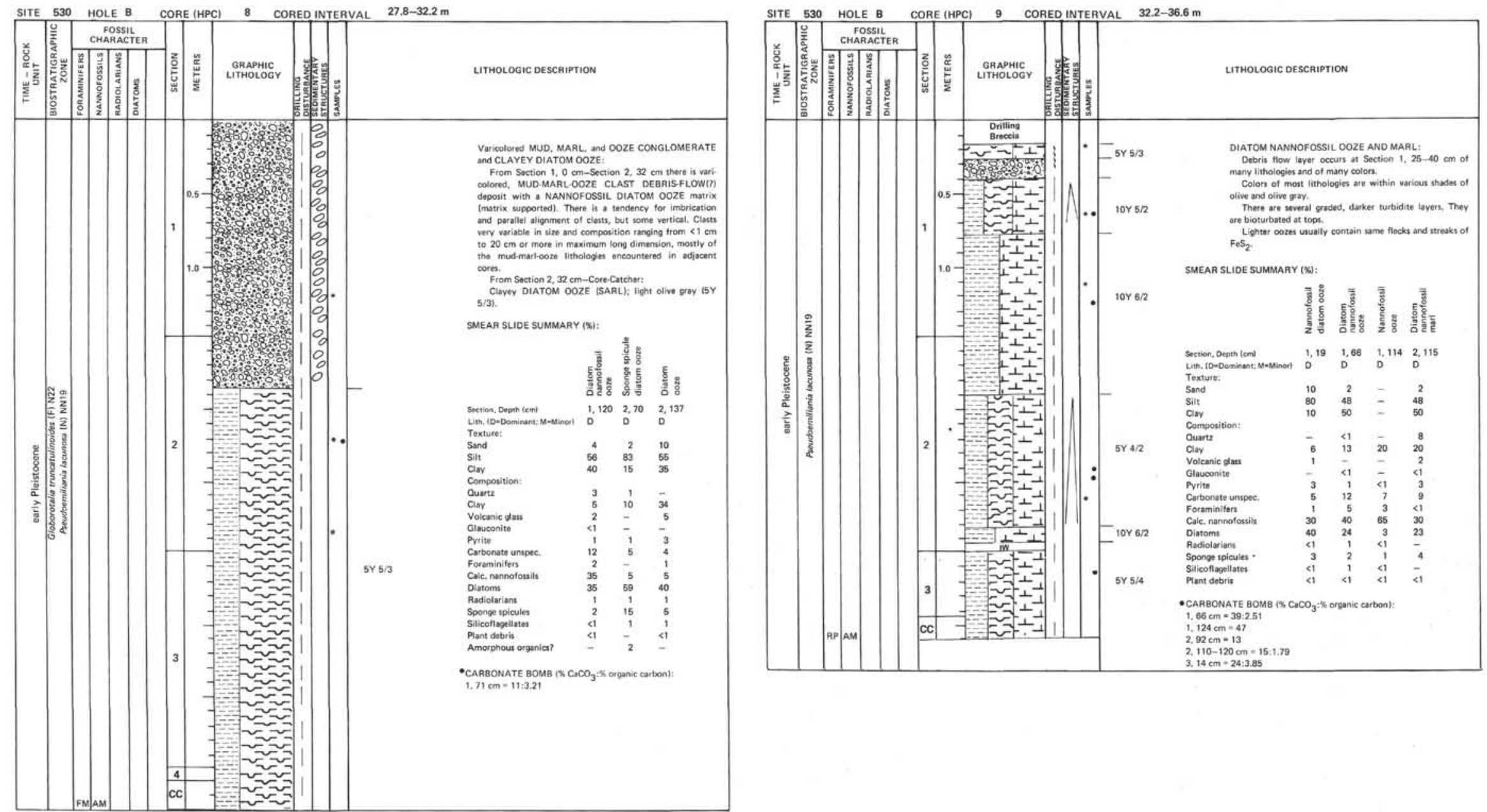


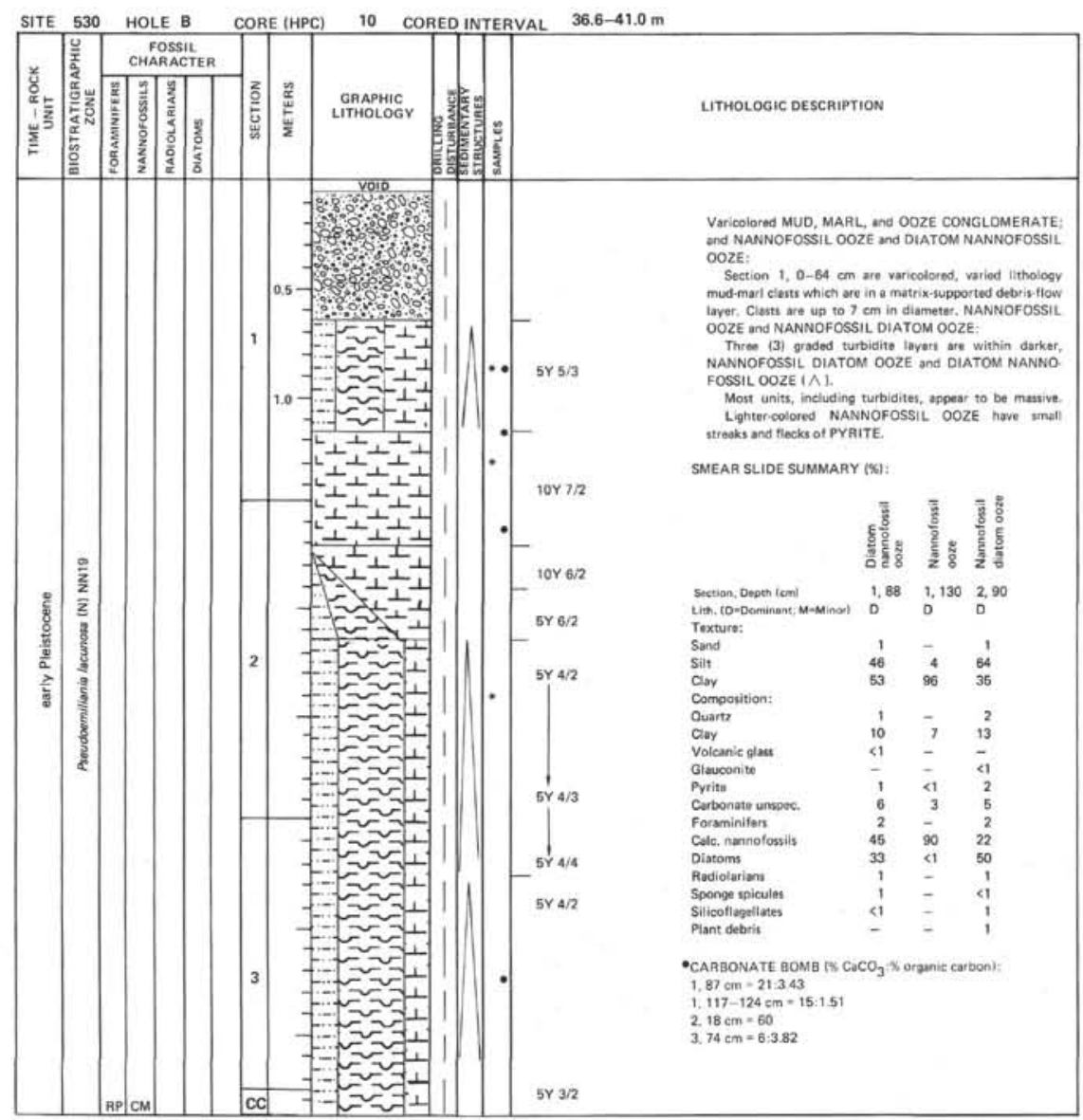

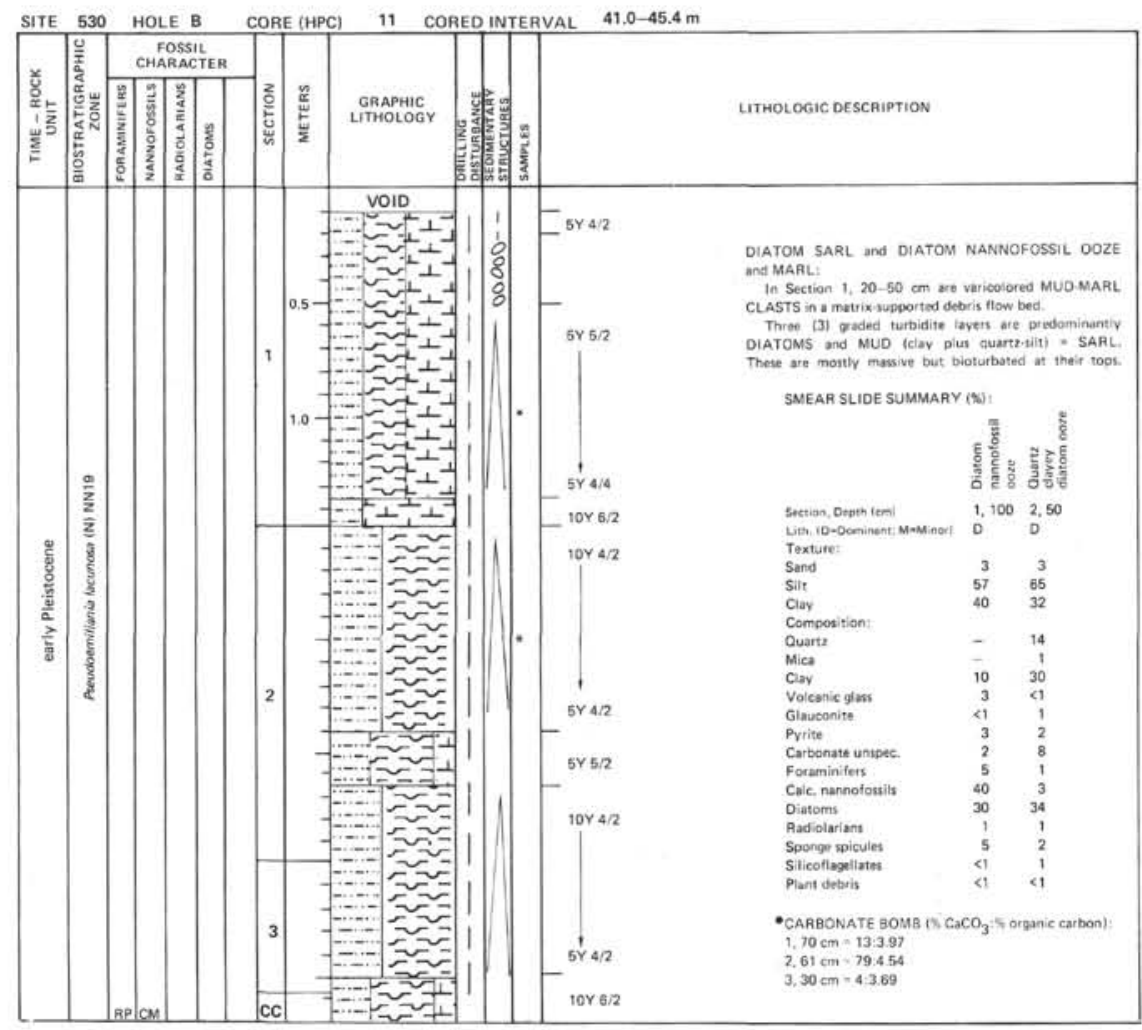



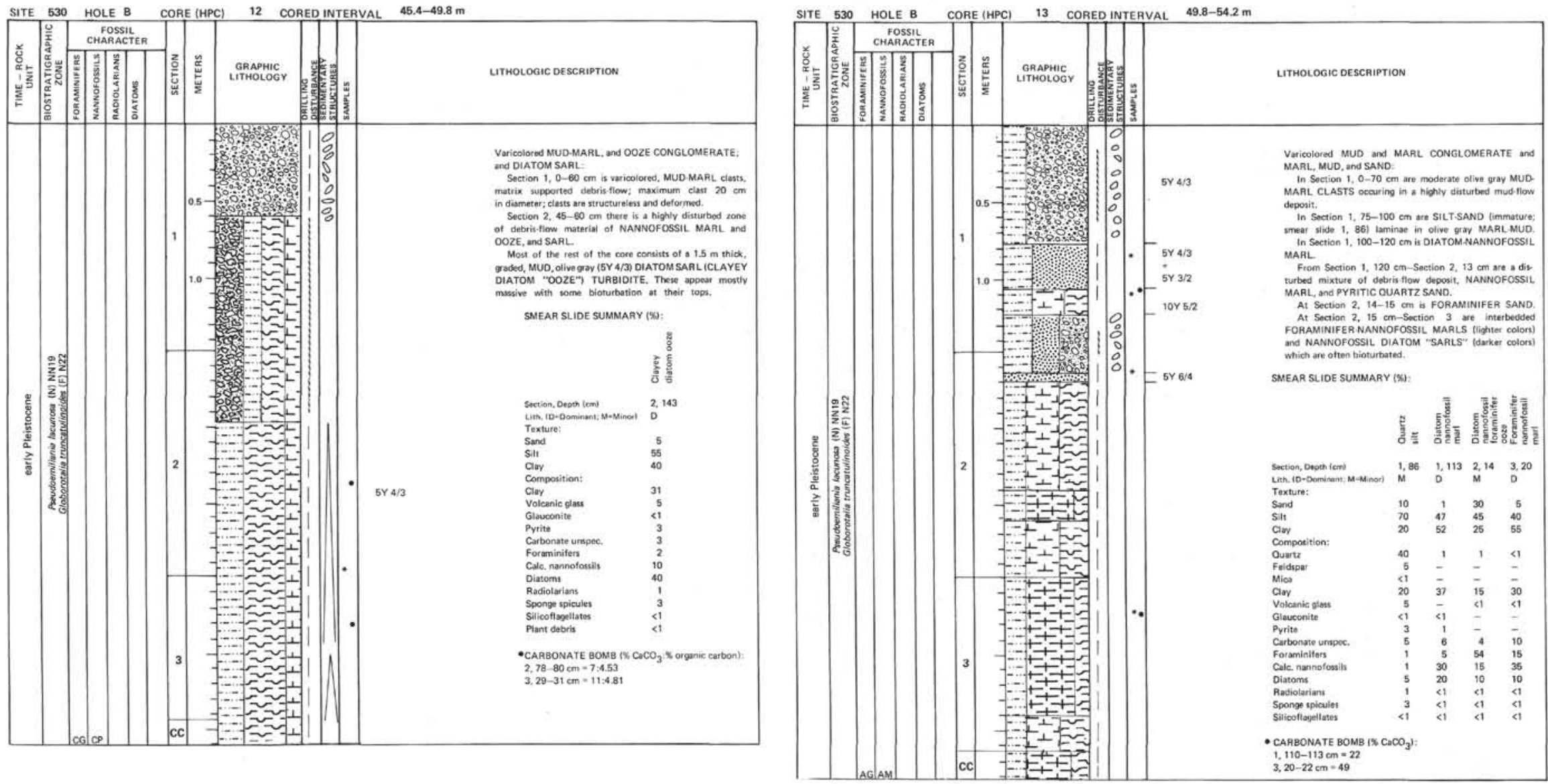


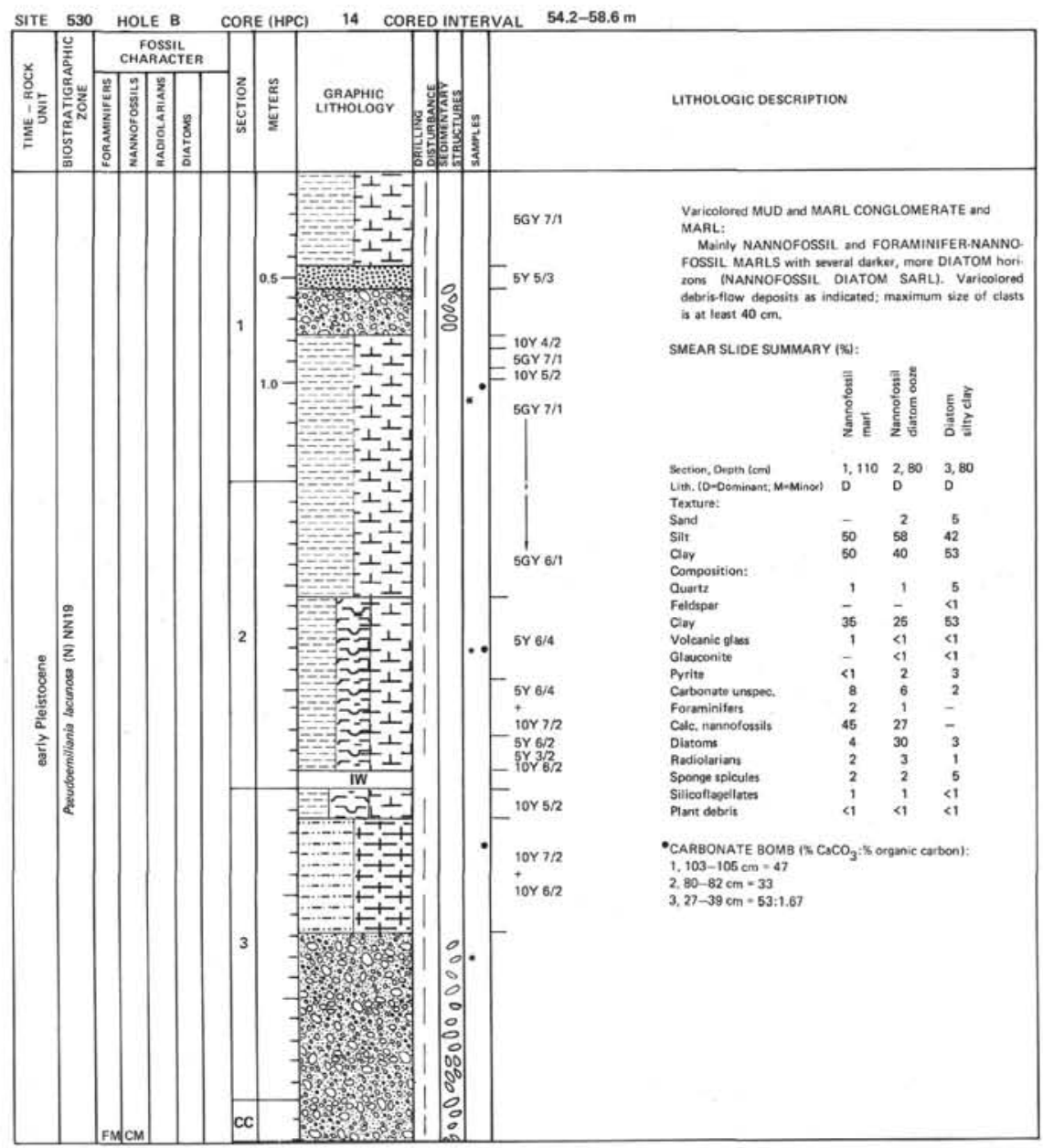

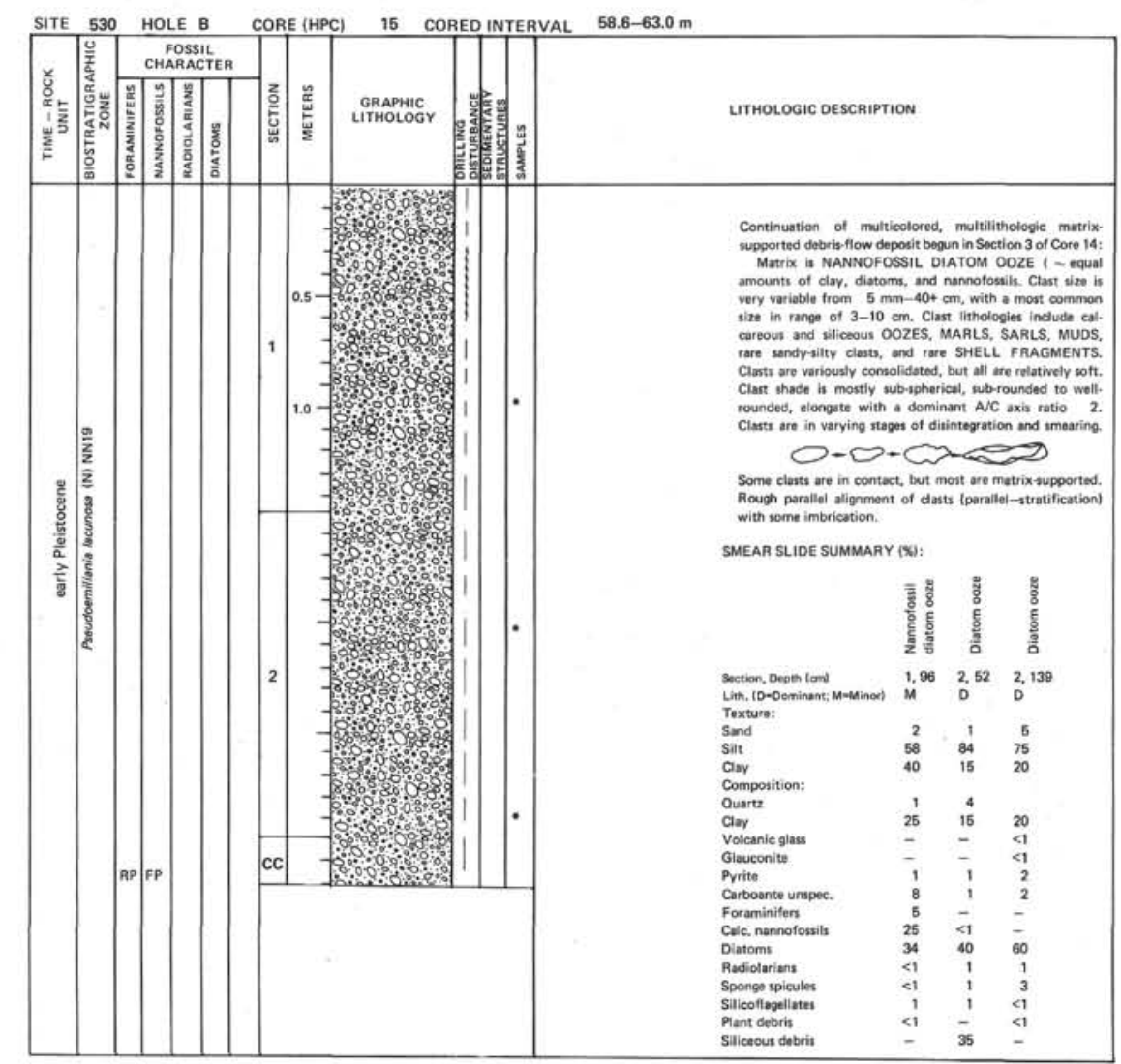



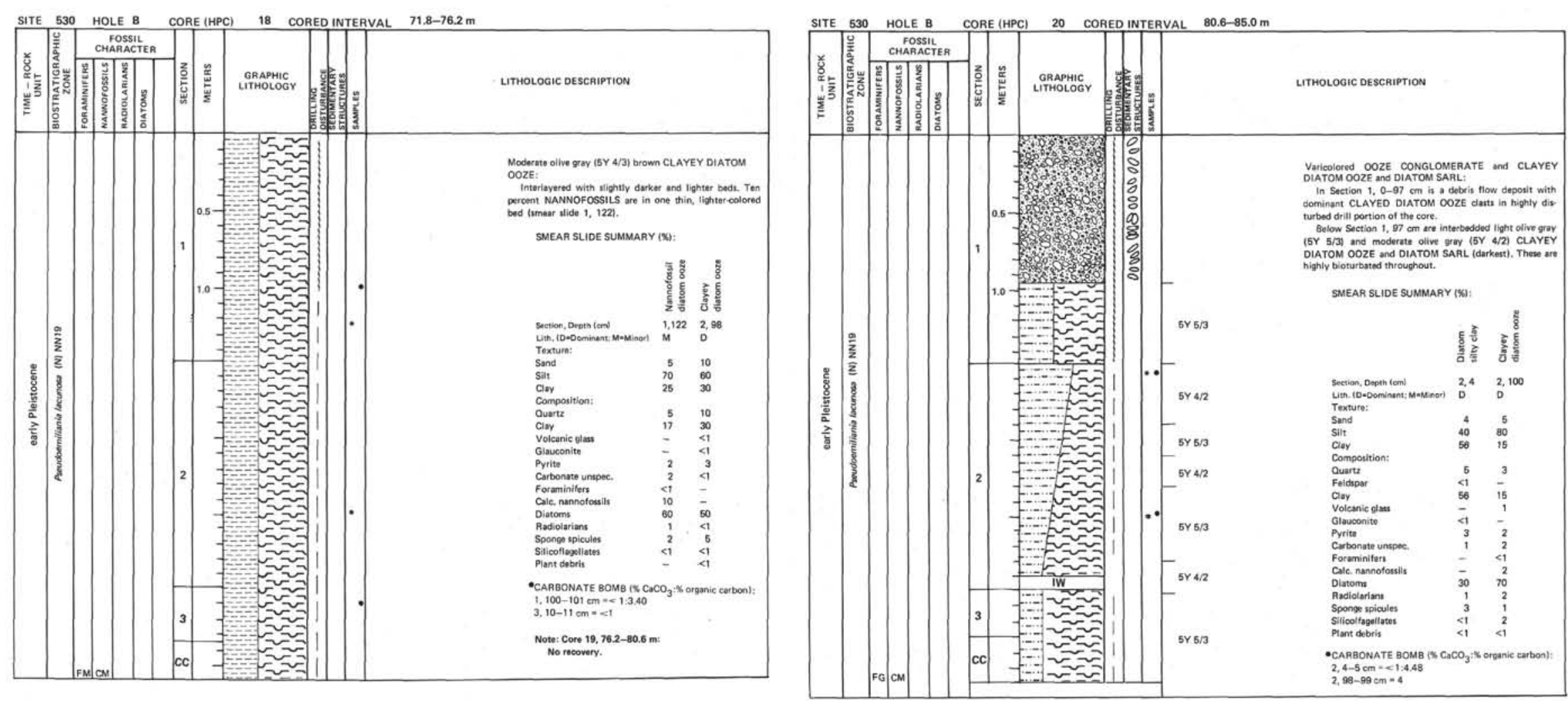

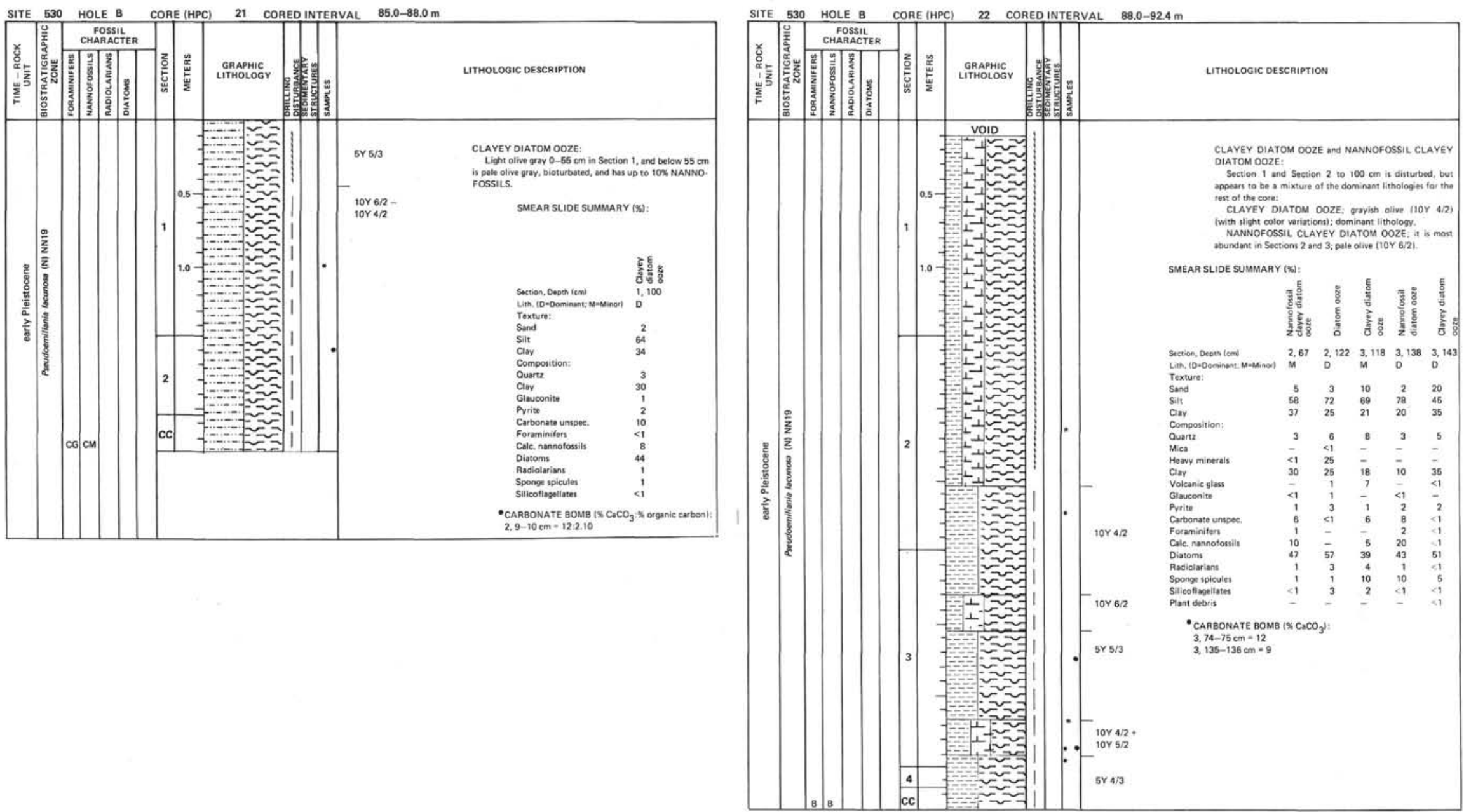

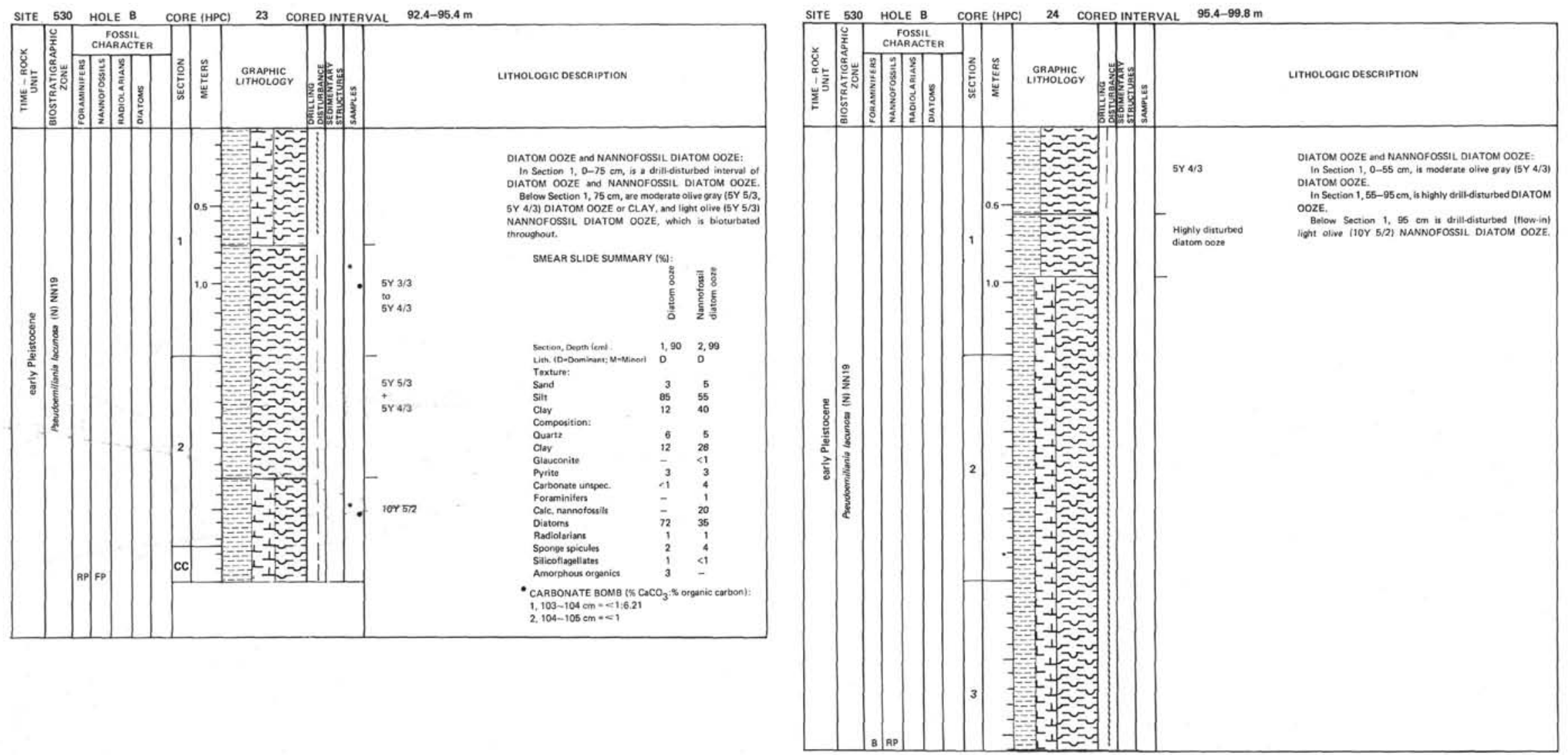

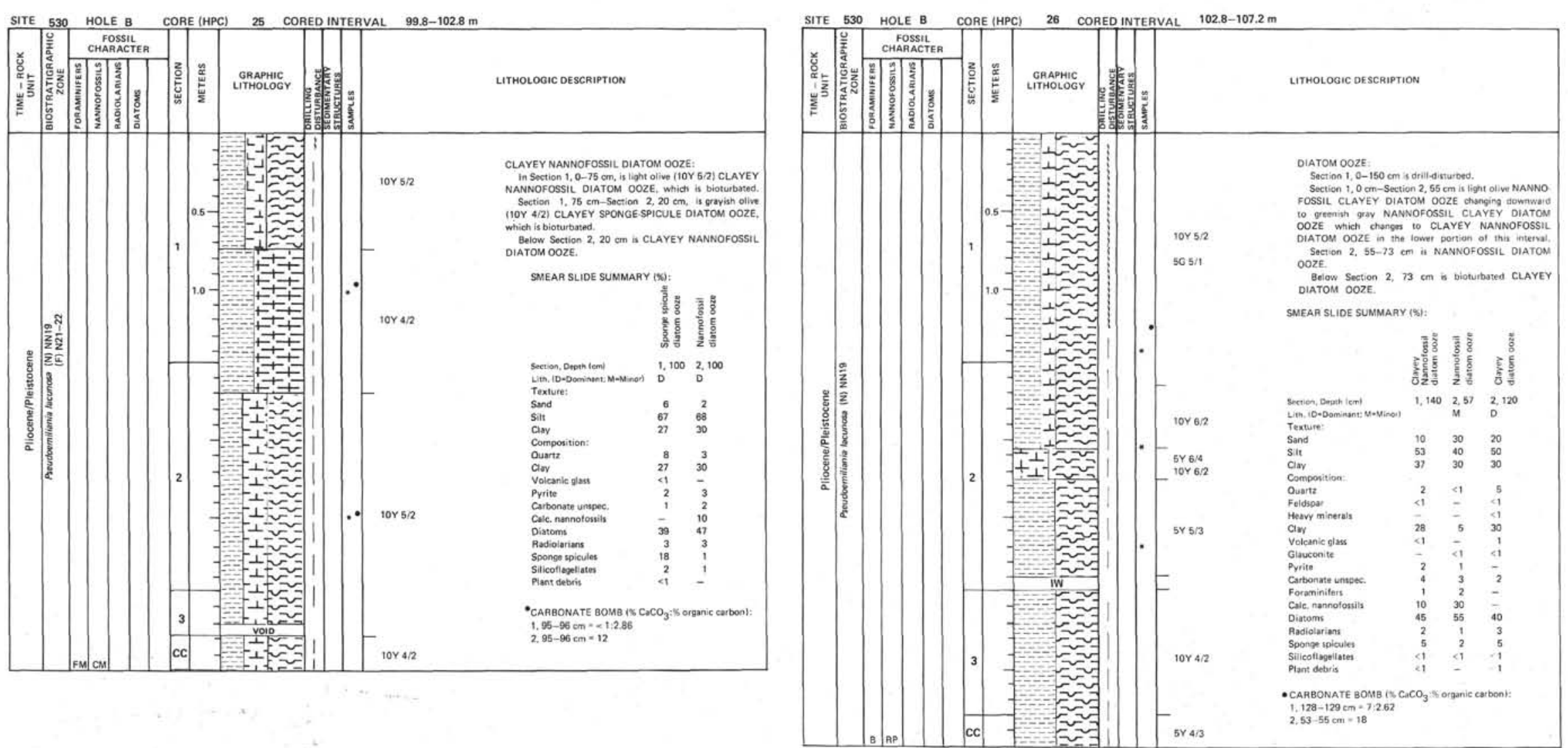

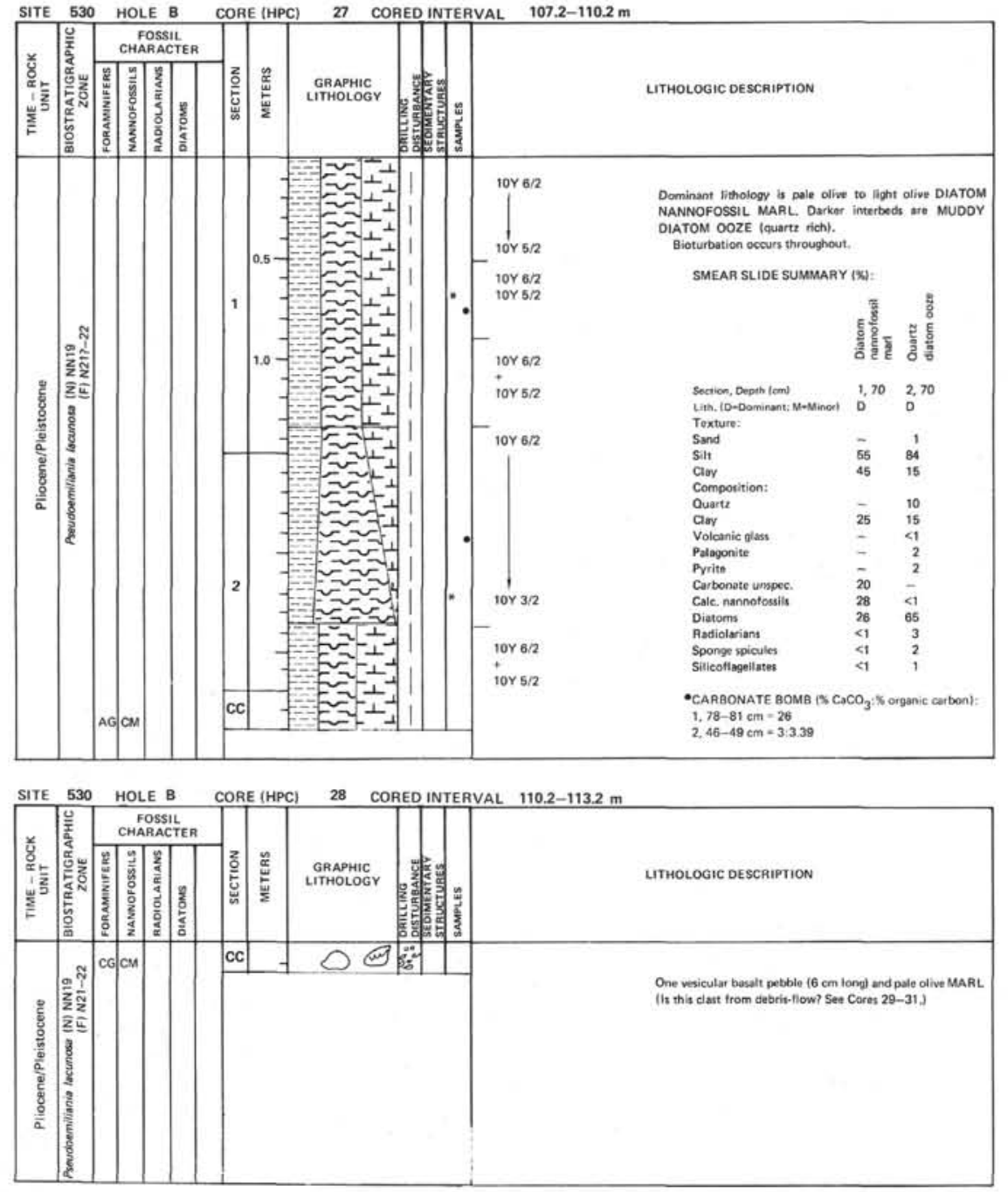

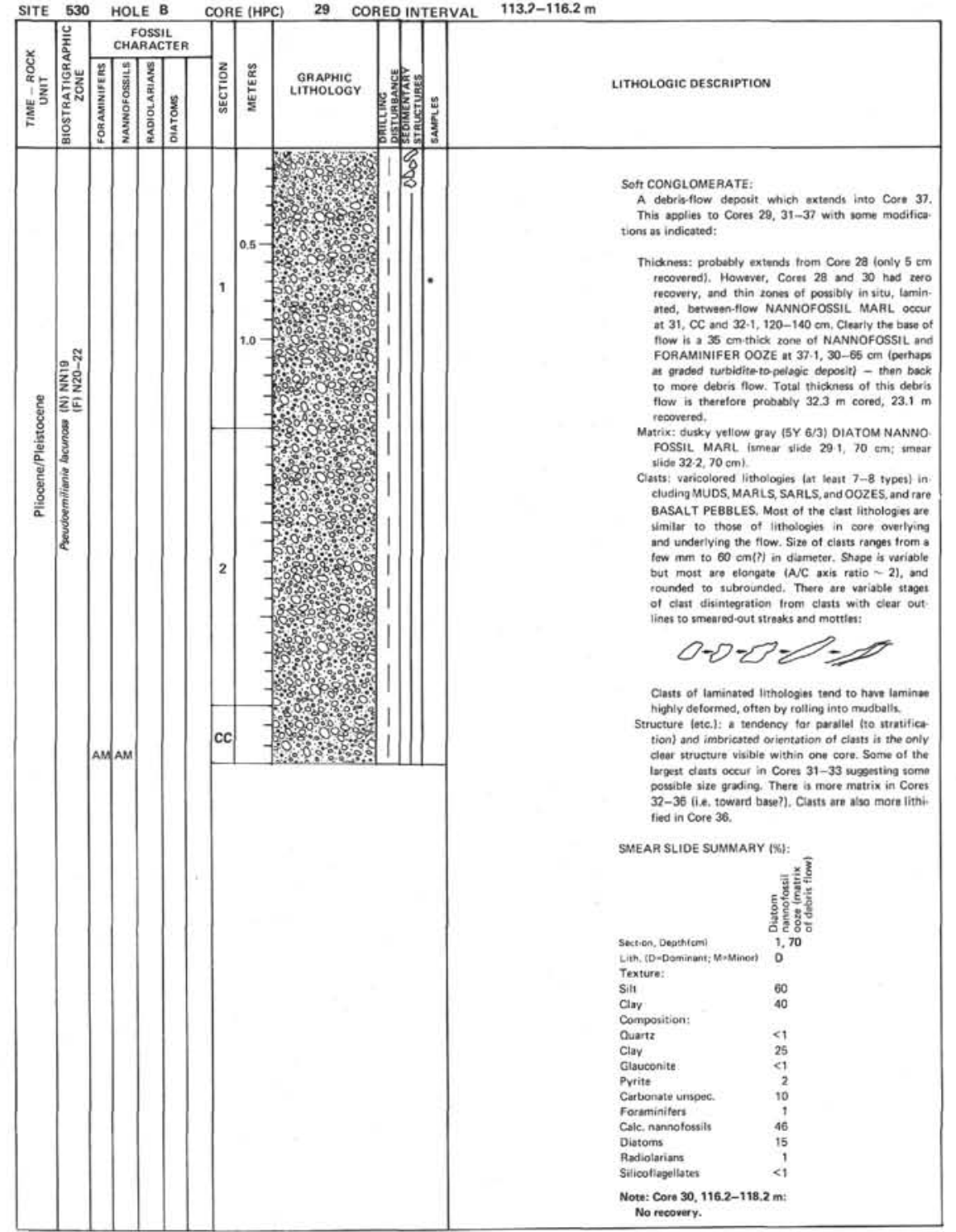




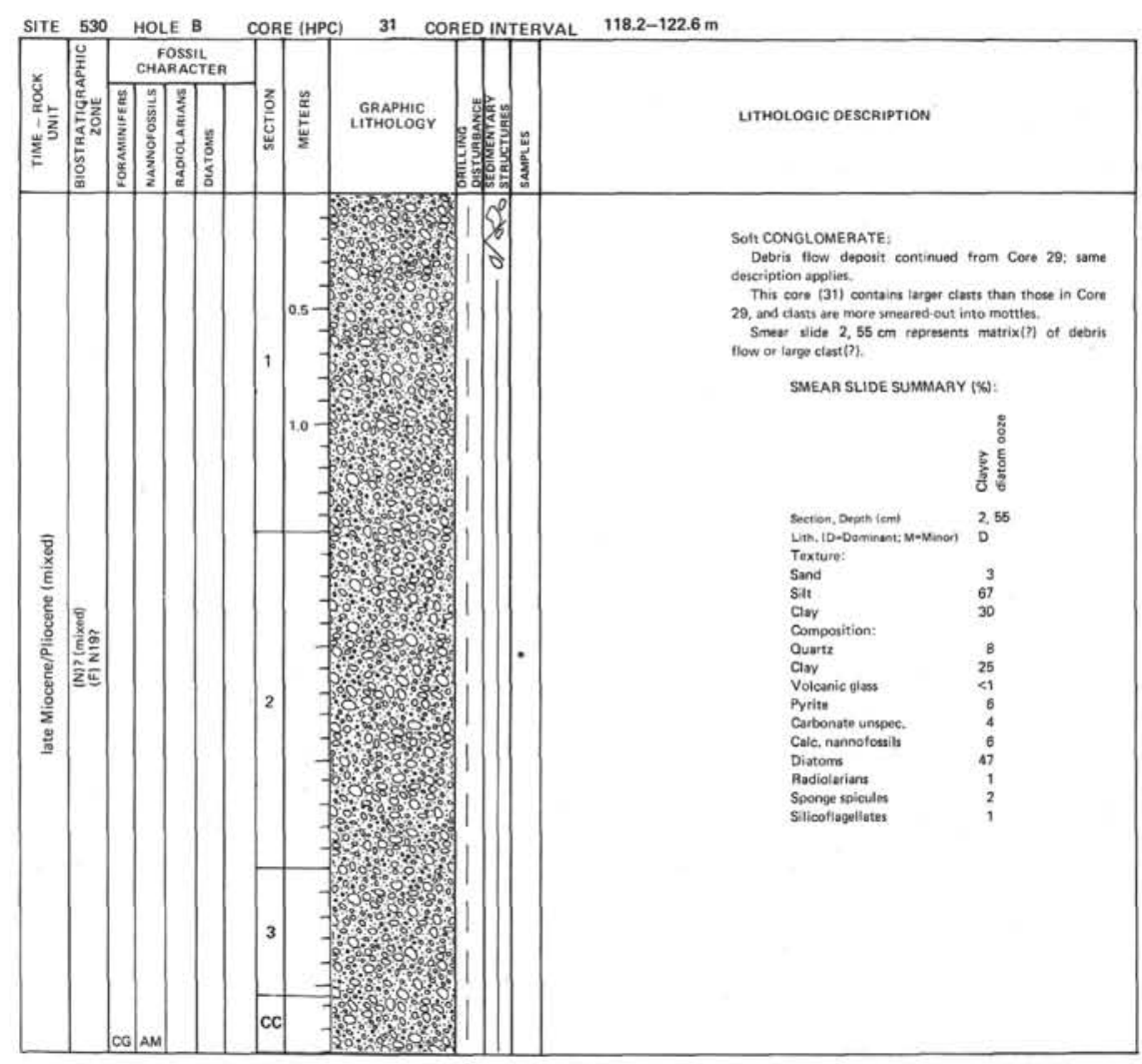

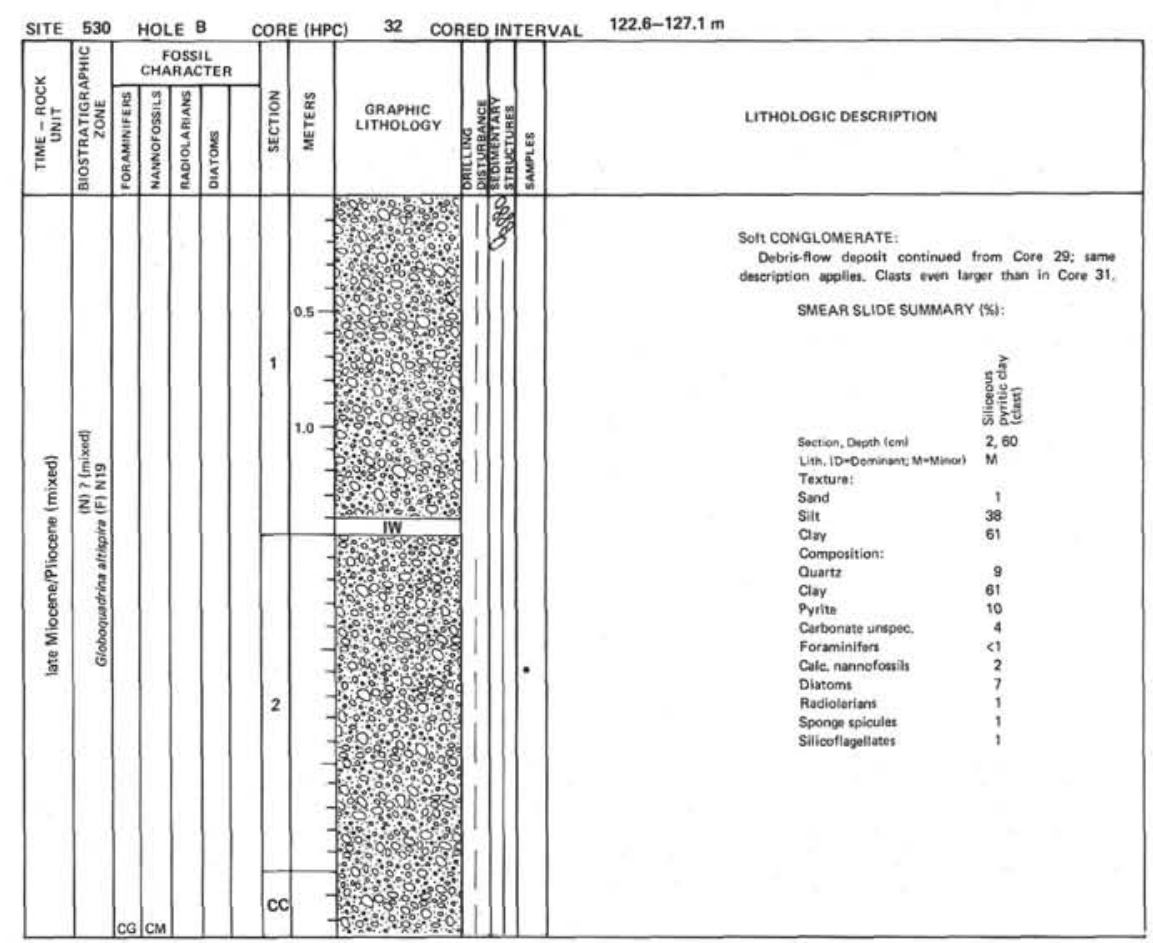



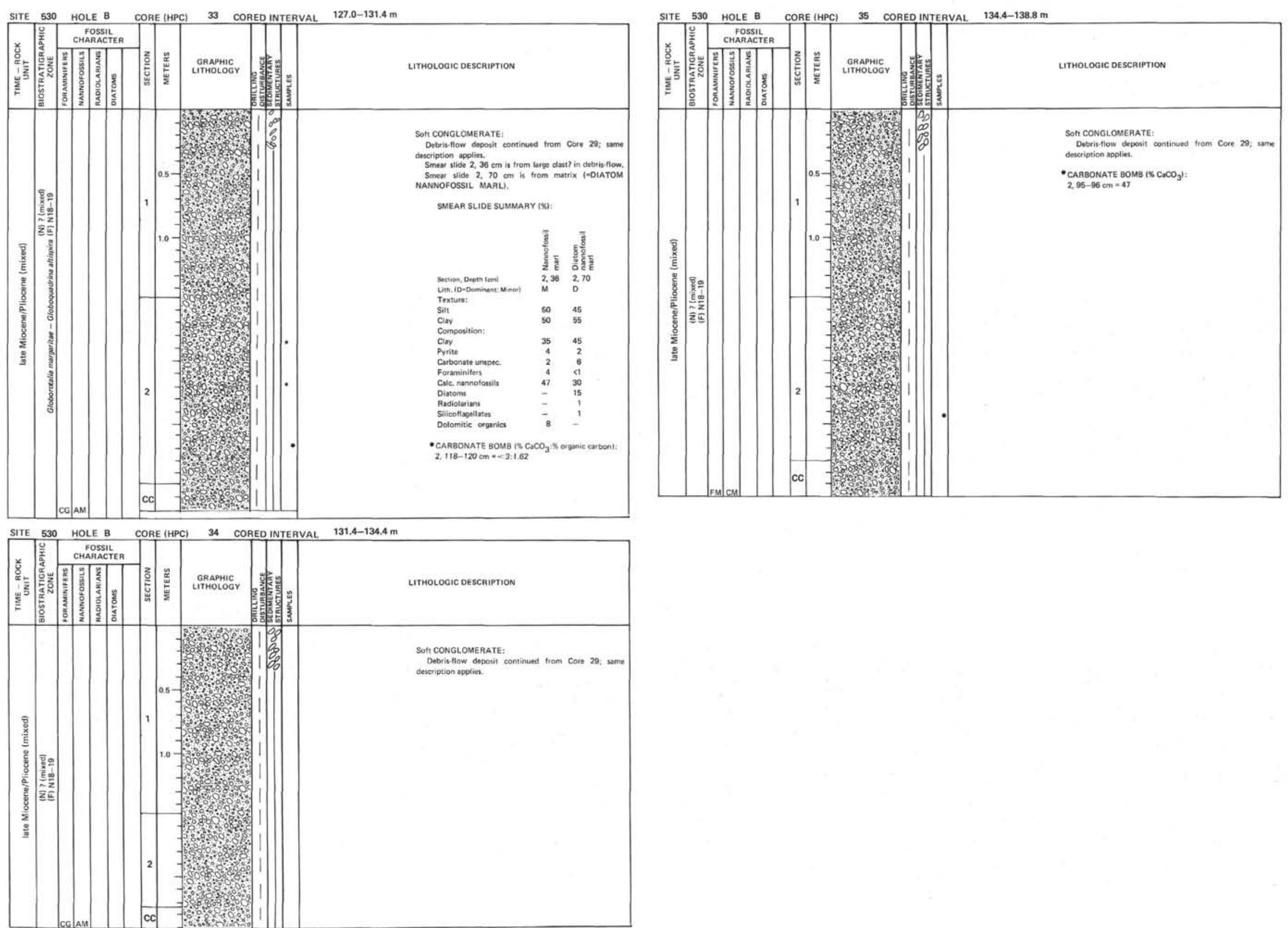

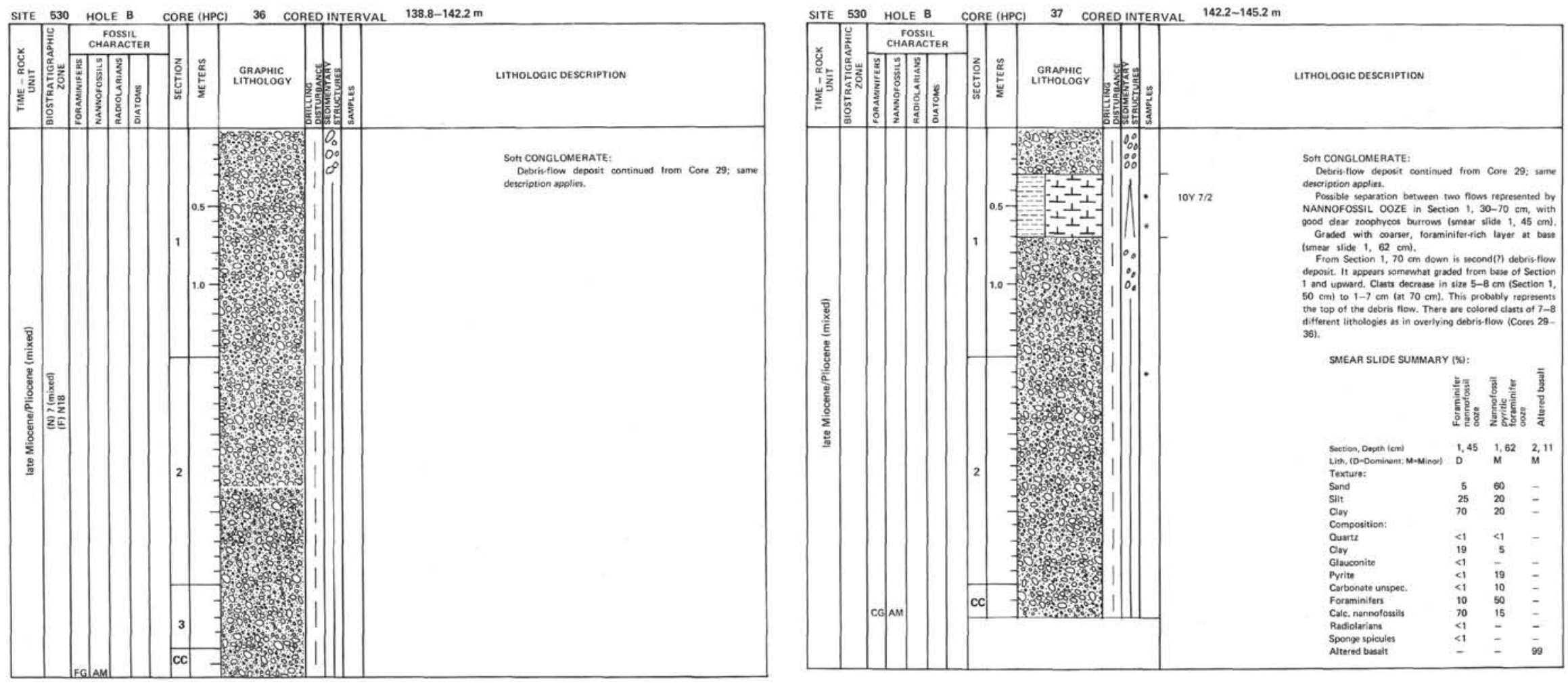


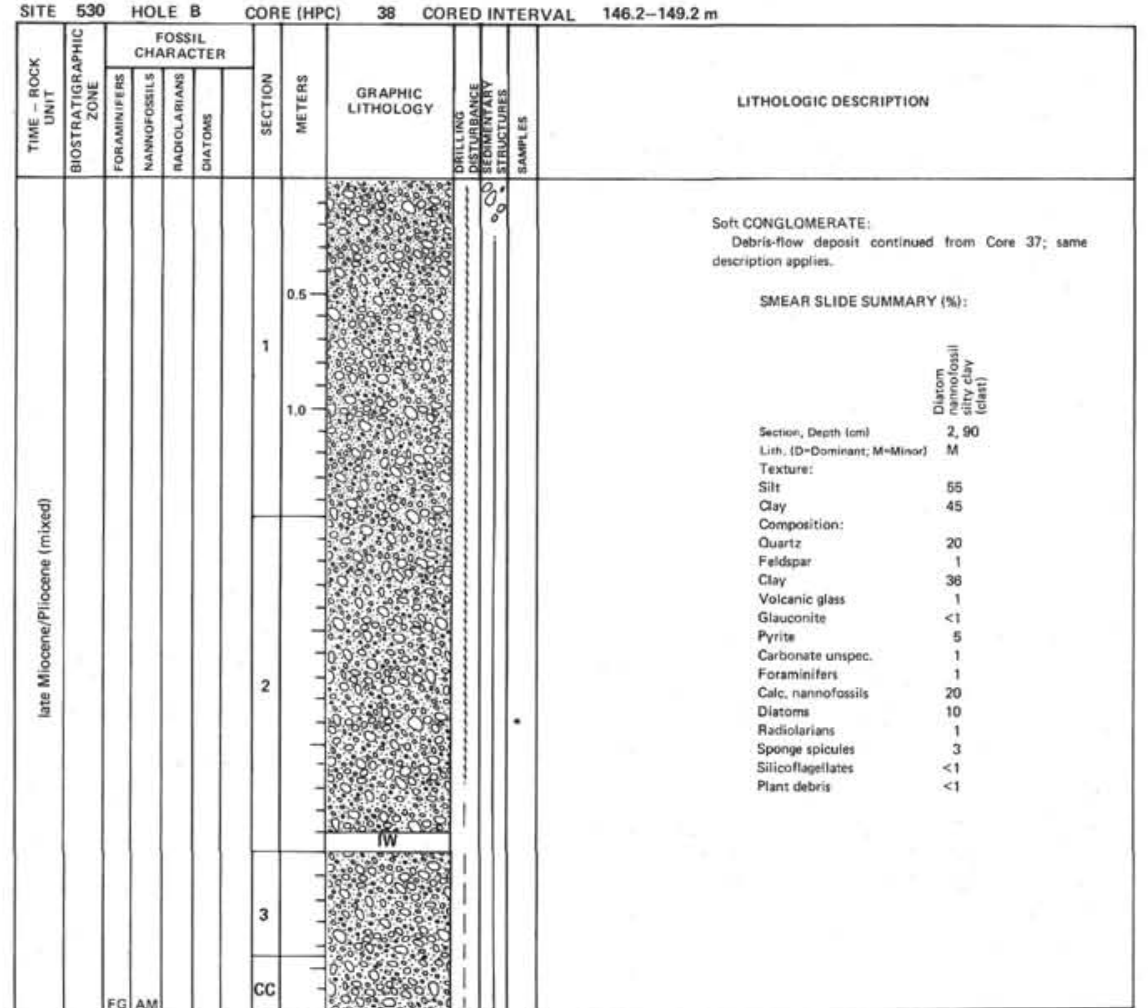

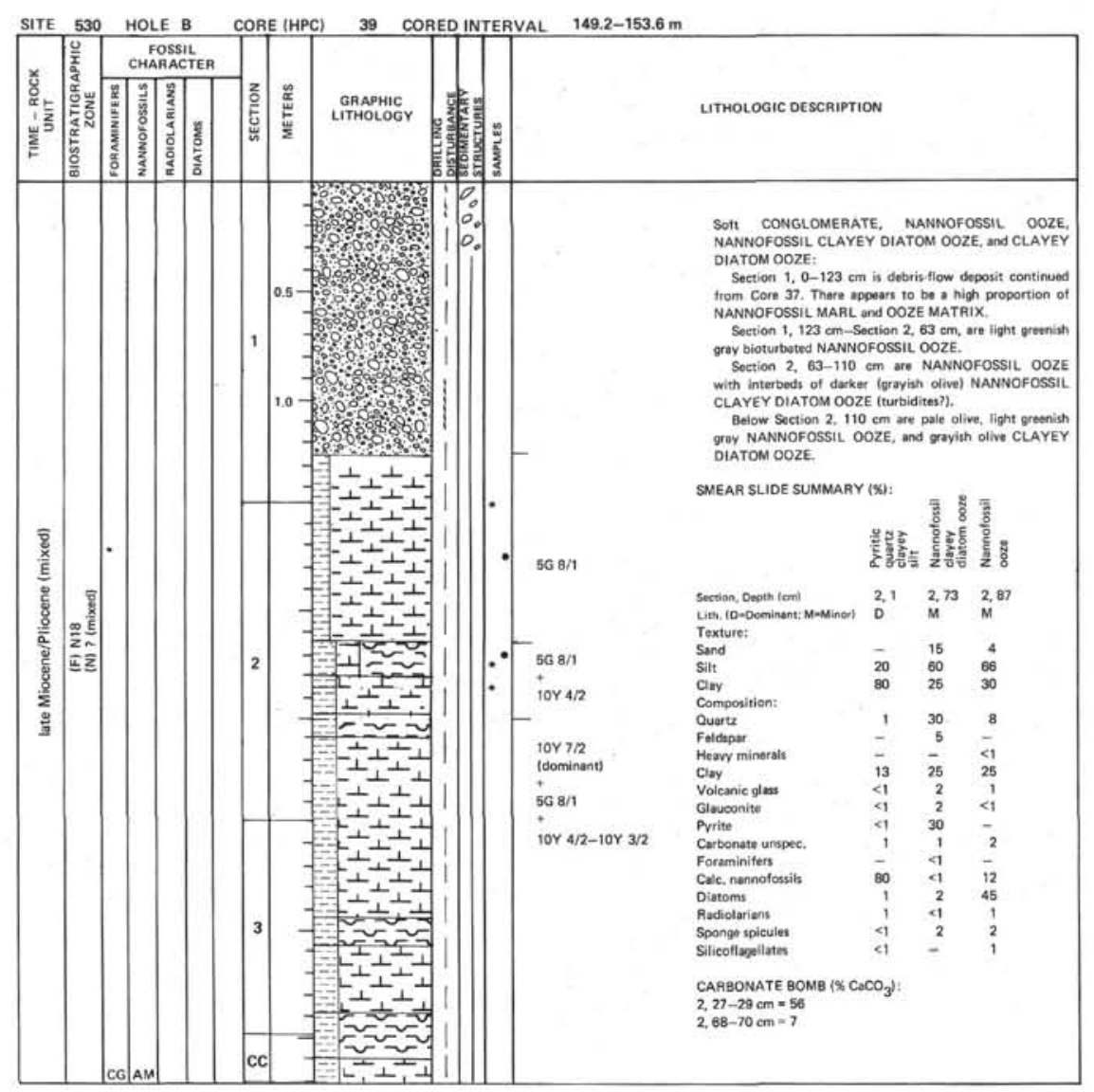



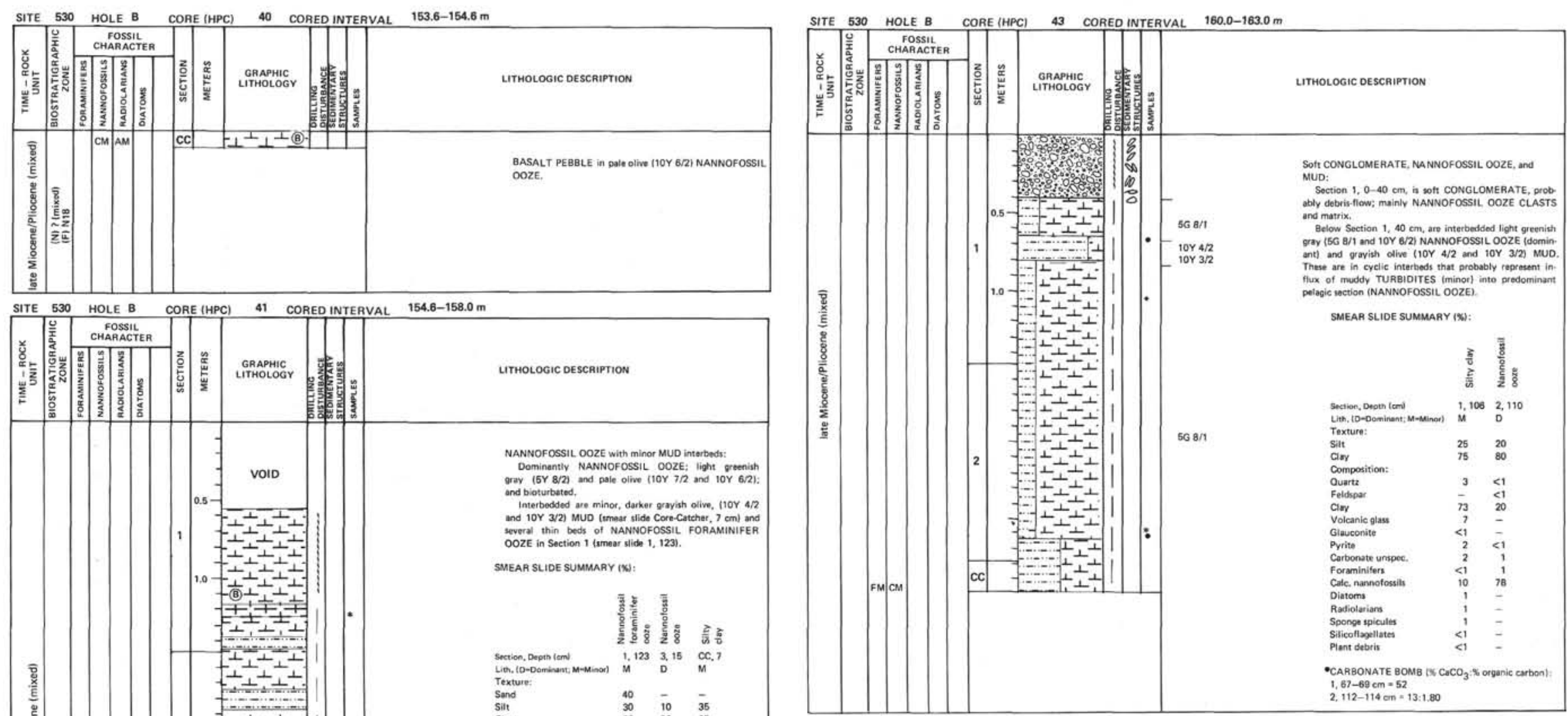

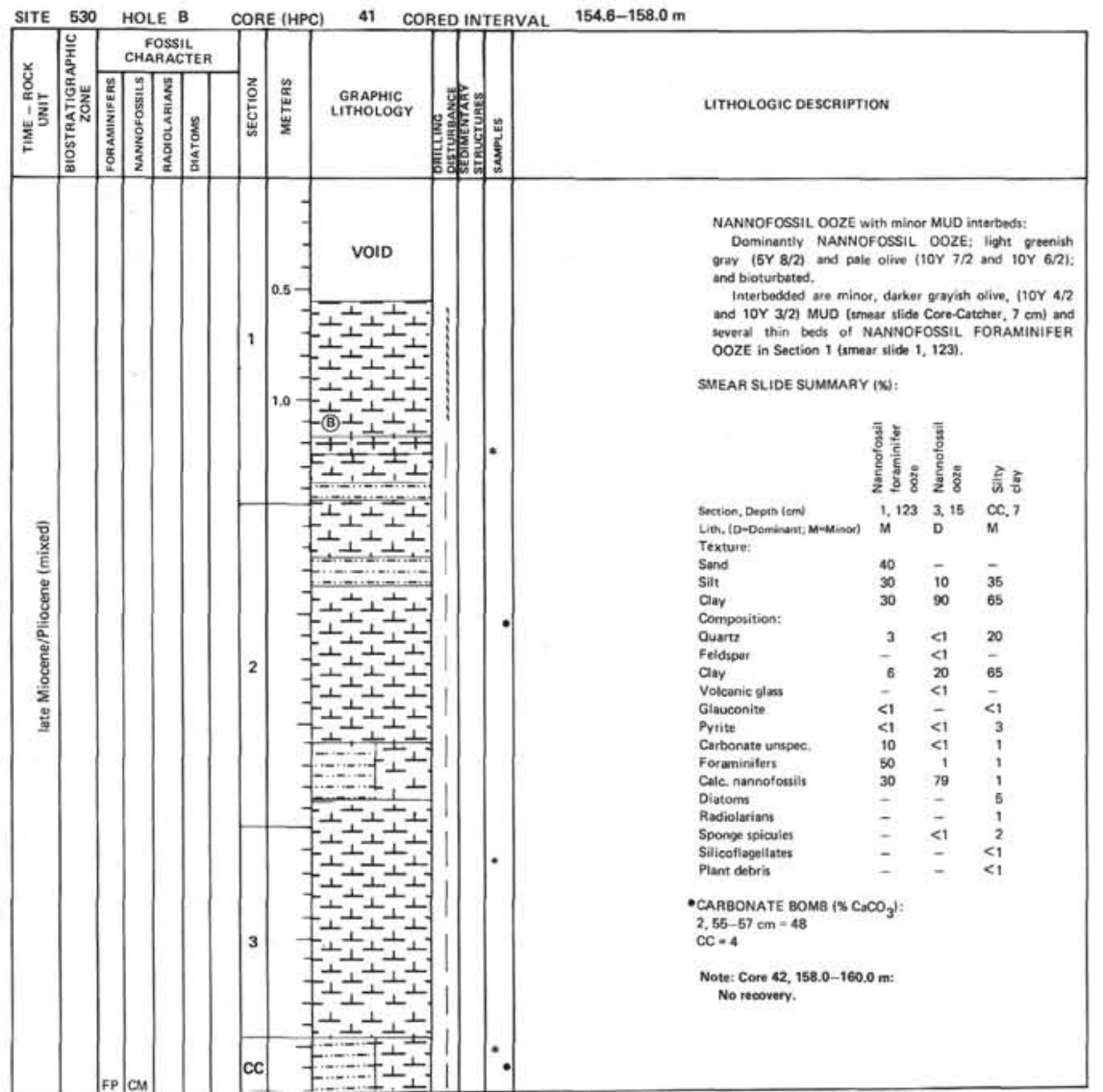




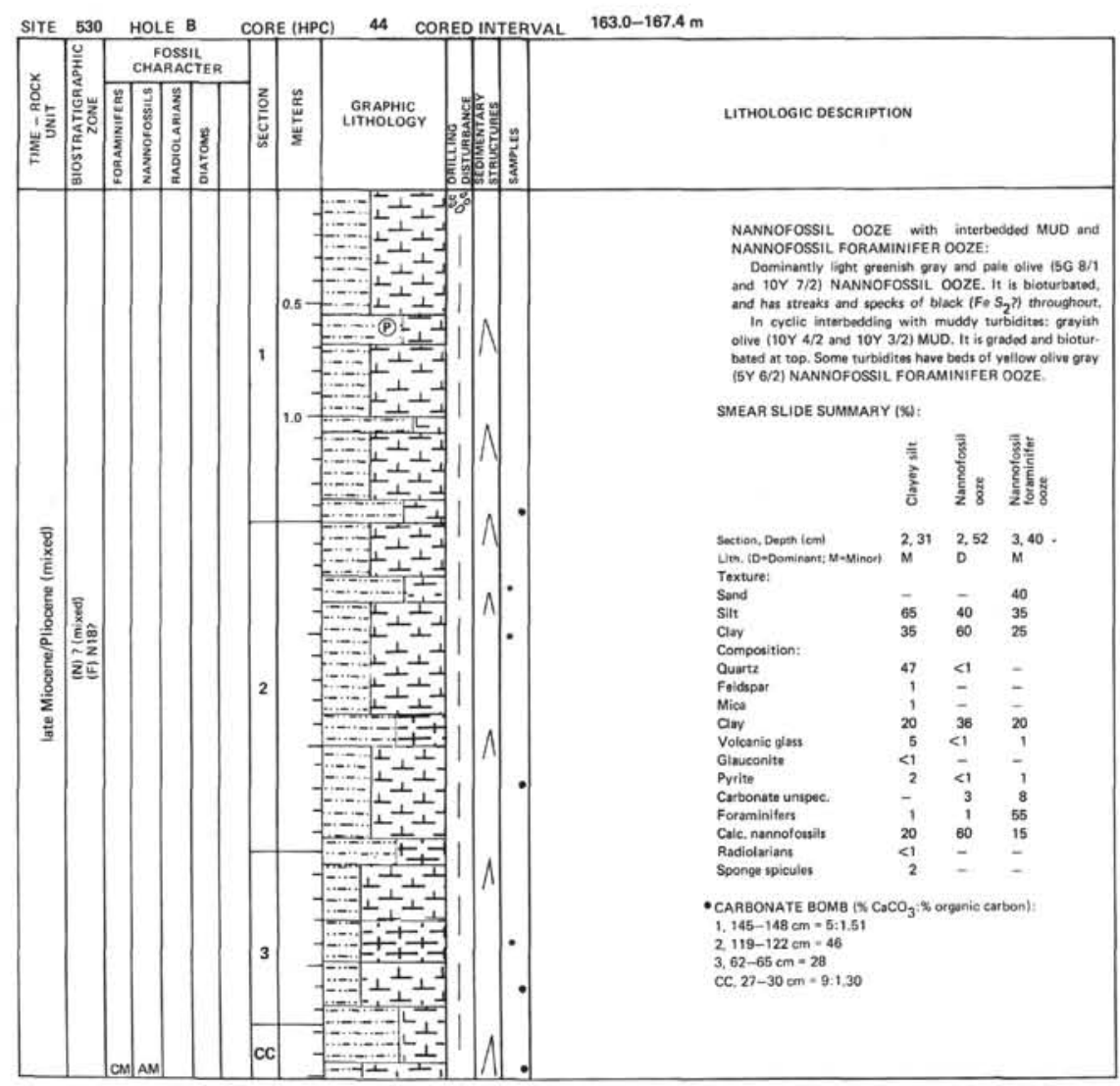

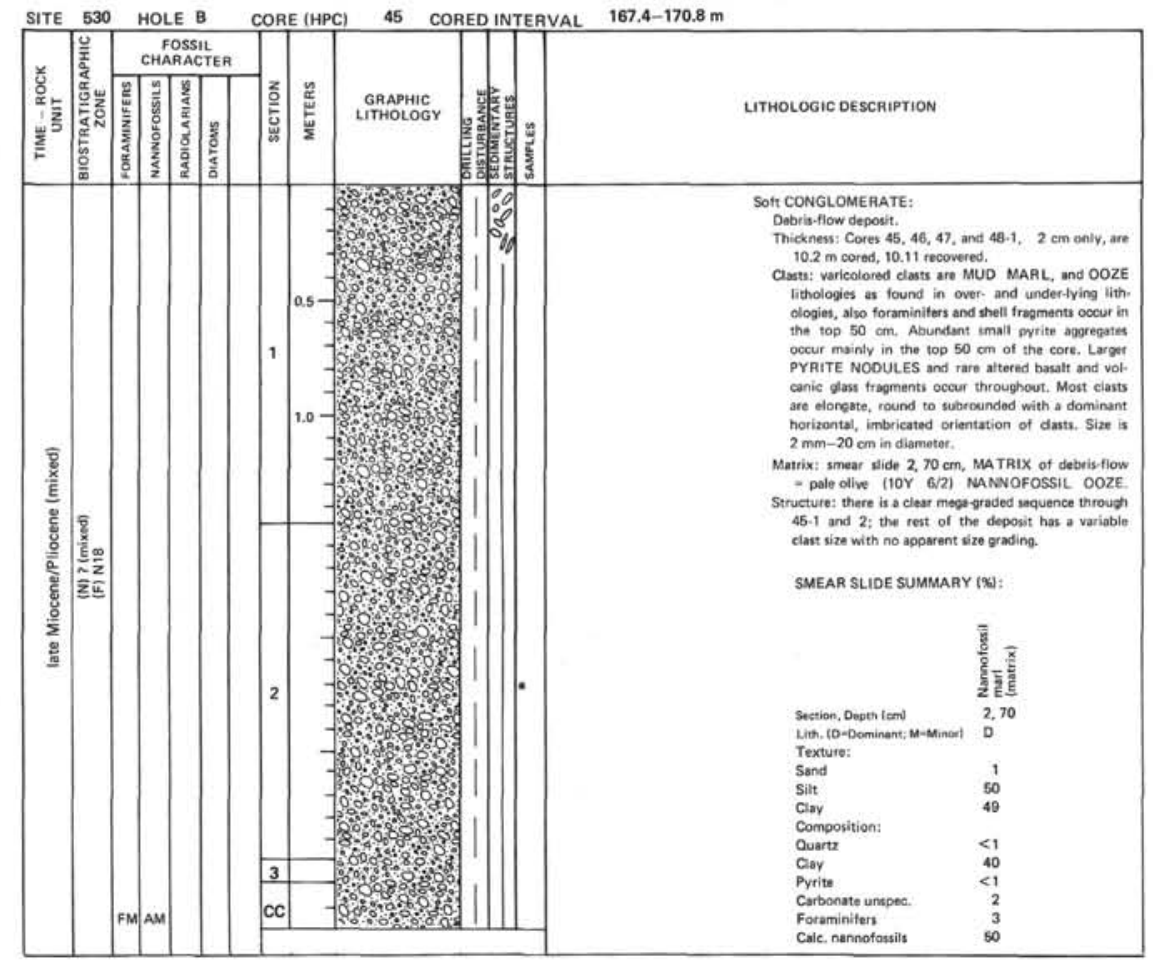



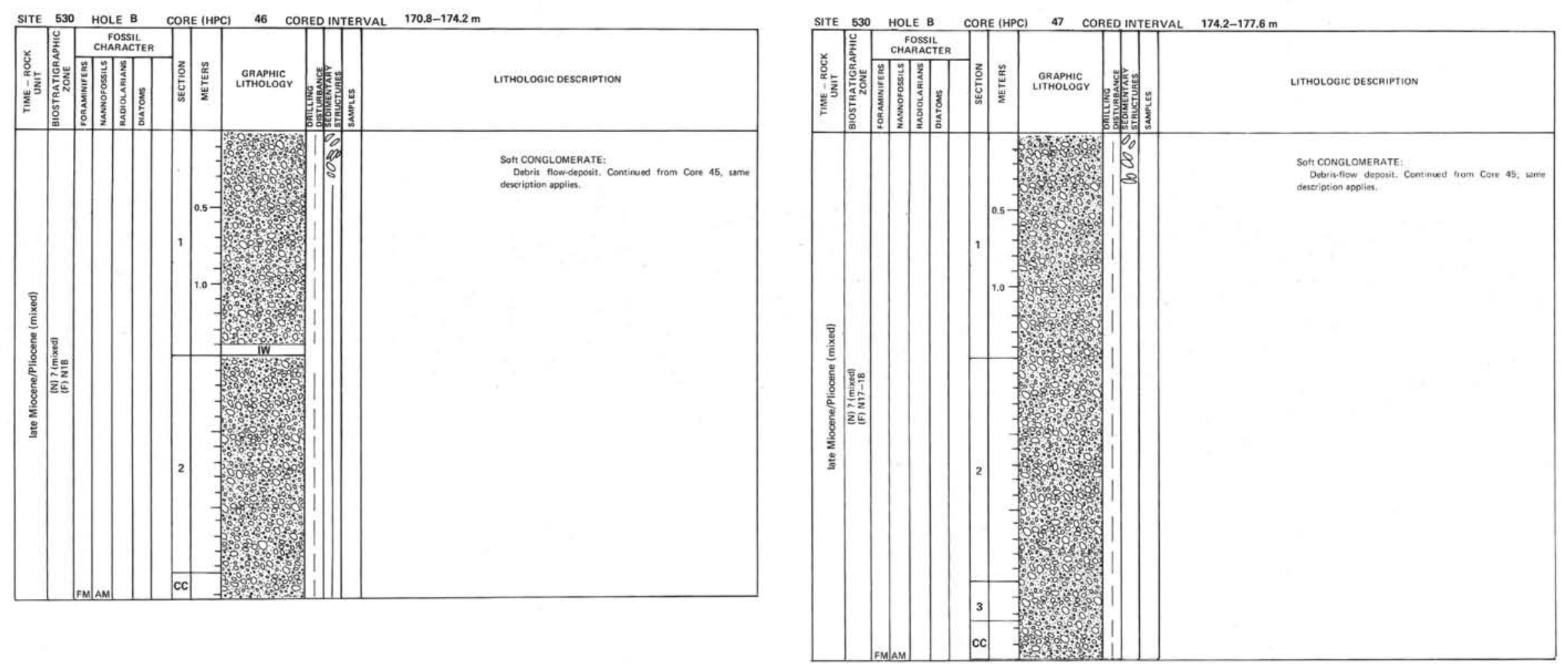

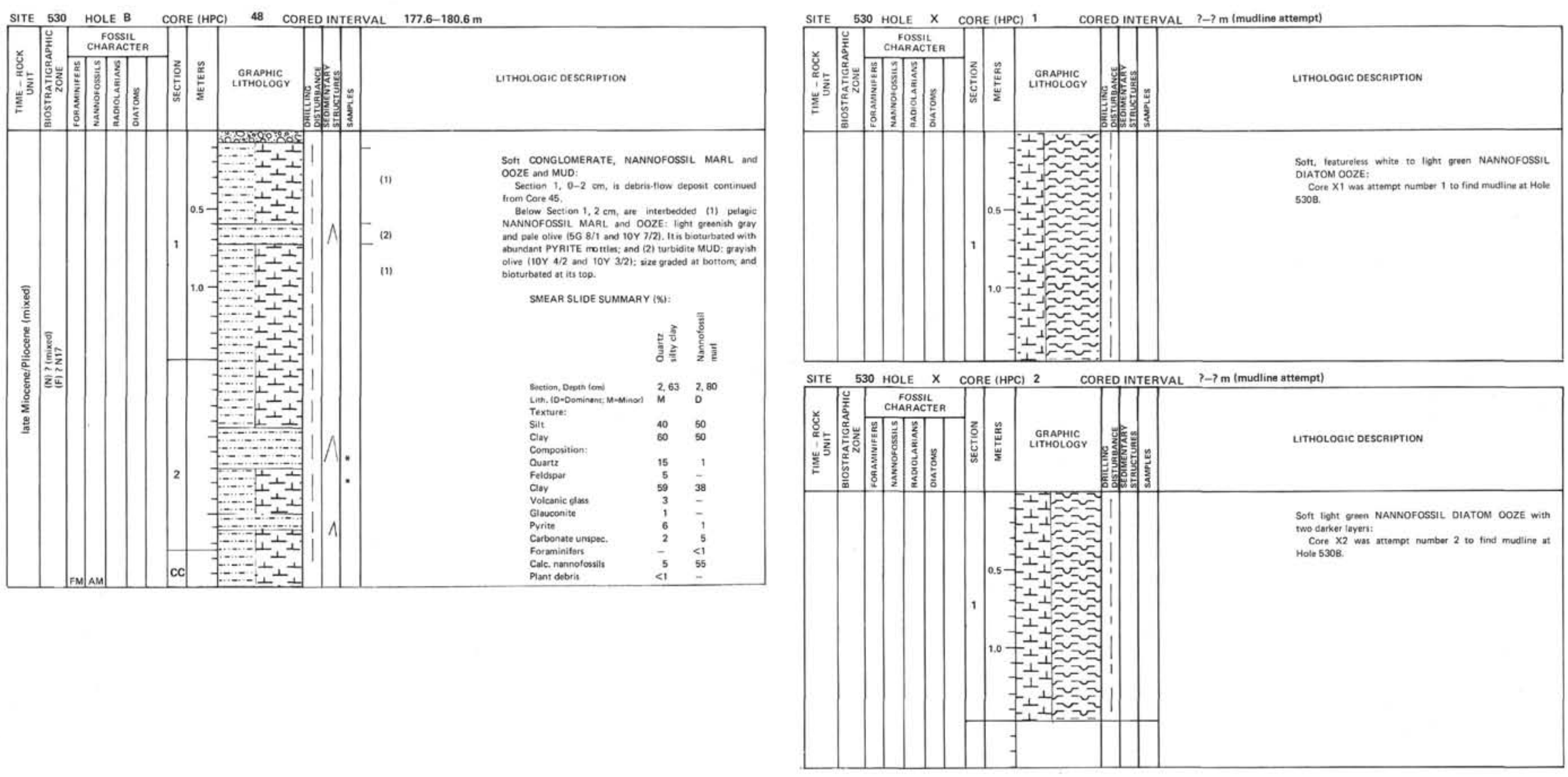

SITE 530 HOLE $\times$ CORE (HPC) 3 CORED INTERVAL ? $\rightarrow$ m (mudline attempt)

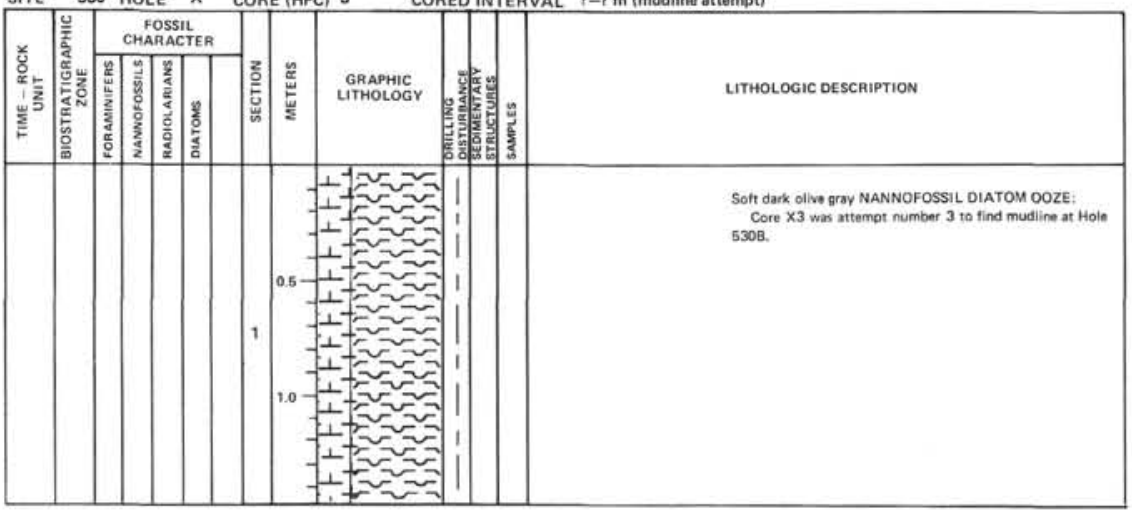


SITE 530

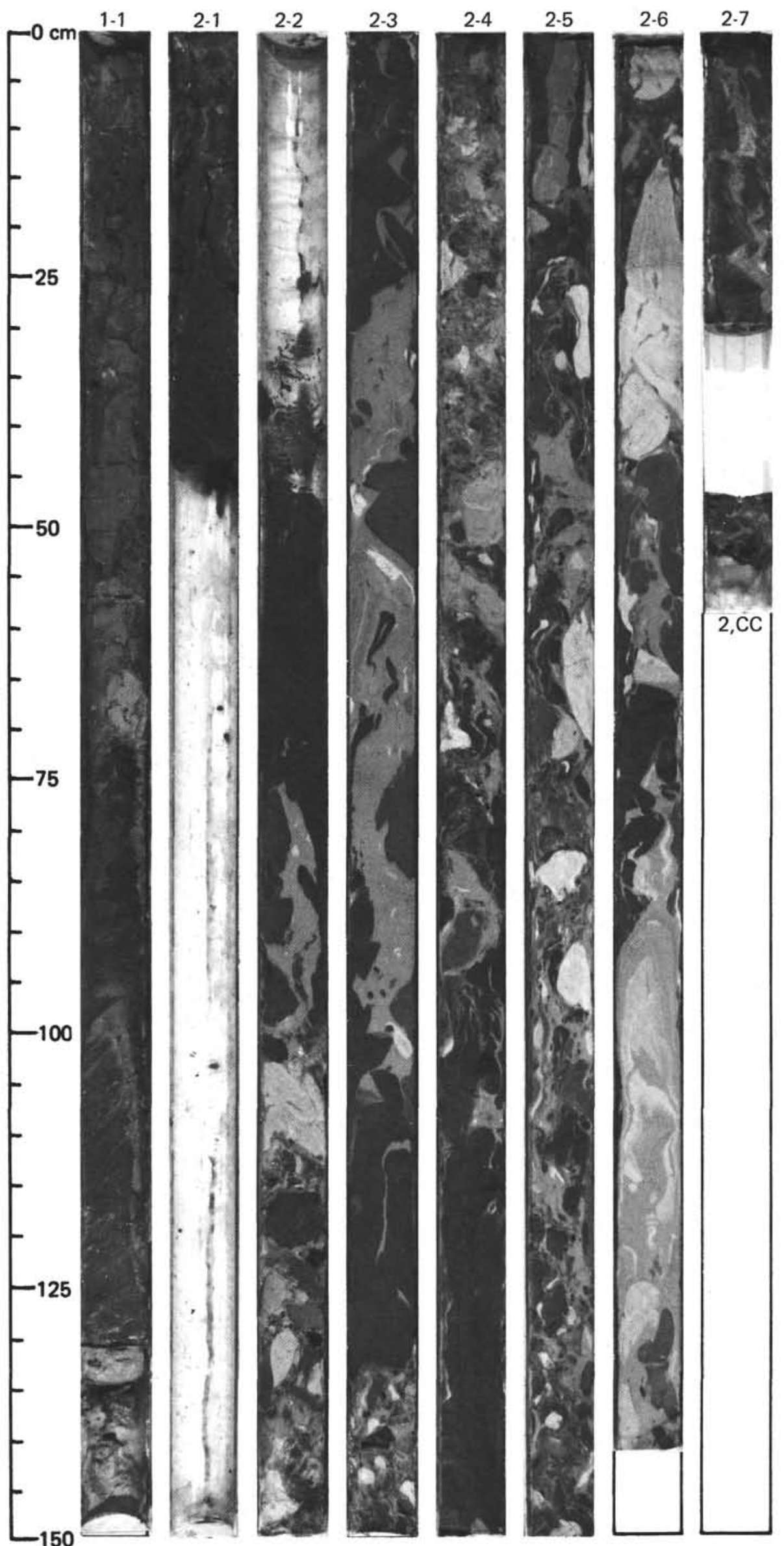


SITE 530

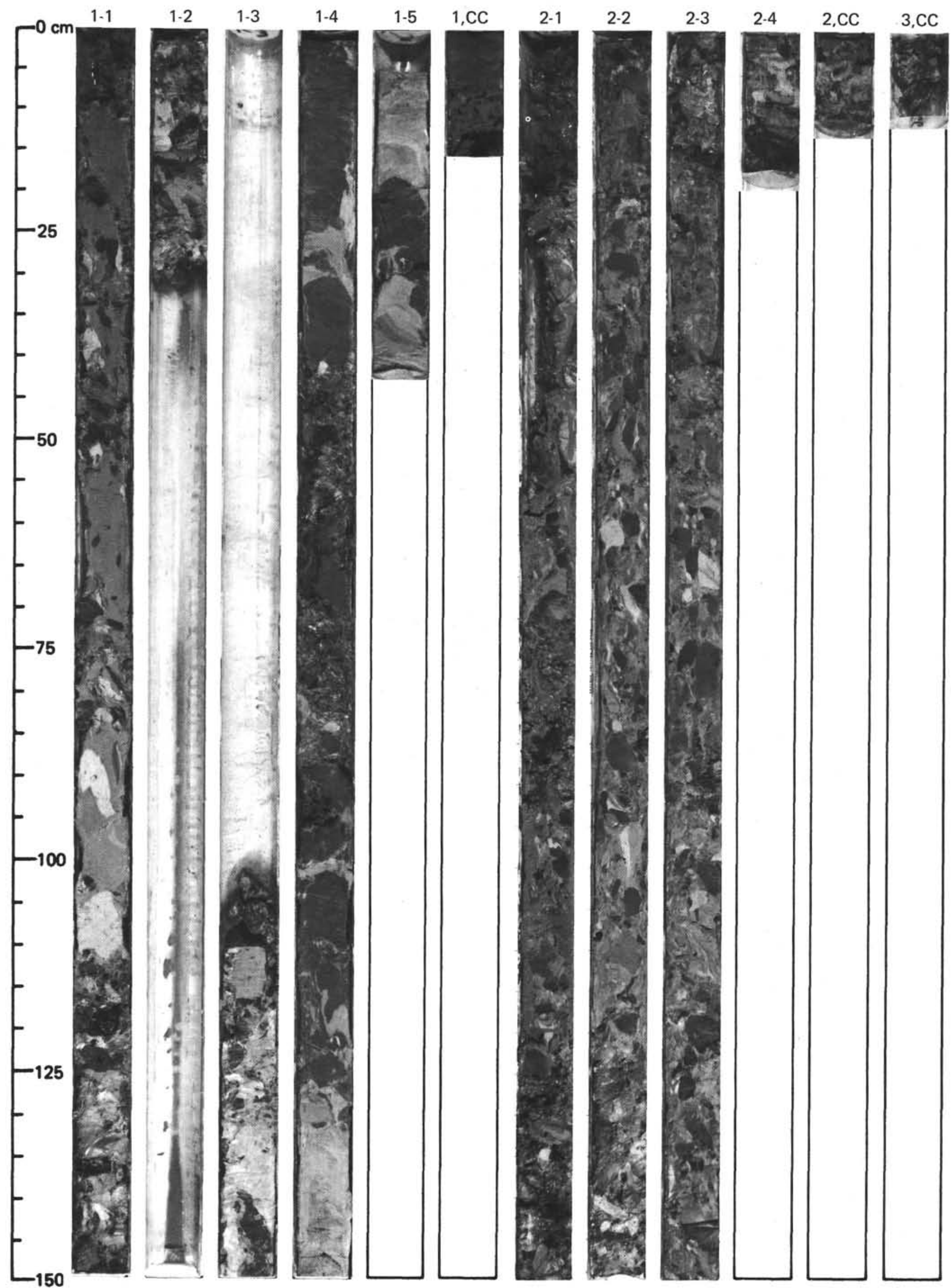




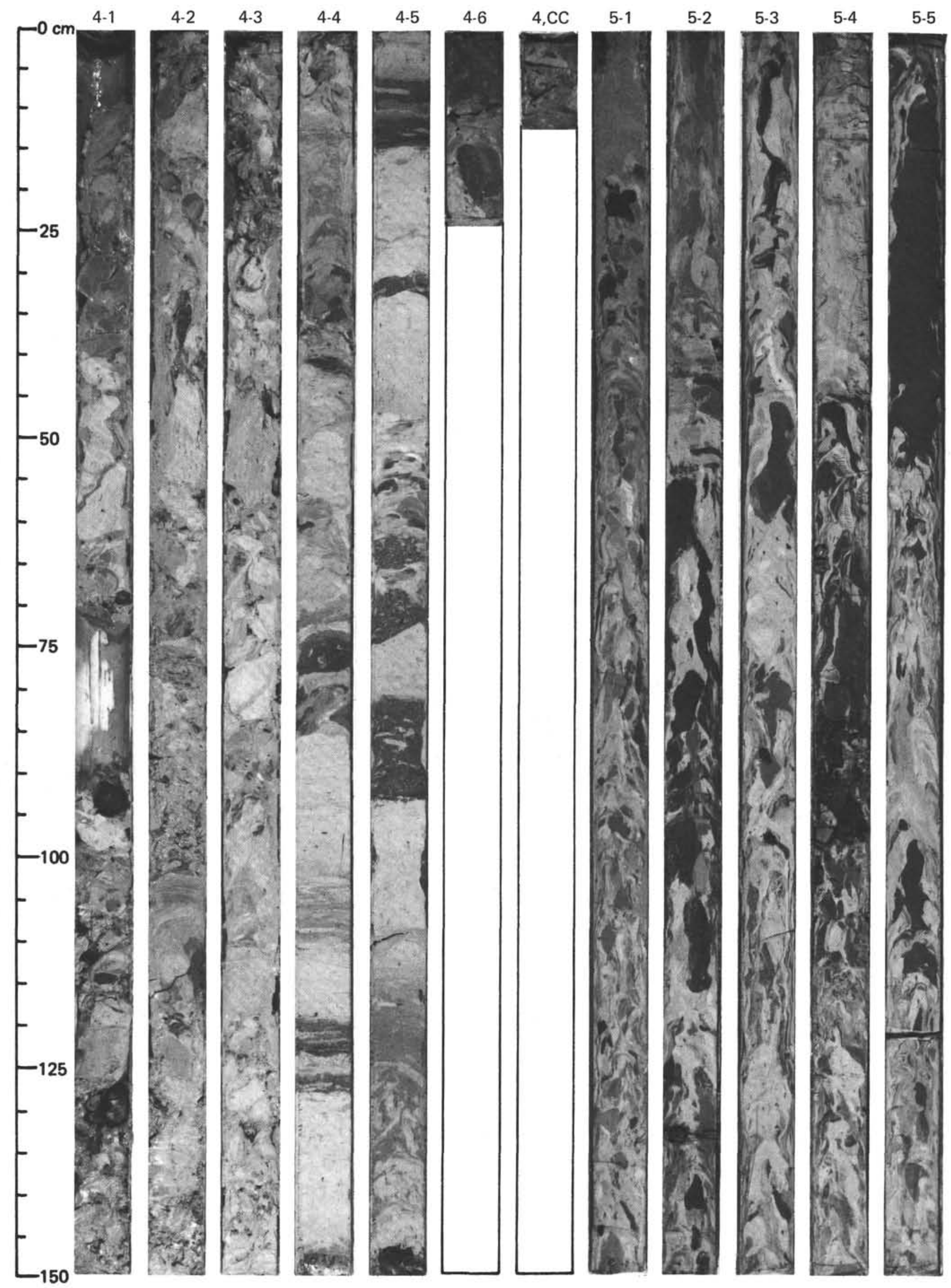




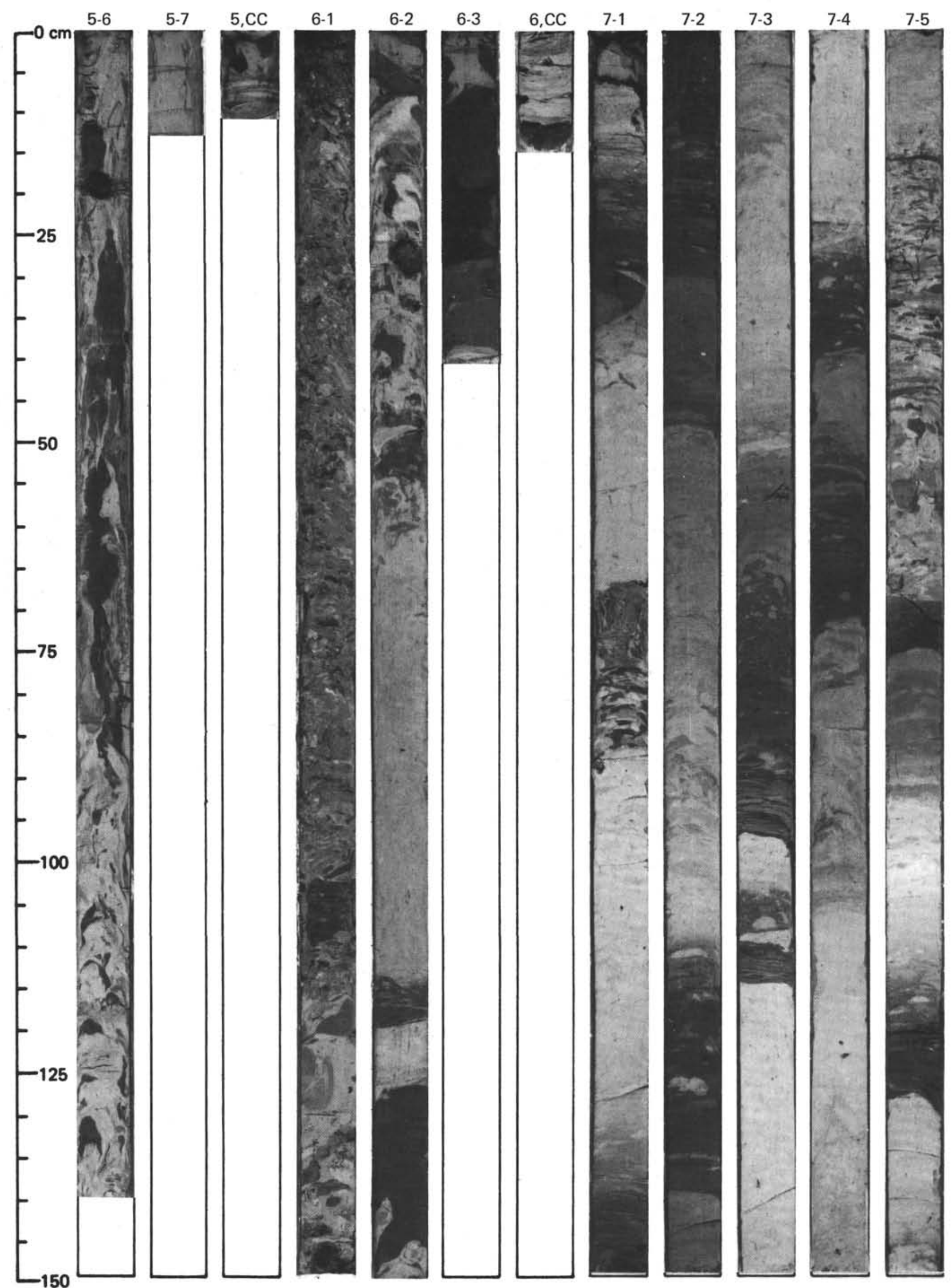




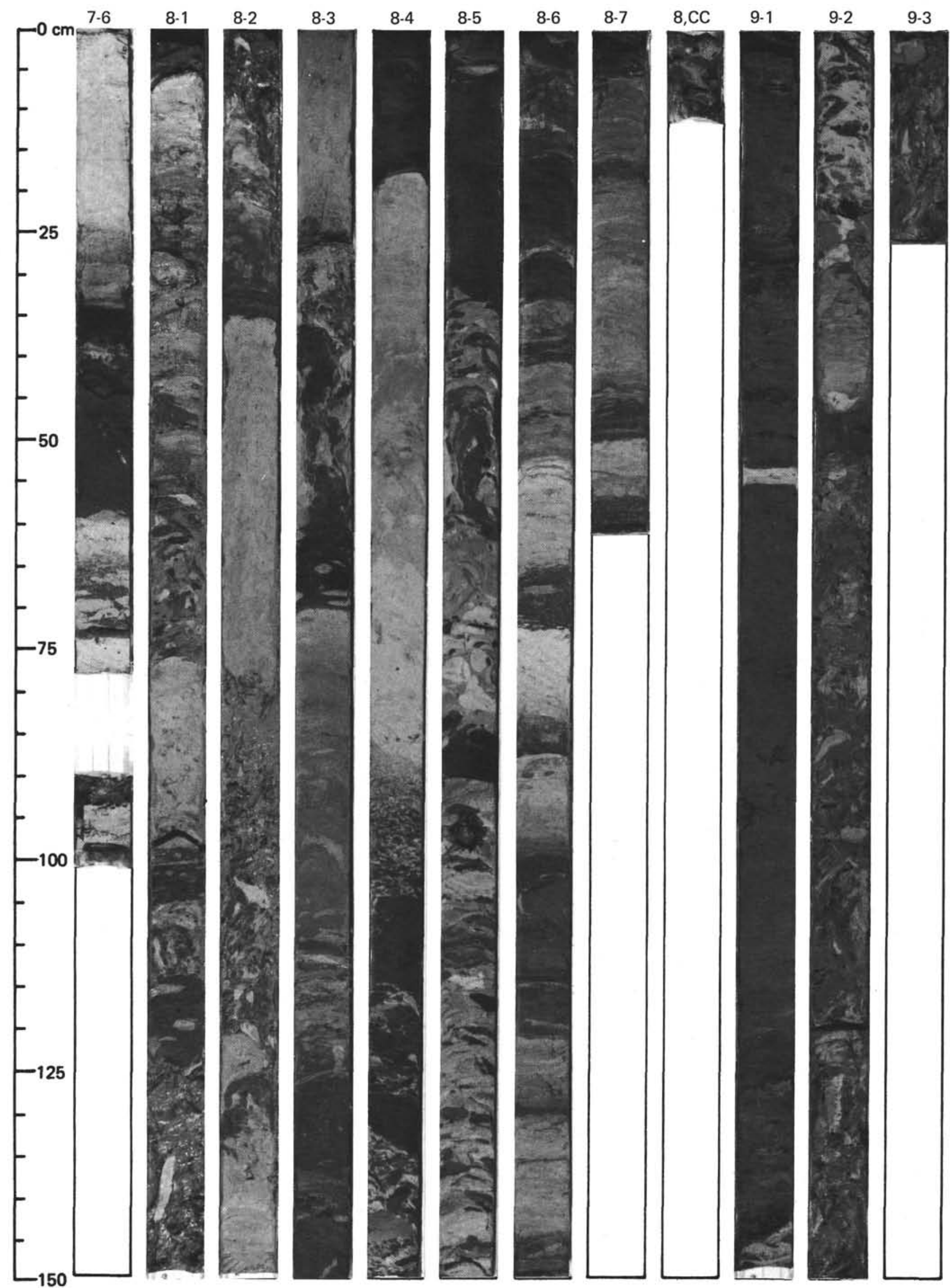




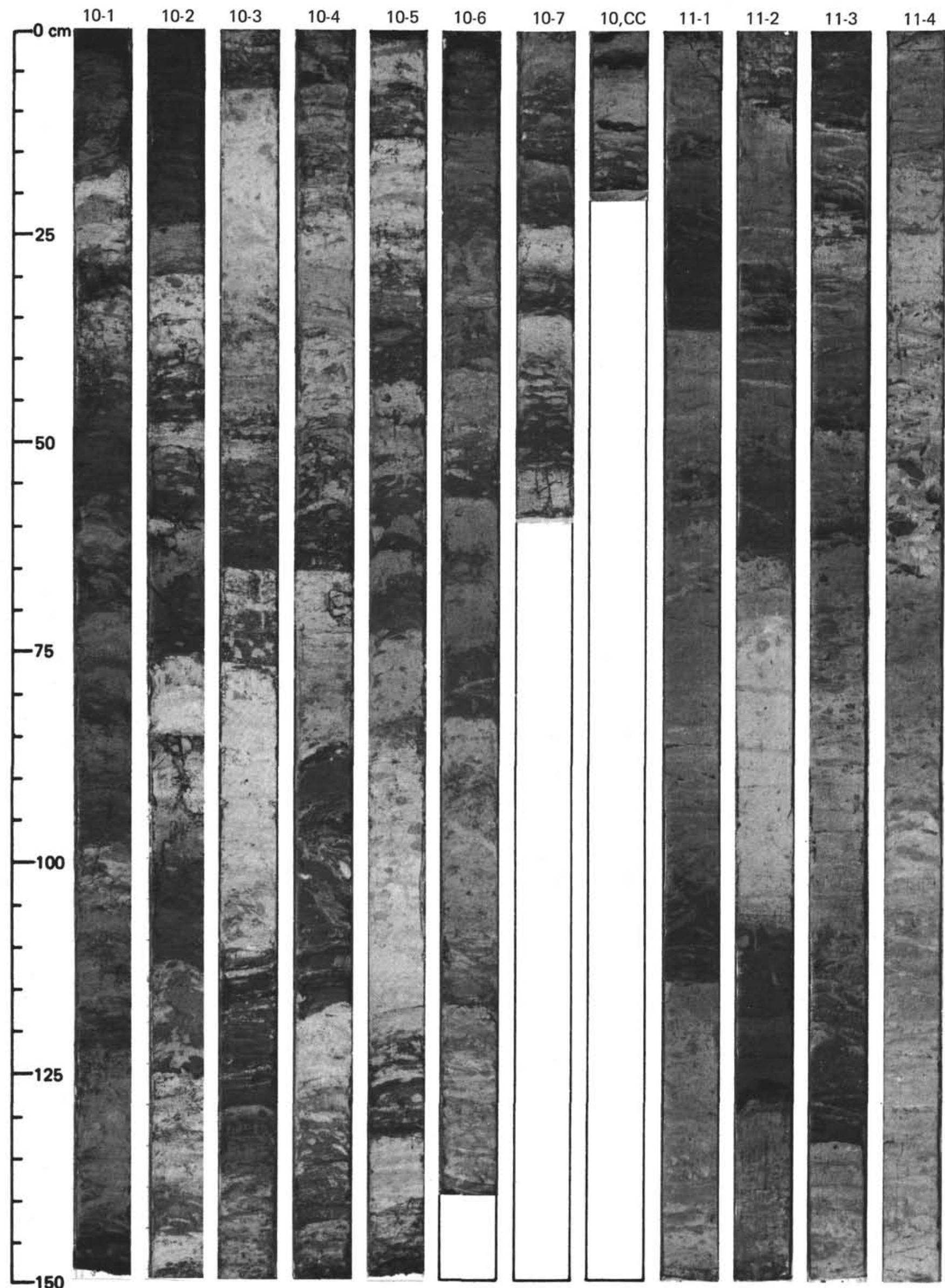




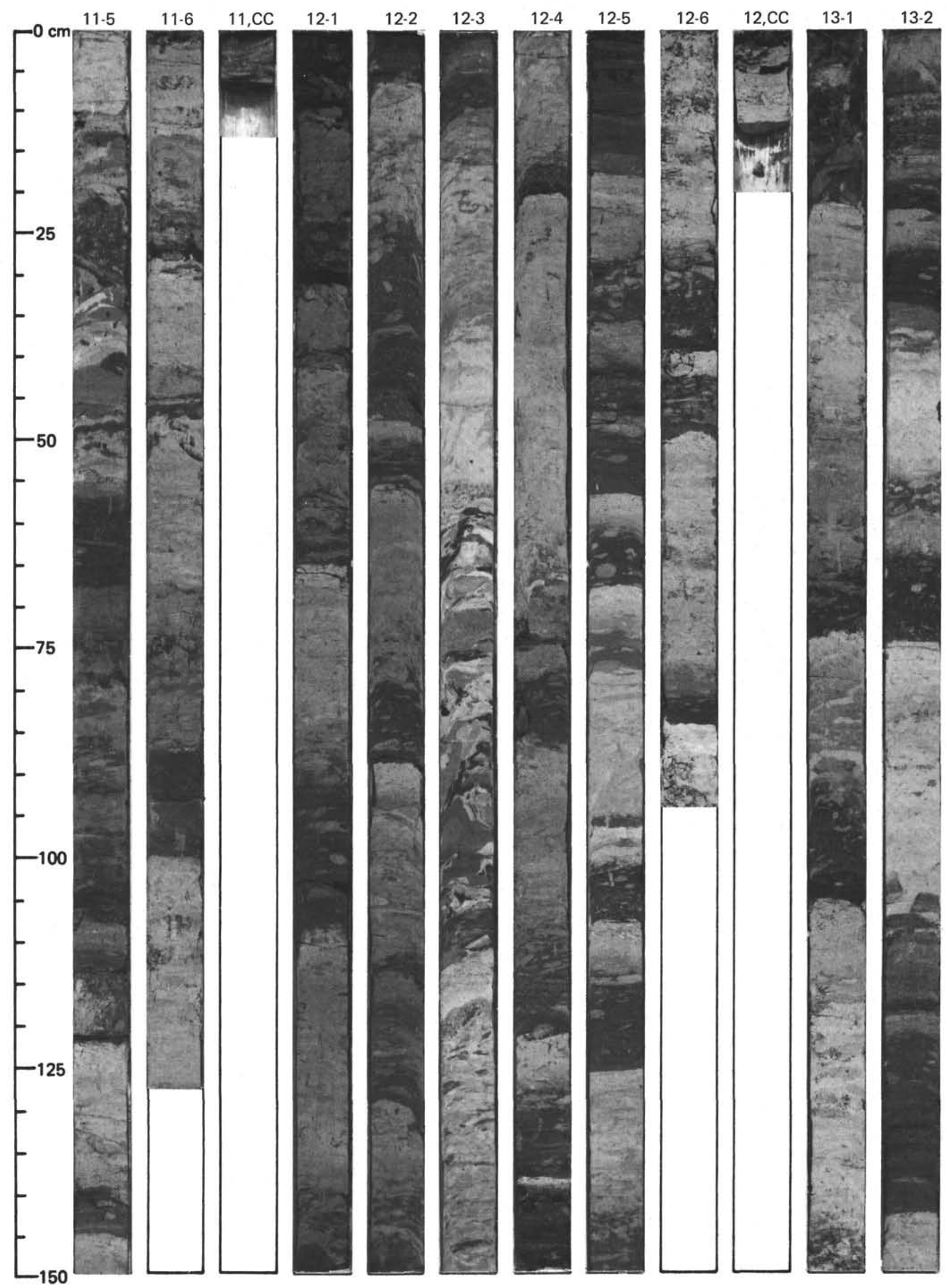




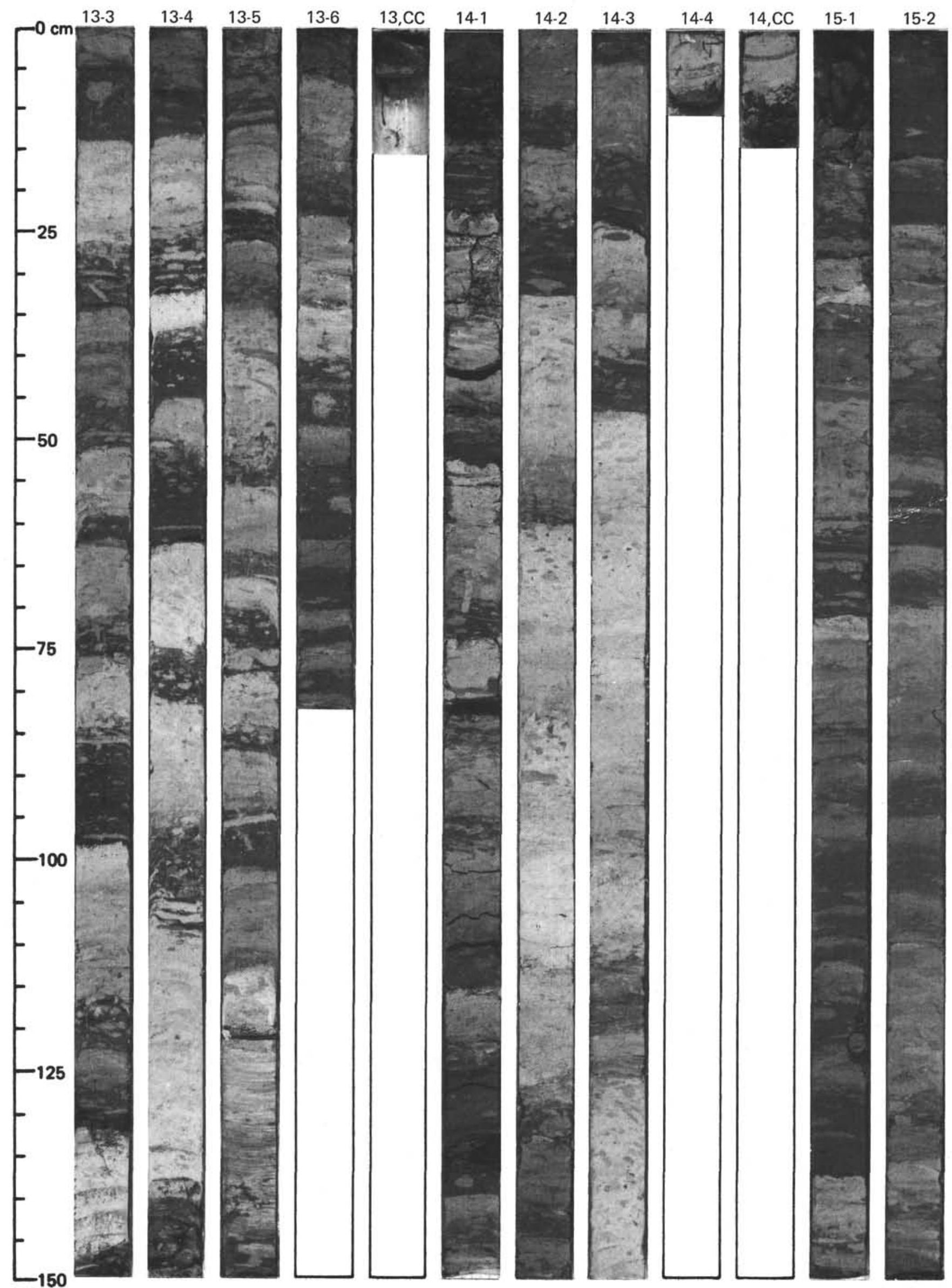




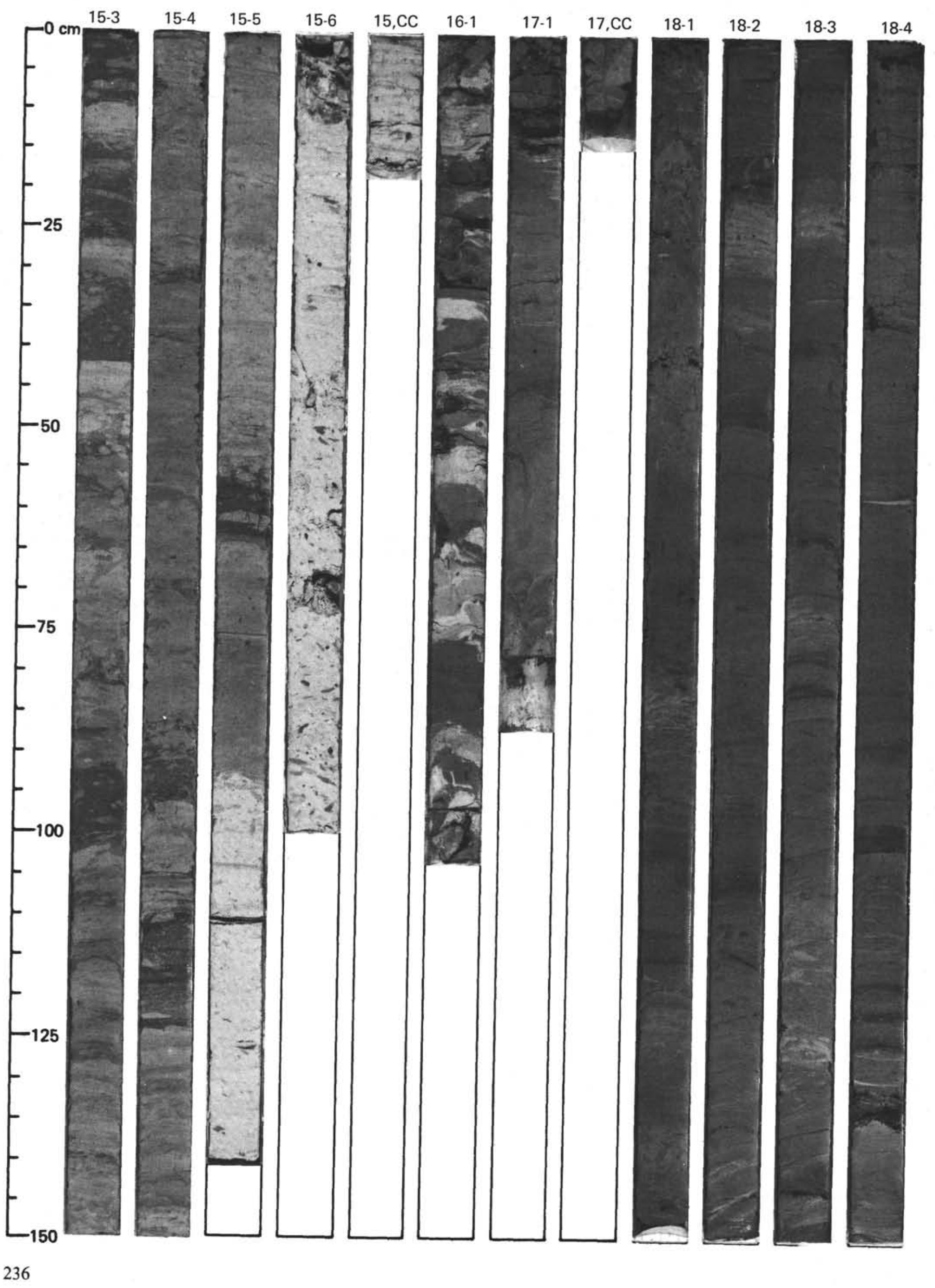


SITE 530

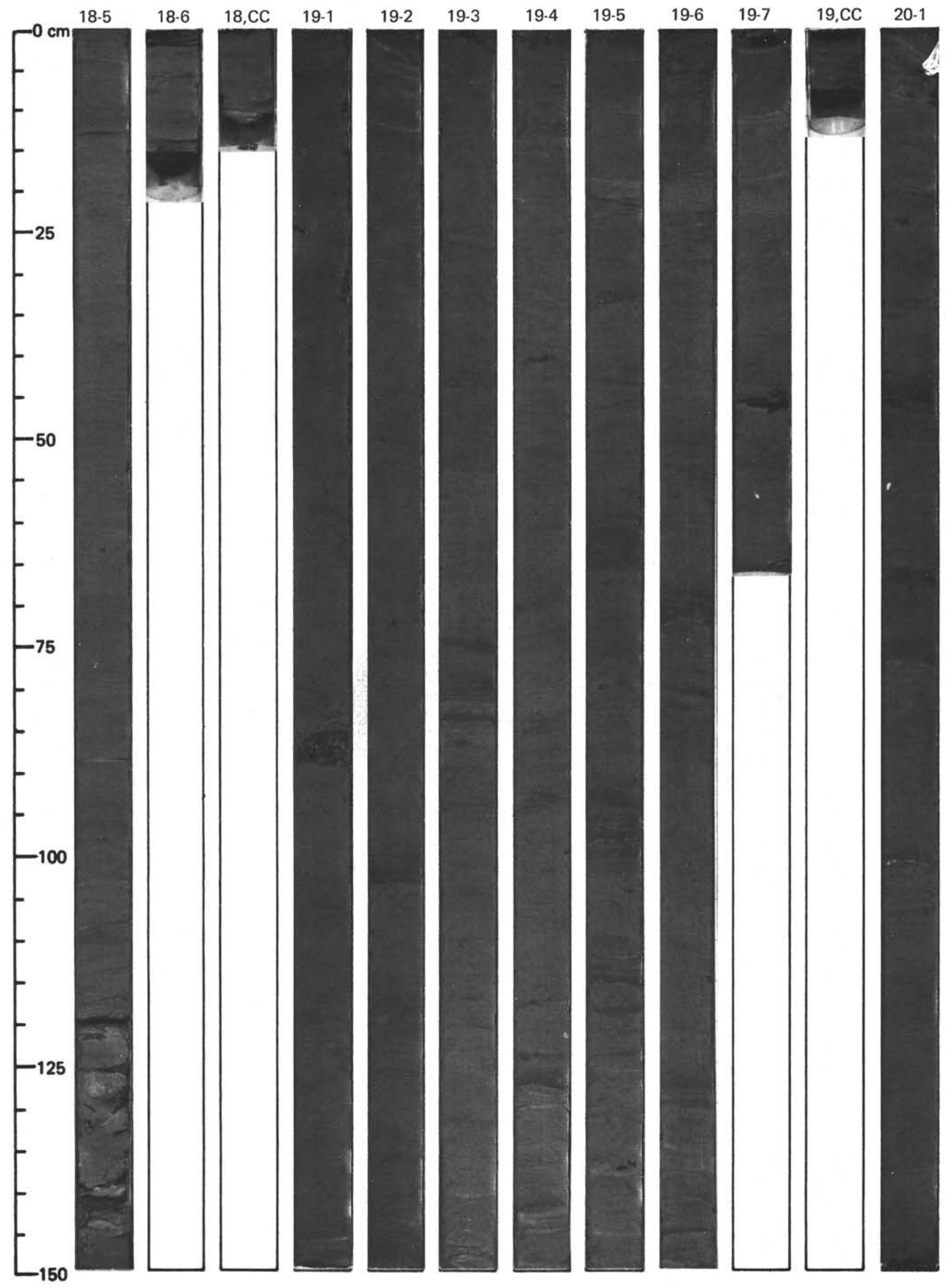




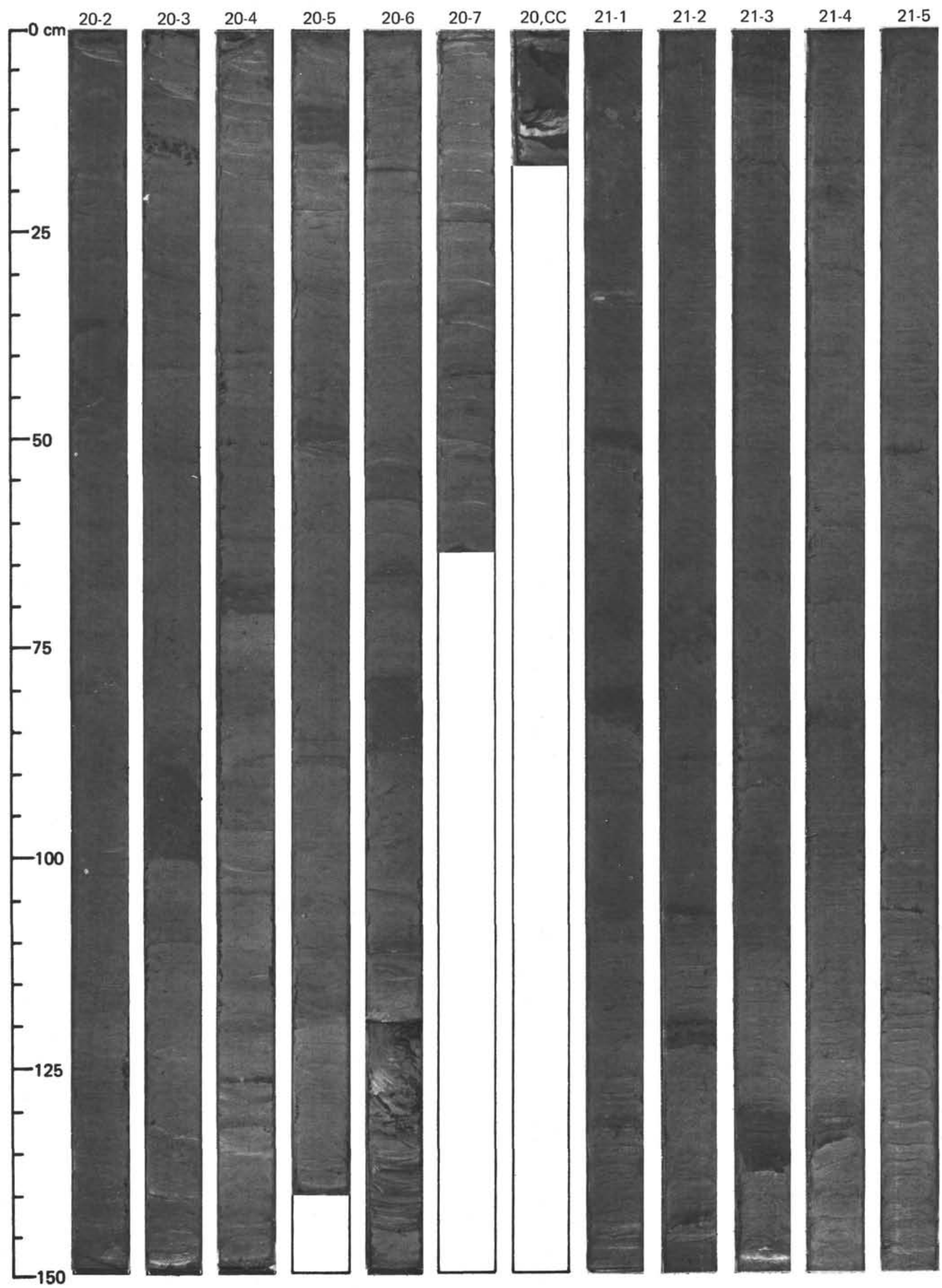




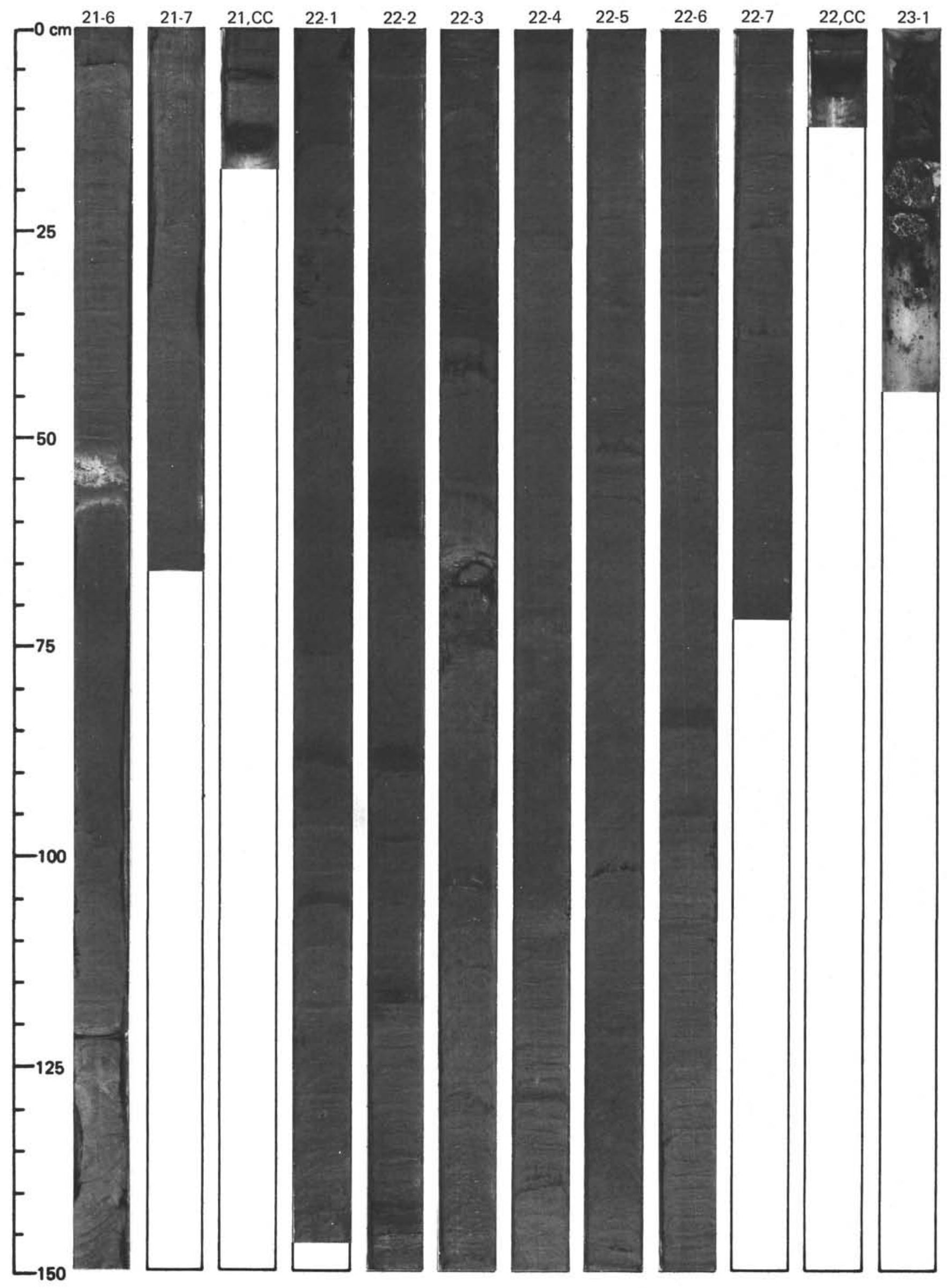




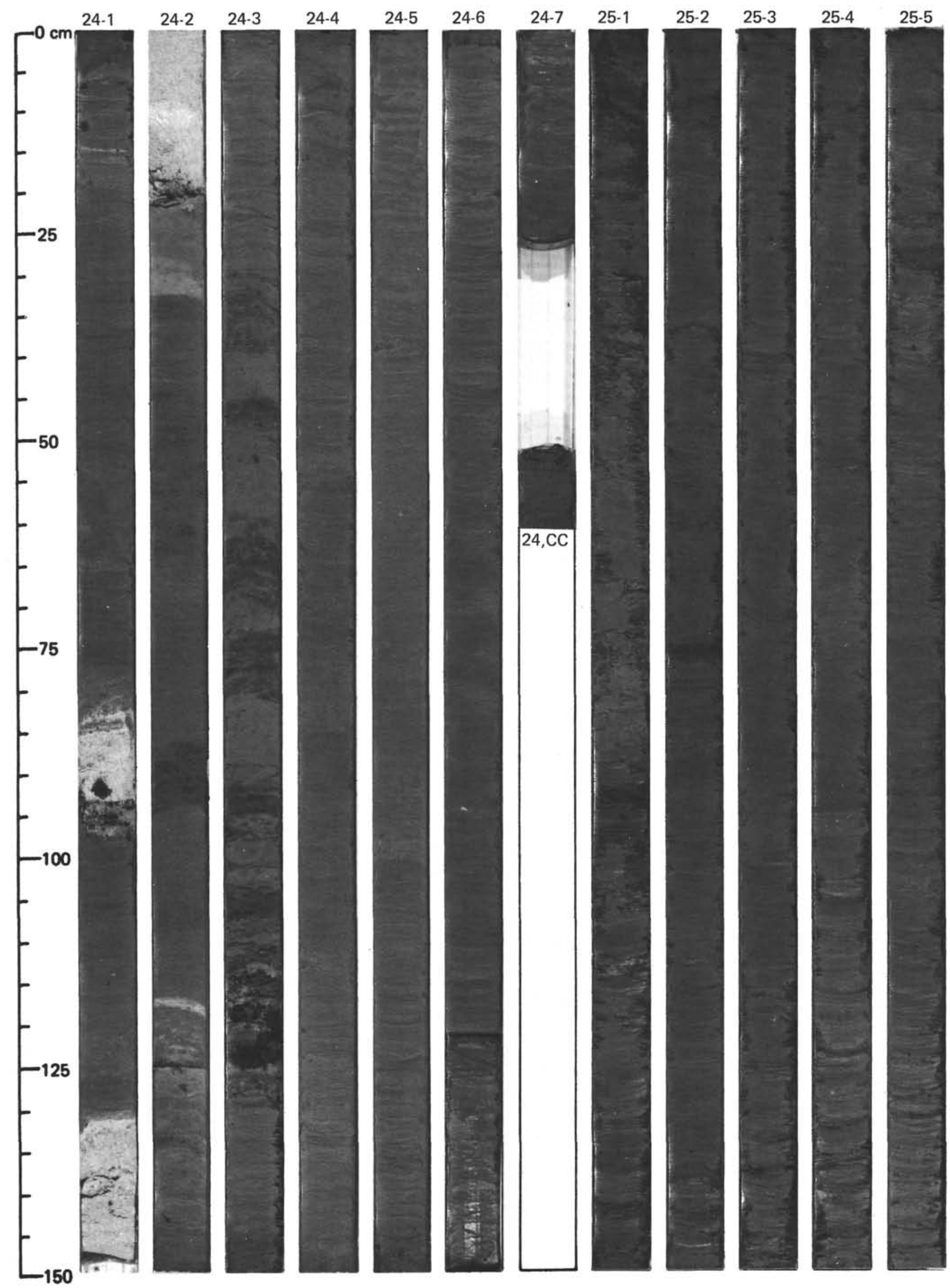




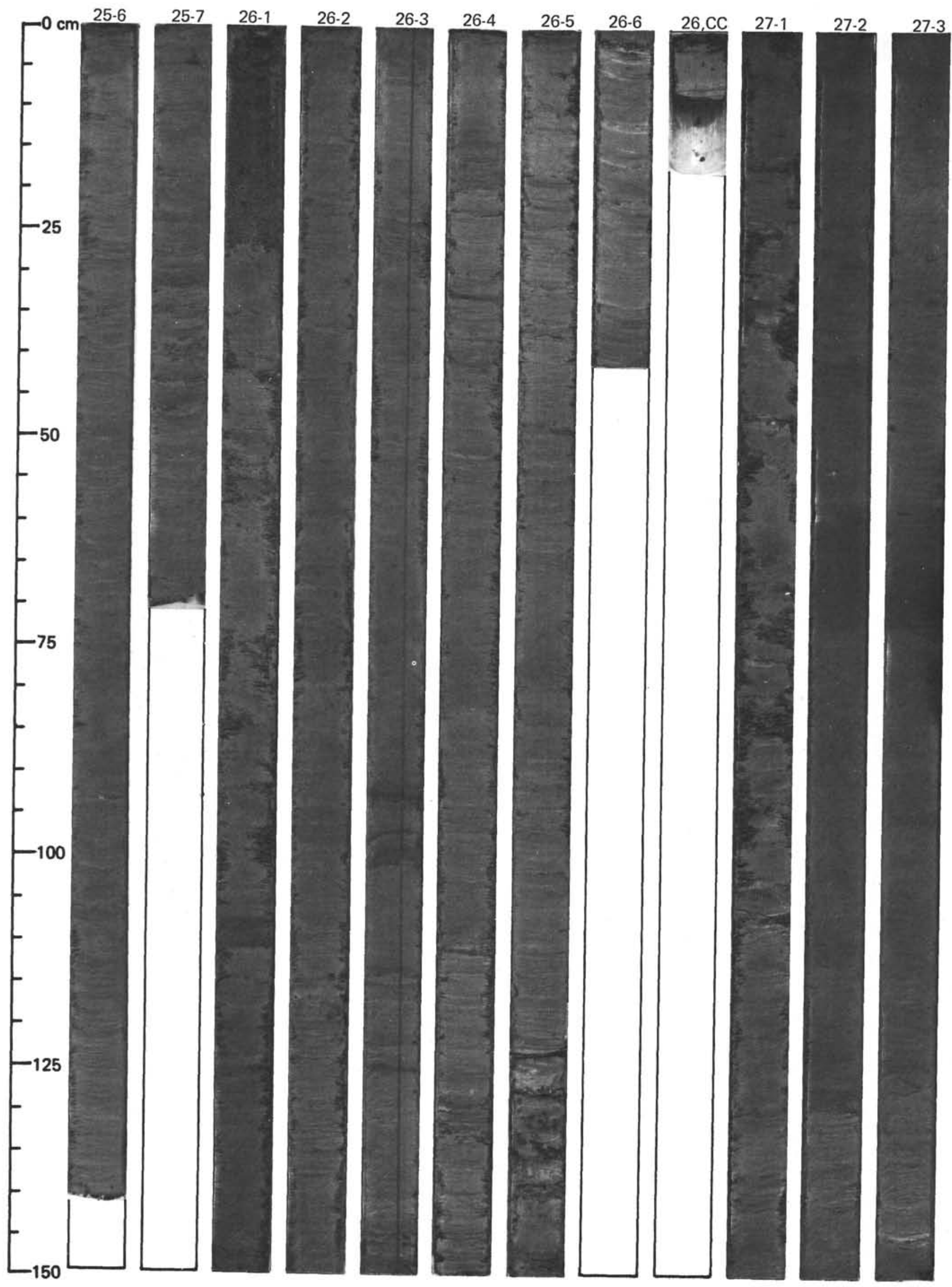




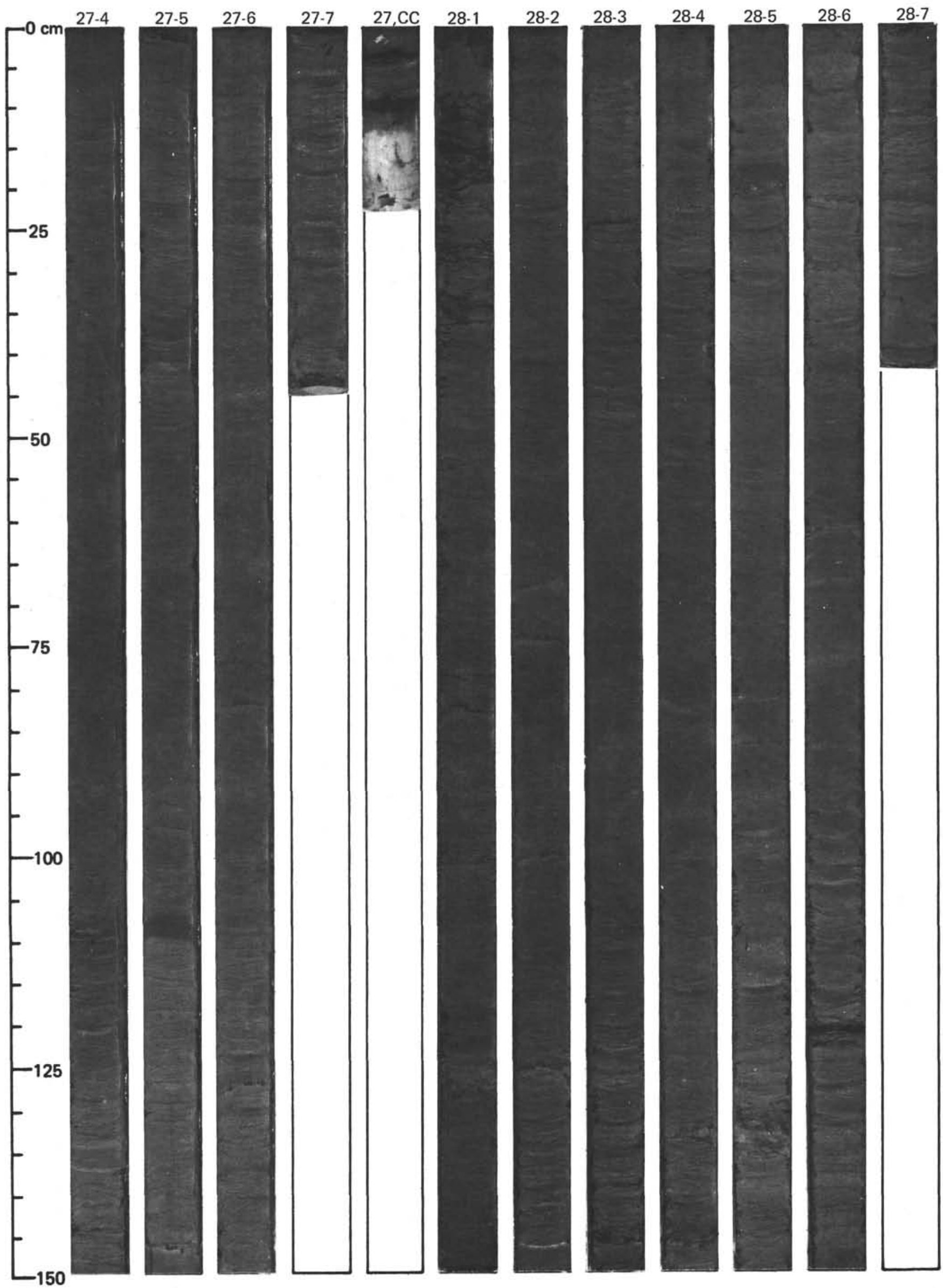


SITE 530

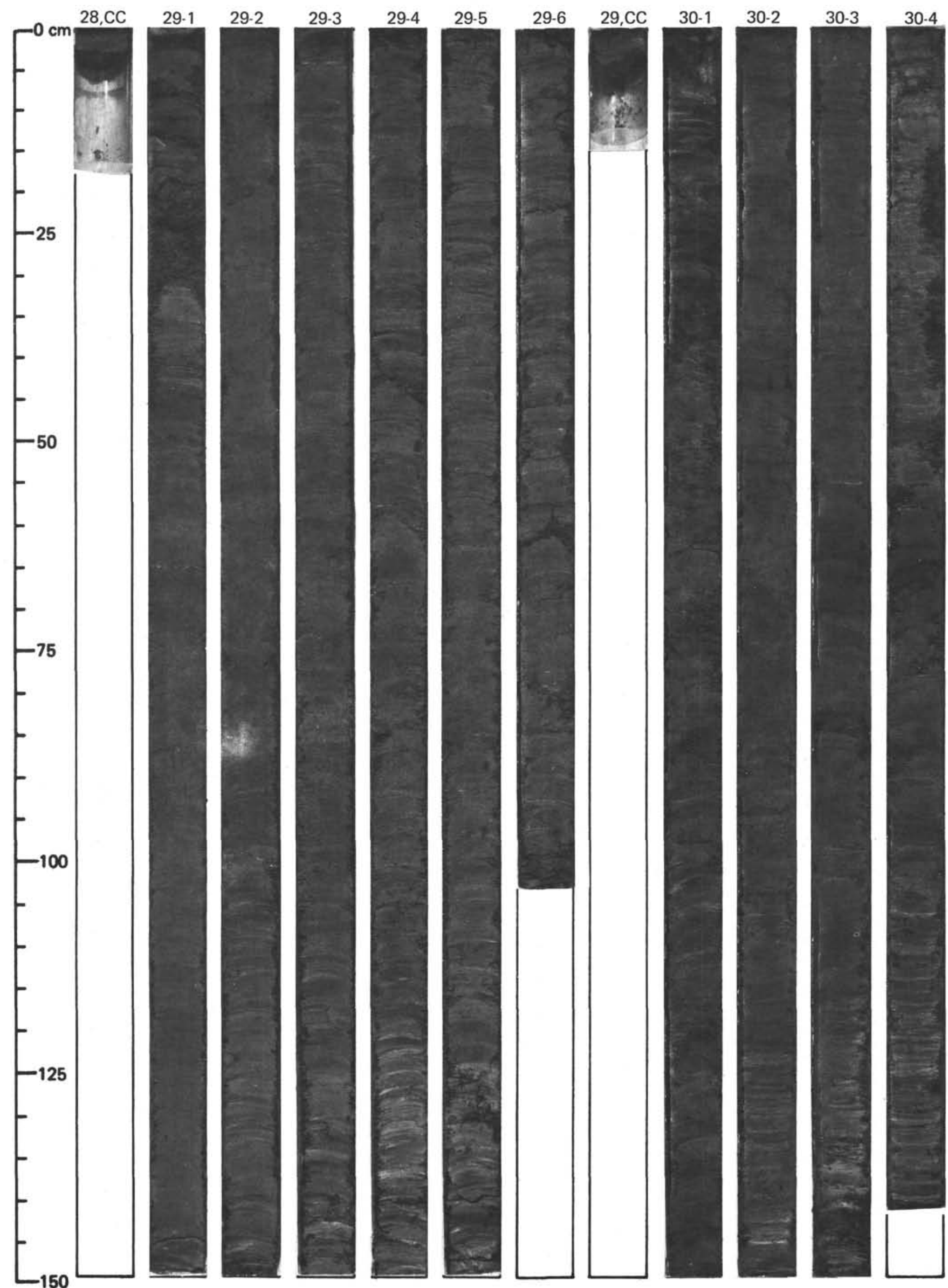




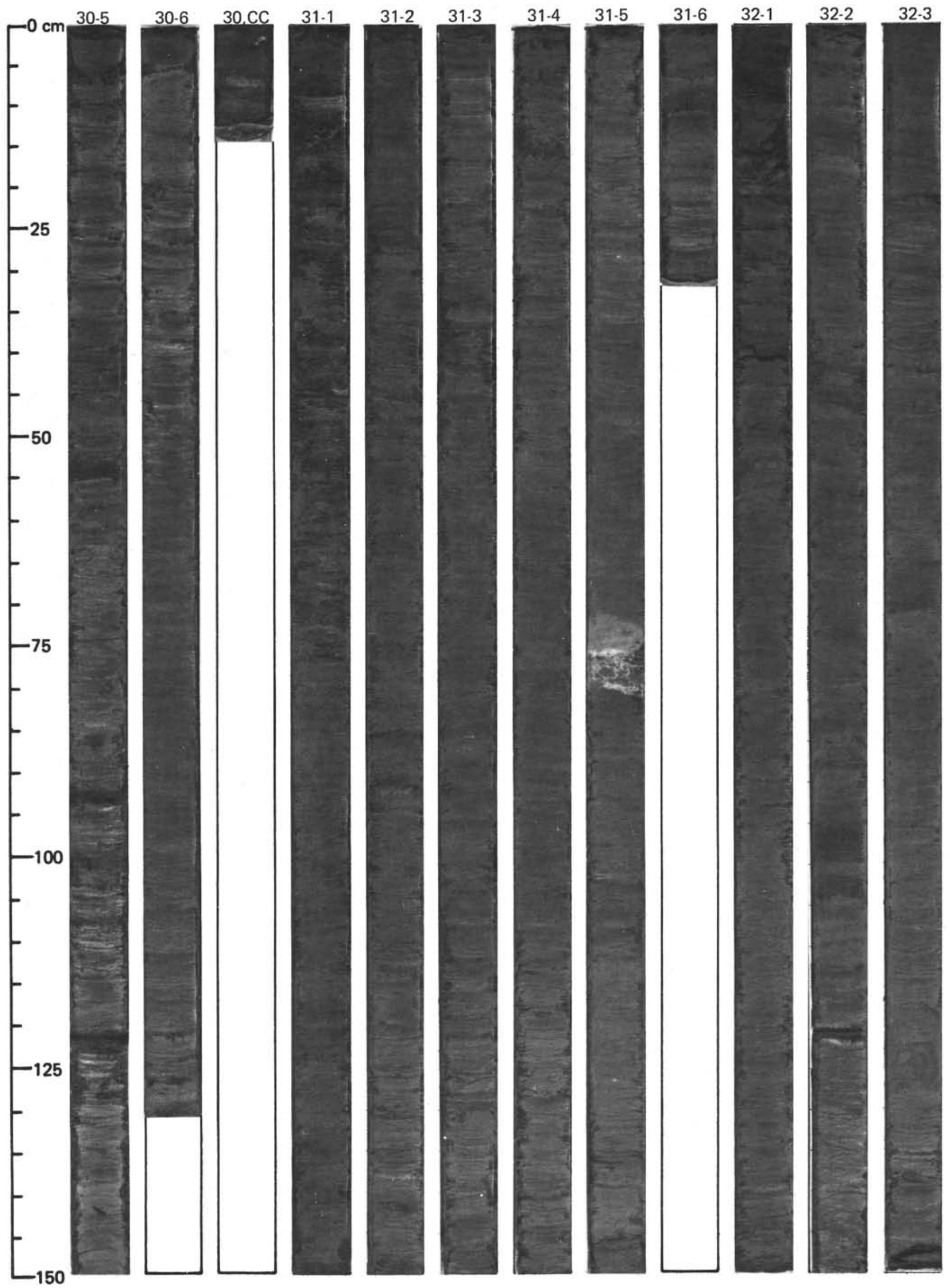




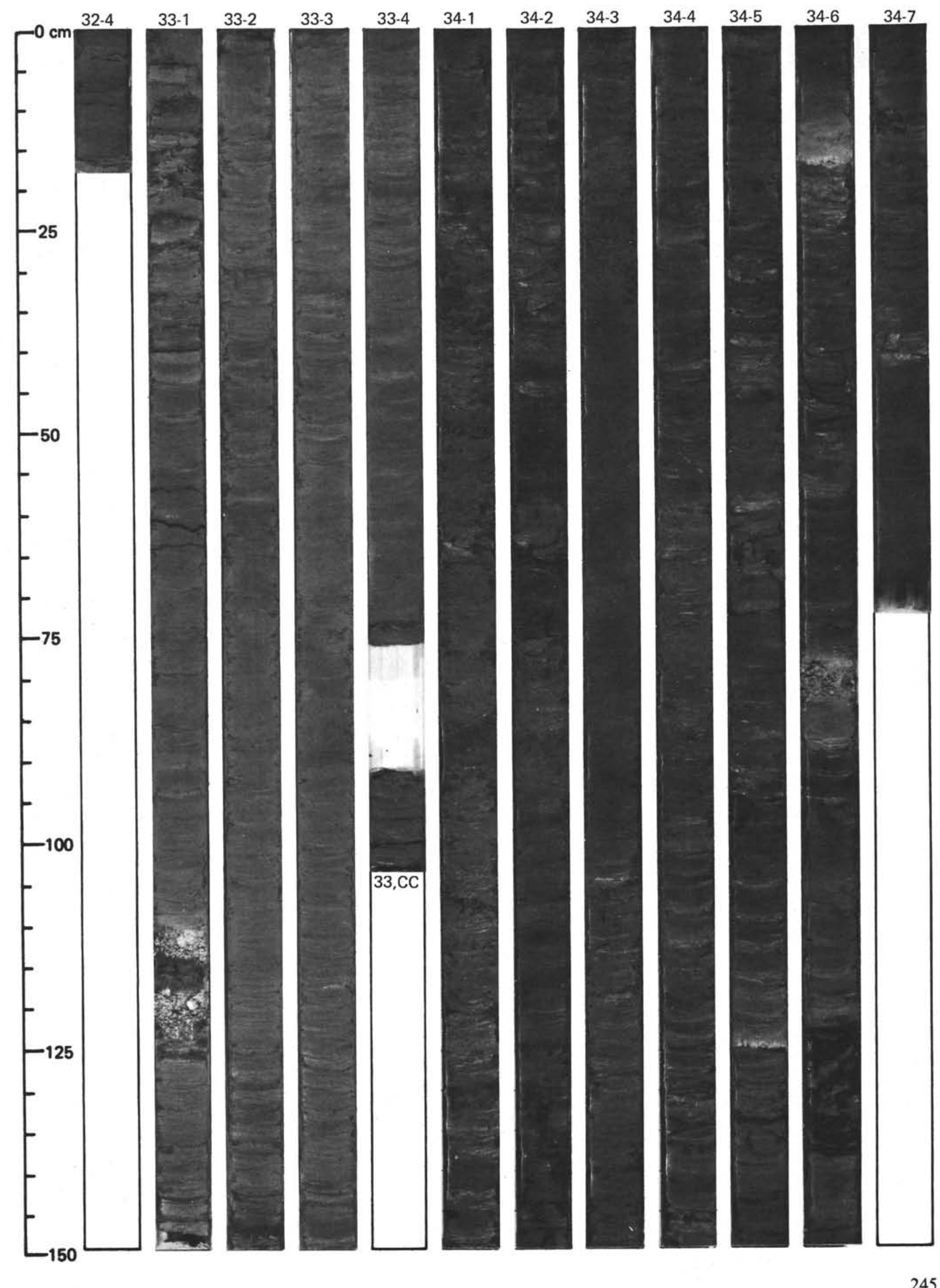




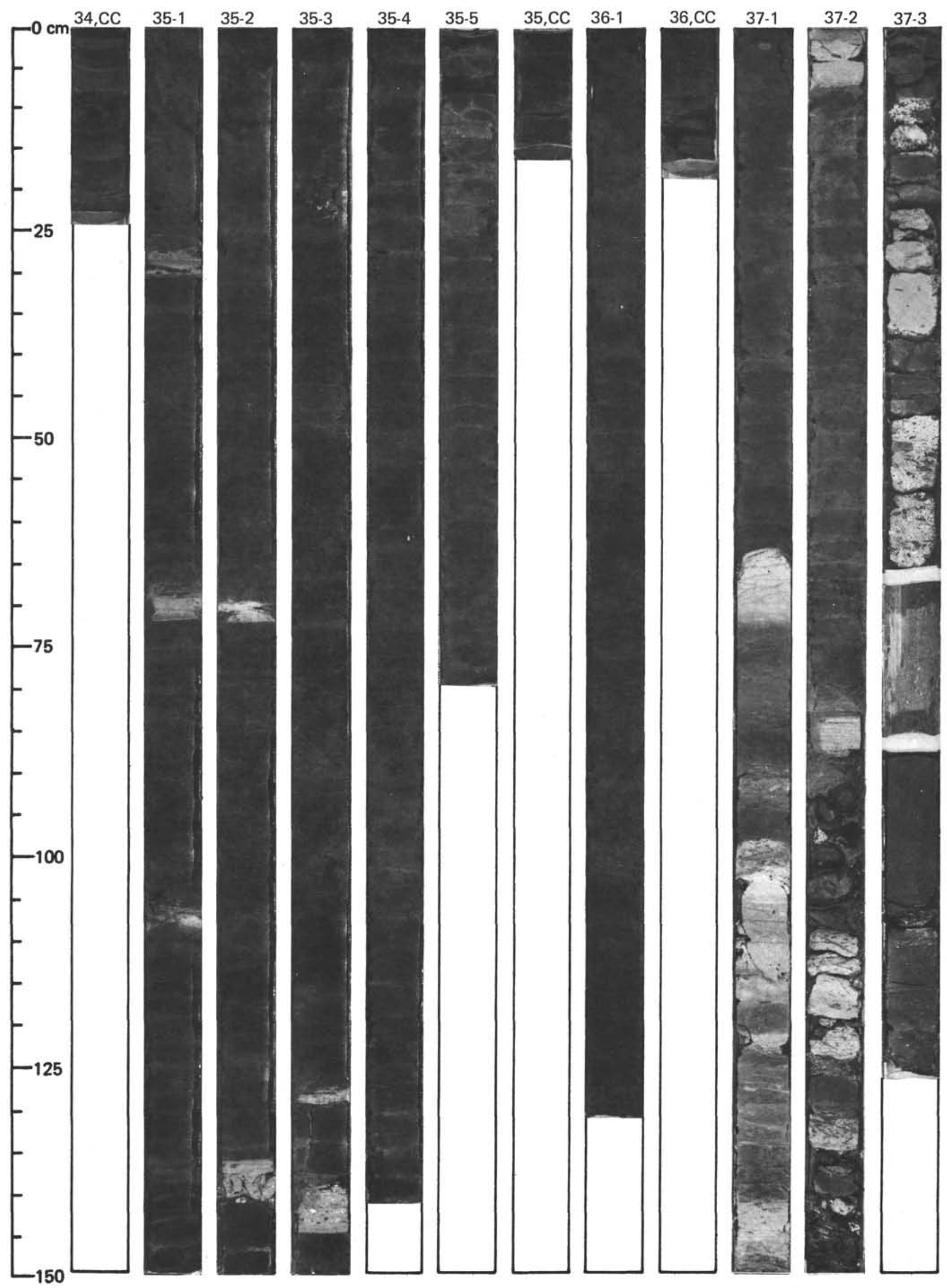




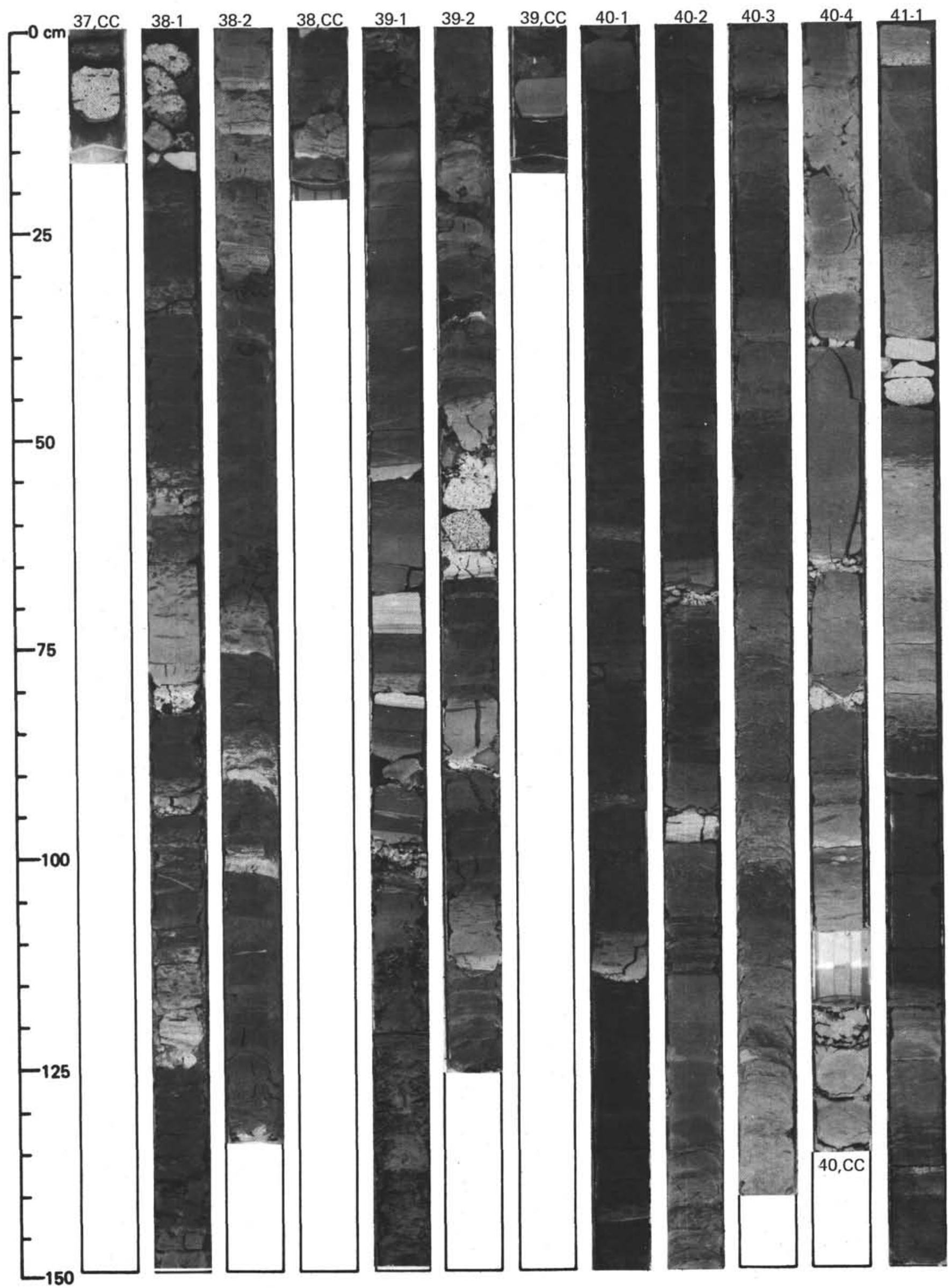




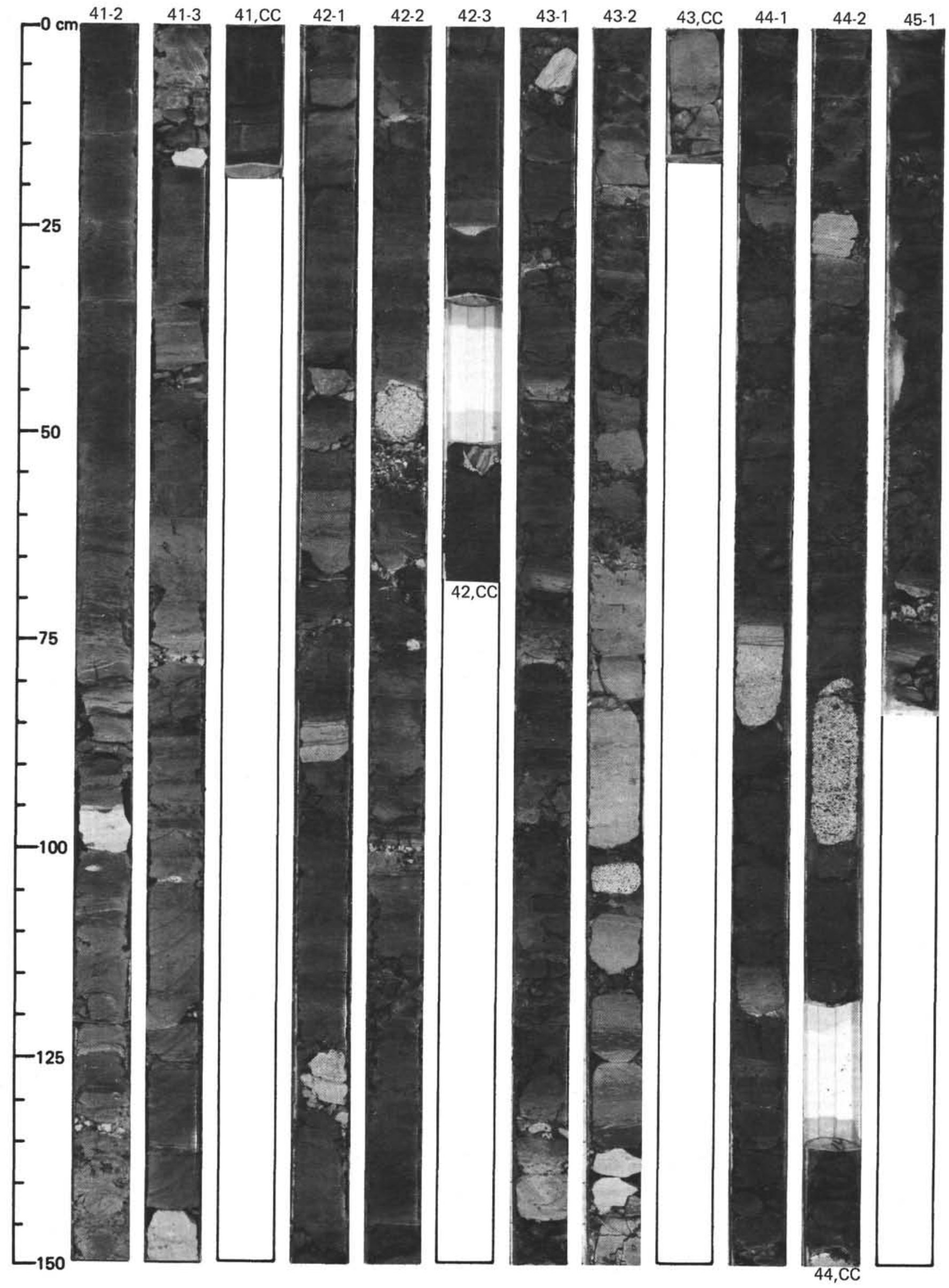


SITE 530

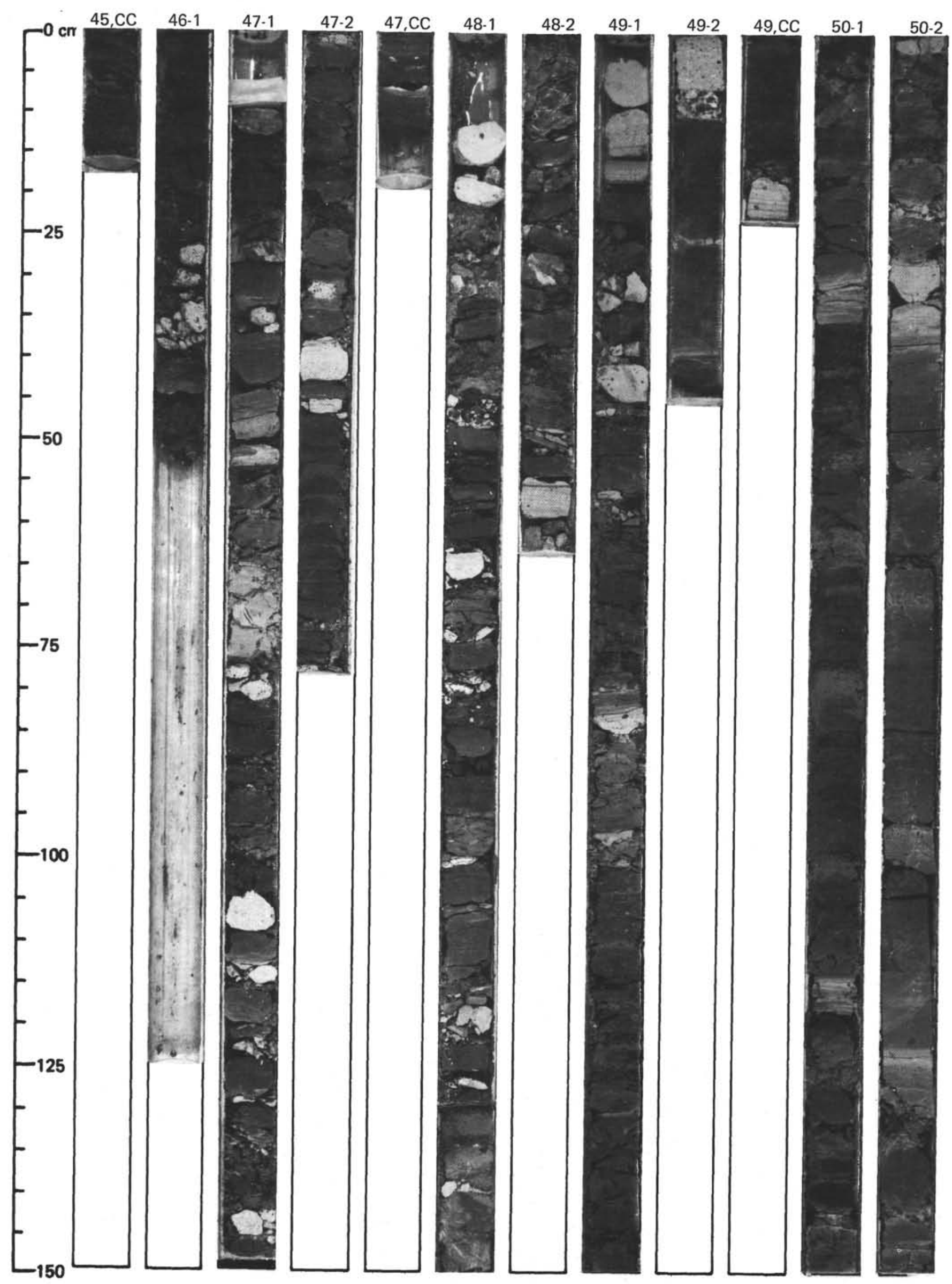




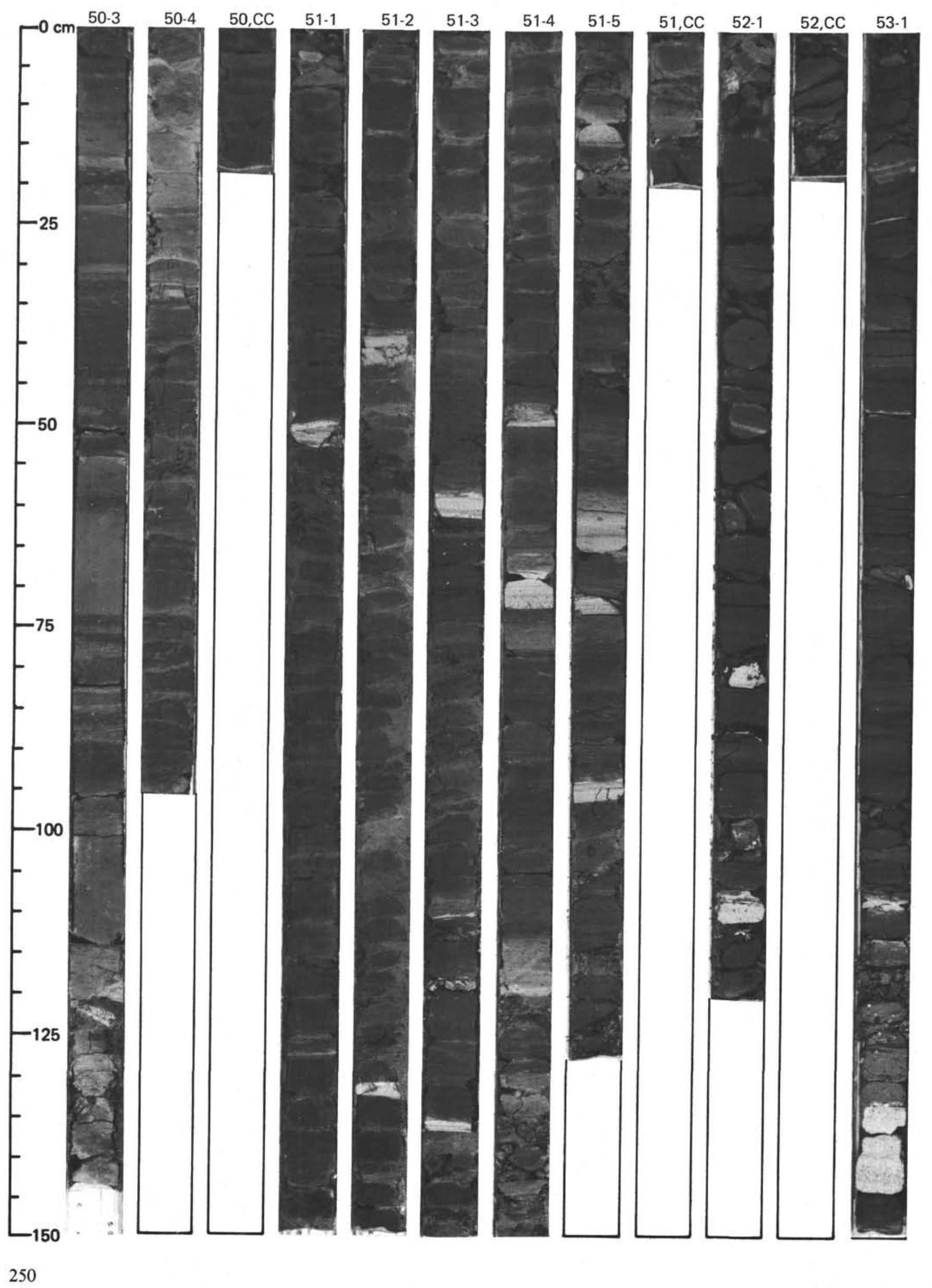




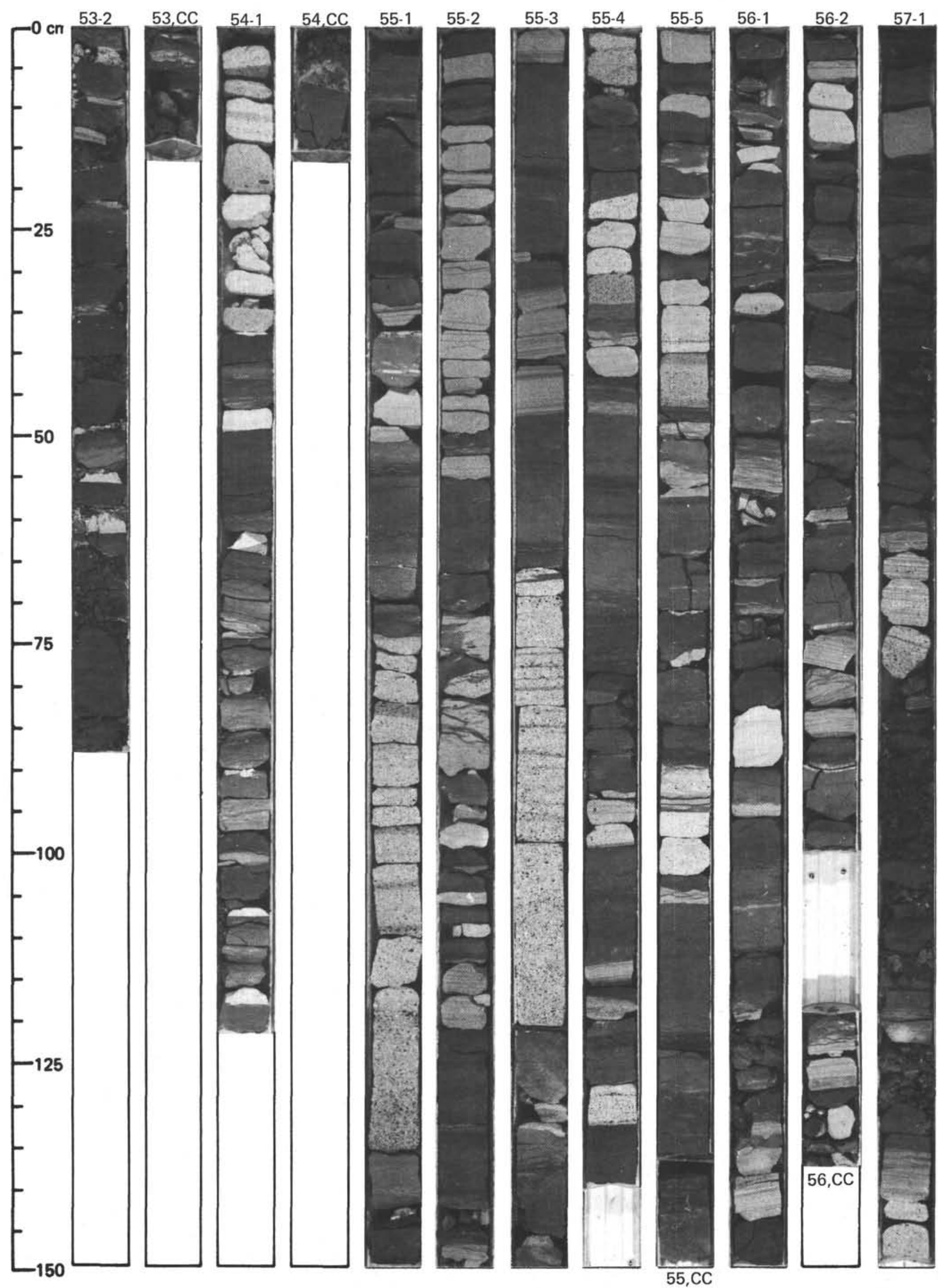




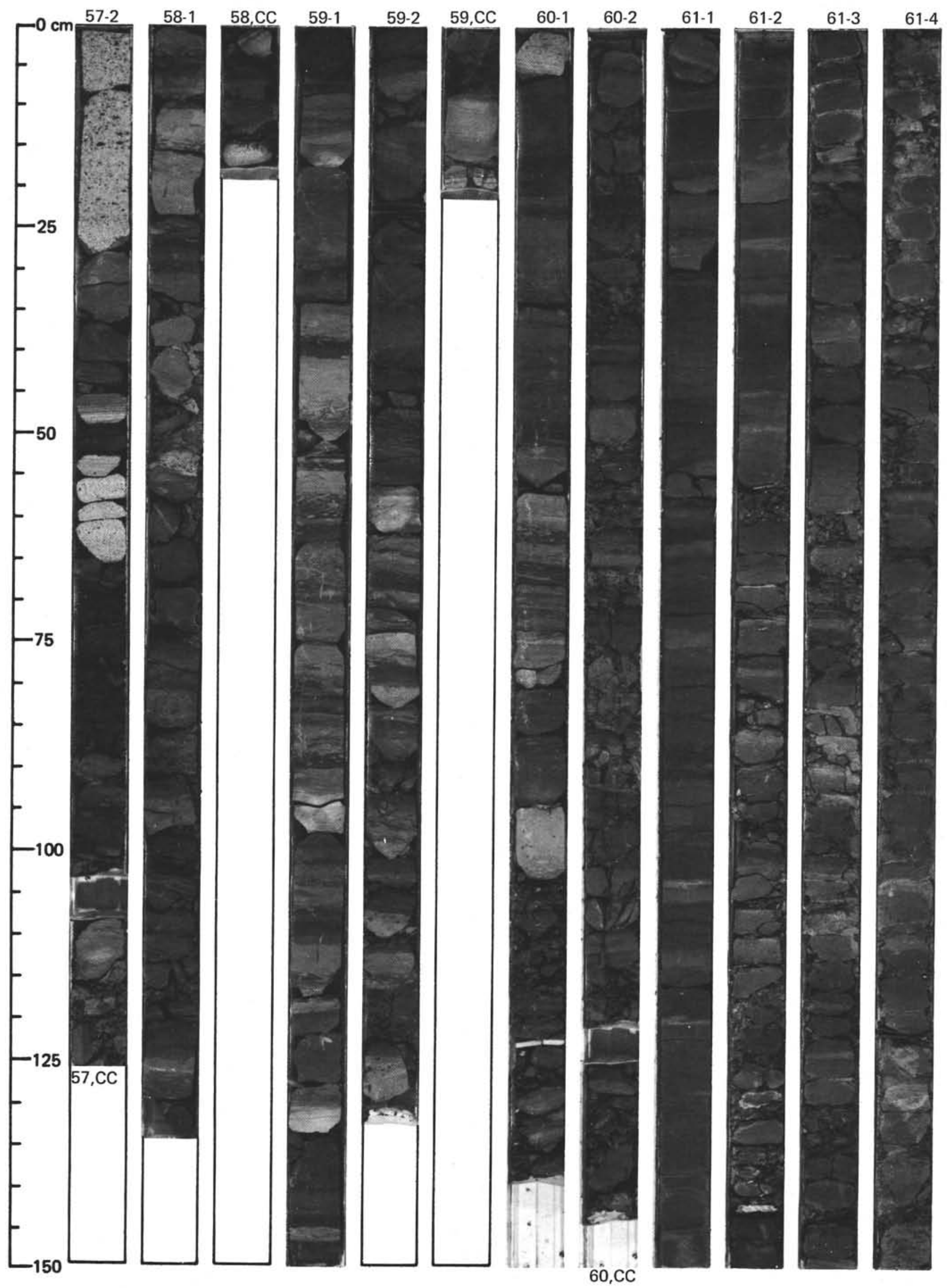




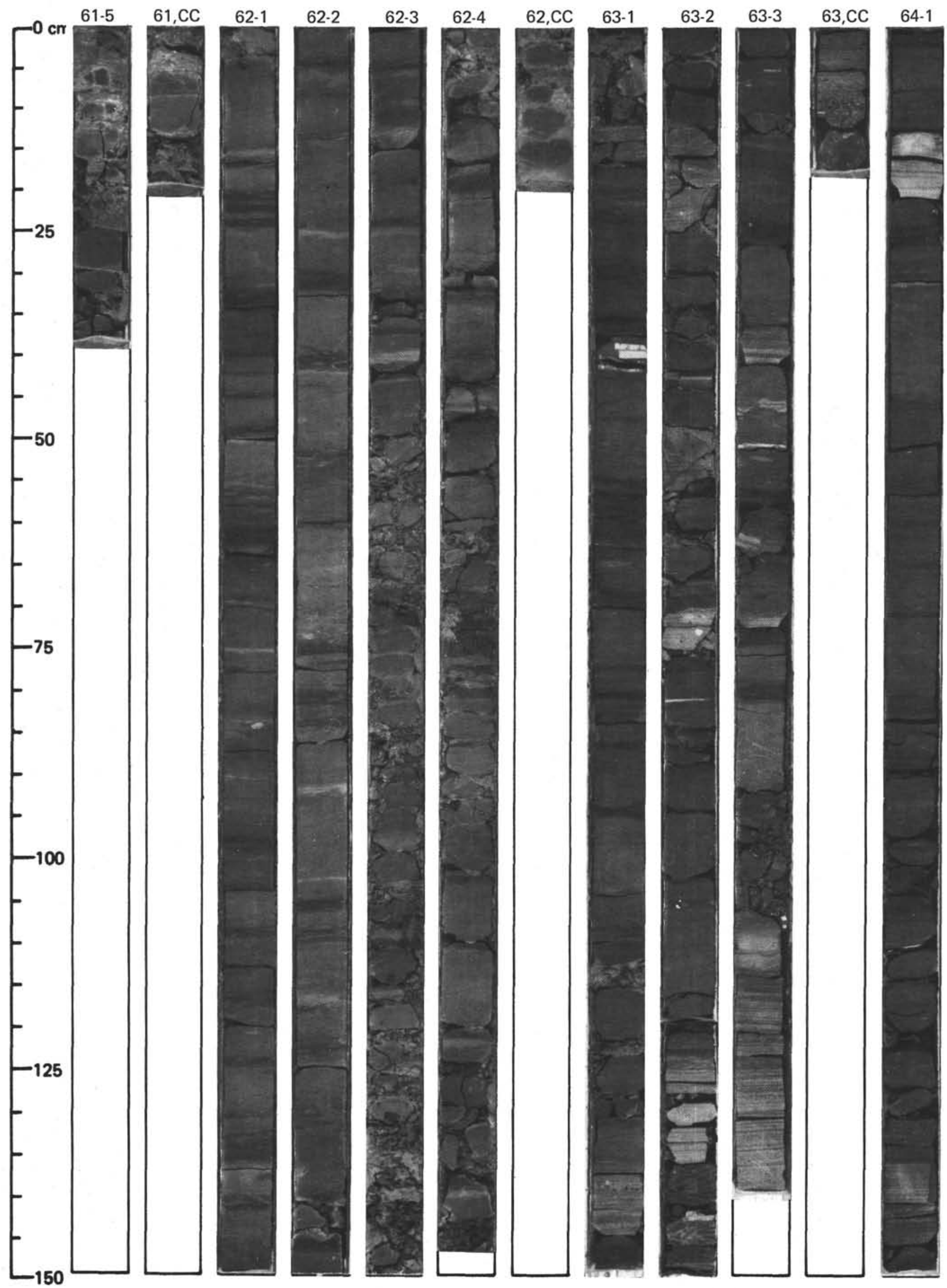




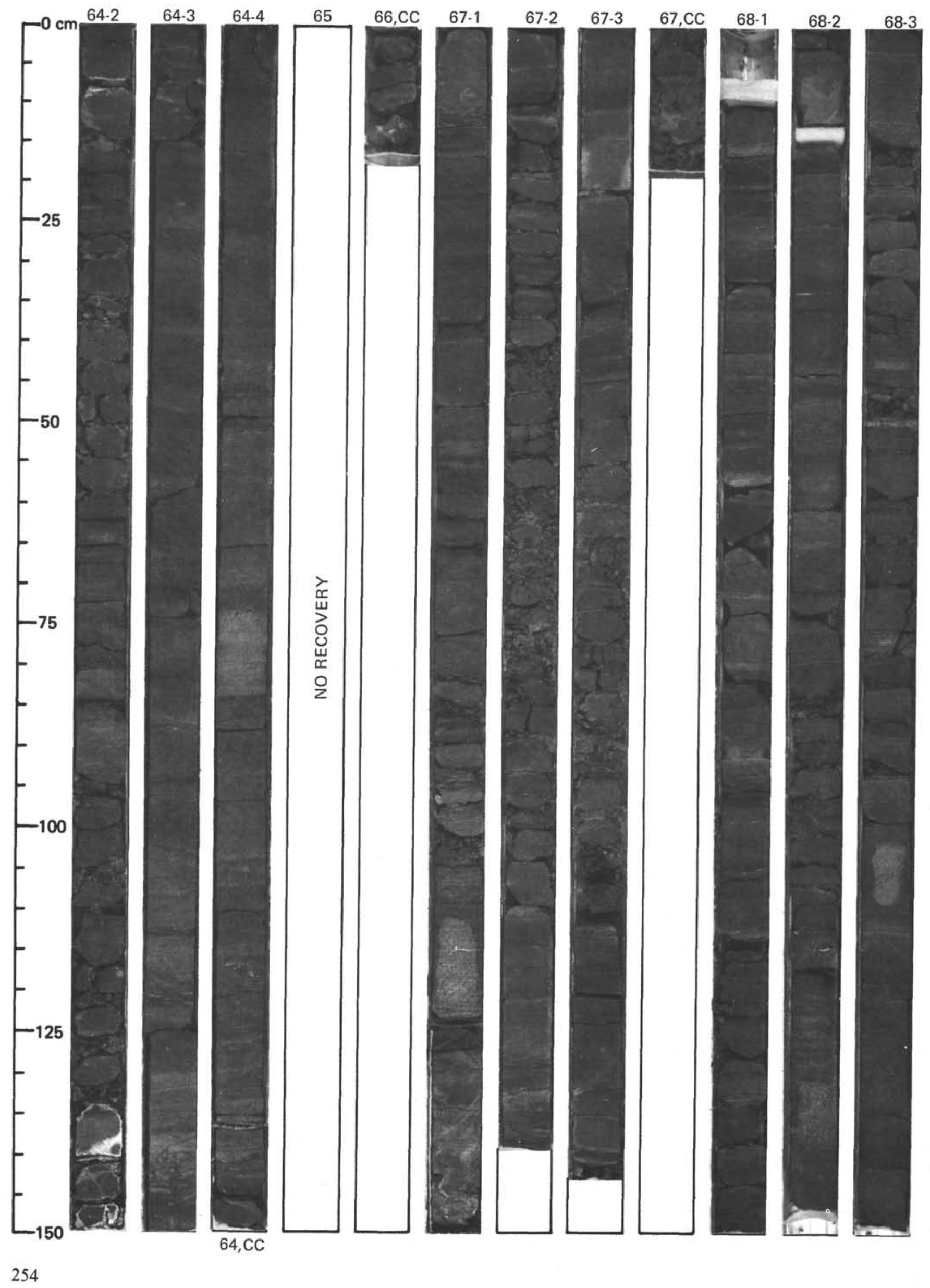




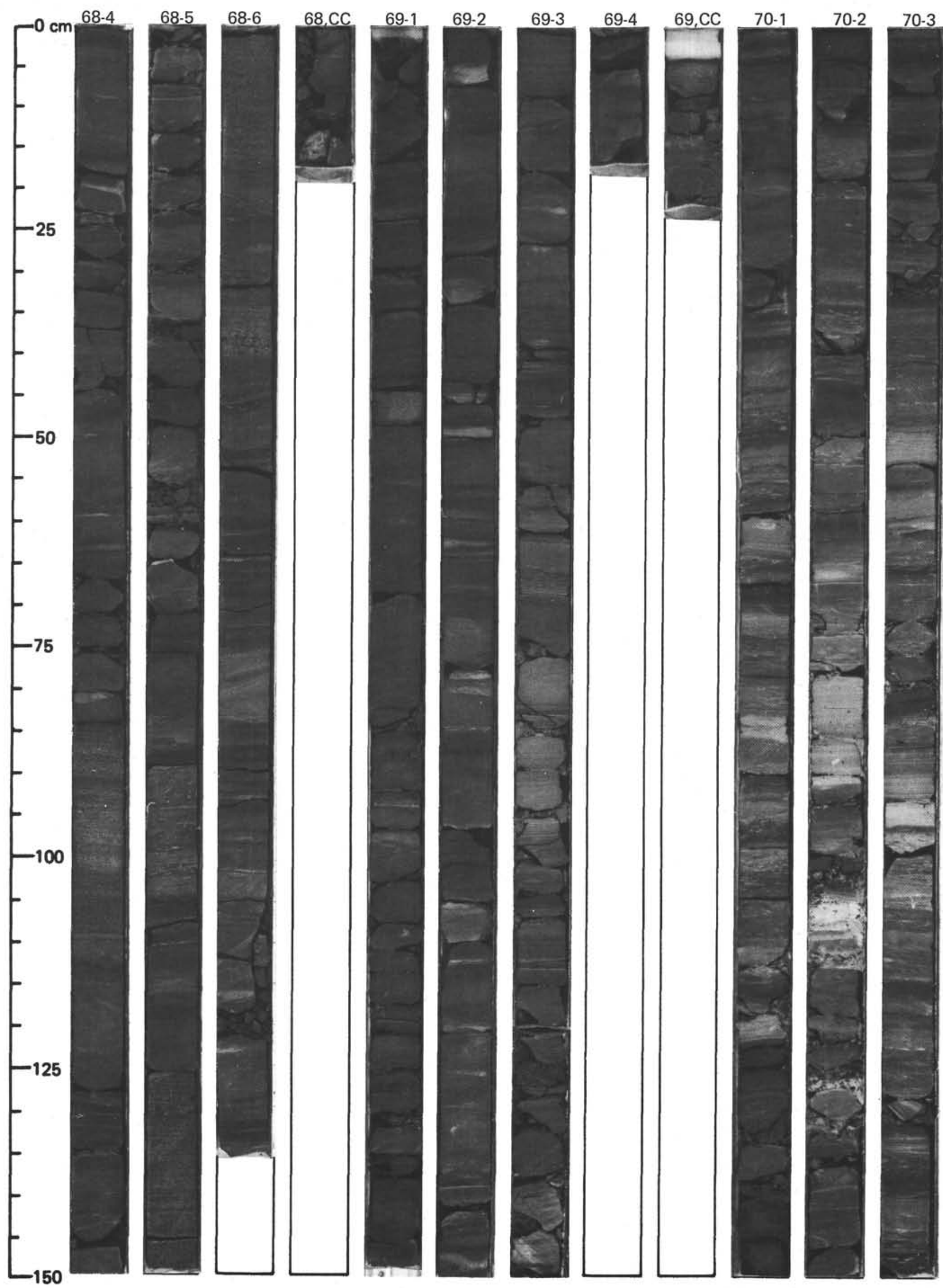




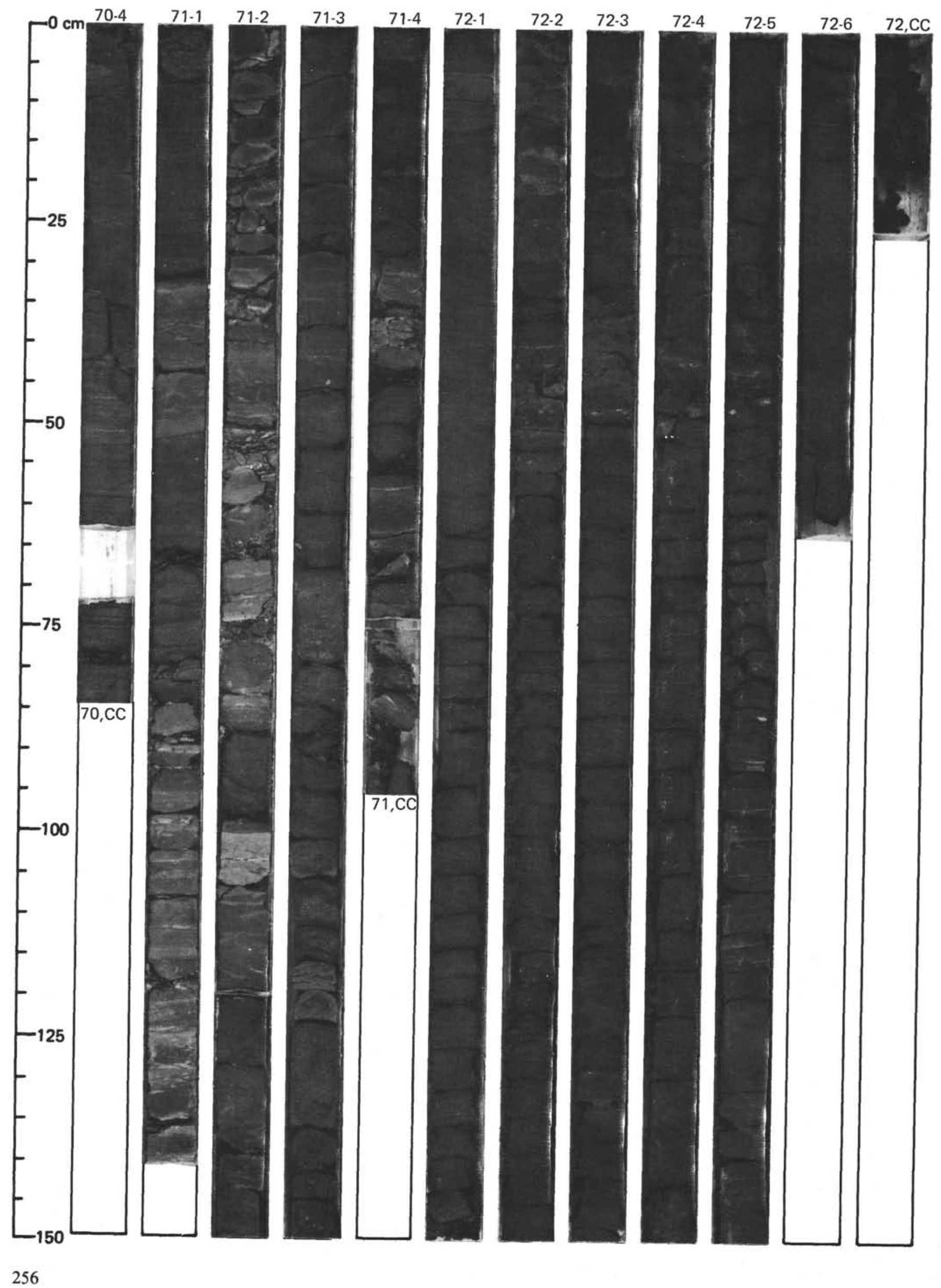




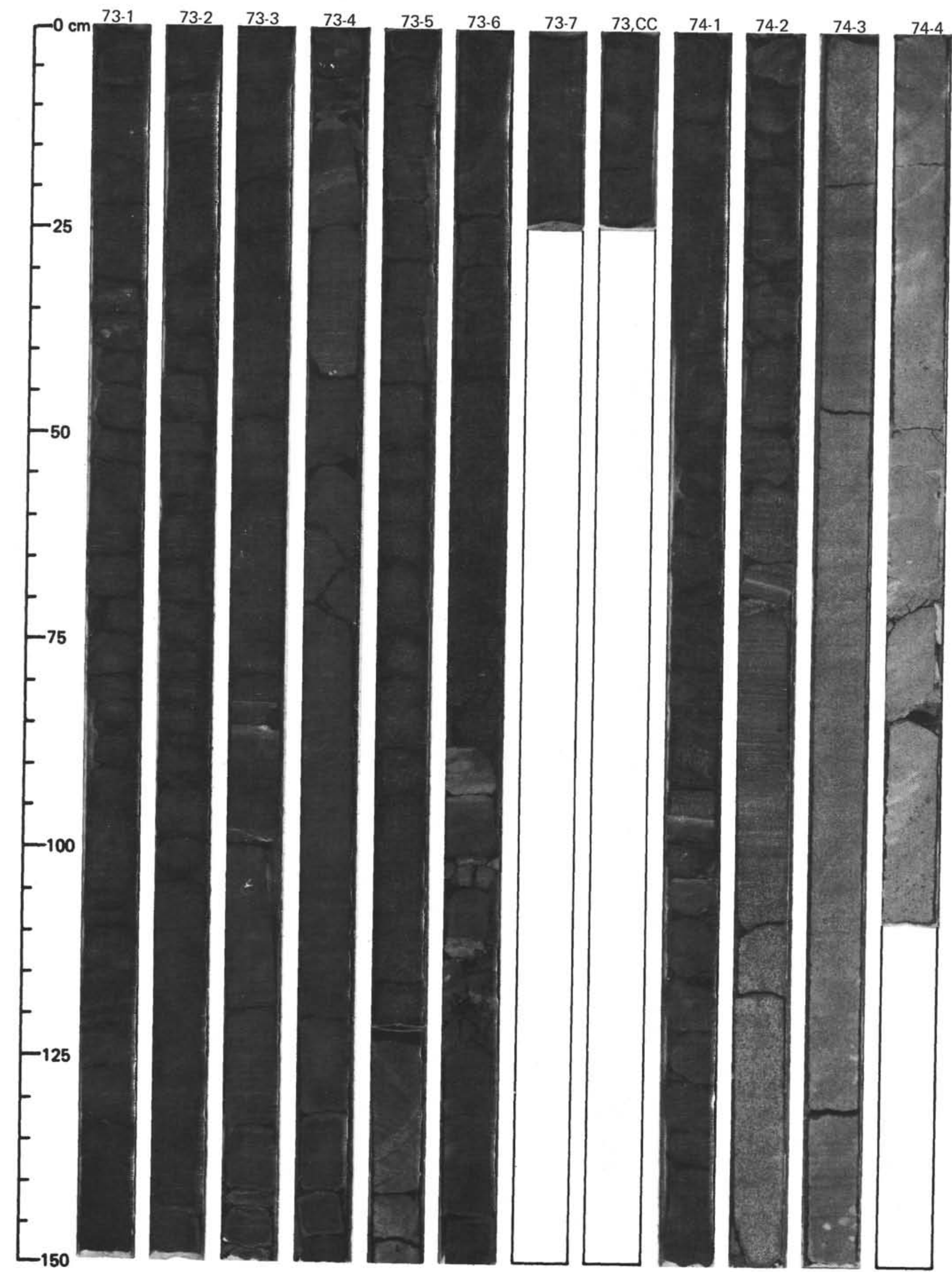




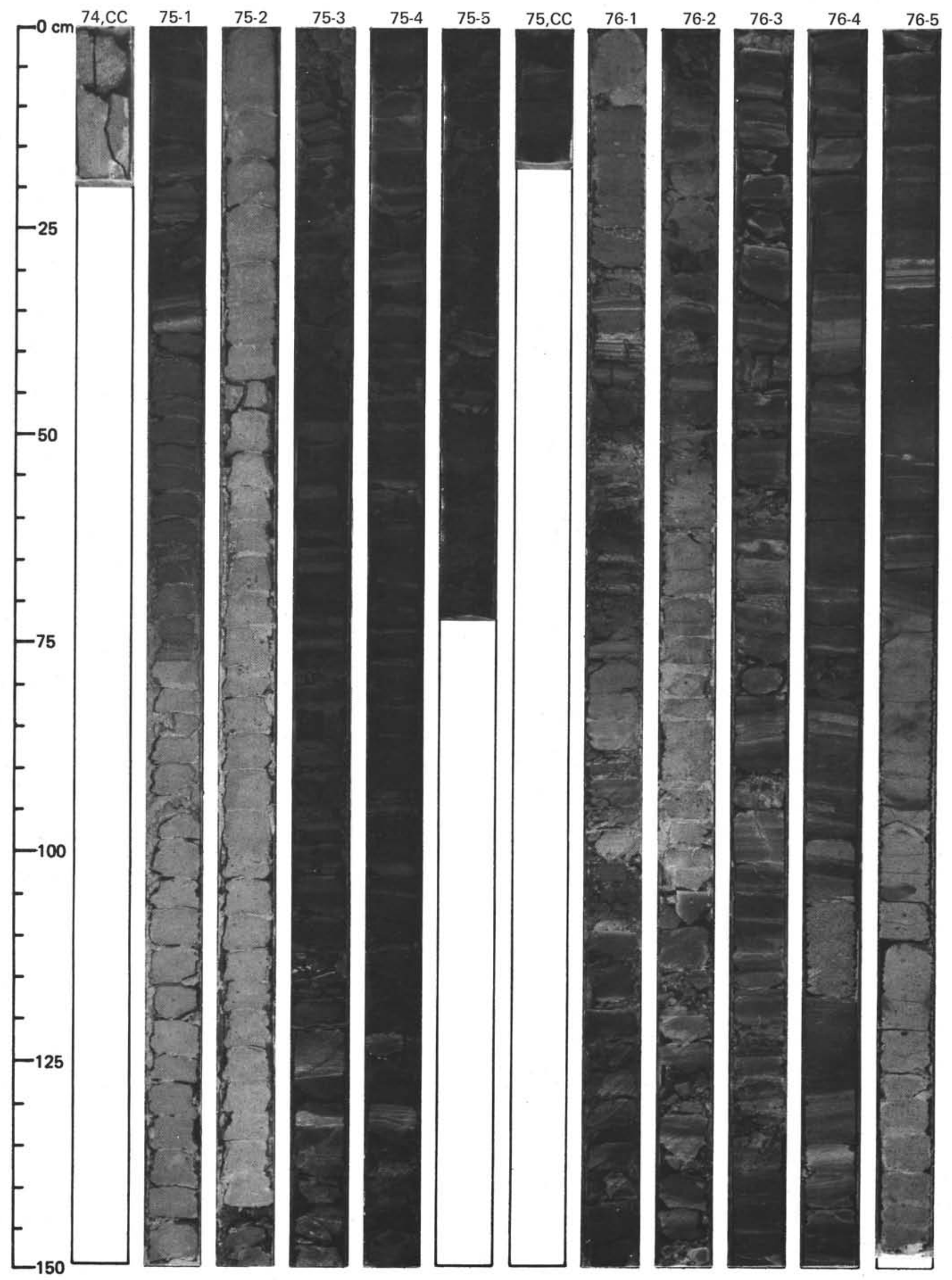




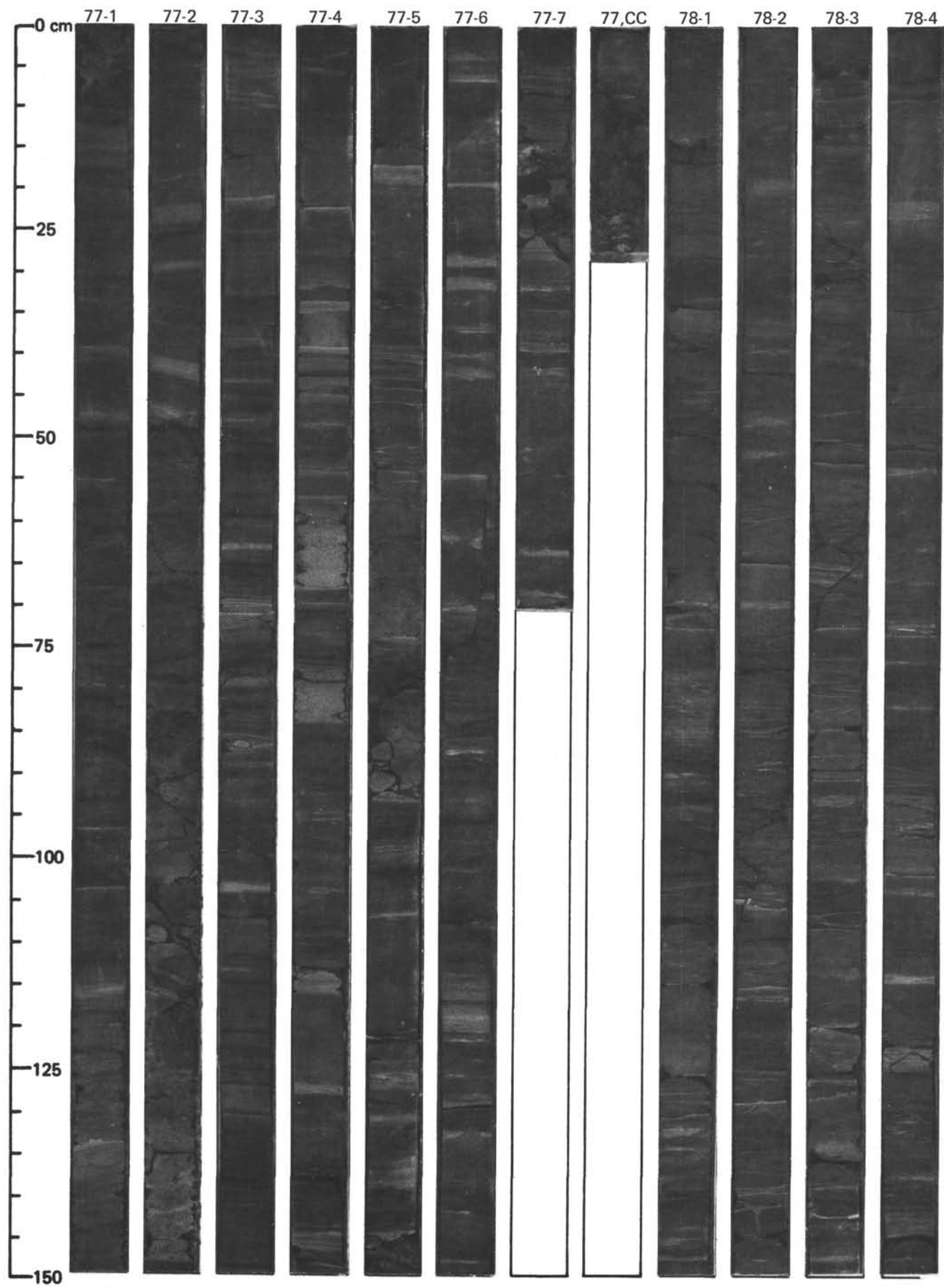




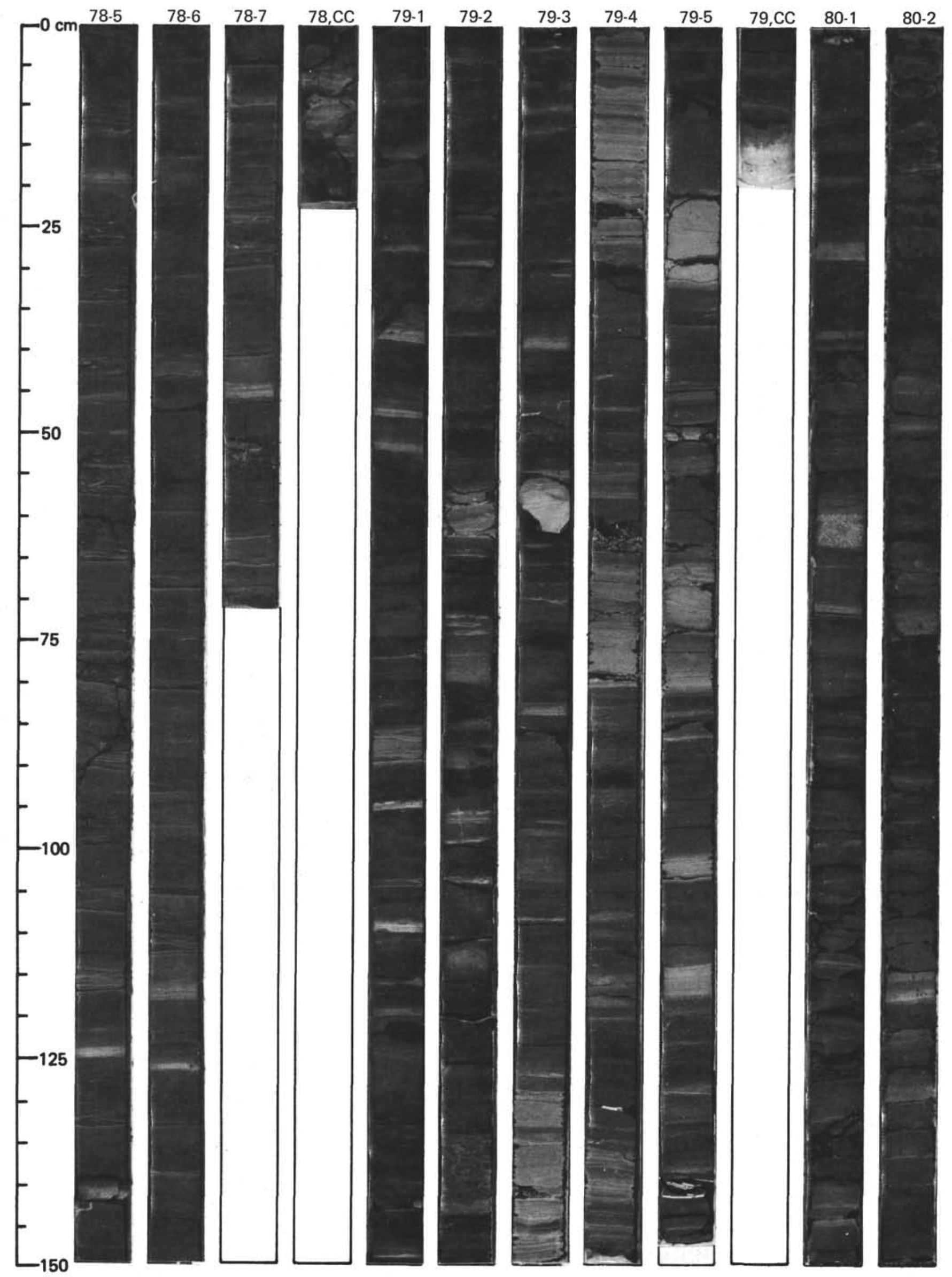




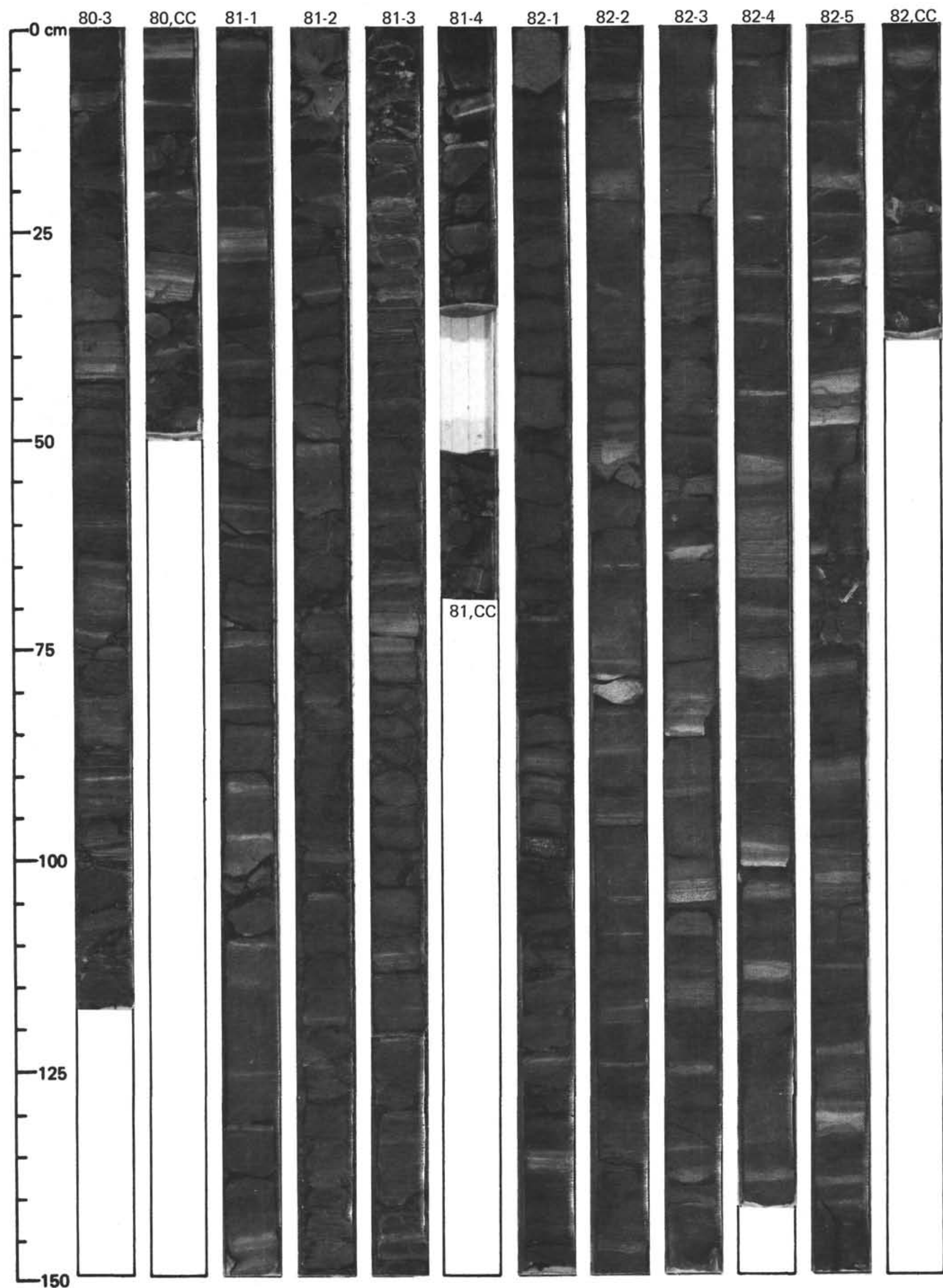




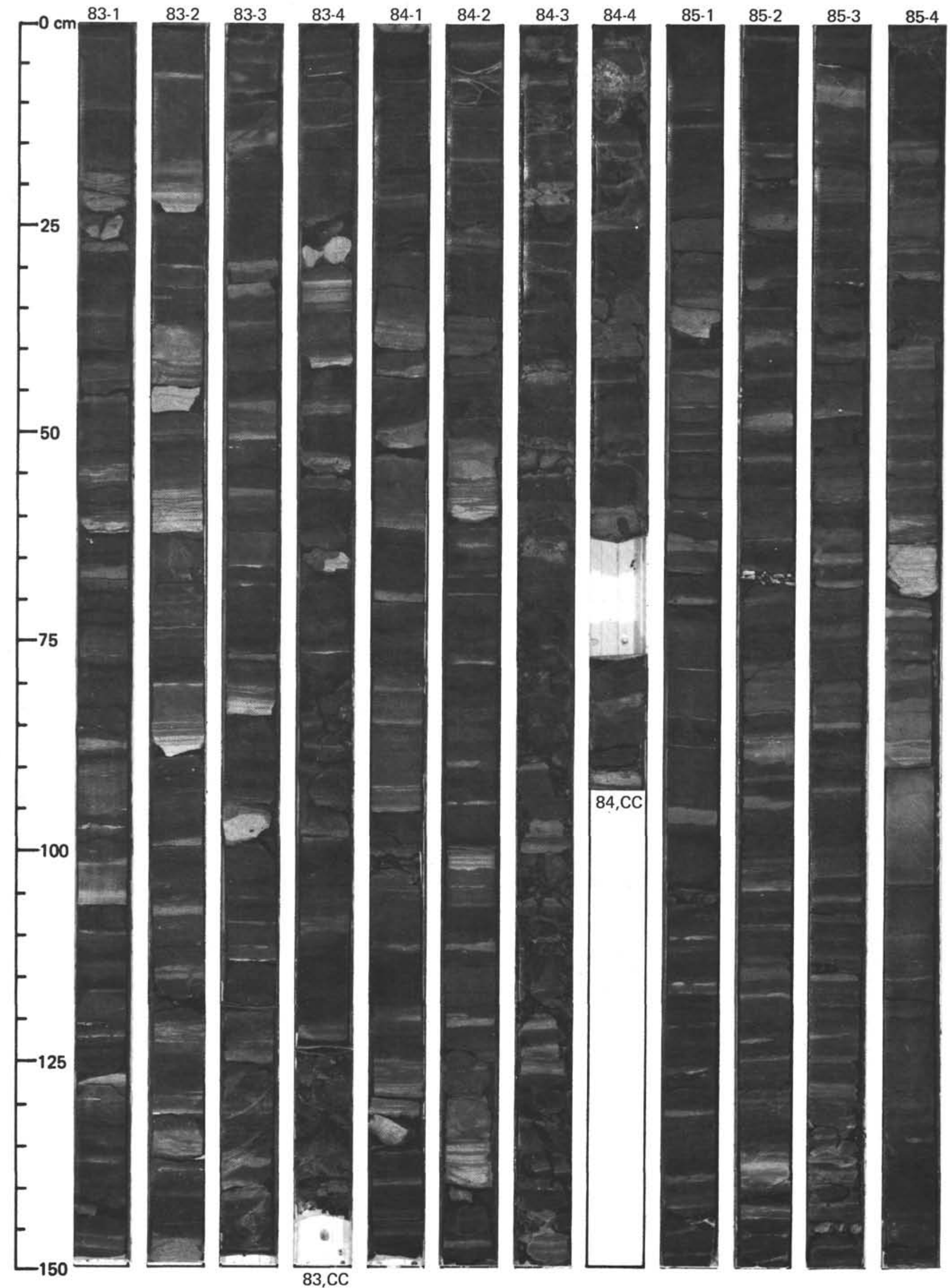




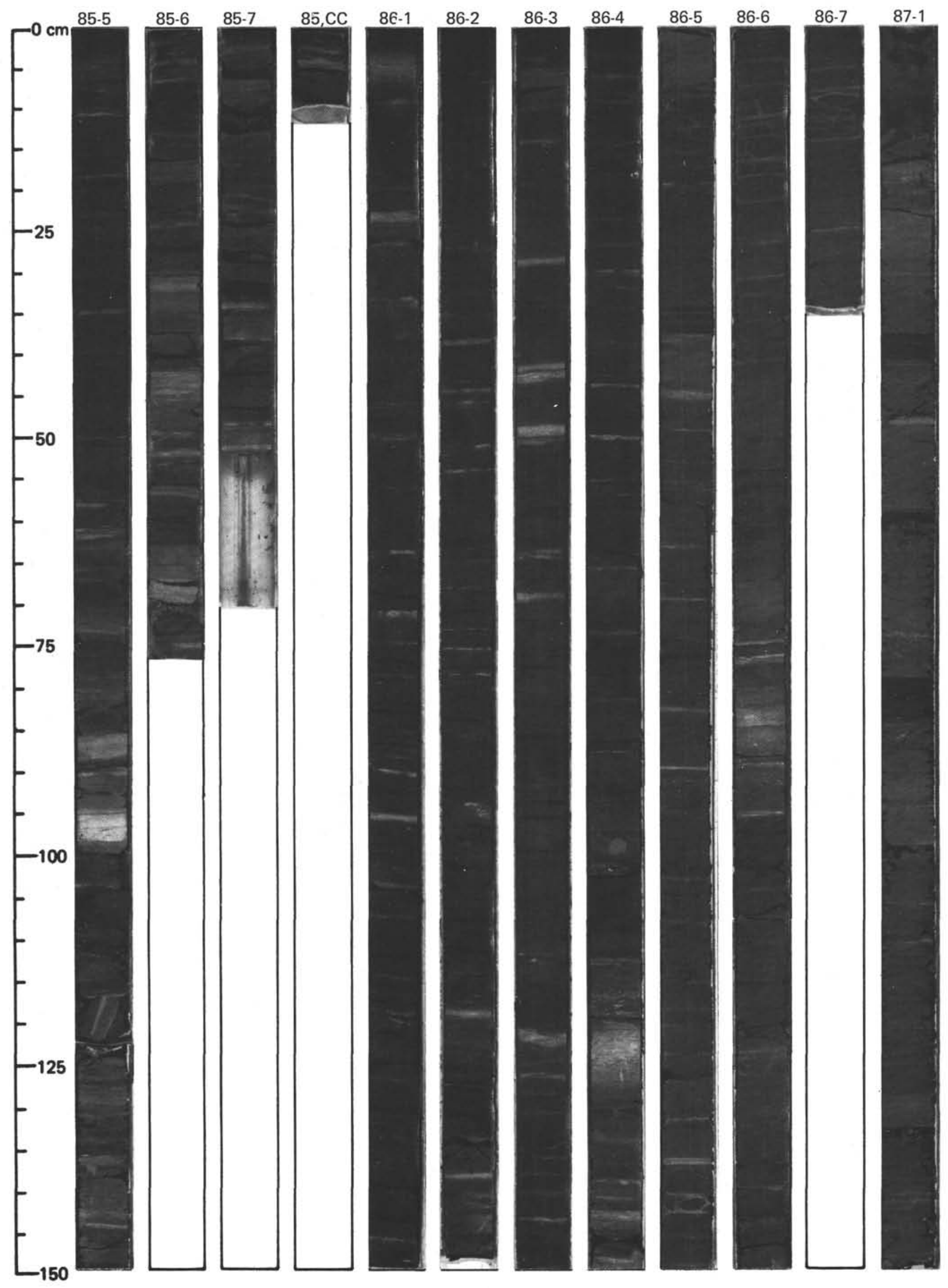




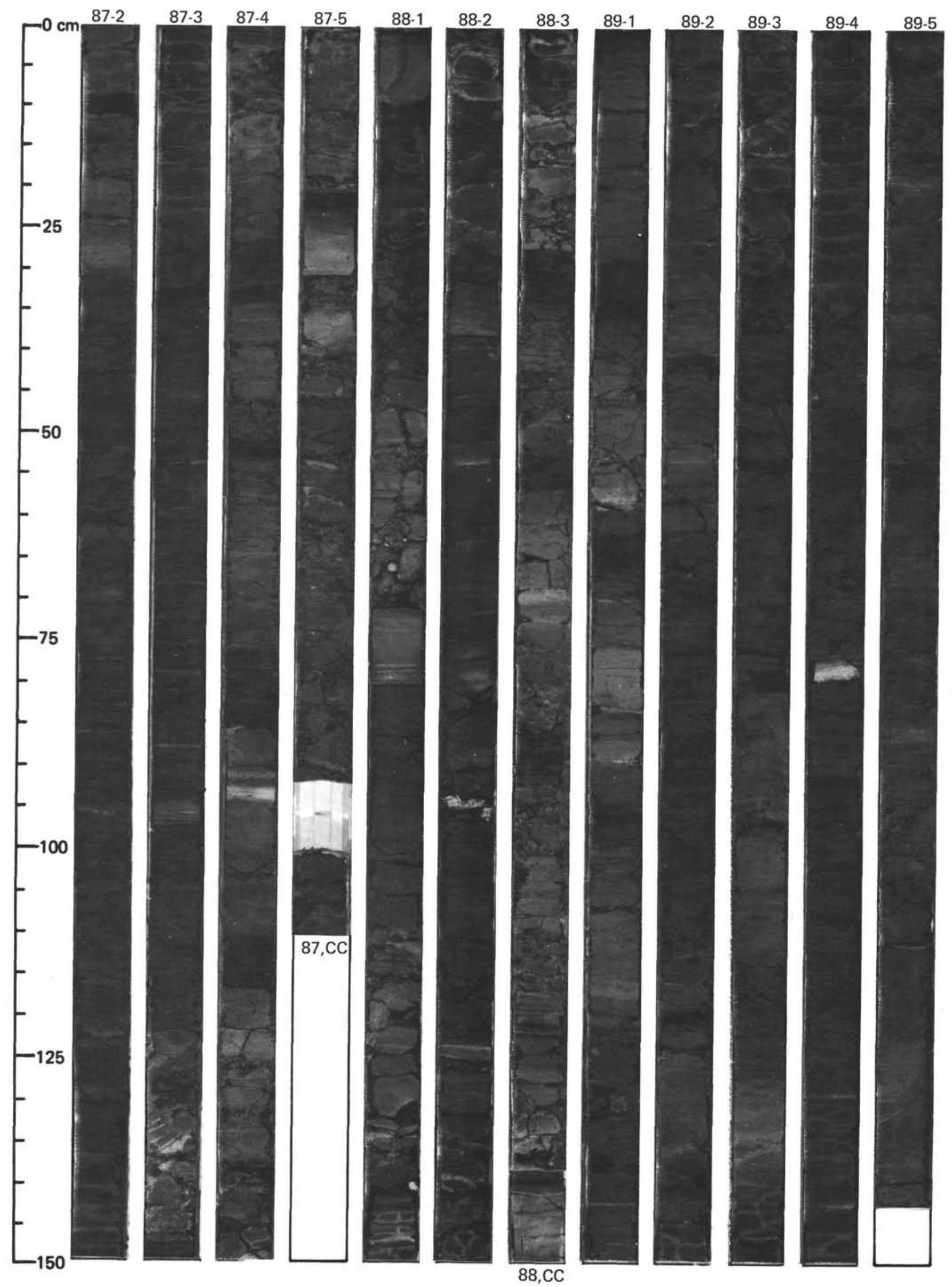




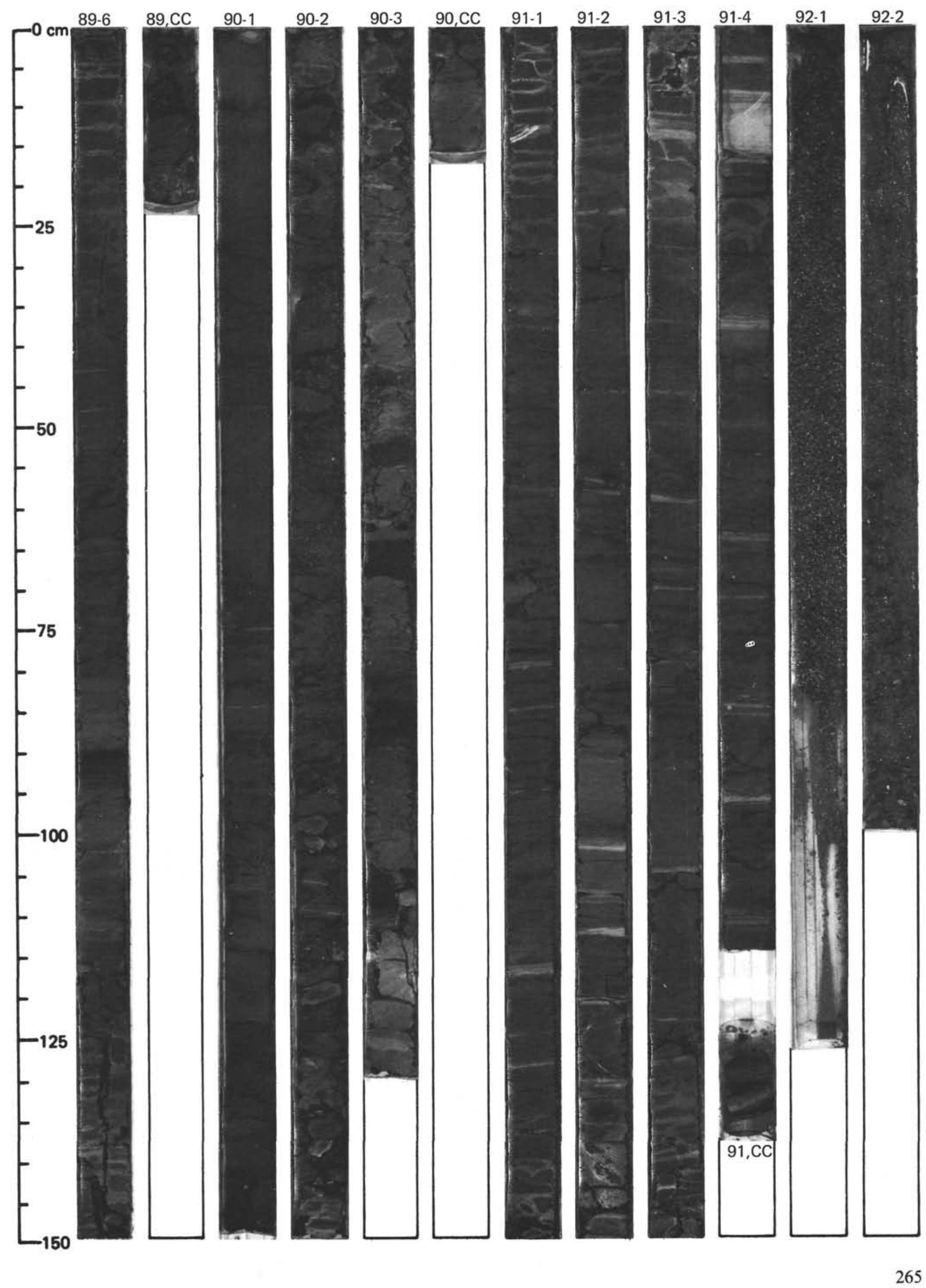


SITE 530

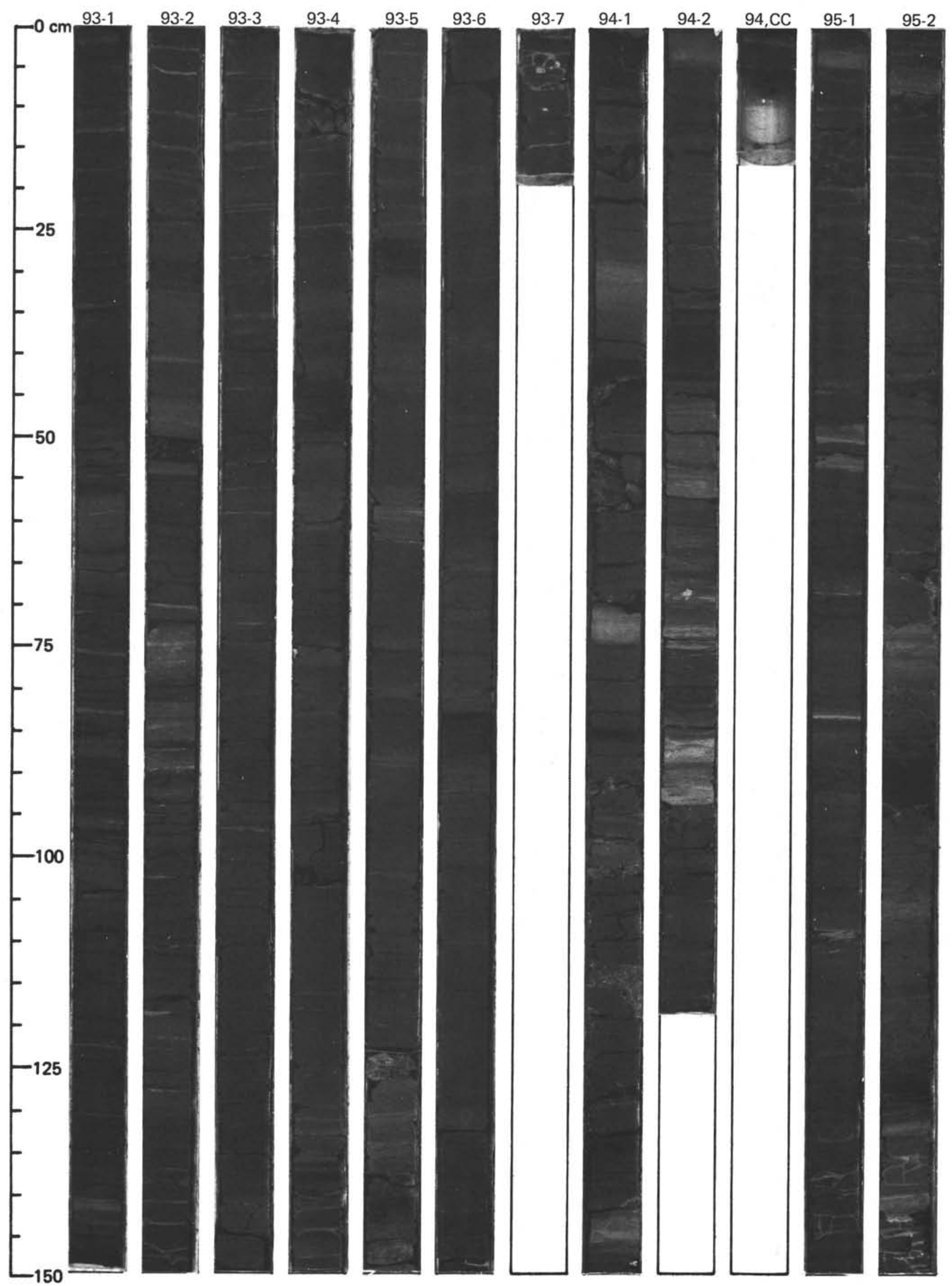




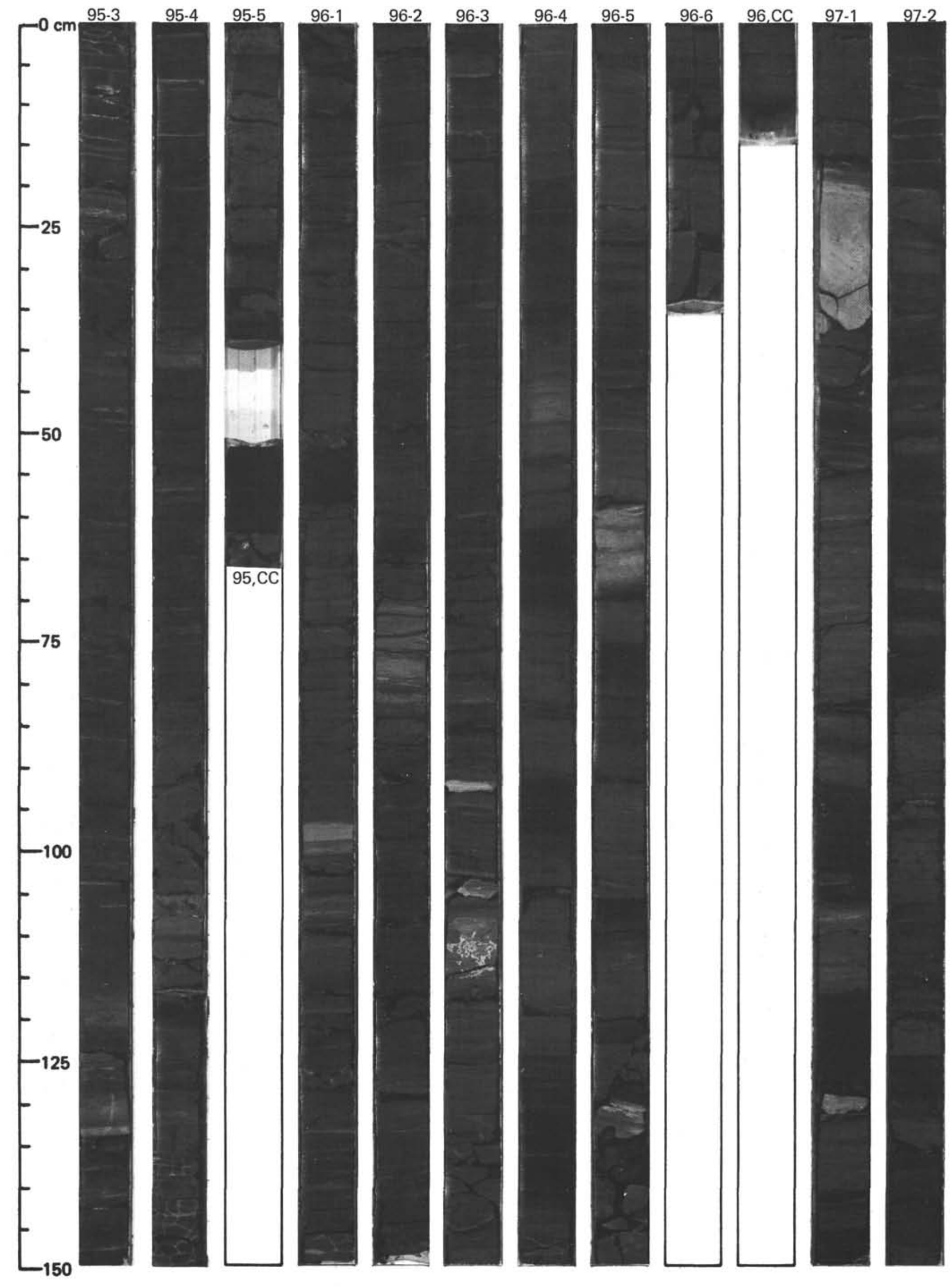




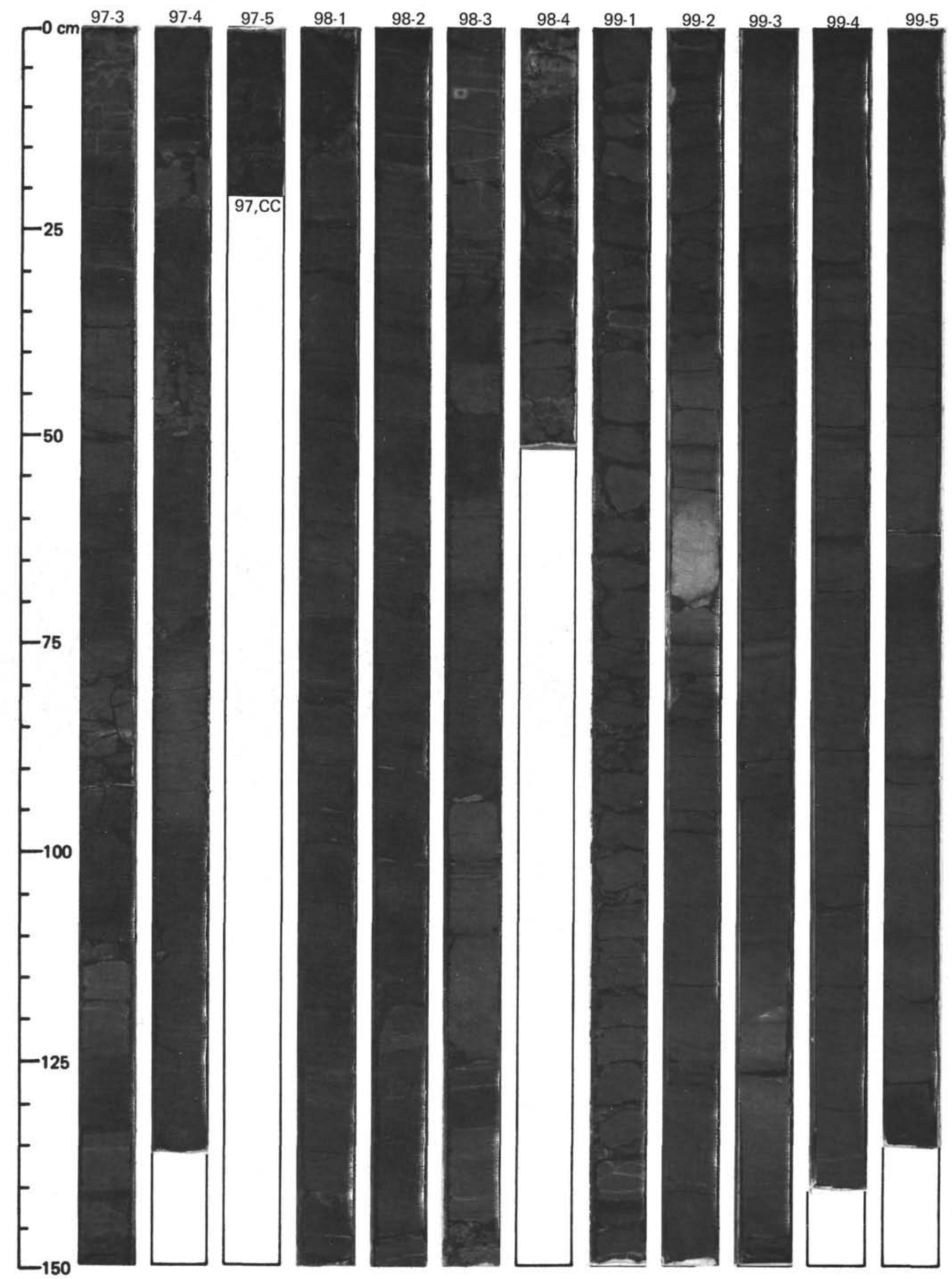




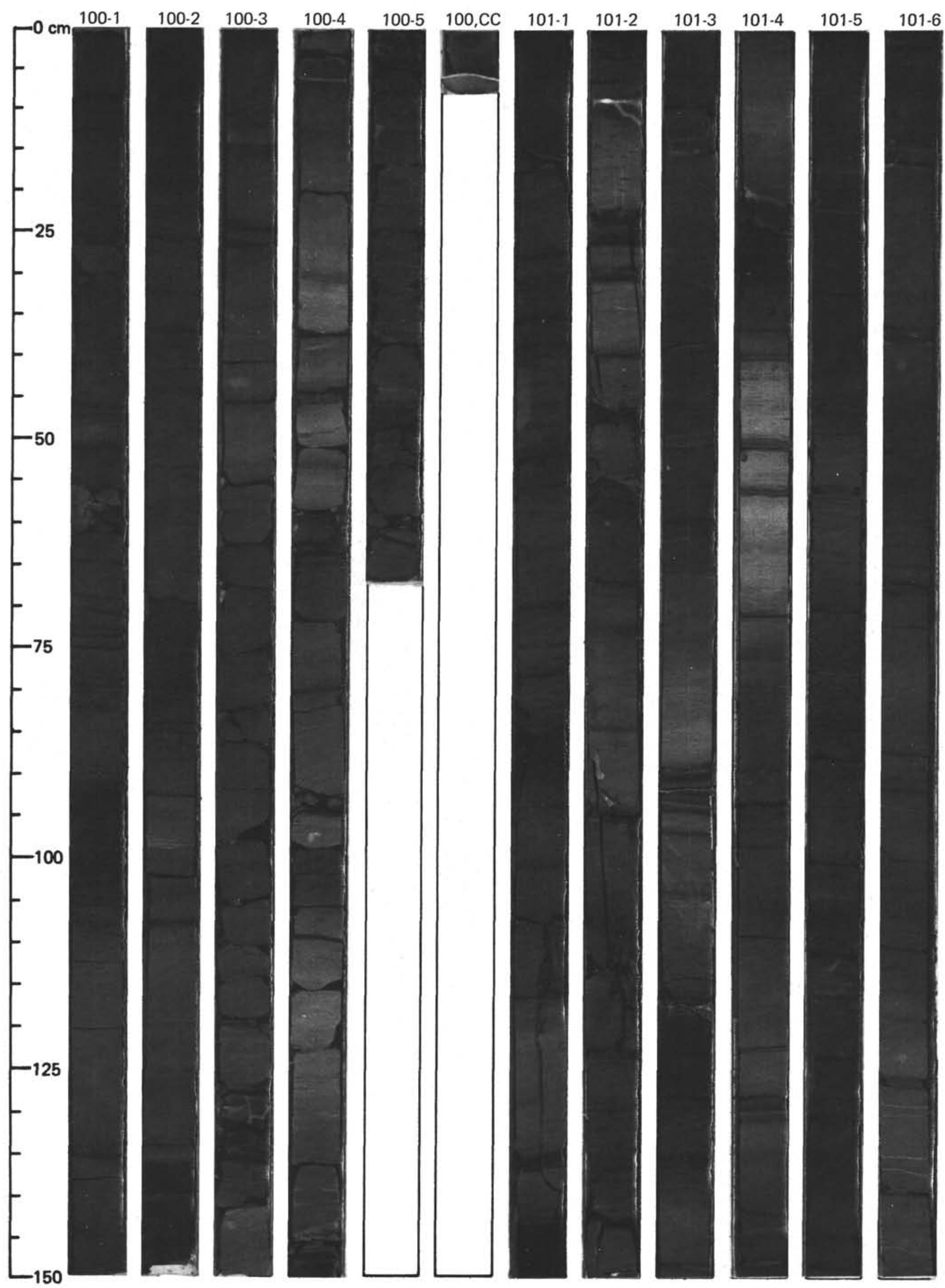




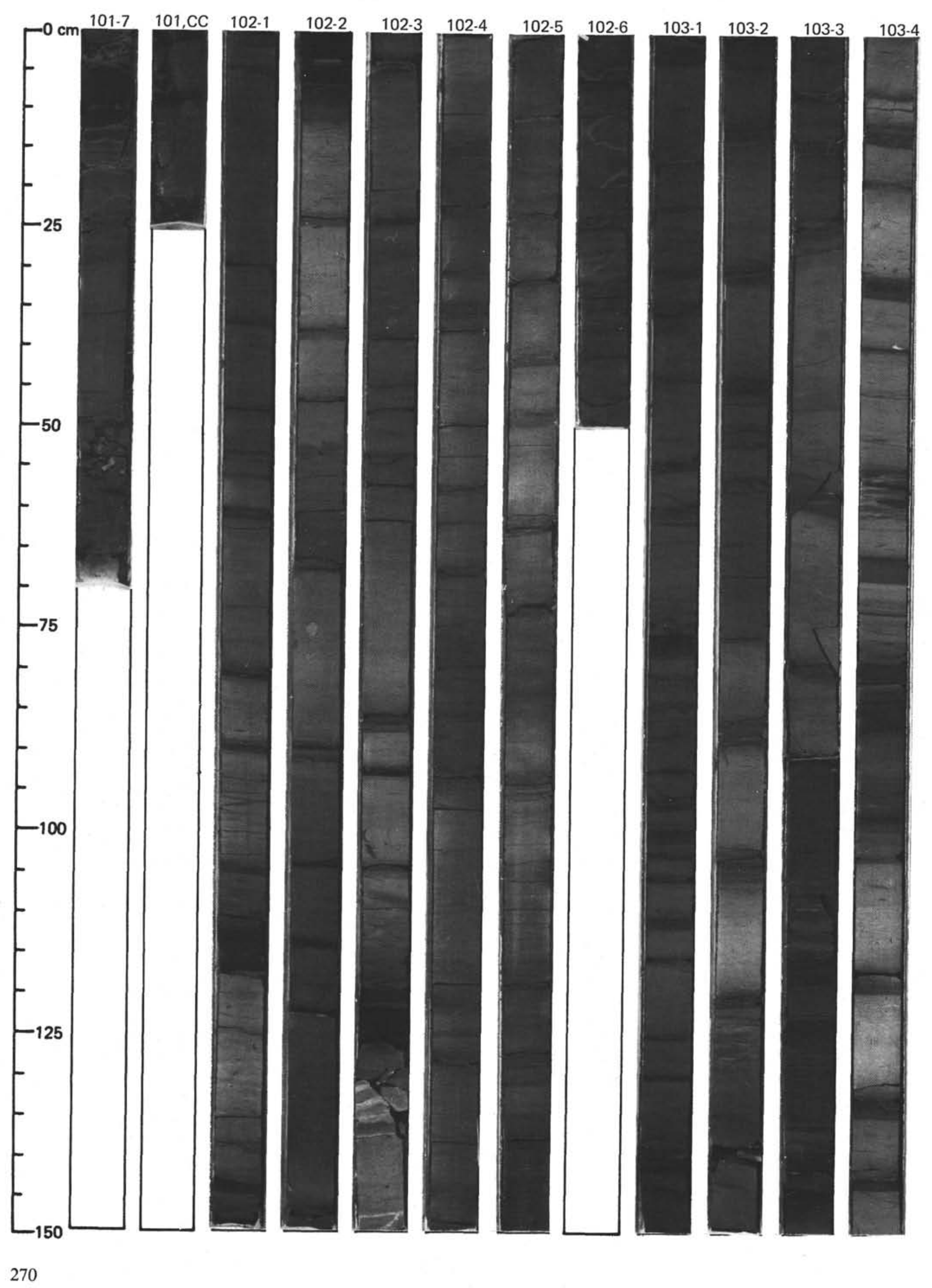




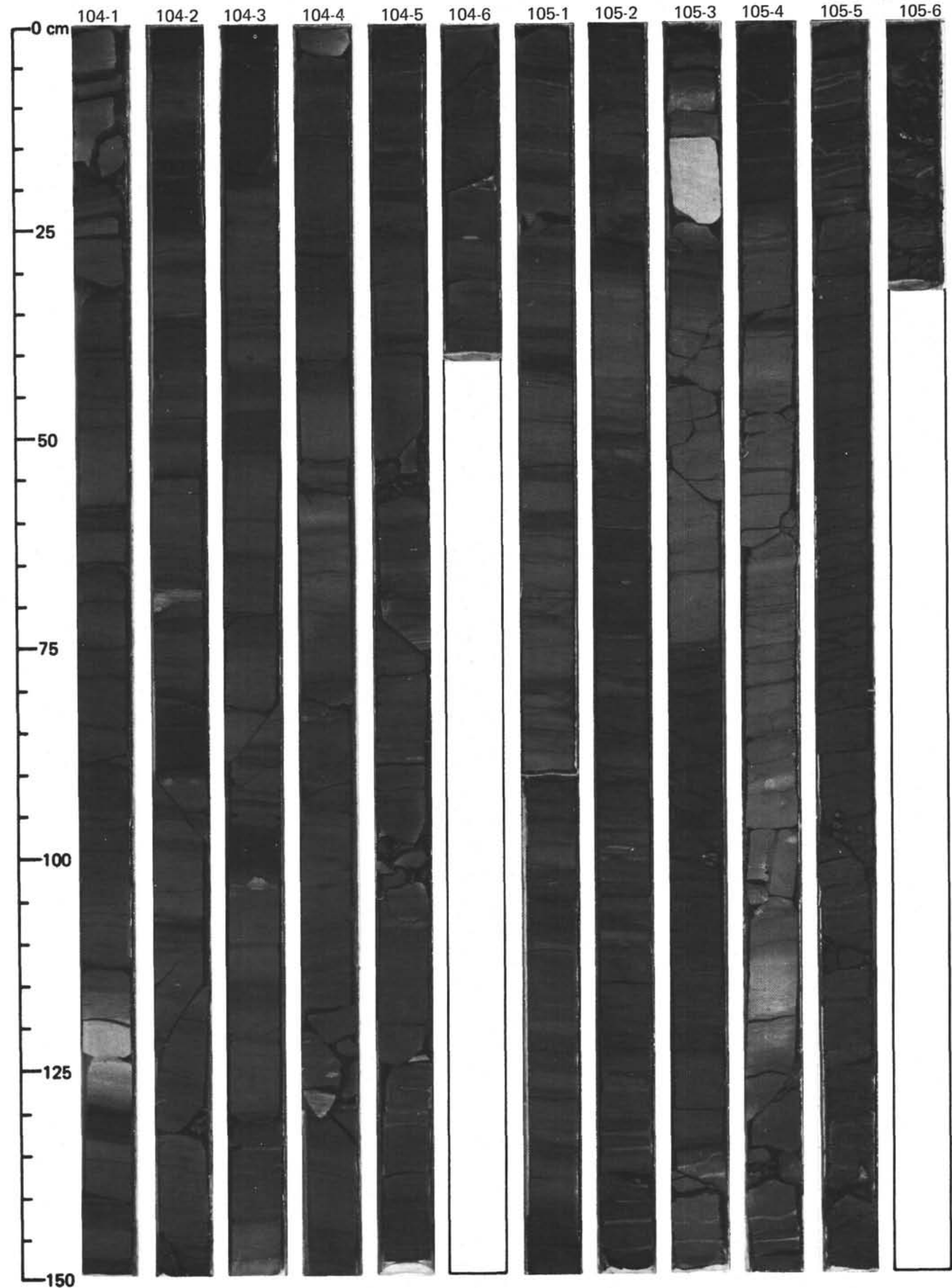




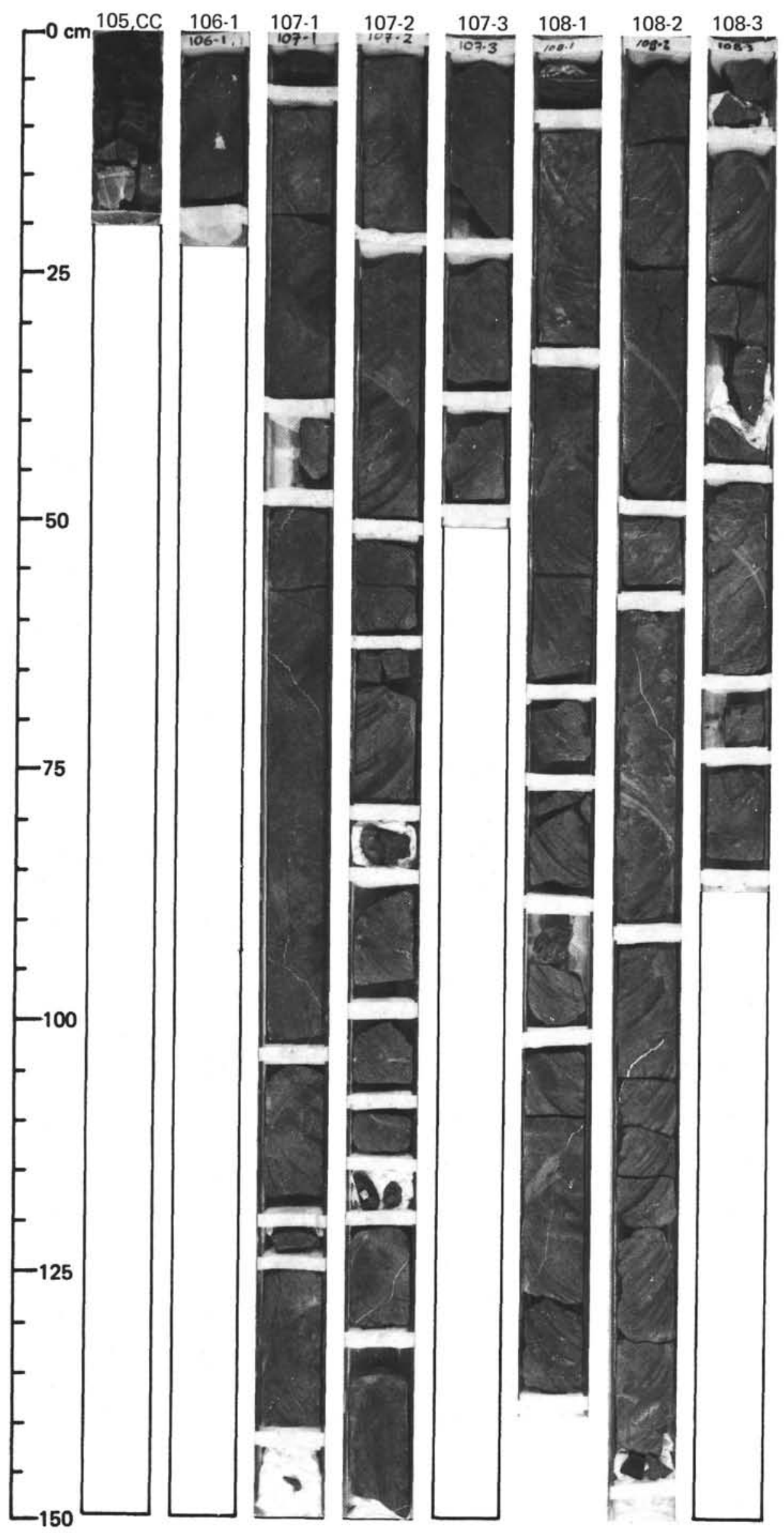




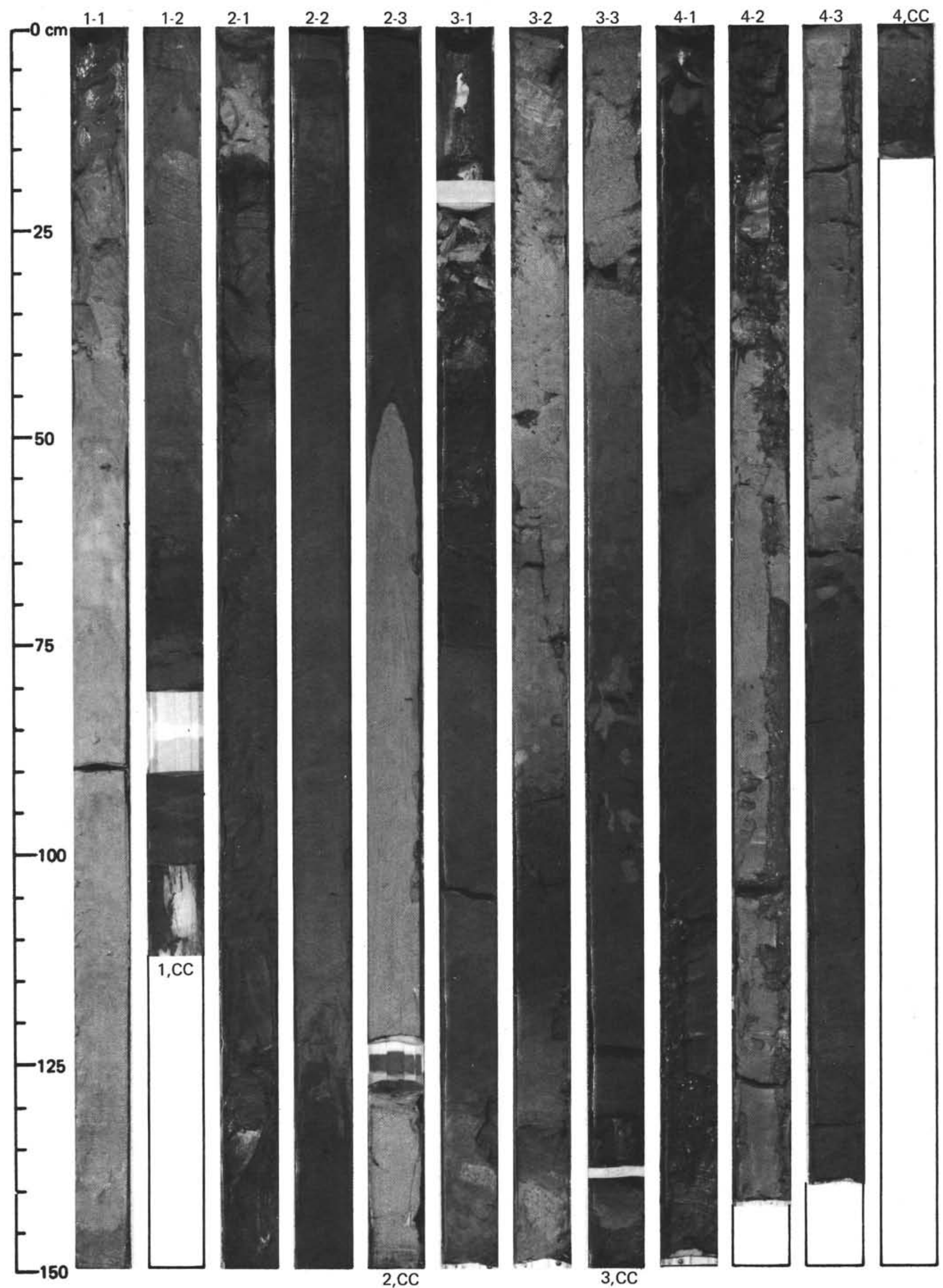




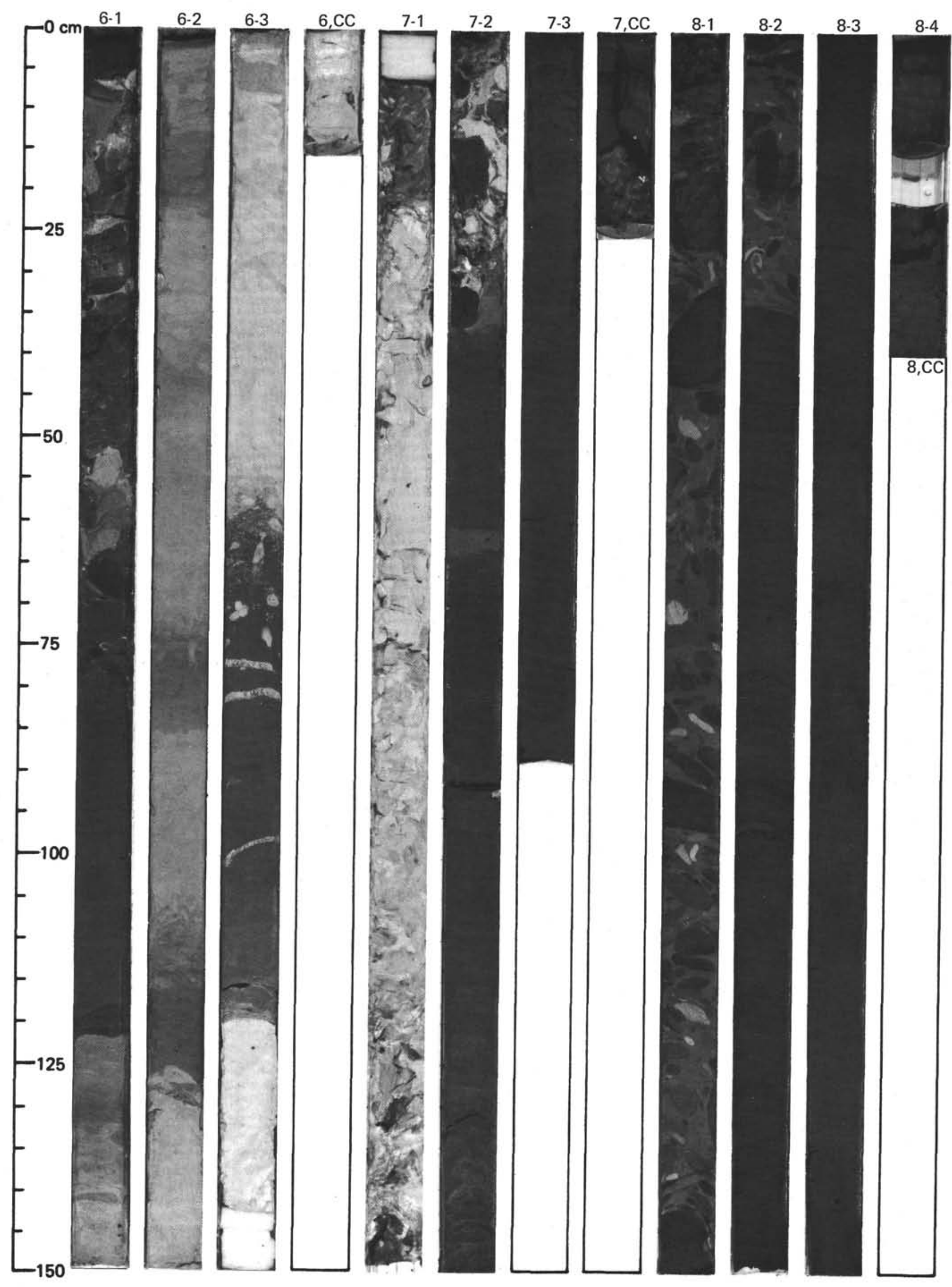




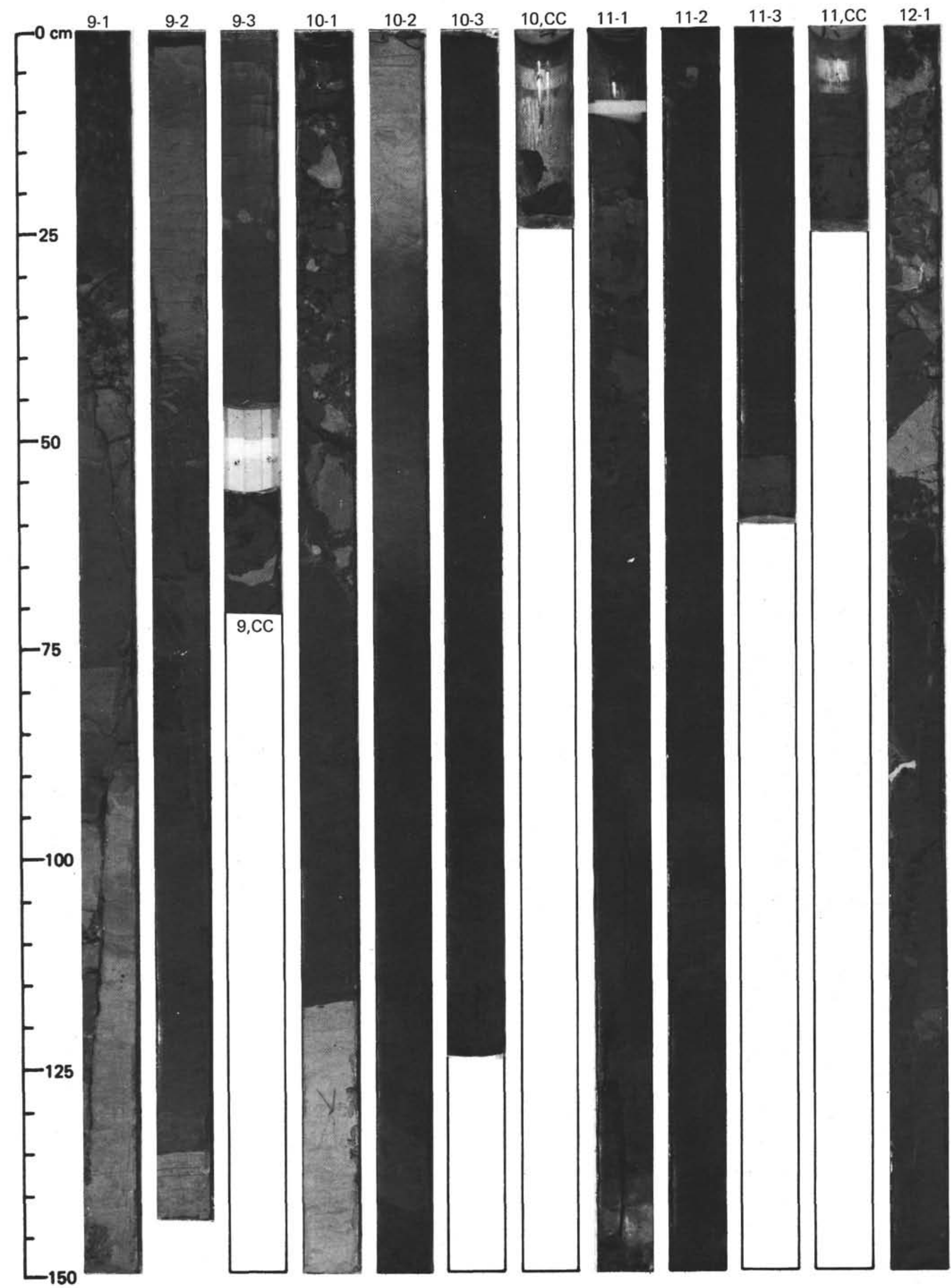




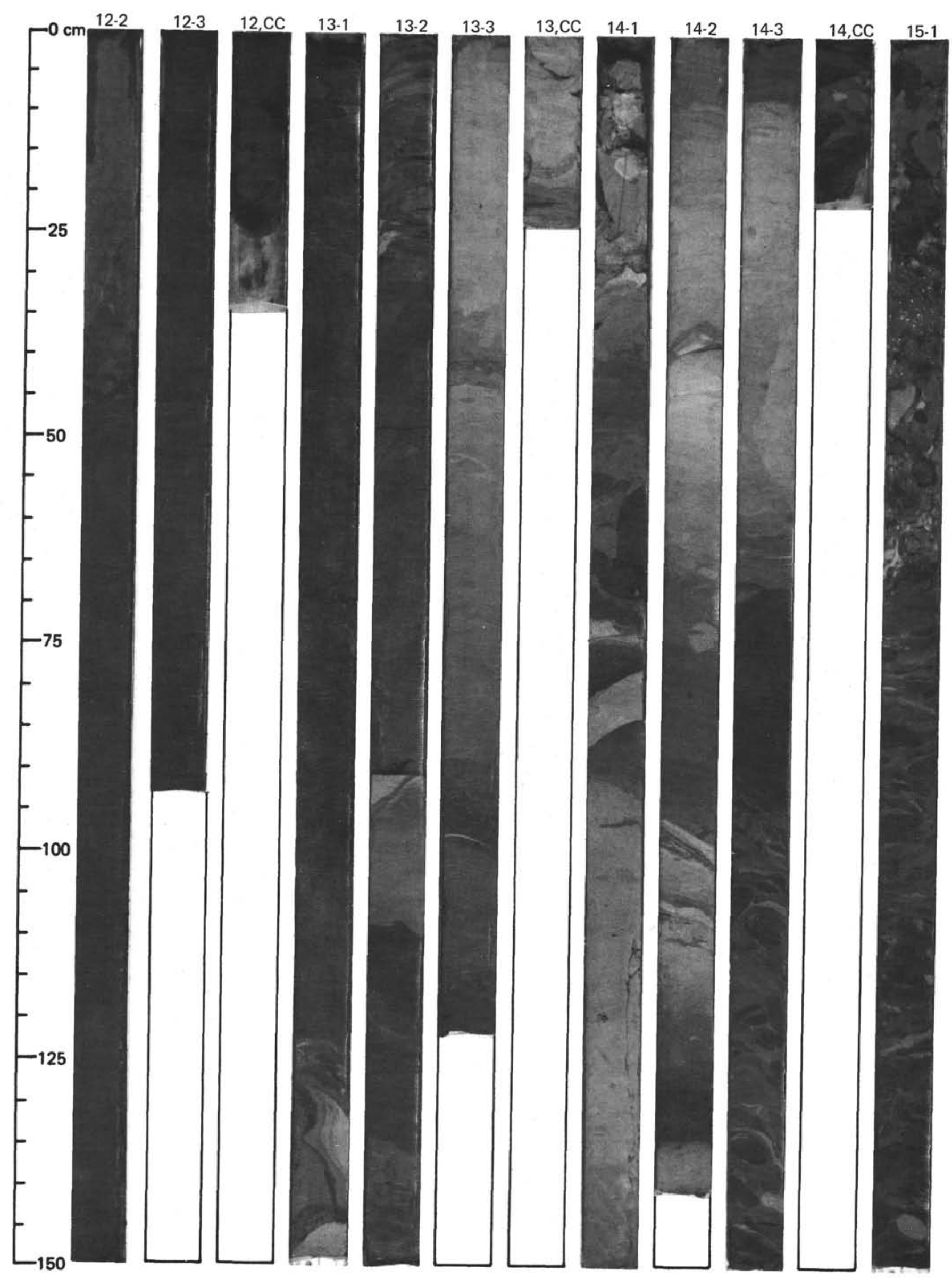




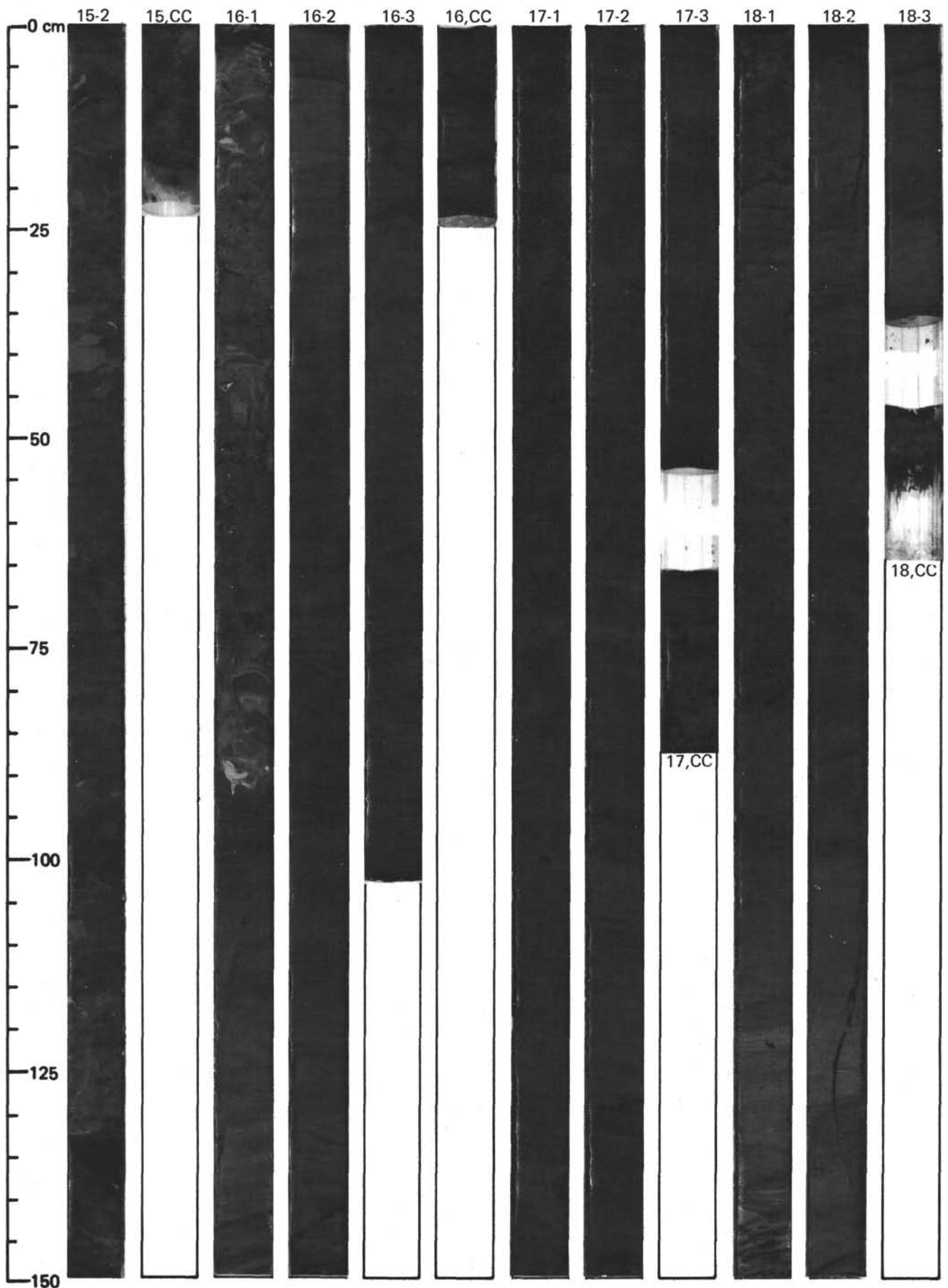




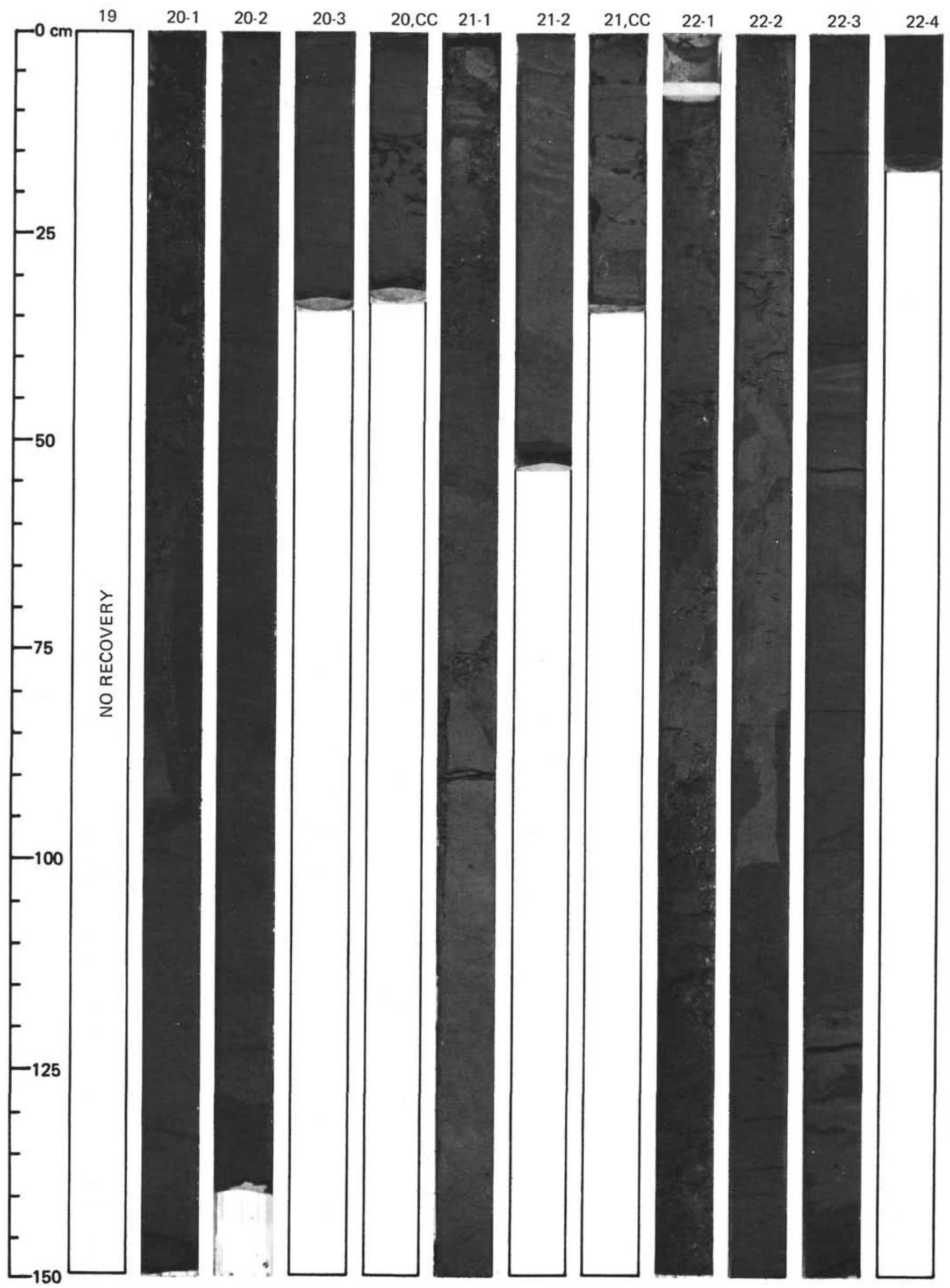




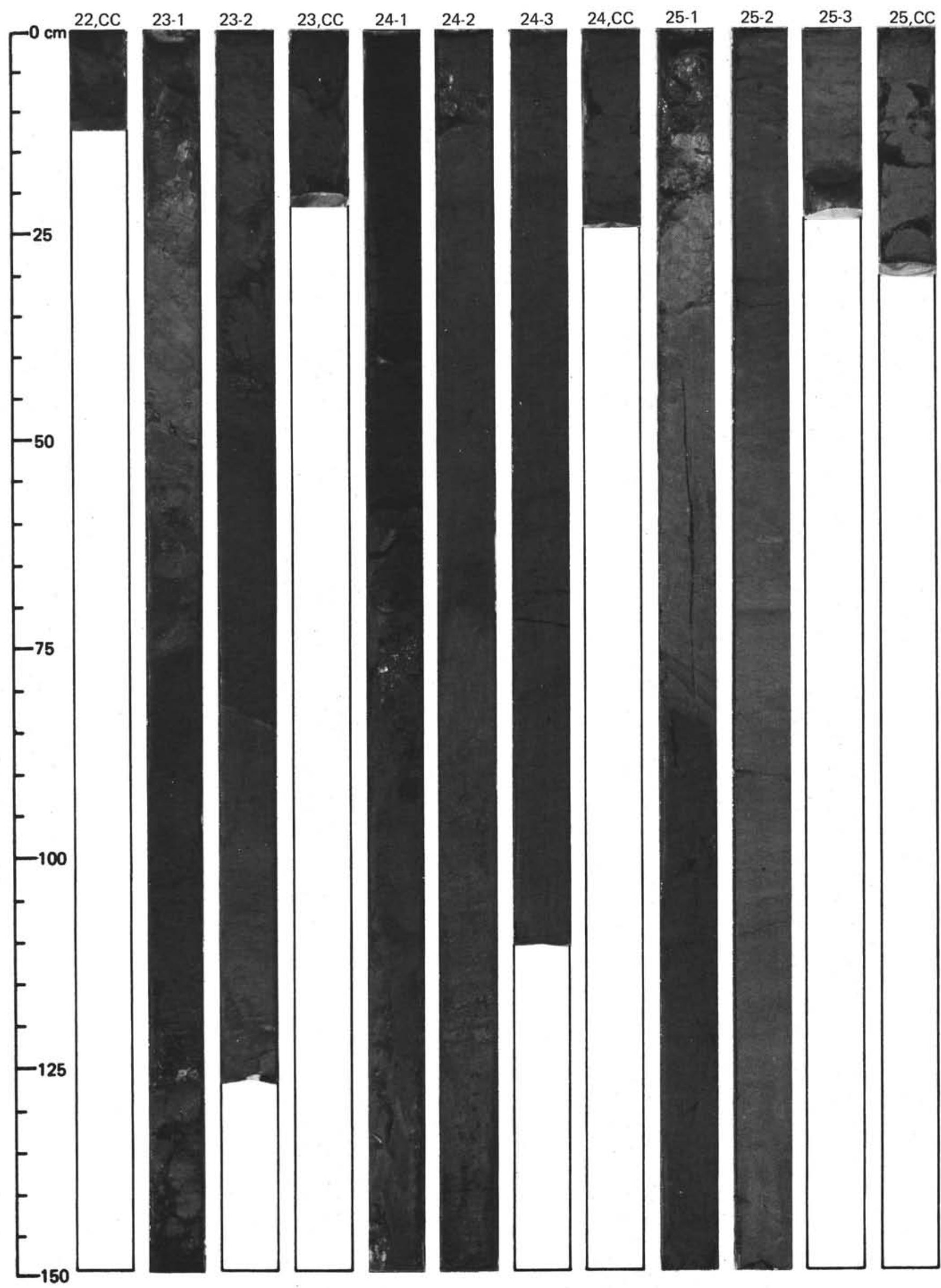




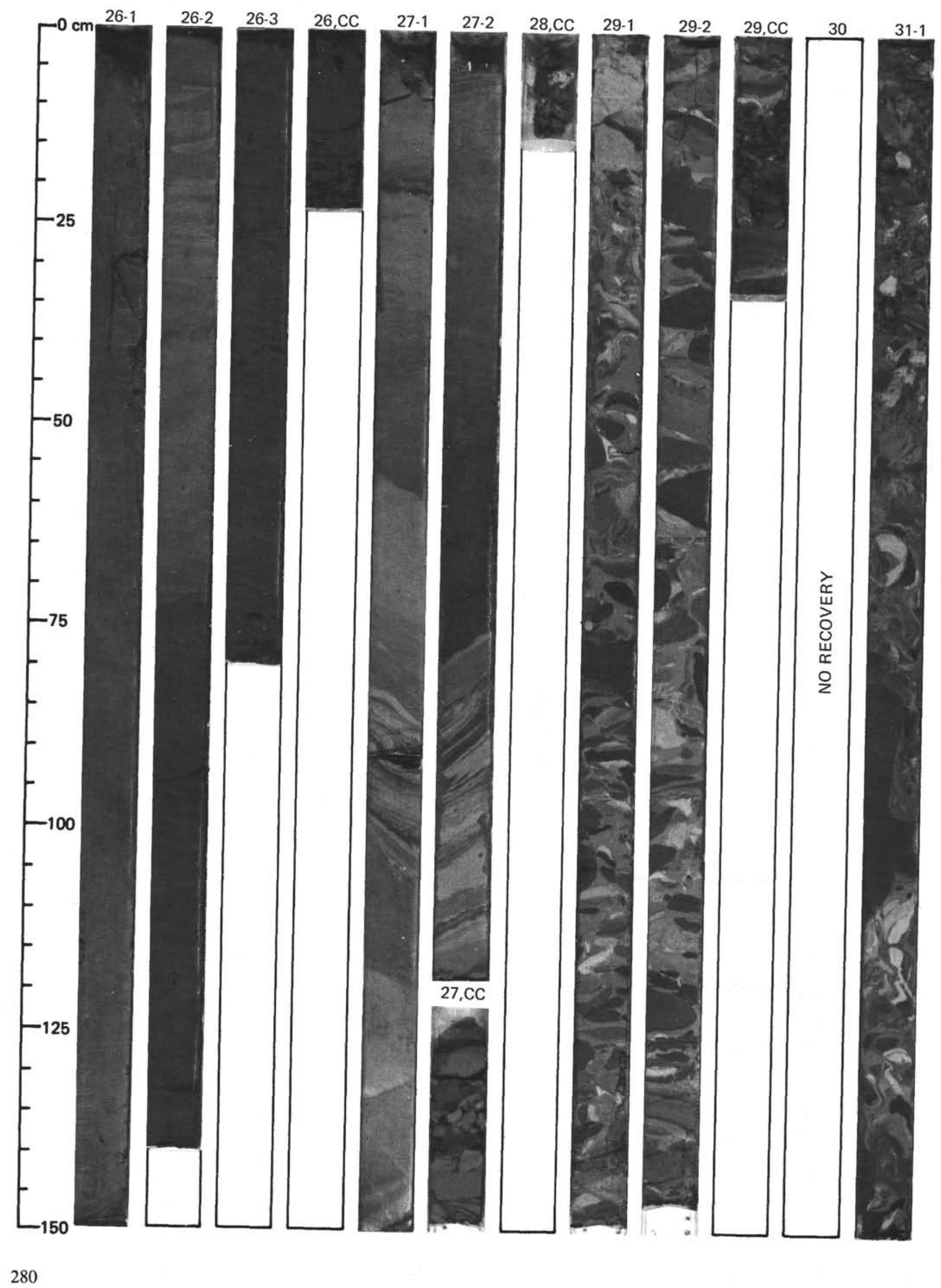




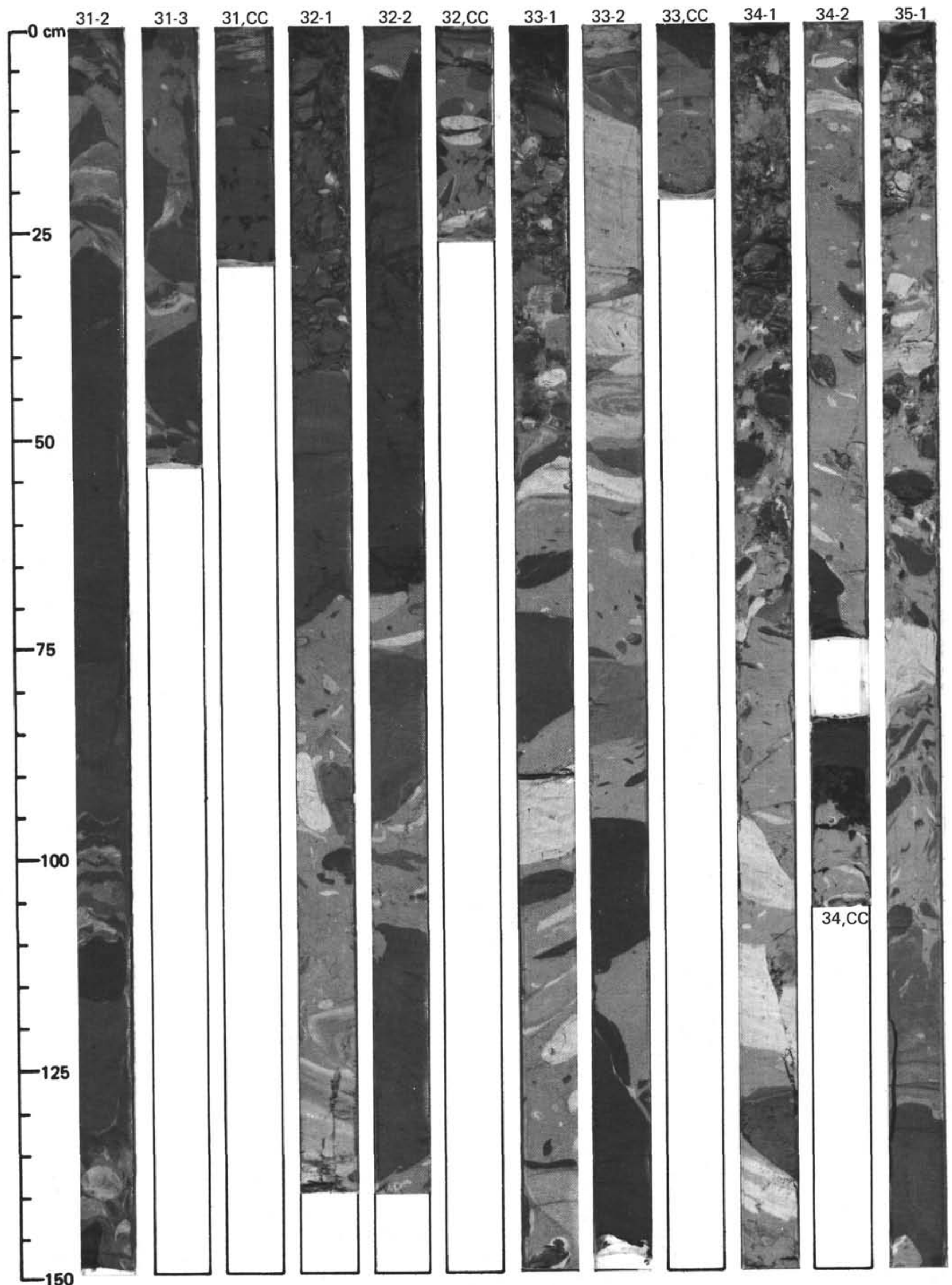




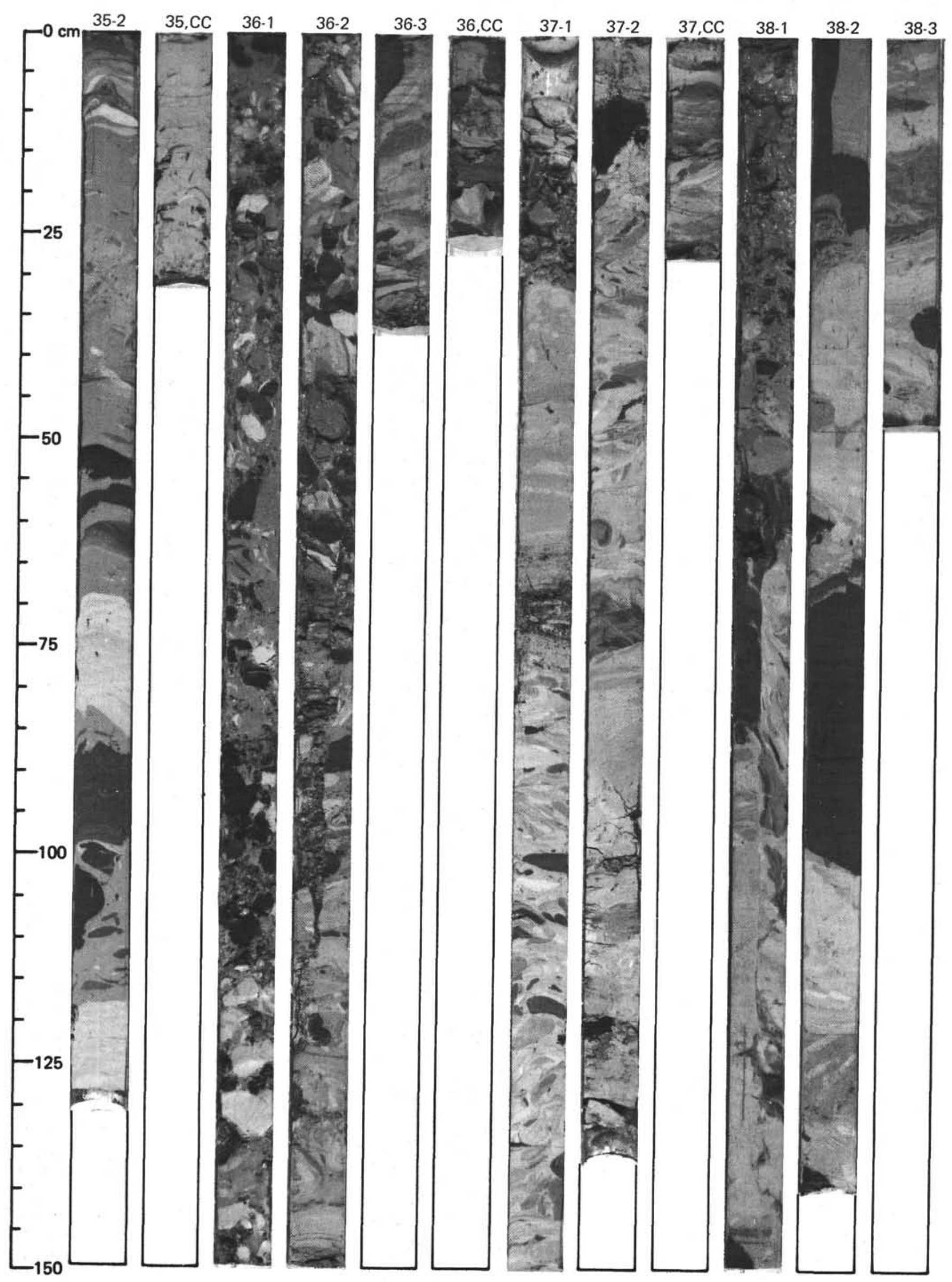




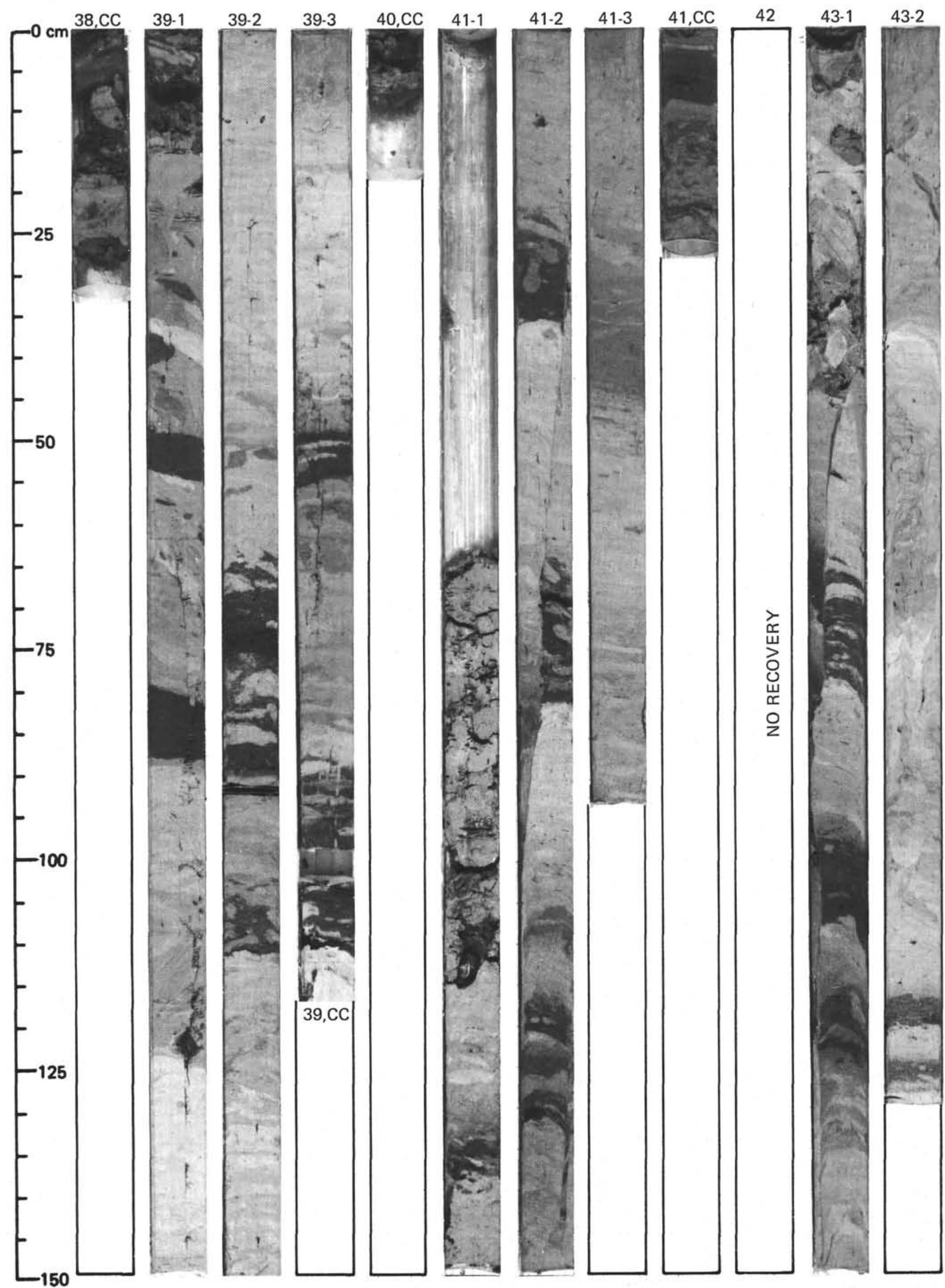




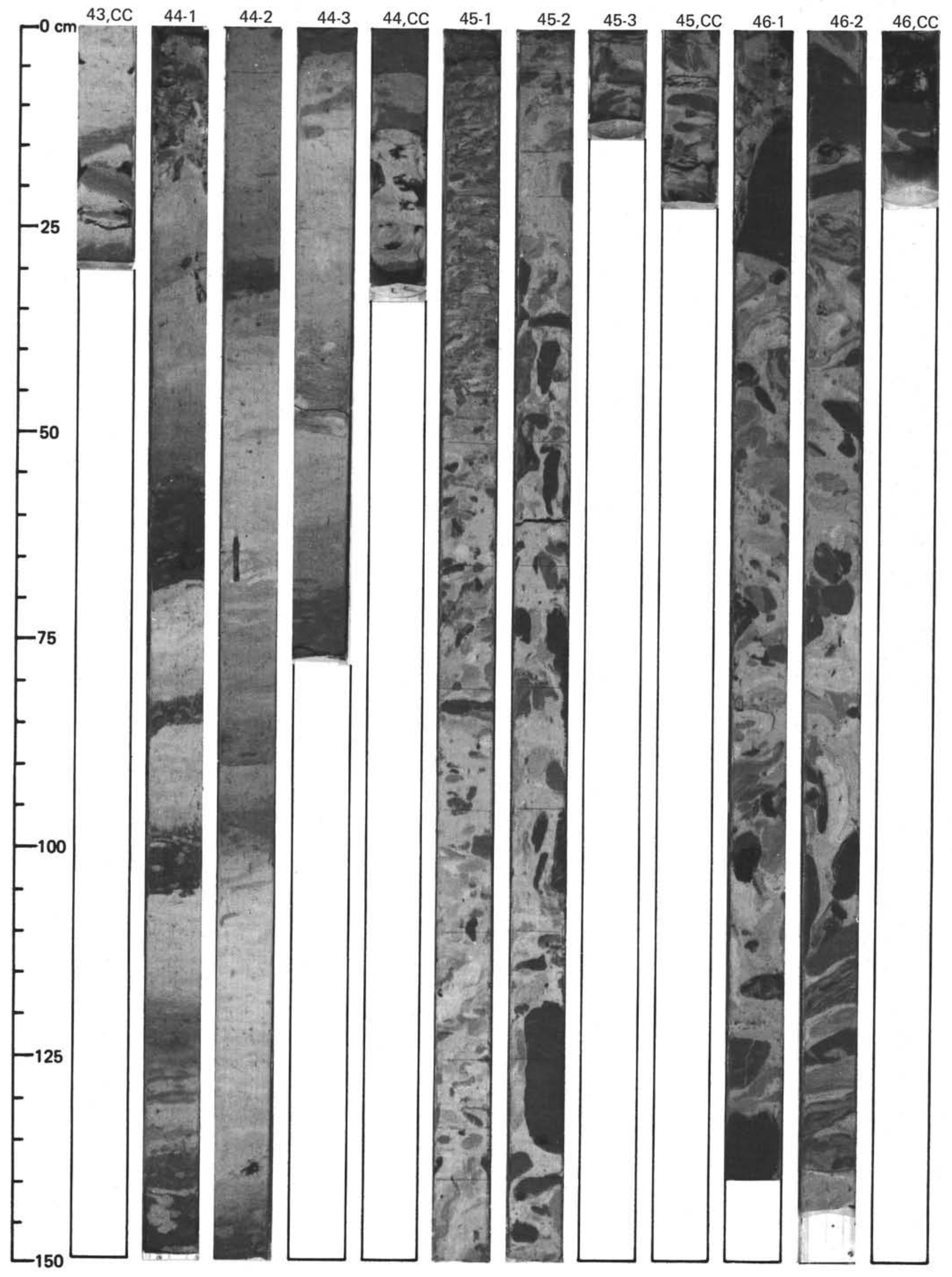




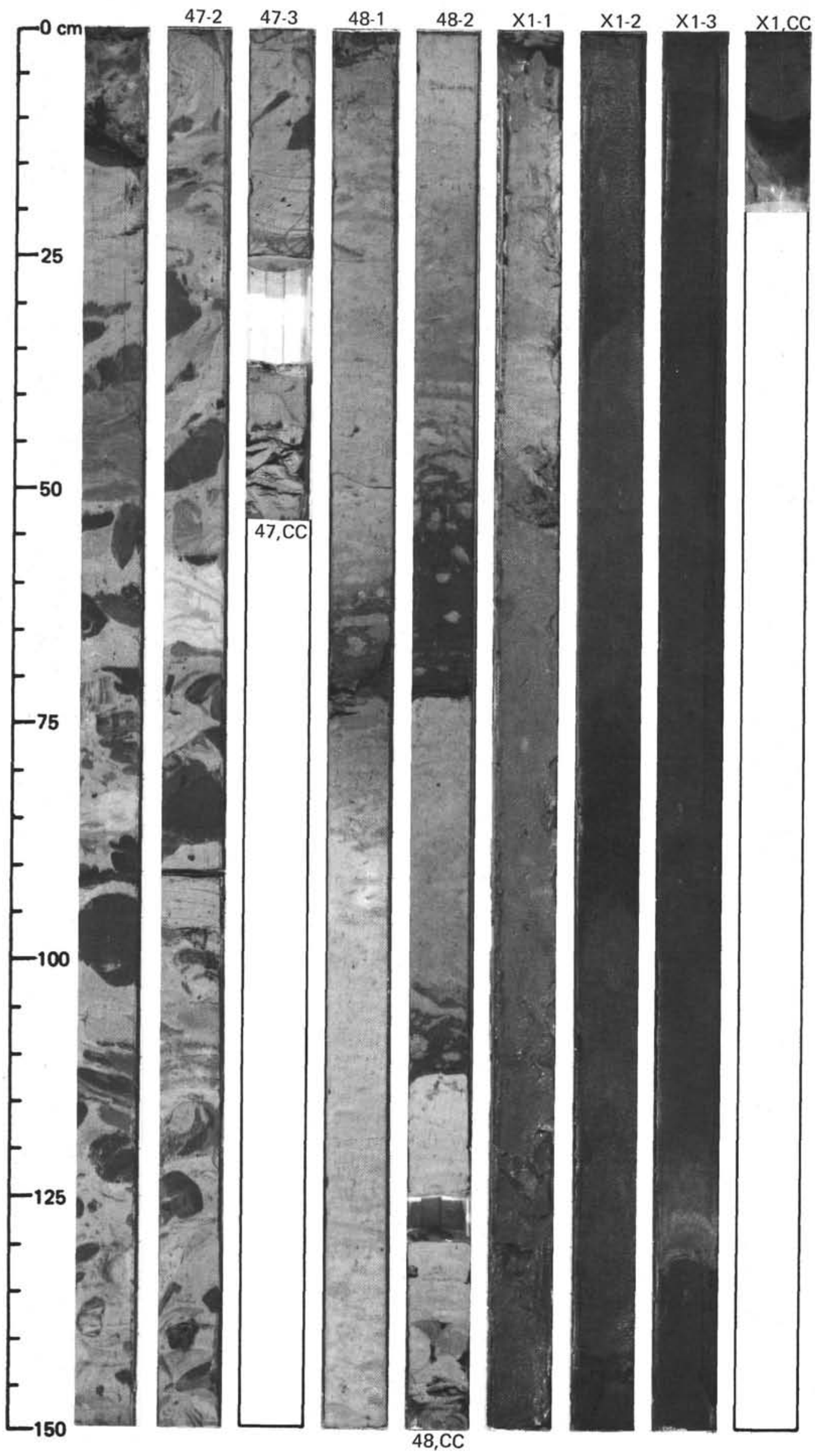

